\title{
THE U. S. GEOLOGICAL SURVEY
}

$-25=$

$\sec$

$-2-x-y+2$
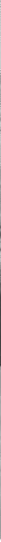

40)
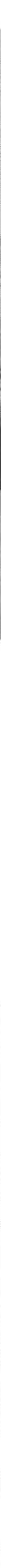

Cover photographs, clockwise from the top:

Geologists on Augustine Island, an active volcano

(Photo by Hans-Ulrich Schmincke, Bochum, W. Germany)

Geologic mapping in central Alaska

Helicopter being used in Survey activities

Instruments at Sitka Observatory

The Survey's vessel used in coastal work in Alaska 


\section{The United States Geological Survey in Alaska: Accomplishments during 1979}

Nairn R. D. Albert and Travis Hudson, Editors

GEOLOGICAL SURVEY CIRCULAR 823-B 
United States Department of the Interior

JAMES G. WATT, Secretary

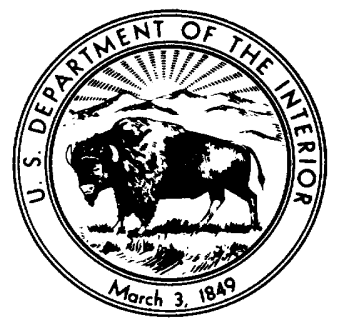

Geological Survey

Doyle G. Frederick, Acting Director 


\section{CONTENTS}

Abstract

Summary of important results

Introduction

Statewide Project

Landsat data interpretation in the south-central Brooks Range and in southeastern Alaska, by James R. LeCompte and Wm. Clinton Steele -Northern Alaska

National Petroleum Reserve in Alaska-data release, by Robert D. Carter.

Depositional history of the Nanushuk Group and related strata, by C. M. Molenaar

Compositional variation in sandstones of the Nanushuk Group, Arctic North Slope, by Susan Bartsch-Winkler and A. C. Huffman ...

Minimum age of beach deposits north of Teshek puk Lake, Arctic Coastal Plain, by L. David Carter and Stephen W. Robinson.

Paleoenvironments during deposition of a section of the Gubik Formation exposed along the lower Colville River, North Slope, by R. E. Nelson

New stratigraphic assignment for rocks along Igilatvik (Sabbath) Creek, William O. Douglas Arctic Wildlife Range, Alaska, by Robert L. Detterman and Robert A. Spicer.

Further notes on the ground-water supply beneath Selin Creek near Cape Lisburne, northwestern Alaska, by Alvin J. Feulner and John R. Williams

Mafic rocks in the Avan Hills ultramafic complex, De Long Mountains, by Jay Zimmerman, Charles O. Frank, and Sean Bryn.

Gravity measurements useful in exploration and evaluation of the Nimiuktuk barite deposit, by David F. Barnes.

Late Mississippian to Pennsylvanian radiolarian assemblages in the Siksikpuk(?) Formation at Nigu Bluff, Howard Pass quadrangle, Alaska, by Benita L. Murchey, Patricia B. Swain, and Steven Curtis

Depositional model for the fluvial Upper Devonian Kanayut Conglomerate, Brooks Range, Alaska, by T. H. Nilsen, W. P. Brosgé, J. T. Dutro, Jr., and T. E. Moore

Episodic Holocene alluviation in the central Brooks Range: chronology, correlations, and climatic implications, by Thomas D. Hamilton_ 21

Significance of Middle Devonian clastic rocks in the eastern Brooks Range, Alaska, by William

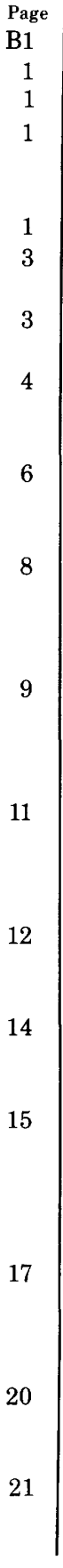

\section{Page}

P. Brosgé, H. N. Reiser, and J. T. Dutro, Jr. .... B24

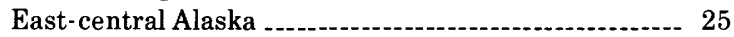

New chemical and isotope data for the hot springs along Big Windy Creek, Circle A-1 quadrangle, Alaska, by Terry E. C. Keith, Theresa S. Presser, and Helen L. Foster ------- 25

Laumontite occurrence in the Circle A-1 quadrangle, Alaska, by Terry E. C. Keith, Ivan Barnes, and Helen L. Foster.

Geologic reconnaissance of the east half of Kantishna River quadrangle and adjacent areas, by Robert M. Chapman and Warren Yeend.---- 30

Ordovician graptolites and early Paleozoic radiolarians in the Lake Minchumina area date a regional shale and chert belt, by Robert $M$. Chapman, Michael Churkin, Jr., Claire Carter, and James H. Trexler, Jr.

Geochronologic studies in the Yukon-Tanana Upland, east-central Alaska, by John N. Aleinikoff, Cynthia Dusel-Bacon, and Helen L. Foster.

A minimum age for Prindle Volcano, YukonTanana Upland, by Helen L. Foster

Metalliferous mineral resource potential of the Big Delta quadrangle, by W. D. Menzie, H. L. Foster, and D. L. Mosier

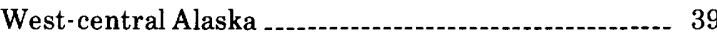

$\mathrm{K}$-Ar age measurements on obsidian from the Little Indian River locality in interior Alaska, by Thomas P. Miller and Marvin A. Lanphere _- 39

Lower Paleozoic platform carbonate sequence in the Medfra quadrangle, west-central Alaska, by J. T. Dutro, Jr., and W. W. Patton, Jr.

Southwestern Alaska.

Lower Paleozoic radiolarian chert and associated rocks in the Tikchik Lakes area, southwestern Alaska, by J. M. Hoare and D. L. Jones

$\mathrm{K} \cdot \mathrm{Ar}$ ages on intrusive rocks and altered zones in the Chignik and Sutwik Island quadrangles, by Frederic H. Wilson

Southern Alaska

Revised ages of paleozoic and Mesozoic rocks in the Talkeetna quadrangle, south-central Alaska, by D. L. Jones, N. J. Silberling, Bruce Wardlaw, and Don Richter.

Evidence for northwestward thrusting of the Talkeetna superterrane, and its regional significance, by Béla Csejtey, Jr. and Dennis R. St. Aubin 49 
Southern Alaska-Continued

Clearwater Mountains and vicinity, southcentral Alaska, by N. J. Silberling, D. H. Richter, and D. L. Jones

Paleolatitude of Triassic basalt in the Clearwater Mountains, south- central Alaska, by John W. Hillhouse and Sherman Grommé

Structural relations along the leading edge of the Wrangellia terrane in the Clearwater Mountains, Alaska, by Peter J. Coney, N. J. Silber ling, D. L. Jones, and D. H. Richter

Paleomagnetic investigation in the Chulitna terrane, south-central Alaska, by John W. Hillhouse and Sherman Grommé

$\mathrm{K}$-Ar ages of the Nikolai Greenstone from the McCarthy quadrangle, Alaska-the "docking" of Wrangellia, by Miles L. Silberman, Edward M. MacKevett, Jr., Cathy L. Connor, Paul R. Klock, and Georgiana Kalechitz.

Recognition of two subterranes within the Wrangellia terrane, southern Mount Hayes quadrangle, Alaska, by Warren J. Nokleberg, Nairn R. D. Albert, Paige L. Herzon, Ronny T. Miyaoka, and Richard E. Zehner

Cross section showing accreted Andean-type arc and island arc terranes in southwestern Mount Hayes quadrangle, Alaska, by Warren J. Nokleberg, Nairn R. D. Albert, Paige L. Herzon, Ronny T. Miyaoka, and Richard E. Zehner _.....- 66

Placer gold deposits, Mount Hayes quadrangle, Alaska, by Warren Yeend.

Tectonic implications of framework grain mineralogy of sandstone from the Yakutat Group, by G. R. Winkler and George Plafker

Paleomagnetic evidence for northward movement of the Chugach terrane, southern and southeastern Alaska, by Sherman Grommé and John W. Hillhouse.

Blocks and belts of blueschist and greenschist in the northwestern Valdez quadrangle. by G. R. Winkler, R. J. Miller, and J. E. Case 72

Layered gabbroic belt of regional extent in the Valdez quadrangle, by G. R. Winkler, R. J. Miller, M. L. Silberman, Arthur Grantz, J. E. Case, and W. J. Pickthorn

Surficial deposits of the Valdez quadrangle, Alaska, by John R. Williams and Kathleen M. Johnson

Deglaciation and sea-level fluctuations in Port Valdez, Alaska, John R. Williams and Henry W. Coulter

Isotopic data bearing on the origin and age of the epithermal lode gold deposits in the Hope-Sunrise mining district, northern Kenai Peninsula, Alaska, by Miles L. Silberman, Peter A. Mitchell, and James R. O'Neil .

New invertebrate fossils, but still no land vertebrates, from nonmarine Tertiary rocks of the Kenai Peninsula, Alaska, by Patrick $\mathrm{H}$. McClellan and Dennis M. Giovannetti. 84

Petrography, provenance, and tectonic signifi-
Southern Alaska-Continued cance of Middle and Upper Jurassic sandstone from Tuxedni Bay, Cook Inlet, Alaska, by Robert M. Egbert and Leslie B. Magoon -..--.-- B86

Petrography and provenance of Upper Cretaceous sandstone from Saddle Mountain in the Iniskin-Tuxedni area, lower Cook Inlet, Alaska, by Robert M. Egbert

Southeastern Alaska

Emplacement age of the Crillon-La Perouse pluton, Fairweather Range, by Travis Hudson and George Plafker

Carboniferous biostratigraphy, southeastern Alaska, by J. T. Dutro, Jr., A. K. Armstrong, R. C. Douglass, and B. L. Mamet 94

The Coast plutonic complex sill, southeastern Alaska, by David A. Brew and Arthur B. Ford _. 96

Orthogneiss of Mount Juneau-an early phase of Coast Mountains plutonism involved in Barrovian regional metamorphism near Juneau, by Arthur B. Ford and David A. Brew.

The nature and position of the Border Ranges fault on Chichagof Island, by John Decker and Bruce R. Johnson.

Upper Triassic volcanogenic massive-sulfide metallogenic province identified in southeastern Alaska, by Henry C. Berg -

Newly recognized alkali granite stock, southwestern Kupreanof Island, Alaska, by David A. Brew, Ronald A. Sonnevil, Susan J. Hunt, and A. B. Ford

Structural and stratigraphic significance of Upper Devonian and Mississippian fossils from the Cannery Formation, Kupreanof Island, southeastern Alaska, by D. L. Jones, H. C. Berg, Peter Coney, and Anita Harris.

The Chilkat-Prince of Wales plutonic province, southeastern Alaska, by Ronald A. Sonnevil..-- 112

Age of basalt flows in the Blue River valley, Bradfield Canal quadrangle, by Raymond L. Elliot, Richard D. Koch, and Stephen W. Robinson ... 115

New data concerning the geology of the North Bradfield River iron prospect, sou theastern Alaska, by Ronald A. Sonnevil.

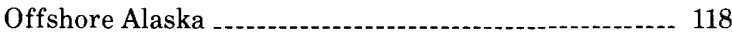

Preliminary interpretation of the geologic structure beneath the northern Bering sea shelf, including Norton Basin, by Michael A. Fisher, Mark L. Holmes, and William W. Patton, Jr..-- 118

Environmental geologic studies of the northern Bering Sea, by Devin R. Thor and C. Hans Nelson 121

Geologic constraints for petroleum development of the lower Cook Inlet, Alaska, Outer Continental Shelf lease area, by John W. Whitney and Dennis K. Thurston.

Distribution of gas-charged sediment and pockmarks in the northeastern Gulf of Alaska, Yakutat Bay to Cross Sound, by Bruce F. Molnia.

Depth changes in Icy Bay, Alaska, caused by sedimentation and melting of ice-cored 
Offshore Alaska-Continued moraine, by Bruce F. Molnia

Benthic foraminifers as indicators of the Pleistocene-Holocene boundary in the eastern Gulf of Alaska, by Paula Quinterno, Paul R. Carlson, and Bruce F. Molnia _......_._. . . 128

Unusually diverse and well preserved Eocene foraminifers in dredge samples from the eastern Gulf of Alaska continental slope, by Weldon W. Rau
Offshore Alaska-Continued

Onshore and offshore studies, Amlia Island area, Aleutian Ridge, by Jonathan R. Childs, David W. Scholl, and Tracy Vallier _.............. B134

Reports on Alaska published by the U. S. Geological Survey in 1979, compiled by Edward H. Cobb _........ 138

Reports on Alaska published by U. S. Geological Survey authors in outside publications, 1979, compiled by Ellen R. White _............ 146

\section{ILLUSTRATIONS}

FIGURE 1. Map showing regions of Alaska used in this report Page

2. Landsat image mosaic showing the Survey Pass quadrangle region, south-central Brooks Range. 3

3. Generalized stratigraphic section of Nanushuk Group in eastern NPRA

4. Seismic section of Nanushuk Group and Torok Formation in northeastern NPRA

5. Map of NPRA showing location of measured sections in Nanushuk Group rocks

6. Ternary diagrams showing modal analyses of Nanushuk Group sandstones

7. Map showing regional distribution of beach deposits exposed at Teshekpuk Lake

8. Map showing North Slope fossil localities discussed in text

9. Generalized stratigraphic section of Gubik Formation near Ocean Point

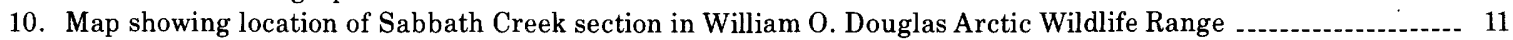

11. Schematic cross section along Selin Creek

12. Schematic topographic and gravity profiles across Nimiuktuk barite deposit and derived contours

13. Generalized columnar section, Siksikpuk Formation, and correlative radiolarian assemblages....................... 19

14. Paleogeographic sketch map showing the Kanayut delta, northern Alaska___.

15. Chart of Holocene radiocarbon dates from the central Brooks Range

16. Generalized cross section of Devonian sequences in Arctic quadrangle

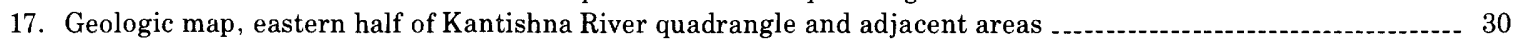

18. Photograph of linear sand dunes, Kantishna River quadrangle

19. Concordia diagram for zircon from augen gneiss, Big Delta quadrangle

20. Photograph of Prindle Volcano, Tanacross quadrangle... 37

21. Sketch map showing tracts permissive for the occurrence of mineral deposits, Big Delta quadrangle

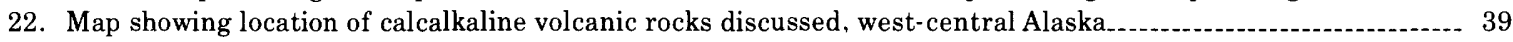

23. Generalized stratigraphic section of lower Paleozoic rocks, Medfra quadrangle

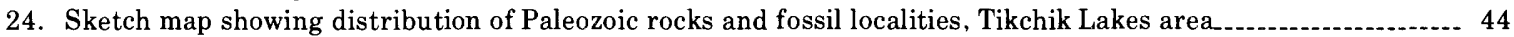

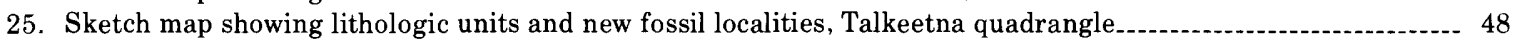

26. Generalized cross section, southeastern Healy quadrangle

27. Geologic map, northeastern Talkeetna Mountains and Clearwater Mountains

28. Tectonic map and generalized cross section, Clearwater Mountains

29. Plot of mean magnetic directions from Chulitna redbed section, south-central Alaska ..........................................

30. Map of Alaska showing selected Mesozoic terranes in southern Alaska

31. Initial argon diagram for Nikolai Greenstone

32. Comparison of stratigraphic columns, eastern Alaska Range, Mount Hayes quadrangle............... 65

33. Generalized cross section, eastern Alaska Range, Mount Hayes quadrangle

34. Q-F-L and rock fragment composition diagrams of Yakutat Group sandstone

35. Map of northern Pacific and Arctic regions showing paleomagnetic poles .

36. Schematic geologic map of part of Valdez quadrangle

37. Map showing surficial deposits, Valdez quadrangle

38. Skech map of Port Valdez area

39. Geologic sketch map of northern Kenai Peninsula area

40. Map of Kenai Peninsula showing locality and photograph of fossil clam and leaves from the Sterling Formation 85

41. Q-F-L ternary diagrams and compositional data for sandstone from Tuxedni Bay, Cook Inlet .................... 87

42. Ternary diagrams and petrographic data for sandstone from Saddle Mountain, Iniskin-Tuxedni area ........... 89

43. Photograph showing contact between Crillon-La Perouse pluton and amphibolite 
Page

44. Photograph showing leucocratic dikes near contact between Crillon-La Perouse pluton and amphibolite..----..- B93

45. Generalized stratigraphic sections showing correlation of Carboniferous rocks in southeastern Alaska......... 95

46. Map of part of southeastern Alaska showing Coast plutonic complex

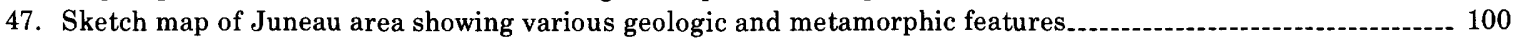

48. Ternary diagram of orthogneiss from Mount Juneau pluton

49. Generalized structure section across western Chichagof Island

50. Maps of southeastern Alaska showing locations of massive sulfide and related mineral occurrences ............-.. 105

51. Map of part of northern southeastern Alaska showing northwestern part of Kuiu-Etolin belt................. 109

52. Map of Keku strait area showing fossil localities

53. Schematic columnar section of Keku Strait area

54. Map of northern southeastern Alaska showing various geologic and structural features

55. Ternary diagram of plutonic rocks from the Chilkat-Prince of Wales plutonic province

56. Sketch map of part of Bradfield Canal quadrangle showing Blue River volcanic flows

57. Generalized geologic map of North Bradfield River iron prospect area

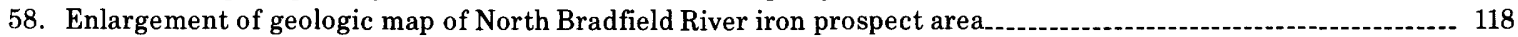

59. Schematic cross section of North Bradfield River iron prospect area

60. Map of northern Bering Sea area showing shelf structures .

61. Map of Norton Basin area showing potentially hazardous areas

62. Map of lower Cook Inlet showing bathymetry and 1977 lease tracts

63. Map of northeastern Gulf of Alaska showing locations of six gas-charged areas

64. Map of Icy Bay showing depth changes in the lower basin

65. Map of part of northeastern gulf of Alaska showing seismic profile locations and line drawings of seismic profiles

66. Map of part of northeastern Gulf of Alaska showing locations of dredged bedrock samples ............................

67. Map of Amlia Island area showing geologic sampling locations, sonobouy lines, and geophysical track lines .--- 136

\section{TABLES}

TABLE 1. Principal mafic rock types in the transition and mafic zones of the Avan Hills ultramafic complex

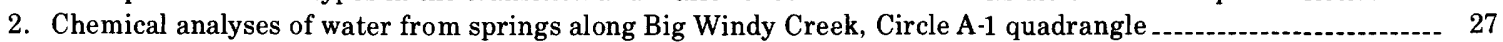

3. U-Th-Pb isotopic data for the augen gneiss, Big Delta quadrangle and the Taylor Mountain batholith, Eagle and Tanacross quadrangles.

4. Chemical analyses of rhyolitic tuff and obsidian from the Little Indian River locality

5. K-Ar ages and analytical data for obsidian from the Little Indian River locality

6. New fossil localities in the northwestern part of the Talkeetna quadrangle, south-central Alaska ............... 47

7. Fossils and ages from the Wrangellia terrane, south-central Alaska

8. K-Ar ages of whole-rock Nikolai Greenstone samples.

9. Summary of major oxide, trace element, and modal data for the layered gabbroic plutonic belt in the Valdez quadrangle

10. Stable isotope data for vein quartz, northern Kenai Peninsula and vicinity

11. K-Ar age data, northern Kenai Peninsula and vicinity

12. Description and K-Ar data for samples from the contact zone of Crillon-La Perouse pluton, Fairweather Range_ 92

13. Average chemical composition of orthogneiss of Mount Juneau pluton

14. Descriptions of rock and mineral samples, southeastern Alaska

15. New fossil localities in the Keku Strait area, southeastern Alaska

16. Percentage distribution of benthic foraminifers from the eastern Gulf of Alaska

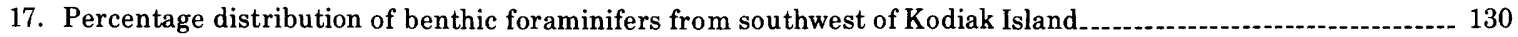

18. Percentage distribution of benthic foraminifers from Bering Trough

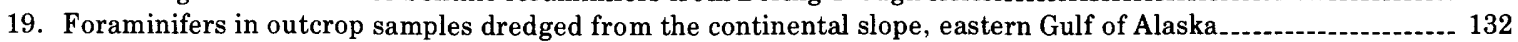

20. Coordinates for samples dredged from eastern Gulf of Alaska continental shelf 


\title{
The United States Geological Survey in Alaska:
}

\author{
Accomplishments during 1979
}

\author{
Nairn R. D. Albert and Travis Hudson, Editors
}

\begin{abstract}
United States Geological Survey projects in Alaska cover a wide range of topics of economic and scientific interest. Accomplishments during 1979 include contributions to economic, regional, environmental, marine, and engineering geology and to geochronology, paleontology, geophysics, stratigraphy, and hydrology. Many maps and reports covering various aspects of the geology and mineral and water resources of the State were published in 1979 .
\end{abstract}

\section{SUMMARY OF IMPORTANT RESULTS}

\section{INTRODUCTION}

Significant new scientific and economic geologic information has resulted from many topical and field investigations of the U.S. Geological Survey in Alaska during 1979. Discussions of the findings or, in some instances, narratives of the course of the investigations are grouped in eight subdivisions corresponding to the six major onshore geographic regions (fig. 1), the offshore projects, and one project that is statewide in scope.

\section{STATEWIDE PROJECT}

Landsat data interpretation in the south-central Brooks Range and in southeastern Alaska

By James R. Le Compte and Wm. Clinton Steele

Landsat images of numerous 1:250,000-scale quadrangles were studied during 1979 as part of the Alaska Mineral Resources Assessment Program (AMRAP) (see Reed, 1980). Of these studies, Landsat data from the Survey Pass quadrangle region in the south-central Brooks Range and the Bradfield Canal, Petersburg, and Ketchikan quadrangles region in southeastern Alaska show the most promising geologic and mineralogical correlations.

Previous Landsat investigations in other areas of Alaska (Albert and Steele, 1976, 1978; Steele and Albert, 1978) have demonstrated a good correlation between Landsat-observed circular features and exposed intrusive bodies. Numerous similar circular features have been observed on imagery of the Survey Pass quadrangle and adjacent areas (Le Compte, 1980); these features range from about 10 to $50 \mathrm{~km}$ in diameter and are defined by numerous semi-concentric, arcuate topographic features such as broad valley bottoms, narrow canyon troughs, and ridgelines.

Circular features spatially coincide with nearly the entire outcrop area of each of the major granitic masses exposed in the region (Le Compte, 1980): the Arrigetch and Igikpak plutons (Nelson and Grybeck, 1980) in the central part of the Survey Pass quadrangle; the Shishakshinovik pluton (Alaska Division of Geological and Geophysical Surveys, 1974) in the easternmost part of the Ambler River quadrangle; and the Ernie Lake pluton (Nelson and Grybeck, 1980) in the westernmost part of the Wiseman and easternmost part of the Survey Pass quadrangles.

In addition to these pluton-coincident circular features, however, several other circular features are present in the Survey Pass quadrangle that do not enclose exposed granitic rocks. Three of these features, near Shulakpachak Peak, the Nigu River, and Plateau Mountain, in the northern part of the quadrangle, are particularly noteworthy. Donald Grybeck (oral commun., 1979) and John Cathrall (oral commun., 1980) interpret the occurrence of numerous vein-type mineral deposits (principally $\mathrm{Cu}, \mathrm{Pb}, \mathrm{Zn}$, and $\mathrm{Ag}$ ) (Grybeck and Nelson, 1980) and anomalous geochemical values (principally La, Th, Be, and Sn) (J. B. Cathrall, unpub. data) in these areas as indicative of plutonic bodies at depth. The occurrence of circular features encompassing these same mineral deposits and geochemically anomalous locales may be additional evidence for the presence of these plutonic bodies.

In the Bradfield Canal, Petersburg, and Ketchikan quadrangles region, intersections of numer- 


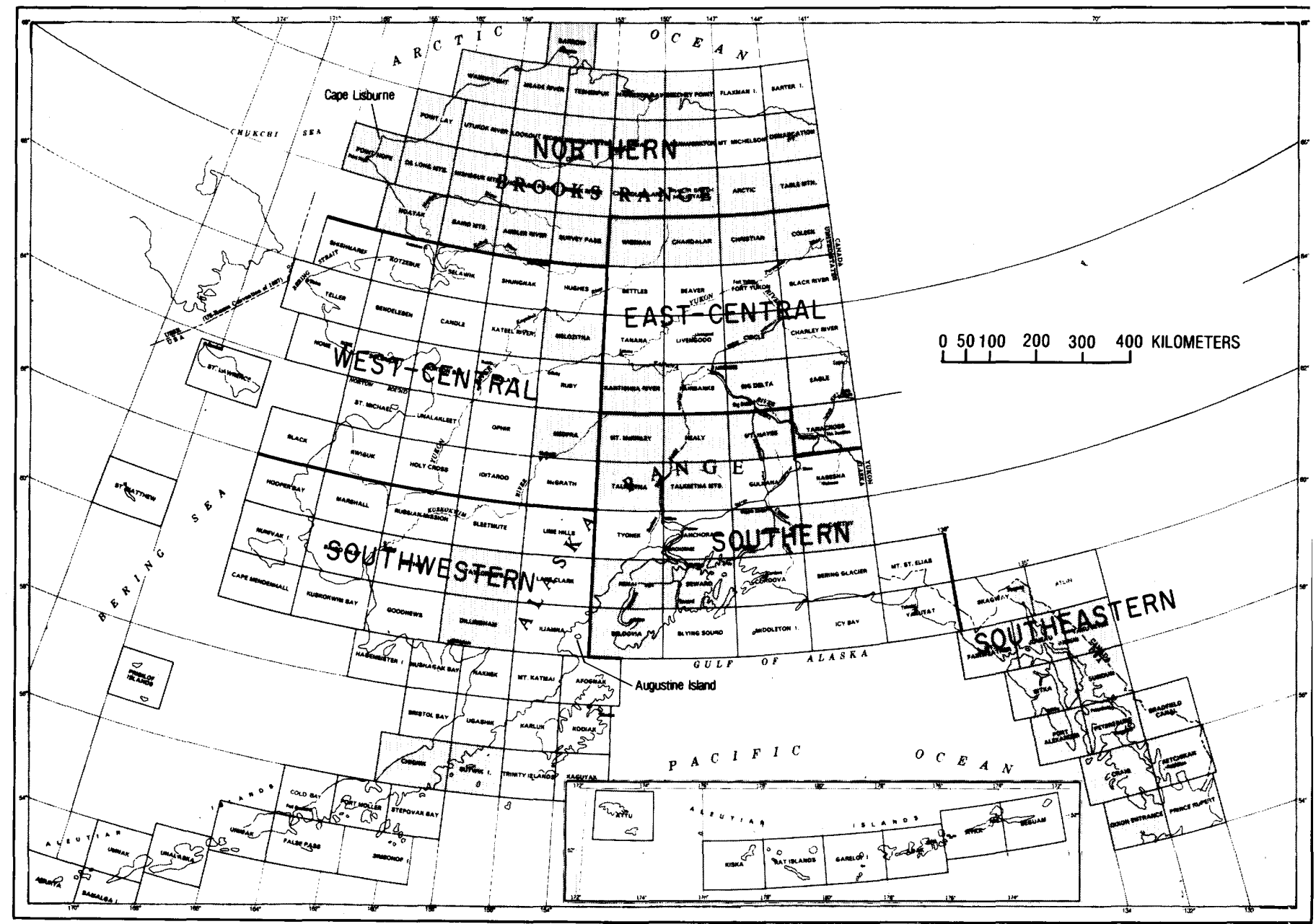

FIGURE 1.-Regions of Alaska discussed in this report (shaded).

ous lineament "zones" ( J. R. Le Compte, unpub. data) (the term "zone" is herein defined as a group of alined or nearly alined, well-defined lineaments that includes nearby parallel lineaments) observed on Landsat imagery coincide with sites of significant porphyry molybdenum mineralization (Hudson and others, 1979; R. L. Elliott, oral commun., 1980; D. A. Brew, oral commun., 1980). Raines (1978) has noted a similar spatial coincidence between sites of important porphyry copper mineralization and the intersections of northeast-trending lineaments ("shear zones") and north-northwest-trending lineaments in northern Sonora, Mexico.

Porphyry molybdenum mineralization in this southeastern region of Alaska is associated with relatively small granitic masses (stocks and sills) of middle to late Tertiary age (Hudson and others,
1979). Mo-bearing granite and quartz porphyry bodies, which spatially coincide with the intersections of well-developed, northeast-and easttrending lineament zones, are exposed at Quartz Hill and Burroughs Bay (Elliott and others, 1978) in the Ketchikan quadrangle and at Groundhog Basin (Twenhofel and others, 1946) in the Petersburg quadrangle. Although vein-type molybdenum mineralization present at Walker Cove, in the central part of the Ketchikan quadrangle, is not known to be associated with a middle to late Tertiary granitic body (Elliott and others, 1978), it is coincident with a lineament zone intersection (J. R. Le Compte, unpub. data). The occurrence of this intersection with the molybdenum mineralization suggests that an undetected middle to late Tertiary granitic intrusive body may be present (either at depth or as yet 


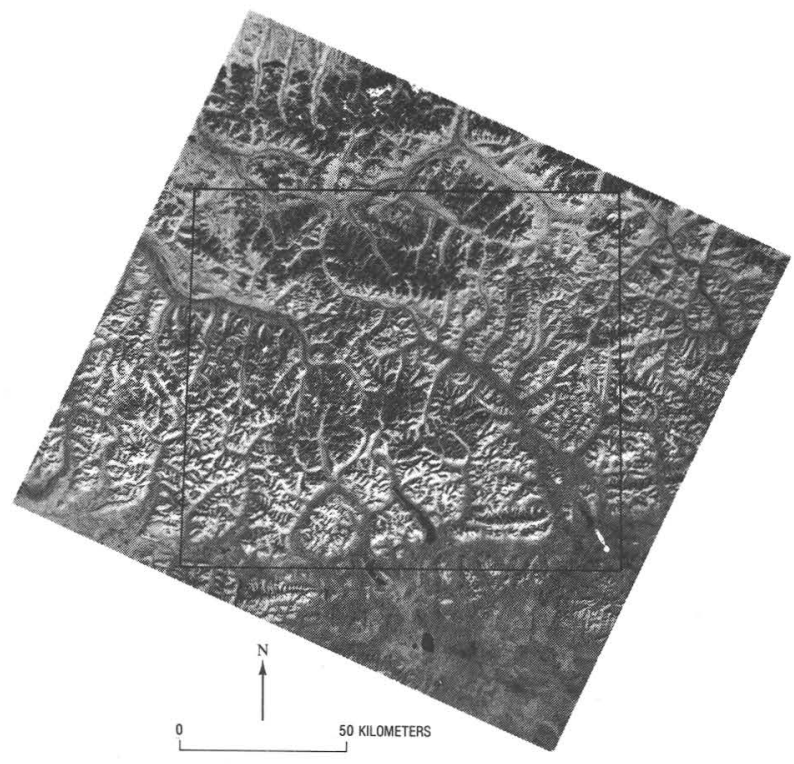

Figure 2.-Computer-enhanced Landsat image mosaic of the Survey Pass quadrangle region, south-central Brooks Range. Images used for computer enhancement are scenes 1758-21195 and 1758-21201, taken August 20, 1974 (Band 7). Dark lines show Survey Pass quadrangle boundaries. Computer-compatible types were processed by Pat S. Chavez, Jr., Teresa E. Grow, and Linda Sowers, U.S. Geological Survey, Flagsțaff, Arizona.

unrecognized at the surface) at this locality and may be the source of the molybdenum.

Similar intersections that encompass neither known molybdenum deposits or occurrences nor known, exposed middle to late Tertiary granitic intrusive bodies are noted elsewhere within this region (J. R. Le Compte, unpub. data) and may warrant further field investigations regarding their geologic and mineralogical significance.

\section{REFERENCES CITED}

Alaska Division of Geological and Geophysical Surveys, 1974, Brooks Range Project, in Annual report 1973: Anchorage, Alaska, p. 6-9.

Albert, N. R. D., and Steele, W. C., 1976, Interpretation of Landsat imagery of the Tanacross quadrangle, Alaska: U.S. Geological Survey Miscellaneous Field Studies Map MF-767C, 3 sheets, scale 1:250,000.

- 1978, Map showing interpretation of Landsat imagery of the Big Delta quadrangle, Alaska: U.S. Geological Survey Open-File Report 78-529C, 2 sheets, scale 1:250,000.

Elliott, R. L., Berg, H. C., and Karl, Susan, 1978, Map and table describing metalliferous and selected non- metalliferous mineral deposits, Ketchikan and Prince Rupert quadrangles, Alaska: U.S. Geological Survey Open-File Report 78-73B, scale 1:250,000.

Grybeck, Donald, and Nelson, S. W., 1981, Mineral deposits map of the Survey Pass quadrangle, Brooks Range', Alaska: U.S. Geological Survey Miscellaneous Field Studies Map MF-1176F, scale 1:250,000 (in press).

Hudson, Travis, Smith, J. G., and Elliott, R. L., 1979, Petrology, composition, and age of intrusive rocks associated with the Quartz Hill molybdenite deposit, southeastern Alaska: Canadian Journal of Earth Sciences, v. 16, no. 9, p. $1805-1822$.

Le Compte, J. R., 1981, Maps showing interpretation of Landsat imagery of the Survey Pass quadrangle, Brooks Range, Alaska: U.S. Geological Survey Miscellaneous Field Studies Map MF-1176H, 2 sheets, scale 1:250,000 (in press).

Nelson, S. W., and Grybeck, Donald, 1980, Geologic map of the Survey Pass quadrangle, Brooks Range, Alaska: U.S. Geological Survey Miscellaneous Field Studies Map MF1176A, scale 1:250,000.

Raines, G. L., 1978, Porphyry copper exploration model for northern Sonora, Mexico: U.S. Geological Survey Journal of Research, v. 6, no.1, p. 51-58.

Reed, K. M., ed., 1980, The United States Geological Survey in Alaska: 1980 programs: U.S. Geological Survey Circular 823-A, 112p.

Steele, W. C., and Albert, N. R. D., 1978, Interpretation of Landsat imagery of the Talkeetna quadrangle, Alaska: U.S. Geological Survey Miscellaneous Field Studies Map MF-870C, 2 sheets, scale 1:250,000.

Twenhofel, W. S., Robinson, G. D., and Gault, H. R., 1946, Molybdenite investigations in southeastern Alaska: U.S. Geological Survey Bulletin 947-B, p. 7-38.

\section{NORTHERN ALASKA}

National Petroleum Reserve in Alaska-data release

By Robert D. Carter

The Geological Survey in 1979 continued the policy of timely release of data generated by the petroleum assessment program in the National Petroleum Reserve in Alaska (NPRA). The logs and histories of the six wells completed during the 1977-78 drilling season, all the seismic information gathered from 1972 through 1977, and a summary interpretive report on the seismic data were made available to the public through the Environmental Data Service of the National Oceanic and Atmospheric Administration (NOAA), Boulder, Colorado.

During the past year, the Geological Survey has delivered additional material to NOAA for processing and release in 1980. Included are the seismic reflection data gathered in the summer of 1977 and the winter of 1978, an aerial gamma-ray and magnetic survey, a summary geologic report, logs 
and histories of five wells completed in 1979, paleontological data on all completed wells, and four reports pertaining to the Barrow area.

A policy was initiated in May to provide information expeditiously on the test wells currently being drilled in NPRA. Geological Survey NPRA offices in Anchorage and Menlo Park now provide a weekly summary of each of these wells. The drilling depth, status, test and core data, and formation tops are available by telephone and copies of the logs are obtainable locally. These preliminary data, available prior to the more comprehensive NOAA releases, are useful to those involved in evaluating nearby lease sales, to scientists interested in geologic problems in the area, and to all those concerned with arctic problems and North Slope management.

Depositional history of the Nanushuk Group and related strata By C. M. Molenaar

The Nanushuk Group of Albian to Cenomanian (Early and Late Cretaceous) age is a passivemargin deltaic deposit that crops out in the Northern Foothills and is present in much of the subsurface in the western and central Arctic Slope. Most of the previous stratigraphic studies of the Nanushuk group have been based on data obtained from outcrops; however, subsurface data acquired since 1974 have provided an excellent opportunity to study the Nanushuk and related strata in the subsurface. Subsurface data are provided by more than 40 well penetrations (18 since 1975) in and adjacent to National Petroleum Reserve in Alaska (NPRA) and a 10- to 20$\mathrm{km}$ grid of seismic lines over much of. NPRA. By using seismic data and extrapolating stratigraphic data from previous outcrop studies (Chapman and Sable, 1960; Detterman and others, 1963; Chapman and others, 1964; Brosgé and Wittington, 1966; Ahlbrandt and others, 1979; A. C. Huffman, unpub. data), widely spaced wells throughout the area have been correlated with a fair degree of confidence. These correlations and the integration of outcrop and subsurface data enable the interpretations of the basin geometry and depositional history of the Nanushuk Group and related strata that are summarized below.

The Nanushuk Group is at least 3,444 m thick in outcrops at Corwin Bluff (Smiley, 1969) along the Chukchi Sea on the west to a pinchout edge in the area of the present Colville delta on the east side of NPRA (fig. 3). The lower part of the Nanushuk consists of a thick sequence of intertonguing shallow marine sandstone and neritic shale and siltstone that grades seaward into the Torok For. mation (Early Cretaceous), which consists of prodelta shale and siltstone with some deep-water sandstone or turbidites. The upper part of the Nanushuk consists of a dominantly nonmarine facies of paludal shale, coal, and fluvial sandstone that grades seaward into the marine facies. Figure 3 shows the stratigraphic relations of these facies and formations in the eastern part of NPRA.

On seismic sections, the Nanushuk Group is represented by topset reflectors (alluvial-delta plain and marine shelf) that can be traced seaward to foreset (basin slope) and bottomset (basin floor) reflectors of the Torok Formation (fig. 4) (Bird and Andrews, 1979). Thus parts of the Nanushuk and the Torok are coeval over most of the area (figs. 3 and 4 ). The directions of depositional dip of the foreset bedding and the Nanushuk facies patterns indicate that Nanushuk and Torok units prograded across the Colville basin toward the east-northeast (Bird and Andrews, 1979). This progradation suggests a major source to the southwest in the present Chukchi Sea area. Another source area in the ancestral Brooks Range to the south is indicated by surface studies southeast of NPRA (Ahlbrandt and others, 1979). This southern-source delta (called the Umiat delta) did not control the direction of progradation except along the south side of the basin. I interpret this limited northward progradation to be the result of greater subsidence and deeper water on the south side of the basin and dominance of the western delta complex (the Corwin delta). However, sand from the Umiat delta is further interpreted as having contributed to the east-northeasterly prograding system, probably by longshore drift, when the wide prodelta shelf of the easterly prograding delta was juxtaposed with the southern delta.

In prograding east-northeastward across the basin, the base of the Nanushuk rises stratigraphically in response to basin subsidence and (or) sea level rise. Between the Tunalik well on the west side of NPRA to the Atigaru Point well on the east, a distance of $350 \mathrm{~km}$, the total incremental stratigraphic rise is about $2,100 \mathrm{~m}$. The basin slope angle, as indicated by the foreset beds and calculated with respect to topset (shelf) beds, ranges from less than $2^{\circ}$ in the west to as much as $6^{\circ}$ in the eastern part of NPRA. Allowing for compaction, the original slope angle was 
slightly steeper than these figures indicate. Calculations of the relief between topset and bottomset (basinal) beds, which are approximations of water depths in the basin less post-topset compaction, indicate depths ranging from 450 to 900 $\mathrm{m}$. Furthermore, in the progradational process, the western delta constructed a prodelta shelf between 75 and $150 \mathrm{~km}$ wide. The shelf break is abrupt, as indicated on seismic lines (fig. 4), and rises stratigraphically in response to sea level rise (or basin subsidence) as it progrades eastnortheastward across the basin.

Bottomset beds of the Torok Formation downlap onto or near the pebble shale unit, a distinctive basal Cretaceous (Neocomian) transgressive unit in northern NPRA. Inasmuch as these bottomset beds can be traced seismically to correlate with Nanushuk beds to the west, the thin interval of Torok between the bottomset beds and the pebble shale unit is a condensed or nondepositional zone representing part of Neocomian, all of Aptian, and part of Albian time (fig. 3 ). This starved depositional system is interpreted as reflecting the period when the deeper part of the Colville basin to the south received all the sediment being derived from the south and southwest after deposition of the pebble shale unit. Not until the latest stages of the Nanushuk-Torok depositional cycle did the Colville basin fill enough for sediment to reach the northern part of NPRA.

The same progradational, downlapping depositional pattern continues in younger strata to the east and northeast of NPRA. Turonian-age shales of the Colville Group, which overlie the Nanushuk in the eastern part of NPRA, lap down onto or near the pebble shale unit in the Prudhoe Bay area $100 \mathrm{~km}$ to the east (Bird and Andrews, 1979, p. 35 ).

\section{REFERENCES CITED}

Ahlbrandt, T. S., Huffman, A. C., Fox, J. E., and Pasternack, Ira, 1979, Depositional framework and reservoir quality studies of selected Nanushuk Group outcrops, North Slope, Alaska, in Ahlbrandt, T. S., ed., Preliminary geologic, petrologic, and paleontologic results of the study of Nanushuk Group rocks, North Slope,

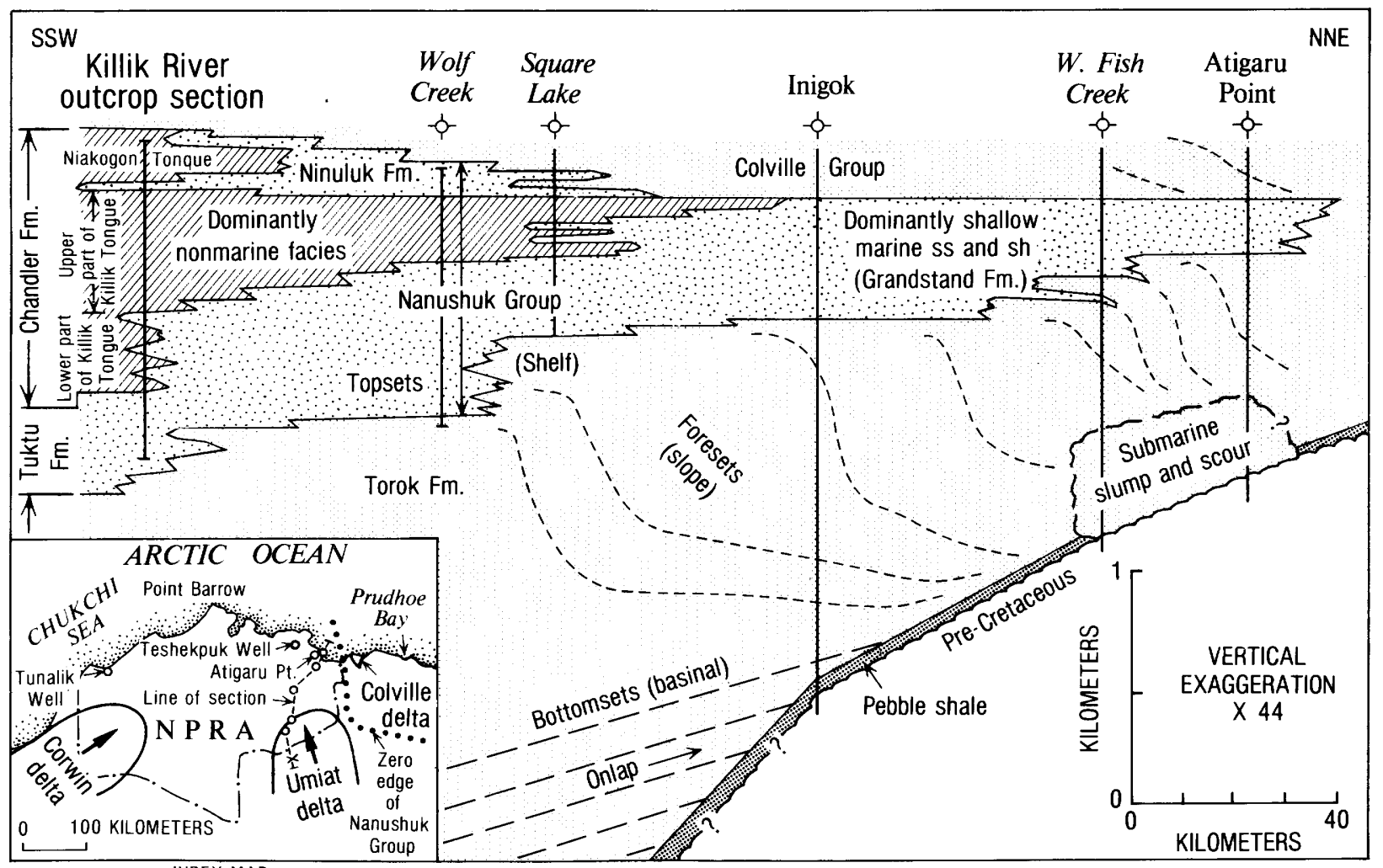

INDEX MAP

FIGURE 3.-Stratigraphic cross section of the Nanushuk Group and related strata across eastern part of NPRA. Section is oriented to show both east-northeasterly deltaic progradation and southward thickening of the Torok Formation. Dashed lines in Torok are time lines based on seismic reflectors. 
Alaska: U.S. Geological Survey Circular 794, p. 14-31.

Bird, K. J., and Andrews, Jack, 1979, Subsurface studies of the Nanushuk Group, North Slope, Alaska, in Ahlbrandt, T. S., ed., Preliminary geologic, petrologic, and paleontologic results of the study of Nanushuk Group rocks, North Slope, Alaska: U.S. Geological Survey Circular 794, p. 32-41.

Brosgé, W. P., and Whittington, C. L., 1966, Geology of the Umiat-Maybe Creek region, Alaska: Geological Survey Professional Paper 303-H, p. 501-638

Chapman, R. M., Detterman, R. L., and Mangus, M. D., 1964, Geology of the Killik-Etivluk Rivers region, Alaska: U.S. Geological Survey Professional Paper 303-F, p. 325-407.

Chapman, R. M., and Sable, E. G., 1960, Geology of the Utukok-Corwin region, northwestern Alaska: U.S. Geological Survey Professional Paper 303-C, p. 47-174.

Detterman, R. L., Bickel, R. S., and Gryc, George, 1963, Geology of the Chandler River region, Alaska: U.S. Geological Survey Professional Paper 303-E, p. 223-324.
Smiley, C. J., 1969, Floral zones and correlations of Cretaceous Kukpowruk and Corwin Formations, northwestern Alaska: American Association of Petroleum Geologists Bulletin, v. 53, no. 10, p. 2079-2093.

Compositional variation in sandstones of the Nanushuk Group, Arctic North Slope

By Susan Bartsch-Winkler and A. C. Huffman

The Nanushuk Group, of Albian to Cenomanian (Early and Late Cretaceous) age, is a transitional unit containing deltaic, interdeltaic, and shallow marine sequences that crop out in the western and central foothills belt of the Arctic North Slope. Sandstones collected from eight measured

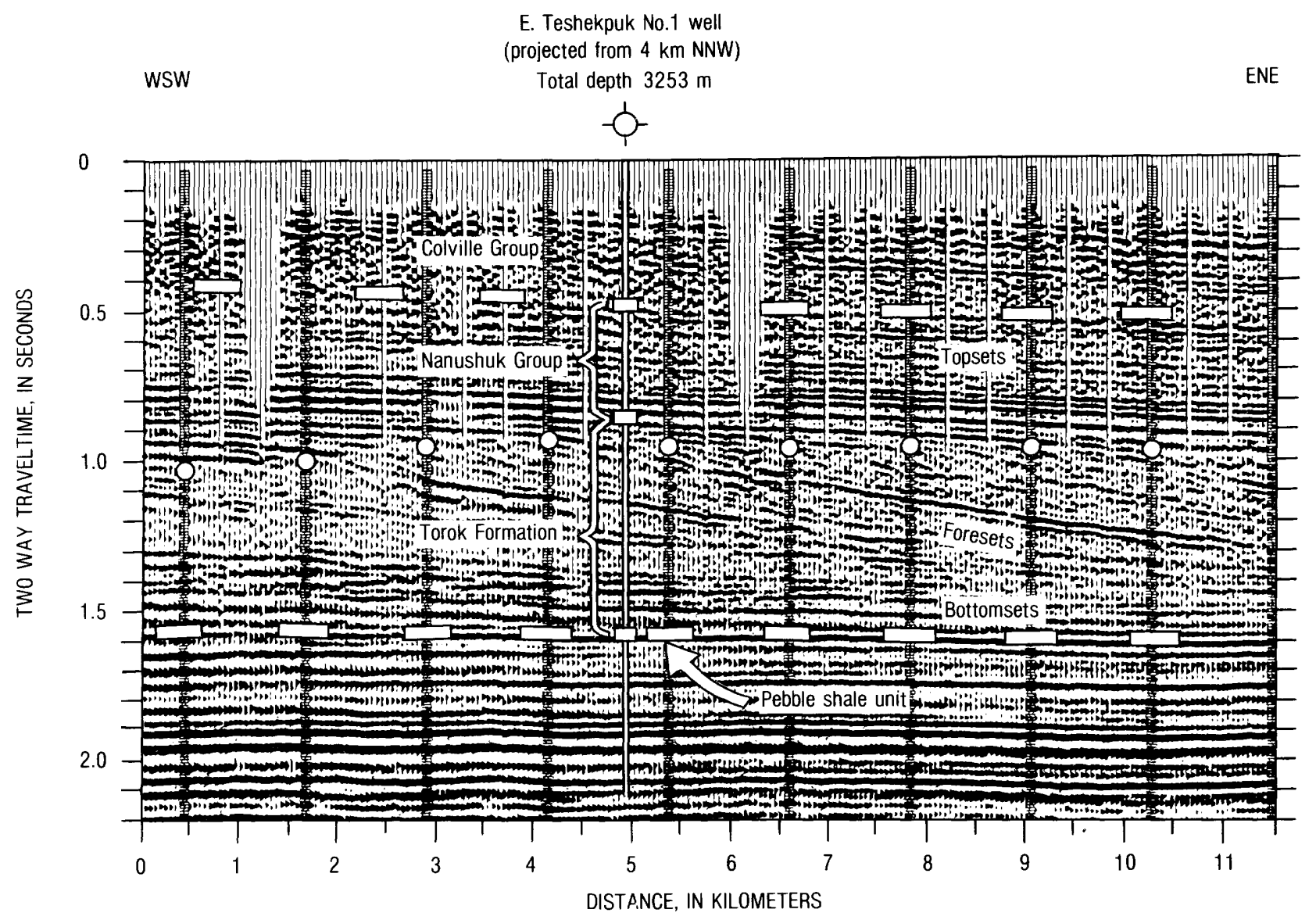

FIGURE 4.-Seismic section in northeastern NPRA showing relations of topset bedding of the Nanushuk Group and uppermost part of the Torok Formation, foreset bedding of the Torok, and bottomset bedding of the lower part of the Torok. Upper dashed line is contact of the Colville and Nanushuk Groups, lower dashed line is contact of the Torok Formation and pebble shale, and dots represent position of shelf break. Note stratigraphic rise of shelf break from west to east. See figure 3 for location of Teshekpuk well. 
sections (fig. 5) in the Nanushuk Group were examined for compositional differences in order to verify and expand previous preliminary petrographic observations (Bartsch-Winkler, 1979, unpub. data; Huffman, 1979). Results of the 139 modal analyses discussed here are shown in figure 6 . The entire suite of sandstones is classified as litharenite and feldspathic litharenite when plotted on a Q-L-F ternary diagram (Folk, and others 1970 ) (fig. $6 A$ ).

Two depositional lobes (western and eastern) can be distinguished by variations in the lithic component of the sandstone modal analyses (fig. $6 B)$. This conclusion is supported by facies analyses (Ahlbrandt, 1979; Huffman, unpub. data) as well as paleontologic data (Fred May, oral commun., 1979). Sandstones from the Barbara syncline, Corwin Bluff, Tupikchak Mountain, and Carbon Creek sections in the western lobe show a greater proportion of sedimentary lithic component, especially calcareous and argillaceous/carbonaceous grains, and thus are sedimentary litharenites, according to Folk, Andrews, and Lewis (1970). In contrast, sandstones from the Tuktu Bluff, Kurupa anticline, Arc Mountain, and Marmot syncline sections in the eastern lobe contain more volcanic lithic grains (particularly quartzite and foliated quartz-mica) and metamorphic lithic grains. These sandstones are predominantly phyllarenite, although some samples may be categorized as sedimentary litharenite and volcanic litharenite.

Sources for the sandstones of the Nanushuk Group must have differed for the two lobes. The greater amounts of calcareous and argillaceous material found in the western lobe were derived predominantly from the Lisburne Group, the Shublik Formation, and the Siksikpuk Formation (Huffman, 1979; Bartsch-Winkler, 1979). Material found in the eastern lobe probably was shed from the Endicott Group, consisting of the Upper Devonian Hunt Fork Shale and Kanayut Conglomerate and the Lower Mississippian Kayak Shale. The greater proportion of quartzose and metamorphic lithic debris in the eastern lobe was derived from the Endicott Group (BartschWinkler, unpub. data).

\section{REFERENCES CITED}

Ahlbrandt, T. S., ed., 1979, Preliminary geologic, petrologic, and paleontologic results of the study of Nanushuk Group rocks, North Slope, Alaska: U.S. Geological Survey Circular $794,163 \mathrm{p}$.

Bartsch-Winkler, Susan, 1979, Textural and mineralogical study of some surface and subsurface sand-

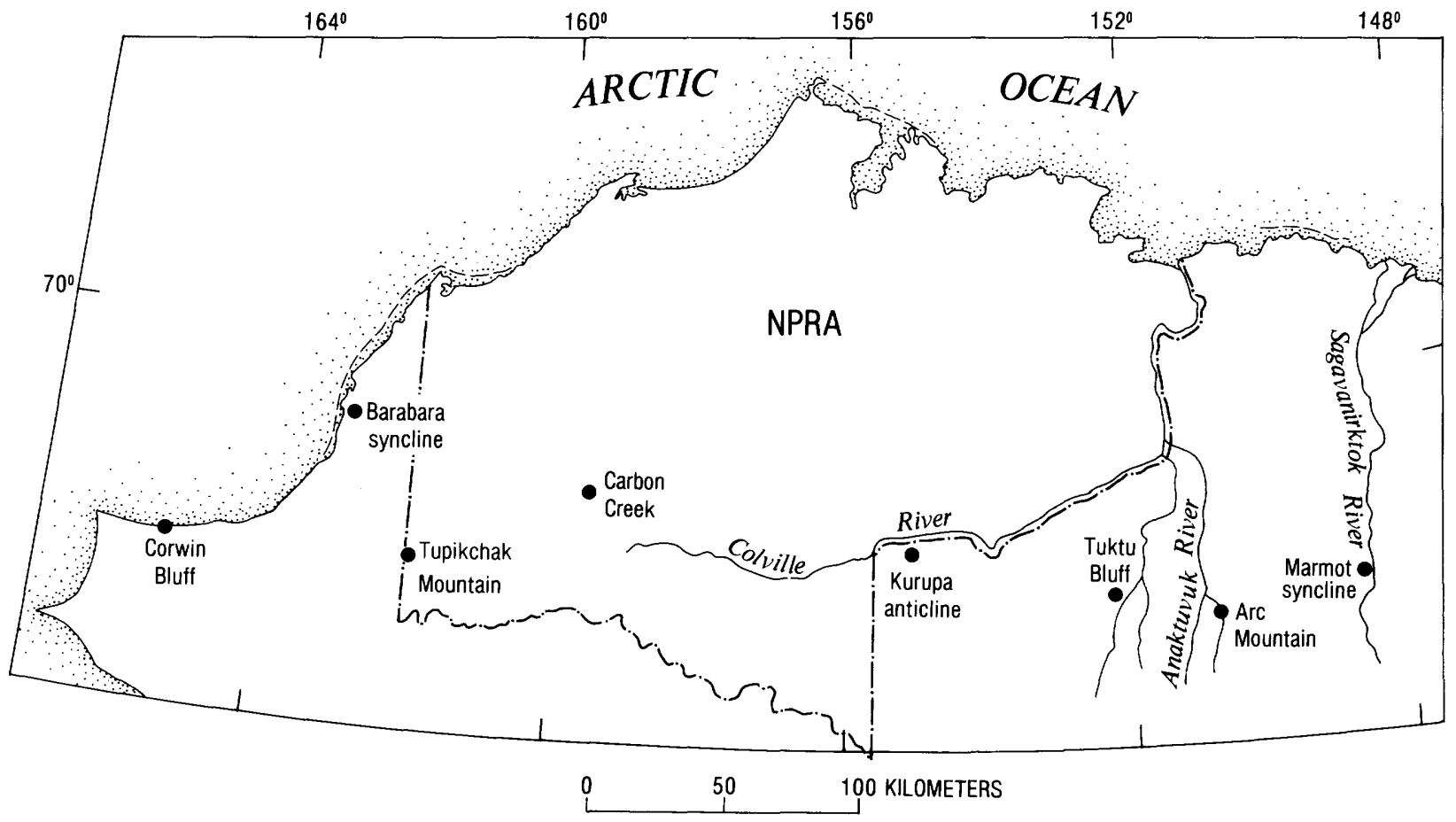

FIGURE 5.-Location of measured sections in the Nanushuk Group, Arctic North Slope. 
stones from the Nanushuk Group, western North Slope, Alaska, in Ahlbrandt, T. S., ed., Preliminary geologic, petrologic, and paleontologic results of the study of the Nanushuk Group rocks, North Slope, Alaska:
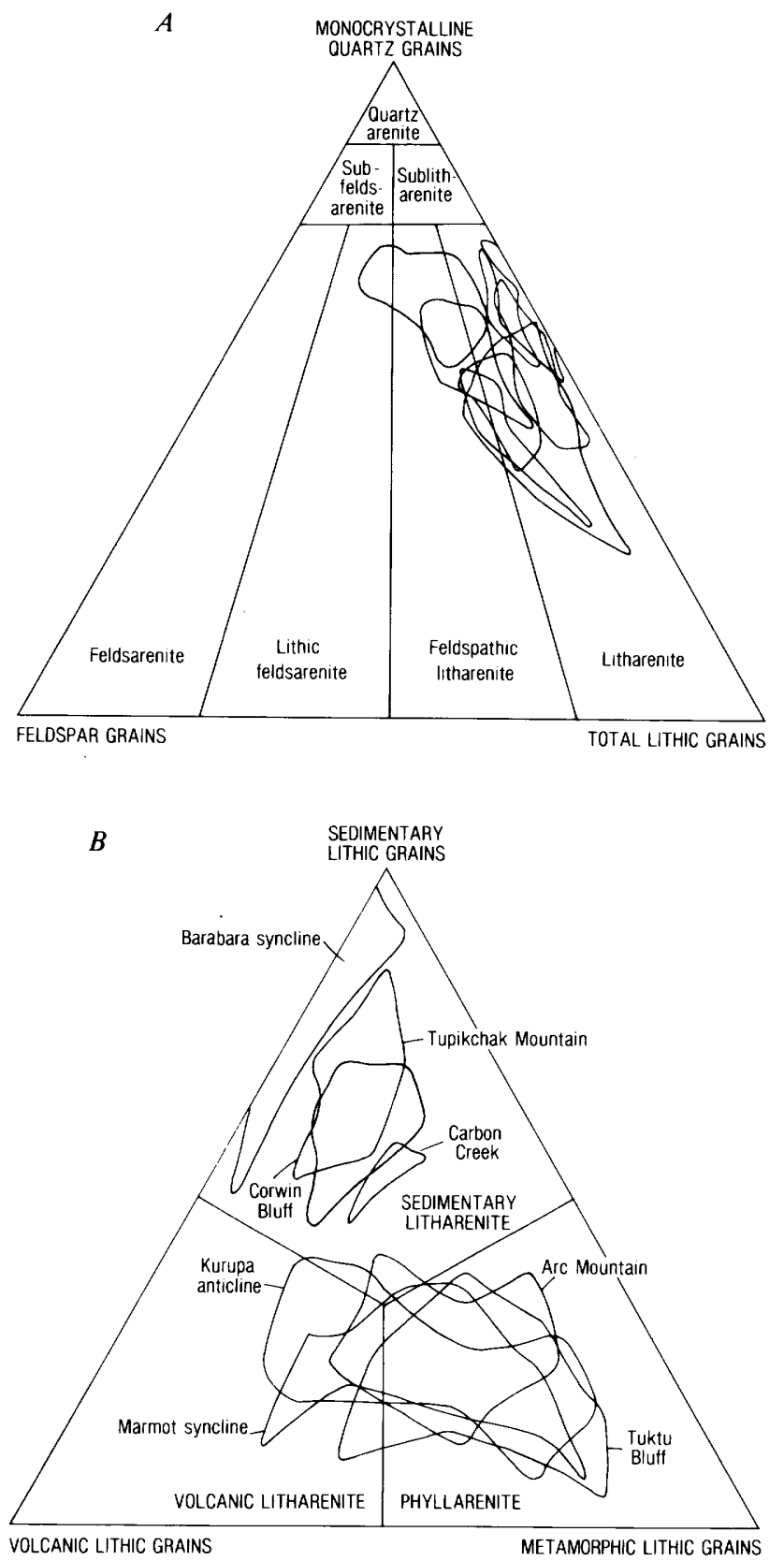

Figure 6.-Modal analyses of sandstones of the Nanushuk Group. A, Ternary plot with monocrystalline quartz, feldspar, and lithic end-members shows that the sandstone is predominantly litharenite and feldspathic litharenite (Folk and others, 1970). B, Ternary plot with lithic endmembers indicates that the sandstone may be divided into two units; a western sedimentary litharenite unit, and an eastern phyllarenite unit.
U.S. Geological Survey Circular 794, p. 61-76.

Folk, R. L., Andrews, P. B., and Lewis, D. W., 1970, Detrital sedimentary rock classification and nomencalture for use in New Zealand: New Zealand Journal of Geology and Geophysics, v. 13, no. 4, p. 937-968.

Huffman, A. C., Jr., 1979, Stratigraphy and petrography of a measured section on the south limb of Barbara syncline, North Slope, Alaska, in Ahlbrandt, T. S., ed., Preliminary geologic, petrologic, and paleontologic results of the study of the Nanushuk Group rocks, North Slope, Alaska: U.S. Geological Survey Circular 794, p. 77-88.

Minimum age of beach deposits north of Teshekpuk Lake, Alaskan Arctic Coastal Plain

By L. David Carter and Stephen W. Robinson

Radiocarbon dating of organic materials within and overlying beach deposits exposed in bluffs along the north side of Teshekpuk Lake (fig. 7) indicate that the beach deposits were formed more than 51,000 years ago. These are the youngest beach deposits identifiable between Teshekpuk Lake and the modern coast. They are overlain by deposits that are interpreted here as deltaic in origin and that are either approximately the same age as the beach deposits or are considerably younger and represent a separate transgressive event.

Bluffs along the north side of Teshekpuk Lake are as much as $12 \mathrm{~m}$ high and, from the base upward, typically consist of 0.3 to $2.5 \mathrm{~m}$ of clay (unit 1), 3.5 to $6.0 \mathrm{~m}$ of sand and pods of gravelly sand (unit 2), $3.5 \mathrm{~m}$ of silty very fine sand to

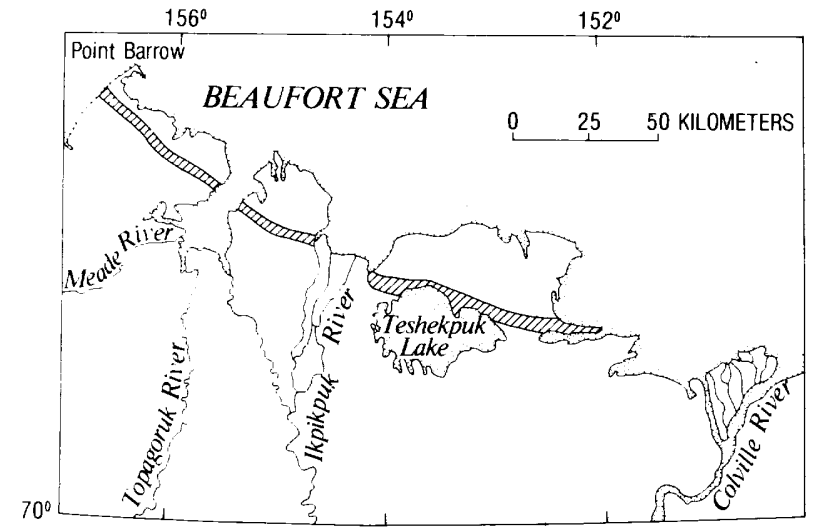

FIGURE 7.-Regional distribution of beach deposits (patterned) exposed at Teshekpuk Lake. 
sandy silt ( unit 3 ), and 1 to $2 \mathrm{~m}$ of peat. The clay (unit 1) is massive, dark gray, and plastic. The sand and gravelly sand of unit 2 are fossiliferous and distinctly crossbedded and commonly contain highly abraided detrital wood. some of the driftwood is as much as $25 \mathrm{~cm}$ in diameter. Unit 3 is generally massive in appearance but in places contains a few pebble lenses from 5 to $10 \mathrm{~cm}$ thick. A $3-$ to $8 \cdot \mathrm{cm}$-thick horizon containing macerated fine- to medium-grained detrital peat commonly occurs at the base of unit 3 , and similar horizons are present in the lower $2 \mathrm{~m}$. The upper $1 \mathrm{~m}$ of the unit contains lumps of peat presumably incorporated by thaw lake activity.

Units 1 and 2 are identifiable as marine deposits because they contain abundant marine foraminifers and ostracodes. Unit 2 also contains the shells of marine mollusks and some sea mammal remains. the molluscan assemblage indicates a nearshore environment.

Unit 3 lacks marine megafossils and driftwood. In samples examined for microfossils, foraminifers, marine and nonmarine ostracodes, seeds, plant fragments, insect parts, and Daphnia ephippia were found. On the basis of the presence of both marine and nonmarine fossils and its finegrained texture, unit 3 is interpreted as a deltaic facies.

The pods of gravelly sand of unit 2 at Teshekpuk Lake can be traced eastward to Harrison Bay and westward to near Barrow (fig. 7; Williams and others, 1978). The linear distribution of the gravelly sand, together with the driftwood and shallow water molluscan fauna, demonstrates that unit 2 is a beach deposit. The base of unit 2 at Teshekpuk lake ranges from 1.8 to $4.0 \mathrm{~m}$ above sea level, and the top is as high as $8 \mathrm{~m}$.

A driftwood log collected from the beach deposits has been radiocarbon dated as greater than 44,000 years old (USGS-360). Furthermore, detrital peat from the base of the overlying deltaic deposits yielded a radiocarbon date of $>51,000$ years (USGS-676). Therefore, the beach deposits are more than 51,000 years old.

Sediments north of these beach deposits are predominantly marine mud, and marine and alluvial sand occurs to the south. The beach and deltaic deposits at Teshekpuk Lake and the marine mud to the north may be equivalent in age and may constitute the youngest marine deposits on this part of the coastal plain. However, Sellmann and Brown (1973) proposed that the youngest of the marine transgressions of the Arctic Coastal
Plain occurred during middle Wisconsinan time and extended to a few kilometers south of Teshekpuk Lake. Their age estimate is based on radiocarbon dates of organic materials in marine deposits near Barrow that range from $25,300 \pm 2,300(\mathrm{I}-1384)$ to $>44,000(\mathrm{~W}-2676)$. If the deltaic deposits of unit 3 prove to be considerably younger than the beach deposits, then unit 3 may represent the transgression proposed by Sellmann and Brown (1973).

\section{REFFRENCES CITED}

Sellmann, P. V., and Brown, Jerry, 1973, Stratigraphy and diagenesis of perennially frozen sediments in the Barrow, Alaska region, in North American Contribution to the 2nd International Permafrost Conference, Yakutsk: Washington, National Academy of Science, p. 171-181.

Williams, J. R., Carter, L. D., and Yeend, W. E., 1978, Coastal plain deposits of NPRA, in Johnson, K. M., ed., United States Geological Survey in Alaska: Accomplishments during 1977: U.S. Geological Survey Circular 772-B, p. B2022 .

Paleoenvironments during deposition of a section of the Gubik Formation exposed along the lower Colville River, North Slope By R. E. Nelson

Palynological investigations have been completed for a section of the Gubik formation ex. posed along the Colville River near Ocean Point (fig. 8), $2.3 \mathrm{~km}$ upstream from the Big Bend bench mark in the Harrison Bay $\mathrm{A}-3$ quadrangle. The age and fauna of these strata are discussed by Carter and others (1977). This report presents the interpretations of regional paleoenvironments based on pollen analysis of the sedimentary deposits. Details of the study, including pollen dia-

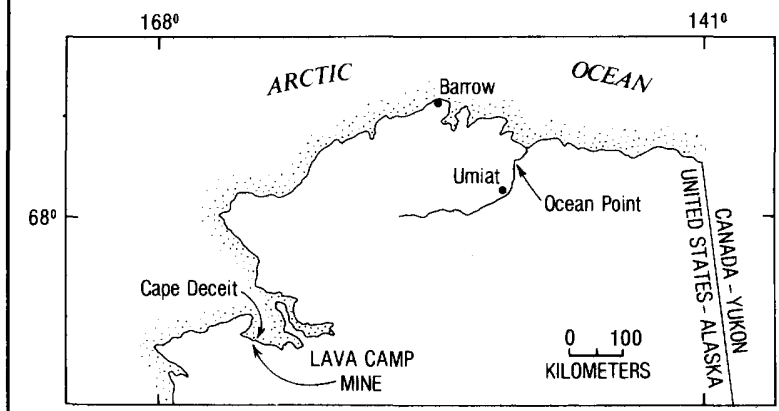

Figure 8.-North Slope fossil localities mentioned in this report. 
grams, have been reported elsewhere (Nelson, 1979).

The Gubik Formation at the Ocean Point locality consists of $16 \mathrm{~m}$ of marine and nonmarine sediments that unconformably overlie strata of considerably greater age (fig. 9). Although fissiontrack dating of an ash within these older beds indicated an age of Eocene (Carter and others, 1977), recent work on pollen floras indicates an age of Maestrichtian to Danian (J.A. Wolfe, oral commun., 1979). These strata are labeled "Danian" in figure 9.

Pollen from the marine strata of the Gubik at this locality indicate that a forest dominated by spruce and tree birch occupied the North Slope during deposition of the sediments. Hardwoods and hemlocks were not present in the forest, and pines and true firs were rare. The overall environment suggested by the pollen analysis is one similar to that of present-day Anchorage.

On the basis of the present knowledge of the evolution of the Alaskan flora (Péwé, 1975), the flora in the marine strata is almost certainly considerably older than the early Pleistocene flora at Cape Deceit (Matthews, 1974; fig. 8), where

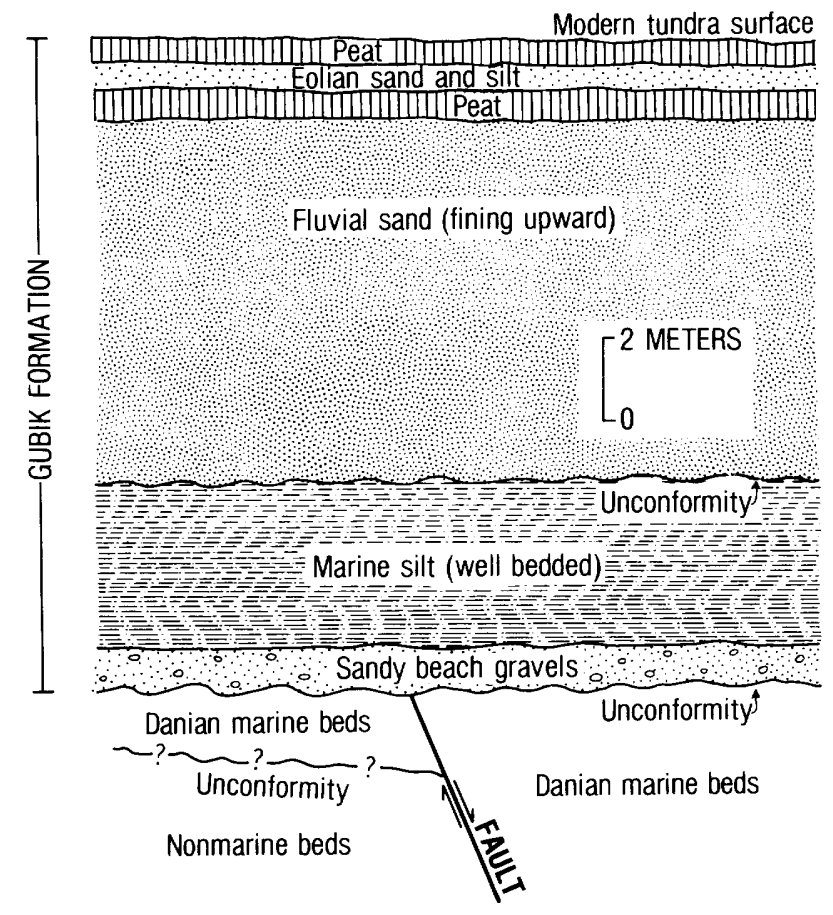

FIGURE 9.-Stratigraphy of the Gubik Formation exposed near Ocean Point. (Modified from an unpublished diagram by L. D. Carter.) tundra was recorded, but not as old as the 5.7m.y. Lava Camp flora of Seward Peninsula (Hopkins and others, 1971; fig. 8). The Lava Camp flora, consisting of pollen and plant macrofossils, indicates a rich coniferous forest including at least 10 species of conifers. The Gubik marine pollen record at the Ocean Point site agrees well with Repenning's suggested age of 2-3 m.y. for this unit on the basis of sea otter remains (Carter and others, 1977, p. B13).

Comparison of the present-day climatic environment of the North Slope with that of modern Anchorage suggests that mean annual temperature has decreased about $12^{\circ} \mathrm{C}$, and mean July temperatures $3^{\circ}-5^{\circ} \mathrm{C}$, between the late Pliocene and the present day. Precipitation probably has also decreased, perhaps by as much as 50 percent. Similarities between the climate of modern Anchorage and the inferred climate of the North Slope during deposition of the marine beds suggest that the Arctic Ocean was largely free of ice in the late Pliocene, and permafrost, if present, was discontinuous and probably limited to north-facing slopes.

Pollen spectra from fluvial strata overlying the marine beds indicate tundra conditions that were, for the most part, harsher than those of the present day at inland North Slope sites. Woody taxa were rare during deposition of the fluvial beds, and the overall character of the North Slope vegetation was probably similar to that of the Barrow area today. An increase in alder and birch pollen percentages in midsection to values higher than those of the present Ocean Point environment may represent an interstadial or interglacial warming. The bulk of these sediments, however, appear to have been deposited during a time of glaciation in the Brooks Range to the south.

The strongly glacial character of the pollen spectra from the nonmarine beds suggests that the unconformity between the marine and nonmarine strata of the Gubik Formation may represent a considerable hiatus (fig. 9). It is impossible to assign an age to these strata on the basis of the pollen, since pollen spectra from any glacial period are much like those from any other glacial period in the same region. On the basis of the pollen analysis and unpublished field studies by L. D. Carter, it seems most likely that these beds are of early or middle Pleistocene age.

The nearest locality to Ocean Point where modern climatic records are available is Umiat. Comparing this record to the one for Barrow suggests 
that early or middle Pleistocene glacial temperatures may have been as much as $6^{\circ} \cdot 8^{\circ} \mathrm{C}$ cooler in July than they are today. Mean annual temperatures may have been comparably depressed, although this cannot be determined by the pollen studies. Relative abundances of the pollen of grasses, sage, and chenopods are greater in the fluvial strata than in modern Colville River sediment and suggest that the paleoenvironment during the deposition of these beds was more arid than that of the present day.

\section{REFERENCES CITED}

Carter, L. D., Repenning, C. A., Marincovich, L. N., Hazel, J. E., Hopkins, D. M., McDougall, Kristin, and Naeser, C. W., 1977: Gubik and pre-Gubik Cenozoic deposits along the Colville River near Ocean Point, North Slope, Alaska, in Blean, K. M., ed., The United States Geological Survey in Alaska: Accomplishments during 1976: U.S. Geological Survey Circular $751-\mathrm{B}$, p. B12-B14.

Hopkins, D. M., Matthews, J. V., Wolfe, J. A., and Silberman, M. L., 1971, A Pliocene flora and insect fauna from the Bering Strait region: Paleogeography, Paleoclimatology, Paleoecology, v. 9, p. 211-231.

Matthews, J. V., Jr., 1974, Quaternary environments at Cape Deceit (Seward Peninsula, Alaska): evolution of a tundra ecosystem: Geological Society of America Bulletin, v. 85, p. 1353-1384.

Nelson, R. E., 1979, Quaternary environments of the Arctic Slope of Alaska: Seattle, University of Washington, M. S. thesis, $141 \mathrm{p}$.

Péwé, T. L., 1975, Quaternary geology of Alaska: U.S. Geological Survey Professional Paper 835, 145 p.

New stratigraphic assignment for rocks along Igilatvik (Sabbath) Creek, William O. Douglas Arctic Wildlife Range, Alaska

By Robert L. Detterman and Robert A. Spicer ${ }^{1}$

New age data have been obtained over the past few years on a 3,322-m-thick section of nonmarine clastic rocks exposed for $9 \mathrm{~km}$ along Sabbath Creek, a tributary of the Jago River, in the northern part of the William O. Douglas Arctic Wildlife Range (fig. 10). These rocks in the Arctic Coastal Plain have an important bearing on the petroleum potential not only of the William $O$. Douglas Arctic Wildlife Range, but also of the offshore Beaufort Sea area.

\footnotetext{
${ }^{1}$ Imperial college, London, England.
}

The rocks in the Sabbath Creek section, first measured in 1971, were assigned by Detterman and others (1975) to the Bathtub Graywacke and Nanushuk Group. At that time no definitive fossil data were obtained. The rocks are barren of megafaunal remains but contain abundant plant scraps. These fossils were not identifiable, however, and results of the analyses of numerous samples for pollen were inconclusive. Lithologically, the rocks seemed to be more closely related to the Lower Cretaceous Bathtub Graywacke and Lower and Upper Cretaceous Nanushuk Group than to the Upper Cretaceous and Tertiary rocks of northern Alaska because they lack pyroclastic material either as discrete beds or as matrix and detrital components. All previously known Upper Cretaceous and Tertiary sequences in Northern Alaska, some of which are exposed within $15 \mathrm{~km}$ of the Sabbath Creek section, contain pyroclastic material.

In 1978 an intensive search was made for identifiable fossil material in beds known to contain abundant plant debris. Three collections of broad-leaf plant fossils (dicotyledon angiosperms) and one of swamp-type vegetation were obtained. The broad-leaf dicotyledon angiosperms are important age indicators as they are unknown before the Late Cretaceous in Alaska and, consequently, place a lower age limit on the section. Although the identification of the fossils is incomplete, preliminary data suggest that the plants are of late Late Cretaceous or early Tertiary age.

The presence of these fossils in the rocks exposed along Sabbath Creek precludes their correlation with the Bathtub Graywacke and Nanushuk

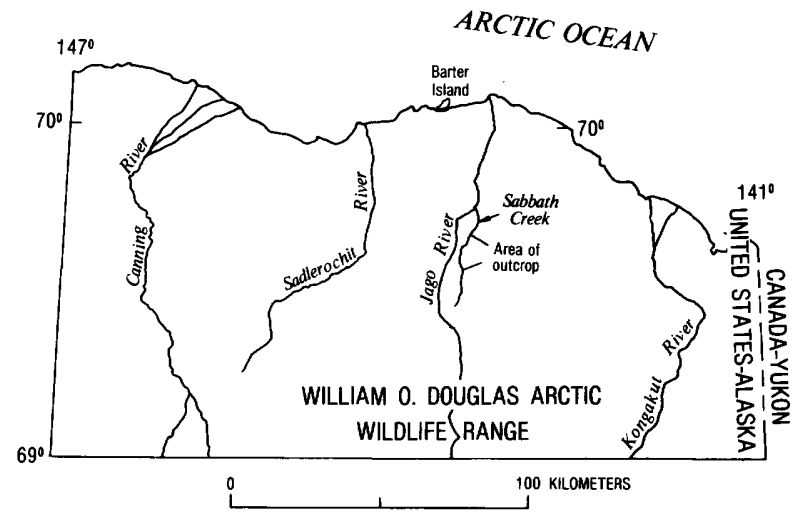

FiguRE 10.-Location of Sabbath Creek section in William O. Douglas Arctic Wildlife Range. 
Group (Detterman and others, 1975, figs. 9 and 11). Because one fossil collection came from the base of the exposed section, one from the top, and the other two from the upper middle, the entire section is younger than originally thought. On the basis of these discoveries, Reiser and others $(1978,1980)$ assigned the Sabbath Creek rocks to the Upper Cretaceous and Tertiary sequences of northern Alaska.

The age and lithologic correlation of the Sabbath Creek section have important implications for the petroleum potential of the northern William O. Douglas Arctic Wildlife Range and Beaufort Sea. This 3,322-m-thick sequence is dissimilar from known Upper Cretaceous or lower Tertiary rocks farther west in northern Alaska in that it lacks pyroclastic material and thick coal beds, even though Upper Cretaceous sedimentary rocks typical of western northern Alaska are exposed nearby. This evidence suggests that the Sabbath Creek section belongs to a different depositional basin. The Sabbath Creek section appears to be genetically similar to and is correlated with the Moose Channel Formation-a thick, mainly nonmarine fluvial sequence exposed in the Northwest Territories and found in boreholes on the MacKenzie Delta, Canada (Young, 1971, 1972; Holmes and Oliver, 1973). The Sabbath Creek section therefore may represent a westward extension of the large basin that had a depocenter in the MacKenzie Delta area rather than an eastward extension of the basin to the west that includes Prudhoe Bay. The contact of the Sabbath Creek section with underlying rocks is not exposed, but a major unconformity that would account for the more than $3,000-\mathrm{m}$ thickness of the section may be present. Whether this unconformity would cut underlying source beds of the Lower Cretaceous is not known. Samples collected from outcrops of the Sabbath Creek section have a thermal alteration index in the hydrocarbon producing range (Palmer and others, 1979). In the MacKenzie Delta area, these rocks produce mainly gas.

\section{REFERENCES CITED}

Detterman, R. L., Reiser, H. N., Brosgé, W. P., and Dutro, J. T., Jr., 1975, Post-Carboniferous stratigraphy, northeastern Alaska: U.S. Geological Survey Professional Paper 886,46 p.

Holmes, D. W., and Oliver, T. A., 1973, Source and depositional environments of the Moose Channel Formation, Northwest Territories: Bulletin of Canadian Petroleum Geology, v. 21, no. 4, p. 435-478.
Palmer, I. F., Bolm, J. G., Maxey, L. R., and Lyle, W. M., 1979, Petroleum source rock and reservoir quality data from outcrop samples, onshore North Slope of Alaska east of Prudhoe Bay: U.S. Geological Survey Open-File Report $79-1634,52 \mathrm{p}$.

Reiser, H. N., Brosgé, W. P., Detterman, R. L., and Dutro, J. T., Jr., 1978, Geologic map of the Demarcation Point quadrangle, Alaska: U.S. Geological Survey Open-File Report 78-526, scale 1:200,000.

- 1980, Geologic map of the Demarcation Point quadrangle, Alaska: U.S. Geological Survey Miscellaneous Investigations map I-1133, scale 1:250,000.

Young, F. G., 1971, Mesozoic stratigraphic studies, northern Yukon Territory and northwestern district of MacKenzie: Geological Survey of Canada Paper 71-1, Part A, p. 245247.

— 1972, Cretaceous stratigraphy between Blow and Fish Rivers, Yukon Territory: Geological Survey of Canada Paper 72-1, Part A, p. 229-235.

Further notes on the ground-water supply beneath Selin Creek near Cape Lisburne, northwestern Alaska

By Alvin J. Feulner and John R. Williams

Selin Creek is a short intermittent stream flowing northward to the Chukchi Sea $4 \mathrm{~km}$ east of Cape Lisburne in northwestern Alaska. It lies within the zone of thick, continuous permafrost in which ground-water supplies have been difficult to develop. A water supply has been obtained from the formerly frozen alluvial gravel beneath the incised creek bed by methods that have effectively simulated the cold-water thaw techniques used to prepare frozen placer deposits for mining. These methods include: removal of the tundra vegetation and the upper part of the alluvium to allow warming of the gravel in summer; construction of an upstream reservoir from which warmed water recharges the alluvium in summer; use of snow fences to retard seasonal frost penetration and to provide early recharge; and installation of galleries downvalley to collect the water. These methods for developing the alluvial aquifer have been described in detail by Feulner and Williams (1967), and the use of galleries in permafrost regions has been discussed by Feulner (1964).

In 1951 a 24-m-long lateral gallery was placed at the base of shallow unfrozen gravel beneath the creek, but it yielded water for only a few weeks following cessation of streamflow in the fall seasons of 1951 and 1952. In 1953 a reservoir was constructed about $210 \mathrm{~m}$ upstream from the gallery; stored water was available in summer, but it leaked so rapidly through the permeable 
gravel beneath the reservoir that, despite efforts to seal the bottom, no water was available for winter use. Storage tanks were then constructed, to be filled from the creek in summer. Snowmelting equipment was used to augment storage but was found to be both unsatisfactory and uneconomical. Between 1951 and 1955 the tundra vegetation cover and surface gravel were stripped from the stream valley to provide material for road construction. In 1955 a $60-\mathrm{m}$ well was drilled in frozen alluvium and bedrock but provided no water. A test drilling program in 1960 indicated that the permafrost table in the alluvium between the reservoir and the roadway crossing the stream had been lowered to a depth as great as $4.8 \mathrm{~m}$ and that a potential aquifer had formed between the lower limit of seasonal frost and the receding permafrost table, apparently as a result of the stripping of gravel and the downvalley percolation of water warmed in the reservoir. Clearing the roadway of snow during winter and the presence of a lens of clay within the alluvium apparently retarded seaward movement of ground-water below the road.

In 1961 a new gallery was constructed just above ( south of) the road where the thickness of thawed alluvium was greatest. This gallery was used to supplement water from the storage tanks and was normally not pumped after January. In 1963 and again in 1965, however, as much as 996,000 liters of water was pumped from the gallery between February and May. The gallery was not used during late winter from 1965 to 1970 . In 1970 the gallery dried in January, and each succeeding year brought an earlier drying of the gallery until in 1975 it was dry by mid-November. Studies made in 1975 to rehabilitate the ground-water supply included seismic and resistivity measurements by the U.S. Geological Survey to determine the depth to which permafrost had receded. By that time the permafrost table had receded to $27.5 \mathrm{~m}$ at the site of the 1961 gallery and to more than $6 \mathrm{~m}$ at the site of the 1953 reservoir. Downstream from (north of ) the roadway, near the 1961 gallery, the depth to the top of permafrost was only about 3 $\mathrm{m}$. On the basis of these studies, a well was drilled near the 1961 gallery in 1976, reaching impermeable shale at a depth of $12 \mathrm{~m}$. Seasonal frost at the site of the well extended to a depth of $5.1 \mathrm{~m}$, and fluid ground water was present from 5.1 to $12 \mathrm{~m}$. The well was screened from 8.5 to $11.5 \mathrm{~m}$, and about 1,514,000 liters of water was pumped from the well at a rate of 57 liters per minute to meet immediate needs during late March and early April of 1976. This well, like the 1961 gallery, is intended to provide water through the mid-winter months and to supplement water drawn from tank storage during late winter. The availability of water during these critical months depends upon the maintenance of a high permafrost table north of the road and on the depth to which seasonal frost can penetrate to complete a barrier to the movement of water from the aquifer to the sea. Water available to the well is estimated to be limited, and because of the lower impermeable zone below the aquifer, storage is unlikely to be increased by depression of the permafrost beneath the present base of the aquifer. Assuming a model of the aquifer with a planar upper boundary at the base of seasonal frost and its base on the top of either bedrock or frozen alluvium, a width ranging from $60 \mathrm{~m}$ near the reservoir to 75 $\mathrm{m}$ at the site of the 1961 gallery (fig. 11), no inflow or outflow, a cover of about $4.5 \mathrm{~m}$ of seasonal frost, and average porosity of 20 percent for the gravel, the estimated storage above the top of the well screen is about $2,271,000$ liters. This estimate of total storage may require modification in light of one or more factors. The porosity estimate does not take into account the bouldery silt found in the gravel in most of the test wells drilled in 1960 and may therefore be too high. If the water level could be drawn down into the well screen, however, considerable amounts of additional water could be obtained, perhaps as

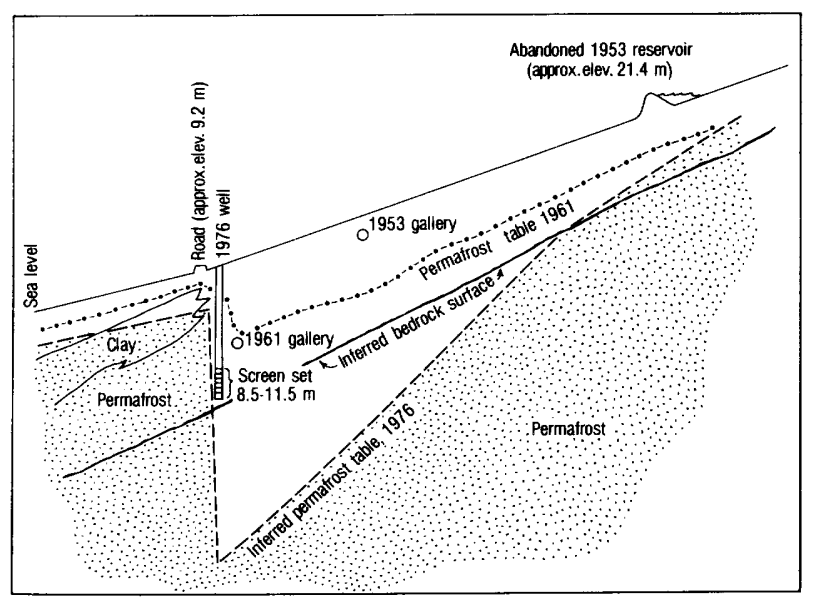

FIGURE 11.-Schematic cross section along Selin Creek showing water-supply installations and approximate recession of permafrost table between 1961 and 1976. (Not to scale; elevations as noted). 
much as 568,000 liters, depending upon how far the water could be drawn down. Other variables can also affect the estimate. We conclude that the amount of water available to the well in late winter is probably only enough to augment the surface streamflow stored in tanks and is generally insufficient for a year-round water supply.

The history of the Cape Lisburne water supply, covering more than 25 years of construction activities, shows that water can be obtained from fluvial aquifers in continuous-permafrost regions by cold-water thaw methods such as those described here. The record also provides information of a kind not generally available, on the rate and depth of thaw of permafrost when the thermal regime is disturbed by man. At Cape Lisburne, thawing of permafrost probably was accelerated considerably by conductive heat transfer from ground water moving through coarse material toward a pumping gallery or well.

\section{REFERENCES CITED}

Feulner, A. J., 1964, Galleries and their use for development of shallow ground-water supplies, with special reference to Alaska: U.S. Geological Survey Water-Supply Paper 1809-E, p. El-El6.

Feulner, A. J., and Williams, J. R., 1967, Development of a ground-water supply at Cape Lisburne, Alaska, by modification of the thermal regime of permafrost, in Geological Survey Research 1967: U.S. Geological Survey Professional Paper 575-B, p. B199-B202.

Mafic rocks in the Avan Hills ultramafic complex, De Long Mountains

By Jay Zimmerman ${ }^{1}$ Charles O. Frank ${ }^{2}$, and Sean Bryn ${ }^{3}$

The Avan Hills ultramafic complex in the De Long Mountains of the western Brooks Range is an allochthonous ophiolite probably emplaced by northward thrust transport during Mesozoic or early Tertiary time (Roeder and Mull, 1978). The complex overlies Paleozoic and Mesozoic sedimentary rocks and mafic volcanic rocks of uncertain age along a subhorizontal thrust contact. No genetic relation between the ultramafic complex and the underlying volcanic rocks has been established. The complex consists of three major lithologic units; in ascending order they are: a

\footnotetext{
123 Southern Illinois University at Carbondale.
}

zone of ultramafic tectonites, a transition zone about $1 \mathrm{~km}$ thick, and the remnants of a mafic zone, presently about $2.5 \mathrm{~km}$ thick, consisting of coarse-grained, dominantly gabbroic rocks (Zimmerman and Soustek, 1979). In most models of complete ophiolites coarse-grained mafic rocks grade upsection into mafic extrusive rocks with or without an intervening section of sheeted dikes. The uppermost rocks in the Avan Hills are phanaritic, and if sheeted dikes and extrusive rocks originally formed part of the sequence, they have been removed, probably during obduction or subsequent thrust transport.

Samples of mafic constituents of the transition and overlying mafic zones were collected in 1979 from exposures in the northernmost part of the complex. In this area, compositional layering and S-surfaces strike northwest and have an average dip of $62^{\circ} \mathrm{NE}$. The results of preliminary thinsection examination of 33 samples are given in table 1. Gabbroic rocks comprise over two-thirds of the material collected, although field observations suggest that at least 90 percent of the rocks in the mafic zone are gabbroic. Among the gabbros, leucogabbro predominates, and some of the "diorites" reported from other parts of the complex by Zimmerman and Soustek (1979) probably should be reclassified as leucogabbro. Nongabbroic rocks (anorthosite, tonalite, and granite), although volumetrically minor, should be significant in the construction of models of the petrologic evolution of the mafic zone.

The base of the transition zone is defined at the first appearance of mafic rocks in a matrix of ul-

TABLE 1.-Principal mafic rock types in the transition and mafic zones of the Avan Hills ultramafic complex

[Rocks are not listed in stratigraphic sequence]

\begin{tabular}{|c|c|c|}
\hline Zone & Rock name 1 & $\begin{array}{c}\text { Number of } \\
\text { thin sections } \\
\text { examined }\end{array}$ \\
\hline \multirow[t]{11}{*}{ Mafic } & Leucogabbro-1- & 14 \\
\hline & Olivine leucogabbro-- & 1 \\
\hline & Hornblende leucogabbro--.-- & 1 \\
\hline & Olivine gabbro-- & 4 \\
\hline & Melagabbro-- & 1 \\
\hline & Olivine melagabbro-_- & 1 \\
\hline & Troctolite- & 1 \\
\hline & Serpentinite- & 2 \\
\hline & Anorthosite--- & 2 \\
\hline & Tonalite--1-ne- & 2 \\
\hline & Biotite granite-- & 2 \\
\hline Transition & Leucogabbro-n- & 2 \\
\hline
\end{tabular}

${ }^{1}$ From Streckeisen (1973). 
tramafic material. Along the 1979 traverse line, these rocks are leucogabbros that occur in several layers less than $1 \mathrm{~cm}$ to about $60 \mathrm{~cm}$ thick, parallel to foliation planes in the enclosing dunite and peridotite. In contrast to rocks of similar composition and stratigraphic level elsewhere in the complex, these show little evidence of intense strain and are not obviously tectonitic. No other mafic rocks occur along the traverse line until about 20 $\mathrm{m}$ below the top to the transition zone where thin (1- to $4-\mathrm{cm})$ leucogabbros occur in clinopyroxenite, the dominant ultramafic rock type at this level. The basal mafic units of the transition zone are thus separated from their nearest upsection counterparts by more than $900 \mathrm{~m}$ of intervening ultramafite.

The contact between the transition and the mafic zones is abrupt. Rocks immediately above the contact are olivine gabbros and leucogabbros with characteristic centimeter-scale compositional layering due to variations in relative abundances of plagioclase feldspar and dark minerals, typically clinopyroxene and olivine. Ultramafic rocks in the zone are limited to a few widely separated layers or lenses of serpentinite.

Although rocks of gabbroic composition are widely distributed over the entire preserved thickness of the mafic zone, and unquestionably define the most abundant rock type, the sequence in general tends to become more leucocratic upward. Anorthosite, troctolite, tonalite, and biotite granite recur at intervals separated by varying thicknesses of layered gabbro although there is no direct evidence of regular cyclic repetition of units. For example, in the central part of the mafic zone, the following layering sequence occurs: leucogabbro, biotite granite $(0.7 \mathrm{~m})$, olivine leucogabbro: $(13.0 \mathrm{~m})$, serpentinite $(8.0 \mathrm{~m})$, biotite granite $(3.3 \mathrm{~m})$, olivine gabbro $(30.0 \mathrm{~m})$, leucogabbro $(3.0 \mathrm{~m})$. Note that the granites are interlayered and do not cut across the compositional planes of adjacent rocks. Although mylonites occur toward the upper part of the zone, there are no convincing indications of tectonic repetition of the sequence on the scale of a few meters, and we conclude that the striking lithologic variations are the results of magmatic or other nontectonic processes.

Throughout the mafic zone, most rocks (including biotite granite) appear foliated owing to preferred orientations of dark minerals. In thin section, however, rocks from the lower and central parts of the zone show only moderate strain, typi- cally in the form of undulose extinction. In contrast, most material from the highest preserved parts of the zone has been intensely deformed. Thin compositional layers can be extremely attenuated, intrafolial folds are common in some samples, and neoblastic feldspars surrounding internally strained relict crystals define characteristic textures. Deformation at these locations may be related to proximity of the rocks to the thrust fault along which the complex was emplaced, although similar gabbroic tectonites and mylonites found elsewhere in the complex have been attributed to earlier tectonic phases.

Part of this study is funded by National Science Foundation Grant EAR-7815479.

\section{REFERENCES CITED}

Roeder, Dietrich, and Mull, C. G., 1978, Tectonics of Brooks Range ophiolites, Alaska: American Association of Petroleum Geologists Bulletin, v. 62, no. 9, p. 1696-1702.

Streckeisen, A. L., 1973, Plutonic rocks; classification and nomenclature recommended by the IUGS Subcommission on the Systematics of Igneous Rocks: Geotimes, v. 18, no. 10 , p. $26-30$.

Zimmerman, Jay, and Soustek, P. G., 1979, The Avan Hills ultramafic complex, De Long Mountains, Alaska, in Johnson, K. M., and Williams, J. R., eds., The United States Geological Survey in Alaska: Accomplishments during 1978: U.S. Geological Survey Circular 804-B, p. B8B11.

Gravity measurements useful in exploration and evaluation of the Nimiuktuk barite deposit

By David F. Barnes

The high specific gravity of barite (approximately 4.35) suggests that massive deposits of the mineral should be easily detected and that their masses could be evaluated by precise and detailed gravity surveys. Published gravity studies of barite deposits (Uhley and Scharon, 1954; Visarion and others, 1974) have already shown small positive anomalies ( 0.5 to $1.0 \mathrm{mgal}$ ), which provided satisfactory tonnage estimates, and unpublished information suggests that gravity data have been useful in other commercial barite exploration. In July, 1979, two gravity profiles showed that a 2 -mgal anomaly is associated with the Nimiuktuk barite deposit reported earlier by Mayfield and others (1979) in the western Brooks Range of northern Alaska. 
This Nimiuktuk barite deposit crops out as a small hill at $68^{\circ} 24.80^{\prime} \mathrm{N}$. and $159^{\circ} 53.80^{\prime} \mathrm{W}$., which is within the new Noatak National Monument and about $25 \mathrm{~km}$ south of its boundary with the National Petroleum Reserve in Alaska. The outcrop is approximately $2.5 \mathrm{~km}$ west of the confluence of the Nimiuktuk River and Klim Creek. The hill forms a small, ovoid dome about $8 \mathrm{~m}$ high, $50 \mathrm{~m}$ wide, and $80 \mathrm{~m}$ long. Barite rubble and a few solid outcrops cover the entire hill; accessory minerals are few and minor in concentration. Mayfield and others (1979) originally estimated that the outcrop exposes a minimum of 12,500 metric tons of high-grade barite, but measurements of the dome's topography during the gravity survey have doubled this estimate of exposed tonnage. The tonnage of concealed barite, however, is much larger. the hill rises above the gently rolling tundra-covered lowland on the south flank of the Brooks Range. The gentle topography of the area makes the deposit an attractive target for a gravity survey because terrain corrections are minimal.

The specific gravities of seven samples collected from the outcrop range from 4.36 to 4.40 and average 4.37. Two small samples of much lower density chert and limestone also were collected at the outcrop, but the small proportion of these contaminants in the deposit could not be estimated. Specific gravities of two samples of graywacke from the end of the northern profile were 2.55 and 2.59 , but the volcanic rocks that crop out on the hill south of the barite deposit commonly have specific gravities close to 2.75 . Specific gravities of 4.37 for the barite and 2.67 for the host rock have been used in modeling the anomaly.

The gravity measurements were made on July 20 and 21,1979 with a high-precision, model-D LaCoste gravimeter along two profiles that intersect on a flat shoulder of the hill approximately 15 $m$ east of its summit. A gravity base station (marked with a USGS hexagonal marker) was established approximately $3.6 \mathrm{~m}$ north of this intersection; the observed gravity of this base was measured as $982,424.88$ on the IGSN-71 datum, and an approximate elevation of $421 \mathrm{~m}(1,380 \mathrm{ft})$ was determined by altimetry. A transit was used for stadia measurements of distance and elevation along the profiles. A standard density of 2,670 $\mathrm{kg} / \mathrm{m}^{3}$ and the 1967 International Ellipsoid were used for data reduction. Although no terrain corrections have been made, their maximum relative magnitude has been estimated as less than 0.3 mgal. Station spacing was about $8 \mathrm{~m}$ near the barite outcrop and increased to nearly $60 \mathrm{~m}$ at the outer end of the southern profile.

The measured topography and gravity along the two profiles are shown in figure 12 along with a derived contour map that compares the Bouguer gravity anomaly with the barite outcrop area and adjacent drainage. The measured anomaly has a

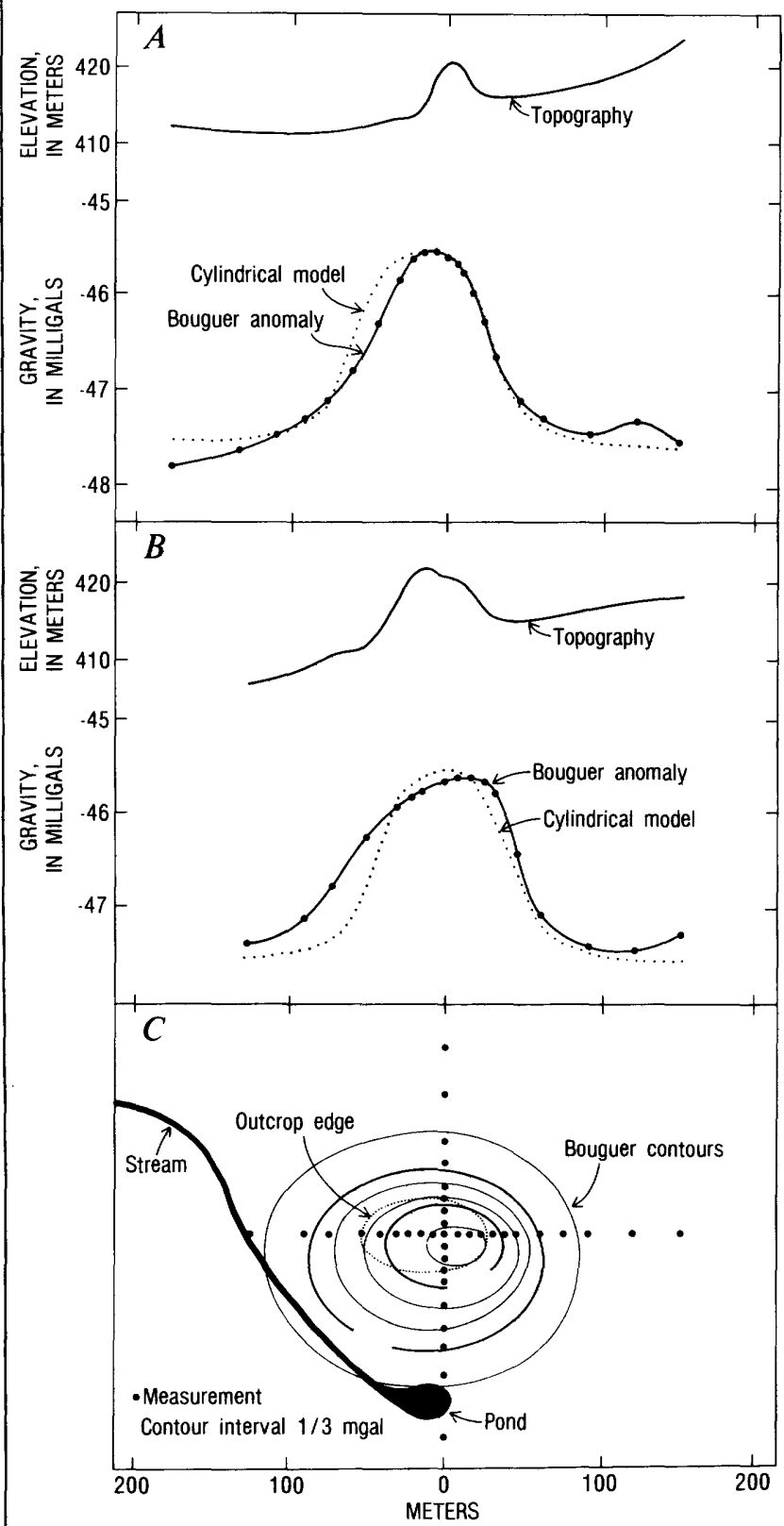

FIGURE 12.-Topographic and gravity profiles across the Nimiuktuk barite deposit and derived contours. $A$, Northsouth profiles. $B$, West-east profiles. $C$, Gravity contour map. 
magnitude of approximately $2 \mathrm{mgal}$, which is significantly larger than the anomalies reported by Uhley and Scharon (1954) for commercial barite deposits in Missouri. Because the width of the anomaly is significantly greater than the outcrop, the hidden dimensions of the deposit may be larger than the hill itself. The slight asymmetry of both gravity profiles suggests that the deposit may dip to the south and west. Additional gravity data between the southern and western profiles may show a further extension of the barite deposit toward the southwest.

Various mathematical techniques (such as those of Nettleton, 1976) have been used to study the anomaly. Integrating the magnitude of the anomaly over a horizontal surface suggests by Gauss' theorem that its total causative mass must exceed 1.5 million metric tons, but such calculations are usually low because of the difficulties in estimating the limits of integration ("tailing-off" error). However, mathematical models also tend to support this 1.5 -million tonnage estimate. A sphere with a radius of $45 \mathrm{~m}(150 \mathrm{ft})$, tangent to the Earth's surface, and having a specific gravity of 4.37 in a 2.67 host rock has a similar mass of about 1.5 million tons. The anomaly calculated for such a spherical body has an amplitude similar to that measured at the Nimiuktuk deposit, but its calculated shape is too narrow and thus suggests a broader source body. A better mathematical model is an exposed, horizontal, cylindrical disk $55 \mathrm{~m}$ thick and having the same $45-\mathrm{m}$ radius, density, and density contrast as the spherical body and a similar total mass that slightly exceeds 1.5 million metric tone. The calculated anomaly for this cylinder disk is shown as dotted lines in figure 12 and seems to be a good approximation on the northern and eastern sides of the anomaly. The gentler gradients on the other two sides would be better represented by more rounded and (or) gently dipping contacts. Other calculations have shown that lower density but thicker disks produce bounding gradients that are significantly smaller than in the observed profile. Thus the anomaly observed at the Nimiuktuk deposit can best be explained by a shallow, highdensity source, although high-density impurities such as galena could reduce the postulated grade. Combined models suggest that the ore body may be qualitatively described as a southwestward elongate and plunging ellipsoid (bean shape) containing a total mass of more than 1.5 million metric tons of high-grade barite.

Mayfield and others (1979) geochemically sampled the stream (figure 12) that drains the area around the deposit as well as other streams flowing into the upper Nimiuktuk River. The highest barium concentrations were actually measured in some of these other streams, and similar high barium concentrations are common in geochemical samples from other parts of northern Alaska (Theobald and Barton, 1978). The source of these high barium concentrations could be either massive deposits like the Nimiuktuk deposit or smaller and more diffuse veinlets. The distinct gravity anomaly associated with the massive Nimiuktuk barite deposit suggests that gravity exploration could locate other massive deposits. A properly planned combination of geochemical and gravitational exploration could prove economically successful in an area where barium is abundant.

\section{REFERENCES CITED}

Mayfield, C. F., Curtis, S. M., Ellersieck, I. F., and Tailleur, I. L., 1979, Reconnaissance geology of the Ginny Creek zinc-lead-silver and Nimiuktuk barite deposits, northwestern Brooks Range, Alaska: U.S. Geological Survey Open-File Report 79-1092, 20 p., 2 pl.

Nettleton, L. L., 1976, Gravity and magnetics in oil prospecting, McGraw-Hill, New York, 464 p.

Theobald, P. K., and Barton, H. N., 1978, Basic data for the geochemical evaluation of the National Petroleum Reserve, Alaska: U.S. Geololgical Survey Open-File Report 78-700, $102 \mathrm{p}$.

Uhley, R. P., and Scharon, LeRoy, 1954, Gravity surveys for residual barite deposits in Missouri: Mining Engineering, v. 6 , no. 1, p. 52-56.

Visarion, M., Rosca, V. and Sava, C. S., 1974, High accuracy gravity surveys as applied to locate barite ores: Revue Roumaine de Geologie, Geophysique, et Geographie. Serie de Geophysique, v. 18, p. 113-125.

Late Mississippian to Pennsylvanian radiolarian assemblages in the Siksikpuk(?) Formation at Nigu Bluff, Howard Pass quadrangle, Alaska

By Benita L. Murchey, Patricia B. Swain, and Steven Curtis

Analysis of radiolarians obtained from a $92 \cdot \mathrm{m}$ thick section of the Siksikpuk(?) Formation at Nigu Bluff in the Howard Pass quadangle, Alaska, 
indicates that the formation ranges in age from late Mississippian to Pennsylvanian. The section is lithologically similar, although not identical, to the type Siksikpuk formation, but may not be its stratigraphic equivalent. Although radiolarian cherts from the type locality in the Chandler Lake quadrangle have not been studied, megafossils indicate that part of the Siksikpuk Formation is probably Permian (Patton and Tailleur, 1964).

The section exposed at Nigu Bluff in a cutbank of the Nigu River was selected for study because it appeared to be a structurally simple, stratigraphically continuous sequence (fig. 13). This Siksikpuk(?) sequence structurally underlies spiculitic limestone, interbedded dark-gray chert and shale, and diabase. The entire sequence dips steeply south. Micropaleontological evidence suggests that the sequence is inverted.

The Siksikpuk(?) Formation stratigraphically overlies the limestone unit; the contact between the two is gradational. The lower $78 \mathrm{~m}$ of the Siksikpuk(?) sequence consists of dark-gray radiolarian chert that weathers to a distinctive variegated green and orange. The chert beds, which are interbedded with minor shales, range in thickness from $5 \mathrm{~cm}$ to $30 \mathrm{~cm}$. Some beds contain mammillary structures, which project above the bedding surface as much as $125 \mathrm{~mm}$. The upper 14 $\mathrm{m}$ of Siksikpuk(?) exposed at this locality is very thinly bedded (to $20 \mathrm{~mm}$ thick) maroon and green argillite and argillaceous radiolarian chert.

Twenty-nine chert and limestone samples were collected from the entire Nigu Bluff section for radiolarian processing. Conodonts and poorly preserved radiolarians and foraminifers were extracted from dark shale and chert at the south end of the section, but no positive age determinations have yet been made from these microfossils. Sponge spicules and a few poorly preserved radiolarians of possible Late Mississippian age were recovered from the limestone unit that stratigraphically underlies the Siksikpuk(?) and four distinct radiolarian assemblages were found in the samples from the Siksikpuk(?) Formation. These assemblages can be correlated with the late Paleozoic radiolarian zonation (fig. 13) developed by Holdsworth and Jones (1980).

Assemblage A: Samples from the basal Siksik$\operatorname{puk}($ ?) formation (base to $15 \mathrm{~m}$ ) contain abundant sponge spicules and a few poorly preserved radiolarians of the Paronaella impella Ormiston and Lane Group. Low diversity and poor preservation of the radiolarians make statigraphic correlation of this assemblage uncertain, but the absence of 'Spongotripus' Haeckel or undescribed tetrahedral Spongodiscaceins indicates that these samples may be Late Mississippian.

Assemblage B: Samples from the Siksikpuk(?) Formation collected between $15 \mathrm{~m}$ and $26 \mathrm{~m}$ contain abundant Paronaella of the $P$. impella Ormiston and Lane Group. Two samples contain Albaillella. 'Spongotripus' Haeckel and tetrahedral Spongodiscaceins are absent. These samples correspond to the lower part of the Chesterian to Morrowan Albaillella-3 assemblage.

Assemblage C: Samples from the Siksikpuk(?) Formation collected between $50 \mathrm{~m}$ and $58 \mathrm{~m}$ contain abundant 'Spongotripus' Haeckel and undescribed tetrahedral Spongodiscaceins as well as a few specimens of Albaillella sp. aff. Albaillella pennata Holdsworth. These samples correspond to the upper part of the Chesterian to Morrowan Albaillella-3 assemblage.

Assemblage D: Samples collected from the Siksikpuk(?) maroon and green argillite between 78 $\mathrm{m}$ and $92 \mathrm{~m}$ contain excellently preserved specimens of Psuedoalbaillella sp. (Holdsworth and Jones, 1980), complex Paronaellas, narrow-armed Spongodiscaceins, and many other Spumellarians. The species of Pseudoalbaillella is similar to those known to be older than the Permian $P$. $u$-forma (Holdsworth and Jones, 1980). This assemblage corresponds to the lower part of the Pseudoalbaillella assemblage of late Morrowan to Leonardian age.

Radiolarians collected from throughout the Nigu Bluff section represent the first systematic collection from a Paleozoic section in the Brooks Range. The results indicate that the Paleozoic radiolarian zonations developed by Holdsworth and Jones (1980) work well in this area. This study extends the range of varicolored radiolarian cherts in the Brooks Range, previously considered to be of Pennsylvanian to Triassic age, into the Mississipian.

\section{REFERENCES CITED}

Holdsworth, B. K., and Jones, D. L., 1980, Preliminary radiolarian zonation for late Devonian through Permian time: Geology, v. 8, p. 281-285.

Patton, W. W., and Tailleur, I. L., 1964, Geology of the KillikItkillik region, Alaska: U.S. Geological Survey Professional Paper 303-G, p. 427-30. 


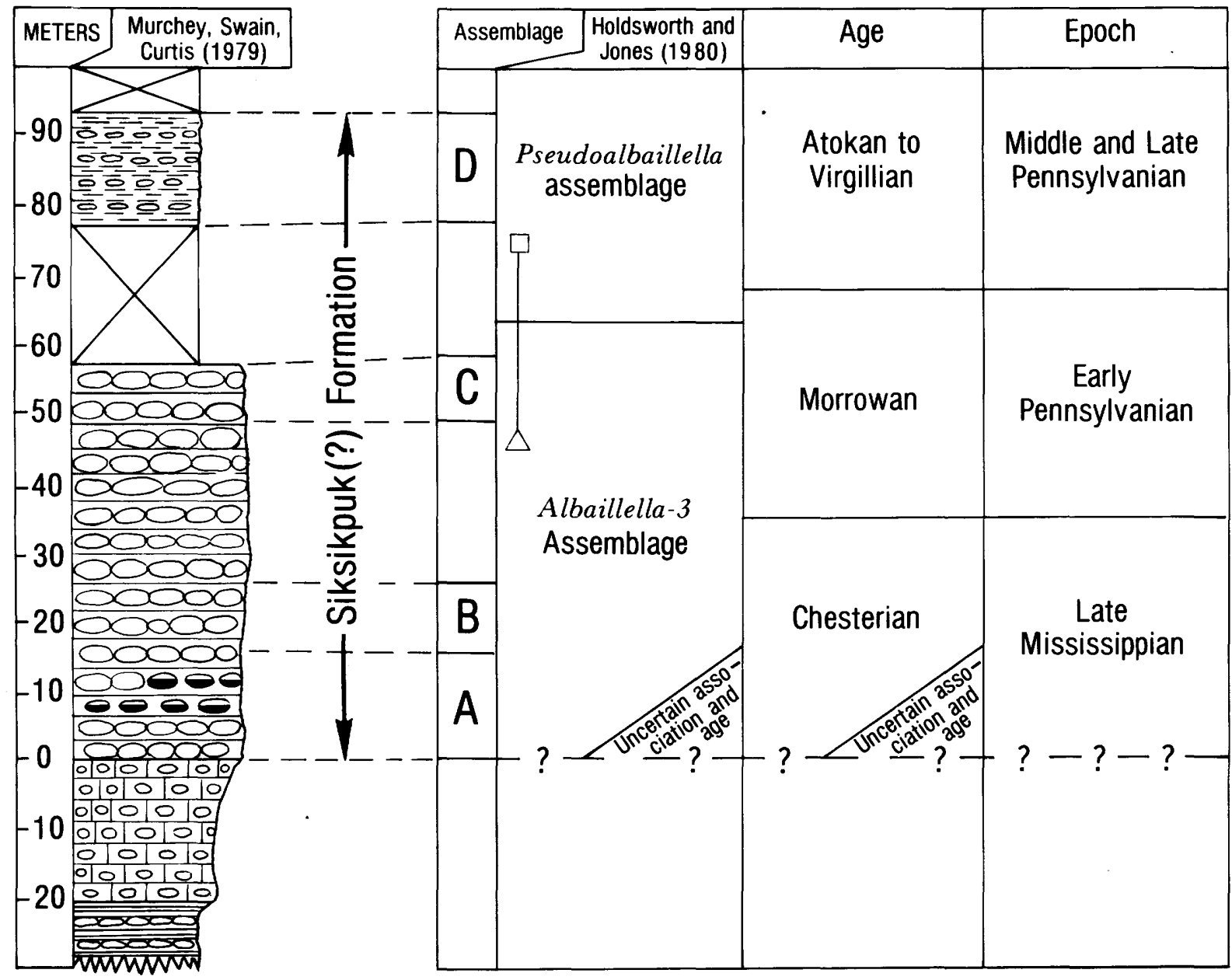

\section{EXPLANATION}

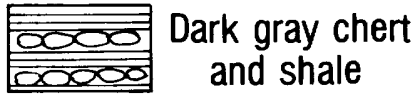

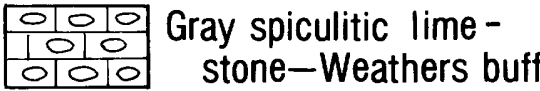

Gray chert-Weathers

$$
\text { orange and green }
$$

흫ㅎㅎㅎㅎㅎㅎㅎㅎㅎㅁ Maroon and green argillite

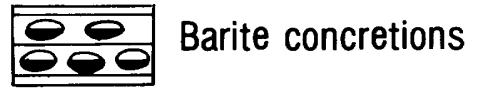

Top tetrahedral Spongodiscaceid

$\triangle \quad$ Base tetrahedral Spongodiscaceid

FIGURF :3.-Correlation of radiolarian assemblages with the Siksikpuk Formation measured section at Nigu Bluff (lat $68^{\circ} 29^{\prime}$ N., long $156^{\circ} 27^{\prime}$ W.). 
Depositional model for the fluvial Upper Devonian Kanayut Conglomerate, Brooks Range, Alaska

By T. H. Nilsen, W. P. Brosgé, J. T. Dutro, Jr., and T. E. Moore

The Upper Devonian (Famennian) Kanayut Conglomerate is one of the thickest and most widespread nonmarine clastic sequences in North America. It is as much as $2,000 \mathrm{~m}$ thick and extends across the Brooks Range for more than 600 $\mathrm{km}$ from east to west and 50 to $100 \mathrm{~km}$ from north to south. Fossiliferous marine strata of the Upper Devonian Hunt Fork Shale and Lower Mississippian Kayak Shale respectively underlie and overlie it. The Kanayut records the southwestward advance of a major coarse-grained fluvialdominated delta (fig. 14) analogous in many respects to Devonian and Mississippian deltaic de- posits of the Canadian Arctic Islands, Black Warrior Basin, Catskill Basin, and Old Red Continent of northern Europe and Greenland.

Throughout most of its east-west extent, the Kanayut contains three fluvial members-a coarse middle member consisting of interbedded conglomerate and sandstone deposited by braided streams, and upper (Stuver Member) and lower members composed mostly of fining-upward cycles of sandstone, siltstone, and shale deposited by meandering streams. A fourth member crops out in the west half of the Brooks Range beneath these fluvial members and consists of interbedded fluvial and fossiliferous nearshore marine sandstone and shale. This member grades downward and laterally into the underlying Upper Devonian (Famennian and Frasnian) Hunt Fork

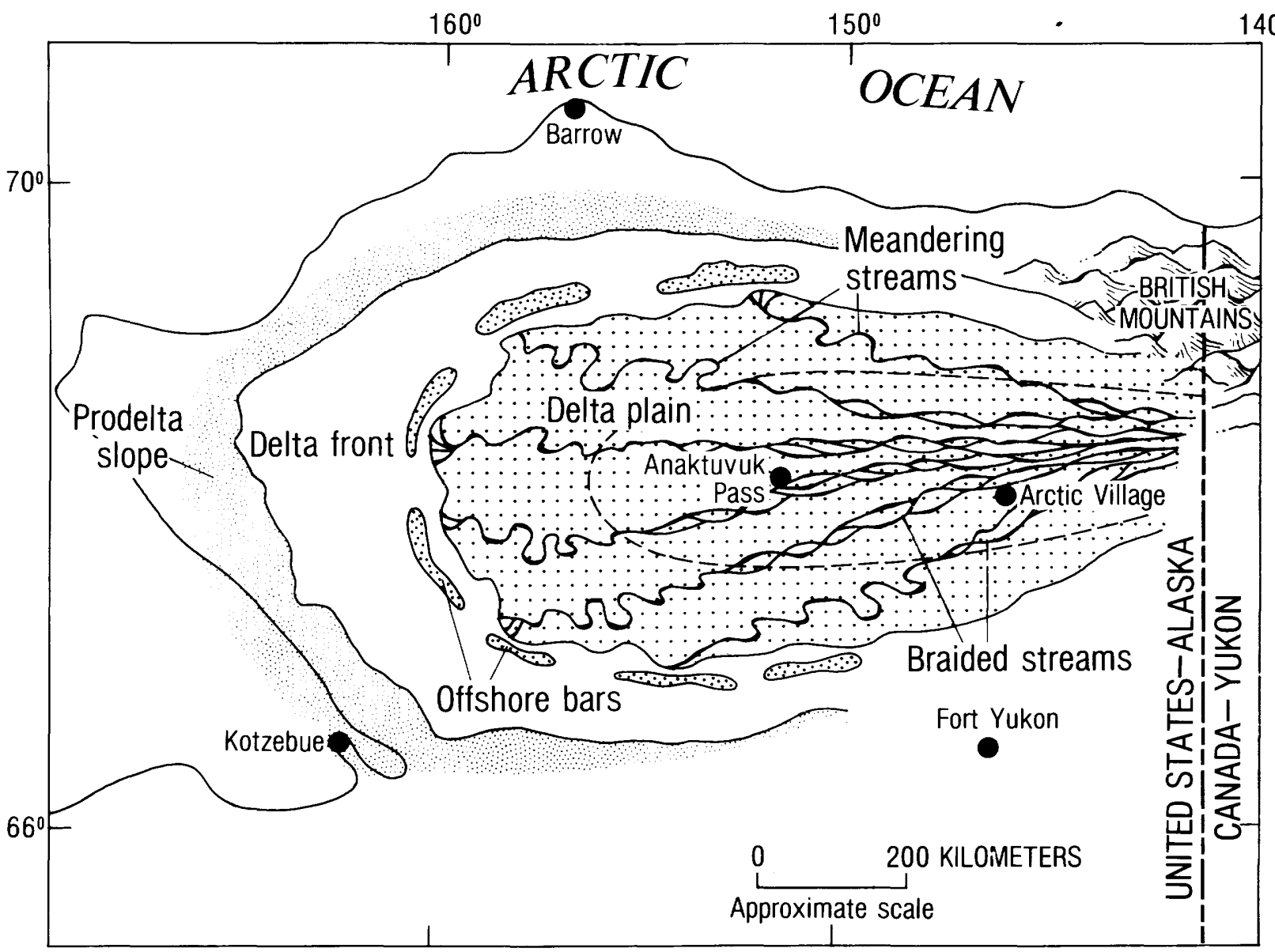

FigURE 14.-Paleogeographic sketch showing extent of Kanayut delta during deposition of the middle member of the Kanayut Conglomerate. Outline of delta is superimposed on sketch map of northern Alaska so that south half of delta is in present location of outcrops of the Kanayut Conglomerate, although the unit is allochthonous. Dashed line indicates approximate boundary between braided stream facies and meandering stream facies. 
Shale, which comprises the prodelta and deeper marine part of the deltaic complex. To the south and southwest, the upper and lower fluvial members thin and pinch out (Brosgé and others, 1979), and the middle member thins and fines.

Sedimentary features indicate that the Kanayut was derived from a chert-rich terrane to the east and northeast. The areal distribution of maximum size of conglomerate clasts suggests a source to the northeast, and paleocurrent measurements indicate sediment transport dominantly toward the southwest. The conglomerates are texturally and compositionally mature, containing mostly chert clasts with lesser amounts of quartz, quartzite, and argillite. The largest clasts, generally quartzite or quartz, are about $60 \mathrm{~cm}$ long. Finer conglomerates are rich in chert because chert tends to break into smaller fragments more easily than quartz or quartzite. The sandstone are also compositionally and texturally mature, consisting chiefly of subrounded grains of quartz, chert, and argillite with negligible amounts of feldspar (Nilsen and others, 1980).

The Kanayut outcrops are bounded on the east and northeast by large anticlinoria near the Canadian border, where the much thinner Mississippian Kekiktuk Conglomerate rests with angular unconformity on Precambrian and lower Paleozoic basement rocks (Reiser and others, 1974). These basement rocks, which include a thick unit of Cambrian or Ordovician bedded chert, were exposed to erosion in Late Devonian time and probably formed part of the source area for the Kanayut Conglomerate. In some of its easternmost outcrops, the Kanayut rests directly on sheared conglomerate and reefoid limestone of the Upper Devonian (Frasnian) Beaucoup Formation (Dutro and others, 1979), which underlies the Hunt Fork Shale farther west in the Brooks Range. This eastern pinch-out of the Hunt Fork suggests an unconformity beneath the Kanayut close to its source area.

The Beaucoup Formation, Hunt Fork Shale, Kanayut Conglomerate, and Kayak Shale record a major progradational-retrogradational deltaic cycle. The lower marine member of the Kanayut and underlying and overlying marine units consist of prodelta, delta-margin, and delta-front deposits. The lower and upper (Stuver Member) nonmarine members of the Kanayut consist of meandering fluvial delta-plain deposits, and the middle non- marine member of the Kanayut consists of braided fluvial delta-plain and, possibly in easternmost outcrops, alluvial fan deposits. This deltaic complex reflects major middle Paleozoic mountain building (Dutro, 1980), but because of uncertainties regarding the original Paleozoic position of the Brooks Range, it is not clear whether this tectonism was associated with the Acadian, Ellesmerian, or Antler orogenies.

\section{REFERENCES CITED}

Brosgé, W. P., Reiser, H. N., Dutro, J. T., Jr., and Nilsen, T. H., 1979, Geologic map of Devonian rocks in parts of the Chandler Lake and Killik River quadrangles, Alaska: U.S. Geological Survey Open-File Report 791224 , scale $1: 200,000$.

Dutro, J. T., Jr., 1981, Geology of Alaska bordering the Arctic Ocean, in Nairn, A. E., Churkin, Michael, and Stehli, F. G., eds., Ocean Basins and Margins, vol. 5: The Arctic Ocean: New York, Plenum Publishing Corp. (in press).

Dutro, J. T., Jr., Brosgé, W. P., Reiser, H. N., and Detterman, R. L., 1979, Beaucoup Formation, a new Upper Devonian stratigraphic unit in the central Brooks Range, northern Alaska, in Sohl, N. F., and Wright, W. B., eds., Changes in stratigraphic nomenclature by the U.S. Geological Survey, 1978: U.S. Geological Survey Bulletin 1482-A, p. A63-A69.

Nilsen, T. H., Moore, T. E., Dutro, J. T., Jr., Brosgé, W. P., and Orchard, D. M., 1980, Preliminary report on the sedimentology and stratigraphy of Kanayut Conglomerate and associated units, central and eastern Brooks Range, Alaska: U.S. Geological Survey Open-File Report 80-888, 40 p.

Reiser, H. N., Brosgé, W. P., Dutro, J. T., Jr., and Detterman, R. L., 1974, Preliminary geologic map of the Demarcation Point quadrangle, Alaska: U.S. Geological Survey Miscellaneous Field Studies Map MF-610, scale $1: 200,000$.

Episodic Holocene alluviation in the central Brooks Range: chronology, correlations, and climatic implications

By Thomas D. Hamilton

Radiocarbon dates from Holocene alluvial terraces within valleys of the central Brooks Range cluster into assemblages that appear to reflect periods of alluviation alternating with downcutting or stability (fig. 15). These events evidently were contemporaneous with fluctuations of local cirque glaciers and reflect significant climatic changes comparable to those reported from central Alaska (Hamilton and Robinson, 1977).

Terrace history is clearest and most consistent within the Itkillik Valley close to the north flank 
AGE, IN YEARS BEFORE PRESENT

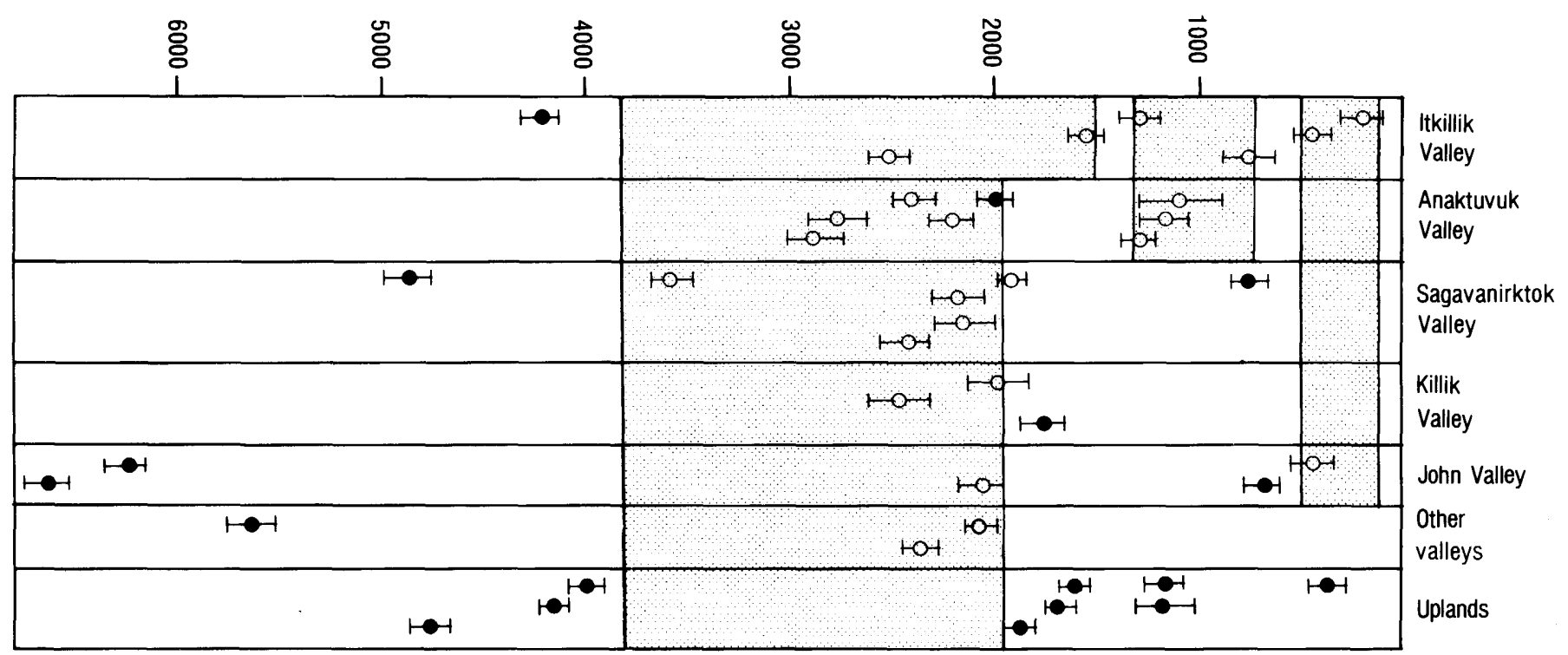


of the Brooks Range, where large active cirque glaciers occupy the heads of every major tributary valley. Four alluvial terraces in this part of the Itkillik drainage system form morphologically separate surfaces; each terrace contains abundant datable organic material. Earliest alluviation, to a height of about $11 \mathrm{~m}$ above modern river level, followed accumulation of a massive peat deposit dated at $4,220 \pm 95$ yr B.P. Subsequent downcutting to a position at or below modern river level was followed by three successive periods of terrace building, each bracketed by radiocarbon dates:

$\begin{array}{ccc}\begin{array}{c}\text { Terrace height } \\ \text { (m above stream level) }\end{array} & \begin{array}{c}14 \text { C date } \\ (y r B P .)\end{array} & \begin{array}{c}\text { Position of sample } \\ \text { in terrace }\end{array} \\ 3.5 \text { to } 4.1 & 210 \pm 75 & \text { Near top. } \\ & 430 \pm 50 & \text { Near base. } \\ 6.5 & 770 \pm 130 & \text { Near top. } \\ & 1275 \pm 80 & \text { Near base. } \\ 7.8 \text { to } 8.3 & 1505 \pm 80 & \text { Near top. } \\ & 2505 \pm 190 & \text { Near base. }\end{array}$

Radiocarbon dates from the Anaktuvuk River region show similar clustering, although the dates are from more widely separated areas and terrace heights consequently are less consistent. The two oldest dates (fig. 15) probably correspond to major expansion of cirque glaciers near Anaktuvuk Pass, which caused alluviation of coarse outwash to $6 \mathrm{~m}$ height in Inukpasugruk Valley about 2,800 yr B.P. (Porter, 1964) and formed a terrace that decreases in height northward down Anaktuvuk Valley. Two somewhat younger dates represent rapid delta building into the south end of Shainin Lake, probably in response to increased sediment yield from glaciers at the head of Alapah Creek. A date of $1935 \pm 80$ yr B.P., from massive bryophytic peat, repesents either a pause or a reversal in rapid terrace alluviation along Anaktuvuk River. The three youngest dates, which cluster around 1,100 yr B.P., appear chronologically separate but cannot be related to geomorphically younger terraces. Alluviation possibly continued between about 3,000 and 1,000 yr B.P., but more likely it was interrupted by a period of widespread downcutting.

Five dates from the Sagavanirktok River region fall within a time span comparable to that of the oldest suite of Anaktuvuk dates. An early phase of alluviation in the Ribdon Valley dates at
3,570 \pm 90 yr B.P.; this event can be related to expansion of cirque glaciers at the valley head and to formation of a widespread outwash terrace (Hamilton, 1978, 1979). Younger dates in the range of 2,500 to 2,000 yr B.P. mark alluviation to terrace levels of 4-6 m near Atigun Canyon. An apparently older surface dated at $4,830 \pm 155 \mathrm{yr}$ B.P. probably was abandoned by stream downcutting prior to renewed alluviation (Hamilton, 1979, p. 16). The youngest date, $740 \pm 100 \mathrm{yr}$ B.P., was obtained near the base of a massive peat layer near river level in alluvial deposits near Atigun Canyon. The river evidently had cut down to a position close to its present datum before the peat began to form.

Two dates from the Killik Valley define construction of a $5-\mathrm{m}$ terrace about 2,500-2,000 yr B.P. through a stretch of the valley dominated by large glacier-fed tributaries. A younger date, $1,740 \pm 120$ yr B.P., was obtained from eolian deposits that formed close to modern river level after the Killik River had incised to a position close to or below its modern datum.

Within the John Valley system, two middle Holocene dates define episodes of peat formation and forest growth following early postglacial alluviation. Renewed alluviation to terrace levels of about $3.5 \mathrm{~m}$ is dated at about 2,000 and $450 \mathrm{yr}$ B.P. in two widely separated tributary valleys. A date of $695 \pm 75 \mathrm{yr}$ B.P. from a buried forest floor in alluvial deposits within the main valley suggests that the terraces may represent two distinct episodes of alluviation separated by stability or downcutting.

Sparse data from terrace deposits in other valleys tend to support the alluvial history summarized in figure 15. An episode of lacustrine deposition, later terminated by renewed alluviation, was taking place about 5,600 yr B.P. in the Chandalar Valley. Alluviation to a 3.5-m terrace occurred about 2,000 yr B.P. near the Alatna Valley, and an episode of flooding, probably associated with accelerated fan building, began about $350 \mathrm{yr}$ earlier in the Koyukuk Valley.

Independent data on late Holocene climatic changes are provided by upland surfaces that remained stable for an interval and then were buried by loess, solifluction sheets, or frostchurned deposits. Nine of these successions have been dated in the central Brooks Range (fig. 15), the dates falling into two or perhaps three separate groups. The older dates, which range between about 4,000 and 4,750 yr B.P. represent 
buried peats overlain by frost-churned stony silt. Five younger dates, which cluster within the time span of 1,850 to $1,150 \mathrm{yr}$ B.P., represent buried peats and organic soils that were overridden by solifluction sheets in three localities and blanketed by loess at two other sites. The youngest date, $360 \pm 95$ yr B.P., also is from a peat bed buried beneath solifluction deposits. These dates suggest intensification of cold-climate processes after relatively mild intervals that terminated about $4,000 \mathrm{yr}$ B.P., began again perhaps $1,900 \mathrm{yr}$ ago and lasted several hundred years, then recurred again within the last 1,000 yr.

Direct dating of cirque-glacier fluctuations by lichenometry has recently been attempted in the Atigun Pass area of the central Brooks Range (Ellis, 1978; Calkin and Ellis, 1980). Preliminary results suggest that major cirque-glacier expansions began shortly before 4,000 yr B.P. after a long mild interval that spanned the middle Holocene. Glaciers subsequently retreated from advanced positions, fluctuated for a period of perhaps 1,000 yr or more, then readvanced strongly about 1,100 yr B.P.,(Ellis and Calkin, written commun., 1979). A final readvance occurred within the past $500 \mathrm{yr}$ and culminated between 100 and $200 \mathrm{yr}$ ago. The youngest two advances appear synchronous with the two youngest alluvial episodes summarized in figure 15; the earlier glacial fluctuations show good general correspondence to the older alluviation between about 3,800 and 2,000 yr B.P.

\section{REFERENCES CITED}

Calkin, P. E., and Ellis, J. M., 1980, A lichenometric dating curve and its application to Holocene glacier studies in the central Brooks Range, Alaska: Arctic and Alpine Research, v. 12 , no. 3, p. 245-264.

Ellis, J. M., 1978, Neoglaciation of the Atigun Pass area, eastcentral Brooks Range, Alaska: State University of New York at Buffalo, M. A. thesis, 113 p.

Hamilton, T. D., 1978, Surficial geology, Phillip Smith Mountains quadrangle, Alaska: U. S. Geological Survey Miscellaneous Field Studies Map MF-879-A, scale $1: 250,000$.

- 1979, Radiocarbon dates and Quaternary stratigraphic sections, Phillip Smith Mountains quadrangle, Alaska: U.S. Geological Survey Open-File Report 79- 866, 44, p.

Hamilton, T. D., and Robinson, Stephen, 1977, Late Holocene (Neoglacial) environmental changes in central Alaska [abs.]: Geological Society of America Abstracts with Programs, v. 9, no. 7, p. 1003.

Porter, S. C. 1964, Late Pleistocene glacial chronology of north-central Brooks Range, Alaska: American Journal of Science, v. 262, no. 4, p. 446-460.
Significance of Middle Devonian clastic rocks in the eastern Brooks Range, Alaska

By William P. Brosgé, H. N. Reiser, and J. T. Dutro, Jr.

In the northeastern Brooks Range, and in the parts of the Arctic Coastal Plain that have been explored by deep drilling, Mississippian rocks commonly rest with angular unconformity on folded basement rocks of Precambrian to Silurian age. In the central and western Brooks Range, however, a thick section of Devonian clastic and carbonate rocks lies conformably beneath the Mississippian rocks.

Although most of the Arctic quadrangle in northern Alaska contains a stratigraphic sequence of Paleozoic rocks similar to that in the central Brooks Range, including about 1,000-2,000 $\mathrm{m}$ of Middle and Upper Devonian strata, the northernmost part of the quadrangle is typical of the northeastern Brooks Range, in that Devonian rocks are generally absent or occur as thin remnants beneath the regional pre-Carboniferous unconformity.

The oldest formation in the southern part of the Arctic quadrangle is the Skajit Limestone, about $600 \mathrm{~m}$ of relatively pure, platform carbonate rocks, which contain Silurian and Devonian fossils. Because the Skajit extends laterally for about $600 \mathrm{~km}$ in the southern Brooks Range, it has been assumed to have once been continuous to the northern part of the Brooks Range and to interfinger with the Middle(?) Devonian Nanook Limestone and the underlying Katakturuk Dolomite (Devonian or older) (Tailleur and Brosgé, 1970). These two carbonate units are present beneath the pre-Carboniferous unconformity in the Sadlerochit and Shublik Mountains about $50 \mathrm{~km}$ north of the Arctic quadrangle (Dutro, 1970). In most of the Brooks Range, the Skajit is unconformably overlain by an Upper Devonian sequence consisting of the marine Beaucoup Formation, the marine Hunt Fork Shale (Frasnian and Famennian), and the dominantly nonmarine Kanayut Conglomerate (Famennian) (Dutro and others, 1979).

Recent mapping has shown that in the northeastern Arctic quadrangle, about $40 \mathrm{~km}$ north of the exposed Skajit Limestone, Early and (or) Middle Devonian is represented by at least $300 \mathrm{~m}$ 
of black shale interbedded with ferruginous argillaceous fossiliferous limestone, quartzite, and conglomerate and intruded by thin mafic sills. Preliminary studies suggest that shelly fossils from the limestone are of latest Early Devonian (Emsian) or early Middle Devonian (Eifelian) age. These newly discovered Devonian rocks are probably transitional to the much thinner Middle Devonian (Eifelian?) shallow marine clastic sequences that occurs locally beneath the preCarboniferous unconformity in the northeast corner of the Arctic quadrangle and adjacent areas to the east (fig. 16). About $15 \mathrm{~km}$ east of the Arctic quadrangle, these Devonian strata are unconformable on Cambrian or Ordovician chert that forms part of the Precambrian and lower Paleozoic core of the northeastern Brooks Range (Reiser and others, 1974).

Because Middle Devonian clastic rocks intervene between the areas in which the Skajit an Nanook Limestones crop out, it is unlikely that a Middle Devonian carbonate shelf was ever continuous across northeastern Alaska. The Nanook and Katakturuk carbonate rocks may have been deposited on a shelf that extended northward from the pre-Mississippian fold belt of the northeastern Brooks Range.

In addition, the similarity of the Middle Devonian clastic rocks in the northern Arctic quadrangle to the Middle Devonian clastic rocks of the southernmost part of the northeastern Brooks Range sequence suggests that there has not been much horizontal displacement on the thrust faults that now separate the two sequences.

\section{REFERENCES CITED}

Dutro, J. T., Jr., 1970, Pre-Carboniferous carbonate rocks, northeastern Alaska, in Adkison, W. L., and Brosgé, M. M., eds., Proceedings of the geological seminar on the north slope of Alaska: Los Angeles, Calif., American Association of Petroleum Geologists, Pacific Section, p. M1 -M8.

Dutro, J. T., Jr., Brosgé, W. P., Reiser, H. N., and Detterman, R. L., 1979, Beaucoup Formation, a new Upper Devonian stratigraphic unit in the central and eastern Brooks Range, northern Alaska, in Sohl, N. F., and Wright, W. B., eds., Changes in stratigraphic nomenclature by the U.S. Geological Survey, 1978; U.S. Geological Survey Bulletin 1482-A, p. A63-A69.

Reiser, H. N., Brosgé, W. P., Dutro, J. T., Jr., and Detterman, R. L., 1974, Preliminary geologic map of the Demarcation
Point quadrangle, Alaska: U.S. Geological Survey Miscellaneous Field Studies Map MF-610, scale 1:200,000.

Tailleur, I. L., and Brosgé, W. P., 1970, Tectonic history of northern Alaska, in Adkison, W. L., and Brosgé, M. M., eds., Proceedings of the geological seminar on the north slope of Alaska: Los Angeles, Calif., American Association of Petroleum Geologists, Pacific Section, p. E1-E19.

\section{EAST-CENTRAL ALASKA}

New chemical and isotope data for the hot springs along Big Windy Creek, Circle A-1 quadrangle, Alaska

By Terry E. C. Keith, Theresa S. Presser, and Helen L. Foster

A small hot spring area on Big Windy Creek (Circle A-1 quadrangle) was visited in July 1978 (Keith and Foster, 1979) and again on July 8, 1979. The purpose of the second visit was to collect water samples for uranium analysis and to study the geologic setting of the springs. Springs and travertine deposits are present on both sides of Big Windy Creek, but because of accessibility, only the springs on the north side were studied.

The hot springs along Big Windy Creek occur near the northwest margin of a granitic pluton, one of five granitic plutons alined along a northeasterly trend in the southern Circle A-1 quadrangle. The southwesternmost pluton also has an active hot-spring system, Chena Hot Springs, located within the pluton near its northern boundary. The alined plutons range in size from about 4 $\mathrm{km}^{2}$ to more than $150 \mathrm{~km}^{2}$, and the one associated with the hot springs of Big Windy Creek has an area of about $32 \mathrm{~km}^{2}$. The plutons intrude a metamorphic terrane consisting of quartz-mica schist, quartzite, pelitic schist, marble, and minor amphibolite.

In the western part of the Big Windy Creek hot-spring area, warm springs issue along subhorizontal joints in granitic rock. Green algae grows in abundance where warm water runs over the granitic rock. The flow rates of several springs are on the order of $1 \mathrm{~L} / \mathrm{min}$. A water temperature of $25^{\circ} \mathrm{C}$ and a $\mathrm{pH}$ of approximately 7.5 were measured in several different places. The results of partial chemical analysis of the slightly saline $\mathrm{NaHCO}_{3}$ water (79AFr3000A) are listed in table 2.

The hottest spring waters are located in the eastern part of the spring area. Here the water temperatures are mostly between $40^{\circ}$ and $48^{\circ} \mathrm{C}$, 
A
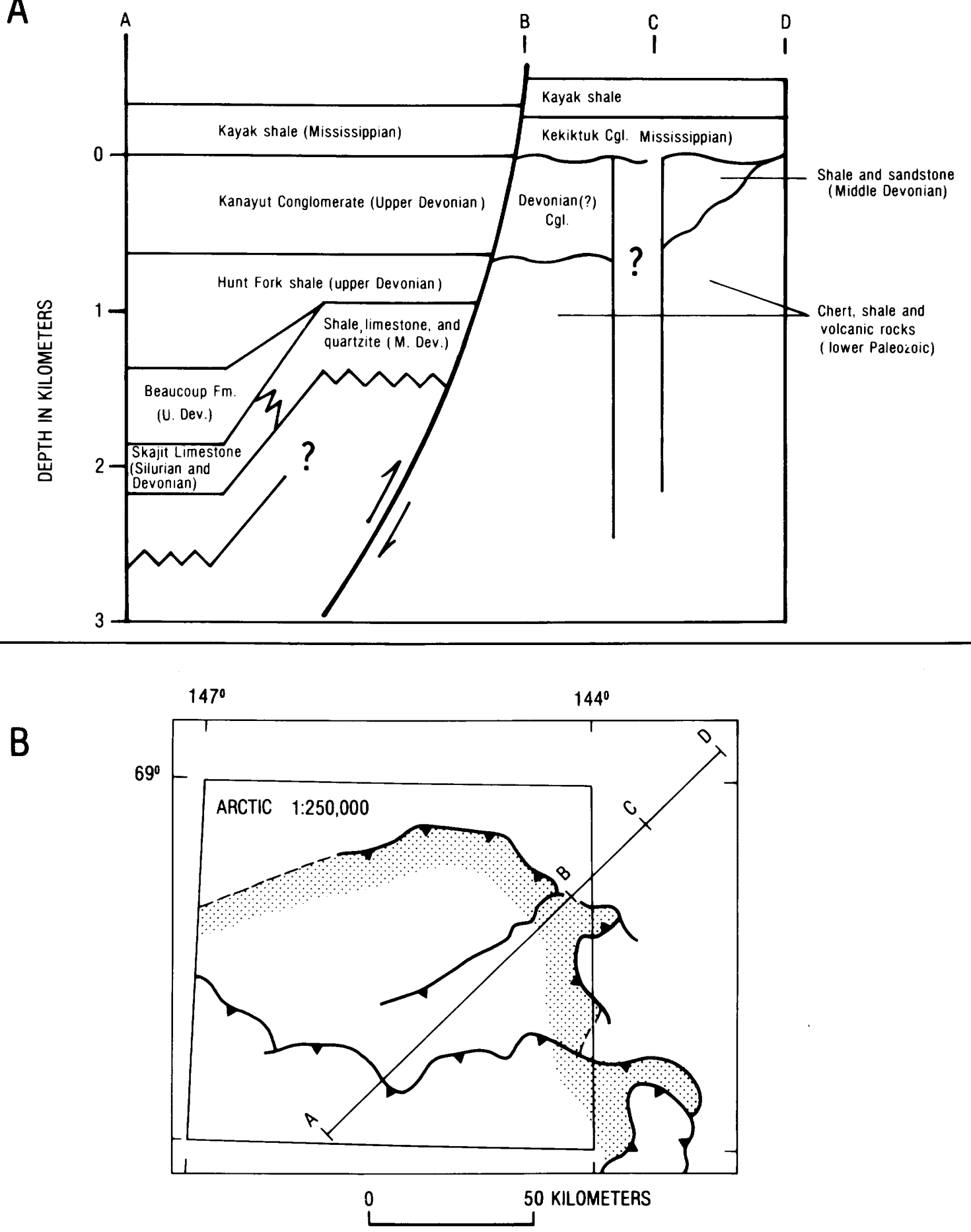

FIGURE 16.-A, Devonian rocks, Arctic quadrangle. Schematic section of Devonian sequences in southern and northern parts of Arctic quadrangle and adjacent areas. $B$, Map shows location of section and of major thrust faults (sawteeth on upper plate) that affect Devonian rocks. Dotted pattern is along northern and eastern margins of area of known Upper Devonian rocks. 
but temperatures as high as $61^{\circ} \mathrm{C}$ have been meas ured. The $\mathrm{pH}$ at the eastern spring vents is very close to 7 , and flow rates from individual vents are as much as $8 \mathrm{~L} / \mathrm{min}$. A chemical analysis of the water from one of the hottest vents $(79 \mathrm{AFr} 3000 \mathrm{H})$ is listed in table 2 . The analyzed waters (table 2), together with an additional hotspring sample from this area reported by Keith and Foster (1979), vary only in temperature, $\mathrm{pH}$, $\mathrm{HCO}_{3}$, and $\mathrm{Ca}$.

The hottest spring waters issue through travertine which is deposited on granitic bedrock. Old

TABLE 2.-Chemical analysis of water from springs along Big Windy Creek, Circle A-1 quadrangle

[Concentrations are in mg/L. Samples not filtered in the field. Cations determined on an acidified sample. Isotopic compositions are in parts per million $(\% / o)$ reported relative to Standard Mean Ocean Water for oxygen and hydrogen, and Peedee Belemnite for carbons (L. D. White, analysts). Analytical methods are outlined by Brown, Skougstad, and Fishman (1970) and by Presser and Barnes (1974). $\mathrm{pH}$ (lab), $\mathrm{HCO}_{3}$, and $\delta^{13} \mathrm{C}$ values are approximate owing to lack of field determination or preservation. $\mathrm{SiO}_{2}$ values may be a minimum owing to polymer formation. $U$ values may be a minimum owing to nonacidification of the sample; analyst: Earl Skinner, Denver Central Lab.]

Temperature

$\mathrm{pH}$ (field)

$\mathrm{pH}$ (lab)

Total alkalinity as $\mathrm{HCO}_{3}-(\mathrm{lab})$

$\mathrm{Na}$

$\mathrm{Ca}$

$\mathrm{Mg}$

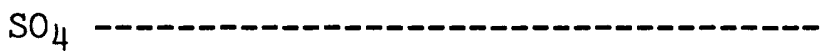

$\mathrm{CI}$

F

$\mathrm{SiO}_{2}$

B

$\mathrm{U}$

$\delta^{18} 0$

$\delta D$

$\delta^{13} \mathrm{C}-\mathrm{SrCO}_{3}$ $25^{\circ} \mathrm{C}$

7-7.5

8.45

630

430

21

16

3.2

76

270

9.1

136

3.2

0.001

$-19.65$

$-161.7$

$-0.01$ $52^{\circ} \mathrm{C}$

7-7.5

7.75

730

430

21

44

4.0

80

270

9.0

133

3.2

$<0.001$

$-20.00$

$-163.0$

$-1.55$ 
travertine deposits occur 3 to $5 \mathrm{~m}$ above the present active orifices. The granitic rock is partly leached by the flowing hot water. Green and orange algae line the numerous water channels that cross the travertine terraces and flow into Big Windy Creek. Travertine is probably being deposited locally. Two minor-element analyses of the travertine are given by Keith and Foster (1979). A thin coating of amorphous silica was detected with the scanning electron microscope as an irregular, late-forming deposit on the travertine.

The $\delta^{13} \mathrm{C}$ values of the dissolved carbon species $(-0.01 \%$ and $-1.55 \%$ indicate a marine limestone (Craig, 1953). The $\delta^{18} \mathrm{O}$ and $\delta \mathrm{D}$ values (table 2) fall on the curve for waters of meteoric origin (Craig, 1961); the very light isotopes are due to the northern latitude. These values are comparable to those reported by Miller, Barnes, and Patton (1975) for other hot-spring waters from similar geologic settings in west and central Alaska.

The chemistry of the water can be explained by the deep circulation of meteoric waters that become heated at depth. During the return to the surface, these waters react with thinly bedded metamorphosed limestone known to crop out in the area. The waters probably also react with feldspars in the granitic and metamorphic rocks of the area. Other minerals in the metamorphic rocks that come in contact with the waters are generally stable under present physical conditions, and their contribution to the water composition is negligible.

The concentration of uranium in the hot-spring area of Big Windy Creek was of interest because of the anomalous uranium values reported by Barker and Clautice (1977) from the geologically similar Mount Prindle area $120 \mathrm{~km}$ to the west. The Mount Prindle granitic pluton intrudes metamorphic rocks consisting dominantly of quartzite and micaceous quartzite. An artesian spring system occurs in the metamorphic rocks at a fault contact with the Mount Prindle granitic pluton. Barker and Clautice (1977) report uranium concentrations of stream sediments as high as $400 \mathrm{ppm}$ and of spring sediments as high as $570 \mathrm{ppm}$; they do not report any water analyses. The uranium concentrations of $1.0 \mathrm{ppb}$
$(0.001 \mathrm{mg} / \mathrm{L}$, table 2$)$ in the lower temperature water from the hot spring along Big Windy Creek shows that uranium is present in a concentration significant for a thermal spring.

\section{REFERENCES CITED}

Barker, J. C., and Clautice, K. H., 1977, Anomalous uranium concentrations in artesian springs and stream sediments in the Mount Prindle area, Alaska: U.S. Bureau of Mines Open-File Report 130-77, 19 p.

Brown, Eugene, Skougstad, M. W., and Fishman, M. J., 1970, Methods for collection and analysis of water samples for dissolved minerals and gases: U.S. Geological Survey Water Resources Investigation Techniques, Book 5, chapter $\mathrm{A} 1,160 \mathrm{p}$.

Craig, Harmon, 1953, The geochemistry of the stable carbon isotopes: Geochimica et Cosmochimica Acta, v. 3, p. $53-92$.

- 1961, Isotopic variations in meteoric water: Science, v. 133 , p. $1702-1703$.

Keith, T. E. C., and Foster, H. L., 1979, Big Windy Creek hot springs, Circle A-1 quadrangle, Alaska, in Johnson, K. M., and Williams, J. R. eds., United States Geological Survey in Alaska: Accomplishments during 1978: U.S. Geological Survey Circular 804-B, p. B55-B57.

Miller, T. P., Barnes, Ivan, and Patton, W. W., Jr., 1975, Geologic setting and chemical characteristics of hot springs in west-central Alaska: U.S. Geological Survey Journal of Research, v. 3, no. 2, p. 149-162.

Presser, T. S., and Barnes, Ivan, 1974, Special techniques for determining chemical properties of geothermal water: U.S. Geological Survey Water-Resources Investigations $22-74,11 \mathrm{p}$.

Laumontite occurrence in the Circle A-1 quadrangle, Alaska By Terry E. C. Keith, Ivan Barnes, and Helen L. Foster

Several fist-size chunks of massive laumontite float were found in the northwest part of the Circle A-1 quadrangle during reconnaissance mapping in the summer of 1978 . Because massive laumontite is of potential economic interest, the area was revisited in July 1979 to investigate the possible extent and origin of the laumontite. Identification of the laumontite (leonhardite) was confirmed by X-ray diffraction and optical properties. Laumontite was found in outcrop as steeply dipping to vertical intersecting veins in nearly horizontally foliated schist. The veins are several centimeters to several tens of centimeters wide, and some of the longer veins are exposed a verti- 
cal distance of 5 to $10 \mathrm{~m}$ along a steep canyon wall for a horizontal distance of about $100 \mathrm{~m}$. Some veins have a narrow contact zone where the laumontite permeates the host rock. The schistose country rock has a mineral assemblage consisting dominantly of quartz, plagioclase, chlorite, muscovite, phlogopite, biotite, tremolite, and diopside. Other metamorphic rock types that crop out in the area include quartzite, several kinds of quartz-mica schist, marble, and minor amphibolite.

A granitic pluton crops out only a few kilometers west and northwest of the laumontite-veined area. The hot springs of Big Windy Creek (Keith and others, 1980) are presently active on the north side of the pluton. We postulate that the laumontite may have crystallized from mineral constituents derived from ground water circulating through metamorphic rocks in a former hotspring system, perhaps not unlike the hot springs on Big Windy Creek. In fact, the chemical and isotopic data from the hot springs along Big Windy Creek (table 2, Keith and others, 1980) can be used to explain the laumontite occurrence.

The $\delta^{13} \mathrm{C}$ values $(-0.01 \%$ and $-1.55 \%$ of the dissolved carbon species in the hot-spring waters at Big Windy Creek indicate that the bicarbonate originated from a marine carbonate (Craig, 1953). Marble derived from marine carbonate is commonly interlayered in the schists near the springs at Big Windy Creek and near the laumontite locality.

Most of the constituents of the hot-spring water of the Big Windy Creek springs can be explained by reaction of heated meteoric water (Keith and others, 1981) on an underlying marine carbonate some residual metamorphic brine, and some leaching of the feldspars of the granitic rocks. Most mineral constituents of the other interlayered metamorphic rocks, most of which are fairly quartzitic, are stable under the conditions of these reactions.

The reaction of the hot-spring water with the $\mathrm{CaCO}_{3}$-rich marble of the metamorphic rock sequence and the feldspar of the granitic rocks should yield abundant $\mathrm{HCO}_{3}$ and $\mathrm{Ca}^{+2}$ into solution. The amount of $\mathrm{HCO}_{3}$ actually present in the waters indicates that much more $\mathrm{Ca}^{+2}$ should be in solution than is actually present (Keith and others, 1981). Therefore, the $\mathrm{Ca}^{+2}$ must be coming out of solution as a noncarbonate compound. Concentrations of $\mathrm{Na}^{+}$and $\mathrm{Cl}^{-}$in solution are high. If we attribute the $\mathrm{Cl}^{-}$and the corresponding $\mathrm{Na}^{+}$to metamorphic brine, a high $\mathrm{Na}^{+}$concentration still remains in the hot-spring water.

The formation of albite from the spring waters would require much more $\mathrm{Si}^{+4}$ than is available, so $\mathrm{Na}^{+}$stays in solution. Because the water (especially the warmer water) is unsaturated with respect to $\mathrm{SiO}_{2}$, the $\mathrm{SiO}_{2}$ may be combining with $\mathrm{Ca}^{+2}$ to form a calcium silicate mineral. Aluminum was not analyzed in the water, but a logical conclusion from the breakdown of aluminosilicates, primarily feldspars, is that $\mathrm{Al}^{+3}$ is involved in the reaction. Therefore, we conclude that a calcium aluminum silicate mineral is coming out of solution and that this may be laumontite or a structureless laumontite precursor.

Although no laumontite is presently being precipitated by the Big Windy Creek hot springs, a patchy thin coating of amorphous silica, iden. tified by scanning electron microscope, occurs in some places on carbonate of the travertine deposits. As postulated by Barnes, Downes, and Huston (1978, p. 1423), the formation of laumontite may not be by direct precipitation but perhaps through a silica gel precursor. The chemistry of the waters from the springs along Big Windy Creek is very similar to that from several hot springs in New Zealand from which laumontite is being deposited (Barnes and others, 1978, p. 1417).

The laumontite vein deposits may be a result of former hot-spring activity in the area. The amount of laumontite probably is not great, and further consideration of economic potential is not warranted.

\section{REFERENCES CITED}

Barnes, Ivan, Downes, C. J., and Huston, J. R., 1978, Warm springs. South Island, New Zealand, and their potentials to yield laumontite: American Journal of Science, v. 278, p. 1412-1427.

Craig, Harmon, 1953, The geochemistry of the stable carbon isotopes: Geochimica et Cosmochimica Acta, v. 3, p. 53-92.

Keith, T. E. C., Presser, T. S., and Foster, H. L., 1981, New chemical and isotopic data for the hot springs along Big Windy Creek, Circle A-1 quadrangle, Alaska, in Albert, N. R. D., and Hudson, Travis, eds., The United States Geological Survey in Alaska: Accomplishments during 1979: U.S. Geological Survey Circular 823-B, p. B25-B28. 
Gcologic reconnaissance of the east half of Kantishna River quadrangle and adjacent areas

By Robert M. Chapman and Warren Yeend

A preliminary geologic map of the east half of the Kantishna River quadrangle and adjacent parts of the Kantishna River and Mount McKinley quadrangles has been made (fig. 17). Five units of Quaternary unconsolidated deposits and eight bedrock units are distinguished. The interpretations of these units and their ages are tentative because laboratory studies of the 1979 samples are incomplete.

Much of the east half of the Kantishna River quadrangle can be characterized as a great sea of sand and silt blanketing a chert terrane. The dune
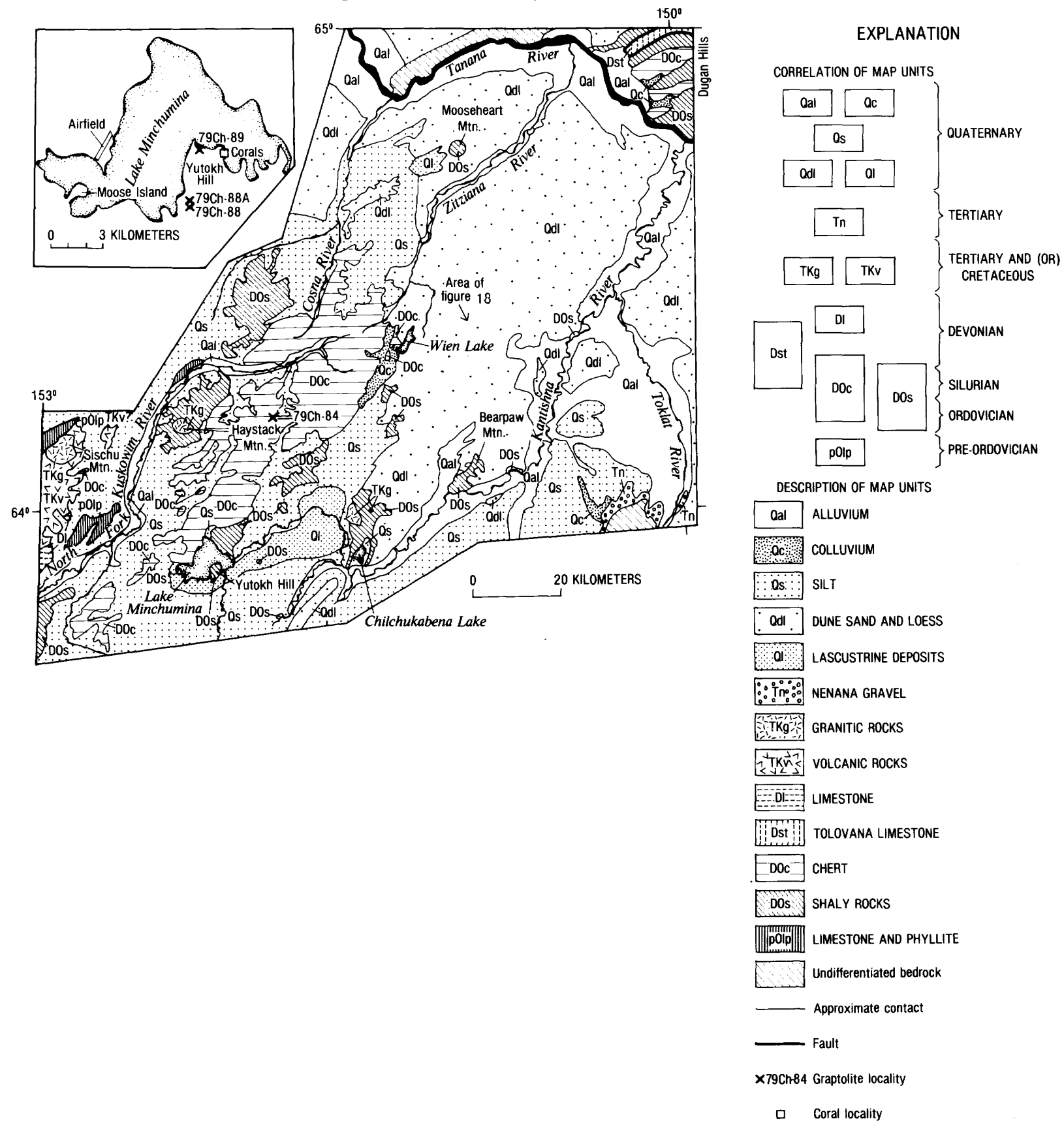

FIGURE 17.-Preliminary geologic map of east half of Kantishna River quadrangle and adjacent areas. 
sand and loess unit includes both medium- and fine-grained sand dunes, some silt dunes, massive silt deposits, particularly on windward slopes, and relatively thin veneers of silt. The linear dunes trend southwest, are commonly several kilometers long and 8 to $20 \mathrm{~m}$ high, and have rounded tops (fig. 18). Silt, more than $1.5 \mathrm{~m}$ thick, conceals bedrock on the lower hills between the Cosna and Kantishna Rivers. Clearly the sand and silt were derived from flood plains of the ancestral Tanana River system and distributed by winds from the northeast. A larger, ancestral Lake Minchumina may have occupied the lowlands that are now dotted by many small lakes. Beach deposits have not been identified, but the morphology of the clay, silt, sand, and gravel deposits near Lake Minchumina and near Mooseheart Mountain suggests a lacustrine origin.

Bedrock exposures are scarce and discontinuous in much of the area, owing to extensive vegetation and surficial deposit cover and generally low relief. Contacts are concealed and therefore are approximate. Some suspected fault contacts are not shown on figure 17.

The limestone and phyllite unit in the vicinity of Sischu Mountain includes impure limestone, dolomite, greenish-gray phyllite, and silty shale, all of very low metamorphic grade. Firm age data are lacking for these rocks, but the rocks are coextensive, at least in part, with probable preOrdovician rocks exposed 10 to $20 \mathrm{~km}$ to the west.

A unit of shaly rocks apparently underlies the

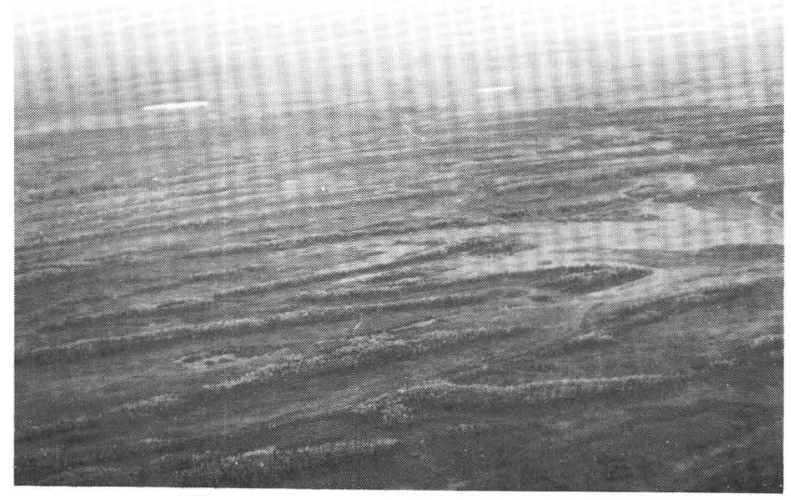

FIGURE 18.-Aerial view to southeast over vegetated linear sand dunes east of Zitziana River, Kantishna River quadrangle. (See fig. 17 for location.) chert unit and includes siltstone-mudstoneargillite, shaly-slaty-phyllitic mudstone, maroon and green slaty argillite, grit, quartzite, calcareous quartz-chert arenite, sandy limestone, and minor amounts of chert, and quartz-mica schist. Ordovician graptolites and an Ordovician coral occur in one part of this section. A coral of "probably Early or Middle Devonian" age (W. A. Oliver, written commun., 1979), found in a lakeshore cobble, also may have come from this unit. An age range of Ordovician to Middle Devonian(?) is provisionally assigned to the chert and shaly rocks, although some pre-Ordovician rocks may be included in the lower part of the shaly rocks. Ages and suggested regional correlations of these two units are discussed more fully in the following paper (Chapman and others, 1981).

A chert unit, which forms a northeast-trending belt of prominent hills between the North Fork of Kuskokwim River and the Zitziana River, includes gray thin- to thick-bedded chert with thin interbeds of silceous siltstone, shaly to slaty mudstone, and shaly tuffaceous argillite. These rocks generally weather to a light and moderate reddish brown and yellowish orange. Radiolarians of early Paleozoic age occur in both the chert and argillaceous rocks, and Ordovician graptolites were found in thin shale beds at one site (fig. 17).

Two limestone units have been identified: Devonian limestone, which is coextensive with a limestone unit of Givetian to Frasnian age in the adjacent Medfra quadrangle (Dutro and Patton, 1981), and the Tolovana Limestone of Silurian and Devonian age, which forms a klippe in the Dugan Hills (Chapman and others, 1975).

Granitic rocks at Sischu, Haystack, and Bearpaw Mountains and near Chilchukabena Lake are included in one unit and provisionally assigned Cretaceous and (or) Tertiary ages pending completion of petrologic and geochronologic studies. A K-Ar age of $64 \pm 2 \mathrm{~m}$.y. has been reported for quartz monzonite from Haystack Mountain (Silberman and others, 1979). All of these granitic rocks are coarse grained and commonly porphyritic. On the basis of field identifications, the rocks at Sischu and Haystack Mountains range from quartz monzonite to diorite. Porphyritic granite forms the pluton near Chilchukabena Lake, and the Bearpaw Mountain outcrops were tentatively identified as porphyritic granite.

The unit of volcanic rocks near Sischu Mountain 
includes rhyolite, dacite, andesite, and some basaltic rocks. Silberman and others assigned this unit a Cretaceous and (or) Tertiary age on the basis of 70- and 71-m.y. whole-rock K-Ar ages of rhyolite from this unit in an adjacent area to the southwest in the Medfra quadrangle.

The Nenana Gravel of Miocene and Pliocene age (Wolfe and Tanai, 1980), a weakly consolidated unit of pebble-cobble polymictic conglomerate with some interbedded sandstone and claystone, forms low, terracelike hills that flank the north end of the Kantishna Hills in the southeast corner of the Kantishna River quadrangle. The southward continuation of this unit has been mapped by Bundtzen and Turner (1979).

\section{REFERENCES CITED}

Bundtzen, T. K., and Turner, D. L., 1979, Geochronology of metamorphic and igneous rocks in the Kantishna Hills, Mount McKinley quadrangle, Alaska, in Short notes on Alaskan geology-1978: Alaska Division of Geological and Geophysical Surveys Geologic Report 61, p. 25-30.

Chapman, R. M., Churkin, Michael, Jr., Carter, Claire, and Trexler, J. H., Jr., 1981, Ordovician graptolites and early Paleozoic radiolarians in the Lake Minchumina area date a regional shale and chert belt, in Albert, N. R. D., and Hudson, Travis, eds., The United States Geological Survey in Alaska: Accomplishments during 1979: U.S. Geological Survey Circular 823- B, p. B32- B34.

Chapman, R. M., Yeend, W. E., and Patton, W. W., Jr., 1975, Preliminary reconnaissance geologic map of the western half of Kantishna River quadrangle, Alaska: U.S. Geological Survey Open-File Report 75-351, scale 1:250,000.

Dutro, J. T., Jr., and Patton, W. W., Jr., 1981, Lower Paleozoic platform carbonate sequence in the Medfra quadrangle, west-central Alaska, in Albert, N. R. D., and Hudson, Travis, eds., The United States Geological Survey in Alaska: Accomplishments during 1979: U.S. Geological Survey Circular 823-B, p. B42-B44.

Péwé T. L., Wahrhaftig, Clyde, and Weber, F. R., 1966, Geologic map of the Fairbanks quadrangle, Alaska: U.S. Geological Survey Miscellaneous Geologic Investigations Map I-455, scale 1:250,000.

Silberman, M. L., Moll, E. J., Chapman, R. M., Patton, W. W., Jr., and Connor, C. L., 1979, Potassium-argon age of granitic and volcanic rocks from the Ruby, Medfra, and adjacent quadrangles, west-central Alaska, in Johnson, $\mathrm{K}$. M., and Williams, J. R., eds., The United States Geological Survey in Alaska: Accomplishments during 1978: U.S. Geological Survey Circular 804-B, p. B63-B66.

Wolfe, J. A., and Tanai, Toshimasa, 1980, The Miocene Seldovia Point flora from the Kenai Group, Alaska: U.S. Geological Survey Professional Paper 1105, 52 p.
Ordovician graptolites and early Paleozoic radiolarians in the Lake Minchumina area date a regional shale and chert belt

By Robert M. Chapman, Michael Churkin, Jr., Claire Carter, and James $H$. Trexler, Jr.

Graptolites and radiolarians discovered in 1979 in the Lake Minchumina area provide new paleontologic age data for the shaly rocks unit and the chert unit that lie in a northeast-trending belt between the North Fork of Kuskokwin and Kantishna Rivers (fig. 17). An Ordovician age has been assigned to the graptolites by Claire Carter, and an early Paleozoic age for the radiolarians has been determined by David L. Jones.

A sequence of interbedded siltstone, argillite, shaly-slaty-phyllitic mudstone, and some quartzitic sandstone and chert at the base of the western and northwestern slopes of Yutokh Hill at Lake Minchumina is part of the shaly rocks unit. These beds strike generally northeast and dip both north and south. A reliable determination of the structure and thickness could not be made because of discontinuous exposures and many slumped outcrops. No faults were identified. Two collections of graptolites from thin shale beds near the south end of the small hill south of Yutokh Hill (inset map, fig. 17) contain Orthoretiolites hami Whittington and Orthograptus ssp., a fauna that approximately correlates with the Climacograptus tubuliferus Zone of Middle Ordovician age (79Ch-88), and unidentifiable biserial graptolites of probable Ordovician age (79Ch-88A). A third collection (79Ch-89), from thin shale beds exposed at the shoreline on the northwest side of Yutokh Hill, contains very poorly preserved specimens of Orthograptus(?) cf. O. quadrimucronatus (Hall), indicating approximately the C. tubuliferus Zone of Middle Ordovician age.

Saffordophyllum sp., a coral that ranges from Middle to Late Ordovician (Oliver and others, 1975), has been found in a bedrock section of calcareous quartz-chert arenite, siltstone, and phyllitic shale on the northeast side of Yutokh Hill at the shoreline. Another coral was found here in 1978 in a beach cobble that is lithologically similar to the local bedrock. W. A. Oliver, Jr., (written commun., 1979) identifies it as probably Xys- 
triphyllum and of Early or Middle Devonian age. According to Oliver, this coral has some features that are unusual for this genus, but it nevertheless belongs to the family Ptenophyllidae, which is primarily of Devonian age but extends into the Silurian, and it is morphologically too complex to be as old as Ordovician. This coral-bearing beach cobble, however, could have been ice rafted or transported by other means and its lithology cannot be unequivocally related to the local bedrock.

A sequence of interbedded very fine to finegrained light-gray partly conglomeratic quartzite, siliceous siltstone, argillite, phyllite, slaty shale, and some sandy limestone on the eastern shore of Lake Minchumina is interpreted, in the absence of fossil evidence, to be part of the shaly rocks unit. The stratigraphic relation of this sequence to that at Yutokh Hill is uncertain. Lithologically similar rocks that are discontinuously exposed to the northeast are provisionally assigned to this unit. The chert unit, consisting of chert, silicic mudstone, and some thin beds of shaly argillaceous and tuffaceous(?) rocks, forms a broad belt immediately north of the shaly rocks unit (fig. 17).

Another graptolite discovery was made in 1979, about $36 \mathrm{~km}$ north of Lake Minchumina (fig. 17). Here, in the chert unit, Carter has identified Pseudoclimacograptus(?) sp., and Didymograptus(?) sp., of Middle(?) Ordovician age (79Ch$84)$. These specimens are fragmentary and not well enough preserved to date these rocks more accurately.

Radiolarians are abundant in many of the chert and argillaceous beds of the chert unit. Although studies of the radiolarian-bearing samples from this unit are incomplete, preliminary identifications of some of the radiolarians by D. L. Jones (oral commun., 1980) indicate an early Paleozoic age (Ordovician to Early Devonian) for the rocks.

The chert unit is provisionally interpreted from field observations to overlie the unit of shaly rocks, and both units are assigned an early Paleozoic age. The contact between these two units was not found, but the presence of some interbedded chert in the sections at Yutokh Hill and Moose Island may indicate a gradational contact. Both units are structurally complex, and more de- tailed studies are needed to determine thickness and the stratigraphic positions of the fossiliferous beds. The chert unit was partly mapped in 1974 as a chert and slate unit of Ordovician age (Chapman and others, 1975; U.S. Geological Survey, 1975 ) on the basis of regional lithologic correlations with the Livengood Dome Chert of Late Or. dovician age in the Livengood area (Chapman and others, 1980). Generally similar units with the same stratigraphic relation occur in the Dugan Hills (fig. 17) where a chert and slaty shale unit overlies a unit of maroon and green argillite and slate with quartzite, grit, and some phyllite. These units have been interpreted as Ordovician and Cambrian or Ordovician in age, respectively, (Chapman and others, 1975); in earlier work (Péwé and others, 1966) they were mapped as units in the Nilkoka Group with, respectively, Cambrian or Ordovician, and pre-Ordovician and, possibly, late Precambrian age.

The chert and shaly rocks units of the Lake Minchumina area fall within, and help to confirm the existence of, an arcuate belt of discontinuously exposed rocks of similar age and lithology that extends across central Alaska from the Canadian border. This belt includes the Ordovician to Devonian Road River Formation in the Charley River area (Brabb and Churkin, 1969), the Livengood Dome Chert in the Livengood area (Chapman and others, 1980), and the lower Paleozoic rocks in the Terra Cotta Mountains 90 $\mathrm{km}$ southwest of Lake Minchumina (Churkin and others, 1977). We believe that this belt of rocks is part of a major Paleozoic shale-out that marks the western margin of the North American continental plate. This Paleozoic margin can be traced from east-central Alaska into the Selwyn Basin of Yukon Territory, and from there south through British Columbia, Idaho, Nevada, and into southern California where it terminates against the San Andreas fault system.

\section{REFERENCES CITED}

Brabb, E. E., and Churkin, Michael, Jr., 1969, Geologic map of the Charley River quadrangle, east-central Alaska: U.S. Geological Survey Miscellaneous Geologic Investigations Map I-573, scale 1:250,000. 
Chapman, R. M., Weber, F. R., Churkin, Michael, Jr., and Carter, Claire, 1980, The Livengood Dome Chert, a new Ordovician formation in central Alaska, and its relevance to displacement on the Tintina fault, in Shorter contributions to stratigraphy and structural geology, 1979: U.S. Geological Survey Professional Paper 1126-F, p. F1-F13.

Chapman, R. M., Yeend, W. E., and Patton, W. W., Jr., 1975, Preliminary reconnaissance geologic map of the western half of Kantishna River quadrangle, Alaska: U.S. Geological Survey Open-File Report 75-351, scale 1:250,000.

Churkin, Michael, Jr., Reed, B. L., Carter, Claire, and Winkler, G. R., 1977, Lower Paleozoic graptolitic section in the Terra Cotta Mountains, southern Alaska Range, in Blean, K. M., ed., The United States Geological Survey in Alaska: Accomplishments during 1976: U.S. Geological Survey Circular 751-B, p. B37-B38.

Oliver, W. A., Jr., Merriam, C. W., and Churkin, Michael, Jr., 1975, Ordovician, Silurian, and Devonian corals of Alaska: U.S. Geological Survey Professional Paper 823-B, p. 24.

Péwé, T. L., Wahrhaftig, Clyde, and Weber, F. R., 1966, Geologic map of the Fairbanks quadrangle, Alaska: U.S. Geological Survey Miscellaneaous Geologic Investigations Map I-455, scale 1:250,000.

U.S. Geological Survey, 1975, Geological Survey Research 1975: U.S. Geological Survey Professional Paper 975, p. 67.

Geochronologic studies in the Yukon-Tanana Upland, eastcentral Alaska

By John N. Aleinikoff, Cynthia Dusel-Bacon, and Helen L. Foster

A U-Th-Pb geochronologic study of igneous and metamorphic rocks in the geologically complex terrane of the Yukon-Tanana Upland was begun in 1978. Prior to this investigation, K-Ar and very limited $\mathrm{Rb}-\mathrm{Sr}$ radiometric dating had been done on some rocks in this area (Dadisman, 1980). Because widespread tectonism, metamorphism, and Mesozoic and Tertiary plutonism apparently have reset many of the $\mathrm{K}$-Ar systems to very young ages, the true ages of many of the igneous and metamorphic rocks in this region are uncertain or unknown. In this study, the U-Th- $\mathrm{Pb}$ method has been used to date an augen gneiss in the Big Delta quadrangle and granodiorite from the Taylor Mountain batholith in the Eagle and Tanacross quadrangles.

The most detailed geochronologic study has been conducted on a large body of augen gneiss, approximately $700 \mathrm{~km}^{2}$ in surface outcrop, in the southeastern part of the Big Delta quadrangle (Weber and others, 1978). The gneiss is characterized by large $(3$ to $7 \mathrm{~cm}$ ) perthitic microcline augen set in a cataclastic to recrystallized matrix of quartz+plagioclase+biolite +white mica \pm $\mathrm{K}$-feldspar with accessory zircon+apa- tite + sphene \pm garnet + opaque minerals. On the basis primarily of textural evidence (Dusel-Bacon and Aleinikoff, 1980; Dusel-Bacon and others, 1979) and the presence of xenoliths at a few localities, the augen gneiss is considered to be a deformed and metamorphosed porphyritic granitic pluton in which the augen represent porphyroclastic megacrysts. Some of the augen retain their original idiomorphic habit, although most have been severely deformed and stretched. Field relations within and around the augen gneiss are unclear, and contacts are poorly exposed. No age assignments could be made during the course of reconnaissance mapping, but Weber and others (1978) state that the protolith of the augen gneiss may have been of Precambrian or Paleozoic age.

$\mathrm{U}-\mathrm{Th} \cdot \mathrm{Pb}$ isotopic data for the augen gneiss are presented in table 3 and plotted in figure 19. Standard techniques for analysis of $\mathrm{U}, \mathrm{Th}$, and $\mathrm{Pb}$ were used, including ion-exchange chemistry (Krogh, 1973) and mass spectrometry (Cameron and others, 1969). Figure 19 is a concordia plot of nine size fractions of zircons from four samples of augen gneiss. Seven of the fractions (with ${ }^{207} \mathrm{~Pb} /{ }^{206} \mathrm{~Pb}$ ages ranging from 523 to 1,420 m.y.) form a linear array. ${ }^{207} \mathrm{~Pb} /{ }^{206} \mathrm{~Pb}$ ages are directly correlative with grain size. The largest size fractions whose zircons frequently contain sizable cores have the oldest ${ }^{207} \mathrm{~Pb} /{ }^{206} \mathrm{~Pb}$ ages, and suc. cessively smaller size fractions are younger. Furthermore, dark grains within a particular size fraction appear to have older ${ }^{207} \mathrm{~Pb} /{ }^{206} \mathrm{~Pb}$ ages than light-colored grains (compare samples AG2 $(+100)$ LT and AG2 $(+100)$ DK, table 3$)$. A best-fit line through these points has intercepts with concordia of about $345 \mathrm{~m} . \mathrm{y}$. and 2,300 m.y. However, because the points plot so close to the lower intercept, the calculated upper intercept has considerable uncertainty. Two other points plot slightly below the line. These samples (AG1 $(+100)$ DK and AG4 $(-100+150)$ DK) were chosen for analysis because they are large and dark and might have plotted farther toward the upper intercept on the best-fit line. However, their ${ }^{207} \mathrm{~Pb} /{ }^{206} \mathrm{~Pb}$ ages of $1,210 \mathrm{~m} . \mathrm{y}$. and $1,220 \mathrm{~m} . \mathrm{y}$., respectively, are not the oldest, and they plot slightly below the best-fit line. We suggest that the recent loss of a small amount of lead from these large metamict crystals accounts for the shift toward the origin from the best-fit line.

Two interpretations of these data are consi- 
dered: (1) the granitic protolith of the augen gneiss is of early Proterozoic age and was severely affected by a metamorphic event about 350 m.y. ago (Weatherill's model for episodic loss of lead, 1956 ); or (2) the protolith of the augen gneiss crystallized $350 \mathrm{~m} . \mathrm{y}$. ago, and the zircons contain significant quantities of inherited radiogenic lead from Proterozoic rocks. The linearity of the data and the correlation of large (perhaps magmatic) zircons with old ages and small (perhaps metamorphic) zircons with young ages seem to support the first interpretation. The extreme degree of discordance displayed by these zircons is very unusual. However, the position of the data points on the best-fit line is probably due to the combined effects of lead loss in the old Proterozoic cores and young overgrowths that formed 350 m.y. ago. Additonal isotopic analyses of areally related rocks, both intrusions into the gneiss and possible wallrocks, as well as dating attempts using other geochronological techniques, such as $\mathrm{Rb}-\mathrm{Sr}$ and $\mathrm{Sm}-\mathrm{Nd}$, are being undertaken in order to arrive at an unequivocal age detemination. The old ${ }^{207} \mathrm{~Pb} /{ }^{206} \mathrm{~Pb}$ ages do indicate, however, that the protolith crystallized in Proterozoic time, or it was derived from or assimilated Proterozoic rocks.

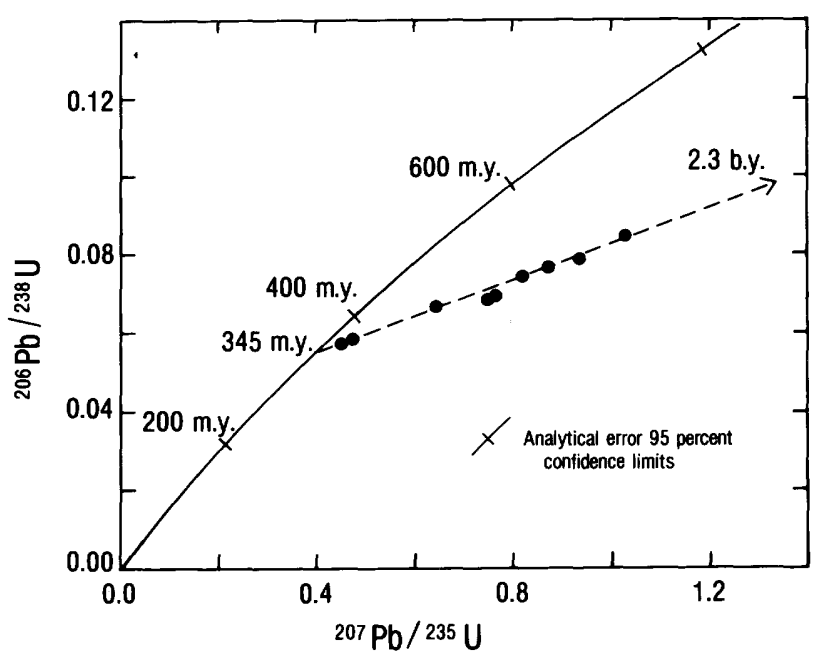

FIGURE 19.-Concordia diagram ( solid line formed by locus of points showing evolution of paired $\mathrm{U} \cdot \mathrm{Pb}$ isotope ratios through time) for zircons from augen gneiss, Big Delta quadrangle. Calculation of best-fit line (dashed) does not include two points below line. See text for explanation.

TABLE 3.-U-Th-Pb isotopic data for the augen gneiss, Big Delta quadrangle and the Taylor Mountain batholith, Eagle and Tanacross quadrangles

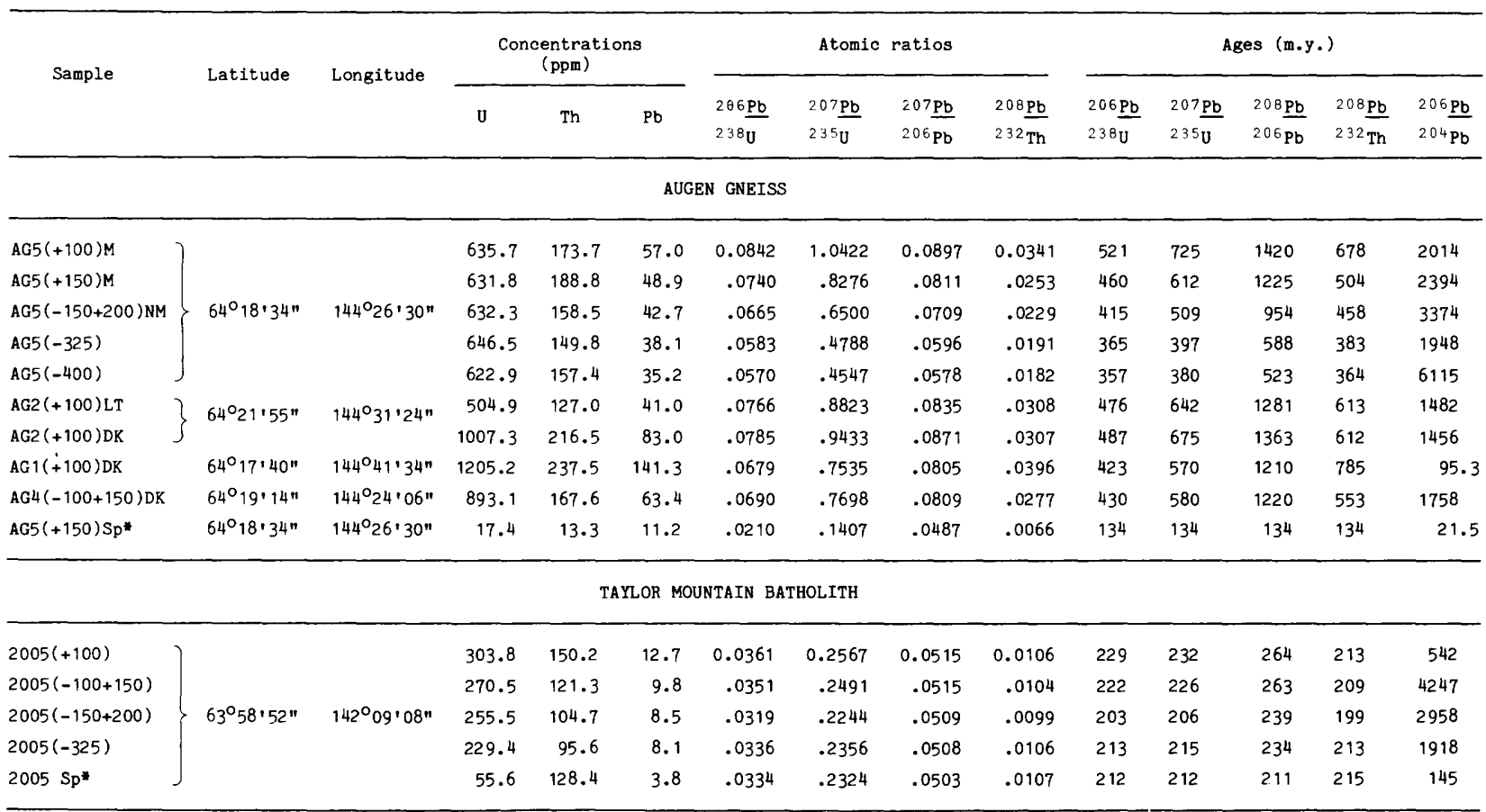


In an effort better to define the timing of metamorphic events affecting the augen gneiss, a sphene sample (AG5 (+150) Sp) was analyzed. All of its U-Th-Pb ages are 134 m.y., almost surely reflecting a partial resetting of some older age by the event or events that reset many $\mathrm{K}$-Ar ages (Foster and others, 1976, 1979).

Zircon and sphene from granodiorite of the Taylor Mountain batholith, a body composed primarily of unfoliated granodiorite with some quartz monzonite, quartz diorite, diorite, and lamprophyre dikes (Foster and others, 1976), were also dated. Previous K-Ar dating of hornblende and biotite by J. G. Smith (Foster and others, 1976) suggested that the batholith was about 195 m.y. old, one of the oldest known undeformed granitic bodies in the upland. $\mathrm{U}-\mathrm{Th}-\mathrm{Pb}$ dating was undertaken to determine the reliability of $\mathrm{K}-\mathrm{Ar}$ ages in the region and to provide information on early Mesozoic and possibly pre-Mesozoic geologic events in the region.

Four size fractions of zircon from one sample of the Taylor Mountain batholith were analyzed. The results are listed in table 3 . The data are scattered and show no linearity. ${ }^{207} \mathrm{~Pb} /{ }^{206} \mathrm{~Pb}$ ages range from 234 to $264 \mathrm{~m}$.y. This data array may be due to either Mesozoic metamorphism of a Paleozoic intrusion, followed by more recent loss of lead, or to inherited radiogenic lead in a Mesozoic intrusion that recently lost lead (see Higgins and others, 1977, for a theoretical treatment of complex isotopic systematics involving inherited lead). The very fresh, unfoliated nature of the rock suggests that the second explanation is probably correct. One analyzed sphene sample from the granodiorite (table 3 ) has a concordant age of 212 m.y. To the east in the Yukon Territory of Canada, the Klotassin batholith, which Tempelman-Kluit (1976, p. 1350) considers equivalent to the Taylor Mountain batholith, has been assigned an approximate age of $210 \mathrm{~m} . \mathrm{y}$. on the basis of $\mathrm{K}$-Ar analyses of boulders in a Lower Jurassic conglomerate (Morrison and others, 1979). Therefore, we conclude that the Taylor Mountain batholith is also Triassic and that it crystallized about $210 \mathrm{~m} . \mathrm{y}$. ago. At least two younger thermal events, 90-110 m.y. and 45-65 m.y. (Foster and others, 1976, 1979), may be responsible for the partial resetting of $\mathrm{K}$-Ar ages for the batholith.

We believe that the existing $\mathrm{U}-\mathrm{Th}-\mathrm{Pb}$ age data, considered in conjunction with previous determined K-Ar ages, indicate at least four and possibly five thermal events that took place since the early Proterozoic. These include an early Proterozoic event (approximately 2.3 b.y.), a middle Paleozoic event (350 m.y.), a Triassic event ( 210 m.y.), and the two young events indicated by K-Ar dating (90-110 m.y. and 45-65 m.y.). These results show that $\mathrm{U}-\mathrm{Th}-\mathrm{Pb}$ radiometric data, used with data from other dating methods and petrographic studies, can make a significant contribution to our understanding of the complex geologic history of the Yukon-Tanana Upland.

\section{REFERENCES CITED}

Cameron, A. E., Smith, D. H., and Walker, R. L., 1969, Mass spectrometry of nanogram-size samples of lead: Analytical Chemistry, v. 41 , p. $525-526$.

Dadisman, S. V., 1980, Radiometric ages of rocks in southcentral Alaska and western Yukon Territory: U.S. Geological Survey Open-File Report 80-183, 82 p., scale $1: 1,000,000$.

Dusel-Bacon, Cynthia, and Aleinikoff, J. N., 1980, Proterozic cataclastic augen gneiss in the southeastern part of the Big Delta quadrangle, Yukon-Tanana upland, east-central Alaska: Geological Society of America Abstracts with Programs, v. 12, no. 3, p. 104-105.

Dusel-Bacon, Cynthia, Stern, T. W., Foster, H. L., and Bentz, J. L., 1979, Preliminary results of an augen gneiss study, Big Delta quadrangle, in Johnson, K. M., and Williams, J. R., eds., The United States Geological Survey in Alaska: Accomplishments during 1978: U.S. Geological Survey Circular 804- B, p. B57- B59.

Foster, H. L., Albert, N. R. D., Barnes, D. F., Curtin, G. C., Griscom, Andrew, Singer, D. A., and Smith, J. G., 1976, The Alaska Mineral Resources Assessment Program: Background information to accompany folio of geologic and mineral resources maps of the Tanacross quadrangle, Alaska: U.S. Geological Survey Circular 734, 23 p.

Foster, H. L., Albert; N. R. D., Griscom, Andrew, Hessin, T. D., Menzie, W. D., Turner, D. L., and Wilson, F. H., 1979, The Alaska Mineral Resources Assessment ProgramBackground information to accompany folio of geologic and mineral resource maps of the Big Delta quadrangle, Alaska: U.S, Geological Survey Circular 783,19 p.

Higgins, M. W., Sinha, A. K., Zartman, R. E., and Kirk, W. S., 1977, U-Pb zircon dates from the central Appalachian Piedmont: A possible case of inherited radiogenic lead: Geological Society of America Bulletin, v. 88, p. 125- 132. 
Krogh, T. E., 1973, A low-contamination method for hydrothermal decomposition of zircon and extraction of $\mathrm{U}$ and $\mathrm{Pb}$ for isotopic age determinations: Geochimica et Cosmochimica Acta, v. 37, p. 485-494.

Morrison, G. W., Godwin, C. I., and Armstrong, R. L., 1979, Interpretation of isotopic ages and ${ }^{87} \mathrm{Sr} /{ }^{86} \mathrm{Sr}$ initial ratios for plutonic rocks in the Whitehorse map area, Yukon: Canadian Journal of Earth Sciences, v. 16, p. 1988-1997.

Tempelman-Kluit, D. J., 1976, The Yukon crystalline terrane: Enigma in the Canadian cordillera: Geological Society of America Bulletin, v. 87, p. 1343-1357.

Weber, F. R., Foster, H. L., Keith, T. E. C., and Dusel-Bacon, Cynthia, 1978, Preliminary geologic map of the Big Delta quadrangle, Alaska: U.S. Geological Survey Open-File Report 78--529A, scale 1:250,000.

Wetherill, G. W., 1956, Discordant uranium-lead ages: American Geophysical Union Transactions, v. 37, p. 320-326.

A minimum age for Prindle Volcano, Yukon-Tanana Upland

By Helen L. Foster

Prindle Volcano is a small, isolated basaltic cone located in the midst of the metamorphic terrane of the eastern Yukon-Tanana Upland, Alaska (Tanacross $\mathrm{C}-2$ quadrangle). The volcano is made up of alkali-olivine basalt flows containing abundant inclusions of peridotite and granulite (Foster and others, 1966). It is of particular interest because of its apparent youth, its remoteness from other similar volcanoes, and the presence of abundant ultramafic and granulite inclusions. The well-preserved form of the volcano suggests that the eruptive activity occurred during Quaternary time (Foster and others, 1966).

A thin layer of white volcanic ash was discovered in 1979 on the lava flow emerging from the volcano's crater (fig. 20). The ash is probably the White River Ash Bed, a layer of white rhyodacite ash that covers large areas in the southwestern Yukon Territory and adjacent parts of east-central Alaska. Prindle Volcano lies in the northern lobe of the ash fall. This lobe has been dated at several localities by carbon-14 on materials obtained immediately above and below the ash. Dated ash at the locality nearest Prindle Volcano has an age of 1,750 \pm 110 years B.P. (Fernald, 1962), although other ages obtained in Yukon Territory suggest that this part of the ash was deposited between 1,850 and 1,900 years B.P. (Hughes and others, 1972). Therefore, a minimum age for lava flow from Prindle Volcano is about 1,850 to 1,900 years B.P.

The basaltic tuff of a small cinder cone about $200 \mathrm{~km}$ to the southeast in the Yukon Territory contains spinel lherzolite nodules very similar in composition to the peridotite inclusions of Prindle Volcano (Sinclair and others, 1978). This cone, also comparatively fresh and uneroded and retaining its constructional form, has not been glacially eroded, although its west edge has been cut by the Yukon River. The cone is mantled by the east lobe of the White River Ash Bed, but the lavas upon which the cone was built lie on unconsolidated glacial outwash and loess. Thus, this cone postdates early Pleistocene glacial deposits but, like Prindle Volcano, predates the ash, although the east lobe of the ash may be a little younger than that which mantles the lava flow at Prindle Volcano (Lerbekmo and Campbell, 1969).

Although these two volcanos are widely separated, their similarities suggest that they are about the same age. Thus Prindle Volcano may be post-early Pleistocene, but older than 1,900 years B.P.

\section{REFERENCES CITED}

Fernald, A. T., 1962, Radiocarbon dates relating to a widespread volcanic ash deposit, eastern Alaska: U.S. Geological Survey Professional Paper 450-B, p. B29-B30.

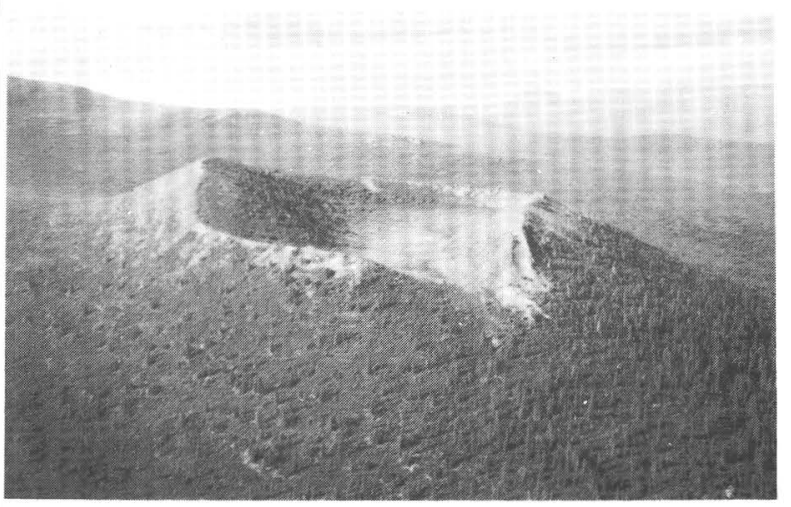

Figure 20.-View north of Prindle Volcano. Base of cone is about $1,006 \mathrm{~m}$ above sea level and is 900 to $1,067 \mathrm{~m}$ in diameter. Highest point on cone, about $1,250 \mathrm{~m}$, is on northwest rim of crater. Crater, breached on the south, is about $91 \mathrm{~m}$ deep. 
Foster, H. L., Forbes, R. B., and Ragan, D. M., 1966, Granulite and peridotite inclusions from Prindle Volcano, YukonTanana Upland, Alaska: U.S. Geological Survey Professional Paper 500-B, p. B115-B119.

Hughes, O. L., Rampton, V. N., and Rutter, N. W., 1972, Quaternary geology and geomorphology, southern and central Yukon (northern Canada): XXIV International Geological Congress, Excursion A-11, p. 20.

Lerbekmo, T. F., and Campbell, F. A., 1969, Distribution, composition, and source of the White River ash, Yukon Territory: Canadian Journal of Earth Sciences, v. 6, p. 109-116.

Sinclair, P. D., Tempelman-Kluit, D. J., and Mendaris, O. L. G., Jr., 1978, Lherzolite nodules from a Pleistocene cinder cone in central Yukon: Canadian Journal of Earth Sciences, v. 15, no. 2, p. 220-226.

Metalliferous mineral resource potential of the Big Delta quadrangle

By W. D. Menzie, H. L. Foster, and D. L. Mosier

The metalliferous mineral resource potential of the Big Delta quadrangle (Menzie and Foster, 1978) has been assessed by delineating eight tracts that are lithologically and geochemically permissive for the occurrence of mineral deposits by type (fig. 21). Several additional deposit types may occur, but tracts cannot be delineated on the basis of present information.

Production of metals from the quadrangle has

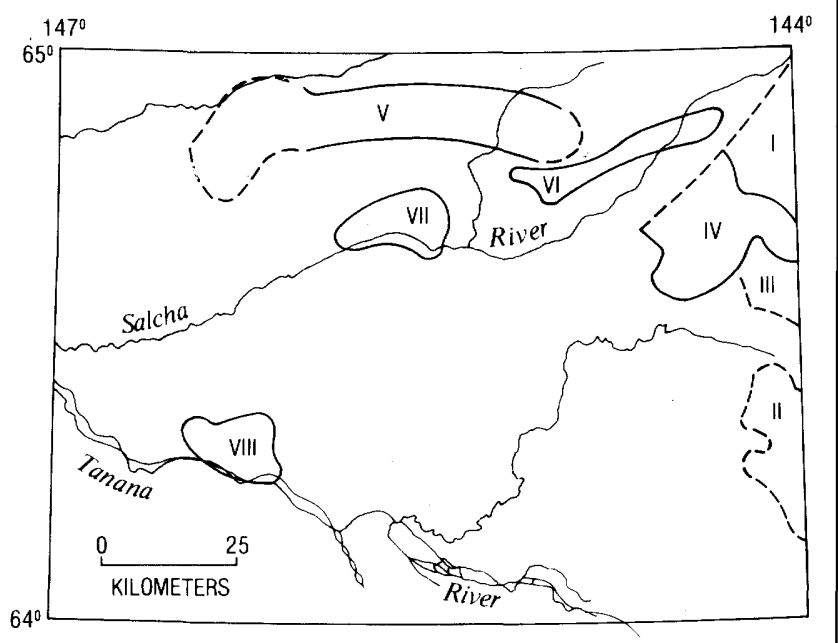

EXPLANATION

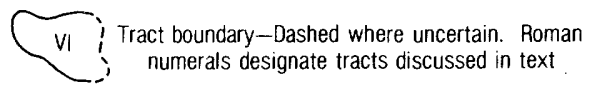

FIGURE 21.-Sketch map of Big Delta quadrangle showing tracts delineated as permissive for occurrence of mineral deposits. been confined to gold, mainly from placer deposits within tract VIII, but including minor production from other placers in tract VII and from vein deposits.

Two tracts (IV and V) contain units that are permissive for the occurrence of $\mathrm{Pb}-\mathrm{Zn} \pm \mathrm{Cu}$ bearing massive sulfide deposits associated with sedimentary and (or) volcanic rocks. Tract IV is underlain by a semischist unit of diverse lithology; protoliths include quartzose sedimentary rocks, limestone, mafic to intermediate volcanic rocks, volcaniclastic sedimentary rocks, shallow intrusive and possibly felsic volcanic rocks (Weber and others, 1978). The tract is characterized geochemically by anomalous levels of lead in stream sediments and oxide residue (O'Leary and others, 1978). In addition, tract IV contains scattered, minor sulfide occurrences. Tract $\mathrm{V}$ is characterized geochemically by anomalous levels of zinc in stream sediments and oxide residue samples. Levels of zinc as high as $750 \mathrm{ppm}$ were recorded in regional stream-sediment samples (O'Leary and others, 1978).

One tract (VI) was delineated as permissive for the occurrence of mafic volcanogenic deposits, mostly because the dominant rock type is greenstone, which locally contains abundant sulfides (Weber and others, 1978; Menzie and Foster, 1979). In addition, copper, lead, and zinc occur in anomalous levels in a few streamsediment samples from tract VI (O'Leary and others, 1978).

Three tracts (I, II, III) were delineated for the occurrence of porphyry copper deposits. These tracts contain lithologies, dominantly granitic rocks including felsic porphyritic rocks, that may permit the occurrence of such deposits; the tracts also contain anomalous levels of copper in stream-sediment samples (O'Leary and others, 1978). Experience to date suggests that Alaskan porphyry copper deposits are lower in grade and smaller in tonnage than other North American porphyry copper deposits (Singer and others, 1976 ); if these tracts contain porphyry copper deposits, the deposits may be expected to have low average grades and small tonnages.

Tract $I$ is also characterized by the presence of anomalous levels of tin and tungsten in pan concentrate samples and must be considered permissive for the occurrence of tin- and tungstenbearing veins and greisens. Areas in the Circle quadrangle adjacent to tract I also contain 
anomalous tin and tungsten in pan concentrates and have been recently staked and investigated by industry.

Areas of strongly anomalous geochemical samples and high concentrations of sulfide and other indications of minerlization are not known in the Big Delta quadrangle. Nevertheless, the quadrangle contains permissive geology, minor amounts of sulfides, and low-level, spatially concentrated geochemical anomalies, which may be useful pathfinders to undiscovered sulfide deposits.

\section{REFERENCES CITED}

Menzie, W. D., and Foster, H. L., 1978, Metalliferous and selected non-metalliferous mineral resource potential in the Big Delta quadrangle, Alaska: U.S. Geological Survey Open-File Report 78-529-D, 61 p.

O'Leary, R. M., Cooley, E. F., Day, G. W., Hessin, T. D., McDougal, C. M., McDanal, S. K., and Clark, A. L., 1978, Spectrographic and chemical analyses of geochemical samples from the Big Delta quadrangle, Alaska: U.S. Geological Survey Open-File Report 78-757.

Singer, D. A., Curtin, G. C., and Foster, H. L., 1976, Mineral resources of the Tanacross quadrangle, Alaska, 1976: U.S. Geological Survey Miscellaneous Field Studies Map MF767-E, scale 1:250,000.

Weber, F. R., Foster, H. L., Keith, T. E. C., and Dusel-Bacon, Cynthia, 1978, Preliminary geologic map of the Big Delta quadrangle, Alaska: U.S. Geological Survey Open-File Report 78-529-A, scale 1:250,000.

\section{WEST-CENTRAL ALASKA}

K-Ar age measurements on obsidian from the Little Indian River locality in interior Alaska

By Thomas P. Miller and Marvin A. Lanphere

Relatively little-known calc-alkaline volcanic rocks crop out in several belts in west-central Alaska and on St. Lawrence and St. Matthew Islands in the Bering Sea (fig. 22A) and may, at least in part, be correlative with the OkhotskChukotsk volcanic belt in northeast Siberia (Patton and others, 1976). These rocks range in composition from high-alumina basalt to highly silicic rhyolite but have nowhere been studied in detail. They have been considered Late Cretaceous and early Tertiary in age on the basis of $\mathrm{K}$-Ar ages ranging from 58 to 77 m.y., but a recently published K-Ar age from St. Lawrence Island (Patton and Csejtey, 1979) and the dating of obsidian from the Little Indian River locality in interior

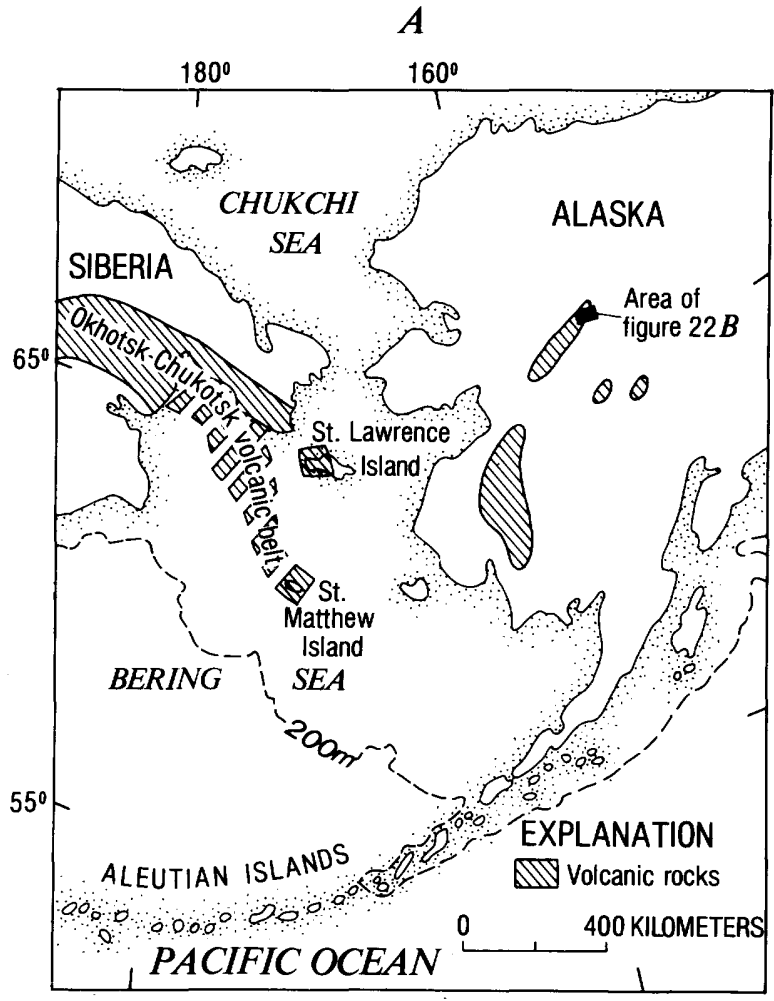

$B$

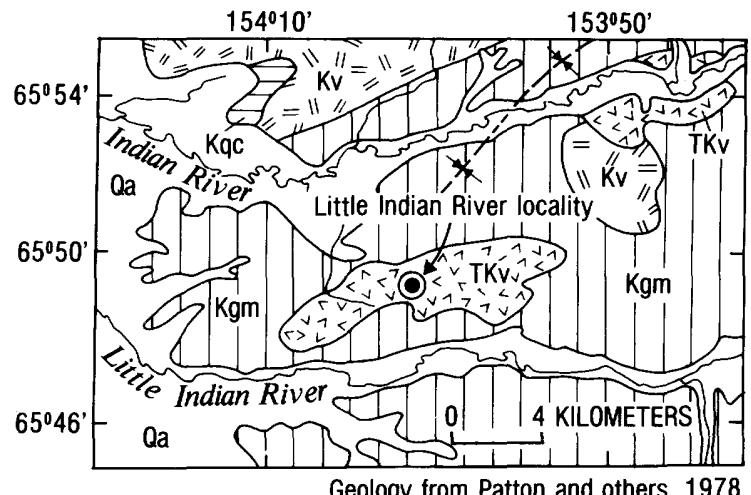

Geology from Patton and others, 1978

EXPLANATION

\begin{tabular}{|c|c|c|}
\hline $\mathrm{Qa}$ & Surficial deposits & QUATERNARY \\
\hline \begin{tabular}{|l|}
${ }_{v} T K_{V}^{T} v_{v}^{T}$ \\
\end{tabular} & Volcanic rocks & $\begin{array}{l}\text { TERTIARY AND } \\
\text { CRETACEOUS }\end{array}$ \\
\hline$-\mathrm{Kqc}-$ & Quartz-pebble conglomerate & \\
\hline Kgm & Volcanic graywacke and mudstone & CRETACEOUS \\
\hline $\mathbb{N}_{\mathbb{N}}^{\prime \prime} \mathrm{Kv}^{\prime \prime}=$ & Andesitic volcanic rocks & \\
\hline
\end{tabular}

FigURE 22.-Maps showing location of calcalkaline volcanic rocks discussed in this report. $A$, Index map of western Alaska and Bering Sea region. $B$, Geologic map of Little Indian River locality. 
Alaska (fig. 22B) suggest that some of these rocks may be considerably younger.

The Little Indian River obsidian locality, first described by Patton and Miller (9170), occurs near the northeast end of a belt of subaerial calc-alkaline volcanic rocks that crop out discontinuously for about $800 \mathrm{~km}$ along the eastern margin of the Yukon Koyukuk volcanogenic province from the lower Kuskokwim River Valley to the Arctic Circle (Patton and others, 1976). The obsidian occurs in a nearly horizontal tabular body of rhyolite flows and tuffs, and possibly in some domes, covering an area of about $40 \mathrm{~km}^{2}$ between the Little Indian and Indian Rivers (fig. $22 B$ ). These volcanic rocks disconformably overlie deformed Cretaceous sedimentary rocks (Patton and Miller, 1970). Frost action has completely reduced exposures to fragments as much as $25 \mathrm{~cm}$ long strewn across a sandy surface of vitric and pumeceous debris. The obsidian probably formed as residual inclusions ("Apache tears") in a hy. drated perlitic glass. Fresh surfaces of the obsidian are glossy black, but slivers as thick as $1 \mathrm{~cm}$ are commonly transparent and show fine fluidal banding. Patton and Miller (1970) consider the bedrock source for obsidian artifacts in northwestern Alaska to be at this locality.

The obsidian is an unaltered, nonhydrated, and undevitrified glass free of microlites and rock fragments; exteriors of the residual obsidian fragments have a frosted and finely pitted hydration rind. The range of refractive indices measured on several samples, from 1.484 to 1.487 , suggests a $\mathrm{SiO}_{2}$ content of more than 77 percent (Williams and others, 1958, p. 28). Chemical analyses (table 4) of the obsidian and associated tuff indicate they are high-silica rhyolites containing more than 77 percent silica and more than 8 percent total alkalis. The low $\mathrm{H}_{2} \mathrm{O}$ content illustrates the nonhydrated character of obsidian. Delayed neutron analyses of obsidian that yielded $14.4 \mathrm{ppm} \mathrm{U}$ and $42.6 \mathrm{ppm}$ Th indicate a strongly uraniferous character; the associated rhyolitic tuff contains $9.1 \mathrm{ppm} \mathrm{U}$ and $39.6 \mathrm{ppm} \mathrm{Th}$, values indicating a loss of $U$ probably as a result of hydration, devitrification, and ground water leaching.

Because of its freshness and unaltered nature, the Little Indian River obsidian seemed unlikely to be as old as Cretaceous or early Tertiary and therefore was dated by K-Ar techniques. Two samples were taken from a large piece of obsidian ( $25 \mathrm{~cm}$ across) and crushed, and the $-10+18$ mesh fraction used for argon analyses. Potassium was measured on an aliquant of this size fraction, which was ground to -200 mesh. Potassium was determined by flame photometry using lithium metaborate fusion (Ingamells, 1970). Argon was measured using procedures described by Dalrymple and Lanphere (1969).

The ages measured on the two samples (table 5 ) agree within analytical uncertainty and yield a weighted mean age of $40.8 \pm 0.8 \mathrm{~m}$.y. for the obsidian. Each sample age was weighted by the inverse of its estimated variance. This is the youngest radiometric age yet obtained from these volcanic rocks on the Alaska mainland but is similar to the K-Ar age 39.3 11 m.y. obtained from biotite from rhyolite tuff on St. Lawrence Island (Patton and Csejtey, 1979). The volcanic rocks on St. Lawrence Island were assigned an Oligocene age on the basis of this date and correlation with nearby volcanic rocks interbedded with sedimen. tary rocks containing Oligocene plant fossils (Patton and Csejtey, 1979). Recent evaluations of the Paleogene time scale (Hardenbol and Berggren, 1978) place the age of the Eocene-Oligocene boundary at about $37 \mathrm{~m} . y$, , thus making the obsidian from Little Indian River and the dated rhyolite tuff from St. Lawrence Island late Eocene in age.

The K-Ar age measurements at the Little Indian River locality and on St. Lawrence Island, together with the correlation of the St. Lawrence Island volcanic rocks with possible Oligocene sedimentary rocks, indicate that silicic volcanic activity was not confined to Late Cretaceous and early Tertiary time in western Alaska. Further study on the composition and other characteristics of this late Eocene volcanic episode is needed to determine whether it is an extension of the Late Cretaceous and early Tertiary volcanism or a separate event with a gap of about 20 m.y. between episodes. In either case, the existence of this volcanic episode may have important implications in the interpretation of the timing and nature of tectonic events in west-central Alaska.

\section{REFERENCES CITED}

Dalrymple, G. B., and Lanphere, M. A., 1969, Potassium-Argon dating: Principles, techniques, and applications to geochronology: San Francisco, W. H. Freeman, 258 p.

Hardenbol, J. and Berggren, W. A., 1978, A new Paleogene numerical time scale: American Association of Petroleum Geologists Studies in Geology No. 6, p. 213-234. 
[Rhyolite analysis from Patton and others (1978); rapid-rock chemical analysis: Hezekiah Smith, analyst. Obsidian analysis from R. L. Smith (oral commun., 1979); classical gravimetric analysis: John E. Thomas, Univ. of Redding, U.K. analyst. n.a., not analyzed.]

\begin{tabular}{|c|c|c|c|c|}
\hline & Rhyolite & Obsidian & Rhyolite & Obsidian \\
\hline $\mathrm{SiO}_{2}$ & 77.5 & 77.3 & $\mathrm{H}_{2} \mathrm{O}+\cdots-\cdots$ & 0.06 \\
\hline 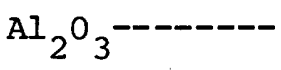 & 12.9 & 12.41 & $\mathrm{H}_{2} \mathrm{O}-\cdots \cdots$ & .04 \\
\hline $\mathrm{Fe}_{2} \mathrm{O}_{3}$ & .09 & .44 & $\mathrm{TiO}_{2} \ldots \cdots-.12$ & .10 \\
\hline FeO-- - - - - & .28 & .26 & $\mathrm{P}_{2} \mathrm{O}_{5}-\cdots-.13$ & .01 \\
\hline MgO------- - & .09 & .04 & MnO - - & .07 \\
\hline $\mathrm{CaO}-\cdots$ & .34 & .39 & $\mathrm{CO}_{2}-\cdots-.02$ & $\mathrm{n} \cdot \mathrm{a}$. \\
\hline $\mathrm{Na}_{2} \mathrm{O}-\cdots-\cdots$ & 4.4 & 4.05 & $\mathrm{C}_{1} \ldots-\cdots$ n.a. & .08 \\
\hline \multirow[t]{2}{*}{$\mathrm{K}_{2} \mathrm{O}------\cdots$} & 4.4 & 4.52 & $\mathrm{~F}-\cdots+\cdots$ n.a. & .12 \\
\hline & & & Sum---- 101 & 99.89 \\
\hline
\end{tabular}

TABLE 5.-K-Ar ages and analytical data for obsidian from the Little Indian River locality

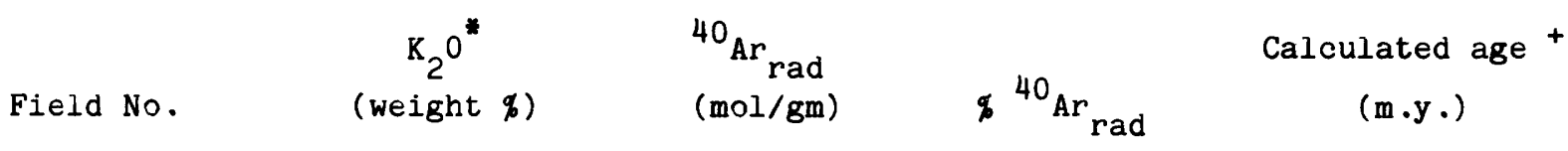

$78 \mathrm{AMm}-156-1$

$4.76 \pm 0.01(4) \quad 2.762 \times 10^{-10}$

37.4

$39.9 \pm 1.2$

$78 \mathrm{AMm}-156-2$

$4.74 \pm 0.01(4)$

2.869

$84 \cdot 5$

$41.6 \pm 1.2$

* Mean value and standard deviation. Number of measurements in parentheses.
$+\lambda_{\varepsilon}=0.581 \times 10^{-10} \mathrm{yr}^{-1}, \lambda_{\beta}=4.962 \times 10^{-10} \mathrm{yr}^{-1}, 40 \mathrm{~K} / \mathrm{K}=1.167 \times 10^{-4}$ mol/mol. The \pm figures are estimates of analytical precision at the 68-percent level of confidence.


Ingamells, C. O., 1970, Lithium metaborate flux in silicate analysis: Analitica Chimica Acta, v. 52, p. 323-334.

Patton, W. W., Jr., and Csejtey, Béla, Jr., 1979, Geologic map of St. Lawrence Island, Alaska: U.S. Geological Survey Open-File Report 79-945, scale 1:250,000.

Patton, W. W., Jr., Lanphere, M. A., Miller, T. P., and Scott, R. A., 1976, Age and tectonic significance of volcanic rocks on St. Matthew Island, Bering Sea, Alaska: U.S. Geological Survey Journal of Research, v. 4, no. 1, p. 67-73.

Patton, W. W., Jr., and Miller, T. P., 1970, A possible bedrock source for obsidian found in archeological sites in northwestern Alaska: Science, v. 169, p. 760-761.

Patton, W. W., Jr., Miller, T. P., Chapman, R. M., and Yeend, Warren, 1978, Geologic map of the Melozitna quadrangle, Alaska: U.S. Geological Survey Miscellaneous Investigation Series, Map I-1071, scale 1:250,000.

Williams, Howell, Turner, F. J., and Gilbert, C. M., 1958, Petrography: San Francisco,W. H. Freeman, 406 p.

Lower Paleozoic platform carbonate sequence in the Medfra quadrangle, west-central Alaska

By J. T. Dutro, Jr., and W. W. Patton, Jr.

More than $5,500 \mathrm{~m}$ of shallow-water lower Paleozoic strata (fig. 23) is exposed in the northern Kuskokwim Mountains of the eastern Medfra quadrangle (Patton, 1978). Most of these are platform carbonate rocks, ranging from Lower Ordovician supratidal laminated silty limestone through a complex array of shallow-shelf limestone facies that include reefoid masses in the Upper Ordovician and Middle Devonian. Dark, platy limestone and shale with Middle Silurian graptolites are the only major evidence of deeper water paleoenvironments.

The oldest rocks are in the Novi Mountain area where nearly $900 \mathrm{~m}$ of Lower Ordovician thinbedded silty to micritic limestone and calcareous siltstone is exposed. This sequence is characterized by $5-$ to $30-\mathrm{m}$-thick cycles that begin with a massive limestone unit, usually with flat carbonate pebbles in its base. Oolites are common in the lower parts of the cycles, which grade upward through thin, irregular, shaly limestone into calcareous siltstone or shale in the uppermost parts. At least a dozen such cyles occur in the interval between 300 and $600 \mathrm{~m}$ above the base of the formation. Rocks below the cyclic interval are divided into two units: a lower $150 \cdot \mathrm{m}$-thick unit that is predominantly siltstone and shale with much bioturbation, and an upper unit, from 150 to 300 $\mathrm{m}$ above the base of the sequence, characterized by massive limestone beds. The upper $300 \mathrm{~m}$ of the sequence consists chiefly of thin, irregularly bedded silty limestone and shale in which cycles

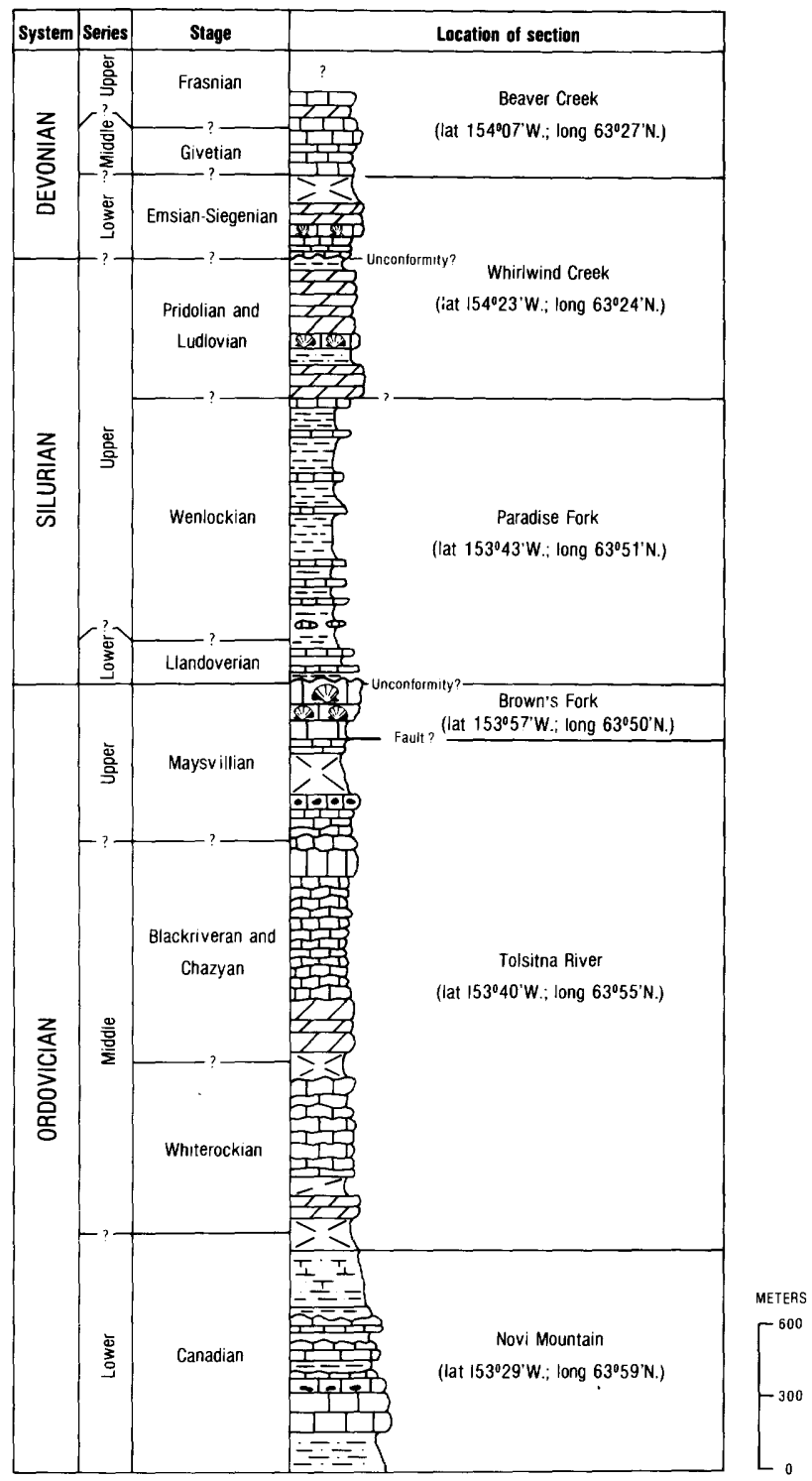

EXPLANATION

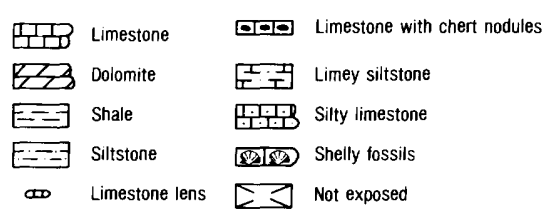

FIGURE 23.-Generalized columnar section of lower Paleozoic rocks, Medfra quadrangle, Alaska. 
are not so clearly delineated. A few poorly preserved trilobites, gastropods, cephalopods, and relatively sparse conodonts indicate that the en. tire sequence is Early Ordovician. The middle cyclic part contains Early Ordovician conodont Faunas C, D, and possibly E, according to John Repetski (written commun., 1978).

Along a high ridge east of the Telsitna River, Novi Mountain beds are overlain by about 2,000 $\mathrm{m}$ of Middle and Upper Ordovician limestone and dolomite that yield conodonts ranging from Middle Ordovician Fauna 3 near the base to probable Maysvillian equivalents near the top. Crude cycles are also developed in this sequence; algal and lime mudstone and laminated dolomite reflect the shallowest environments. Shelly fossils, including ostracodes, brachiopods, and snails, are occasionally found; Maclurites is common throughout. The uppermost beds contain Catenipora and other corals of possible Maysvillian age (W. A. Oliver, Jr., written commun., 1977).

In the Browns Fork area, a 200-m-thick sequence of Upper Ordovician limestone has been mapped tentatively as a separate and distinct unit stratigraphically above the Telsitna River sequence. The Browns Fork sequence is characterized by reefoid masses as much as $10 \mathrm{~m}$ thick that contain Late Ordovician corals and shelly fossils, including trilobites, and by reef flank strata that yield possible Maysvillian conodonts.

South of the Telsitna River area, poorly exposed, deeper water, dark platy limestone and black shale contain latest Llandoverian through early Wenlockian graptolites (Claire Carter, written commun., 1978). At least $1000 \mathrm{~m}$ of these dark beds is exposed in the hills along upper Paradise Fork. No definite lower Llandovery equivalents are known, and the contact with underlying Upper Ordovician rocks may be a fault.

Upper Silurian and Devonian strata are well exposed about $50 \mathrm{~km}$ southwest of Paradise Fork in the ridges east of Whirlwind Creek. This 1000- to 1500-m-thick sequence, a composite of two measured sections, consists of a lower predominantly dolomitic unit, a middle carbonate unit that includes favositid bioherms and shelly fossils, and an upper unit with rugose corals and stromatoporoids. The lower unit, $100 \mathrm{~m}$ thick, consist of algal, laminated dolomite and dolomitic limestone that grade upward into Favositesbearing limestone and ostracode-rich calcareous siltstone of the middle unit. The ostracodes indicate a probable Late Silurian age (J. M. Berdan, written commun., 1979). Limestones high in the middle unit contain shelly fossils and corals probably of Siegenian through Emsian age. No definite Gedinnian is recognized. The upper unit, well exposed above upper Beaver Creek, has many beds of dark, Amphipora-bearing dolomite. Rugose corals, including Smithiphyllum, near the top of the upper unit suggest an early Late Devonian (Frasnian) age (Oliver, written commun., 1977).

In the northwestern part of the outcrop area along the Telsitna River, the lower Paleozoic carbonate sequence overlies metasedimentary and metavolcanic rocks of probable Precambrian age (Silberman and others, 1979; Patton and Dutro, 1979). Along the southeast margin of its outcrop area, this platform carbonate terrane is juxtaposed, along a major northeast-trending strike-slip fault, with deep-water, slightly metamorphosed carbonate rocks of about the same age. Early Ordovician to Early Devonian conodonts have been identified from this apparent slope or basin sequence (Anita Harris, written commun., 1979).

Correlations with other early Paleozoic sequences in Alaska are not secure. Some of these Medfra carbonate units appear to have close affinities with the Ordovician and Silurian sequence of the western Seward Peninsula (Sainsbury and others, 1971) and possibly also with the Paleozoic sequence in the Livengood area. Detailed paleontologic studies now in progress may shed more light on these relations.

\section{REFERENCES CITED}

Patton, W. W., Jr., 1978, Juxtaposed continental and oceanic island-arc terranes in the Medfra quadrangle, westcentral Alaska, in Johnson, K. M., ed., The United States Geological Survey in Alaska: Accomplishments during 1977: U.S. Geological Survey Circular 772-B, p. B38-B39.

Patton, W. W., Jr., and Dutro, J. T., Jr., 1979, Age of the metamorphic complex in the northern Kuskokwim Mountains, west-central Alaska, in Johnson, K. M., and Williams, J. R., eds., The United States Geological Survey in Alaska: Accomplishments during 1978: U.S. Geological Survey Circular 804-B, p. B61 -B63. 
Sainsbury, C. L., Dutro, J. T., Jr., and Churkin, Michael, Jr., 1971 The Ordovician-Silurian boundary in the York Mountains, western Seward Peninsula, Alaska, in Geological Survey Research 1971: U.S. Geological Survey Professional Paper 750-C, p. C52-C57.

Silberman, M. L., Moll, E. J., Patton, W. W., Jr., Chapman, R. M., and Connor, C. J., 1979, Potassium-argon age of granitic and volcanic rocks from the Ruby, Medfra, and adjacent quadrangles, west-central Alaska, in Johnson, $\mathrm{K}$. M., and Williams, J. R., eds., The United States Geological Survey in Alaska: Accomplishments during 1978: U.S. Geological Survey Circular 804-B, p. B63-B66.

\section{SOUTH WESTERN ALASKA}

Lower Paleozoic radiolarian chert and associated rocks in the Tikchik Lakes area, southwestern Alaska

By J. M. Hoare and D. L. Jones

Recently collected radiolarian chert has provided new information on the age and correlation of an isolated terrane of Paleozoic rocks in the Tikchik Lakes area. The Paleozoic rocks are exposed in a triangular-shaped area of about 1,200 $\mathrm{km}^{2}$ with the $35-\mathrm{km}$-wide base at Nuyakuk Lake and the apex $70 \mathrm{~km}$ to the north at the west end of Nishlik Lake (fig. 24). Mertie (1938, p. 37-42) assigned a Mississippian(?) age to most of the rocks in the southern part of this area because they apparently underlie Permian limestone and greenstone. In later reconnaissance mapping (Hoare and Coonrad, 1959, 1961), the rocks in the western part of this area were assigned to the Gemuk Group of Carboniferous to Early Cretaceous age (Cady and others, 1955, p. 27-34). By 1978 , when the present investigation began, megafossils of Permian, Late Triassic, and Early Jurassic age had been found at numerous locations near the perimeter of the Paleozoic terrane (fig. 23), but no fossils had been found in its interior. Three of the four Permian fossil localities north and south of Lake Chauekuktuli near the east side of the terrane and two others north and south of the upper part of Nuyakuk Lake (fig. 24) are in rocks that Mertie (1938) mapped as Mississippian(?). Dominant structural trends at these fossil localities and in the interior of the terrane are west and northwest, so it seemed likely that rocks in the interior of the terrane were also of Permian age.

The recent investigation was directed at determining the age of a thick section of highly deformed chert that is closely associated with limestone and clastic sedimentary and volcanic rocks

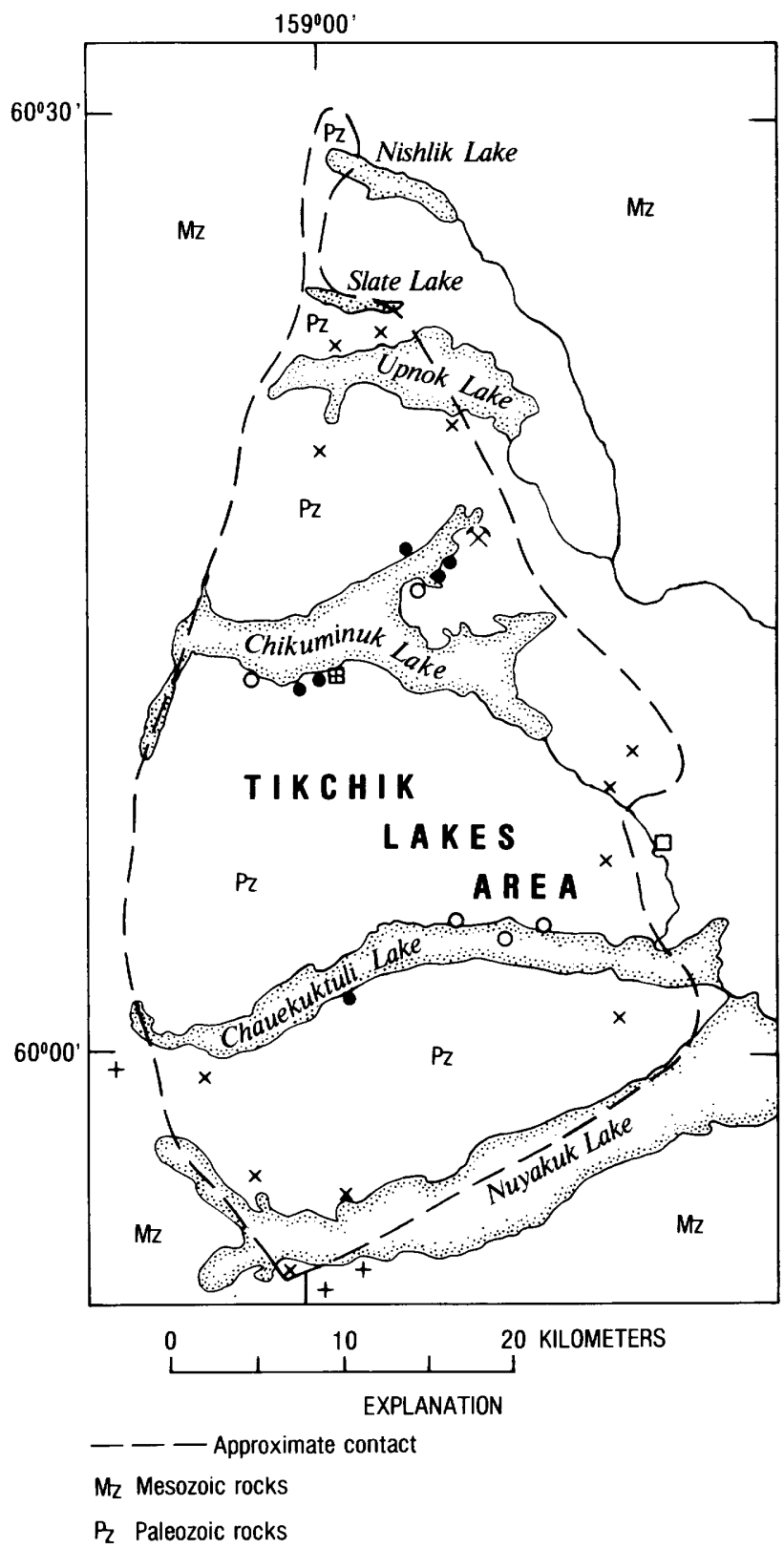

Radiolarian localities and age 田 Triassic

- Paleozoic(?)

O Older Paleozoic (Devonian? and pre-Late Devonian)

FIGURE 24.-Sketch map showing distribution of Paleozoic ( $\mathrm{Pz})$ and Mesozoic (Mz) rocks and fossil localities, Tikchik Lakes area, southwestern Alaska. 
widely exposed in the central part of the Paleozoic terrane. About 50 chert samples were collected along the shores of Chikuminuk, Chauekuktuli, and Nuyakuk Lakes, and Tikchik Lake, which is east of the map area. Six samples contained radiolarians diagnostic of early or middle Paleozoic age. Six other samples yielded poorly preserved forms of Paleozoic(?) age. Five localities yielded radiolarians of Mesozoic age. One of these, on the south shore of Chikuminuk Lake (fig. 24), yielded Triassic, radiolarians and is near the center of the Paleozoic terrane. The other Mesozoic localities-of Triassic, Late Jurassic, and Early Cretaceous age-are several kilometers east of the southeast corner of the terrane, on Tikchik Lake. No radiolarians of Permian or late Paleozoic age were found, although rocks of this age may be present in the unsampled mountainous country between the lakes.

Although chert, cherty tuff, and siliceous siltstone probably constitute 25 percent or more of the older Paleozoic rocks, apparently relatively few contain radiolarians. The Paleozoic radiolarians were found in thin (1- to $5 \cdot \mathrm{m})$ zones of thin-bedded gray chert with shale partings and in thick (more than $30-\mathrm{m}$ ) zones of thin-bedded chert and red siliceous siltstone. The radiolarian cherts are closely associated with, and probably interbedded with, thick sections of massive and thick-bedded, highly fractured, gray, black, white, and brownish chert. Closely associated with the chert is a thick section of interbedded calcareous sandstone and shale, several thick beds of white crystalline limestone, and pyroclastic volcanic rocks altered to greenstone.

The thickness and stratigraphic succession of these rocks are not known because the rocks were deformed twice by isoclinal folding and offset by northwest-trending high-angle faults and northwest-dipping low- and high-angle reverse faults. The older folds trend west or northwest; the younger folds are post-Cretaceous in age, trend northeast, and are commonly recumbent to the southeast.

The older Paleozoic rocks are lithologically unlike, but apparently about the same age as, the Holitna Group, which is Ordovician(?), Silurian, and of Middle Devonian age (Cady and others, 1955 , p. 23-27). In its type locality on the Holitna River $175 \mathrm{~km}$ to the northeast, the Holitna Group consists of massive and thin-bedded limestone and dolomite with an estimated thickness of 2,000 to $3,000 \mathrm{~m}$. Major structural trends in the Holitna Group near the Holitna River parallel those in the Tikchik Lakes area, and the Paleozoic rocks in both areas are truncated to the northwest by segments of the Denali fault system. It seems likely that the Paleozoic rocks in these two areas had a similar tectonic history and are stratigraphically related, although the nature of the relations is still not clear.

\section{REFERENCES CITED}

Cady, W. M., Wallace, R. E., Hoare, J. M., and Weber, E. J., 1955, The central Kuskokwim region, Alaska: U.S. Geolog ical Survey Professional Paper 268, 131 p.

Hoare, J. M., and Coonrad, W. L., 1959, Geology of the Bethel quadrangle, Alaska: U.S. Geological Survey Miscellaneous Geologic Investigations Map I-285, scale 1:250,000.

- 1961, Geologic map of the Goodnews quadrangle: U.S. Geological Survey Miscellaneous Geologic Investigations Map I-339, scale 1:250,000.

Mertie, J. B., Jr., 1938, The Nushagak district, Alaska: U.S. Geological Survey Bulletin 903, 96 p.

K-Ar ages on intrusive rocks and altered zones in the Chignik and Sutwik Island quadrangles

By Frederic H. Wilson

Continued K-Ar dating of intrusive rocks and hydrothermal alteration zones in the Chignik and Sutwik Island quadrangles of the Alaska Peninsula, supplemental to that by Wilson, Detterman, and Silberman (1978) and Wilson (1978), has refined our knowledge of the ages of the igneous rocks and clarified relations between altered zones and igneous events in the area.

Age determinations on approximately 40 samples indicate two major igneous events that include volcanic, plutonic, and hypabyssal rocks. The older of these two events, related to the Meshik and in part to the Tolstoi Formations (Detterman and others, 1980), includes volcanic rocks ranging from leuco-basalt to dacite (Streckeisen, 1979) and volcaniclastic rocks of Eocene and Oligocene age. The K-Ar data suggest that two stages of this event may be distinguishable; a major late Eocene and early or late Oligocene (about 42 to $27 \mathrm{m.y}$.) stage and a minor early Miocene (22 to 19 m.y.) stage. A younger igneous event, starting in the late Miocene (about 10 m.y.) and continuing until the present, also includes rocks of volcanic (leuco-basalt to dacite), plutonic, and hypabyssal origin. The large Devils batholith, a tonalitic to granodioritic pluton cen- 
tered on Devils Bay in the Chignik A-2 quadrangle $(1: 63,360)$, and apparently the large dioritic batholith in the northeast part of the Sutwik Island quadrangle were both emplaced during this later event.

Ages of minerals from zones of copper-porphyry-type mineralization fall within the same time ranges as primary rock ages, and where dating of primary and secondary phases has been possible, there is apparently a significant time gap (1 to 6 m.y.) between emplacement and alteration. At Warner Bay, mineralization occurred between the emplacement of the 10- and 6-m.y.-old phases of the Devils batholith (Wilson and others, 1978). Additional work at the Bee Creek prospect has shown the earlier inferred 7-m.y. age to be in error. Present data do not allow an estimate of the emplacement age of the main Bee Creek hypabyssal pluton, but mineralization that took place about 3.7 m.y. ago was followed by emplacement of a late intrusion about 2.1 m.y. ago. Age determinations at the Mallard Duck Bay prospect indicate a long history of igneous activity spanning at least $6 \mathrm{~m} . \mathrm{y}$. from about 27 to $21 \mathrm{~m} . \mathrm{y}$. ago. Late in this history, alteration and minor mineralization occurred about $21 \mathrm{~m} . \mathrm{y}$. ago. Preliminary data from a small altered zone on Unavikshak Island (Sutwik Island quadrangle, lat $56^{\circ} 30^{\prime} \mathrm{N}$, long $158^{\circ} 40^{\prime} \mathrm{W}$ ) indicate emplacement and alteration during the early and (or) middle Oligocene ( 36 to 29 m.y.). In addition, preliminary data in the plutonic complex on Cathedral Creek and south and east of Black Peak indicate emplacement of some plutons during late early Pliocene time ( 4 to 3 m.y.) and alteration as late as the Pleistocene (1.38 m.y.).

Alteration and mineralization events are well distributed throughout the Tertiary igneous history in the Chignik and Sutwik Island quadrangles. Each alteration episode is a discrete event spatially related to the centers of igneous activity. At present, the petrologic and K-Ar data from the Chignik and Sutwik lsland quadrangles do not reveal any tendency for alteration episodes to be limited to any particular time of igneous activity or to any particular igneous rock type.

\section{REFERENCES CITED}

Streckeisen, A., 1979, Classification and nomenclature of volcanic rocks, lamprophyres, carbonatites, and melitic rocks: Recommendations and suggestions of the IUGS
Subcommission on the Systematics of Igneous Rocks: Geology, v. 7, p. $331-335$.

Wilson, F. H., 1978, Map showing preliminary results of K-Ar studies in the Chignik and Sutwik Island quadrangles, Alaska: U.S. Geological Survey Open-File Report 78-1064, scale 1:250,000.

Wilson, F. H., Detterman, R. L., and Silberman, M. L., 1978, New ages on intrusive rocks and altered zones on the Alaska Peninsula, in Johnson, K. M., ed., The United States Geological Survey in Alaska: U.S. Geological Survey Circular 772-B, p. B63-B65.

\section{SOUTHERN ALASKA}

Revised ages of Paleozoic and Mesozoic rocks in the Talkeetna quadrangle, south-central Alaska

By D. L. Jones, N. J. Silberling, Bruce Wardlaw, and Don Richter

Paleontological data pertaining to the age of sedimentary rocks on the north side of the Denali fault in the central Alaska Range are very scarce. In the Talkeetna quadrangle, only a single preCenozoic (Early Cretaceous) fossil locality has been previously recorded from the north side of the fault (Reed and Nelson, 1977). Consequently, the ages of several linearly extensive and very thick stratigraphic units have remained problematic or unknown. In this report, we present the first paleontologic evidence (table 6 ) for the age of two units, as well as data that substantiate lithic correlations with other dated units farther east in the Alaska Range. These data were collected during reconnaissance investigations related to our ongoing study of the tectonic history of southern Alaska (Jones and Silberling, 1979).

Reed and Nelson (1977) mapped as single unit-their Paleozoic shale and limestone unit (Pzsl)-a thick, isoclinally folded sequence of black, sooty shale, interbedded gray calcareous siltstone, quartzite, and limestone, and tan phyllite. They suggested that these rocks are correlative with graptolite-bearing Lower Ordovician strata exposed to the southwest in the Terra Cotta Mountains (south of the Denali fault). As shown on figure 25, we have subdivided Reed and Nelson's unit into two distinctive assemblages. One, best exposed on Pingston Creek, consists of sooty black shale and interbedded gray calcareous quartzitic siltstone, quartzite, and limestone that contains Triassic conodonts (locs. 1 and 2, fig. 25 ). The other, best exposed in the northern foothills east of Pingston Creek, consists of tan phyllite, minor chert, and a lens of crinoidal 
[Conodont identifications by $\mathrm{B}$. R. Wardlaw; radiolarian age assignments by D. L. Jones]

Locality

number

(fig. 25)
Fauna

Age
1. Conodonts

Neogondolella polygnathiformis

(Budurov and stefanov).
Late Triassic (Karnian and

earliest Norian).

Late Triassic (late Karnian and early Norian).

Epigondolella primitia Mosher. Neogondolella navicula (Huckriede).

3. Conodonts

Adetognathus sp.

Declinognathodus lateralis (Higgins and Bouckaert).

Idiognathodus sinuosus Ellison and Graves.

Idiognathoides convexus (Ellison and Graves).

Neogondolella clarki (Koike).

Xaniognathus sp.

4. Conodonts-

Early Permian (Leonardian).

Neogondolella idahoensis (Youngquist, Hawley, and Miller).

Ellisonia sp.

Radiolarians

5. Conodonts

Neogondolella sp.

Radiolarians

Permian.

6. Moll usks------

Early Cretaceous.

Acroteuthis (?) sp.

Inoceramus sp. 
limestone that contains Pennsylvanian conodonts (loc. 3, fig. 25).

The original relation of these two stratigraphic units is unknown. All present contacts appear to be faults; the Triassic rocks clearly are folded with the Pennsylvanian strata, and both are cut by large intrusions of altered gabbro and diabase.
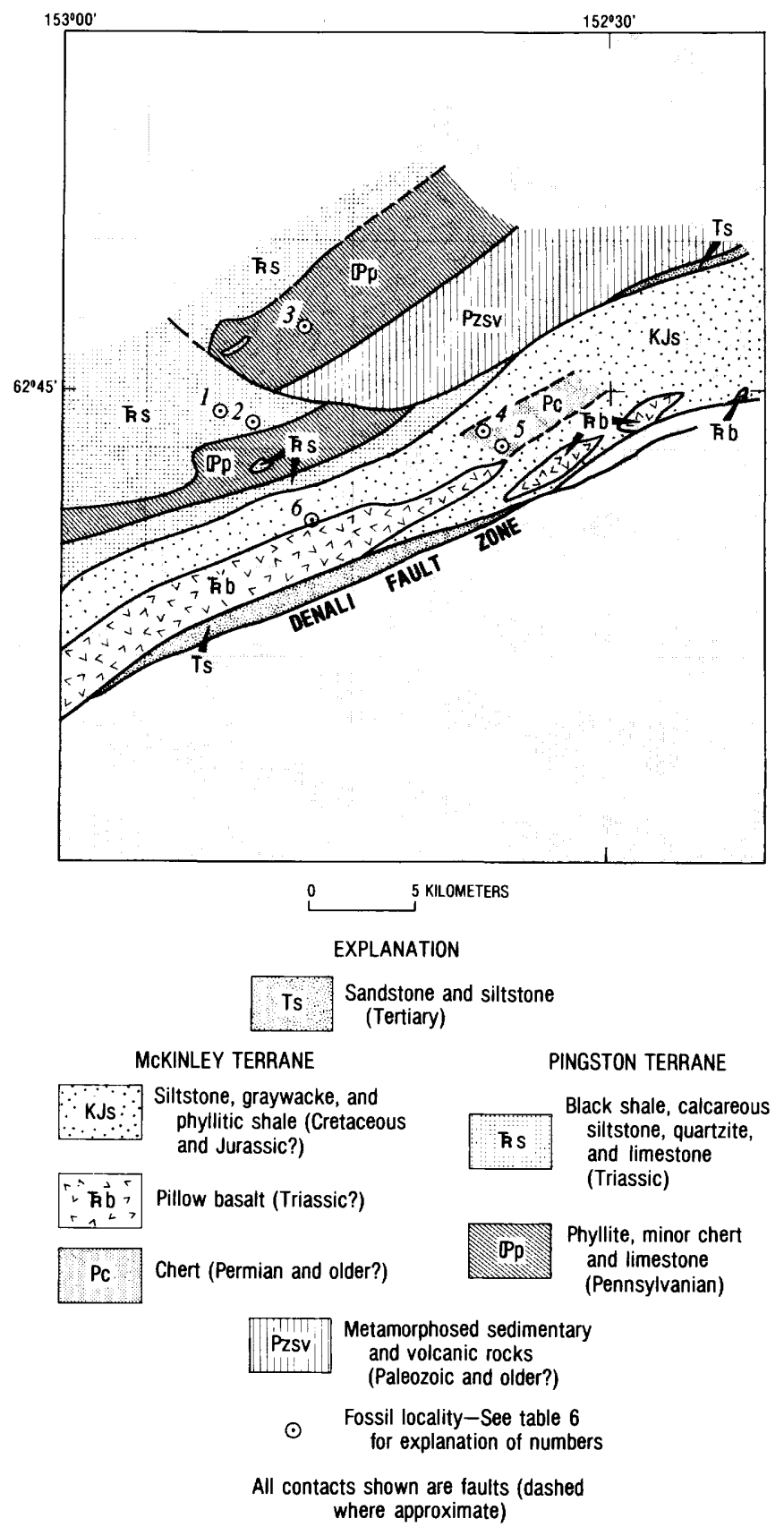

FiguRE 25.-Sketch map, modified from Reed and Nelson (1977), showing lithologic units and position of new fossil localities. Base from U.S. Geological Survey Talkeetna $1: 250,000$ quadrangle, 1958 .
South of the outcrop belt of their Paleozoic shale and limestone unit Reed and Nelson (1977) mapped a thick unit of undivided marine sedimentary rocks of Jurassic and Cretaceous age consisting mainly of phyllite, argillite, graywacke, and siltstone, with lesser amounts of gray, green, and red chert, conglomerate, grit, and impure limestone. A single fossil locality (their loc. 4, which is shown as loc. 6 on fig. 25 of this report) was found in graywacke and contains fragments of belemnites and large scraps of Inoceramus. Such fossils are common in Lower Cretaceous (Barremian) rocks in southern Alaska (Jones, 1973), and their presence is the basis for assigning a late Mesozoic age to the entire assemblage.

Examination of a thick chert unit (unit Pc, fig. 25) at two localities (locs. 4 and 5) resulted in discovery of Permian conodonts and radiolarians of Permian and possibly Mississippian age. Because of limited sampling, the full range in age of this chert unit is unknown. It appears to be in fault contact with Mesozoic clastic rocks, but the relations with nearby thick piles of Triassic(?) pillow basalt (fig. 25) are unknown. The age of the pillow basalt has not been established, but it appears to be similar to Upper Triassic basalt exposed to the east near Polychrome Pass in McKinley National Park, where Wyatt Gilbert (Alaska Division of Geological and Geophysical Surveys) found a small specimen of Halobia of the type that ranges in age from the late Karnian to the early Norian.

Southern Alaska has recently been subdivided into a large number of separate tectonostratigraphic terranes (Jones and Silberling, 1979), each of which exhibits an individual stratigraphic sequence different from that of neighboring terranes. These separate terranes make up the vast tectonic collage of Alaska believed to have formed by accretion during late Mesozoic time (Jones and others, 1977). Rocks lying between the McKinley and Hines Creek strands of the Denali fault in the central Alaska Range belong mainly to the Pingston and McKinley terranes (a third terrane, the Windy, is locally developed immediately north of the McKinley strand). Previously, the only published paleontological data for the age of the Pingston terrane were obtained from the eastern part of McKinley Park, where weakly metamorphosed folded limestone, calcareous quartzitic siltstone and sandstone, and black, sooty slate with Triassic conodonts was mapped 
by Hickman and Craddock (1975) and Gilbert and Redman (1977). Our new find of Triassic conodonts from similar strata on Pingston Creek substantiates the lithic correlation made previously (Jones and Silberling, 1979) between these two areas. Likewise, the presence of upper Paleozoic strata (Pennsylvanian) within the Pingston terrane further complicates this enigmatic assemblage.

The presence of upper Paleozoic chert within the McKinley terrane is equally surprising, as all the previous reliable fossil localities from this terrane substantiated only the presence of Mesozoic rocks (Jones and Silberling, 1979).

\section{REFERENCES CITED}

Gilbert, W. G., and Redman, Earl, 1977, Metamorphic rocks of Toklat-Teklanika Rivers area, Alaska: Alaska Division of Geological and Geophysical Surveys, Geological Report 50,13 p., 1 map.

Hickman, R. G., and Craddock, Campbell, 1975, Geologic map of part of central Healy quadrangle, Alaska: Alaska Division of Geological and Geophysical Surveys, Open-File Report 95, scale 1:63,360.

Jones, D. L., 1973, Structural elements and biostratigraphic framework of Lower Cretaceous rocks in southern Alaska, in Casey, R., and Rawson, P. F., eds., The Boreal Lower Cretaceous: Liverpool, Seel House Press, p. 1-8.

Jones, D. L., and Silberling, N. J., 1979, Mesozoic stratigraphy-the key to tectonic analysis of southern and central Alaska: U.S. Geological Survey Open-File Report 79-1200, 37 p., 2 figs.

Jones, D. L., and Silberling, N. J., and Hillhouse, John, 1977, Wrangellia-a displaced terrane in northwestern North America: Canadian Journal of Earth Sciences, v. 14, no. 11, p. 2565-2577.

Reed, B. L., and Nelson, S. W., 1977, Geologic map of the Talkeetna quadrangle, Alaska: U.S. Geological Survey Miscellaneous Field Studies Map MF-870-A, scale 1:250,000.

Evidence for northwestward thrusting of the Talkeetna superterrane, and its regional significance

By Béla Csejtey, Jr., and Dennis R. St. Aubin

Southern Alaska is part of the accretionary continental margin of western North America, which mostly consists of an undetermined number of allochthonous and diverse tectonostratigraphic terranes. In southern Alaska, these terranes were accreted to the North American continent by generally northward plate motions in late Mesozoic and early Tertiary time (Jones and others, 1977; Csejtey and others, 1978; Jones and Silberling, 1979). The structural method, direction, and the exact time of final emplacement for most of these ter- ranes are still imperfectly known. This report presents evidence from the northern Talkeetna Mountains that one of the largest of these allochthonous terranes of southern Alaska, herein named the Talkeetna superterrane, was emplaced to its present and final position, after collision with the North American Continent, by northwestward thrusting in about middle Cretaceous time.

The Talkeetna superterrane is defined in this report to consist of the Wrangellia and Peninsular terranes of Jones, Silberling, and Hillhouse (1977) and Jones and Silberling (1979). Stratigraphic evidence from the southern Talkeetna Mountains and southern Wrangell Mountains strongly suggests that these two initially unrelated terranes have been tectonically coupled since Middle Jurassic time and that they were emplaced in Alaska together as a structurally cohesive unit. This stratigraphic evidence, according to E. M. MacKevett, Jr. (Csejtey and others, 1978 , p. 9-11), is the similarity in age and lithology between the Middle Jurassic to Upper Cretaceous sedimentary units of the southeastern Talkeetna Mountains, that rest with a depositional unconformity on the volcanogenic Lower Jurassic Talkeetna Formation of the Peninsular terrane, and the Middle Jurassic and younger sedimentary formations of the southern Wrangell Mountains that rest depositionally on the Upper Triassic McCarthy Formation of the Wrangellia terrane (MacKevett, 1978; Jones and Silberling, 1979). Only in the Talkeetna Mountains do the two terranes occur in proximity, where the Wrangellia terrane on the north and the Peninsular terrane on the south have been tectonically juxtaposed along a northeast-trending steep fault (Csejtey and others, 1978). Here, however, the Wrangellia terrane has no indigenous rocks younger than Late Triassic, probably as a result of erosion.

In the Talkeetna Mountains, the leading edge of the Talkeetna superterrane is delineated by the northeast-trending Talkeetna thrust (Csejtey and others, 1978). On its southeast side, the thrust brings dominantly upper Paleozoic and Upper Triassic, chiefly volcanogenic rocks of Wrangellia against a thick, flyschlike sequence of Lower Cretaceous argillite and graywacke. Although the Talkeetna thrust is generally poorly exposed, in the northern Talkeetna Mountains three subsidiary, southeast-dipping imbricate thrust faults structurally above it (fig. 26) are exposed just to 
the south at about $1-$ to $3-\mathrm{km}$ intervals.

The two structurally lowest subsidiary thrust faults consistently bring on the older rocks of Wrangellia (on the south) against younger ones. Geologic mapping shows that the structurally lowest of the subsidiary thrusts is actually a splay of the main Talkeetna thrust, encasing a sliver of Upper Jurassic and Lower Cretaceous (D. L. Jones, oral commun., 1979) volcanic conglomerate, argillite, and arkose. The tectonostratigraphic affinity of these rocks is uncertain; perhaps they are a fragment of the Gravina-Nutzotin belt of Berg, Jones, and Richter (1972).

The structurally highest subsidiary thrust fault, in contrast to the others, brings the younger part of the Nikolai Greenstone of the Wrangellia terrane (on the south) against older rocks of the Nikolai (on the north). However, along this fault for several kilometers in both directions from the line of the cross section of figure 26 , several tectonic slivers of Upper Triassic Chitistone Limestone (D. L. Jones, oral commun., 1979) stratigraphically above the Nikolai. Thus, this fault must be a northwestward directed overthrust that has cut across already folded rocks of Wrangellia.

The direction of tectonic transport is also indicated by the northwestward overturned drag folds, with amplitudes from a few meters to as much as $200 \mathrm{~m}$, which developed in some of the incompetent rocks in the upper plates of the subsidiary thrusts. Furthermore, in a several-kilometer-wide zone north of the Talkeetna thrust, the structurally underlying Lower Cretaceous flysch was also thrown into large, northwestward overturned tight folds, as indicated by bedding attitude and axial plane cleavage measurements.

This thrusting and related deformation are younger than the youngest rocks involved, the Lower Cretaceous flysch, but are older than the undeformed Cretaceous and Paleocene granitic intrusive rocks. In the northernmost Talkeetna Mountains and adjacent central Alaska Range, the oldest undeformed rocks appear to be several flow-foliated granitic plutons that may be 80 to 90 m.y. old (Turner and Smith, 1974). These granites intrude a thrusted and folded region that is underlain by the Lower Cretaceous, a newly discovered terrane of Upper Triassic calcareous sedimentary rocks, and a fine-grained clastic sequence of Silurian or Devonian age.
A still unresolved but critical problem for the tectonic history of southern Alaska is whether the Lower Cretaceous flysch is a separate allochthonous terrane or part of the ancient North American continent. Because of its widespread occurrence in southern Alaska, its age and lithology, and because of its tectonic role as "matrix" between the numerous allochthonous terranes, the Lower Cretaceous flysch in this report is considered to be a para-autochthonous, continental-marginal-type deposit of the ancient North American continent.

Another unresolved tectonic problem is the local but fairly common occurrence of southeastward overturning in large areas north of the Talkeetna superterrane. This overturning is either the result of local contemporaneous stress reversals, very common in alpine-type orogenic belts, or the result of a superimposed Tertiary deformation of rather minor significance.

The geologic features discussed here indicate that the Talkeetna superterrane, one of the largest allochthonous crustal blocks of southern Alaska, was emplaced in its present position after collision with the ancient North American continent by northwestward thrusting. This evidence also strengthens the previous interpretation (Csejtey and others, 1978; Csejtey, 1979) that the smaller allochthonous blocks north of the Talkeetna thrust were emplaced by the "bulldozing" action of the large, northwest-moving Talkeetna superterrane during a middle Cretaceous accretionary orogenic period that produced truly alpine-type structures of gigantic dimensions and great complexity.

\section{REFERENCES CITED}

Berg, H. C., Jones, D. L., and Richter, D. H., 1972, GravinaNutzotin belt-Tectonic significance of an upper Mesozoic sedimentary and volcanic sequence in southern and southeastern Alaska, in Geological Survey Research 1972 : U.S. Geological Survey Professional Paper 800-D, p. D1 D24.

Csejtey, Béla, Jr., 1979, Regional significance of tectonics of the Talkeetna Mountains, south-central Alaska, in Johnson, K. M., and Williams, J. R., eds., The United States Geological Survey in Alaska: Accomplishments during 1978: U.S. Geological Survey Circular 804-B, p. B90-B92.

Csejtey, Béla, Jr., Nelson, W. H., Jones, D. L., Silberling, N. J., Dean, R. M., Morris, M. S., Lanphere, M. A., Smith, J. G., and Silberman, M. L., 1978, Reconnaissance geologic map and geochronology, Talkeetna Mountains quad- 
rangle, northern part of Anchorage quadrangle, and southwest corner of Healy quadrangle, Aladka: U.S. Geological Survey Open-File Report 78-558-A, 60 p., scale $1: 250,000$.

Jones, D. L., and Silberling, N. J., 1979, Mesozoic stratigraphy-The key to tectonic analysis of southern and central Alaska: U.S. Geological Survey Open-File Report 79-1200, $37 \mathrm{p}$.

Jones, D. L., Silberling, N. J., and Hillhouse, John, 1977, Wrangellia-A displaced terrane in northwestern North America: Canadian Journal of Earth Sciences, v. 14, p. 2565-2577.

MacKevett, E. M., Jr., 1978, Geologic map of the McCarthy quadrangle, Alaska: U.S. Geological Survey Miscellaneous Geologic Investigations Map I-1032, scale 1:250,000.

Turner, D. L., and Smith, T. E., 1974, Geochronology and generalized geology of the central Alaska Range, Clearwater Mountains, and northern Talkeetna Mountains: Alaska Division of Geological and Geophysical Surveys Open-File Report 72, 11 p.

Recognition of the Wrangellia terrane in the Clearwater Mountains and vicinity, south-central Alaska

By N. J. Silberling, D. H. Richter, and D. L. Jones

The Wrangellia terrane is one of many tectonostratigraphic terranes that accreted to North America in late Mesozoic time (Jones and Silberling, 1979). Throughout its extent, from southern Alaska to northeastern Oregon, stratigraphy records a distinctive depositional history for Wrangellia in late Paleozoic and Triassic time (Jones and others, 1977), and paleomagnetic data indicate several thousand kilometers of northward transport since middle Triassic time (Hillhouse, 1977). In the Wrangell Mountains and eastern Alaska Range, where it is best known in Alaska, Wrangellia is bounded on the northeast by the active Denali fault, but farther west it diverges from this structure and terminates against an older major fault system (Coney and others, 1981; Csejtey and others, 1978; Csejtey and St. Aubin, 1981).

The presence in the Wrangellia terrane of upper Paleozoic rocks in south-central Alaska as far west as the northwestern Talkeetna Mountains was first proposed by Csejtey (1976). However, the Talkeetna Mountains exposures are separated from rocks typical of Wrangellia in the eastern Alaska Range by a wide, continuous outcrop belt of mafic volcanic rocks (Beikman, 1974), whose age and stratigraphic relations were reported by various workers to be distinctly non-Wrangellia in

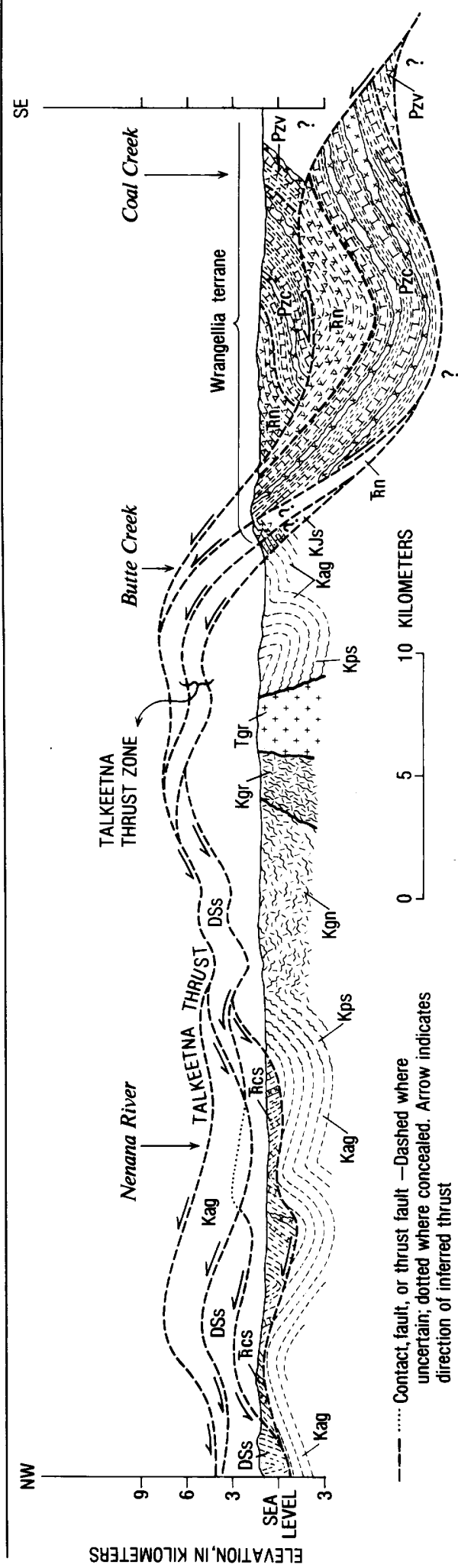


character. For example, all of the pre-Tertiary volcanic rocks in this intervening anomalous outcrop belt were included in the Triassic Amphitheatre Group of Smith and Turner (1973) by Smith (1974, fig. 3) and Stout (1976, fig. 2), and calcareous rocks containing Triassic fossils as young as late Norian in age were regarded as lenses within this predominantly mafic volcanic succession by Smith and Lanphere (1971) and Smith and Turner (1973). Paleozoic volcanic and sedimentary rocks were not identified. In contrast, the distinctive feature of Wrangellia is the presence of Paleozoic volcanic rocks overlain by the nonvolcanic Mankomen Group (Pennsylvanian and Permian), as well as the bracketing in age of its thick basalt unit, which includes the Nikolai Greenstone, Karmutsen Formation of Canada, and others by fossiliferous nonvolcanic strata of late Middle Triassic (Ladinian) and early Late Triassic (late Karnian) age (Jones and others, 1977); basalt of Norian age is absent from the typical Wrangellia section. These differences raised questions as to whether the Amphitheatre Group properly should be included in Wrangellia.

Our field studies in the Clearwater Mountains area during 1978 and 1979 have resolved these questions and have shown that, instead of being interstratified with the volcanic rocks, the fossiliferous Upper Triassic calcareous rocks have been structurally emplaced into them. Moreover, the Amphitheatre Group was found to include both upper Paleozoic and Triassic rocks in a stratigraphic succession that is generally like that of Wrangellia but that was deposited in deeper water. The major units of this succession are described below, from oldest to youngest, and their distribution in and near the Clearwater Mountains is shown in figure 27.

Pennsylvanian and Permian(?) andesitic volcanic rocks (fig. 27 include more than $2,000 \mathrm{~m}$ of gray-green massive volcanic flows, breccias, and minor volcaniclastic rocks, largely of andesitic composition, which are lithologically equivalent to the Tetelna Volcanics of the eastern Alaska Range (Richter and Dutro, 1975), and the Station Creek Formation of the Skolai Group in the Wrangell Mountains (Smith and MacKevett, 1970). These rocks are unfossiliferous but grade upward into Permian and Triassic sedimentary strata that contain Lower Permian, and possibly Pennsylvanian, faunas. The base of these rocks is not exposed.
The lower part of the Permian and Triassic sedimentary rocks (fig. 27) consists of about 700 $\mathrm{m}$ of black argillite with laminae and thin interbeds of volcanic sandstone and minor interstratified crinoidal limestone turbidite and mafic volcanic breccia as thick as a few tens of meters. The upper part of the argillite is overlain by about $100 \mathrm{~m}$ of gray-green, red, and black thin-bedded radiolarian chert. Triassic gabbro sills (fig. 27) greatly expand the section locally and increase in abundance upward, generally obscuring the upper stratigraphic contact with the Nikolai Greenstone. Fossils from these rocks are listed on table 7, and localities are shown on figure 27.

The lower part of the Permian and Triassic sedimentary rocks unit probably is equivalent to part of the Slana Spur Formation of the Mankomen Group (Richter and Dutro, 1975); the upper part is equivalent to the Eagle Creek Formation of the Mankomen Group. Equivalents of the Permian part of the unit in the Wrangell Mountains are the upper volcaniclastic part of the Station Creek and the Hasen Creek Formations of the Skolai Group.

The lower part of the Nikolai Greenstone (fig. 27 ) is laterally variable and includes: thick, complexly interfingered units of massive dark-graygreen nonamygdaloidal basalt; pillow basalt flows interlayered with tuff; and massive dark-graygreen basalt breccia with subangular to rounded clasts as much as $20 \mathrm{~cm}$ in diameter. All of these basaltic rocks probably are of submarine origin. This lower part of the Nikolai is at least 2,000 m thick and is equivalent to the upper part of the Tangle Lakes Formation and the overlying Boulder Creek Volcanics of Stout (1976) in the Amphitheater Mountains.

The upper part of the Nikolai is chiefly darkgray-green to maroon-gray subaerial amygdaloidal basalt flows, aggregating at least $1,000 \mathrm{~m}$ in thickness, that closely resemble the type Nikolai Greenstone in the Wrangell Mountains (MacKevett, 1978) and may equate with the Paxson Mountain Basalt of Stout (1976). Triassic gabbroic sills and dikes, which aggregate hundreds of meters in thickness, are the intrusive equivalents of the Nikolai Greenstone.

The limestone (fig. 27) of Late Triassic age is mainly medium-bedded gray-weathering lime mudstone and wackestone that occur as fault slivers having stratigraphic thicknesses less than 
several tens of meters. Fossils (locs. 10 through 12, fig. 27) are listed in table 7.

The McCarthy Formation (fig. 27) consists of thin- to medium-bedded calcareous argillite and impure limestone, chiefly spiculitic skeletal or intraclastic lime packstone. Intraclasts are spicular phosphatic mudstone and chert. Less than $100 \mathrm{~m}$ is exposed in a fault sliver between the Nikolai Greenstone and upper Paleozoic sedimen- tary rocks. Fossils from locality 13 are of Late Triassic (late Norian) age (table 7; fig. 27).

Jurassic and Cretaceous clastic sedimentary rocks (KJs, fig. 27) consists of conglomerate and lithic sandstone and grit with increasing amounts of black argillite interstratified in the upper part of the exposed section. Clastic grains consist mainly of mafic volcanic rocks and chert, but rare coarse-grained clasts of fossiliferous limestone

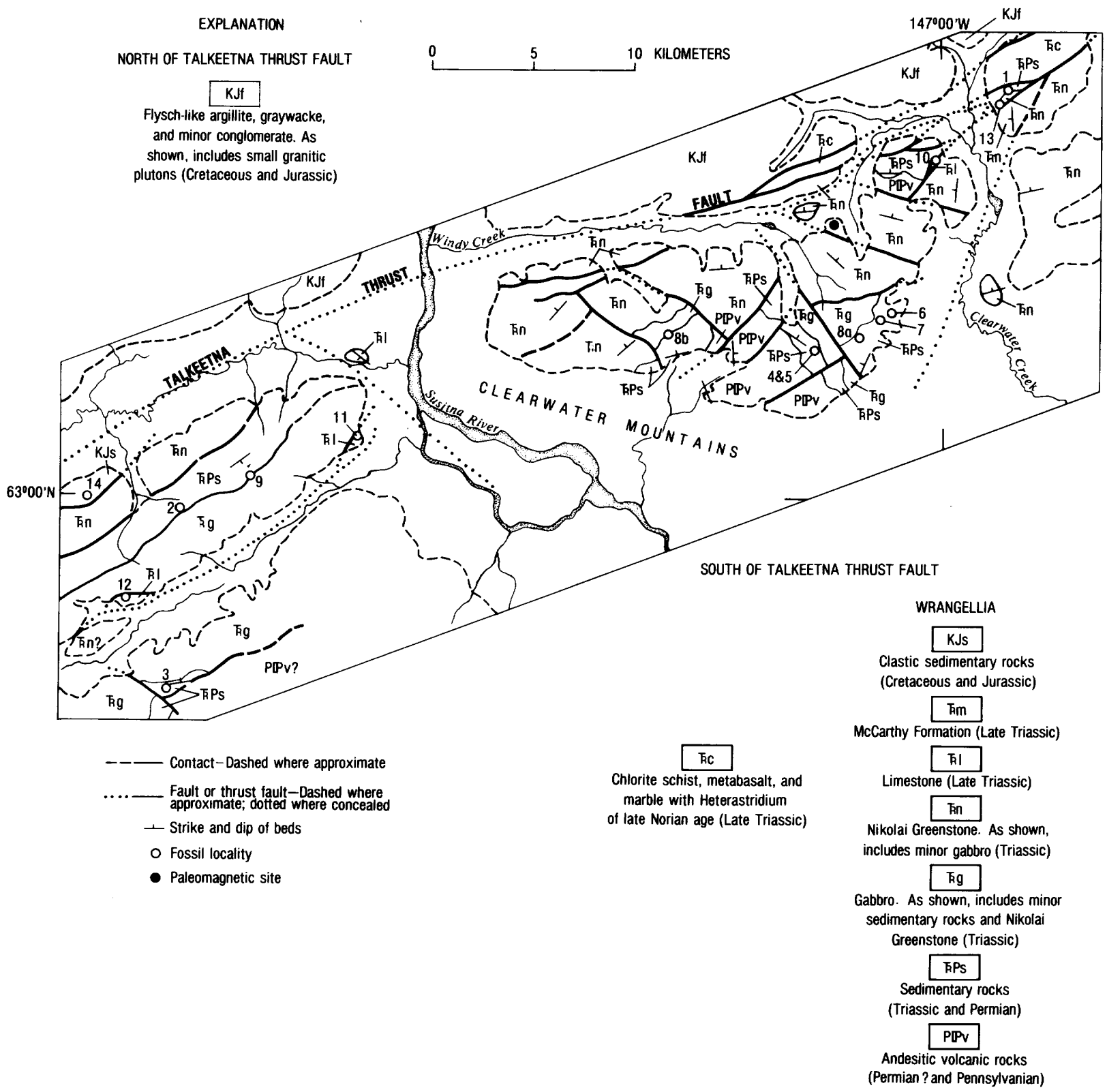

FIGURE 27.-Geologic map of northeastern Talkeetna Mountains and Clearwater Mountains, south-central Alaska. 
like that of the Triassic limestone unit (fig. 27) are also present. Similar, but less deformed rocks, several hundred meters thick, may rest unconformably on the Nikolai Greenstone just west of the map area (loc. 14 on fig. 27); Buchias of Late Jurassic (Kimmeridgian) and Early Cretaceous ages occur near the top of the exposed section.

Although the Triassic and older rocks of the Wrangellia section described above in the Clearwater Mountains area record a depositional history similar to that of more typical parts of
Wrangellia farther east, significant differences are apparent. The basal part of the Clearwater Mountains section accumulated in a depositional environment that was more basinal and distal than the late Paleozoic arc represented by the Tetelna Volcanics and Slana Spur Formation, overlying sedimentary rocks contain much less limestone and perhaps more chert than their eastern counterparts, and the Nikolai Greenstone is much thicker and more of its lower part marine, as compared to typical exposures. This deepwater facies of Wrangellia may be juxtaposed with

TABLE 7.-Fossils and ages from the Wrangellia terrane, south-central Alaska

[Conodonts and brachiopods identified by B. R. Wardlaw]

\begin{tabular}{|c|c|c|c|}
\hline \multicolumn{2}{|c|}{ Locality number } & Fauna & Age \\
\hline & $1,2,3$ & $\begin{array}{l}\text { Crinoid columnals } \\
\text { and bryozoans. }\end{array}$ & Late Paleozoic. \\
\hline & 4 & Radiolarians --------- & $\begin{array}{l}\text { Late Pennsylvanian or early } \\
\text { Permian. }\end{array}$ \\
\hline & 5 & $\begin{array}{l}\text { Radiolarians and } \\
\text { conodonts. }\end{array}$ & Early Permian (Leonardian). \\
\hline & 6 & Brachiopods ---------- & Early Permian. \\
\hline & 7 & Radiolarians ---_----- & Permian. \\
\hline & $8 a$ & Radiolarians --------- & Triassic. \\
\hline & $8 \mathrm{~b}$ & Conodonts --------- & $\begin{array}{l}\text { Early Triassic (late Dienerian } \\
\text { to early Smithian). }\end{array}$ \\
\hline & 9 & $\begin{array}{l}\text { Radiolarians and } \\
\text { conodonts. }\end{array}$ & Middle Triassic. \\
\hline 10 & $\begin{array}{l}\text { (USGS Mes. loc. } 6570 \\
\text { and M6499) }\end{array}$ & $\begin{array}{l}\text { Halobia cf. } H . \\
\text { superba Tropites sp. }\end{array}$ & Late Triassic (late Karnian). \\
\hline 11 & (USGS Mes. 1oc. M5020) & $\begin{array}{l}\text { Halobia sp., } \\
\text { Arcestes sp. }\end{array}$ & Late Triassic. \\
\hline 12 & (USGS Mes. 1oc. M6677) & $\begin{array}{l}\text { Halobia cf. H. } \\
\text { dalliana. }\end{array}$ & Late Triassic (early Norian?). \\
\hline 13 & $\begin{array}{l}\text { (USGS Mes, 1oc. } 6571 \\
\text { and M6500) }\end{array}$ & $\begin{array}{l}\text { Monotis subcircularis, } \\
\text { M. salinaria. }\end{array}$ & Late Triassic (late Norian). \\
\hline
\end{tabular}


that more typical of the terrane along a major fault within the Wrangellia plate on the northeast side of the Amphitheater Mountains (Nokleberg and others, 1981).

\section{REFERENCES CITED}

Beikman, H. M., 1974, Preliminary geologic map of the southeast quadrant of Alaska: U.S. Geological Survey Miscellaneous Field Studies Map MF-612, scale 1:1,000,000.

Coney, P. J., Silberling, N. J., Jones, D. L., and Richter, D. H., 1981, Structural relations along the leading edge of the Wrangellia terrane in the Clearwater Mountains, Alaska, in Albert, N. R. D., and Hudson, Travis, eds., The United States Geological Survey in Alaska: Accomplishments during 1979: U.S. Geological Survey Circular 823-B, p. B56-B58.

Csejtey, Béla, Jr., 1976, Tectonic implications of a late Paleozoic volcanic arc in the Talkeetna Mountains, south-central Alaska: Geology, v. 4, p. 49-52.

Csejtey, Béla, Jr., Nelson, W. H., Jones, D. L., Silberling, N. J., Dean, R. M., Morris, M. S., Lanphere, M. A., Smith, J. G., and Silberman, M. L., 1978, Reconnaissance geologic map and geochronology, Talkeetna Mountains quadrangle, northern part of Anchorage quadrangle, and southwest corner of Healy quadrangle, Alaska: U.S. Geological Survey Open-File Report 78-558-A, 62, p., scale $1: 250,000$.

Cse jtey, Béla, Jr., and St. Aubin, D. R., 1981, Evidence for northwestward trusting of the Talkeetna superterrane, and its regional significance, in Albert, N. R. D., and Hudson, Travis, eds., The United States Geological Survey in Alaska: Accomplishments during 1979: U.S. Geological Survey Circular 832-B, B49-B51.

Hillhouse, J. W., 1977, Paleomagnetism of the Triassic Nikolai Greenstone, McCarthy quadrangle, Alaska: Canadian Journal of Earth Sciences, v. 14, p. 2578-2592.

Jones, D. L., and Silberling, N. J., 1979, Mesozoic stratigraphy-the key to tectonic analysis of southern and central Alaska: U.S. Geological Survey Open-File Report 79-1200.

Jones, D. L., Silberling, N. J., and Hillhouse, John, 1977, Wrangellia-a displaced terrane in northwestern North America: Canadian Journal of Earth Sciences, v. 14, p. 2565-2592.

MacKevett, E. M., Jr., 1978, Geologic map of the McCarthy quadrangle, Alaska: U.S. Geological Survey Miscellaneous Investigations Series, Map I-1032, scale 1:250,000.

Nokleberg, W. J., Albert, N. R. D., Herzon, P. L., Miyaoka, R. T., and Zehner, R. E., 1981, Cross section showing accreted Andean-type arc and island arc terranes in southwestern Mount Hayes quadrangle, Alaska, in Albert, N. R. D., and Hudson, Travis, eds., The United States Geological Survey in Alaska: Accomplishments during 1979: U.S Geological Survey Circular 823-B, p. B66-B67.

Richter, D. H., and Dutro, J. T., Jr., 1975, Revision of the type Mankomen Formation (Pennsylvanian and Permian), Eagle Creek area, eastern Alaska Range, Alaska: U.S. Geological Survey Bulletin 1395-B, p. B1-B25.

Smith, J. G., and MacKevett, E. M., Jr., 1970, The Skolai
Group in the McCarthy D-4, C-4, and C-5 quadrangles, Wrangell Mountains, Alaska: U.S. Geological Survey Bulletin 1274-Q, p. Q1-Q26.

Smith, T. E., 1974, Regional geology of the Susitna-Maclaren River area: Alaska Division of Geological and Geophysical Surveys, Annual Report for 1973, p. 3-6.

Smith, T. E., and Lanphere, M. A., 1971, Age of the sedimentation, plutonism, and regional metamorphism in the Clearwater Mountains region, central Alaska: Isochron/West, no. 2, p. 17-20.

Smith, T. E., and Turner, D. L., 1973, Geochronology of the Maclaren metamorphic belt, south-central Alaska: A progress report: Isochron/West, no. 7, p. 21-25.

Stout, J. H., 1976, Geology of the Eureka Creek area, eastcentral Alaska Range: Alaska Division of Geological and Geophysical Surveys, Geologic Report 46, 32 p.

Paleolatitude of Triassic basalt in the Clearwater Mountains, south-central Alaska

By John W. Hillhouse and Sherman Grommé

Paleomagnetic results have been obtained from Triassic basalt in the Clearwater Mountains (Healy A-1 quadrangle). The basalt, included in the Amphitheatre Group of Smith and Turner (1973) by Smith (1974), is now considered equivalent to the Middle and (or) Upper Triassic Nikolai Greenstone of the McCarthy quadrangle (Silberling and others, 1981). The Nikolai Greenstone and equivalent basaltic sequences in southcentral Alaska help define the northern limit of Wrangellia (Jones and others, 1977), a geologic terrane that extends along the Pacific margin as far south as eastern Oregon. The paleolatitude of the Nikolai Greenstone at McCarthy is anomalously low compared to the expected Triassic paleoposition of the area, well established by coeval paleomagnetic poles from tectonically stable areas of North America (Hillhouse, 1977). Hence, we infer that the Nikolai Greenstone and presumably the other parts of Wrangellia have moved as plate fragments thousands of kilometers north relative to the craton. Our sampling locality in the Clearwater Mountains, $250 \mathrm{~km}$ northwest of McCarthy, espands the paleomagnetic investigation of Wrangellia, and the new results provide additional evidence supporting northward drift of Wrangellia.

Oriented cores were collected from 11 basalt flows exposed on a ridge above the headwaters of Windy Creek (fig. 27). The sampled flows are dis- 
tributed evenly within a $300-\mathrm{m}$-thick stratigraphic section composed of subaerial flows, 1 to $10 \mathrm{~m}$ thick, and minor sedimentary interbeds. Well-exposed flow boundaries of the thinly layered basalts provide structural control. The gray-green and gray-red basalt has a tholeiitic composition; the highly vesicular flows contain amygdules of quartz, chlorite, calcite, prehnite, and pumpellyite. Weak metamorphism at temperatures below $350^{\circ} \mathrm{C}$ is indicated by the suite of secondary minerals.

Stable magnetic directions were obtained from seven flows, each represented by four to eight independently oriented cores. Secondary components of magnetization were removed by partially demagnetizing each specimen in a peak alternating field of $40 \mathrm{mTesla}$ followed by heating to $550 \mathrm{C}$ in a field-free furnace. Unacceptable directional dispersion of the four rejected flows is attributed to lightning. The overall mean magnetic direction of the stably magnetized flows is inclination (I) $=-32.4^{\circ}$, declination (D) $=138.4^{\circ}$ with a 95 percent confidence limit of $11.3^{\circ}$. The corresponding paleolatitude of $18 \mathrm{~N}$. or $18^{\circ} \mathrm{S}$., depending on polarity is compatible with the paleolatitude $\left(15^{\circ} \mathrm{N}\right.$. or S.) of the Nikolai Greenstone, determined at McCarthy. Agreement of results from sites $250 \mathrm{~km}$ apart suggests that the basalt retains its primary remanence and does not have magnetic overprints due to chemical alteration or later thermal events. In addition, primary origin of the Nikolai magnetization is supported by a positive fold test (which means that the magnetization was acquired before the rocks were folded) and the consistent antipolarity of normal and reversed directions at the McCarthy study area.

The paleomagnetically determined latitude of northern Wrangellia is at least $25^{\circ}$ south of the Late Triassic latitude $\left(43^{\circ} \mathrm{N}\right.$.) predicted for south-central Alaska from plate tectonic reconstructions (Hillhouse, 1977). Accordingly, the minimum northward drift of Wrangellia relative to the craton is $2,700 \mathrm{~km}$. If Wrangellia originated in the southern hemisphere, an ambiguity not resolved by the data now available, then its northward drift may have been as great as $61^{\circ}$.

The geographic origin of Wrangellia and the timing of its accretion to North America are not known. Given our paleomagnetic data and the positions of the continents in the Late Triassic, we can constrain the original position of Wrangellia only to the proto-Pacific equatorial zone. The terrane may have been a Pacific island or a fragment torn from the continental margin of North America, South America, or Asia. Wrangellia was subsequently carried north thousands of kilometers, probably as part of a proto-Pacific oceanic plate now destroyed by subduction.

\section{REFERENCES CITED}

Hillhouse, J. W., 1977, Paleomagnetism of the Triassic Nikolai Greenstone, McCarthy quadrangle, Alaska: Canadian Journal of Earth Sciences, v. 14, p. 2578-2592.

Jones, D. L., Silbering, N. J., and Hillhouse, J. W., 1977, Wrangellia-A displaced terrane in northwestern North America: Canadian Journal of Earth Sciences, v. 14, p. 2565-2577.

Silberling, N. J., Richter, D. H., and Jones, D. L., 1981, Rec ognition of the Wrangellia terrane in the Clearwater Mountains and vicinity, south-central Alaska, in Albert, N. R. D., and Hudson, Travis, eds., The United States Geological Survey in Alaska: Accomplishments during 1979: U.S. Geological Survey Circular 823-B, p. B51-B55.

Smith, T. E., 1974, Regional geology of the Susitna-Maclaren River area: Alaska Division of Geological and Geophysical Surveys, Annual Report for 1973, p. 3-6.

Structural relations along the leading edge of the Wrangellia terrane in the Clearwater Mountains, Alaska

By Peter J. Coney, N. J. Silberling, D. L. Jones, and D. H. Richter

Structural analysis along $200 \mathrm{~km}$ of the north edge of the Wrangellia terrane in the central and eastern Alaska Range reveals a collisional suture of complex geometry and evolutionary history. The suture zone generally separates weakly metamorphosed upper Paleozoic through Triassic rocks of the Wrangellia terrane (Jones and others, 1977) on the south from several totally distinct and highly variable sedimentary, igneous, and metamorphic terranes on the north (Jones and Silberling, 1979). The wide suture zone itself, named the Talkeetna thrust by Csejtey and others (1978), displays many faults and intense but variable deformation, particularly in a flysch terrane of assumed Late Jurassic and Early Cretaceous age.

In the Clearwater Mountains (fig. 28) of the central Alaska Range, where our most detailed observations have been made, the Wrangellia terrane is separated by deformed flysch from rocks of the Maclaren metamorphic belt (Smith and 
Turner, 1973). North of the Maclaren metamorphic belt is the less metamorphosed terrane composed of Triassic silty limestone, argillite, and gabbro sills (D. L. Jones, N. J. Silberling, Béla Csejtey, P. J. Coney, and D. H. Richter, field observations, 1979) exposed at the headwaters of the Nenana River. These terranes north of the suture trend northeast across the Clearwater Mountains and are truncated obliquely by the Denali fault between the Susitna and Delta Rivers. East of the Delta River, the boundary of Wrangellia is the Denali fault.

In the Clearwater Mountains, structures within the Wrangellia block are of large scale but simple geometry (Silberling and others, 1981) Faultbounded slabs of the Nikolai Greenstone (basalt flows) and gabbro sills and the underlying upper Paleozoic volcanic and sedimentary sequence dip $30^{\circ}$ to $40^{\circ}$ northward toward the suture zone. Faults bounding these slabs dip steeply and strike transversely to the regional northeast trend of the terrane. Metamorphism in the Wrangellia terrane is low greenschist grade, with only very minor and locally developed penetrative fabric. In contrast to structures in the Clearwater Mountains, the Wrangellia sequence west of the Susitna River is exposed in southeast-dipping slabs apparently bounded by southeast-dipping thrust faults that imbricate and repeat the section (Béla Csejtey and P. J. Coney, field observations, 1979).

The northern boundary fault of Wrangellia, where exposed in the Clearwater Mountains, is vertical to very steeply south dipping. It separates north-dipping Nikolai basalt on the south from strongly deformed vertical to north-dipping green phyllite and marble of the Clearwater terrane of Silberling and others (1981) (fig. 27) on the north. The clearwater terrane, herein named for the Clearwater Mountains, is an up to $2 \cdot \mathrm{km}$-wide and $24-\mathrm{km}$-long, steeply dipping slice of contorted Triassic limestone marble, limestone conglomerate, metatuff, and minor pillow basalt. It has no known equivalents in this part of Alaska and is caught between Wrangellia to the south and deformed flysch to the north. The fault bounding the north side of the Clearwater terrane dips about $65^{\circ} \mathrm{S}$. West of Susitna River, the Wrangellia boundary fault, where mapped as the Talkeetna thrust fault by Csejtey and others (1978), dips about $45^{\circ} \mathrm{SE}$.
Structures in flysch of the suture zone include isoclinal and recumbent folds, numerous faults, development of pervasive and penetrative cleavage, and even partial to total dismemberment of original lithologic layering. Most structural elements verge northwest in the central and southern part of the suture zone but verge south along the northern margin of the zone. At least two southeast-dipping thrust faults juxtapose flysch sequences of contrasting lithology and metamorphic grade. A significant discontinutity in lithologies and metamorphic grade also marks the northern boundary of the suture zone where a northwest-dipping fault places heterogeneous greenschist, part of the Maclaren metamorphic belt, over phyllite of the flysch terrane.

We interpret the Maclaren metamorphic belt as a large, southeast-vergent, overturned antiform. In the core of the antiform is amphibolite-facies biotite gneiss that contains sillimanite and kyanite (Smith and Turner, 1973). Enveloping and partly intrusive into the gneiss is a "synkinematic" sheath of faintly to strongly foliated biotitehornblende granodiorite. On Rusty Hill in the Cleatwater Mountains, this pluton is a northdipping foliated sill that underlies the gneiss and structurally overlies the greenschist terrane to the south. The greenschist terrane, the structurally lowest unit of the Maclaren belt, includes chlorite schist, biotite, garnet, and staurolite schist, garbenschiefer, calc-schist, and amphibolite. The metamorphic assemblages of the Maclaren belt, therefore, are inverted with higher grade rocks above lower grade rocks, as Smith (1970) first observed. Minor structures in the Maclaren belt are polyphase and include numerous northwest-plunging, south-vergent folds within the north-dipping foliation planes.

The original age of the Maclaren protoliths is not known. K-Ar cooling ages on both the granitic sill and metamorphic rocks mostly indicate a Late Cretaceous age of metamorphism (Smith and Lanphere, 1971; Smith and Turner, 1973).

The south-verging structures typical of the Maclaren belt become dominant eastward toward Delta River such that the entire suture zone and its margins become the north-dipping Broxson Gulch thrust fault system (Stout, 1976). East of Delta River, Wrangellia is bounded by the Denali fault. Near Mankomen Lake, the strata and folia- 
tion in both Wrangellia to the southwest and diverse terranes to the northeast dip into and toward the Denali fault zone (see Richter and others, 1977).

The opposed structural vergence across the suture zone is an important characteristic of Wrangellia's leading edge. The increasing predominance of south-verging thrust faults east of the Clearwater Mountains to the juncture with the Denali fault, where some of the faulting clearly is as young as middle to late Tertiary (Stout, 1976; Weber and Turner, 1977), suggests that some of the more brittle south-verging deformation has, in part, overprinted an earlier geornetry. It also suggests that the faulting is tectonically related to Tertiary right-lateral movement on the Denali fault. Otherwise, the major structural features of the Wrangellia suture are known only to postdate the Late Jurassic and Early Cretaceous flysch. Many of the major structures and most of the penetrative metamorphic fabrics of the Maclaren belt also predate the early Tertiary plutons that intrude it. We assume that major collisional structures of Wrangellia's leading edge and its suture zone are of middle or latest Cretaceous age. Tertiary postcollisional intraplate movement on the Denali fault and associated transpressive deformation is apparently evolving to the present day.

\section{REFERENCES CITED}

Csejtey, Béla, Jr., Nelson, W. H., Jones, D. L., Silberling, N. J., and others, 1978, Reconnaissance geologic map and geochronology, Talkeetna Mountains quadrangle, northern part of Anchorage quadrangle, and southwest corner of Healy quadrangle, Alaska: U.S. Geological Survey Open-File Report 78-558-A, 62 p., scale 1:250,000.

Jones, D. L., and Silberling, N. J., 1979, Mesozoic stratigraphy-the key to tectonic analysis of southern and central Alaska: U.S. Geological Survey Open-File Report 79-1200, $37 \mathrm{p}$.

Jones, D. L., Silberling, N. J., and Hillhouse, John, 1977, Wrangellia-a displaced terrane in northwestern North America: Canadian Journal of Earth Sciences, v. 14, p. 2565-2577.

Richter, D. H., Sharp, W. N., Dutro, J. T., Jr., and Hamilton, W. B., 1977, Geologic map of parts of the Mount Hayes A-1 and A-2 quadrangles, Alaska: U.S. Geological Survey Miscellaneous Investigations Map I-1031, 1:63,360.

Silberling, N. J., Richter, D. H., and Jones, D. L., 1981, Recognition of the Wrangellia terrane in the Clearwater Mountains and vicinity, south-central Alaska, in Albert, N. R. D., and Hudson, Travis, eds., The United States Geological Survey in Alaska: Accomplishments during 1979: U.S. Geological Survey Circular 823-B, p. B51-B55.
Smith, T. E., 1970, Inverted metamorphic zonation in the northern Clearwater Mountains, Alaska [abs.], in Geological Survey Research 1970: U.S. Geological Survey Professional Paper 700-A, p. A47-A48.

Smith, T. E., and Lanphere, M. A., 1971, Age of sedimentation, plutonism, and regional metamorphism of the Clearwater Mountains region, central Alaska: Isochron/West, no. 2, p. $17-20$.

Smith, T. E., and Turner, D. L., 1973, Geochronology of the Maclaren metamorphic belt, south-central Alaska: A progress report: Isochron/West, no. 7, p. 21-25.

Stout, J. H., 1976, Geology of the Eureka Creek area, eastcentral Alaska Range: Alaska Division of Geological and Geophysical Surveys, Geological Report 46, 32 p.

Weber, F. R., and Turner, D. L., 1977, A late Tertiary thrust fault in the central Alaska Range, in Blean, K. M., ed., The United States Geological Survey in Alaska: Accomplishments during 1976: U.S. Geological Survey Circular 751 -B, p. B66-B67.

Paleomagnetic investigation in the Chulitna terrane, southcentral Alaska

By John W. Hillhouse and Sherman Grommé

A paleomagnetic investigation of Upper Triassic redbeds and basalts has been completed in the upper Chulitna district (Healy A-6 quadrangle). Pre-Cenozoic rocks within the district are part of the Chulitna terrane, a unique assemblage of upper Paleozoic and Triassic volcanic and sedimentary rocks that were deposited on Devonian ophiolite (Jones and others, 1979). Uniqueness of the assemblage is underscored by the occurrence of Lower Triassic limestone and Upper Triassic redbeds found nowhere else in Alaska. The Triassic depositional history of the Chulitna terrane is unlike the coeval history inferred in nearby Wrangellia, a large terrane whose northwestern boundary lies a short distance southeast of Chulitna (Jones and others, 1977).

Paleomagnetic evidence indicates Wrangellia is an exotic terrane that has moved northward more than $3000 \mathrm{~km}$ relative to the North American craton sometime after the Late Triassic. The anomalously low paleolatitude of Wrangellia was determined from the Triassic Nikolai Greenstone in the McCarthy quadrangle (Hillhouse, 1977) and from equivalent rocks in the Healy quadrangle (Hillhouse and Grommé, 1981). We sampled Upper Triassic rocks in the Chulitna terrane to determine its paleolatitude for comparison with the exotic paleoposition inferred for Wrangellia. Un- 
fortunately, our objective was not realized because the remanent magnetization in basalts and redbeds of the Chulitna terrane originated long after the rocks were deposited.

Recent geologic mapping and paleontologic studies (Jones and others, 1979), combined with earlier work (Hawley and Clark, 1974), establish the stratigraphy of the Chulitna terrane. The oldest rocks make up an ophiolitic sequence that includes serpentinite in fault contact with gabbro, diabase, pillow basalt, and red radiolarian chert of Devonian age. Upper Paleozoic rocks composed of volcanic conglomerate, sandstone, chert, argil- lite, and limestone lie structurally above the ophiolite. In the northeastern part of the district, Permian limestone is in depositional contact with Upper Triassic redbeds. Red chert pebbles in the redbeds were probably derived from the ophiolite. In the northwestern part of the district, a distinctive Upper Triassic sequence of pillow basalt interbedded with gray limestone underlies the redbeds, but the base of the basalt and limestone unit is not exposed. Upper Triassic redbeds in the central area of the terrane are gradationally overlain by brown marine sandstone and siltstone as young as Early Jurassic. The youngest unit of

EXPLANATION

Ks Schist (Cretaceous)

Kgr Granodiorite (Cretacous)

Kgn Gneiss (Cretaceous)

KJf Flysch (Cretaceous and Jurassic)

KC Clearwater terrane (Triassic)

$\mathrm{Kn}$ Nikolai Greenstone and gabbro sills (Triassic)

$\mathrm{P}_{\mathrm{Zu}}$ Undifferentiated volcanic and sedimentary rocks (upper Paleozoic)

- Contact

$\longrightarrow$ Fault

ــ Thrust fault-Dashed where approximate

$\ldots$.45 Strike and dip of beds

_. Stike and dip of foliation
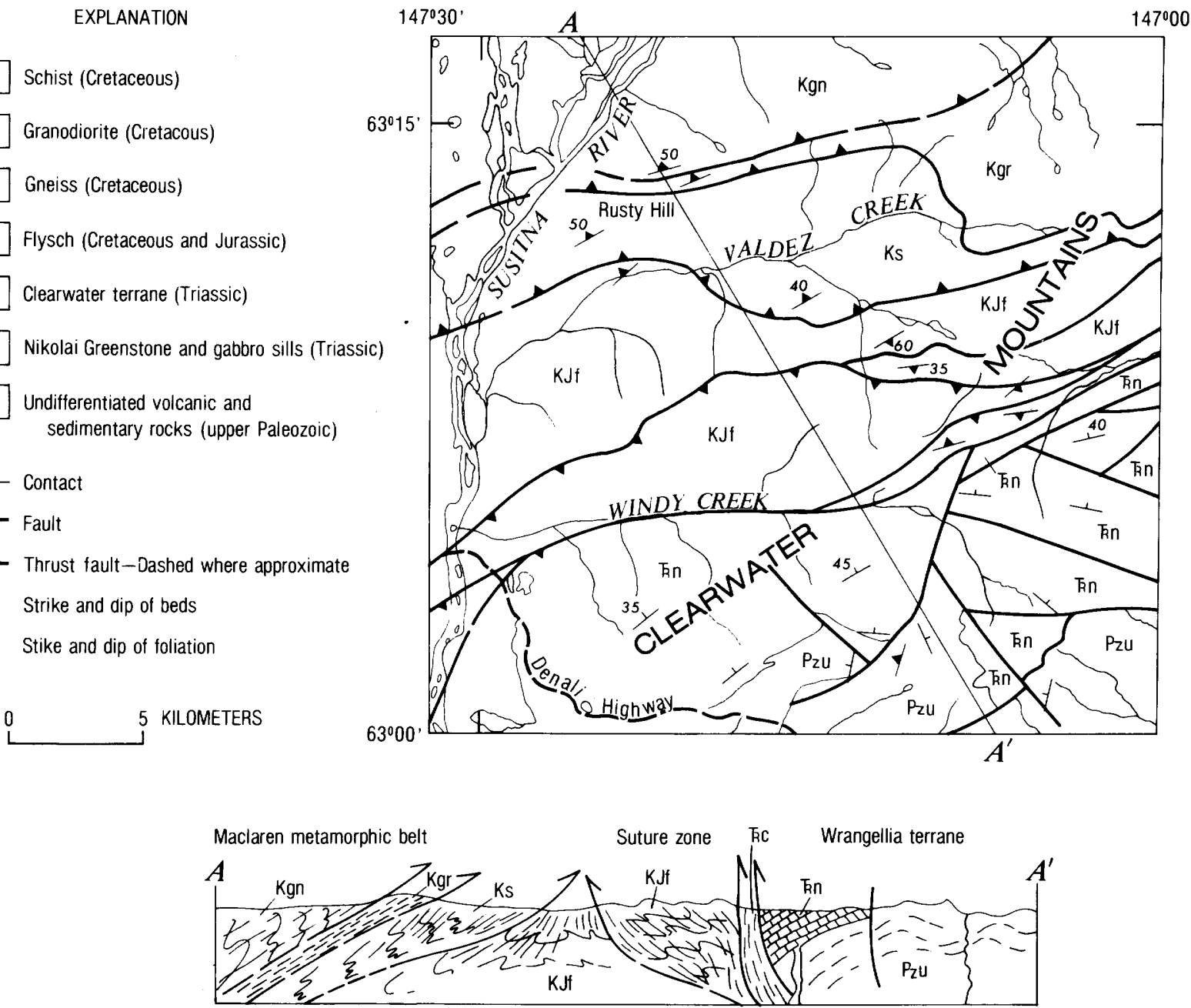

GIJRE 28.-Tectonic-terrane map and interpretive structure section of Clearwater Mountains. Tectonic map compiled from Jones, Silberling, Richter, and Coney (field investigations, 1979) and Csejtey and Coney (field investigations, 1979). Other than foliated granodiorite sill north of Valdez Creek, plutons are not shown. 
the Chulitna terrane consists of dark-gray argillite, gray to black chert, and thin beds of limestone of Late Jurassic and Eary Cretaceous age.

Fourteen redbed sections, each having different structural attitudes, were sampled in the vicinity of Long Creek, Blind Creek, and Christy Creek. Thermal demagnetization of the redbed specimens revealed well-grouped magnetic directions that were stable up to $675^{\circ} \mathrm{C}$ (fig. 29). However, cor-
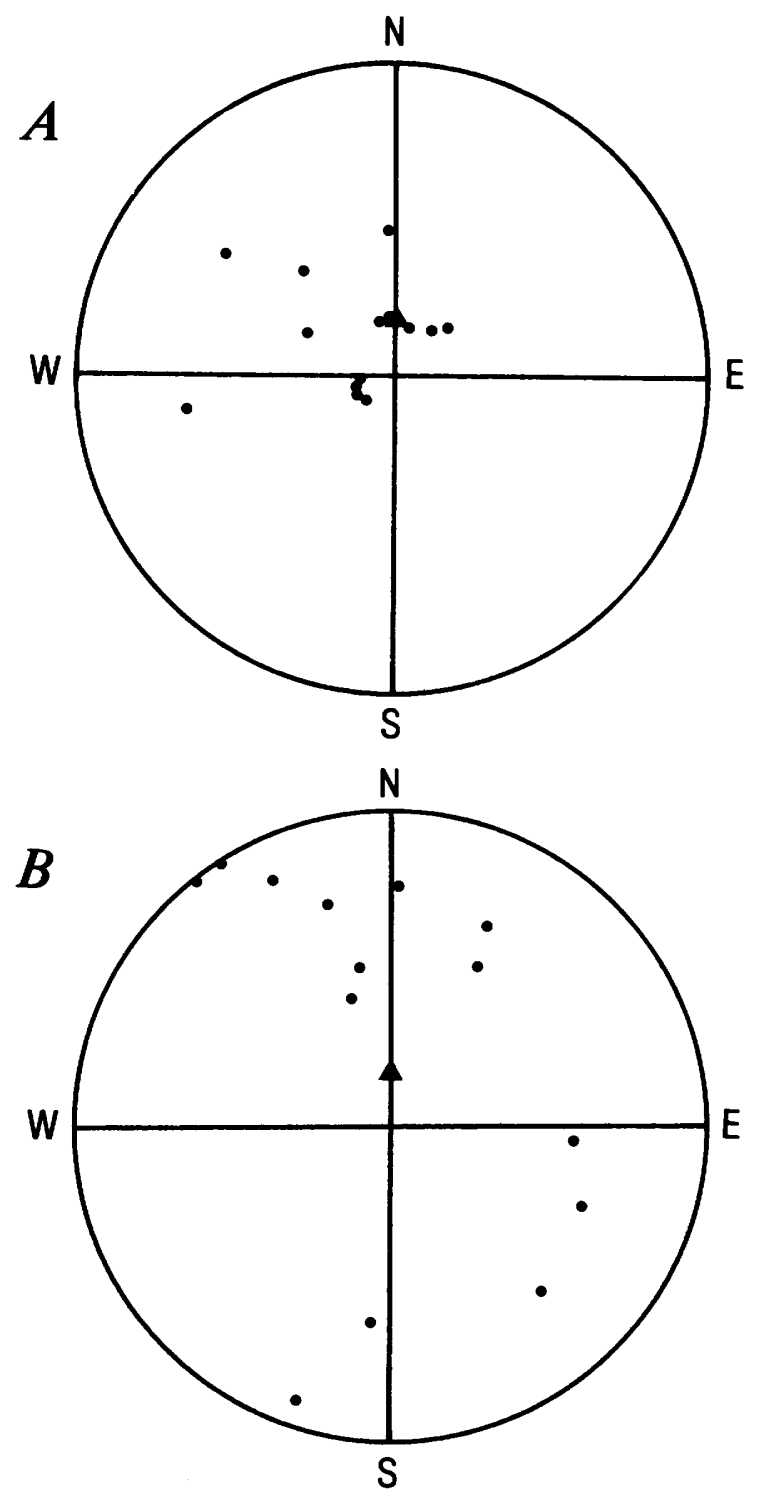

Figure 29.-Mean magnetic directions from redbed sections of the Chulitna terrane. $A$, Before application of structural tilt correction. $B$, After. Present axial dipole direction shown by triangle. recting the directions for tilt of the bedding substantially increased the directional scatter of the overall data set. Therefore, we conclude that the redbeds were remagnetized on a regional scale after the Chulitna terrane was folded and thrusted, sometime after deposition of the Cretaceous flysch now exposed in the Chulitna River valley.

The postdepositional remanence of the Chulitna redbeds resides in hematite, as indicated by high coercivity of remanence and blocking temperatures up to $675^{\circ} \mathrm{C}$. Of the possible magnetization processes, we can rule out detrital remanent magnetization (DRM) as the source of remanence, because the fold test is negative. The remaining processes that may account for Chulitna redbed magnetization are: 1) viscous remanent magnetization (VRM) acquired at low temperature during the Brunhes normal polarity epoch; 2 ) thermoremanent magnetization (TRM) acquired at elevated temperatures during regional metamorphism; 3 ) chemical remanent magnetization (CRM) acquired by the gradual growth of hematite crystals and the pseudomorphic replacement of iron-bearing minerals by hematite. Demagnetization experiments indicate that recent-field VRM makes up a small percentage of the remanence, but the thermal stability of remarence of these redbeds is too high to be explained by VRM alone (Dunlop and Stirling, 1977). A high-temperature TRM is also unlikely because metamorphic minerals of low greenschist facies in the nearby volcanic rocks place an upper limit of about $350^{\circ} \mathrm{C}$ on heating due to regional metamorphism. However, magnetic domains with high blocking temperatures measured in the laboratory can be remagnetized at lower temperatures in nature if the heating occurs over millions of years. The most likely explanation for the Chulitna redbed magnetization is a combination of TRM and CRM acquired at slightly elevated temperatures $\left(150^{\circ} \mathrm{C}\right.$ to $\left.300^{\circ} \mathrm{C}\right)$.

The conditions necessary for the creation of the CRM-TRM combination were probably met when the thrust sheets were deeply buried and hot ground water systems were active. A number of small stocks and dikes near the Golden Zone mine suggest that rising magma may have created a chemical environment favorable to the formation of CRM. We do not imply that all hematite in the Chulitna redbeds was created by this process, for 
the red hematite pigment most likely predates the episode of folding. Instead, the hematite domains responsible for the stable remanence probably grew long after the pigment formed, by the gradual replacement of titanomagnetite and ferromagnesian silicates in the volcanic-rich detritus. The absence of mixed polarity magnetizations suggests that remagnetization of the Chulitna redbeds occurred during a single normal polarity epoch. Later tectonic movements slightly rotated the virtual geomagnetic poles (VGP), so the age of remagnetization cannot be inferred from the mean VGP.

In addition to the redbed sections, seven basalt flows were sampled in the Upper Triassic limestone and basalt unit in the northwestern part of the terrane. Secondary mineral assemblages of the basalts are of lower greenschist facies, and original igneous textures are preserved. However, alternating field demagnetization to 60 mTesla reveals several superimposed components of mag. netization that preclude calculation of a statistically valid paleomagnetic pole. We conclude that the remaining original thermoremanence, if any, has been masked by several secondary components acquired during a long history of metamorphism and deformation.

Triassic remanent magnetism of the redbeds and basalts has been lost, so we cannot infer the early tectonic history of the Chulitna terrane. The exotic nature of the Chulitna terrane has been inferred from dissimilarities in its lithostratigraphy compared to neighboring coeval terranes, but unlike Wrangellia, an exotic origin for the Chulitna terrane cannot be substantiated by paleomagnetic methods.

\section{REFERENCES CITED}

Dunlop, D. J., and Stirling, J. M., 1977, "Hard" viscous remanent magnetization (VRM) in fine-grained hematite: Geophysical Research Letters, v. 4, p. 163-166.

Hawley, C. C., and Clark, A. L., 1974, Geology and mineral deposits of the Upper Chulitna District, Alaska: U.S. Geological Survey Professional Paper 758-B, 47 p.

Hillhouse, J. W., 1977, Paleomagnetism of the Triassic Nikolai Greenstone, McCarthy quadrangle, Alaska: Canadian Journal of Earth Sciences, v. 14, p. 2578-2592.

Hillhouse, J. W., and Grommé, Sherman, 1981, Paleolatitude of Triassic basalt in the Clearwater Mountains, southcentral Alaska, in Albert, N. R. D., and Hudson, Travis, eds., The United States Geological Survey in Alaska: Accomplishments during 1979: U.S. Geological Survey Circular 823-B, p. B55-B56.
Jones, D. L., Silberling, N. J., Csejtey, Béla, Jr., Nelson, W. H., and Blome, C. D., 1979, Age and significance of ophiolite and adjoining rocks in the Upper Chulitna district, south-central Alaska: U.S. Geological Survey Professional Paper 1121 -A, 21 p.

Jones, D. L., Silberling, N. J., and Hillhouse, J. W., 1977, Wrangellia-A displaced terrane in northwestern North America: Canadian Journal of Earth Sciences, v. 14, p. 2565-2577.

K-Ar ages of the Nikolai Greenstone from the McCarthy quadrangle, Alaska the "docking" of Wrangellia

By Miles L. Silberman, Edward M. MacKevett, Jr., Cathy L. Connor, Paul R. Klock, and Georgiana Kalechitz ${ }^{1}$

The Nikolai Greenstone, a 3,000-m-thick sequence of theoleiitic, dominantly subaerial basalt flows exposed in the Wrangell Mountains and nearby areas of southern Alaska and the Yukon Territory, forms an important part of the allochthonous terrane of Wrangellia that, on the basis of paleomagnetic data (Hillhouse, 1977; Jones and others, 1977), is believed to have formed at low latitudes and been tectonically transported to its present location. Fossils in the underlying and overlying formations indicate that the Nikolai was emplaced in the Middle and (or) Upper Triassic (MacKevett, 1978). Specific information on the time of accretion (the "docking date") of Wrangellia has not been available. Jones and Silberling (1979) suggest, on the basis of widespread, localized deformation of, and overthrusting of older terranes upon, Upper Jurassic and Lower Cretaceous flysch deposits throughout the region (fig. 30), that final accretion of the many Mesozoic terranes of southern Alaska, including Wrangellia and the adjacent Peninsular terrane, occurred during middle to Late Cretaceous time.

Stratigraphic and structural studies by Csejtey and St. Aubin (1981) in the northern Talkeetna Mountains suggest that Wrangellia impinged upon and joined the North American continent between the Early Cretaceous and the Late Cretaceous or early Paleocene. Evidence for this age range comes from the thrusting of Wrangellian rocks over severely deformed Lower Cretaceous argillite and graywacke in this area and from the oldest undeformed rocks in this region, granitic

${ }^{1}$ Teledyne Isotopes, Westwood, New Jersey. 
plutonic rocks, which intrude the deformed argillite and graywacke and give Late Cretaceous and Paleocene K-Ar ages (Csejtey and others, 1978; Csejtey and St. Aubin, 1981).

The Nikolai Greenstone is mostly fine-grained, porphyritic, amygdaloidal basalt with plagioclase and less abundant clinopyroxene phenocrysts. It has been regionally affected by alteration and (or) prehnite-pumpellyite facies metamorphism. Secondary minerals are abundant chlorite, less abundant iron oxides, epidote, clay minerals, calcite, sericite, prehnite, serpentine, pumpellyite, quartz, and rare zeolites. Most amygdules contain chlorite with or without calcite; the rest are chalcedonic quartz and epidote (MacKevett, 1971; 1978).

We chose seven samples of Nikolai Greenstone

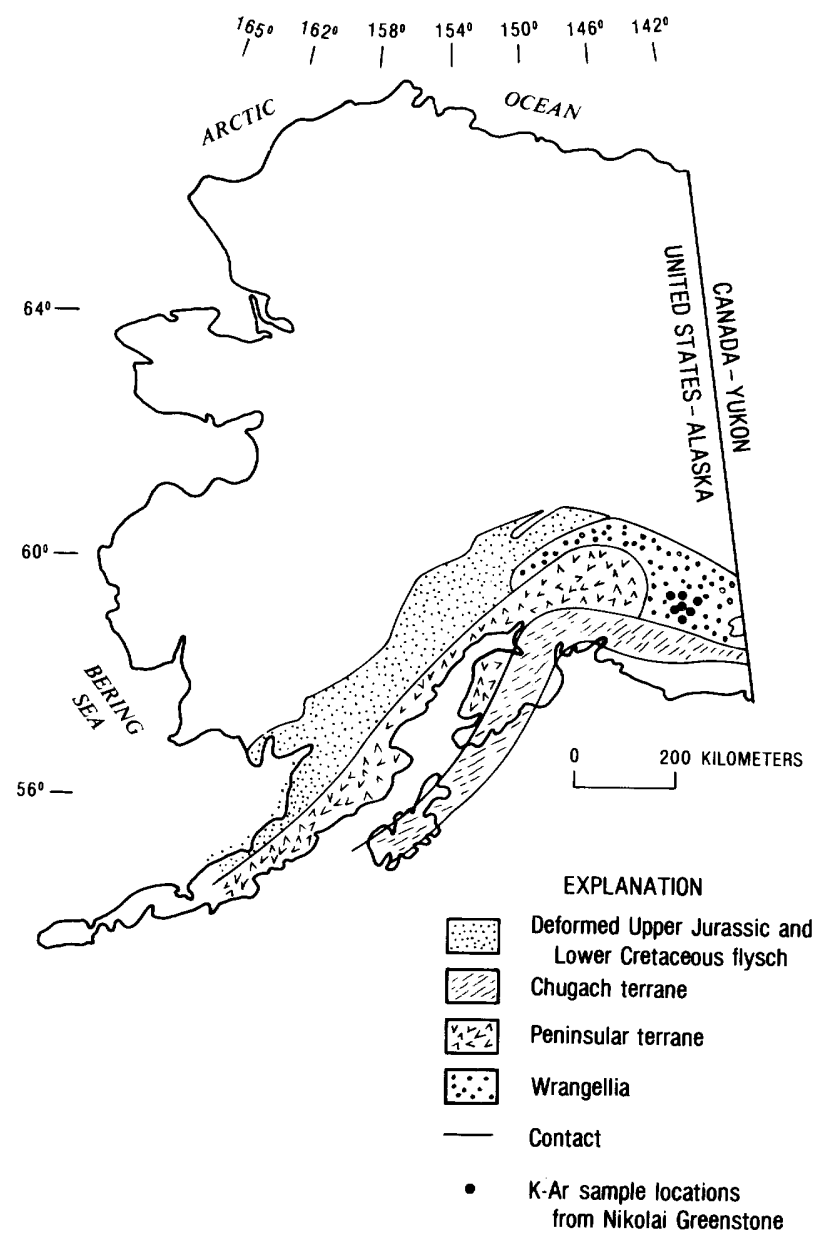

FIGURE 30.-Map showing selected Mesozoic terranes in southern Alaska. Modified from Jones and Silberling (1979). from the central part of the McCarthy quadrangle (fig. 30) near the Kennecott mines for whole-rock $\mathrm{K}$-Ar age determinations. The main alteration or metamorphic phases in these samples are chlorite, followed by altered plagioclase and variable amounts of the other common minerals mentioned above. The individual ages range from 91 to 131 m.y. (table 8). The K-Ar data have been plotted on an "initial argon" diagram (fig. 31) (Shafiqullah and Damon, 1974); the slope yields an age of $112 \pm 11 \mathrm{~m} . \mathrm{y}$. and an intercept of zero on the argon axis. A zero intercept on this type of diagram indicates that the rock system does not have appreciable argon loss or excess argon, and agreement of the slope age with the average of the individual ages (112 m.y.) is generally understood to mean that a crystallization age for the system has been obtained (Shafiqullah and Damon, 1974).

Besides the thermal episode defined by our isochron age of the Nikolai, two other events affected Wrangellia that may have caused heating of the greenstone. The first was a major orogeny that resulted in folding and thrust faulting of older rocks and intrusion of granitic rocks of the Chitina Valley batholith in the eastern and southern parts of the McCarthy quadrangle in the Late Jurassic (MacKevett, 1978). The second event occurred in the late Tertiary and is related to eruption of lava-the Wrangell Lava-that is widely

TABLE 8.-K-Ar ages of whole-rock Nikolai Greenstone samples

[All $\mathrm{K}_{2} \mathrm{O}$ analyses by Paul Klock, U.S. Geological Survey, Menlo Park, Calif. Sample N2, argon analysis run at U.S. Geological Survey, Menlo Park, Calif. Analysis: M. L. Silberman and C. L. Connor. Other samples run by Teledyne Isotopes, Westwood, N.J. Analyst: Georgiana Kalechitz.]

\begin{tabular}{|c|c|c|c|c|}
\hline Number & Location & $\begin{array}{c}\mathrm{K}_{2} \mathrm{O} \\
(\text { percent) }\end{array}$ & Age ( & $(\mathrm{m} \cdot \mathrm{y} \cdot)$ \\
\hline Swan & Swan Lake -- -- & 0.448 & 90.9 & $9 \pm 4.5$ \\
\hline $\mathrm{N} 1$ & Nikolai Creek -- & .531 & 105 & \pm 5 \\
\hline N2 & -- do. --------- & .285 & 111 & \pm 6 \\
\hline N4 & --do. -- - - - - - & .814 & 109 & \pm 6 \\
\hline $18 \mathrm{~A}$ & Bonanza Ridge -- & .268 & 120 & \pm 6 \\
\hline 8 & --do. ---------- & 1.29 & 131 & \pm 7 \\
\hline $11 \mathrm{C}$ & --do. -- - ------ & .932 & 113 & \pm 6 \\
\hline
\end{tabular}


distributed in the north half of the quadrangle. Hypabyssal granitic and intermediate intrusions probably related to Wrangell volcanism occur throughout the quadrangle and give $\mathrm{K}$-Ar ages between 15 and 4 m.y. (MacKevett, 1978; M. L. Silberman and E. M. MacKevett, Jr., unpub. data). The metamorphic ages of the Nikolai are clearly younger than the first event and appear to be unaffected by the second as well, since no variations in the K-Ar ages of the Nikolai can be related to distance from the hypabyssal intrusions in the area.

Granitic plutons, with associated hydrothermal alteration and disseminated copper and molybdenum mineralization, occur north of the Totschunda fault, mostly in the Nabesna quadrangle, north of the McCarthy quadrangle. K-Ar ages of rocks from these plutons are 105 to 118 m.y. (Richter and others, 1975; Silberman and others, 1977). The nearest of these plutons, however, is more than $80 \mathrm{~km}$ from the dated samples of the Nikolai and could not have affected our results.

We suggest that the 112-m.y.-old recrystallization of the Nikolai Greenstone occurred during frictional heating caused by accretion of Wrangellia. Stratigraphic and structural evidence cited previously (Jones and Silberling, 1979; Csejtey

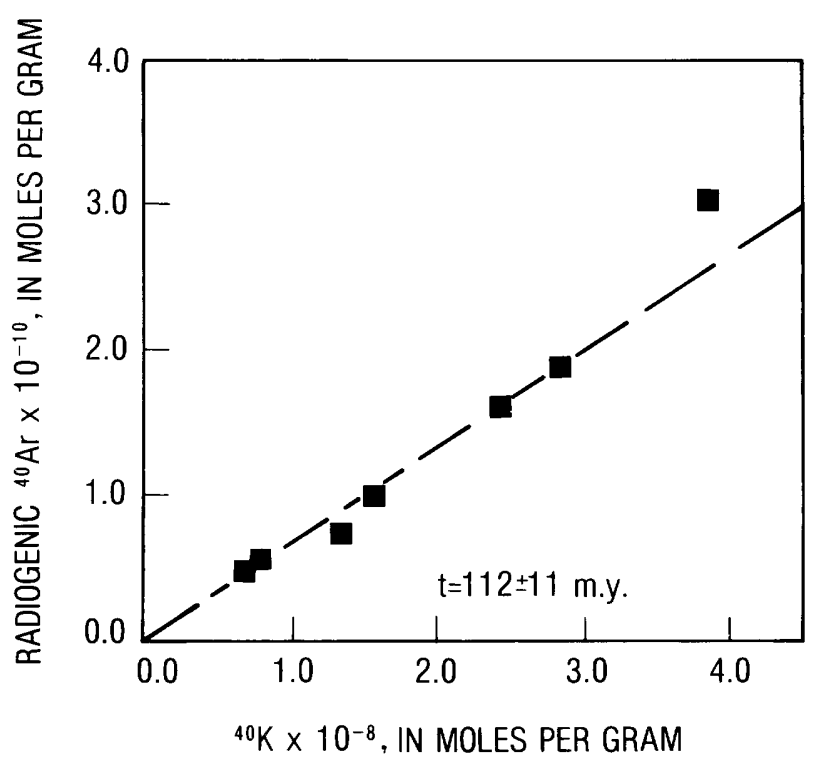

FIGURE 31.-Initial argon diagram for whole-rock samples from the Nikolai Greenstone. and St. Aubin, 1981) suggests that this age is a good estimate of the "docking" of Wrangellia. The data suggest that K-Ar whole-rock ages of greenstones may be useful in determining the tim. ing of accretion in other terranes that contain them, such as the Chugach and Prince William terranes. Evidently, greenstones are susceptible to metamorphic recrystallization during accretion and hold argon well enough to retain it during minor postaccretionary thermal events.

\section{REFERENCES CITED}

Csejtey, Béla, Jr., Nelson, W. H., Jones, D. L., Silberling, N. J., Dean, R. M., Morris, M. S., Lanphere, M. A., Smith, J. G., and Silberman, M. L., 1978, Reconnaissance geologic map and geochronology, Talkeetna Mountains quadrangle, northern part of Anchorage quadrangle, and southwest corner of Healy quadrangle, Alaska: U.S. Geological Survey Open-File Report 78-558-A 60 p., scale $1: 250,000$.

Csejtey, Béla, Jr., and St. Aubin, D. R., 1981, Evidence for northwestward thrusting of the Talkeetna superterrane, and its regional significance, in Albert, N. R. D., and Hudson Travis, eds., The United States Geological Survey in Alaska: Accomplishments during 1979: U.S. Geological Survey Circular 832-B, p. B49-B51.

Hillhouse, J. W., 1977, Paleomagnetism of the Triassic Nikolai Greenstone, McCarthy quadrangle, Alaska: Canadian Journal of Earth Sciences, v. 14, no. 11, p. 2578-2592.

Jones, D. L., and Silberling, N. J., 1979, Mesozoic stratigraphy, the key to tectonic analysis of southern and central Alaska: U.S. Geological Survey Open-File Report 79-1200, $41 \mathrm{p}$.

Jones, D. L., Silberling, N. J., and Hillhouse, J. W., 1977, Wrangellia-A displaced terrane in northwestern North America: Canadian Journal of Earth Sciences, v. 14, no. 11 , p. 2565-2577.

MacKevett, E. M., Jr., 1971, Stratigraphy and general geology of the McCarthy C-5 quadrangle, Alaska: U.S. Geological Survey Bulletin 1323, 35 p.

MacKevett, E. M., Jr., 1978, Geologic map of the McCarthy quadrangle, Alaska: U.S. Geological Survey Miscellaneous Investigations Series Map I-1032, scale 1:250,000.

Richter, D. H., Lanphere, M. A., and Matson, N. A., 1975, Granitic plutonism and metamorphism, eastern Alaska Range, Alaska: Geological Society of America Bulletin, v. 86 , p. 819-829.

Shafiqullah, M., and Damon, P. E., 1974, Evaluation of K-Ar isochron methods: Geochimica et Cosmochimica Acta, v. 38 , p. $1341-1358$.

Silberman, M. L., Morton, J. L., Cox, D. C., and Richter D. H., 1977, Potassium-argon ages of disseminated copper and molybdenum mineralization in the Klein Creek and Nabesna plutons, eastern Alaska Range, in Blean, K. M., ed., The United States Geological Survey in Alaska: Accomplishments during 1976: U.S. Geological Survey Cir. cular 751 -B, p. B54-B56. 
Recognition of two subterranes within the Wrangellia terrane, southern Mount Hayes quadrangle, Alaska

By Warren J. Nokleberg, Nairn R. D. Albert, Paige L. Herzon, Ronny T. Miyaoka, and Richard E. Zehner

A major part of the Mount Hayes quadrangle south of the Denali fault is a mosaic of tectonostratigraphic terranes. One of these, the Wrangellia terrane (Jones and others, 1977), forms an east-trending belt about $180 \mathrm{~km}$ long and $45 \mathrm{~km}$ wide.

Recent fieldwork has established the presence of two subterranes within the Wrangellia terrane of the Mount Hayes quadrangle. The southern subterrane, herein designated the Tangle subterrane, forms a belt also about $180 \mathrm{~km}$ long and with a minimum width of $30 \mathrm{~km}$. The northern subterrane is juxtaposed against the Tangle subterrane along low-angle, north-dipping thrust faults in the central and western parts of the quadrangle (Nokleberg and others, 1981).

The northern subterrane consists of upper Paleozoic island arc rocks and unconformably overlying massive flows of the Triassic Nikolai Greenstone (fig. 32) (Richter and Dutro, 1975; Richter and others, 1977). The upper Paleozoic island arc rocks consist of: (1) andesitic volcanic and epiclastic rocks of the Tetelna Volcanics, here of Pennsylvanian age; (2) volcaniclastic and calcareous volcaniclastic rocks of the Pennsylvanian and Permian Slana Spur Formation; and (3) argillite and limestone of the Permian Eagle Creek Formation. The minimum stratigraphic thickness of the island arc rocks is $3,390 \mathrm{~m}$. About $40 \mathrm{~m}$ of unnamed Middle Triassic shale, chert, and limestone disconformably overlies the upper Paleozoic rocks. The overlying Nikolai Greenstone, of Middle and (or) Late Traissic age, consists of massive, subaerial, amygdaloidal basalt flows about $1,500 \mathrm{~m}$ thick. The Nikolai is disconformably overlain by a thin unit of unnamed gray limestone, about 20 to $150 \mathrm{~m}$ thick, which contains Late(?) Triassic fossils (Richter and others, 1977). The base of Wrangellia is not exposed.

The Tangle subterrane is here named for prominent exposures of rocks near the Tangle Lakes in the southwest part of the quadrangle. These exposures were included by Stout (1976) in the type locality of his Tangle Lakes Formation. Pillow basalt, included in the upper part of the Tangle
Lakes by Stout, are here considered to be the lower member of the Nikolai Greenstone. As so defined, the Tangle subterrane consists of upper Paleozoic sedimentary and tuffaceous rocks, intrusive igneous rocks cutting the upper Paleozoic rocks, and unconformably overlying pillow lava and flows of the Triassic Nikolai Greenstone (fig. 32). The upper Paleozoic sedimentary rocks, at least $875 \mathrm{~m}$ thick, consist of aquagene tuff, darkgray argillite, minor andesite tuff and flows, and very sparse light-gray limestone. Upper Paleozoic bryozoans from the limestone have been collected and identified by N. J. Silberling (oral commun., 1979). The upper Paleozoic rocks are intruded and underlain by thick and extensive diabase, gabbro, and cumulate rocks of the mafic and ultramafic complex of Fish Lake. The Triassic Nikolai Greenstone unconformably overlies the upper Paleozoic rocks. Its lower member is about 1,020 $\mathrm{m}$ thick and consists of pillow basalt, minor volcanic breccia, and very minor argillite with Daonella or Halobia (N. J. Silberling, oral commun., 1979). Its upper member, which conformably overlies the lower member, is at least $4,350 \mathrm{~m}$ thick and consists of massive, subaerial, amygdaloidal basalt flows. The base of the Tangle is not exposed.

There are several important differences between the Tangle and the northern subterranes of Wrangellia (fig. 32): (1) the upper Paleozoic rocks in the Tangle are much thinner than in the northern subterrane; (2) the upper Paleozoic rocks in the Tangle are predominantly aquagene tuff and argillite with minor andesite, whereas the upper Paleozoic rocks in the northern subterrane are mainly andesite flows, breccias, and epiclastic rocks; (3) the lower member of the Nikolai Greenstone in the Tangle is absent in the northern subterrane; and (4) massive basalt flows forming the upper member of the Nikolai Greenstone in the Tangle are at least three times thicker than similar flows in the northern subterrane. These differences in stratigraphy indicate the following differences in geologic history: (1) in the Tangle subterrane, the upper Paleozoic rocks formed in deeper water and at some distance from the site of submarine island-arc volcanism, whereas in the northern subterrane, the upper Paleozoic rocks formed along the axis of volcanism; (2) in the Tangle, Triassic rifting and 
basaltic volcanism were initially submarine, whereas in the northern subterrane, Triassic rifting and basaltic volcanism were initially subaerial; and (3) during the later stages of rifting, basaltic volcanism was much more voluminous in the Tangle than in the northern subterrane. These differences in geologic history indicate that the Tangle and the northern subterrane of Wrangellia: (1) represent distal and near parts, respectively, of the same upper Paleozoic island arc; (2) represent near and distal parts, respectively, of the same Triassic rift system; and (3) have been considerably tectonically shortened and juxtaposed during terrane migration and accretion.

\section{REFERENCES CITED}

Jones, D. L., Silberling, N. J., and Hillhouse, John, 1977, Wrangellia-A displaced terrane in northwestern North America: Canadian Journal of Earth Sciences, v. 14, p. 2565-2577.

\section{Tangle subterrane}

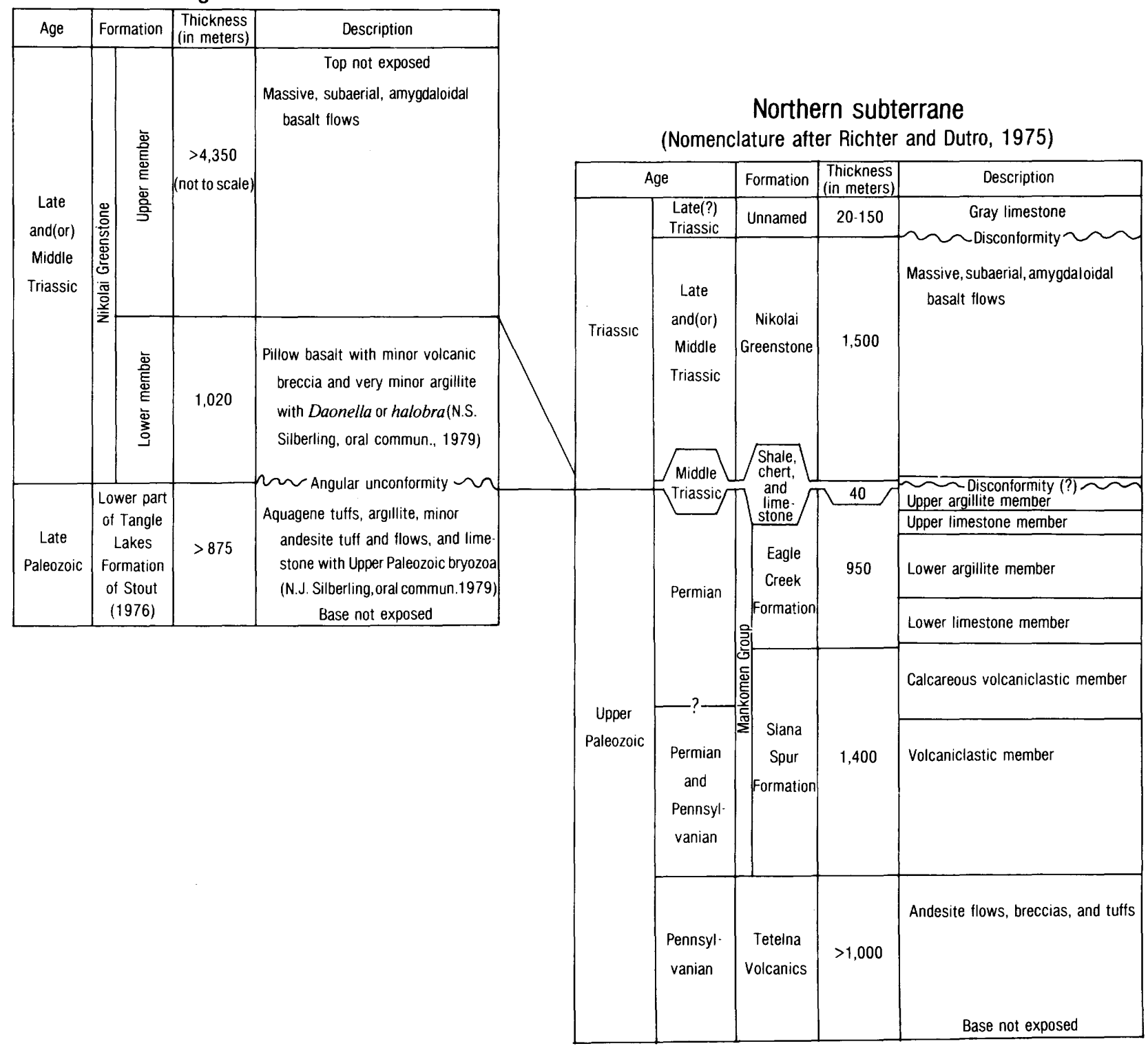

FIGURE 32.-Comparison of stratigraphic columns of two subterranes in the Wrangellia terrane, southern Mount Hayes quadrangle, eastern Alaska Range, Alaska. 
Nokleberg, W. J., Albert, N. R. D., Herzon, P. L., Miyaoka, R. T., and Zehner, R. E., 1981, Cross section showing accreted Andean-type arc and island arc terranes in southwestern Mount Hayes quadrangle, Alaska, in Albert, N. R. D., and Hudson, Travis, eds., The United States Geological Survey in Alaska: Accomplishments during 1979: U.S. Geological Survey Circular 823-B, p. B66-B67.

Richter, D. H., and Dutro, J. T., Jr., 1975, Revision of the type Mankomen formation (Pennsylvanian and Permian), Eagle Creek area, eastern Alaska Range, Alaska: U.S. Geological Survey Bulletin 1395-B, 25 p.

Richter, D. H., Sharp, W. N., Dutro, J. T., Jr., and Hamilton, W. B., 1977, Geologic map of parts of the Mount Hayes A-1 and A-2 quadrangles, Alaska: U.S. Geological Survey Map I-1031, scale 1:63,360.

Stout, J. H., 1976, Geology of the Eureka Creek area, eastcentral Alaska Range: Alaska Division of Geological and Geophysical Surveys Geologic Report 46, 32 p.

Cross section showing accreted Andean-type arc and island arc terranes in southwestern Mount Hayes quadrangle, Alaska

By Warren J. Nokleberg, Nairn R. D. Albert, Paige L. Herzon, Ronny T. Miyaoka, and Richard E. Zehner

The southwestern part of the Mount Hayes quadrangle, south of the Denali fault, is composed of two large tectonostratigraphic terranes, one of which is subdivided into two subterranes. These terranes and subterranes are well exposed along a traverse parallel to the north-south cross section (fig. 33), which is based on geologic map- ping accomplished in 1978 and 1979 and on earlier mapping by Stout (1976). From north to south, the terranes occurring along the cross section are: (1) the Maclaren terrane, a fragment of an Andean-type arc and (2) the Wrangellia terrane, a fragment of an island arc with overlying rift basalts (Jones and others, 1977).

The preceding paper (Nokleberg and others, 1980) has differentiated two subterranes within the Wrangellia terrane of the Mount Hayes quadrangle, a northern subterrane and the Tangle subterrane. Although both subterranes record a history of island-arc volcanism, comparison of their stratigraphic columns indicates that the Tangle represents a deeper-water counterpart of the northern subterrane.

The southern part of the Maclaren terrane consists of the Maclaren metamorphic belt (Smith, 1973), and the northern part consists of the regionally deformed and metamorphosed East Susitna batholith. The Maclaren metamorphic belt is a tectonically shortened, prograde, Barrovian-type metamorphic belt and varies from slightly metamorphosed argillite with lower greenschist-facies metamorphism, to phyllite with upper greenschist-facies metamorphism, and to schist with amphibolite- and upper amphibolitefacies metamorphism. The age of the original

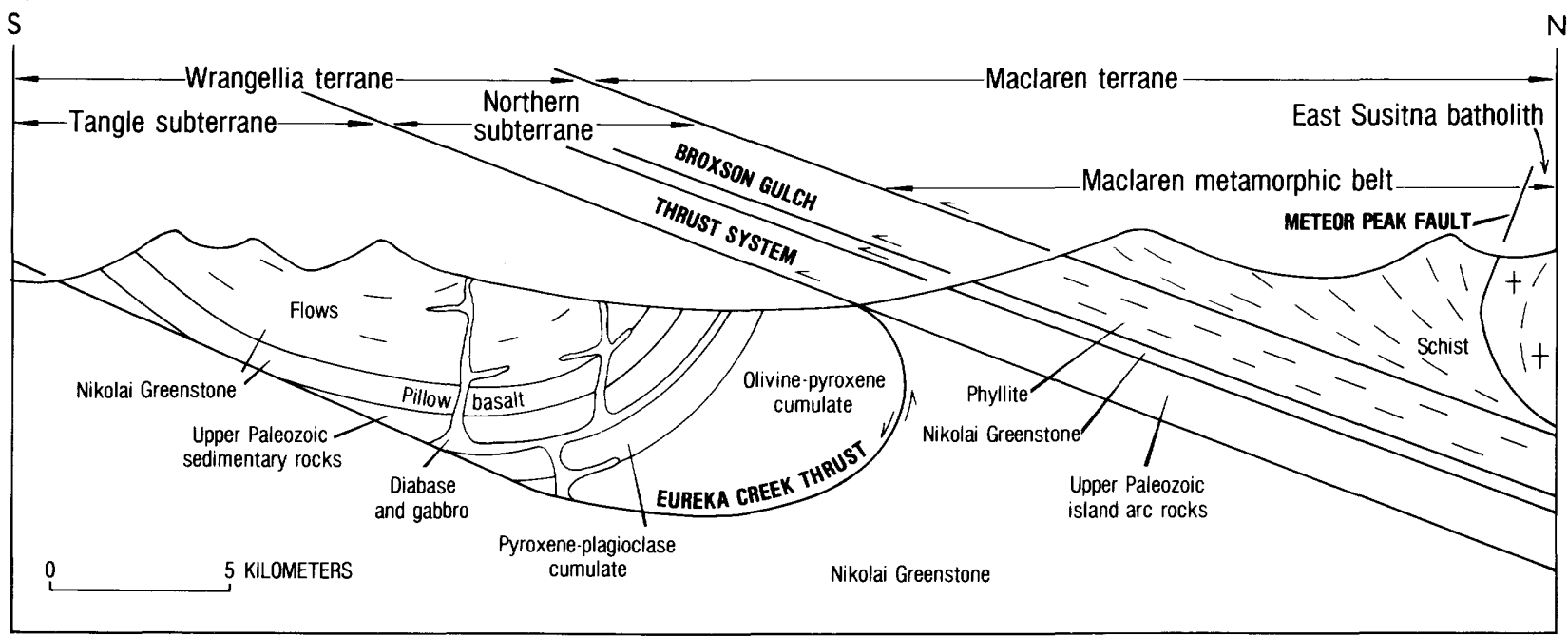

FiguRE 33.-North-south cross section showing accreted Andean-type arc and island arc terranes in southwestern Mount Hayes quadrangle, eastern Alaska Range, Alaska. North end of section is about $5 \mathrm{~km}$ west of Broxson Gulch. South end of section is about $1 \mathrm{~km}$ east of Glacier Lake. 
sedimentary rocks forming the Maclaren metamorphic belt is unknown. Immediately north of the Maclaren metamorphic belt, the relatively younger East Susitna batholith consists predominantly of regionally metamorphosed and deformed diorite and more siliceous granitic rocks. The contact between the East Susitna batholith and the Maclaren metamorphic belt is mainly a tectonically shortened intrusive contact along which occur fault-bounded lenses of metamorphic and plutonic rock and sparse dikes. The Maclaren terrane is bounded on the north by the rightlateral, strike-slip Denali fault and to the south by the Broxson Gulch thrust system.

The Wrangellia terrane, south of the Maclaren terrane, includes two subterranes. The northern subterrane, consisting mainly of upper Paleozoic island arc rocks and discomformably overlying massive rift basalt flows of the Triassic Nikolai Greenstone (Stout, 1976; Richter and others, 1977), occurs as tectonically dismembered thrust slices within the Broxson Gulch thrust system (fig. 33). The upper Paleozoic island arc rocks consist mainly of andesite flows, breccia, epiclastic rocks, argillite, and limestone of Pennsylvanian and Permian age (Richter and other, 1977). The Nikolai Greenstone consists of massive, subaerial, amygdaloidal basalt flows (Richter and others, 1977). The base of Wrangellia is fault bounded.

The recently identified Tangle subterrane is a deeper water variant of the northern subterrane described above, consisting of a relatively thin sequence of upper Paleozoic sedimentary and tuffaceous rocks and a relatively thick sequence of unconformably overlying Triassic pillow lava and flows of the Nikolai Greenstone. This subterrane is defined and described in more detail in the companion paper (Nokleberg and others, 1981). The Tangle is bounded on the north partly by the Broxson Gulch thrust system and partly by the Eureka Creek thrust fault, both of which separate it from the northern subterrane. The base of the Tangle is fault bounded. Included in the Tangle are gabbro dikes and sills and the large mafic and ultramafic stratiform complex of Fish Lake previously designated the ophiolite of Tangle Lakes (Nokleberg and others, 1979). Detailed mapping during 1979 shows that this complex grades up- ward into gabbro and diabase, which intrude and contact metamorphose the lower member of the Nikolai Greenstone. Therefore, the term ophiolite of Tangle Lakes is herein replaced by the term mafic and ultramafic complex of Fish Lake.

Along the folded Fish Lake thrust, part of the Tangle, including the mafic and ultramafic complex of Fish Lake, is thrust over the Nikolai Greenstone that is also part of the Tangle subterrane (fig. 33).

The Nikolai Greenstone and the mafic and ultramafic complex of Fish Lake represent rift-type magmatism occurring along a Triassic spreading center (Nokleberg and others, 1981). Initially, rifting was submarine in the Tangle and mainly subaerial in the northern subterrane. The stratigraphic and structural characteristics of the fault-bounded Maclaren and Wrangellia terranes, as well as of Wrangellia's two subterranes, are so greatly different that they indicate different geologic histories. Large-scale tectonic movements are required to juxtapose and accrete such diverse terranes and subterranes.

\section{REFERENCES CITED}

Jones, D. L., Silberling, N. J., and Hillhouse, John, 1977, Wrangellia-A displaced terrane in northwestern North America: Canadian Journal of Earth Sciences, v. 14, p. 2565-2577.

Nokleberg, W. J., Albert, N. R. D., Herzon, P. L., Miyaoka, R. T., and Zehner, R. E., 1981, Recognition of two subterranes within the Wrangellia terrane, southern Mount Hayes quadrangle, Alaska, in Albert, N. R. D., and Hudson, Travis, eds., The United States Geological Survey in Alaska: Accomplishments during 1979: U.S. Geological Survey Circular 823-B, p. B64-B66.

Nokleberg, W. J., Albert, N. R. D., and Zehner, R. E., 1979, The ophiolite of Tangle Lakes in the southern Mount Hayes quadrangle, eastern Alaska Range: An accreted terrane?, in Johnson, K. M., and Williams, J. R., eds., the United States Geological Survey in Alaska: Accomplishments during 1978: U.S. Geological Survey Circular 804-B, p. B96-B98.

Richter, D. J., Sharp, W. N., Dutro, J. T., Jr., and Hamilton, W. B., 1977, Geologic map of parts of the Mount Hayes A-1 and A-2 quadrangles, Alaska: U.S. Geological Survey Map I-1031, scale 1:63,360.

Smith, T. E., 1973, The Maclaren metamorphic belt, southcentral Alaska, in Alaska Division of Geological and Geophysical Surveys Annual Report, 1972, p. 8-10.

Stout, J. H., 1976, Geology of the Eureka Creek area, eastcentral Alaska Range: Alaska Division of Geological and Geophysical Surveys Geologic Report 46, 32 p. 
Placer gold deposits, Mount Hayes quadrangle, Alaska By Warren Yeend

Placer gold deposits have been worked discontinuously in the Mount Hayes quadrangle since the early 1900's. Gold production in the Slate Creek district, the most active, is in excess of 100,000 troy ounces. During the summer of 1979 , four different properties in the south half of the quadrangle were being worked, of which three were in the Slate Creek area.

The Tertiary through Holocene history of the Slate Creek area is complex. The area has been fragmented by Tertiary faulting and subsequently glaciated. Local base level was thus raised subsequent to the development of the preglacial, gold-bearing ancestral Slate Creek.

The gold throughout the quadrangle occurs in poorly sorted gravel of diverse origin-alluvium, fans, colluvium, and drift. Well-rounded boulders and cobbles derived from Tertiary(?) conglomerate are common in the deposits. Gold nuggets are rare and seldom exceed $6 \mathrm{~mm}$ in diameter. The bulk of the gold occurs as thin plates less than 1 $\mathrm{mm}$ in diameter. Large quantites of black sand in the heavy concentrate make complete separation of the gold more difficult.

The source of the gold seems most likely to be the Tertiary(?) conglomerate that occurs in small isolated outcrops and commonly as small fault slivers. In the Slate Creek area, Tertiary(?) conglomerate caps the high hills to the north between Slate Creek and the Chistochina Glacier. This conglomerate has been locally referred to as "round wash" because of the abundance of wellrounded boulders (as much as $30 \mathrm{~cm}$ diameter) capping the mountain tops. This concentration of rounded boulders represents a regolith developed on the underlying mafic conglomerate, which here dips approximately $30^{\circ} \mathrm{N}$. This same conglomerate has been faulted down into a graben in this locality and occurs as isolated, narrow outcrop slivers in Slate Creek. The conglomerate here has been vertically offset by as much as $460 \mathrm{~m}$. Heavily stained and tarnished gold from Tertiary(?) conglomerate was panned in low concentrations as far away as $50 \mathrm{~km}$ west of Slate Creek within the Rainy Creek drainage. Gold from Tertiary(?) conglomerate now occurs in economic or near economic grade only by virtue of the concentrating powers of the Pleistocene and Holocene streams.
Tectonic implications of framework grain mineralogy of sandstone from the Yakutat Group

By G. R, Winkler and George Plafker

Highly deformed and variably metamorphosed Cretaceous flysch, greenstone, and melange form an arcuate belt at least $1,700 \mathrm{~km}$ long and as much as $100 \mathrm{~km}$ wide along the continental margin of southern Alaska (Plafker and others, 1977). This belt of Cretaceous rocks has been termed the Chugach terrane by Berg, Jones, and Richter (1972), inasmuch as the widest part of the belt comprises the core of the Chugach Mountains. Flyschoid sandstone and pelitic rocks predominate in the belt and are known as the Shumagin and Kodiak Formations, the Valdez Group, the flysch facies of the Yakutat Group, and part of the Sitka Graywacke. In contrast to other rocks of the Chugach terrane, the Yakutat Group occupies a structurally anomalous position seaward of the Fairweather fault and crops out only on a separate crustal plate, the Yakutat block (Plafker and others, 1978; George Plafker, unpub. data).

The Yakutat Group petrographically contrasts with coeval rocks of the Chugach terrane. Modal analyses of 35 thin sections of sandstone from the Yakutat Group have shown a distinctive mineralogy that differs from the mineralogy of other sandstones within the Chugach terrane. Mean values for framework grain compositions of sandstones from the Shumagin (Moore, 1973) and Kodiak Formations (Winkler, 1979) and the Valdez Group (Mitchell, 1979) are plotted with new data from the Yukatat Group on Q-F-L and rockfragment ternary diagrams (fig. 34). The abundance of volcanogenic detritus in the Chugach terrane demonstrates its general magmatic arc provenance. Mean rock-fragment abundances generally are above 50 percent for samples from the Chugach terrane, but the samples from the Yakutat contain much more quartzofeldspathic detritus, which is indicative of derivation dominantly from a plutonic terrane (Dickinson, 1970). The greater abundance of feldspar in the Yakutat samples is especially pronounced. The rockfragment component of the Yakutat samples is correspondingly less. Additionally, the proportions of various rock-fragment types for the Yakutat samples differ greatly from those for Chugach terrane samples (Zuffa and others, 1980 ). More than one-quarter of the rock frag- 
ments in sandstone from the Yakutat Group, on the average, were derived from intermediate plutonic rocks; for the Chugach terrane, the proportion of plutonic rock fragments averages only about one-twentieth, although plutonic detritus seems to increase eastward (Zuffa and

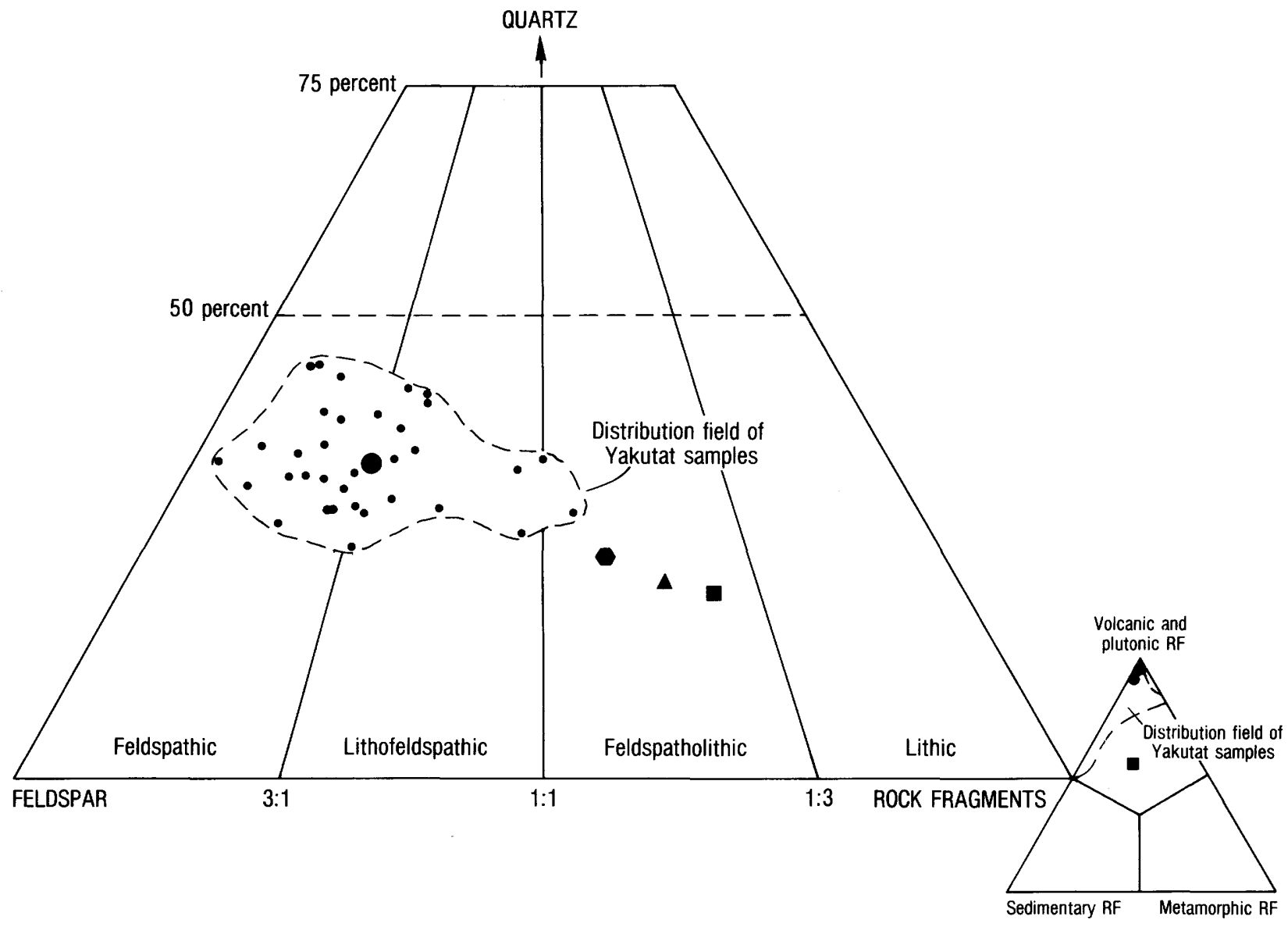

EXPLANATION

\begin{tabular}{|c|c|c|c|c|c|c|c|c|c|c|}
\hline \multirow{2}{*}{ Unit } & \multirow{2}{*}{$\mathrm{n}$} & \multicolumn{9}{|c|}{ Means } \\
\hline & & 0 & $\mathrm{~F}$ & $L$ & $\mathrm{C} / \mathrm{Q}$ & $\mathrm{P} / \mathrm{F}$ & v & $\mathrm{Pl}$ & S & $M$ \\
\hline - Yakutat Group & 35 & 34 & 49 & 17 & .04 & .88 & .59 & 31 & 8 & 2 \\
\hline - Valdez Group & 19 & 20 & 24 & 56 & 34 & .82 & 50 & 5 & 26 & 19 \\
\hline - Kodiak Formation & 3 & 24 & 32 & 44 & .10 & .95 & 90 & 6 & 3 & 1 \\
\hline $\begin{array}{ll}\text { - Shumagin } \\
\text { Formation }\end{array}$ & 27 & 21 & 28 & 51 & .13 & .92 & 90 & 4 & -- & -- \\
\hline
\end{tabular}

Q-Total quartzose grains

P-Plagioclase

PI-Plutonic RF

C-Polycrystalline quartzose grains

$\mathrm{L}-$ Total rock fragments (RF)

S-Sedimentary RF

F-Total feldspar

$\mathrm{V}$-Volcanic RF

M-Metamorphic RF

FIGURE 34.-Q-F-L and rock-fragment composition diagrams for modal analyses of sandstone samples from the Yakutat Group. Mean values for samples from the Valdez Group (Mitchell, 1979), Kodiak Formation (Winkler, 1979), and Shumagin Formation (Moore, 1973) are shown for comparison. 
others, 1980). This increase may indicate progressively deeper erosion of the source arc to the east, with widespread exposure of its roots.

The characteristically high proportion of plutonic detritus in sandstone from the Yakutat Group may have important implications for the configuration of the Chugach terrane. If the Yakutat Group is correlated correctly with other flysch, greenstone, and melange of the Chugach terrane, then the abundance of plutonic detritus in the Yakutat Group may indicate that it had the most easterly source of any of the Chugach rocks. However, the Yakutat Group crops out northwest of more volcanogenic facies of the terrane-the Valdez Group and unnamed rocks in Alsek and Fairweather Ranges (Plafker and Campbell, 1979) and the Sitka Graywacke (Brew and Morrell, 1979)-and is separated from them by the dextral-slip Fairweather fault. The present position of the Yakutat Group is most likely to have resulted from large-scale post-Cretaceous displacement of the Yakutat block northwestward with respect to other parts of the Chugach terrane. Alternatively, the distinctive petrography of sandstone from the Yakutat Group may be interpreted to preclude correlation with the other flysch sequences in the Chugach terrane. It is possible that the Yakutat block could be a totally independent structural element that has been fortuitously juxtaposed against coeval rocks of the Chugach terrane.

\section{REFERENCES CITED}

Berg, H. C., Jones, D, L., and Richter, D. H., 1972, GravinaNutzotin belt-tectonic significance of an upper Mesozoic sedimentary and volcanic sequence in southern and southeastern Alaska, in Geological Survey Research 1972: U.S. Geological Survey Professional Paper 800-D, p. D1 D24.

Brew, D. A., and Morrell, R. P., 1979, Correlation of the Sitka Graywacke, unnamed rocks in the Fairweather Range, and Valdez Group, southeastern and south-central Alaska, in Johnson, K. M., and Williams, J. R., eds., The United States Geological Survey in Alaska: Accomplishments during 1978: U.S. Geological Survey Circular 804-B, p. $\mathrm{B} 123-\mathrm{B} 125$.

Dickinson, W. R., 1970, Interpreting detrital modes of graywacke and arkose: Journal of Sedimentary Petrology, v. 40, p. 690-707.

Mitchell, P. A., 1979, Geology of the Hope-Sunrise (gold) mining district, north-central Kenai Peninsula, Alaska: Stanford University, M.S. thesis, 123 p.
Moore, J. C., 1973, Cretaceous continental margin sedimentation, southwestern Alaska: Geological Society of America Bulletin, v. 84, p. 595-614.

Plafker, George, and Campbell, R. B., 1979, The BorderRanges fault in the Saint Elias Mountains, in Johnson, K. M., and Williams, J. R., eds., The United States Geological Survey in Alaska: Accomplishments during 1978: U.S. Geological Survey Circular 804-B, p. B102-B104.

Plafker, George, Hudson, Travis, Bruns, Terry, and Rubin, Meyer, 1978, Late Quaternary offsets along the Fairweather fault and crustal plate interactions in southern Alaska: Canadian Journal of Earth Sciences, v. 15, no. 5, p. 805-816.

Plafker, George, Jones, D. L., and Pessagno, E. A., Jr., 1977, A Cretaceous accretionary flysch and melange terrane along the Gulf of Alaska margin, in Blean, K. M., ed., The United States Geological Survey in Alaska: Accomplishments during 1976: U.S. Geological Survey Circular 751 B, p. B41 - B43.

Winkler, G. R., 1979, Sedimentary petrography, in Nilsen, T. H., and Moore, G. W., Reconnaissance study of Upper Cretaceous to Miocene stratigraphic units and sedimentary facies, Kodiak and adjacent islands, Alaska: U.S. Geological Survey Professional Paper 1093, p. 23-29.

Zuffa, G. G., Nilsen, T. H., and Winkler, G. R., 1980, Rockfragment petrography of the Upper Cretaceous Chugach terrane, southern Alaska: U.S. Geological Survey OpenFile Report 80-713, 28 p.

Paleomagnetic evidence for northward movement of the Chugach terrane, southern and southeastern Alaska

By Sherman Grommé and John W. Hillhouse

The Chugach terrane is subparallel to the continental margin of southern and southeastern Alaska (Berg and others, 1972, 1978) and is composed of late Mesozoic flysch and mafic volcanic rocks that are intruded by mafic and granitic igneous rocks. Plafker, Jones, and Pessango (1977) and Plafker and Campbell (1979) have recently shown that this tectonostratigraphic terrane is continuous from Kodiak Island on the northwest to Baranof Island on the southeast. Paleomagnetic poles have been obtained from two widely separated localities within the Chugach terrane (fig. 35). The northwestern locality consists of sheeted mafic dikes and pillow basalt forming much of the Resurrection Peninsula south of Seward. These rocks are part of the Valdez Group and are probably of Late Cretaceous age (Tysdal and others, 1977). The southeastern locality is in the Fairweather Range west of Glacier Bay, where the Chugach terrane is intruded by several large plutons of layered gabbro 
(Rossman, 1963). The paleomagnetic data come from two of these gabbro plutons, the La Perouse and Astrolabe. Radiometric age dating indicates that the La Perouse gabbro pluton is probably 41 m.y. old (Hudson and Plafker, 1981); the concordance of paleomagnetic directions in the twogabbro bodies indicates that they are the same age.

The paleomagnetic poles obtained from these two areas are markedly anomalous (fig. 35). In both cases, the paleomagnetic declinations are approximately $90^{\circ} \mathrm{W}$. of what would be predicted from the known polar wandering path for the North American craton. However, at both sites, the observed paleomagnetic latitudes are $25^{\circ}$ to $26^{\circ} \mathrm{S}$. of the latitudes predicted for their respective ages. The notable coincidence of these two results apparently requires that the entire Chugach terrane moved northward through about $25^{\circ}$ in latitude and rotated counterclockwise

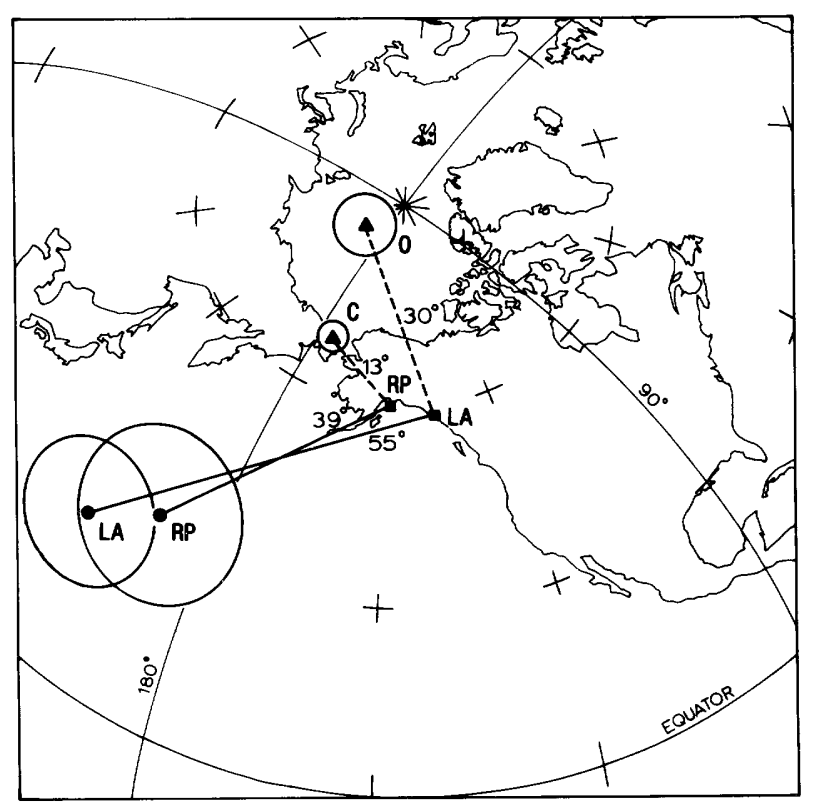

FIGURE 35.-Paleomagnetic poles from the Resurrection Peninsula (RP) and the La Perouse and Astrolabe gabbro plutons (LA). Squares are sampling localities, dots are observed paleomagnetic poles, and triangles are reference paleomagnetic poles for the North American craton in Cretaceous (C) and Oligocene (O) time. Paleomagnetic poles are enclosed by circles of 95 percent confidence. Observed paleomagnetic meridians are shown as solid lines; predicted paleomagnetic meridians are shown as dashed lines. $\mathrm{Ob}$ served and predicted paleomagnetic colatitudes are shown beside the respective meridians. about $90^{\circ}$. Because the two observed paleomagnetic declinaton anomalies are nearly identical, one possible interpretation is that the Chugach terrane was not significantly distorted in its overall shape during accretion. However, the arcuate shape of the terrane and the structural trends within it, which follow the so-called "Alaska orocline," may be evidence against this interpretation. Alternatively, all of the Chugach terrane could have moved northward at the same time, with gross deformation accompanying collision, and therefore the similarity of the paleomagnetic declination anomalies would be fortuitous.

The age determinations for the La Perouse gabbro pluton require that all of the northward movement of the Chugach terrane has occurred since about $41 \mathrm{~m} . \mathrm{y}$. ago. A constraint on the time of collision is the existence of the Yakataga Formation, which is distributed seaward of the Chugach terrane from Middleton Island, south of Prince William Sound, eastward to Icy Point not far from the La Perouse gabbro. The Yakataga Formation is Miocene through Holocene in age and consists of a thick sequence of glaciomarine deposits interbedded with normal marine clastic rocks. Plafker and Addicott (1976) have shown that the lithology, sedimentary structures, and molluscan fauna of the formation suggest the presence of active tidal glaciers or an ice shelf along the landward margin of the basin, possibly beginning in early or early middle Miocene time. Clearly, the Yakataga Formation, and therefore the Chugach terrane to the north, must have been nearly as far north in Miocene time as they are today. If the entire northward movement of the Chugach terrane took place between $41 \mathrm{~m} . \mathrm{y}$ and 20 m.y. ago, then the minimum rate of crustal plate motion was $14 \mathrm{~cm} / \mathrm{yr}$; this rate is slightly more than the upper limit of contemporary absolute plate velocities.

\section{REFERENCES CITED}

Berg, H. C., Jones, D. L., and Coney, P. J., 1978, Map showing pre-Cenozoic tectonostratigraphic terranes of southeastern Alaska and adjacent areas: U.S. Geological Survey Open-File Report 78-1085, scale 1:1,000,000, 2 sheets.

Berg, H. C., Jones, D. L., and Richter, D. H., 1972, GravinaNutzotin belt-tectonic significance of an upper Mesozoic sedimentary and volcanic sequence in southern and southeastern Alaska: U.S.Geological Survey Professional Paper 800-D, p. D1-D24. 
Hudson, Travis, and Plafker, George, 1981, Emplacement age of the Crillon-La Perouse pluton, Fairweather Range, in Albert, N. R. D., and Hudson, Travis, eds., The United States Geological Survey in Alaska: Accomplishments during 1979: U.S. Geological Survey Circular 823-B, p. B90-B94.

Plafker, George, and Addicott, W. O., 1976, Glaciomarine deposits of Miocene through Holocene age in the Yakataga Formation along the Gulf of Alaska margin, Alaska: U.S. Geological Survey Open-File Report 76-84, 36 p.

Plafker, George, and Campbell, R. B., 1979, The Border Ranges fault in the Saint Elias Mountains, in Johnson, $\mathrm{K}$. M., and Williams, J. R., eds., The United States Geological Survey in Alaska: U.S. Geological Survey Circular 804-B, p. B102-B104.

Plafker, George, Jones, D. L., and Pessagno, E. A., Jr., 1977, A Cretaceous accretionary flysch and melange terrane along the Gulf of Alaska margin, in Blean, K. M., ed., the United States Geological Survey in Alaska: Accomplishments during 1976: U.S. Geological Survey Circular 751 -B, p. B41 B43.

Rossman, D. L., 1963, Geology and petrology of two stocks of layered gabbro in the Fairweather Range, Alaska: U.S. Geological Survey Bulletin $1121-\mathrm{F}, 50 \mathrm{p}$.

Tysdal, R. G., Case, J. E., Winkler, G. R., and Clark, S. H. B., 1977, Sheeted dikes, gabbro, and pillow basalt in flysch of coastal southern Alaska: Geology, v. 5, p. 377-383.

Blocks and belts of blueschist and greenschist in the northwestern Valdez quadrangle

By G. R. Winkler, R. J. Miller, and J. E. Case

Newly discovered blue amphibole-bearing schistose rocks have two distinct modes of occurrence in the northwestern Valdez quadrangle: (1) as blocks in melange along regional faults, and (2) as a continuous belt, $40 \mathrm{~km}$ long and as much as 4 $\mathrm{km}$ wide, which is enclosed by the $\mathrm{McHugh} \mathrm{Com}$ plex of Jurassic and (or) Cretaceous age.

Blocks of schistose rocks occur in at least two areas in the northwestern part of the quadrangle (locs. A and B, fig. 36). The western block is enclosed within a melange zone $4 \mathrm{~km}$ wide that consists dominantly of serpentinized ultramafic rocks, rodingite, and sheared gabbro and also contains diverse metamorphosed and virtually unmetamorphosed volcanic and sedimentary rocks ranging in age from Triassic to Paleocene(?). The larger eastern block is at least $2 \mathrm{~km}$ in strike length and perhaps $250 \mathrm{~m}$ thick and is associated with elongate bodies of marble that mark a major fault within the McHugh Complex.
The discrete belt of schistose rocks divides the McHugh Complex west of Klutina Lake into northern and southern segments of about equal width. Four klippen of the main belt (locs. $\mathrm{C}$ and $D$, fig. 36) occur in the southern segment of the McHugh Complex. The belt of schistose rocks is bounded on its upper and lower contacts by melange ranging in thickness from only a few meters to more than a kilometer. The most conspicuous components are blocks of marble of widely varying size and shape, which are suspended in an argillite to phyllite matrix. The belt of schistose rocks and bounding melange is enclosed by the McHugh Complex, which consists of relatively coherent volcanogenic clastic rocks, bedded chert, marble, pillow basalt, and mafic breccia and tuff that are cut by numerous faults.

Regardless of their occurrence, the schistose rocks are chiefly intercalated greenschist and blueschist but include nearly pure muscovite and actinolite schists, graphitic schist (particularly near contacts with melange), and highly siliceous or calcareous rocks. In most blueschist, the typical mineral suite of crossite, epidote, and calcite and the sporadic presence of garnet indicate relatively high temperatures and pressures, which are transitional with greenschist metamorphic conditions. Affinities with the greenschist facies also are indicated by the common occurrence of assemblages containing some combination of chlorite, muscovite, actinolite, stilpnomelane, and albite. In some blueschist, however, the coexistence of glaucophane and lawsonite with epidote and and calcite indicates relatively lower temerature, high-pressure metamorphic conditions. At present, parageneses are not well defined, but nearly complete thermal upgrading of glaucophanelawsonite assemblages may be responsible for the dominance of relatively higher temperature minerals.

The greenschist and associated blueschist in the northwestern Valdez quadrangle are similar, in mineralogy and lithologic associations, to rocks on the Kodiak Islands and near Seldovia (Carden and others, 1977), near the Knik River (Carden and Decker, 1977), and near Chitina (Metz, 1976). Forbes and others (1979) have interpreted these occurrences as segments of a discontinuous subduction assemblage stretching from the Kodiak Islands to Chichagof Island in northern south- 
eastern Alaska. K-Ar data from the Kodiak, Seldovia, and Knik River schistose rocks suggest that they were emplaced by Early Jurassic time, prior to development of the McHugh Complex and prior to late Mesozoic or early Cenozoic suturing along the Border Ranges fault (MacKevett and Plafker, 1974). However, recently determined $\mathrm{K}$-Ar ages on actinolite and sericite concentrates from greenschist and associated blueschist on Chichagof Island range from 106 to $91 \mathrm{~m} . \mathrm{y}$. or middle Cretaceous (Decker and others, 1980).
Thus a distinctly younger age of emplacement is probable for schistose rocks in southeastern Alaska.

The position of the newly discovered greenschist and blueschist belt south of the Border Ranges fault system in the interior of the McHugh Complex likewise may indicate preservation of a middle Cretaceous subduction assemblage, but blocks of blueschist to the north in the melange and along regional faults may be related to either the Early Jurassic or middle Cretaceous emplacement

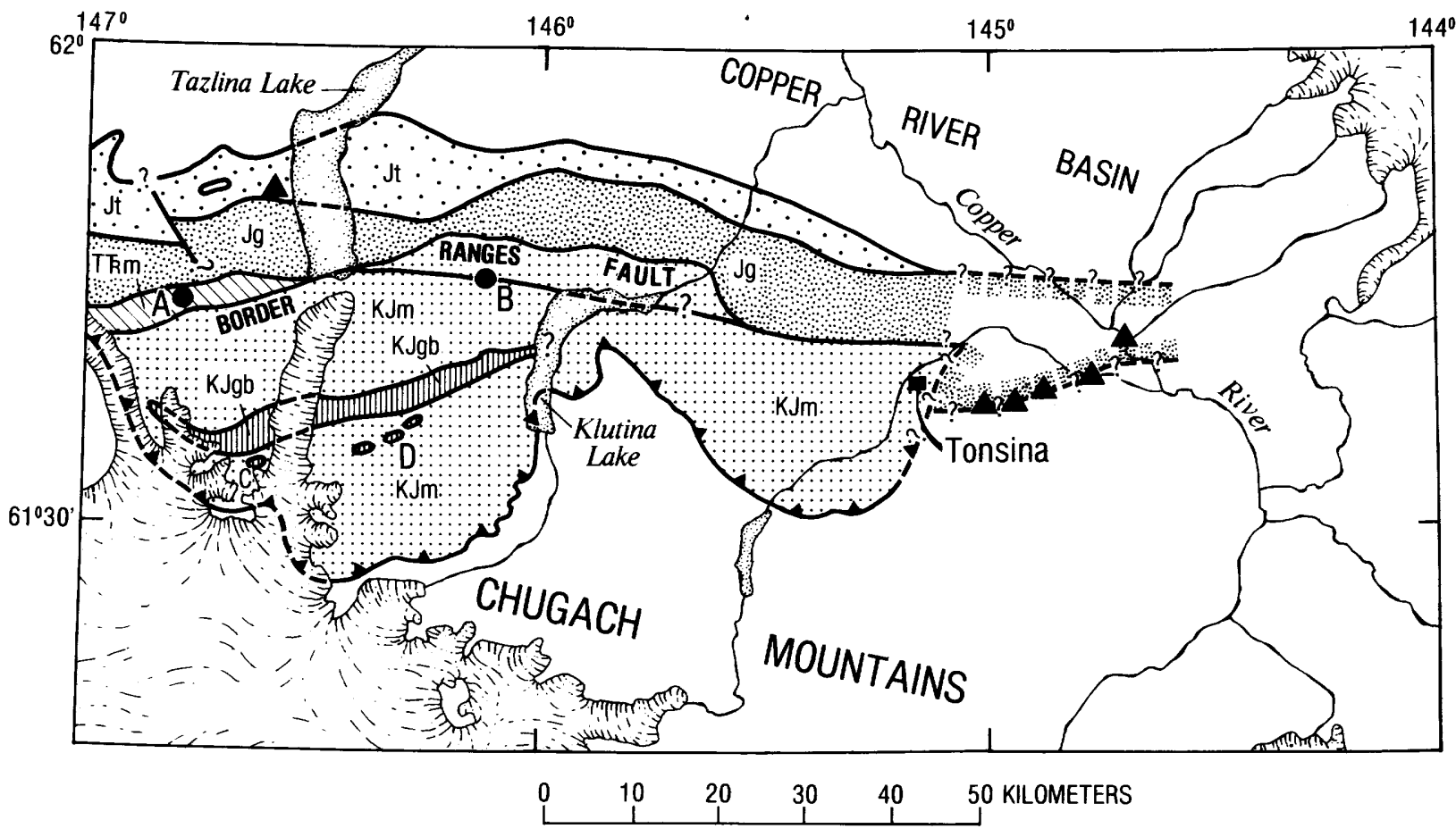

EXPLANATION
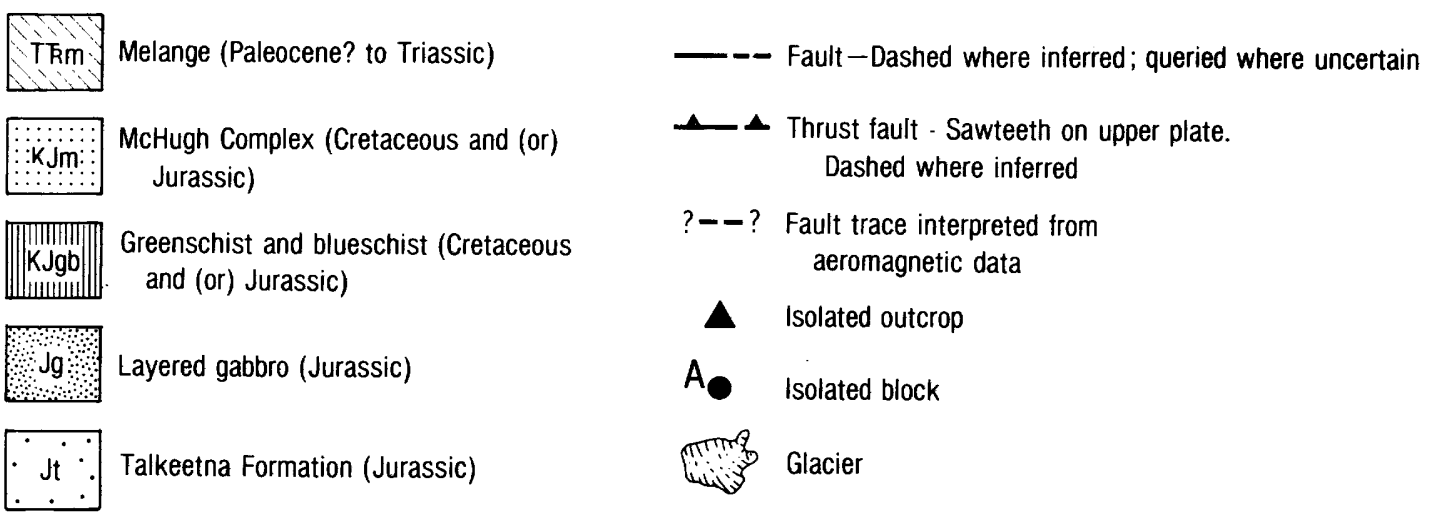

FIGURE 36.-Schematic geologic map of part of the Valdez quadrangle, showing layered gabbroic belt and greenschist and blueschist belt and isolated blocks in relation to adjacent bedrock units. (All contacts shown are faults). 
events. These alternatives are being tested by our continuing geochronology studies in the Valdez quadrangle.

\section{REFERENCES CITED}

Carden, J. R., Connelly, William, Forbes, R. B., and Turner, D. L., 1977, Blueschists of the Kodiak Islands, Alaska: An extension of the Seldovia schist terrane: Geology, v. 5, no. 9 , p. $529-533$.

Carden, J. R., and Decker, J. E., 1977, Tectonic significance of the Knik River schist terrane, south-central Alaska, in Short notes on Alaskan geology, 1977: Alaska Division of Geological and Geophysical Surveys, Geologic Report, 55, p. 7-9.

Decker, J. E., Wilson, F. H., and Turner, D. L., 1980, MidCretaceous subduction event in southeastern Alaska [abs.]: Geological Society of America, Abstracts with Programs, v. 12, no. 3, p. 103.

Forbes, R. B., Carden, J. R., Turner, D. L., and Connelly, William, 1979, Regional tectonic implications of Alaskan blueschist terranes, in Sisson, A., ed., The relationship of plate tectonics to Alaskan geology and resources: Anchorage, Alaska Geological Society, symposium proceedings, p. L1-L28.

MacKevett, E. M., Jr., and Plafker, George, 1974, The Border Ranges fault in south-central Alaska: U.S. Geological Survey Journal of Research, v. 2, no. 3, p. 323-329.

Metz, P. A., 1976, Occurrences of sodic amphibole-bearing rocks in the Valdez C-2 quadrangle, in Short notes on Alaskan geology, 1976: Alaska Division of Geological and Geophysical Surveys, Geologic Report 51, p. 27-29.

Layered gabbroic belt of regional extent in the Valdez quadrangle

By G. R. Winkler, R. J. Miller, M. L. Silberman, Arthur Grantz, J. E. Case, and W. J. Pickthorn

A mafic plutonic belt, at least $120 \mathrm{~km}$ long and as much as $10 \mathrm{~km}$ wide, extends from east to west across two-thirds of the Valdez 1:250,000 quadrangle (fig. 36) and continues westward into the Anchorage quadrangle, at least as far as the Matanuska Glacier. In the Valdez quadrangle, the plutonic belt consists mostly of distinctly layered gabbro, with minor ultramafic and dioritic rocks. The layered gabbro coincides with very large positive aeromagnetic and gravity anomalies (Andreason and others, 1958; Barnes, 1977; U.S. Geological Survey, 1979), permitting extrapolation of its position eastward as a continous belt beneath surficial deposits of the Copper River basin to at least as far as the Copper River.

In the northwestern part of the Valdez quadrangle, the southern margin of the layered gabbro is cut by a melange zone as wide as $4 \mathrm{~km}$ that de- limits the Border Ranges fault zone. The melange includes extensive serpentinized ultramafic rocks and rodingite, as well as blocks of layered gabbro, glaucophane schist, pillow basalt, marble, chert of Triassic and Cretaceous ages, and diverse metamorphosed and virtually unmetamorphosed sedimentary rocks, including conglomerate that is similar to the Chickaloon Formation of Paleocene age. East of the bordering melange, the southern margin of the layered gabbro has a much narrower faulted boundary. Cataclastic modification of mineral layer ing in the gabbro near the boundary is severe, and in many places the fabric of the gabbro is totally sheared and includes boudins of country rock.

South of the layered gabbro and separated from it by the Border Ranges fault is the Jurassic and (or) Cretaceous McHugh Complex, a subduction assemblage of relatively uniform and coherent volcanogenic clastic rocks, bedded chert, and mafic basalt and tuff cut by numerous fault zones marked by melange. Widely scattered throughout this complex are bodies of thouroughly sheared and altered mafic plutonic rocks, which may be remnants of the layered gabbroic belt that were incorporated within the McHugh as it formed.

The northern boundary of the layered gabbro generally is not well exposed, but in most places it appears to be a narrow fault zone. In at least two places, however, apophyses of the main gabbro intrude mafic volcanic and volcaniclastic rocks of the Lower Jurassic Talkeetna Formation, and septa of apparent hornfelsed rocks of the formation are widely scattered in the northern part of the pluton. Two preliminary K-Ar hornblende ages of 153 and 152 m.y. (Late Jurassic) for the gabbro are consistent with this interpretation.

Compositional layering in the gabbro is present in many places and generally is quite conspicuous. In a few places, large blocks of more leucocratic rock-also layered-have foundered into the main pluton, but volumetrically these blocks are minor. The gabbro consists predominantly of calcic plagioclase, pyroxene, and deuteric hornblende replacing or molded upon pyroxene (table 9 ) and has color indices averaging about 40. Magnetite and quartz are common accessory minerals, and pyrite, $\mathrm{K}$-feldspar, and biotite are present in a few samples.

The layered fabricandmineralogy of the gabbroic 
TABLE 9.-Summary of major oxide, trace element, and modal data for the layered gabbroic plutonic belt in the Valdez quadrangle

[Major oxides analyzed by X-ray spectroscopy; analyst: G. Kawakita. Trace elements analyzed by emission spectroscopy; analysts: A. Dorrzapf and K. Mohlmann. Modal analyses based on thin-section point counts (800-1100 points per sample); analyst: W. J. Pickthorn.]

Major oxides (normalized in percent, five samples)

\begin{tabular}{|c|c|c|}
\hline & Range & Mean \\
\hline $\mathrm{SiO}_{2}$ & $43 \cdot 3-56 \cdot 5$ & 48.40 \\
\hline $\mathrm{Al}_{2} \mathrm{O}_{3}-$ & $17.0-29.6$ & 22.26 \\
\hline $\mathrm{Fe}_{2} \mathrm{O}_{3}{ }^{*}-\cdots$ & $3.6-11.8$ & 8.73 \\
\hline 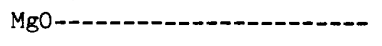 & $3.9-5.9$ & 4.76 \\
\hline 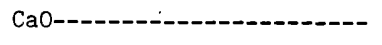 & $7.8-16.7$ & 12.01 \\
\hline $\mathrm{Na}_{2} \mathrm{O}--------$ & $1.3-3.1$ & 2.37 \\
\hline $\mathrm{K}_{2} \mathrm{O}-\mathrm{-}-\mathrm{-}-\mathrm{-}$ & $0.01-1.15$ & 0.40 \\
\hline $\mathrm{TiO}_{2}----1-1-1$ & $0.06-1.01$ & 0.71 \\
\hline $\mathrm{P}_{2} \mathrm{O}_{5}$ & $0.14-0.34$ & 0.22 \\
\hline MnO-- & $0.06-0.21$ & 0.14 \\
\hline
\end{tabular}

Trace elements (parts per million, five samples)

\begin{tabular}{|c|c|c|}
\hline & Range & Mean \\
\hline 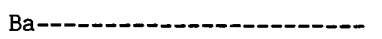 & $96-420$ & 207 \\
\hline 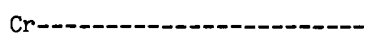 & $14-83$ & 41 \\
\hline $\mathrm{Cu}$ & $16-140$ & 73 \\
\hline Ni--:- & $14-60$ & 28 \\
\hline 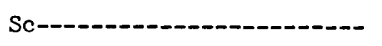 & $14-62$ & 37 \\
\hline 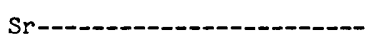 & $370-930$ & 674 \\
\hline 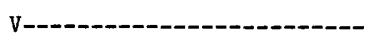 & $44-280$ & 199 \\
\hline Y ------------------------- & $2-22$ & 13 \\
\hline 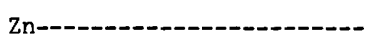 & $83-190$ & 123 \\
\hline Zr------------------------- & $4-90$ & 44 \\
\hline
\end{tabular}

Modal analyses (normalized in percent, 11 samples)

\begin{tabular}{|c|c|c|}
\hline Mineral & Range & Mean \\
\hline K-feldspar---_-------- & $0.0-1.6$ & 0.15 \\
\hline Plagioclase------_----_-- & $34.8-70.1$ & 59.17 \\
\hline 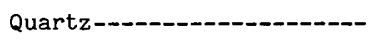 & $0.0-3 \cdot 3$ & 1.46 \\
\hline Amphibole/Pyroxene-------- & $25.8-63.0$ & $37 \cdot 37$ \\
\hline Magnetite-------------- & $0.0-5.2$ & 1.67 \\
\hline 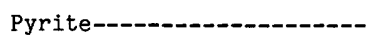 & $0.0-0.6$ & 0.18 \\
\hline
\end{tabular}

*Total iron as $\mathrm{Fe}_{2} \mathrm{O}_{3}$. rocks led Ragan and Grybeck (1966), on the basis of limited observations near Tonsina, to describe them as hornblende-pyroxene granulite and quartz diorite gneiss. Our regional fieldwork, however, confirms the basic plutonic character of the layered gabbro belt.

In many places, partially layered and incompletely serpentinized ultramafic rocks are interlayered with the gabbroic rocks. The ultramafic rocks are diverse and include the predominantly dunite bodies at Bernard Mountain and Dust Creek (Hoffman, 1974) and numerous smaller bodies near the southern margin of the gabbro that are predominantly peridotite and clinopyroxenite. The widespread spatial association of gabbro and ultramafic rocks suggests an approximate contemporaneity and a genetic link.

Chemically, the gabbro has tholeiitic affinities, as indicated by relatively low mean oxide values for $\mathrm{SiO}_{2}, \mathrm{Na}_{2} \mathrm{O}$, and $\mathrm{K}_{2} \mathrm{O}$ and by a relatively high mean value for $\mathrm{CaO}$ (table 9 ). The relatively low mean value of $\mathrm{TiO}_{2}$ and low mean values for the trace elements $\mathrm{Cr}, \mathrm{Ni}, \mathrm{Y}$, and $\mathrm{Zr}$ are very similar to values for so-called "island-arc" tholeiites, as defined by Jakes and Gill (1970), Pearce and Cann (1973), and Pearce (1975). The Valdez gabbroic rocks may represent the tholeiitic base or most mafic part of a magmatic arc, but such a hypothesis cannot be verified at present, inasmuch as coeval or younger arc-related volcanic or volcaniclastic rocks have not been identified. For example, it is not yet clear whether the layered gabbro is an unusually mafic westward extension of the Tonsina-Chichagof Mesozoic plutonic belt of Hudson (1979) or whether it is an entirely distinct belt.

\section{REFERENCES CITED}

Andreason, G. E., Demsy, W. J., Henderson, J. R., and Gilbert, F. P., 1958, Aeromagnetic map of the Copper River basin, Alaska: U.S. Geological Survey Geophysical Investigations Map GP-156, scale 1:250,000.

Barnes, D. F., 1977, Bouguer gravity map of Alaska: U.S. Geological Survey Geophysical Investigations Map GP913 , scale $1: 2,500,000$.

Hoffman, B. L., 1974, Geology of the Bernard Mountain area, Tonsina, Alaska: Fairbanks, University of Alaska, M.S. thesis, $68 \mathrm{p}$.

Hudson, Travis, 1979, Mesozoic plutonic belts of southern Alaska: Geology, v. 7, p. 230-234.

Jakes, P., and Gill, J., 1970, Rare-earth elements and the island arc tholeiitic series: Earth and Planetary Science Letters, v. 9, p. 17-28. 
Pearce, J. A., 1975, Basalt geochemistry used to investigate past tectonic environments on Cyprus: Tectonophysics, v. 25 , p. $41-67$.

Pearce, J. A., and Cann, J. R., 1973, Tectonic setting of basic volcanic rocks determined using trace element analyses: Earth and Planetary Science Letters, v. 19, p. 290-300.

Ragan, D. M., and Grybeck, Donald, 1966, Rocks of the basement complex at Tonsina on the north margin of the Chugach Range, Alaska [abs.]: Geological Society of America Special Paper 87, p. 225-226.

U.S. Geological Survey, 1979, Aeromagnetic map of part of the Valdez $1^{\circ} \times 3^{\circ}$ quadrangle, Alaska: U.S. Geological Survey Open-File Report 79-381, scale 1:250,000.

Surficial deposits of the Valdez quadrangle, Alaska

By John R. Williams and Kathleen M. Johnson

A 1:250,000-scale map (generalized in fig. 37) showing the distribution and character of surficial deposits is being prepared as part of the Alaska Mineral Resources Assessment Program (AMRAP) folio for the Valdez quadrangle. This map is intended to provide information needed for development of the mineral resources, including sand and gravel; it describes foundation conditions for access roads and structures, availability of granular material for borrow, slope stability, and extent of permafrost. The map is based on field studies by J. R. Williams (unpub. data, 1952-57), D. R. Nichols (Nichols and Yehle, 1969 ), L. A. Yehle (Yehle, 1980), H. W. and E. B. Coulter (Coulter and Coulter, 1961,1962), and by the authors in 1978 and 1979. The quadrangle includes part of the Chugach Mountains, the southern part of the Copper River basin, and the southwestern flank of Mount Wrangell, and active Volcano.

The Chugach Mountains border the Gulf of Alaska with a fiord-indented coastline that includes Port Valdez. Much of the southern and central parts of the mountains is covered by snow fields and glaciers, the distribution of which reflects a snowline that becomes lower southward toward the source of moisture-laden winds off the ocean. During late Wisconsinan time, snowline also sloped southward but was 200-300 m lower (Péwé, 1975, fig. 9), and snowfields extended farther north, feeding valley glaciers that extended from the northern Chugach Mountains into the Copper River basin beyond the northern limits of the quadrangle. Some of the front ranges of the northern Chugach Mountains did not support local glaciers in late Wisconsinan time and were invaded by glaciers moving down the major valleys to form complex morainal systems and local glacial lakes, such as those in the area between Hudson and St. Anne Lakes. Retreat of these glaciers beginning about 11,000-12,000 years ago (Ferrians and Nichols, 1965, p. 111) left a mosaic of glacial till, kame-esker deposits, alluvial fans, and talus cones that has been cut by outwash channels and by modern streams. Heads of the mountain valleys that supported local glaciers have complexes of end moraines and rock glaciers, the positions of which depend on the extent to which the surrounding mountains intercepted local firn line during its post-late Wisconsinan rise. Before 8,000 years ago, glaciers in most mountain valleys had retreated to positions near or headward of their present positions; many readvanced to form Holocene moraines within 1-3 $\mathrm{km}$ of present galcier termini.

The late Wisconsinan glaciers filled the Copper River basin within the Valdez quadrangle and fronted in a glacial lake (Lake Atna of Nichols, 1965 ). The lake persisted during the retreat of the ice, as shown by lake sediments extending far into mountain valleys and by the locally prominent shoreline about $750 \mathrm{~m}$ above sea level. Stability of this shoreline probably reflects the presence of a threshold to the north of the quadrangle while the waters were held in by a solid ice dam along the Copper River in the Chugach Mountains. Retreat of the glaciers weakened the ice dam, and the lake drained southward through the Copper River canyon before 9,000 years ago (Ferrians and Nichols, 1965, p. 93,111), or perhaps before 10,000 years ago. As the lake drained, many transitory shorelines (mapped by Nichols and Yehle, 1969) were formed. Levels of stability during drainage of the lake are shown by strandlines at $700 \mathrm{~m}$ above sea level that are most prominent north of the quadrangle (Ferrians and Nichols, 1965 , figs. 8-40) and by deltas on several tributaries to the Copper River at 475-488 m above sea level. After final drainage of the glacial lake, streams rapidly incised the former lake floor, exposing lacustrine, glacial, fluvial, and diamicton deposits of late Wisconsinan age and underlying deposits of the same type, indicating that similar sequences of events took place in earlier glacial episodes. Post-late Wisconsinan deposits include cliffhead dune, flood-plain, terrace, and fan deposits.

The summit of Mount Wrangell is covered by a large snowfield that supplies glaciers that flow or 


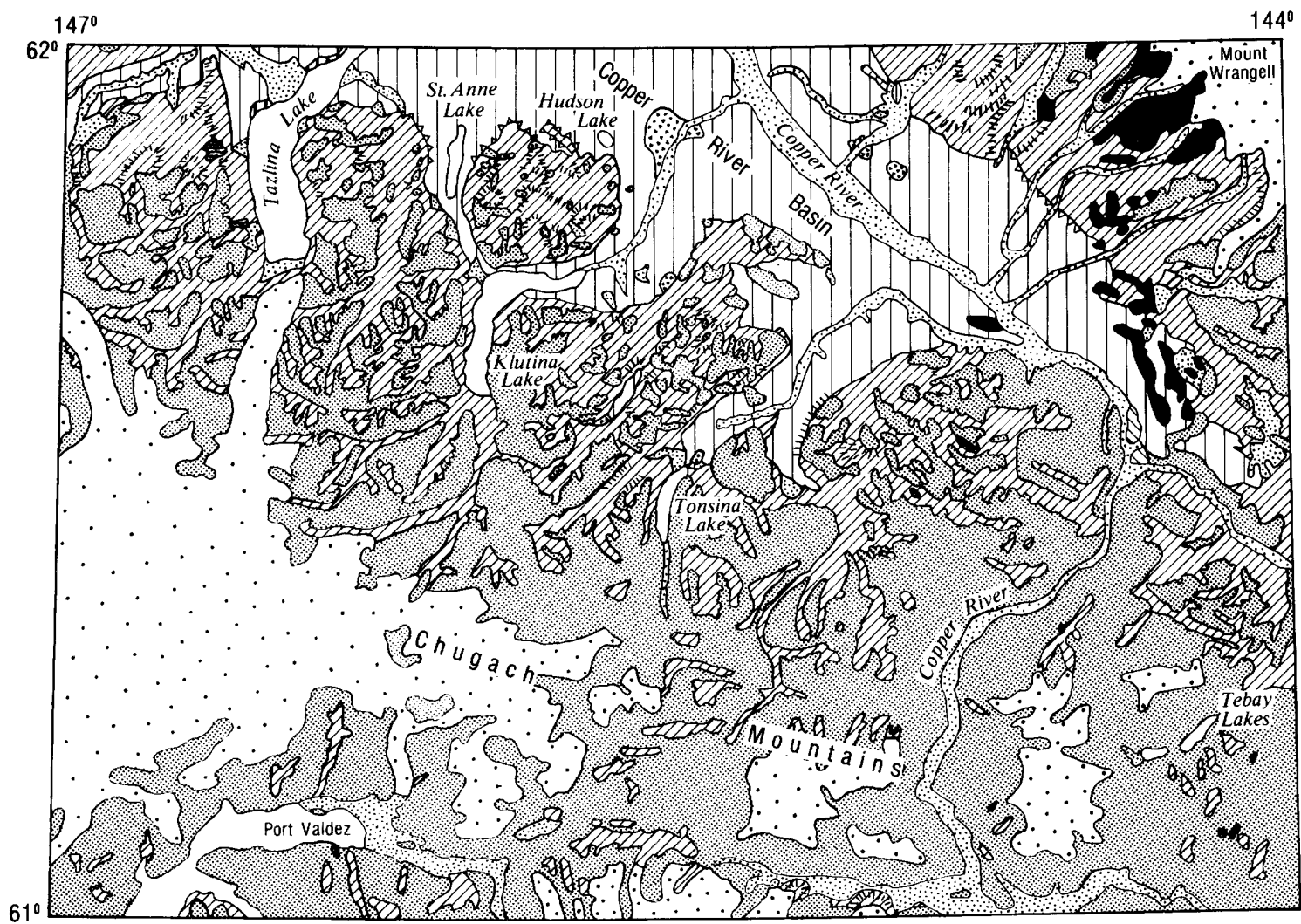

$\begin{array}{lllll}0 & 10 & 20 & 30 & 40\end{array} \quad$ KILOMETERS

EXPLANATION

Fluvial deposits, including flood-plain, outwash, terrace, and fan deposits (Quaternary)

Glacial deposits, chiefly till, but includes outwash, flood-plain, tan, talus cone, ground, end, and lateral morainal, and rock glacier deposits in mountain valleys (Quaternary)

Beach deposits (Quaternary)

Eolian deposits (Quaternary)

Landslide deposits (Quaternary)
Glaciolacustrine deposits, includes silt, clay, sand, and stony silty or clayey diamicton (Quaternary)

Deltaic deposits bordering glacial lake (Quaternary)

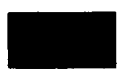

Volcanic flows (and debris flows west of Copper River) (middle Tertiary to Quaternary) (Richter, 1976)

Undifferentiated bedrock (pre-middle Tertiary)

(G.R. Winkler, unpub. data, 1979)

Contact

S Prominent shoreline of 750-m glacial lake

(11,11111, Prominent end and lateral moraines

$\therefore$ Modern glaciers

FIGURE 37.-Surficial deposits of Valdez quadrangle, Alaska. 
cascade into the upper ends of deep valleys cut through the flanks of the mountain. During late Wisconsinan time these deep valleys were filled with glaciers that joined the glacier moving northward in the Copper River basin. No significant flows of lava have been erupted since late Wisconsinan time, but lava flows mantled by late Wisconsinan drift are interlayered with Quaternary unconsolidated deposits as far west as the Copper River. Volcaniclastic debris flows, also interbedded with unconsolidated deposits, extend as much as $65 \mathrm{~m}$ southwest of the summit of Mount Wrangell but in most localities are stratigraphically lower than the lava flows.

Although the surficial deposits of the Valdez quadrangle are largely a product of late Wisconsinan glacial and glaciolacustrine deposition, 26 radiocarbon dates have failed to define the age of the last drift and lacustrine deposits more precisely than between 10,250 years and greater than 40,000 years, the approximate limit of the dating method. Many of the dates, however, are useful in providing ages for formation of bogs on the surface of the youngest drift and for formation of cliffhead dunes, as well as providing minimum ages for the underlying deposits.

\section{REFERENCES CITED}

Coulter, H. W., and Coulter, E. B., 1961, Geology of the Valdez (A-5) quadrangle, Alaska: U.S. Geological Survey Geologic Quadrangle Map GQ-142, scale 1:63,360, 2 sheets.

- 1962, Preliminary geologic map of the Valdez-Tiekel belt, Alaska: U.S. Geological Survey Miscelaneous Geologic Investigations Map I- 356, scale 1:96,000.

Ferrians, O. J., Jr., and Nichols, D. R., 1965, Copper River Basin, in Schultz, C. B., and Smith, H. T. U., eds., Guidebook for Field Conference F, central and southcentral Alaska: Nebraska Academy of Sciences, International Association for Quaternary Research, VII Congress, Lincoln, p. 93-114.

Nichols, D. R., 1965, Glacial history of the Copper River Basin, Alaska [abs.]: International Association for Quaternary Research, International Congress, 7th, Boulder, Colorado, 1965, Proceedings, v. 22, p. 360.

Nichols, D. R., and Yehle, L. A., 1969, Engineering geologic map of the southeastern Copper River basin, Alaska: U.S. Geological Survey Miscellaneous Geologic Investigations Map I-524, scale 1:125,000.

Péwé, T. L., 1975, Quaternary geology of Alaska: U.S. Geological Survey Professional Paper 835, 145 p., 1 pl.

Richter, D. H., 1976, Geologic map of the Nabesna quadrangle, Alaska: U.S. Geological Survey Miscellaneous Investigations Series Map I-932, scale 1:250,000.
Yehle, L. A., 1980, Preliminary surficial geologic map of the Valdez C-1 quadrangle, Alaska: U.S. Geological Survey Miscellaneous Field Studies Map MF-1132, scale 1:63,360.

Deglaciation and sea-level fluctuations in Port Valdez, Alaska By John R. Williams and Henry W. Coulter

Port Valdez is the upper part of a fiord extending from Prince William Sound northward and eastward into the glacier-clad Chugach Mountains (fig. 38). Shoup and Valdez Glaciers, fed by the vast snowfields of the central Chugach Mountains, are separated from Port Valdez by outwash deltas. Lowe River and Mineral Creek also form deltas at the margin of Port Valdez. Previous studies (Tarr and Martin, 1914; von Huene and others, 1967) have established that Port Valdez is a very deep, flat-bottomed, glacially scoured valley that has been partly filled with Holocene sediments trapped behind the bedrock threshold at Valdez Narrows. In late(?) Wisconsinan time, Port Valdez was filled by glacier ice that reached about $975 \mathrm{~m}$ above sea level and moved westward toward the outlet at Valdez Narrows, as shown by the position of hanging valleys and freshly scoured rocky mountainsides. Although no recessional moraines of the Port Valdez glacier have been found, tributary valley glaciers in the mountains to the south wer e extended beyond their present positions during or after retreat of the glacier at Port Valdez and formed recessional moraines near the southwest corner of the oil terminal and reached the south shore of Port Valdez along Allison Creek. Glacial striae on bedrock at tidewater east of the Fort Liscum landslide suggest that a tributary glacier entered Port Valdez after recession of the main glacier. Lateral moraines bordering Shoup Glacier, an end moraine beneath the spit at the mouth of Shoup Bay, end moraines adjacent to Valdez Glacer, and moraines adjacent to some of the smaller glaciers are believed to be of Holocene age.

Stratigraphic evidence bearing on the recession of the Port Valdez glacier and subsequent rise in sea level was obtained from test borings at the new site of the city of Valdez on the Mineral Creek fan (Shannon and Wilson, 1964) after destruction of the old city during the 1964 earth: 
quake (Coulter and Migliaccio, 1966). Mineral Creek has deposited a high-energy fan-delta complex amid bedrock islands in Port Valdez (fig. 38 ) as shown in the log of borehole 6 (Shannon and Wilson, 1964):

Log and interpretation of sediments in borehole 6

\begin{tabular}{|c|c|}
\hline $\begin{array}{l}\text { Elevation above or } \\
\text { below mean low low } \\
\text { water (meters) }\end{array}$ & Log of materials \\
\hline+2.4 to +2.0 & $\begin{array}{l}\text { Organic and silt, } \\
\text { roots, reeds, etc. }\end{array}$ \\
\hline+2.0 to -6.0 & $\begin{array}{l}\text { Medium dense to } \\
\text { very dense sand } \\
\text { and gravel. }\end{array}$ \\
\hline-6.0 to -14.2 & $\begin{array}{l}\text { Medium dense, very } \\
\text { fine to medium } \\
\text { silty sand with } \\
\text { occasional zones } \\
\text { of gravel. }\end{array}$ \\
\hline-14.2 to -15.9 & $\begin{array}{l}\text { Stiff dark-gray } \\
\text { slightly clayey } \\
\text { silt, with traces of } \\
\text { sand and sandy } \\
\text { silt partings, } \\
\text { wood, and shell } \\
\text { fragments. }\end{array}$ \\
\hline-15.9 to -16.2 & $\begin{array}{l}\text { Stiff yellow-brown } \\
\text { peat ( sampled for } \\
\text { spores and pollen } \\
\text { for radiocarbon } \\
\text { analysis) }\end{array}$ \\
\hline-16.2 to -18.8 & $\begin{array}{l}\text { Hard, slightly clayey } \\
\text { silt with gravel } \\
\text { and rock } \\
\text { fragments. }\end{array}$ \\
\hline-18.8 to -22.0 & $\begin{array}{l}\text { Very dense sand and } \\
\text { gravel. }\end{array}$ \\
\hline-22.0 to -30.0 & $\begin{array}{l}\text { Stiff to very stiff } \\
\text { clayey silt with } \\
\text { occasional gravel. }\end{array}$ \\
\hline
\end{tabular}

A sample of peat from -15.9 to $-16.2 \mathrm{~m}$ was radiocarbon dated by Meyer Rubin, U.S. Geological Survey (written commun., 1965) at $9,520 \pm 350$ years (W-1654). Examination of this sample for spores and pollen by Estelia Leopold, U.S. Geological Survey (U.S. Geological Survey paleobotanical locality D3791; written commun., 1972 ) shows that the environment of deposition of the primitive flora, largely fern pollen and moss spores, was:

a shallow-water environment, and that the local vegetation was mainly herbs, shrubs, ferns, and mosses. The scarcity of tree pollen indicates that the forest border was miles away ***
The great abundance of ferns is perplexing, and probably indicates a high precipitation or very humid conditions. The pollen ${ }^{* * *}$ corroborates evidence for a low stand of sea level for this late glacial or early postglacial interval.

The high fern content is similar to that in the lower part of bog sections studied by Heusser (1960, p. 94, fig. 19) on Montague and Hinchinbrook Islands at the southern margin of Prince William Sound and on Perry Island in western Prince William Sound where the basal date is $9,440 \pm 350$ years. However, the Valdez bog was apparently drained and its deposits oxidized before burial by marine sediments sometime shortly after 9,520 years ago, whereas the bogs studied by Heusser, being above present sea level, continued to receive deposits that contained increasing amounts of tree pollen as the forests developed in early postglacial time.

The section in borehole 6 at Valdez shows that the sediments below $-16.2 \mathrm{~m}$ were probably deposited by a late Wisconsinan glacier that retreated from Port Valdez before 9,520 years ago, that a subaerial fresh-water bog developed on these deposits about 9,520 years ago, and that, after that date, the bog was drained and covered by marine sediments and by foreset and topset beds deposited as the Mineral Creek fan-delta advanced into Port Valdez as sea level rose. The date for deglaciation of this part of Port Valdez, more than 9,520 years ago, compares well with the less precise estimates by von Huene and others (1967, p. 263-264) of 7,000 years ago (limits 3,900 to 9,800 years) based on the rate of accumulation of sediment and volume of Holocene sediments impounded in Port Valdez behind the bedrock threshold at Valdez Narrows.

Burial of the fresh-water peat by marine sediments at a depth of $16 \mathrm{~m}$ below present sea level is assumed to have taken place shortly after 9,520 years ago, but no limiting younger date is available to define the interval between deposition of the bog and burial by marine sediments. Eustatic sea level during the period shortly after 9,520 years ago was about $-20 \mathrm{~m}$ (Fairbridge, 1961, fig. 14 ; Flint, 1971 , p. 326 , fig. $12-3$ ) in a time of fluctuating, rapidly rising sea level. About 8,600 years ago, sea level attained a minor high stand of $-13 \mathrm{~m}$ (Fairbridge, 1961, fig. 14). The Valdez record, therefore, appears to fall within the limits of the world wide record, despite the fact that it is in a tectonically active region. 


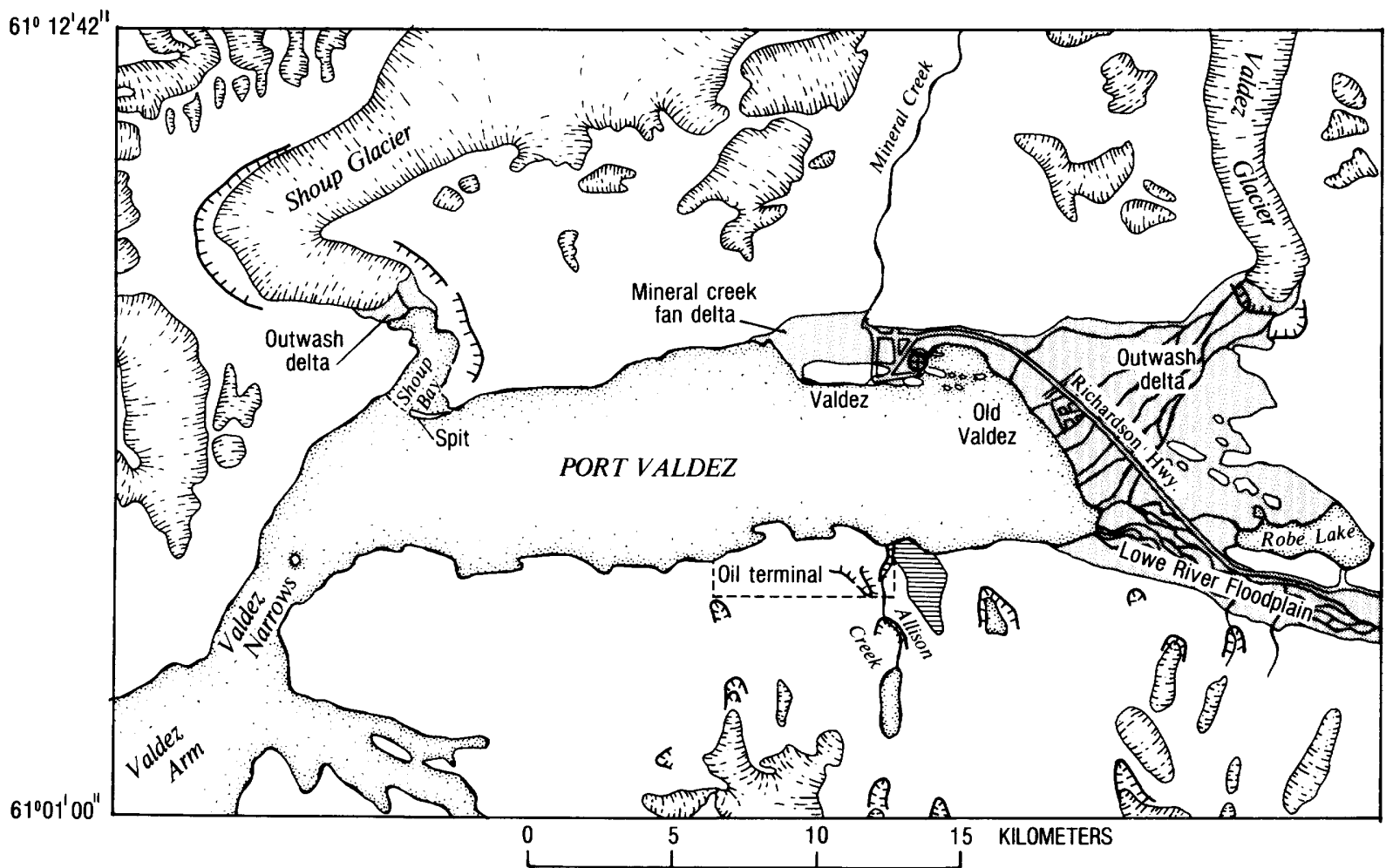

EXPLANATION

Truplu Glaciers End and lateral moraines of Holocene
and late Wisconsinan age

Fort Liscum landslide

Outwash deltas, fan deltas, and floodplains grading into deltas at margin of Port Valdez $\square$ Bedrock locally mantled by till and rubble

- Contact

$\oplus$ Drillhole location

Figure 38.-Sketch map of Port Valdez area, Alaska.

\section{REFERENCES CITED}

Coulter, H. W., and Migliaccio, R. R., 1966, Effects of the earthquake of March 27, 1964, at Valdez, Alaska: U.S. Geological Survey Professional Paper 542-C, p. C1-C36.

Fairbridge, R. W., 1961, Eustatic changes in sea level, in Ahrens, L. H., Press, Frank, Rankama, Kalervo, and Runkorn, S. K., eds., Physics and chemistry of the Earth, v. 4: New York, Pergamon Press, p. 99-185.

Flint, R. F., 1971, Glacial and Quaternary geology: New York, John Wiley and Sons, 892 p.

Heusser, C. J., 1960, Late-Pleistocene environments of North Pacific North America: American Geographical Society Special Publication 35, $308 \mathrm{p}$.
Shannon and Wilson, Inc., 1964, Report on subsurface investigation for Mineral Creek Townsite, City of Valdez, Alaska: U.S. Army Engineer District, Anchorage, Alaska, Contract DA-95-507-CIVENG-64-18(NEG): Seattle, $28 \mathrm{Au}$ gust, 12 p., 8 figs., 2 appendices.

Tarr, R. S., and Martin, Lawrence, 1914, Alaskan Glacier studies of the National Geographic Society in the Yakutat Bay, Prince William Sound, and lower Copper River regions: Washington, National Geographic Society, 498 p., 9 maps.

von Heune, Roland, Shor, G. G., Jr., and Reimnitz, Erk, 1967, Geological interpretation of seismic profiles in Prince William Sound, Alaska: Geological Society of America Bulletin, v. 78 , no. 2 , p. $259-268$. 
Isotopic data bearing on the origin and age of the epithermal lode gold deposits in the Hope-Sunrise mining district, northern Kenai Peninsula, Alaska

By Miles L. Silberman, Peter A. Mitchell', and James R. O'Neil

Preliminary stable isotope and K-Ar age data on the gold-bearing veins in the Hope-Sunrise mining district help establish their origin and age of emplacement. Volcaniclastic-rich sedimentary rocks of the Valdez Group, which crop out in an approximately north-south belt in the region (fig. 39) have been metamorphosed to lower greenschist facies and now consist of schistose graywacke, metasiltstone, and slate. The fissure vein deposits are localized by steep westnorthwest- (dominant set) and north-trending joints and faults in the metasedimentary rocks that are believed to have formed after the development of regional axial plane cleavage oriented approximately N. $20^{\circ}$ E. and dipping steeply east and west (Mitchell, 1979). Granitic dikes, some of which are mineralized, are localized by the same steep structures as are the fissure veins.

Thin irregular quartz veins occur throughout the area and in general parallel the regional cleavage. These veins, which consist of white, fine-grained and massive quartz, are believed to be the product of metamorphic segregation. They are notably free of sulfides and iron-oxide. Goldbearing veins contain quartz and calcite as principal gangue minerals, locally accompanied by alkali feldspar. Zoning of the gangue minerals is common (quartz-calcite-quartz), however, quartz is always the earliest phase and generally is more abundant. Quartz in the mineralized veins is milky to blue gray, coarse grained, and vuggy. Minor amounts of free gold, sulfides, and iron oxides occur in the mineralized veins; arsenopyrite is the dominant sulfide, with lesser amounts of pyrite, sphalerite, galena, chalcopyrite, and pyrrhotite.

Filling temperatures of fluid inclusions from mineralized quartz veins indicate that early quartz ( \pm sulfides) was deposited at approximately $200^{\circ} \mathrm{C}$ and that late mineral assemblages dominated by calcite ( \pm sulfides) were deposited at about $125^{\circ} \mathrm{C}$ (Mitchell and others, 1980). The absence of daughter minerals in the fluid inclusions suggests that the ore fluids were dilute.
The hydrogen isotopic composition of fluid inclusions and the oxygen isotopic composition of quartz were determined for three mineralized quartz veins and one nonmineralized quartz vein localized along regional cleavage (fig. 38). The average $\delta \mathrm{D}$ value of fluid-inclusion waters of the

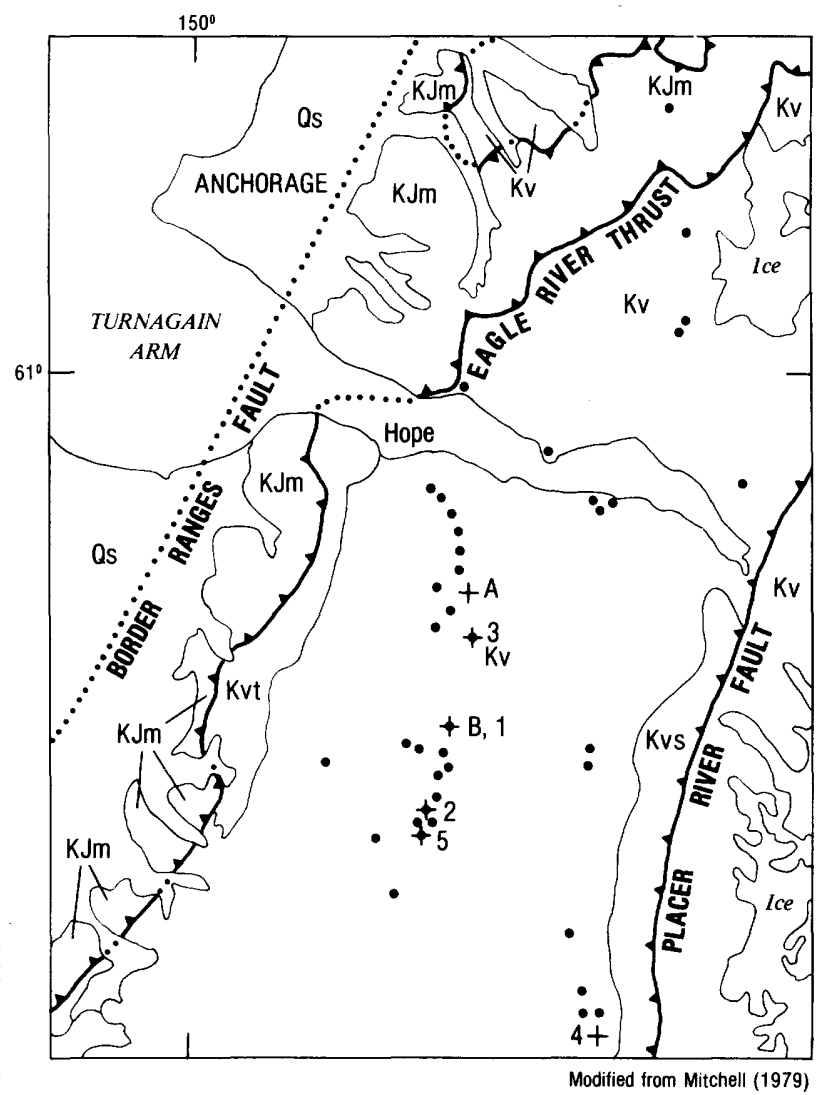

EXPLANATION

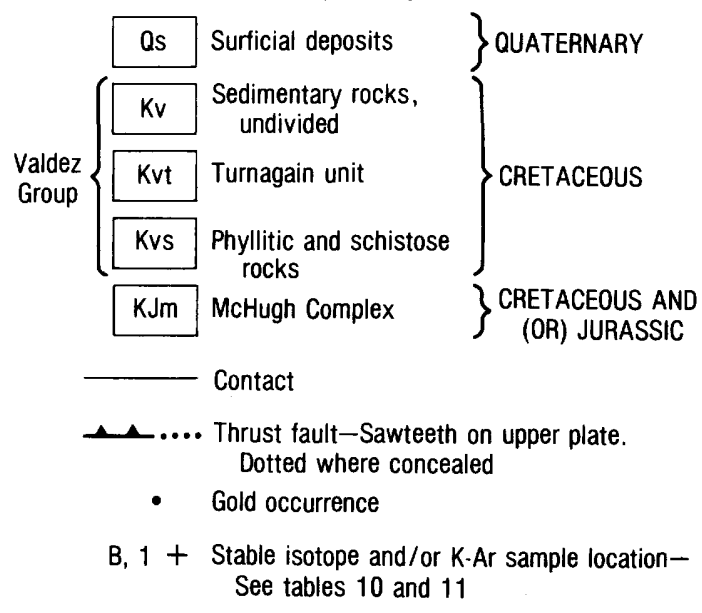

FIGURE 39.-Geologic sketch map of northern Kenai Peninsula area. 
three mineralized quartz veins is $-106 \pm 6$ (table 10 ), which is about the same as that of modern meteoric water $(-110)$ in this area (Taylor, 1974). The data indicate that the ore fluid was dominantly meteoric water. This conclusion is consistent with the dilute nature of the ore fluid suggested by the absence of daughter minerals in the fluid inclusions. Calculations using the relation between $\delta \mathrm{D}$ and $\delta^{18} \mathrm{O}$ value in meteoric waters (Craig, 1961) show that the water in the fluid inclusions had an original $\delta^{18} \mathrm{O}$ value of -14.5 .

The average $\delta^{18} \mathrm{O}$ value of the three mineralized quartz samples is $+16.6 \pm 0.3$ (table 10 ). Using the fluid-inclusion filling temperature, and the quartz-water oxygen isotope fractionation relation of Bottinga and Javoy (1973), we calculate a $\delta^{18} \mathrm{O}$ value of +2.0 for water in equilibrium with mineralized quartz at $200^{\circ} \mathrm{C}$. Meteoric water of original $\delta^{18} \mathrm{O}$ value of -14.5 could attain a $\delta^{18} \mathrm{O}$ value of +2.0 by oxygen isotopic exchange with host-rock silicate minerals at elevated temperatures. To undergo a shift in $\delta^{18} \mathrm{O}$ of this magnitude, the water-to-rock ratio must have been small. Similar oxygen isotope shifts in ore fluids (dominantly meteoric water) that deposited gold-bearing quartz veins in sedimentary and low-grade metamorphic host rocks in central Nevada have been documented by O'Neil and Silberman (1974).
Hydrogen isotopic analyses of fluid-inclusion waters from the cleavage-localized quartz veins are not yet available. The $\delta^{18} \mathrm{O}$ value of this quartz is higher than that of the mineralized quartz (table 10), and using the Bottinga and Javoy (1973) quartz-water fractionation and an estimated temperature of $350^{\circ} \mathrm{C}$ for lower greenschist-facies metamorphism, we calculate that water in equilibrium with metamorphic segregation quartz would have a $\delta^{18} \mathrm{O}$ value of about +11 . This fluid is considerably richer in ${ }^{18} \mathrm{O}$ than the ore fluid and is within the range of $\delta^{18} \mathrm{O}$ for metamorphic waters (Taylor, 1974; White, 1974). The fluids in equilibrium with mineralized quartz and metamorphic segregation quartz appear to have significantly different isotopic compositions. The structures that control localization of the mineralized veins cut the regional cleavage, along which the metamorphic segregation quartz occurs. Thus, gold mineralization must have occurred after metamorphism.

Muscovite separated from a hydrothermally altered albite-granite dike that intrudes metasandstone and is itself cut by thin mineralized quartz veins has a K-Ar age of $53.2 \pm$ 1.6 m.y. (sample A, fig. 39, table 11). A wholerock sample of hydrothermally altered felsic dike, intruding phyllitic siltstone, from the Kenai Star mine (sample B, fig. 38, table 11) has an age of

TABLE 10.-Stable isotope data for vein quartz, northern Kenai Peninsula and vicinity

\begin{tabular}{|c|c|c|c|c|c|}
\hline $\begin{array}{c}\text { Map } \\
\text { location }\end{array}$ & $\begin{array}{l}\text { Sample } \\
\text { number }\end{array}$ & Source & Origin & $\delta^{18} 0^{1}$ & $\begin{array}{l}\delta \mathrm{D} \\
\text { (fluid inclusion) }\end{array}$ \\
\hline 1 & $2203 \mathrm{~V}$ & $\begin{array}{l}\text { Kenai Star } \\
\text { mine. }\end{array}$ & Hydrothermal---- & +17.1 & -101 \\
\hline 2 & $2243 \mathrm{U}$ & $\begin{array}{l}\text { Hirshey and } \\
\text { Carlson } \\
\text { mine. }\end{array}$ & Hydrothermal---- & +16.6 & -117 \\
\hline 3 & 2179BB & $\begin{array}{l}\text { Nearhouse } \\
\text { and Smith } \\
\text { mine. }\end{array}$ & Hydrothermal---- & +16.2 & -100 \\
\hline 4 & 2444 & Outcrop-------- & $\begin{array}{l}\text { Metamorphic } \\
\text { segregation. }\end{array}$ & +19.9 & -- \\
\hline
\end{tabular}

${ }^{1} \delta$ values given in permil relative to the Vienna SMOW standard. 
$52.7 \pm 1.6$ m.y. The dike is strongly brecciated, cut by mineralized quartz-carbonate veins and contains disseminated arsenopyrite (Mitchell, 1979). From these data, we infer that hydrothermal alteration and mineralization occurred in the earliest Eocene. Regional relations suggest that these processes occurred late in the accretionary history of the Chugach terrane.

Regional cleavage developed in sedimentary rocks of the Valdez Group during penetrative deformation of the sedimentary wedge as it was accreted to the North American Continent (Berg and others, 1972), a process that MacKevett and Plafker (1974) suggest occurred in the Late Cretaceous or early Tertiary. Small felsic granitic plutons of probable anatectic origin form the Sanak-Baranof plutonic belt and were intruded into the sedimentary prism between 60 and 43 m.y. ago (Hudson, 1979; Hudson and others, 1979). The plutons were undeformed and must have been intruded after accretion. In the Kenai Peninsula, K-Ar ages of these granitic rocks range from 59 to 55 m.y. (Tysdal and Case, 1979). Thermal effects of the accretionary process led to high-grade metamorphism and partial melting of the lower parts of the sedimentary wedge after it was joined to the continent (Hudson and others, 1979 ). We suggest that lower grade metamor- phism occurred in the upper parts of the prism, generating the cleavage-localized veins of metamorphic segregation quartz and the greenschist-facies mineral assemblage. Small hydrothermal convective cells dominated by meteoric water were generated as metamorphic temperatures waned, perhaps as a result of uplift. The hydrothermal fluids dissolved silica, carbonate, sulfur, and metals from the unstable volcanic components in the sedimentary prism (Mitchell, 1979) and deposited these compounds as lodes in the steep structures that formed after the stress caused by accretionary vergence of the terrane was released, perhaps during uplift.

\section{REFERENCES CITED}

Berg, H. C., Jones, D. L., and Richter, D. H., 1972, GravinaNutzotin belt-tectonic significance of an upper Mesozoic sedimentary and volcanic sequence in southern and southeastern Alaska: U.S. Geological Survey Professional Paper 800-D, p. D1-D24.

Bottinga, Y., and Javoy, M., 1973, Comments on oxygen isotope geothermometry: Earth and Planetary Science Letters, v. 20, p. 250-265.

Craig, Harmon, 1961, Isotopic variations in meteoric waters: Science, v. 133, p. 1702-1703.

Hudson, Travis, 1979, Calc-alkaline plutonism along the Pacific rim of southern Alaska: U.S. Geological Survey Open-File Report 70-953, 31 p.

TABLE 11.-K-Ar age data, northern Kenai Peninsula and vicinity

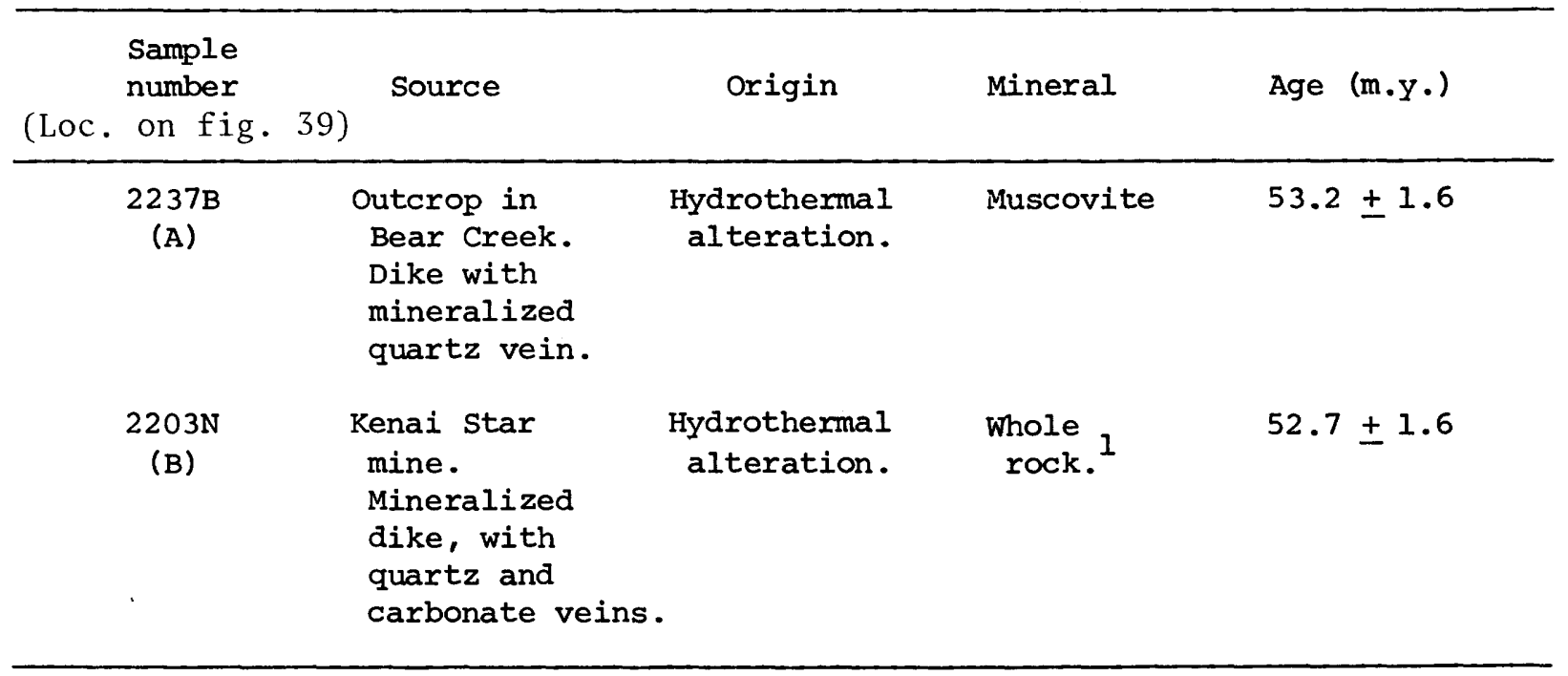

${ }^{1}$ Sample recrystallized to assemblage of muscovite, quartz, calcite, albite, and chlorite and contains disseminated arsenopyrite. The dike is cut by mineralized quartz-carbonate veins. 
Hudson, Travis, Plafker, George, and Peterman, Z. E., 1979, Paleogene anatexis along the Gulf of Alaska margin: Geology, v. 7, p. 573-577.

MacKevett, E. M., Jr., and Plafker, George, 1974, The Border Ranges fault in south-central Alaska: U.S. Geological Survey Journal of Research, v. 2, no. 3, p. 323-329.

Mitchell, P. A., 1979, Geology of the Hope-Sunrise (gold) mining district, north-central Kenai Peninsula, Alaska: Stanford, Calif., Stanford University M.S. thesis, 123 p.

Mitchell, P. A., Silberman, M. L., and O'Neil, J. R., 1980, Gold vein mineralization, north-central Kenai Peninsula, Alaska [abs.]: Geological Society of America Abstracts with Programs, v. 12 , no. 3 , p. 142.

O'Neil, J. R., and Silberman, M. L., 1974, Stable isotope relations in epithermal Au-Ag deposits: Economic Geology, v. 69 , p. 902-909.

Taylor, H. P., Jr., 1974, The application of oxygen and hydrogen isotopic studies to problems of hydrothermal alteration and ore deposition: Economic Geology, v. 69, no. 6, p. 843-883.

Tysdal, R. G., and Case, J. E., 1979, Geologic map of the Seward and Blying Sound quadrangles, Alaska: U.S. Geological Survey Miscellaneous Geologic Investigation Series Map I-1150, scale 1:250,000.

White, D. L., 1974, Diverse origins of hydrothermal ore fluids: Economic Geology, v. 69, no. 6, p. 954-973.

New invertebrate fossils, but still no land vertebrates, from nonmarine Tertiary rocks of the Kenai Peninsula, Alaska

By Patrick H. McClellan and Dennis M. Giovannetti

For four days during August 1979 we examined parts of the nonmarine Tertiary sequence of the Kenai Peninsula in search of vertebrate fossils. This sequence and other nonmarine rocks elsewhere in Alaska were previously prospected for vertebrate fossils between 1960 and 1963 by field parties from the University of Michigan Museum of Paleontology (UMMP) (Dorr, 1964). However, after a total of nine months of summer fieldwork by these parties (J.A. Dorr, written commun., 1979) at 13 widely scattered Tertiary localities, "not a single fragment was found of fossilized vertebrate bone of non-marine origin" (Dorr, 1964, p. 1202). Although vertebrate fossils are known from numerous localities in Alaska, the oldest (in the late Blancan Cape Deceit fauna; Repenning, 1980) are less than 2.5 m.y. old and Pleistocene in paleoecological aspect. The continued absence of a pre-Pleistocene land vertebrate record in the Alaskan Tertiary prompted our field study summarized below.

Only two occurrences of pre-Pleistocene vertebrates are known from nonmarine rocks in
Alaska, and these are of freshwater fishes. Schlaikjer (1937) describes two fish species, Boreocentrarchus smithi and Catostomoides alaskensis, from one occurrence in coal-bearing rocks of Oligocene or Miocene age (MacNeil and others, 1961 , p. 1806) on the north side of the Alaska Range, near Suntrana, in central Alaska. The second occurrence includes three skeletons (one incomplete) of a trout-perch (identified by R. R. Miller, UMMP; J. A. Dorr, written commun., 1979), which were preserved in a "cannonball" concretion collected $2.4 \mathrm{~km}$ west of Homer, near the mouth of Bidarki Creek, on the Kenai Peninsula. The two halves of the concretion, which contain counterparts of the fish skeletons, were found by two different private collectors between 1962 and 1964 (Dorr, 1964, p. 1202). One of the counterpart halves is on display in Homer in the Pratt Museum of the Homer Historical Society. Rocks at the Bidarki Creek locality are mapped as the Beluga Formation (Magoon and others, 1976) and belong to the Miocene Homerian Stage of land-plant biostratigraphy (Wolfe and others, 1966, plate 1). This stage is middle and late Miocene in age (Wolfe and others, 1966, p. A20), and its upper boundary with the Clamgulchian Stage is dated at $8.0 \mathrm{~m} . \mathrm{y}$. by K-Ar and fissiontrack radiometry (Triplehorn and others, 1977).

We limited our investigation to the Beluga Formation and the overlying Sterling Formation (late Miocene and Pliocene), the uppermost units of the Kenai Group (Calderwood and Fackler, 1972), exposed along and within $2 \mathrm{~km}$ inland of Kachemak Bay, and to outcrops of the Sterling Formation between Ninilchik and Clam Gulch along Lower Cook Inlet (fig. 40A). These outcrops contain abundant nonmarine plant fossils (Wolfe and others, 1966) and thus also are likely to contain vertebrate fossils. Our brief study of these formations, however, revealed no new vertebrate fossils.

Although we found numerous fossil leaves in both the Kachemak Bay and Lower Cook Inlet areas, and a petrified conifer cone at Clam Gulch, we found nonmarine animal fossils at only one locality. In an outcrop of the Sterling Formation (Magoon and others, 1976) $16 \mathrm{~km}$ northeast of Homer along the access road to MacNeil Creek (lat $59^{\circ} 43.30^{\prime}$, long $151^{\circ} 16.25^{\prime}$; T. 5 S., R. 12 W., sec. 26 ; Seldovia quadrangle), we found freshwa- 

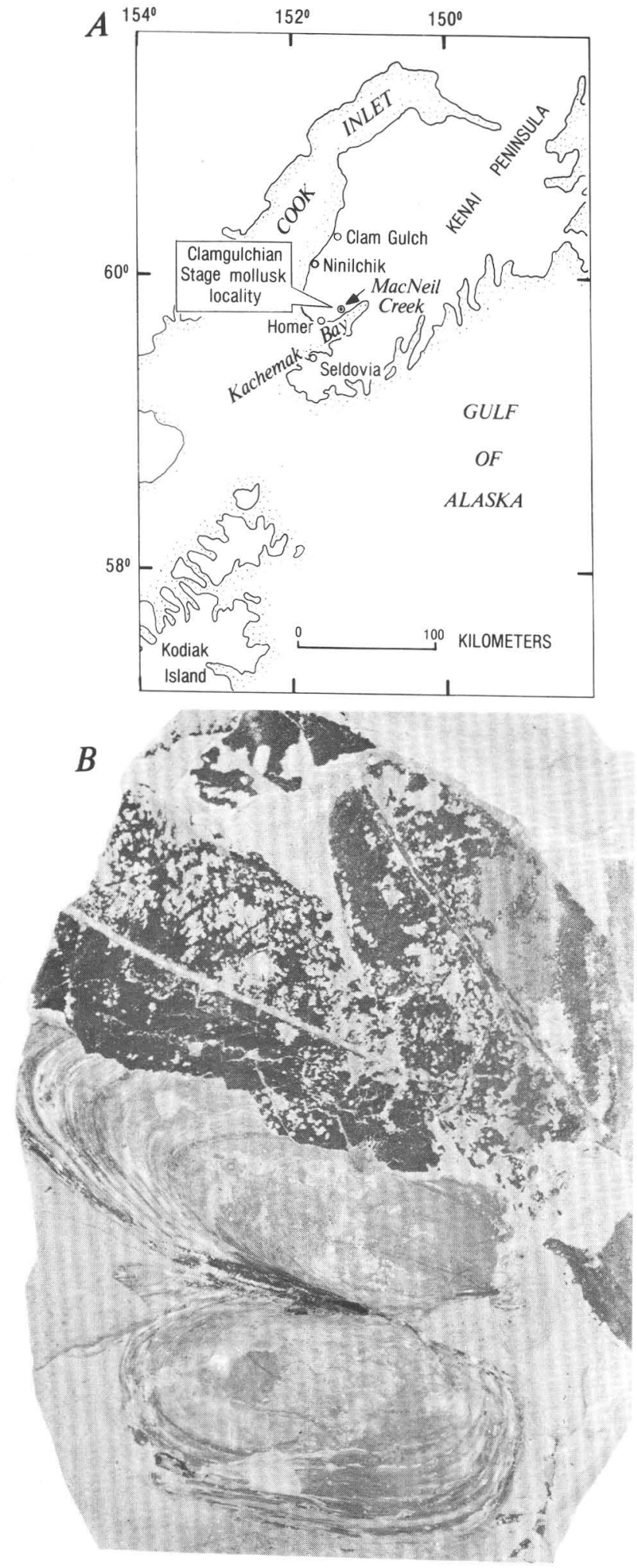

Figure 40.-Invertebrate fossils from nonmarine Tertiary rocks, Kenai Peninsula, Alaska. A, Map of Kenai Peninsula showing fossil mollusk locality. $B$, Fossil unionid clam with leaves of Salix sp., (x1), lower Clamgulchian, from the Sterling Formation. ter mollusks interbedded, and in some places in contact, with fossil leaves (fig. $40 \mathrm{~B}$ ). This locality is approximately $1 \mathrm{~km}$ inland from the coastal fossil plant localities along Kachemak Bay previously studied by Wolfe, Hopkins, and Leopold (1966). The exact stratigraphic position of the mollusk-bearing leaf bed is uncertain. However, the fossils are inferred to occur in the lower Clamguchian Stage of Wolfe, Hopkins, and Leopold (1966), probably 200 to $300 \mathrm{~m}$ above the base of the stage. This conclusion is based on extrapolation of the gentle and uniform northeastward dips of the Kenai along Kachemak Bay from the position of the Clamgulchian Stage-Homerian Stage boundary as located by Wolfe (in Triplehorn and others, 1977, p. 1158) to the vicinity of the fossil locality.

Our preliminary identification of the mollusks (four specimens) is that they are unionid pelecypods (clams), probably belonging to the subfamily Anodontinae. The only other invertebrate fossil known from the Clamgulchian Stage is a specimen of the clam Unio athlios from near Ninilchik, described by Mayer (in Heer, 1869, p. 40). Our specimens represent the second record of nonplant fossils in the Clamgulchian and, to our knowledge, the sixth published occurrence of identifiable invertebrate fossils in the nonmarine Neogene stages of Alaska. Of the four remaining fossil occurrences, Wolfe, Hopkins, and Leopold (1966, p. A17) note that, "with one exception, all *** are from beds definitely of Seldovian age" (that is, of pre-Homerian Neogene age). The exception is the occurrence of the clam Hypriopsis (identified by D. W. Taylor, in Wolfe and others, 1966 , p. A17), of probable Homerian age, along the Beluga River north of Cook Inlet.

The fossil record of pre-Pleistocene land vertebrates in Alaska is still nonexistent. The record of nonmarine invertebrates is not much better. However, the occasional discovery of freshwater mollusks in the well-defined land-plant stages of southern Alaska suggests that freshwater invertebrate fossils someday may provide a tool for correlating the Alaskan plant stages with nonmarine rocks that lack plant fossils diagnostic of those provincial stages.

\section{REFERENCES CITED}

Calderwood, K. W., and Fackler, W. C., 1972, Proposed stratigraphic nomenclature for Kenai Group, Cook Inlet Basin, Alaska: American Association of Petroleum Geologists Bulletin, v. p. 739-754. 
Dorr, J. A., 1964, Tertiary non-marine vertebrates in Alaskathe lack thereof: American Association of Petroleum Geologists Bulletin, v. 48, p.1198-1203.

Heer, Oswald, 1869, Flora fossilis alaskana: Kungliga Svenska Vetenskapskademiens Handlingar, v. 8, no. 4, p. 1- 41 .

MacNeil, F. S., Wolfe, J. A., Miller, D. J., and Hopkins, D. M., 1961, Correlation of Tertiary formations in Alaska: American Association of Petroleum Geologists Bulletin, v. 45, p. $1801-1809$.

Magoon, L. B., Adkison, W. L., and Egbert, R. M., 1976, Map showing geology, wildcat wells, Tertiary plant fossil localities, $\mathrm{K}-\mathrm{Ar}$ age dates, and petroleum operations, Cook Inlet area, Alaska: U.S. Geological Survey Miscellaneous Investigations Series Map I-1019, scale $1: 250,000$.

Repenning, C. A., 1980, Faunal exchanges between Siberia and North America: Canadian Journal of Anthropology, v. 1 , no. 1 , p. $37-44$.

Schlaikjer, E. M. 1937, New fishes from the continental Tertiary of Alaska: American Museum of Natural History Bulletin, v. 74, p. $1-23$.

Triplehorn, D. M., Turner, D. L., and Naeser, C. W., 1977, $\mathrm{K}-\mathrm{Ar}$ and fission-track dating of ash partings in coal beds from the Kenai Peninsula, Alaska: A revised age for the Homerian Stage-Clamgulchian Stage boundary: Geological Society of America Bulletin, v. 88, p. 11561160 .

Wolfe, J. A., Hopkins, D. M., and Leopold, E. B., 1966, Tertiary stratigraphy and paleobotany of the Cook Inlet region, Alaska: U.S. Geological Survey Professional Paper 398- A, p. A1 - A29.

Petrography, provenance, and tectonic significance of Middle and Upper Jurassic sandstone from Tuxedni Bay, Cook Inlet, Alaska

By Robert M. Egbert and Leslie B. Magoon

Modal analyses of 88 thin sections from Middle and Upper Jurassic sandstone in the Tuxedni Bay area, western Cook Inlet, show systematic changes in framework composition, hornblende content, and type of cement with stratigraphic position. The changes appear to reflect uplift and unroofing of the Alaska-Aleutian Range batholith in Jurassic time. Compaction and cementation have occluded all visible porosity in the sandstone and should be considered in evaluating the hydrocarbon-reservoir potential of Middle and Upper Jurassic sandstone in Cook Inlet.

The Middle and Upper Jurassic sequence in Tuxedni Bay is more than 3,000 $\mathrm{m}$ thick and includes the Middle Jurassic Tuxedni Group and Chinitna Formation and the Upper Jurassic Naknek Formation (Detterman and Hartsock, 1966;
Imlay and Detterman, 1973). We studied 21 thin sections from the Tuxedni Group, 23 thin sections from the Chinitna Formation (11 from the Tonnie Siltstone Member and 12 from the Paveloff Siltstone Member), and 44 thin sections from the Naknek Formation.

An average of 470 points were counted for each thin section in order to obtain a minimum count of 300 framework grains $(\mathrm{Q}=$ quartz, $\mathrm{F}=$ feldspar, $\mathrm{L}=$ lithic fragments), which were used to determine framework composition (fig. 41). The Q-F-L populations were normalized to 100 percent. The remaining points counted were cements and accessory minerals shown on figure 41 as percentages of total constituents, including quartz, feldspar, and lithic fragments. In addition, secondary parameters in the form of ratios, C/Q (polycrystalline quartz to total quartz), P/F (plagioclase to total feldspar), and $\mathrm{V} / \mathrm{L}$ (volcanic lithic to total lithic fragments), were calculated to aid in differentiating sandstone from the three stratigraphic units (fig. 41).

Average framework compositions (Q-F-L) change systematically up section from the Tuxedni Group through the Chinitna Formation and into the Naknek Formation, becoming progressively more feldspathic and less lithic. Quartz content remains nearly constant.

All of the sandstones studied contain less than 10 percent quartz, most of which is monocrystalline. However, in samples from the Tuxedni Group, quartz has features indicative of volcanic derivation ( clear, unstrained, resorbed margins, or bleb inclusions), whereas quartz in samples from the Chinitna and Naknek Formations has features indicative of plutonic or metamorphic derivation. Polycrystalline quartz, although not abundant, systematically decreases upward through the section from the Tuxedni Group to the Naknek Formation (see $\mathrm{C} / \mathrm{Q}$ ratios, fig. 41). Most of the polycrystalline quartzose fragments probably represent silicified volcanic detritus.

Feldspars are the most abundant mineral grains in the sandstone and increase in abundance from an average of 43 percent of the framework grains in the Tuxedni Group to 73 percent in the Naknek Formation. Plagioclase is the dominant feldspar and averages greater then 90 percent of the feldspar population throughout the stratigraphic section ( see $\mathrm{P} / \mathrm{F}$ ratios, fig. 41). The plagioclase is 
highly altered and is mostly albitized or replaced by laumontite.

The lithic fragment populations decrease up section as the feldspar populations increase. Lithic fragments average 51 percent in the Tuxedni Group, 35 percent in the Chinitna Formation (43 percent in the Tonnie Siltstone Member and 29 percent in the Paveloff Siltstone Member), and 21 percent in the Naknek Formation. Most of the lithic fragments are volcanic grains of intermediate composition. $\mathrm{V} / \mathrm{L}$ ratios decrease slightly up section but are accounted for by the appearance of plutonic rock fragments in the upper part of the Chinitna Formation and in the Naknek Formation.

Accessory minerals include: hornblende, epidote, biotite, and opaque minerals. Hornblende is absent or present only in trace amounts in samples from the Tuxedni Group and Tonnie Siltstone Member of the Chinitna Formation but is the dominant accessory mineral in the Paveloff Siltstone member of the Chinitna Formation and in the Naknek Formation, averaging 7 and 11 percent, respectively.

Three types of cement, chlorite, laumontite, and calcite, fill intergranular spaces in the sandstones. Chlorite is ubiquitous in the Tuxedni Group and in the lower part of the Chinitna Formation, apparently forming from the chemical breakdown of the abundant volcanic rock fragments. Laumontite is a common cement in the upper part of the Chinitna Formation and is the dominant cement in the Naknek Formation; laumontite probably formed in response to chemical alteration of plagioclase that is abundant in these units. Sampling was biased toward noncalcareous sandstone in order to obtain accurate modal analyses, as calcite may replace framework grains. However, calcite-cemented sandstone was found in all units but was not common. No porosity was observed in any of the sandstone; initial pore space has been totally occluded by compaction and deformation of volcanic lithic grains, and by chlorite, laumontite, and calcite cements.
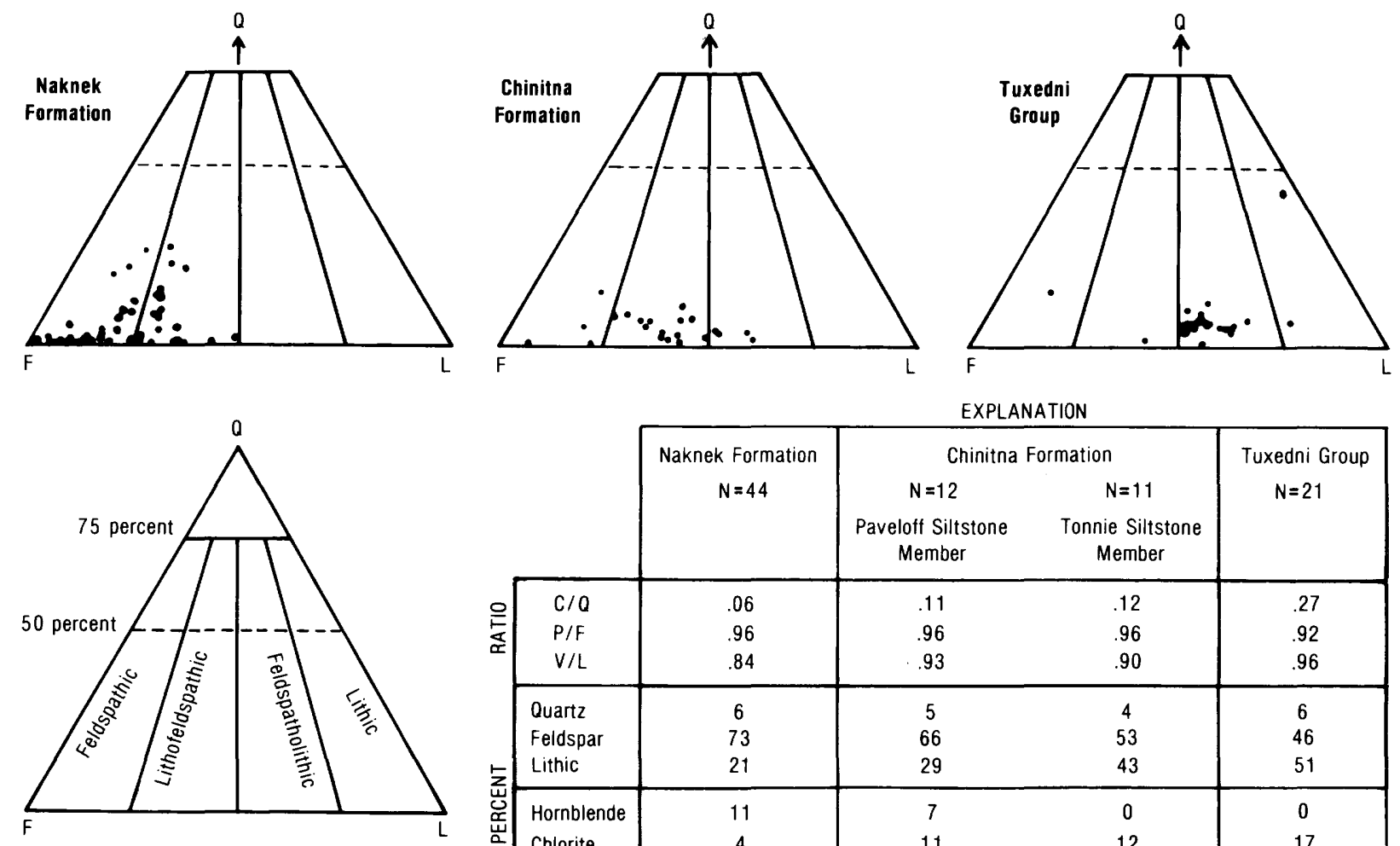

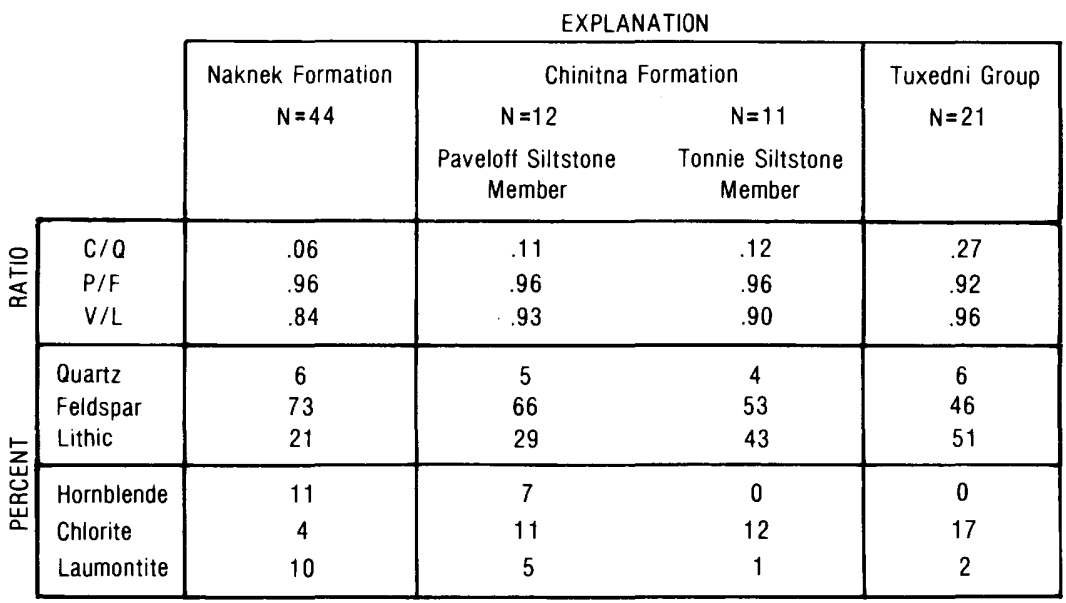

FIGURE 41.-Q-F-L ternary diagrams and compositional data of sandstone from Tuxedni Bay. Sandstone classification after Crook (1960) and Dickinson (1970). N equals number of thin sections (see text for discussion of other symbols). 
Sandstone of the Tuxedni Group was derived largely from a volcanic terrane, as indicated by the high percentages of volcanic lithic grains and volcanic quartz. Several important changes in sandstone composition occur between the two members of the Chinitna Formation. The Tonnie Siltstone Member is rich in volcanic and lithic fragments and virtually devoid of hornblende and has chlorite as the dominant cement, whereas the overlying Paveloff Siltstone Member is much more feldspathic (contains less lithic material), averages 7 percent hornblende, and has laumontite as a common cement in addition to chlorite (fig. 41). These differences indicate a change from a dominantly volcanic source for the Tonnie Siltstone Member to a mixed volcanic and plutonic provenance for the Paveloff Siltstone Member. Sandstone of the Naknek Formation was derived mainly from a plutonic source, as indicated by the high percentages of feldspar and hornblende.

The composition of sandstone from the Tuxedni Group and Chinitna and Naknek Formations is directly related to Jurassic tectonic events in south-central Alaska. During the Early Jurassic, 1,800 to $2,700 \mathrm{~m}$ of volcanic and volcaniclastic rocks (Talkeetna Formation) accumulated in the area of the present-day Alaska and Aleutian Ranges, forming a volcanic arc at least $800 \mathrm{~km}$ long (Detterman and Hartsock, 1966; Reed and Lanphere, 1973). During the Middle and Late Jurassic, hornblende-rich diorites and quartz diorites of the Alaska Range batholith intruded the Early Jurassic volcanic arc sequence and older rocks (Detterman and Reed, 1965; Hudson, 1979). Uplift and erosion of the ancestral Alaska Range in the Middle Jurassic shed volcanic detritus into the adjacent forearc basin; deposits represented by the Tuxedni Group. Continued uplift and erosion of the Alaska Range in the late Middle Jurassic partially unroofed the Alaska Range batholith, and both volcanic and plutonic detritus was deposited in the adjacent basin to form the Chinitna Formation. By Late Jurassic time, when rocks of the Naknek Formation were being deposited, the Alaska Range batholith was mostly unroofed, supplying dominantly plutonic detritus to the basin. These conclusions are consistent with previous work, most recently by Detterman and Reed (1980). They base their conclusions mainly on comparison of age and composition of conglomerate clasts in the Naknek Formation to underlying units. We suggest, however, that the Alaska Range batholith was unroofed earlier during the deposition of the Paveloff Siltstone Member of the Chinitna Formation.

\section{REFERENCES CITED}

Crook, K. A. W., 1960, Classification of arenites: American Journal of Science, v. 258, p. 419-428.

Detterman, R. L., and Hartsock, J. K., 1966, Geology of the Iniskin-Tuxedni region, Alaska: U.S. Geological Survey Professional Paper 512, 78 p.

Detterman, R. L., and Reed, B. L., 1965, Jurassic plutonism in the Cook Inlet region: U.S. Geological Survey Professional Paper 525, p. D16-D21.

- 1980, Stratigraphy, structure, and economic geology of the Iliamna quadrangle, Alaska: U.S. Geological Survey Bulletin 1368B, 86 p.

Dickinson, W. R., 1970, Interpreting detrital modes of graywacke and arkose: Journal of Sedimentary Petrology, v. 40 , p. $695-707$.

Hudson, Travis, 1979, Mesozoic plutonic belts of southern Alaska: Geology, v. 7, p. $230-234$.

Imlay, R. W., and Detterman, R. L., 1973, Jurassic paleobiogeography of Alaska: U.S. Geological Survey Professional Paper 801, 34, p.

Reed, B. L., and Lanphere, M. A., 1973, Plutonic rocks of the Alaska-Aleutian Range batholith, in Pitcher, M. G., ed., Arctic geology: American Association of Petroleum Geologists Memoir 19, p. 421 - 428 .

Petrography and provenance of Upper Cretaceous sandstone from Saddle Mountain in the Iniskin-Tuxedni area, lower Cook Inlet, Alaska

By Robert M. Egbert

Modal analysis of five sandstone samples from an 83.6-m-thick section of nonmarine Upper Cretaceous rocks on Saddle Mountain in the IniskinTuxedni area indicates that the sandstone was derived from a mixed volcanic and $\mathrm{K}$-feldspar-rich plutonic terrane. F. R. Griesbach assigned a Maestrichtian age to the rocks on the basis of sporomorphs (Magoon and others, 1980). The Upper Cretaceous section unconformably overlies the Upper Jurassic Pomeroy Arkose Member of the Naknek Formation and is unconformably overlain by the lower Tertiary West Foreland Formation. The Upper Cretaceous Saddle Mountain section correlates with part of the Upper Cretaceous section penetrated in the lower Cook Inlet COST No. 1 well and with Upper Cretaceous rocks in the 
Cape Douglas area (Magoon and others, 1980).

The five sandstone samples are all medium to coarse grained, subangular to subrounded, and moderately sorted. A minimum of 300 framework grains $(\mathrm{Q}=$ quartz, $\mathrm{F}=$ feldspar, $\mathrm{L}=$ lithic fragments) were counted for each thin section, and the ratios $\mathrm{C} / \mathrm{Q}$ (polycrystalline quartz to total quartz), $\mathrm{P} / \mathrm{F}$ (plagioclase to total feldspar), and $\mathrm{V} / \mathrm{L}$ (volcanic lithic to total lithic fragments) were calculated (fig. 42). Modes of four of the five samples plot within the lithofeldspathic field in a Q-F-L ternary diagram, the remaining sample mode plots in the feldspatholithic field (fig. 42 ).

The average composition of the five samples is $\mathrm{Q}_{23} \mathrm{~F}_{40} \mathrm{~L}_{23}$. Quartz makes up an average of 32 percent of the framework grains and has a $\mathrm{C} / \mathrm{Q}$ ratio of 0.04 . Ninety-six percent of the quartz is monocrystalline, and the remaining 4 percent is polycrystalline. Feldspar makes up an average of 40 percent of the framework grains and has a $\mathrm{P} / \mathrm{F}$ ratio of 0.59 . Fifty-nine percent of the feldspar is plagioclase, and the remaining 41 percent is

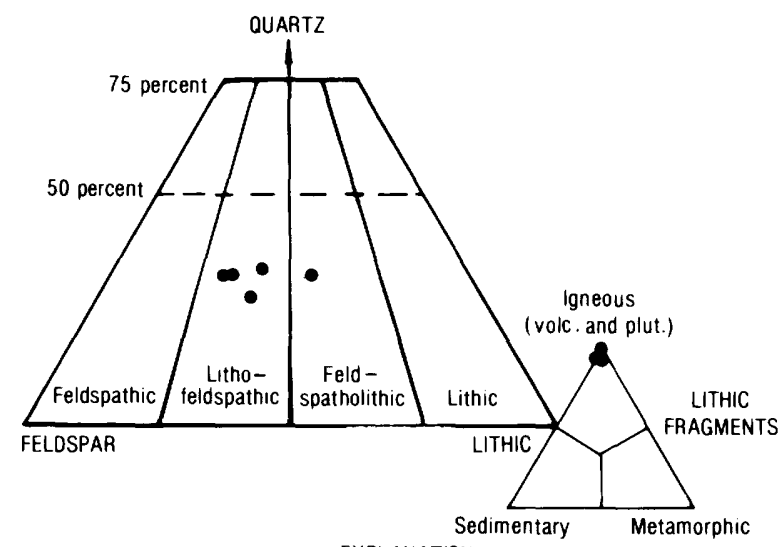

\begin{tabular}{|c|c|c|c|c|c|c|c|}
\hline Sample number & $\begin{array}{c}77 \mathrm{AMb} \\
140 \mathrm{a}\end{array}$ & $\begin{array}{l}77 \mathrm{AMb} \\
140 \mathrm{~b}\end{array}$ & $\begin{array}{c}77 \mathrm{AMb} \\
141 \mathrm{~b}\end{array}$ & $\begin{array}{c}77 \mathrm{AMb} \\
142\end{array}$ & $\begin{array}{c}77 \mathrm{AMb} \\
143 \mathrm{a}\end{array}$ & Mean & $\begin{array}{l}\text { Standard } \\
\text { Deviation }\end{array}$ \\
\hline $\begin{array}{l}\text { Quartz } \\
\text { Feldspar } \\
\text { Lithıc }\end{array}$ & $\begin{array}{l}28 \\
43 \\
29 \\
\end{array}$ & $\begin{array}{l}33 \\
44 \\
23 \\
\end{array}$ & $\begin{array}{l}34 \\
38 \\
28 \\
\end{array}$ & $\begin{array}{l}33 \\
46 \\
21 \\
\end{array}$ & $\begin{array}{l}33 \\
29 \\
38\end{array}$ & $\begin{array}{l}32 \\
40 \\
28\end{array}$ & $\begin{array}{l}2.4 \\
6.8 \\
6.6\end{array}$ \\
\hline $\begin{array}{l}\text { Igneous (volc. } \\
\text { and plut.) }\end{array}$ & 100 & 94 & 95 & 93 & 92 & 98 & 3.1 \\
\hline Sedimentary & 0 & 6 & 5 & 7 & 4 & 4 & 2.7 \\
\hline Metamorphic & 0 & 0 & 0 & 0 & 4 & 1 & 1.8 \\
\hline Cement & 21 & 20 & 22 & 32 & 24 & 24 & 4.8 \\
\hline $\mathrm{C} / \mathrm{a}$ & .03 & .02 & .02 & .08 & .05 & .04 & .03 \\
\hline$P / F$ & .55 & .53 & .70 & .57 & .61 & .59 & .07 \\
\hline$V / L$ & .60 & .54 & .75 & .72 & .76 & .67 & .10 \\
\hline
\end{tabular}

FiguRE 42.-Ternary diagrams and petrographic data of five point-counted sandstone samples from Upper Cretaceous rocks on Saddle Mountain, Iniskin-Tuxedni area. Sandstone classification modified from Crook (1960) and Dickinson (1970).
K-feldspar. K-feldspar makes up an average of 12 percent of the whole rock. Relatively high percentages of $\mathrm{K}$-feldspar are also found in Upper Cretaceous sandstone penetrated in the lower Cook Inlet COST No. 1 well (Schluger, 1977). However, Upper Cretaceous sandstone in the Cape Douglas area lacks abundant K-feldspar (Steve Lankford, oral commun., 1979).

Lithic fragments make up an average of 28 percent of the framework grains and have a $\mathrm{V} / \mathrm{L}$ ratio of 0.67. Felsitic and microlitic volcanic rock fragments, in equal proportions, account for 67 percent of the lithic fragments; the remaining 33 percent are K-feldspar-rich plutonic rock fragments. Metamorphic and clastic lithic fragments average less than 1 percent in the sandstone.

Accessory minerals average less than 7 percent. In order of decreasing abundance, the accessory minerals are muscovite, magnetite, epidote, olivine, and biotite. Cement includes phyllosilicate minerals and calcite. X-ray diffraction analysis of one sandstone sample shows the presence of smectite and chlorite. In phyllosilicatecemented samples, smectite formed first as a pore lining, and subsequent chlorite grew radially into the remaining pore space. The phyllosilicate cements probably formed from the chemical breakdown of volcanic rock fragments. In noncalcareous sandstone samples, a pseudomatrix of deformed volcanic fragments is present. Much of the sandstone in the Saddle Mountain section, however, is calcareous. In thin section, the calcite cement is sparry and has a poikilotopic texture. The absence of compaction features in the calcareous sandstone samples, coupled with the poikilotopic texture, indicates an early formation for the calcite cement.

The assemblage of lithic fragments indicates a mixed volcanic and $\mathrm{K}$-feldspar-rich plutonic source terrane. The volcanic lithic fragments were probably derived from the Lower Jurassic Talkeetna Formation, a volcaniclastic sequence that extends from Becharof Lake on the Alaska Peninsula to the Talkeetna Mountains (Reed and Lanphere, 1973). The plutonic rock fragments indicate that rocks of the Alaska Range batholith also contributed detritus to the Upper Cretaceous deposits on Saddle Mountain. Rocks of the batholith were emplaced in at least three discrete inrusive epochs, Middle and Late Jurassic, Late Creta- 
ceous and early Tertiary, and middle Tertiary (Reed and Lanphere, 1973; Hudson, 1979).

Middle and Late Jurassic plutonic rocks are mostly intermediate to mafic in composition and generally have little K-feldspar. Late Cretaceous and Tertiary plutons, generally restricted to the northern part of the Alaska Range batholith are, however, relatively rich in $\mathrm{K}$-feldspar (Reed and Lanphere, 1969). The Late Cretaceous plutons seem to be a likely source of the relatively high percent of $\mathrm{K}$-feldspar and $\mathrm{K}$-feldspar-rich plutonic rock fragments found in the Upper Cretaceous sandstone on Saddle Mountain. A similar source terrane is also likely for the $\mathrm{K}$-feldspar-rich sandstone found in Upper Cretraceous rocks penetrated in the lower Cook Inlet COST No. 1 well drilled southeast of Saddle Mountain in Cook Inlet. The absence of abundant $\mathrm{K}$-feldspar in Upper Cretaceous sandstone in the Cape Douglas area may be due to the absence of Late Cretaceous plutons in the adjacent southern part of the Alaska Range batholith.

\section{REFERENCES CITED}

Crook, K. A. W., 1960, Classification of arenites: American Journal of Science, v. 258, p. 419-428.

Dickinson, W. R., 1970, Interpreting detrital modes of graywacke and arkose: Journal of Sedimentary Petrology, v. 40 , p. 695-707.

Hudson, Travis, 1979, Mesozoic plutonic belts of southern Alaska: Geology, v. 7, p. 230-234.

Magoon, L. B., Griesbach, F. R., and Egbert, R. M., 1980, Nonmarine Upper Cretaceous rocks, Cook Inlet, Alaska: American Association of Petroleum Geologists Bulletin, v. 64, no. 8, p. 1259-1266.

Reed, B. L. and Lanphere, M. A., 1969, Age and chemistry of Mesozoic and Tertiary plutonic rocks in south-central Alaska: Geological Society of America Bulletin, v. 80, p. 23-44.

- 1973, Alaska-Aleutian Range batholith; Geochronology, chemistry, and relation to Circum-Pacific plutonism: Geological Society of America Bulletin, v. 84, 2583-2610.

Schluger, P. R., 1977, Petrographic summaries of sidewall cores from 1,810-4,560 ft; core 1 and core 2, Atlantic Richfield lower Cook Inlet COST No. 1: Mobil Oil Corporation; obtainable from the U.S. Geological Survey, Conservation Division, Office of the Oil and Gas Supervisor, Anchorage, Alaska, $10 \mathrm{p}$.

\section{SOUTHEASTERN AIASKA}

Emplacement age of the Crillon-La Perouse pluton, Fairweather Range

By Travis Hudson and George Plafker

The Crillon-La Perouse pluton is the largest of several layered gabbroic stocks in a distinct 18- $\mathrm{km} \cdot$ long belt from Mirror Harbor on Chichagof Island northwest to Mount Fairweather in the high parts of the Fairweather Range (Rossman, 1963, p. F11 and fig. 2). The difficulty of applying radiometric dating techniques to these mafic rocks has precluded direct detemination of their ages and has lead to differing age assignments for the Crillon-La Perouse pluton, based primarily on regional correlations and age interpretations of the country rocks that it intrudes. Rossman (1963, p. 40) concluded that the Crillon-La Perouse pluton was post-Early Cretaceous, whereas Brew and others $(1977,1978)$ inferred it to be Precambrian or early Paleozoic. Plafker and Campbell (1979) extended the regional correlations originally suggested by Rossman (1963) that indicated a Cretaceous age for the country rocks and therefore a Late Cretaceous or Tertiary age for the crosscutting Crillon-La Perouse pluton. Brew and Morrell $(1979,1980)$ have recently revised their earlier age assignment for the belt of gabbroic stocks to Tertiary.

This report presents $\mathrm{K}-\mathrm{Ar}$ data on rocks from the contact zone of Crillon-La Perouse pluton suggesting that it was emplaced between about 20 and 40 m.y. ago, most likely about 40 m.y. ago. As described by Rossman (1963, p. F11-F13), the contact of Crillon-La Perouse pluton, although generally sharp and locally discordant, is marked by a zone "as much as 100 feet wide containing rock that apparently is a mixture of the gabboric rock and schists that were assimilated by the gabbroic magma. The schist has been thoroughly recrystallized around both the Crillon-La Perouse and Astrolabe-DeLangle stocks; and the effects of recrystallization, discernible in the rock for several miles away from the contact become progressively more pronounced toward the stocks. Near the contact, the schist contains almandine garnet, andalusite, staurolite, hornblende, biotite, kyanite, magnetite, ilmenite, and sulfides." The relations described by Rossman indicated to us that thermally recrystallized rocks, amenable to $\mathrm{K}-\mathrm{Ar}$ dating and indicative of the emplacement age of Crillon-La Perouse pluton, were present in the contact zone. During 1978, we examined the contact of the pluton at a well-exposed locality northeast of Crillon Lake (Rossman's locality a37, pl.1, 1963 ; lat $58^{\circ} 36^{\prime} 15^{\prime \prime} \mathrm{N}$., long $137^{\circ} 16^{\prime} 6^{\prime \prime} \mathrm{W}$.) where we collected four float samples $(67 \mathrm{~A}, \mathrm{~B}, \mathrm{C}$, and D) from talus derived directly from the contact zone (fig. 43) and a fifth sample (67F) from amphibolite talus about $600 \mathrm{~m}$ west of the contact 
(fig. 43). Descriptions of these samples and the $\mathrm{K}$-Ar data for biotite and hornblende separates from them are listed in table 12.

The dated samples include two country rock amphibolites (75B and 67D), a hornblendite (67A) that is probably from the Crillon-La Perouse pluton, a garnet-bearing rock (67C) of uncertain affinity, and a pegmatite (67D) from the suite of silicic dikes that intrude both the country rocks and the Crillon-La Perouse pluton in the vicinity of the contact (fig. 44; Rossman, 1963, p. F8). The K-Ar ages from these samples range from $19.3 \pm 0.7 \mathrm{~m} . \mathrm{y}$. for biotite from the pegmatite (67D) to $44.2 \pm 3.3$ m.y. for hornblende from amphibolite $(67 \mathrm{~F})$ about $600 \mathrm{~m}$ distant from the contact. Pyroxene hornblendite, believed to be part of the Crillon-La Perouse pluton, yielded hornblende with an age of $41.4 \pm 2.2$ m.y. Country rock amphibolite $(67 \mathrm{~B})$, directly from the contact zone gave an intermediate age on hornblende of $32.5 \pm 2.5$ m.y. Biotite from the garnet-bearing rock $(67 \mathrm{C}$, either an inclusion from the pluton, baked country rock, or part of the crosscutting dike system) gave a 22.8 \pm 0.9 -m.y. age.

The K-Ar data are believed to bracket the emplacement age of the Crillon-La Perouse pluton; a maximum age $(44.2 \pm 3.3$ m.y. $)$ is provided by the amphibolite $(67 \mathrm{~F})$ distant from the contact

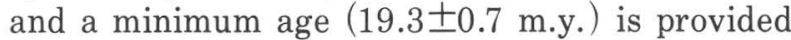
by the late crosscutting pegmatite (67D). On the basis of regional considerations, an age at or between either of these two extremes is possible. An age of about 40 m.y. would make the Crillon-La Perouse pluton similar in age to many tonalitic

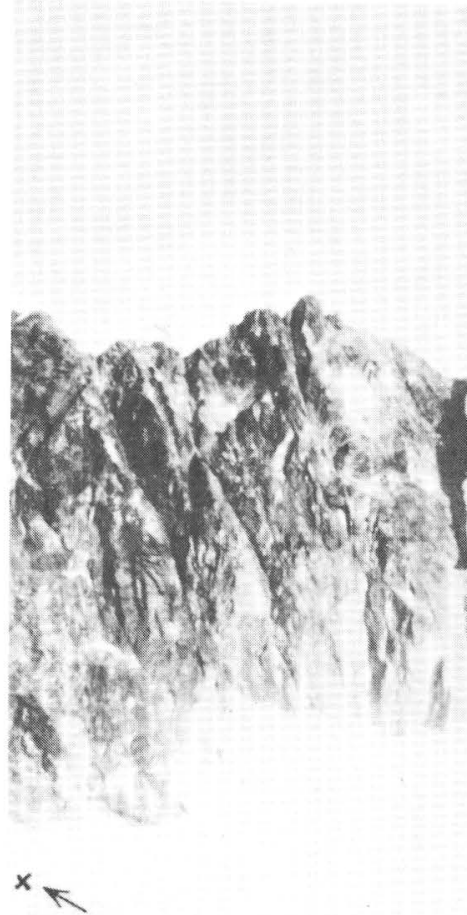

Sample $67 \mathrm{~F}$

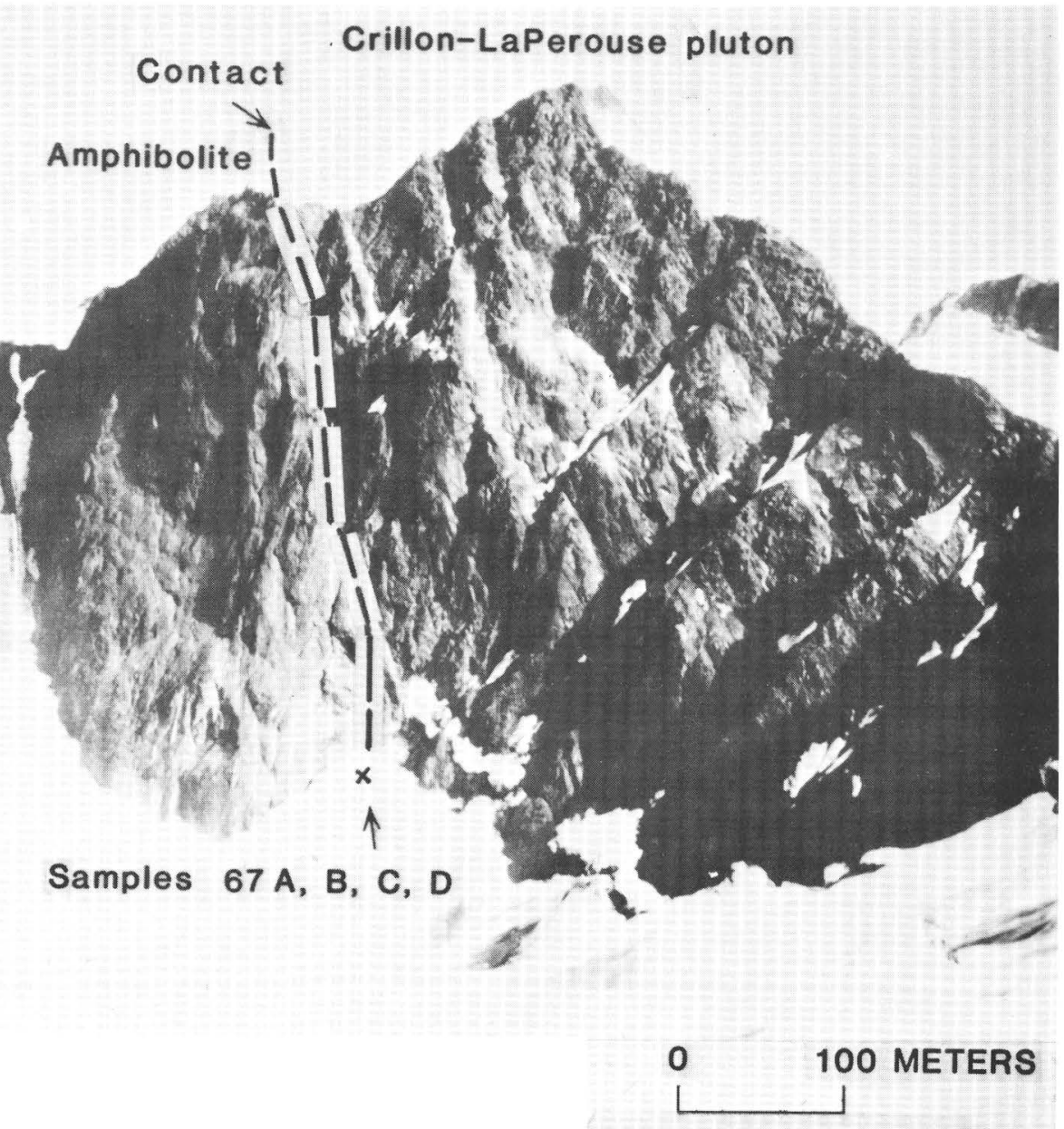

Approximate scale

Figure 43.-Contact of Crillon-La Perouse pluton against amphibolite at Rossman's locality a37 (1963, plate 1). Steep eastdipping contact is exposed over a vertical distance of about 550 meters. Samples 67A, B, C, and D were collected from talus cone at base of ravine developed along contact. Sample $67 \mathrm{~F}$ was collected from talus cone about 600 meters west of contact. 


\begin{tabular}{|c|c|c|c|c|c|c|c|}
\hline $\begin{array}{c}\text { Sample } \\
\text { No. }\end{array}$ & Mineral & $\begin{array}{l}\text { Percent } \\
\text { K }\end{array}$ & $\begin{array}{c}\text { Average } \\
\text { percent } \\
\text { K }\end{array}$ & $\begin{array}{c}{ }^{40} \mathrm{Ar} \mathrm{rad} \\
(\mathrm{ppm})\end{array}$ & $\begin{array}{l}\text { Average } \\
{ }^{40} \mathrm{Ar} \text { rad } \\
(\mathrm{ppm})\end{array}$ & $\frac{{ }^{40} \mathrm{Ar} \mathrm{rad}}{{ }^{40} \mathrm{Ar} \text { total }}$ & $\begin{array}{l}\text { *Apparent } \\
\text { age (m.y.) }\end{array}$ \\
\hline $67 \mathrm{~A}$ & Hornblende & $\begin{array}{r}0.701 \\
.691\end{array}$ & 0.696 & $\begin{array}{r}0.002090 \\
.001953\end{array}$ & 0.002022 & $\begin{array}{r}0.421 \\
.375\end{array}$ & $41 \cdot 1 \pm 2.2$ \\
\hline $67 \mathrm{~B}$ & --do.------ & $\begin{array}{r}.358 \\
.359\end{array}$ & .358 & $\begin{array}{l}.000838 \\
.000797\end{array}$ & .000818 & $\begin{array}{l}.322 \\
.251\end{array}$ & $32.5 \pm 2.5$ \\
\hline $67 \mathrm{C}$ & Biotite & $\begin{array}{l}7.027 \\
7.073\end{array}$ & 7.050 & $\begin{array}{l}.01082 \\
.01163\end{array}$ & .01123 & $\begin{array}{l}.527 \\
.433\end{array}$ & $22.8 \pm 0.9$ \\
\hline $67 \mathrm{D}$ & --do.----- & $\begin{array}{l}6.731 \\
6.784\end{array}$ & 6.757 & $\begin{array}{l}.008996 \\
.009222\end{array}$ & .09109 & $\begin{array}{r}.329 \\
.369\end{array}$ & $19 \cdot 3 \pm 0.7$ \\
\hline $67 \mathrm{~F}$ & Hornblende & $\begin{array}{l}.298 \\
.300\end{array}$ & .299 & $\begin{array}{l}.000869 \\
.000992\end{array}$ & .000931 & $\begin{array}{l}.296 \\
.299\end{array}$ & $44.2 \pm 3.3$ \\
\hline
\end{tabular}

* K-Ar analyses and original calculations by Geochron Laboratories. Ages have been converted to new IUGS constants using tables in Dalyrymple (1979).

67A. Medium-dark-gray fine- to coarse-grained massive pyroxene hornblendite; brown subhedral to irregular coarse hornblende with dark discontinuous lamellaelike bands and parallelogram-shaped patches, anhedral interstitial to equant clinopyroxene, moderately abundant disseminated apatite and subhedral opaque grains, and a trace of interstitial red-brown biotite.

67B. Dark-greenish-gray fine- to medium-grained amphibolite with thin irregular hornblende-rich and quartzofeldspathic bands of variable grain size; green subhedral hornblende (about 70-80\%), intergranular anhedral quartz and simply twinned plagioclase, disseminated equant opaque grains and scattered granular sphene.

67C. Light- to pinkish-gray fine- to medium-grained granoblastic biotite-quartzplagioclase-garnet rock; red-brown inclusion-free biotite, subhedral poikilitic garnet, Carlsbad and pericline twinned plagioclase, and disseminated equant to prismatic opaque grains.

67D. Light-gray medium- to very coarse-grained garnet-biotite-quartz-albite(?) pegmatite; euhedral moderate-red garnet (about 3\%), coarse euhedral biotite (about 6\%), subhedral to interstitial quartz mosaics, and anhedral to subhedral plagioclase.

67F. Dark-greenish-gray fine-grained amphibolite with hazy thin banding; strongly oriented green hornblende (about 70-80\%), intergranular anhedral quartz and simply twinned plagioclase, and disseminated granular opaque grains partly included in hornblende (collected about $600 \mathrm{~m}$ west of above samples; see fig. 42). 
plutons in the Fairweather Range (Travis Hudson and George Plafker, unpub. data), and an age of about 20 m.y. would make the Crillon-La Perouse pluton part of a widespread thermal metamorphic and intrusive event previously recognized in the nearby Yakutat-St. Elias area to the north (Hudson, Plafker, and Lanphere, 1977; Hudson, Plafker, and Turner, 1977).

Complete interpretation of the $\mathrm{K}-\mathrm{Ar}$ ages is not
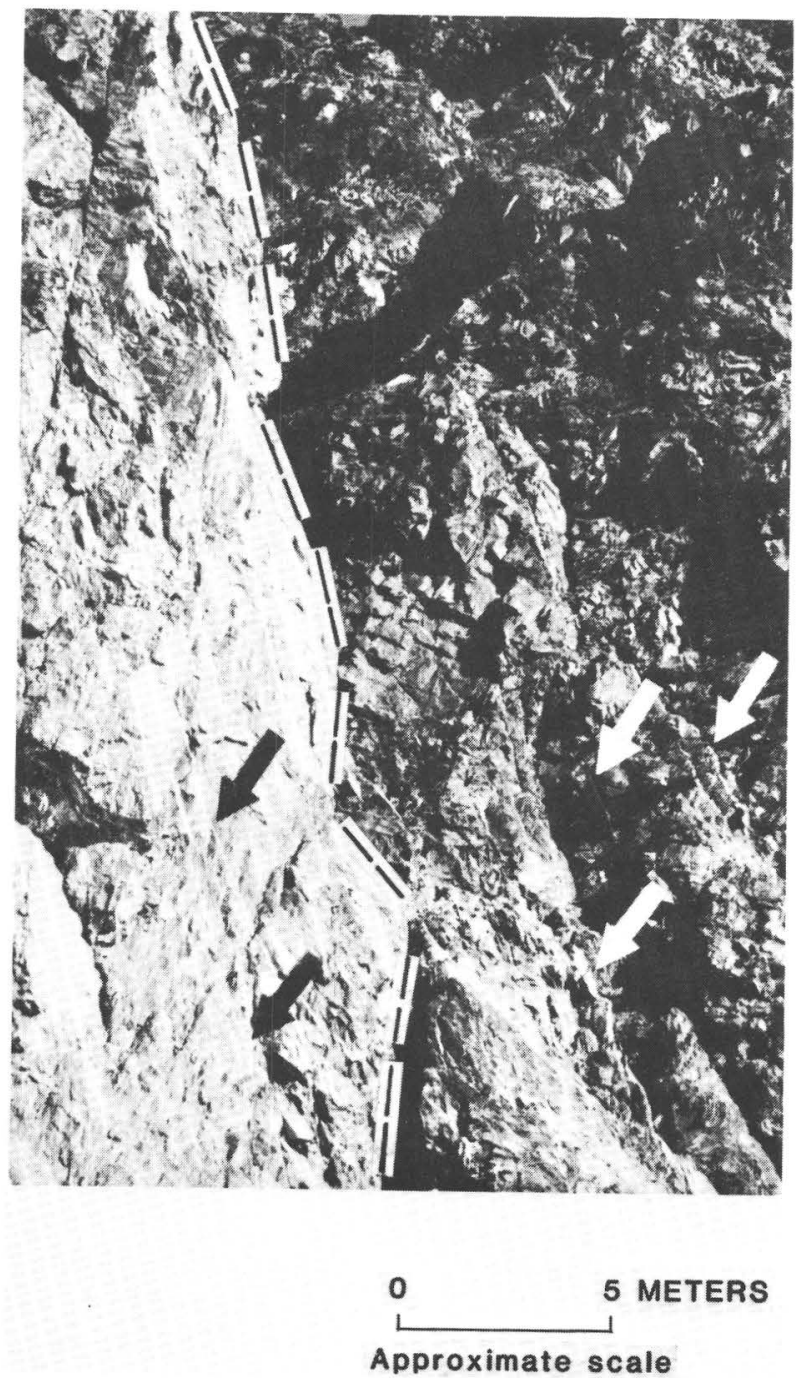

FIGURE 44.-Close-up photograph of contact zone (fig. 43) showing leucocratic dikes (arrows) in amphibolite (left) and in gabbro (right) of Crillon-La Perouse pluton. possible without additional field studies. However, on the basis of the available data, the following interpretation is preferred:

1. The country rocks underwent regional dynamothermal metamorphism during the Late Cretaceous or early Tertiary.

2. The Crillon-La Perouse pluton was emplaced after regional dynamothermal metamorphism and is part of a widespread episode of intermediate and mafic plutonism in the region. Hornblende from the pyroxene hornblendite (67A) probably gives the emplacement age of the Crillon-La Perouse pluton ( $41.1 \pm 2.2$ m.y.).

3. The contact zone of the Crillon-La Perouse pluton localized emplacement of silicic dikes about 20 m.y. ago as indicated by the biotite age (19.3 \pm 0.7 m.y.) from the late crosscutting pegmatite.

4. Contact zone rocks, including amphibolite (67B, 32.5 土2.5 m.y.) and garnet-bearing rock (67C, $22.8 \pm 0.9$ m.y.), were locally recrystallized and partially reset by emplacement of the 20 -m.y.-old dikes.

In any case, the data from the contact zone rocks provide the basis for two general conclusions: (1) K-Ar studies in the contact zones of shallow-seated mafic plutons provide a means of deducing their emplacement ages, and (2) the Crillon-La Perouse pluton was emplaced in the middle Tertiary, between 19 and 44 m.y. ago and probably about 41 m.y. ago.

\section{REFERENCES CITED}

Brew, D. A., Johnson, B. R., Ford, A. B., and Morrell, R. P., 1978, Intrusive rocks in the Fairweather Range, Glacier Bay National Monument Alaska, in Johnson, K. M., ed., The United States Geological Survey in Alaska: Accomplishments during 1977: U.S. Geological Survey Circular 772-B, p. B88-B90.

Brew, D. A., Loney, R. A., Kistler, R. W., Czamanske, G. K., Grommé, C. S., and Tatsumoto, Mitsunobu, 1977, Probable Precambrian or lower Paleozoic rocks in the Fairweather Range, Glacier Bay National Monument, Alaska, in Blean, K. M., ed., The United States Geological Survey in Alaska: Accomplishments during 1976: U.S. Geological Survey Circular 751 -B, p. B91-B93.

Brew, D. A., and Morrell, R. P., 1979, Intrusive rock belts of southeastern Alaska, in Johnson, K. M., and Williams, J. R., eds., The United States Geological Survey in Alaska: Accomplishments during 1978: U.S. Geological Survey Circular 804-B, p. B116-B121. 
Brew, D. A., and Morrell, R. P., 1980, Preliminary map of intrusive rocks in southeastern Alaska: U.S. Geological Survey Miscellaneous Field Studies Map MF-1048, scale $1: 1,000,000$.

Dalrymple, G. B., 1979, Critical tables for conversion of K-Ar ages from old to new constants: Geology, v. 7, p. 558-560.

Hudson, Travis, Plafker, George, and Lanphere, M. A., 1977, Intrusive rocks of the Yakutat-St. Elias area, southcentral Alaska: U.S. Geological Survey Journal of Research, v. 5, no. 2, p. 155-172.

Hudson, Travis, Plafker, George, and Turner, D. L., 1977, Metamorphic rocks of the Yakutat-St. Elias area, southcentral Alaska: U.S. Geological Survey Journal of Research, v. 5, no. 2, p. 173-184.

Plafker, George, and Campbell, R. B., 1979, The Border Ranges fault in the Saint Elias Mountains, in Johnson, K. M., and Williams, J. R., eds., The United States Geological Survey in Alaska: Accomplishments during 1978: U.S. Geological Survey Circular 804-B, p. B102-B104.

Rossman, D. L., 1963, Geology and petrology of two stocks of layered gabbro in the Fairweather Range, Alaska: U.S. Geological Survey Bulletin $1121-$ F, 50 p.

Carboniferous biostratigraphy, southeastern Alaska

By J. T. Dutro, Jr., A. K. Armstrong, R. C. Douglass, and B. L. Mamet $^{1}$

Sedimentary sequences are correlated among three widely separated parts of southeastern Alaska: 1) near Klawak on the west side of Prince of Wales Island; 2) in Saginaw Bay and the Keku Islets on northern Kuiu and Kupreanof Islands; and 3) near Freshwater Bay on Chichagof Island (fig. 45).

The Peratrovich Formation (Eberlein and Churkin, 1970) crops out on Peratrovich Island near Klawak and on Madre de Dios, Toti, and Shelikof Islands farther south. This formation consists of three members in ascending order: a chert member about $60 \mathrm{~m}$ thick, a limestone and chert member that ranges in thickess from 90 to $200 \mathrm{~m}$, and a limestone member more than $300 \mathrm{~m}$ thick. The chert member is poorly dated but is probably all Early Mississippian. The upper two members are well dated by Upper Mississippian foraminifers and corals. The limestone and chert member has a rich assemblage of foraminifers of Mamet Foram Zone 14 in its upper half and may be as old as Zone 10 in the lower beds, although fossil evi-

${ }^{1}$ University of Montreal. dence is sparse. This member also includes a large number of corals: Faberophyllum, Ekvasophyllum, Siphonodendron, Diphyphyllum, Lithostrotionella, and Sciophyllum. Thus, the limestone and chert member is Meramecian in age (Armstrong, 1970). The limestone member also contains Zone 14 fossils in its lower part and yields foraminifers of Zones 15 through 18 in the middle and upper beds. Consequently, it is of late Meramecian and Chesterian age; the Meramecian-Chesterian boundary is about $75 \mathrm{~m}$ above its base.

The Peratrovich is overlain by the Klawak Formation and the Ladrones Limestone (Eberlein and Churkin, 1970). The Klawak Formation occurs in the area north of Craig and includes Early and Middle Pennsylvanian faunas. Fusulinids of Mamet Zones 21 and 22 are described by Douglass (1971). The Ladrones Limestone also contains Zone 21 fusulinids according to Douglass. Branneroceras branneri (Smith) and Glaphyrites sp. were identified from the Ladrones by Gordon (1955), indicating a Morrowan (Zone 20) correlation for part of the formation.

The Saginaw Bay Formation (Muffler, 1967), exposed in Saginaw Bay and on the Keku Islets, has four members in ascending order: a volcanic member, a black chert member, a chert and limestone member, and a silty limestone member. A fault-bounded crinoidal limestone may also be a part of this formation. At least the two middle members are correlative with the Peratrovich Formation, and the upper member is equivalent to the Klawak Formation as it contains a Morrowan shelly fauna and fusulinids of Zone 21 age (Dutro and Douglass, 1961).

Near Freshwater Bay, northeastern Chichagof Island, the Iyoukeen Formation consists of three members: a lower limestone member, a middle member, and an upper limestone member (Loney and others, 1963). The lower two members are probably correlative with the chert member of the Peratrovich and contain a Lower Mississippian shelly fauna. The upper member is equivalent to the upper two members of the Peratrovich. It contains similar Meramecian coral-brachiopod faunas in its lower part and Chesterian foraminifers in its upper part. 


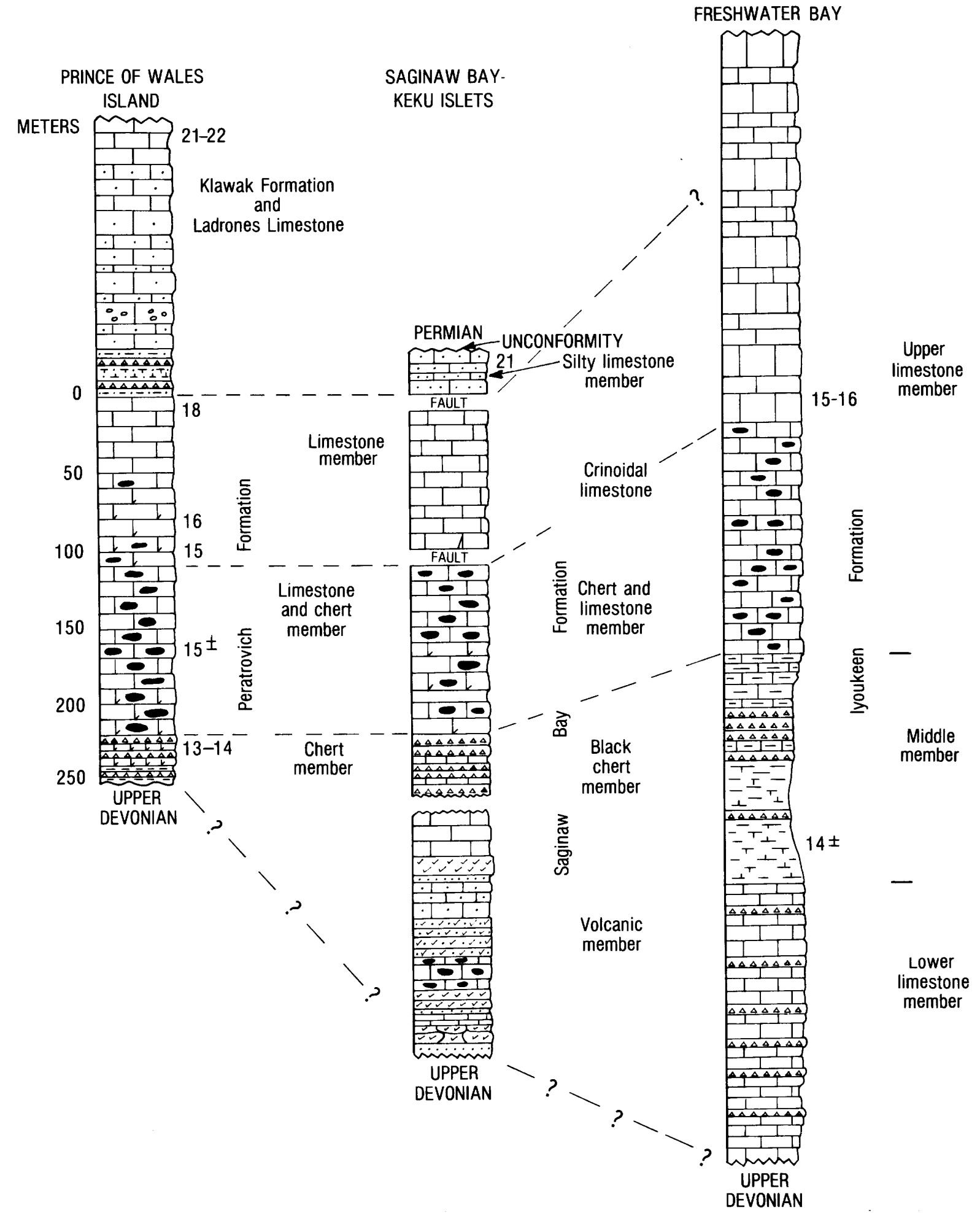

FIGURE 45.-Correlation of Carboniferous rocks in southeastern Alaska. Numbers to right of each section indicate microfaunal zone. 
The overall aspect of the faunas from these three Carboniferous sequences in southeastern Alaska is cosmopolitan. Although the Mississippian foraminifers are dominantly a North American fauna, an additional 25 percent are Tethyan elements. Mamet characterizes the foraminiferal fauna as of mixed island-arc or oceanic arc origin. Corals and brachiopods suggest that the southeastern Alaska faunas are related to faunas from northern California, Alberta, and northern Alaska. No endemism is apparent in these fossil assemblages. The Pennsylvanian fusulinids show particular affinities with faunas from Japan and the central belt of British Columbia, but also show some resemblances to faunas as far away as Spitsbergen and Spain.

The similarities among the three sequences of Carboniferous rocks in southeastern Alaska suggest that they formed in a single Carboniferous depositional basin, and their distribution implies at least $250 \mathrm{~km}$ of right-lateral offset along the Chatham Strait fault (Ovenshine and Brew, 1972). Although the rocks in these particular Carboniferous sequences could have moved northward from as far south as northern California in post-Carboniferous time, nothing specific in the makeup of the faunas suggests such a tectonic history.

\section{REFERENCES CITED}

Armstrong, A. K., 1970, Mississippian rugose corals, Peratrovich Formation, west coast Prince of Wales Island, southeastern Alaska: U.S. Geological Survey Professional Paper 534, 44 p.

Douglass, R. C., 1971, Pennsylvanian fusulinids from southeastern Alaska: U.S. Geological Survey Professional Paper 706, $21 \mathrm{p}$.

Dutro, J. T., Jr., and Douglass, R. C., 1961, Pennsylvanian rocks in southeastern Alaska, in Geological Survey Research 1961: U.S. Geological Survey Professional Paper 424-B, p. B239-B241.

Eberlein, G. D., and Churkin, M., Jr., 1970, Paleozoic stratigraphy in the northwest coastal area of Prince of Wales Island, southeastern Alaska: U.S. Geological Survey Bulletin $1284,67 \mathrm{p}$.

Gordon, M., Jr., 1955, Alaskan Carboniferous goniatites (abstract): Geological Society of America Bulletin, v. 66, no. 12 , pt. 2 , p. 1565 .

Loney, R. A., Condon, W. H., and Dutro, J. T., Jr., 1963, Geology of the Freshwater Bay area, Chichagof Island, Alaska: U.S. Geological Survey Bulletin 1108-C, p. C1-C54.

Muffler, L. J. P., 1967, Stratigraphy of the Keku Islets and neighboring parts of Kuiu and Kupreanof Islands, south- eastern Alaska: U.S. Geological Survey Bulletin 1241 -C, p. C1 -C52.

Ovenshine, A. T., and Brew, D. A., 1972, Separation and history of the Chatham Strait fault, southeastern Alaska, North America: International Geological Congress, 24th, Montreal, Canada, Proceedings, Sec. 3, p. 245-254.

The Coast plutonic complex sill, southeastern Alaska

By David A Brew and Arthur B. Ford

The informal name Coast plutonic complex is currently (Douglas and others, 1970) used for the British Columbia and southeastern Alaska parts of the batholithic complex that forms the core of the western cordillera of North America from the Alaska Peninsula on the north to the tip of Baja California on the south (King, 1969). For almost the whole length of southeastern Alaska and part of British Columbia, the west edge of the complex is a remarkably long and narrow belt of sheet- or sill-like orthogneiss plutons referred to as the Coast plutonic complex sill (Brew and Morrell, $1980 a, b)$. This report briefly describes the distribution and character of this belt (fig. 46).

The locally discontinuous belt of plutons, hereafter referred to simply as "the sill," extends from Lynn Canal near Berners Bay on the north southeastward for more than $620 \mathrm{~km}$ to at least Douglas Channel south of Prince Rupert in British Columbia beyond the limits of figure 46 . The sill is truncated on the north by the Chatham Strait fault (Ovenshine and Brew, 1972); its full extent to the south is not known. The sill ranges in width from about 3 to $25 \mathrm{~km}$, the narrower segments consist of a single pluton and the wider ones of as many as three plutons separated by 1.5 - to $8 \cdot \mathrm{km}$-wide screens of migmatic gneiss. The apparent discontinuity of the sill northeast and east of Ketchikan (fig. 46) (Brew and Morrell, 1980 a,b; Berg, Elliott, and others, 1978) may be due in part to local interruptions and in part to differences in techniques used in the geologic mapping ( H. C. Berg, oral commun., 1979). Interpretation of aeromagnetic data (Jachens, 1977; Griscom, 1977) indicates that the sill is at least 3 $\mathrm{km}$ and probably $8 \mathrm{~km}$ or more deep.

As described by Brew and others (1977), Brew and Ford (1978), and Ford and Brew (1981), the sill in general separates progressively metamorphosed (to amphibolite grade) schists of original late Paleozoic and Mesozoic age on the 


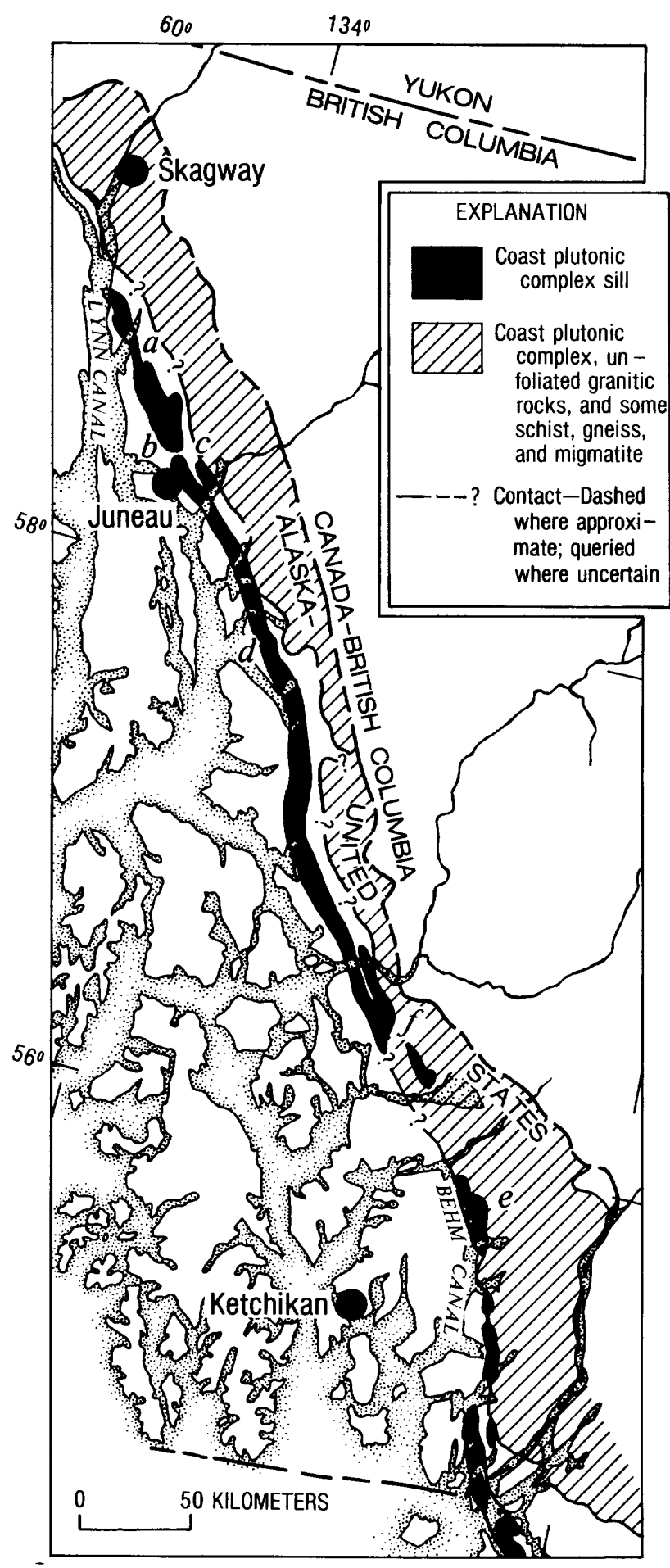

FIGURE 46.-Part of southeastern Alaska, showing Coast plutonic complex sill and other rocks of the complex (modified from Brew and Morrell, 1980b). See text for explanation of lettered points. west from the gneisses and granitic rocks of the rest of the Coast plutonic complex to the east. The granitic rocks are mostly about $50 \mathrm{~m} . \mathrm{y}$. old with minor younger intrusions (Brew and Morrell, $1980 \mathrm{a}, \mathrm{b})$ and were intruded into country rocks of uncertain original age. These country rocks are amphibolite-grade, intermediate temperatureintermediate pressure facies series to the west and hornblende-hornfels grade, high temperature-low pressure facies series to the east; this difference is interpreted (Brew and Ford, 1978) as the result of late Tertiary tilting ( up on the west) of the complex.

The sill includes a variety of rock types, but tonalite, granodiorite, quartz diorite, and quartz monzodiorite (Streckeisen, 1973) are most common (Brew and others, 1977; Ford and Brew, 1980; R. L. Elliott and D. A. Brew, unpub. data; Berg, Elliott, and others, 1978; Smith and others, 1977). Hornblende, biotite, and sphene are the most common mafic minerals. A strong foliation is everywhere apparent, and hornblende lineation is locally present. The sill rocks are actually orthogneisses, and both mineralogy and texture show strong metamorphic effects (Ford and Brew, 1981; Sainsbury, 1953). The relations between age of intrusion, metamorphism, and deformation are discussed below.

The five known ways in which the simple continuity of the sill is interrupted demonstrate that a variety of original intrusive relations existed and that the emplacement of the sill postdates the typical complex folding in the country rocks. (1) Near Berners Bay the sill engulfed, but did not severely disrupt, a highly folded persistent schist and gneiss unit mapped within the Coast plutonic complex (near a, fig. 46). (2) The southeast end of this same part of the sill (known as the Mendenhall pluton; Ford and Brew, 1973) is an abrupt blunt end ( $b$, fig. 46). (3) The north end of the next segment of the sill, comprising the Mount Juneau, Lemon Creek Glacier, and Carlson Creek plutons (Ford and Brew, 1973; Brew and Ford, 1977), consists of a tapering out and disappearance of the individual plutons (c, fig. 46). (4) The northeastern margin of the sill east of Holkham Bay (d, fig. 46) has a series of digitations extending eastward into adjacent migmatites (Brew and other, 1977), but they are too small to 
be shown on the map, as are somewhat similar digitations east of Behm Canal (Berg, Elliott, and others, 1978) (e, fig. 46). (5) East of Wrangell three en echelon sills are separated by complex migmatites (near f, fig. 46).

In discussing the origin of the nearby parallel Coast Range megalineament, Brew and Ford (1978) suggested that the sill was emplaced, probably in Late Cretaceous or perhaps early Tertiary time, along a structural discontinuity representing some kind of plate boundary. Detailed studies of the Mount Juneau pluton (Ford and Brew, 1981) do not demonstrate conclusively either pretectonic, early tectonic, or late tectonic emplacement. Considered in a regional sense, however, the sill clearly was enough involved in the deformation to obtain its foliation and local mineral lineation and enough involved in the metamorphism to have its original mineralogy modified siginificantly. The existence of highly deformed rocks engulfed by the sill and the absence of folding of any of the sill rocks indicates that emplacement postdates most of the deformation. On the basis of intrusive relations, Ford and Brew (1981) bracket the emplacement of the Mount Juneau pluton no more narrowly than post-Late Triassic and pre-early Tertiary and the age of the metamorphism as post-Early Cretaceous and pre-early Tertiary. This bracketing includes consideration of available K-Ar information on the pluton and nearby rocks. There is no evidence to suggest that these conclusions from the Mount Juneau pluton do not apply regionally. Our unpublished data indicate that this seies of deformational, magmatic, and metamorphic events probably had an important influence on the distribution of metallic mineral deposits in the northern part of southeastern Alaska.

Brew and Ford (1978) also implied that the remarkable linearity of the sill was due to the configuration of the hypothetical plate boundary along which it was intruded. Berg, Jones, and Coney (1978) placed an eastward-dipping thrust boundary between their Taku and Tracy Arm terranes very close to the sill; it seems logical to us that a terrane boundary here very likely would coincide with the outcrop of the sill. If the development of this terrane or plate boundary were close in time to the deformation, magmatism, and metamorphism associated with the sill, then we must fit into the overall tectonic history of the region a Late Cretaceous or early Tertiary largescale tectonic event, which must have occurred about $110 \mathrm{~km}$ on the continent side of the Early Cretaceous subduction complex (Plafker and others, 1977; Decker and Johnson, 1981) that marks the continental margin along much of northern southeastern Alaska. If, on the other hand, the deformation, magmatism, and metamorphism postdate the boundary-forming event, then that event can be no older than Early Cretaceous.

\section{REFFRENCES CITED}

Berg, H. C., Elliott, R. L., Smith, J. G., and Koch, R. L., 1978, Geologic map of the Ketchikan and Prince Rupert qaudrangles, Alaska: U.S. Geological Survey Open-File Report 78-73A, scale 1:250,000.

Berg, H. C., Jones, D. L., and Coney, P. J., 1978, Map showing the pre-Cenozoic tectono-stratigraphic terranes of southeastern Alaska and adjacent areas: U.S. Geological Survey Open-File Report 78-1085.

Brew, D. A., and Ford, A. B., 1977, Preliminary geologic and metamorphic-isograd map of the Juneau B-1 quadrangle, Alaska: U.S. Geological Survey Miscellaneous Field Investigations Map MF-846, scale 1:31,680.

1978, Megalineament in southeastern Alaska marks southwest edge of Coast Range batholithic complex: Canadian Journal of Earth Sciences, v.15, no. 11, p. 17631772.

Brew, D. A., Grybeck, Donald, Johnson, B. R., Jachens, R. C., Nutt, C. J., Barnes, D. F., Kimball, A. L., Still, J. C., and Rataj, J. L., 1977. Mineral resources of the Tracy ArmFords Terror Wilderness Study Area and vicinity, Alaska: U.S. Geological Survey Open-File Report 77-649, 300 p.

Brew, D. A., and Morrell, R. P., 1980a, Intrusive rocks and plutonic belts of southeastern Alaska, U.S.A.: U.S. Geological Survey Open-File Report 80-78, 35, p. $1980 \mathrm{~b}$, Preliminary map of intrusive rocks in southeastern Alaska: U.S. Geological Survey Miscellaneous Field Studies Map MF-1048, scale 1:1,000.000. 
Decker, John, and Johnson, B. R., 1981, The nature and position of the Border Ranges fault on Chichagof Island, in Albert, N. R. D., and Hudson, Travis, eds., The United States Geological Survey in Alaska: Accomplishments during 1979: U.S. Geological Survey Circular 823-B, p. B102-B104.

Douglas, R. J. W., Gabrielse, H., Wheeler, J. O., Scott, D. F., and Belyea, H. R., 1970, Geology of western Canada: in Douglas, R. J. W., ed., Geology and economic minerals of Canada: Geological Survey of Canada Economic Geology Report No. 1, p. 365-488.

Ford, A. B., and Brew, D. A., 1973, Preliminary geologic and metamorphic-isograd map of the Juneau B-2 quadrangle, Alaska: U.S. Geological Survey Miscellaneous Field Studies Map MF-527, scale 1:31,680.

- 1981, Orthogneiss of Mount Juneau-an early phase of Coast Mountains plutonism involved in Barrovian regional metamorphism near Juneau, in Albert, N. R. D., and Hudson, Travis, eds., The United States Geological Survey in Alaska: Accomplishments during 1979: U.S. Geological Survey Circular 823-B, p. B99-B102.

Griscom, Andrew, 1977, Interpretation of the aeromagnetic data, in Berg, H. C., and others, Mineral resources of the Granite Fiords wilderness study area, Alaska: U.S. Geological Survey Bulletin 1403, p. 32-36.

Jachens, R. C., 1977, Interpretation of the aeromagnetic data, in Brew, D. A., and others, Mineral resources of the Tracy Arm-Fords Terror Wilderness Study Area and vicinity, Alaska: U.S. Geological Survey Open-File Report 77-649, p. $73-84$.

King, P. B., compiler, 1969, Tectonic map of North America: Washington, D. C., U.S. Geological Survey, scale $1: 5,000,000$.

Ovenshine, A. T., and Brew, D. A., 1972, Separation and history of the Chatham Strait fault, southeast Alaska, North America: International Geological Congress, 24th, Sec. 3, p. 245-254.

Plafker, George, Jones D. L., and Pessagno, E. A., Jr., 1977, A Cretaceous accretionary flysch and melange along the Gulf of Alaska margin, in Blean, K. M., ed., The United States Geological Survey in Alaska: Accomplishments during 1976: U.S. Geological Survey Circular 751-B, p. B41B43.

Sainsbury, C. L., 1953, Geology of the Olds Mountain-Clark Peak area, Juneau vicinity, Alaska: U.S. Geological Survey Open-File Report $84,44 \mathrm{p}$.

Smith, J. G., Elliott, R. L., Berg, H. C., and Wiggins, B. D., 1977, Map showing general geology and location of chemically and radiometrically analyzed samples in parts of the Ketchikan, Bradfield Canal, and Prince Rupert quadrangles, southeastern Alaska: U.S. Geological Survey Miscellaneous Field Investigations Map MF-825, scale $1: 250,000$.

Streckeisen, A. L., chm., 1973, Plutonic rocks-classification and nomenclature recommended by the International Union of Geological Sciences (IUGS) Subcommission on the Systemics of Igneous Rocks: Geotimes, v. 18, no. 10, p. 26-30.
Orthogneiss of Mount Juneau-an early phase of Coast Mountains plutonism involved in Barrovian regional metamorphism near Juneau

By Arthur B. Ford and David A. Brew

The southwest margin of the Coast plutonic complex for more than $225 \mathrm{~km}$ in the northern and central parts of southeastern Alaska is marked by a $3-$ to $8 \cdot \mathrm{km}$-wide belt of foliated biotite-hornblende tonalitic or quartz dioritic sills (Brew and others, 1976; Brew and Ford, 1981). The magmatic origin of the homogeneous gneissose rocks is commonly obscured by metamorphic mineral growth and pervasive crystalloblastic textures. Gneissose foliation typically parallels foliation in amphibolite-grade country-rock schists, and this relation suggests a tectonic (regional metamorphic) origin of the sill foliation. How ever, because this foliation is also generally parallel to contacts of the plutons, other possible origins such as inheritance of a primary structure by mimetic recrystallization cannot be excluded. Consequently, the age relations of plutonism and penetrative deformation during regional metamorphism are not clear.

At the north end of the belt, however, the gneissose rocks forming the west margin of the Coast plutonic complex markedly truncate the regional metamorphic zonation in an adjacent Barrovian schist belt, progressively crossing the sillimanite, kyanite, staurolite, garnet and probably biotite isograds over a distance of about $60 \mathrm{~km}$ northward from near Juneau to Lynn Canal (Brew and Ford, 1977; Ford and Brew, 1973, 1977a). The gneiss belt in this area consists of several individual sheetlike or broadly lenticular plutons of orthogneiss separated by screens of schist or heterogeneous gneiss.

We made detailed studies of one of these orthogneiss bodies, the Mount Juneau pluton (Ford and Brew, 1973), because it is the only body known to cross several isograds and it might, therefore, show the relative timing of plutonism and the Barrovian metamorphism. This pluton consists of mostly homogeneous garnet-biotitehornblende tonalitic orthogneiss, which is continuously traceable in a narrow belt of about 0.6 $1.3 \mathrm{~km}$ width for $20 \mathrm{~km}$ southeastward from 
Mount Juneau to Taku Inlet (fig. 47). It continues to the south across Taku Inlet (Ford and Brew, $1977 \mathrm{~b})$ and is inferred to connect with the Speel River-Fords Terror pluton about $80 \mathrm{~km}$ farther south (Brew and others, 1976). For about $12 \mathrm{~km}$ northwestward from Taku Inlet, the body is an approximately concordant sill in schist and heterogeneous gneiss of sillimanite grade. Farther on, the body swings markedly westward for about $8 \mathrm{~km}$ and, with strong discordance to the contacts within the country-rock schists, progressively crosses isograds of sillimanite, kyanite, and staurolite before reaching the garnet isograd on the east ridge of Mount Juneau (fig. 47). The gneissose foliation is at a high angle to the contact in this discordant part of the pluton and is parallel to the northwest-trending regional synkinematic foliation in the schists, and this evidence indicates that the gneissose folation is clearly related to the penetrative deformation that accompanied regional metamorphism.

In modal composition, the orthogneiss of Mount Juneau is predominantly tonalite, with some quartz diorite and granodiorite (fig. 48). The

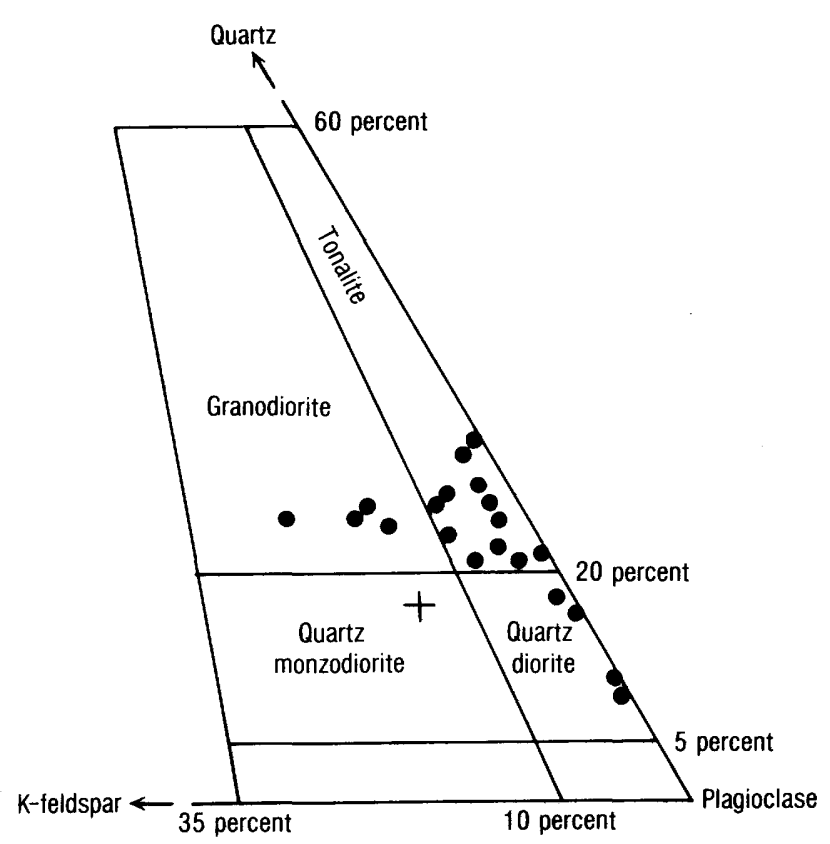

FIGURE 48.-Modal composition of orthogneiss of Mount Juneau pluton. Cross shows average chemical composition in terms of CIPW normative quartz, plagioclase, and orthoclase, from data in table 13.

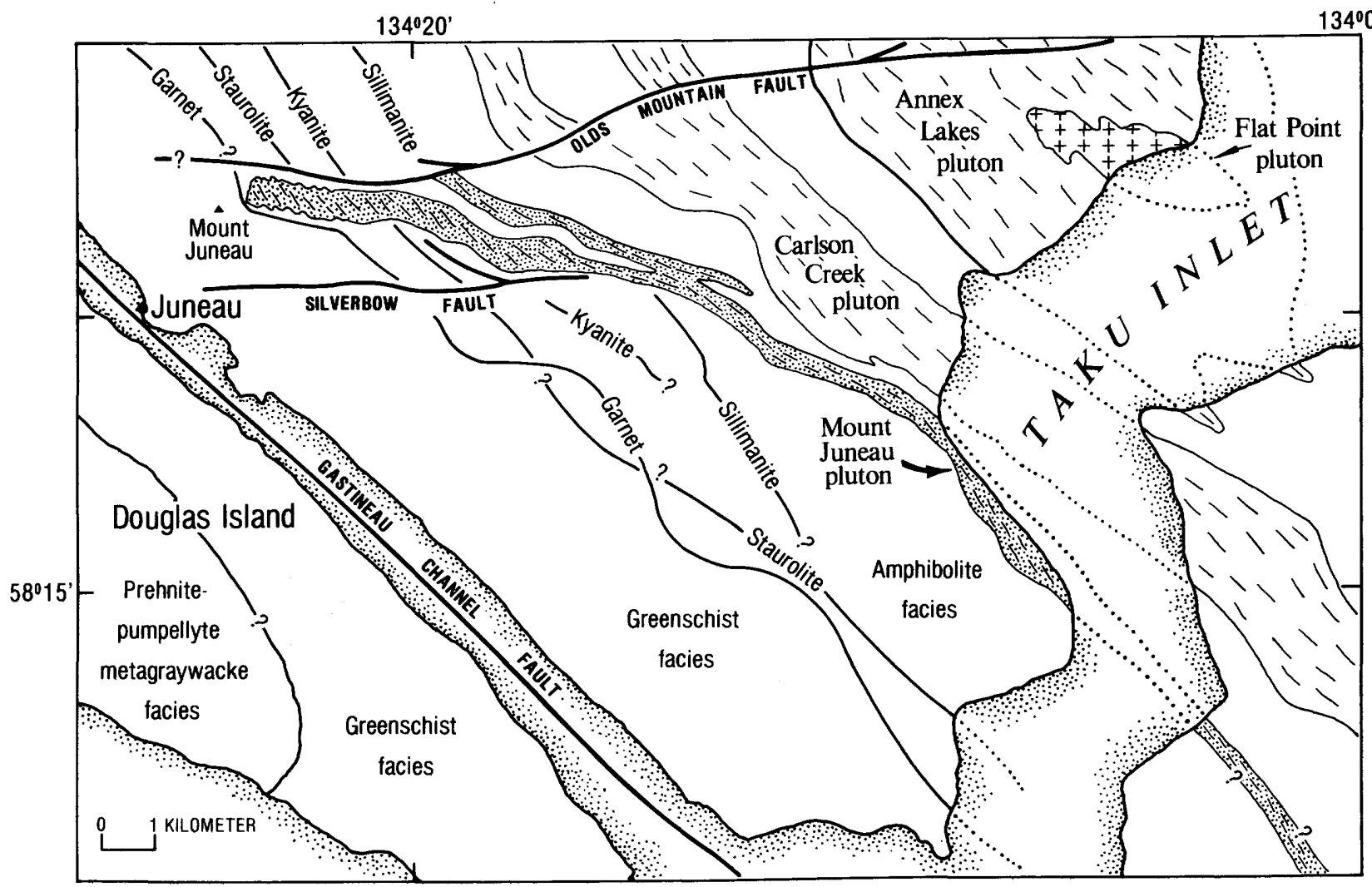

FIGURE 47.-Sketch map of Juneau area, showing distribution of metamorphic facies and isograds, major faults, and plutons of orthogneiss (lined patterns) and post-tectonic granite (crosses). Mount Juneau pluton shaded. 
body shows little systematic chemical variation along trend between Mount Juneau and Taku Inlet, compared to the average composition in table 13, except for somewhat lower $\mathrm{SiO}_{2}$ and $\mathrm{K}_{2} \mathrm{O}$ and higher $\mathrm{Al}_{2} \mathrm{O}_{3}, \mathrm{MgO}$, and $\mathrm{TiO}_{2}$ near Taku Inlet.

The metamorphic mineral assemblage of the orthogneiss consists mainly of quartz, plagioclase, epidote-group minerals, biotite, and green hornblende, with minor amounts of garnet, $\mathrm{K}$-feldspar, sphene, apatite, white mica, and retrograde chlorite and carbonate. Garnet is a characteristic minor phase. Lenticular, augenlike grains of highly albitized plagioclase, clouded with secondary clinozoisite and epidote inclusions, are the only recognizable relicts of magmatic primocrysts. Some of these features were first noted by Sainsbury (1953). Epidote-group minerals are particularly abundant, ranging from 3 to 18 percent and averaging 10 percent, in the northwest end of the body where it cuts subkyanite-grade schists. Epidote-group minerals

TABLE 13.-Average chemical composition of orthogneiss of Mount Juneau pluton

[One standard deviation in parentheses]

\begin{tabular}{|c|c|c|c|}
\hline $\mathrm{SiO}_{2}$ & - - - - - & 59.5 & $(4.4)$ \\
\hline $\mathrm{Al}_{2} \mathrm{O}_{3}$ & -- & 18.0 & $(1.2)$ \\
\hline $\mathrm{Fe}_{2} \mathrm{O}_{3}$ & -- & 2.0 & $(0.5)$ \\
\hline $\mathrm{FeO}$ & -- & 3.9 & $(1.4)$ \\
\hline Mgo & -- & 2.3 & $(1.1)$ \\
\hline $\mathrm{CaO}$ & -- & 6.5 & $(1.4)$ \\
\hline $\mathrm{Na}_{2} \mathrm{O}$ & -- & 3.5 & $(0.4)$ \\
\hline $\mathrm{K}_{2} \mathrm{O}$ & -- & 1.8 & $(0.7)$ \\
\hline $\mathrm{H}_{2} \mathrm{O}+$ & - & 0.9 & $(0.4)$ \\
\hline $\mathrm{H}_{2} \mathrm{O}-$ & - & 0.08 & $(0.04)$ \\
\hline $\mathrm{TiO}_{2}$ & -- & 0.7 & $(0.3)$ \\
\hline $\mathrm{P}_{2} \mathrm{O}_{5}$ & $---\infty$ & 0.28 & $(0.08)$ \\
\hline $\mathrm{MnO}$ & 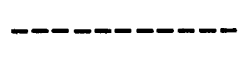 & 0.12 & $(0.03)$ \\
\hline $\mathrm{CO}_{2}$ & -- & 0.04 & $(0.07)$ \\
\hline Tota & al -------- & 99.6 & \\
\hline
\end{tabular}

appear to be present only in trace amounts in the vicinity of Taku Inlet, where the body lies in host rocks of sillimanite grade. This evidence suggests a variation in grade along strike from an epidote-bearing subfacies (Misch, 1968) of the amphibolite facies in the northwest to an epidote-free amphibolite subfacies near Taku Inlet.

The implications regarding timing of plutonism and regional metamorphism are significant. A zonation pattern from epidote-bearing to epidotefree amphibolite subfacies would imply that the body was probably involved in the entire metamorphic event and is pretectonic or at least early tectonic in age. On the other hand, if further studies show that the entire body was recrystallized in the epidote-bearing amphibolite subfacies, then the magma was probably emplaced at a late stage of regional metamorphism, before the cessation of penetrative deformation, but after attainment of the maximum grade of kyanite and sillimanite crystallization.

$\mathrm{K}$-Ar age determinations of crystalline schists in the Juneau area (Forbes and Engels, 1970) and of orthogneisses there and near Tracy Arm (Brew and others, 1977; J. G. Smith, unpub. data) show thermal overprinting by widespread Tertiary ( $a$ bout 50 m.y. old) plutonism to the east. Forbes and Engels (1970) conclude from their K-Ar age data that the synkinematic regional metamorphism occurred in the Late Cretaceous or early Tertiary, an age that we consider to be a minimum for emplacement of the Mount Juneau pluton. The youngest rocks known to be involved in the regional metamorphism contain Inoceramus of Cretaceous (late Early? Cretaceous) age (D. L. Jones, written commun., 1971). The youngest rocks known to be intruded by the Mount Juneau pluton are Late Triassic on the basis of fossils in correlative units (Ford and Brew, 1977b). Thus the emplacement of the Mount Juneau pluton as an early phase of Coast Mountains magmatism is currently bracketed no more narrowly than postLate Triassic to early Tertiary.

\section{REFERENCES CITED}

Brew, D. A., and Ford, A. B., 1977, Preliminary geologic and metamorphic-isograd map of the Juneau B-1 quadrangle, Alaska: U.S. Geological Survey Miscellaneous Field Studies Map MF-846, scale 1:31,680. 
Brew, D. A., and Ford, A. B., 1981, The Coast plutonic complex sill, southeastern Alaska, in Albert, N. R. D., and Hudson, Travis, eds., The United States Geological Survey in Alaska: Accomplishments during 1979: U.S. Geological Survey Circular 823-B, p. B96-B99.

Brew, D. A., Ford, A. B., Grybeck, Donald, Johnson, B. R., and Nutt, C. J., 1976, Key foliated quartz diorite sill along southwest side of Coast Range complex, northern southeastern Alaska, in Cobb, E. H., ed., The United States Geological Survey in Alaska: Accomplishments during 1975: U.S. Geological Survey Circular 733, p. 60.

Brew, D. A., Grybeck, Donald, Johnson, B. R., Jachens, R. C., Nutt, C. J., Barnes, D. F., Kimball, A. L., Still, J. C., and Rataj, J. L., 1977, Mineral resources of the Tracy ArmFords Terror Wilderness Study Area and vicinity, Alaska: U.S. Geological Survey Open-File Report 77-649, 300 p.

Forbes, R. B., and Engels, J. C., 1970, $\mathrm{K}^{40} / \mathrm{Ar}^{40}$ age relations of the Coast Range batholith and related rocks of the Juneau Ice Field area, Alaska: Geological Society of America Bulletin, v. 81, p. 579-584.

Ford, A. B., and Brew, D. A., 1973, Preliminary geologic and metamorphic-isograd map of the Juneau B-2 quadrangle, Alaska: U.S. Geological Survey Miscellaneous Field Studies Map MF-527, scale 1:31,680.

- 1977a, Truncation of regional metamorphic zonation pattern of the Juneau, Alaska, area by the Coast Range batholith, in Blean, K. M., ed., The United States Geological Survey in Alaska: Accomplishments during 1976: U.S. Geological Survey Circular 751-B, p. B85-B87.

- 1977b, Preliminary geologic and metamorphic-isograd map of northern parts of the Juneau A-1 and A-2 quadrangles, Alaska: U.S. Geological Survey Miscellaneous Field Studies Map MF-847, scale 1:31,680.

Misch, Peter, 1968, Plagioclase compositions and non-anatectic origin of migmatitic gneisses in northern Cascade Mountains of Washington State: Contributions to Mineralogy and Petrology, v. 17, p. 1-70.

Sainsbury, C. L., 1953, Geology of the Olds Mountain-Clark Peak area, Juneau vicinity, Alaska: U.S. Geological Survey Open-File Report 84, 44 p.

The nature and position of the Border Ranges fault on Chichagof Island

By John Decker and Bruce R. Johnson

The Border Ranges fault, identified by MacKevett and Plafker (1974), is a major tectonic boundary in south-central Alaska that juxtaposes an upper Mesozoic and Tertiary subduction complex (Chugach terrane) against upper Paleozoic and lower Mesozoic rocks. Plafker and others (1976) and Plafker and Campbell (1979) have extended the Border Ranges fault through the Saint Elias Mountains of western Canada into southeastern Alaska as far south as Peril Strait.

Two different locations have been proposed for the Border Ranges fault on Chichagof Island in southeastern Alaska. Plafker and others (1976) originally interpreted the Border Ranges fault to lie within the Kelp Bay Group (Loney and others, 1975). The Goon Dip Greenstone, Whitestripe Marble, and related crystalline rocks were placed to the east, and the rest of the Kelp Bay Group to the west of the fault. Brew and Morrell (1979) correlated the western limit of the Tarr Inlet suture zone in Glacier Bay National Monument with the Border Ranges fault as mapped by Campbell and Dodds (1979) and Plafker and Campbell (1979) to the north. Brew and Morrell (1979) extended this boundary south through Chichagof Island to the west of the original position, including the entire Kelp Bay Group with older rocks to the east.

On the basis of recent geologic mapping and new $\mathrm{K}-\mathrm{Ar}$ and radolarian age data from western Chichagof Island, we have come to the following conclusions concerning the nature and position of the Border Ranges fault:

1. The Border Ranges fault is located between the Goon Dip Greenstone and Whitestripe Marble to the east and the rest of the Kelp Bay Group to the west as Plafker and others (1976) originally suggested.

2. The fault juxtaposes pre-Late Jurassic rocks on the east against a Lower Cretaceous(?) subduction complex of the Chugach terrane on the west.

3. The fault has a steep westward dip and is interpreted as an overturned thrust fault that is related to a mid-Cretaceous(?) subduction event. Loney and others (1975) included the following formations, in ascending order, in the Kelp Bay Group; Goon Dip Greenstone, Whitestripe Marble, Pinnacle Peak Phyllite, Waterfall Greenstone, and Khaz Formation. For simplicity in the following discussion, the upper part of the Kelp Bay Group is termed the "upper Kelp Bay Group" and, as used herein, includes the Pinnacle Peak, Waterfall, and Khaz Formations.

The Border Ranges fault (fig. 49) forms a consistent lithologic boundary on western Chichagof Island. Rocks immediately to the west (upper Kelp Bay Group) consist of a highly disrupted sequence (melange) of metavolcanic and metasedimentary rocks that has been 
metamorphosed to greenschist and locally blueschist facies. These rocks are dominantly light-green metatuff and dark-gray argillite; they are generally well foliated and commonly phyllitic or schistose. Chert from the upper Kelp Bay Group locally contains Lower Cretaceous (Valanginian) radiolarians (Susan Karl and D. L. Jones, oral commun., 1979). Rocks to the east of the Border Ranges fault consist of a coherent massive to weakly foliated marble (Whitestripe Marble) that overlies massive to weakly foliated commonly amygdaloidal dark-greenish-gray basalt and metabasalt (Goon Dip Greenstone). The marble and greenstone units are extensively intruded by Late Jurassic and post-mid-Cretaceous(?) foliated diorite and quartz diorite-tonalite plutons (Loney and others, 1975). No volumetrically important amygdaloidal greenstone or foliated dioritic rocks are known from the upper Kelp Bay Group west of the fault, and no well-foliated green metatuff or dark-gray argillite are known from the Whitestripe Marble or Goon Dip Greenstone east of the fault.

Where the Whitestripe Marble occurs, the Border Ranges fault follows its western boundary. Bedding, compositional layering, and a weakly developed foliation in the Whitestripe Marble generally follow the regional structural grain and are approximately parallel to its contacts. Along its western contact, however, the marble is locally a recrystallized breccia, and bedding is commonly truncated, generally at a low angle. For several kilometers on southwestern Chichagof Island where the Whitestripe Marble is absent, a thin foliated diorite sill intrudes along the contact between the Goon Dip Greenstone and the upper Kelp Bay Group (Loney and others, 1975). Similar intrusive rocks are found to the east of this sill but not to the west. Farther north, similar foliated sills locally occur between the upper Kelp Bay Group and the Whitestripe Marble as well as within the marble. The ages of the diorite sills are not known, but they probably postdate the midCretaceous metamorphism of the upper Kelp Bay Group (Decker and others, 1980).

Evidence in support of the interpretation that the Border Ranges fault is an overturned thrust fault is entirely circumstantial. The rocks of western Chichagof Island are overturned and dip steeply to the west, they become generally older and of higher metamorphic grade to the east. Turbidites west of and included in the upper Kelp Bay Group commonly have well-preserved sedimentary structures that consistently indicate that tops of beds are to the east (Decker, 1980). Because sedimentary structures indicate that turbidites locally become younger to the east, although in fact formations become older to the east, and because most faults that cut the turbidites are bedding plane faults, we interpret these faults as originally east-dipping thrust faults now overturned to the east. Similarly, the Border Ranges fault on western Chichagof Island dips steeply to the west and is subparallel to the general trend of overturned thrust faults that cut the turbidites. This evidence suggests to us that the

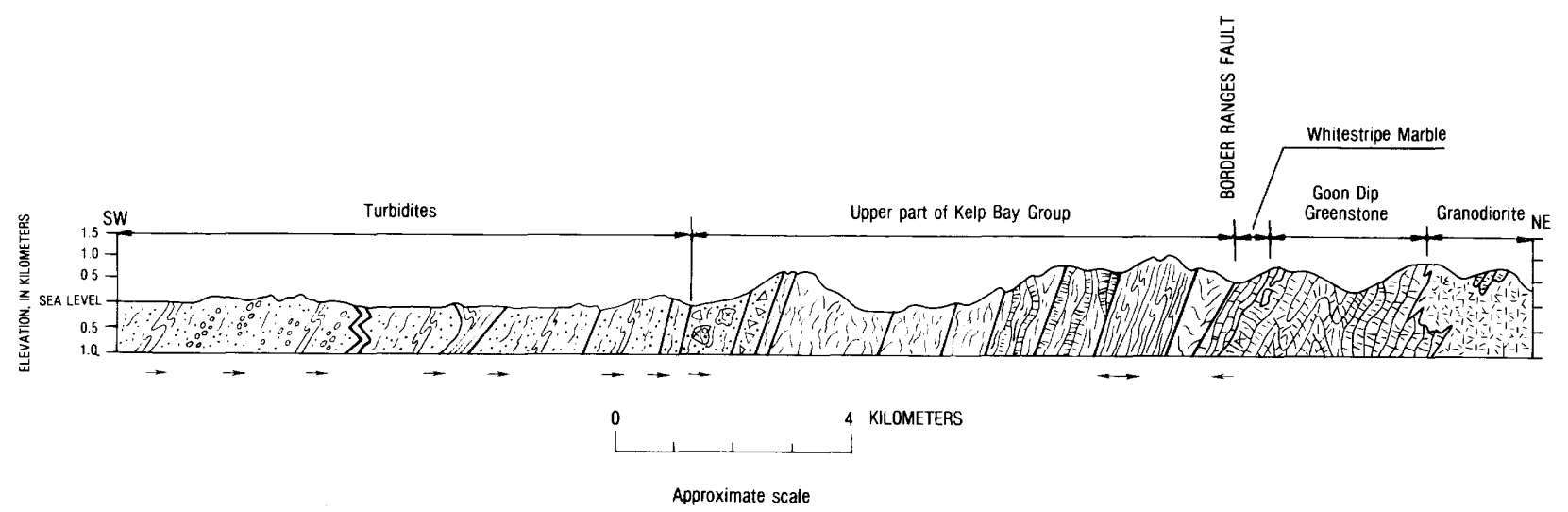

FIGURE 49.-Generalized northeast-southwest structure section across western Chichagof Island. Arrows below structure section indicate direction of stratigraphic tops (local younging direction) based on sedimentary structures and contact relations. 
Border Ranges fault on western Chichagof Island is also a thrust fault overturned to the east. This interpretation is contrary to that of Plafker and others (1976) who describe the Border Ranges fault on northern Baranof Island as having low dips, and Berg, Jones, and Coney (1978) who show the Border Ranges fault on their structure section as having a shallow dip to the east.

Movement along the Border Ranges fault on Chichagof Island can be constrained to the period of time after greenschist-blueschist facies metamorphism of the upper Kelp Bay Group and before emplacement of diorite sills along it. Metamorphism of the upper Kelp Bay Group is dated at 106 m.y. to 91 m.y. (Decker and others, 1980 ). This event produced phyllitic and schistose fabrics in greenschist and blueschist facies metavolcanic and metasedimentary rocks to the west of the fault that contrast strongly with the massive to weakly foliated, highly altered to moderately recrystallized Goon Dip Greenstone and Whitestripe Marble to the east of the fault. The diorite sills are highly altered and have a moderate to well developed mineral foliation; they are not cataclastic and probably postdate the last movement on the fault. The diorite has not been dated but is probably Late Cretaceous or earliest Tertiary because it probably postdates the midCretaceous metamorphism of the upper Kelp Bay Group and because isotopically dated plutons of Eocene age in the vicinity are relatively fresh and nonfoliated.

\section{REFERENCES CITED}

Berg, H. C., Jones, D. L., and Coney, P. J., 1978, Map showing pre-Cenozoic tectonostratigraphic terranes of southeastern Alaska and adjacent areas: U.S. Geological Survey Open-File Report 78-1085, scale 1:1,000,000, 2 sheets.

Brew, D. A., and Morrell, R. P., 1979, The Wrangell terrane ("Wrangellia") in southeastern Alaska: The Tarr Inlet suture zone with its northern and southern extensions, in Johnson, K. M., and Williams, J. R., eds., United States Geological Survey in Alaska: Accomplishments during 1978: U.S. Geological Survey Circular 804-B p. B121B123.

Campbell, R. B., and Dodds, C. J., 1979, Operation Saint Elias, British Columbia, in Current Research, Part A: Geological Survey of Canada Paper 79-1A, p. 17-20.

Decker, John, 1980, Geologic map of western Chichagof Island, southeastern Alaska: U.S. Geological Survey Open-
File Report $80-150$, scale $1: 63,360,2$ sheets.

Decker, John, Wilson, F. H., and Turner, D. L., 1980, MidCretaceous subduction event in southeastern Alaska: Geological Society of America Abstracts with Programs, v. 12 , no. 3 , p. 103 .

Loney, R. A., Brew, D. A., Muffler, L. J. P., and Pomeroy, J. S., 1975, Reconnaissance geology of Chichagof, Baranof, and Kruzof Islands, southeastern Alaska: U.S. Geological Survey Professional Paper 792,105 p.

MacKevett, E. M., Jr., and Plafker, George, 1974, the Border Ranges fault in south-central Alaska: U.S. Geological Survey Journal of Research, v. 2, no. 3, p. 323-329.

Plafker, George, and Campbell, R. B., 1979, The Border Ranges fault in the Saint Elias Mountains, in Johnson, $\mathrm{K}$. M., and Williams, J. R., eds., United States Geological Survey in Alaska: Accomplishments during 1978: U.S. Geological Survey Circular 804-B, p. B102-B104.

Plafker, George, Jones D. L., Hudson, Travis, and Berg, H. C., 1976, The Border Ranges fault system in the Saint Elias Mountains and Alexander Archipelago, in Cobb, E. H., ed., United States Geological Survey in Alaska: Accomplishments during 1975: U.S. Geological Survey Circular 733 , p. 14-16.

Upper Triassic volcanogenic massive-sulfide metallogenic province identified in southeastern Alaska

By Henry C. Berg

Layers and lenses of disseminated and massive pyrite, pyrrhotite, and subordinate arsenopyrite, sphalerite, galena, and chalcopyrite are interbedded with fossiliferous metavolcanic and metasedimentary strata on Kupreanof Island, about $25 \mathrm{~km}$ southwest of the town of Petersburg in southeastern Alaska (fig. 50 and table 14, loc. 1; Berg and Grybeck, 1980). N. J. Silberling (written commun., 1980) describe these fossils as Halobia rugosa, which is a reliable index to the lower Karnian Stage of the Upper Triassic. This mineral discovery in 1979 by the U.S. Geological Survey is the first faunally dated occurrence of Upper Triassic volcanogenic sulfides in southeastern Alaska and one of the few such deposits to be dated by fossils anywhere in Alaska.

Preliminary field and laboratory studies of un. dated but similar mineral deposits in similar rocks elsewhere in the Petersburg area suggest that several massive-sulfide deposits (fig. 50 and table 14 , locs. 2,3,4) and a deposit intermittently mined for barite (fig. 50 and table 14, loc. 5 ) also are Upper Triassic. These deposits occur within the Admiralty subterrane of the Alexander tec- 


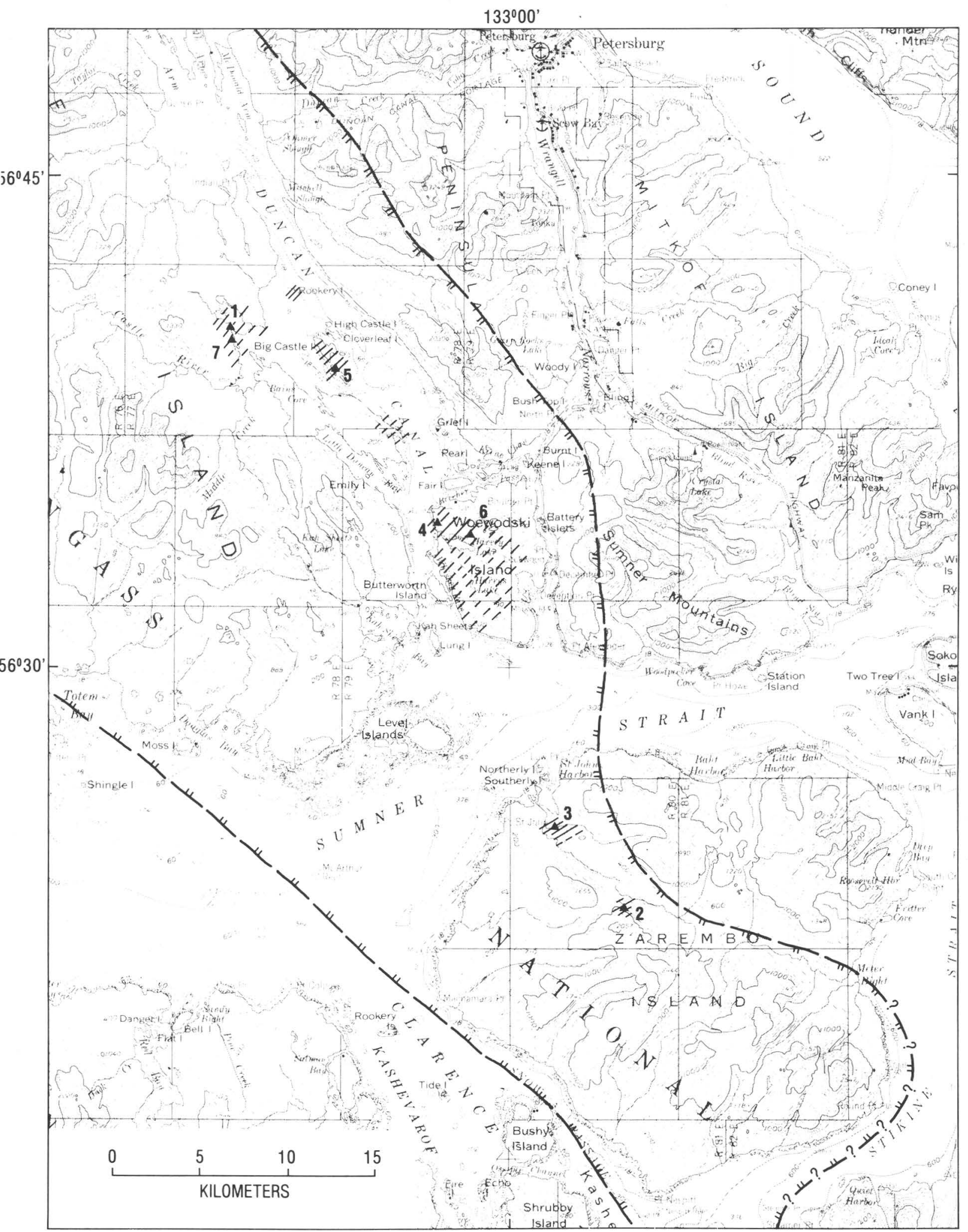

IGURE 50.-Index map showing locations of massive sulfide and related mineral occurrences described in this report (triangles). Line pattern indicates outcrop areas of known, inferred, or suspected (dashed) Upper Triassic strata. Hachured lines indicate approximate boundary of Admiralty subterrane (Berg and others, 1978; Berg, 1979). 


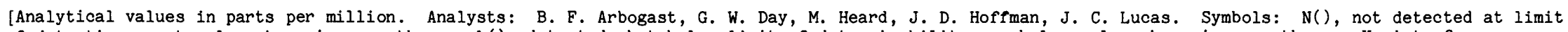

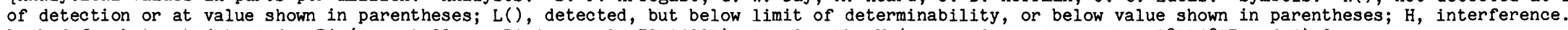
Looked for but not detected: $\mathrm{Bi}$ (except $20 \mathrm{ppm} \mathrm{Bi}$ in sample 79DG102D), Sb, Sn, Th, W (except $2 \mathrm{ppm}$ in samples 78DB185B and E).]

\begin{tabular}{|c|c|c|c|c|c|c|c|c|c|c|c|c|c|c|c|c|c|c|c|c|c|c|c|c|c|}
\hline \multirow{2}{*}{$\begin{array}{l}\text { Locality } \\
\text { number } \\
\text { on } \mathrm{fig} .50\end{array}$} & \multirow{2}{*}{$\begin{array}{c}\text { U.S.G.S. } \\
\text { sample } \\
\text { number }\end{array}$} & \multicolumn{4}{|c|}{ Atomic absorption analyses } & \multicolumn{20}{|c|}{ Semiquantitative spectrographic analyses } \\
\hline & & $\mathrm{Au}$ & $\mathrm{Cu}$ & $\mathrm{Pb}$ & $2 n$ & $\mathrm{Ag}$ & As & B & $\mathrm{Ba}$ & $\mathrm{Be}$ & $\mathrm{Cd}$ & Co & $\mathrm{Cr}$ & $\mathrm{Cu}$ & La & Mo & $\mathrm{Nb}$ & $\mathrm{Ni}$ & $\mathrm{Pb}$ & Sc & $\mathrm{Sr}$ & $\mathrm{v}$ & $\mathrm{Y}$ & $\mathrm{Zn}$ & $\mathrm{Zr}$ \\
\hline 1 & $\begin{array}{r}79 \mathrm{BG} 069 \mathrm{C} \\
79 \mathrm{DG} 135 \mathrm{~A} \\
135 \mathrm{~B}\end{array}$ & $\mathrm{~N}(0.05)$ & $\begin{array}{r}35 \\
100 \\
40\end{array}$ & $\begin{array}{r}25 \\
13000 \\
4200\end{array}$ & $\begin{array}{r}\mathrm{L}(5) \\
120000 \\
20000\end{array}$ & $\begin{array}{r}3 \\
100 \\
15\end{array}$ & $\begin{array}{c}\mathrm{N} \\
1000 \\
1000\end{array}$ & $\begin{array}{l}30 \\
10 \\
10\end{array}$ & $\begin{array}{l}500 \\
150 \\
150\end{array}$ & $\mathrm{~N}$ & $\begin{array}{l}N \\
500 \\
150\end{array}$ & $\begin{array}{l}5 \\
\mathrm{~N} \\
\mathrm{~N}\end{array}$ & $\begin{array}{l}\mathrm{N} \\
\mathrm{N} \\
10\end{array}$ & $\begin{array}{r}50 \\
100 \\
50\end{array}$ & $\mathrm{~N}$ & $\mathrm{~N}$ & $\mathrm{~N}$ & $\begin{array}{l}15 \\
10 \\
10\end{array}$ & $\begin{array}{r}15 \\
5000 \\
1000\end{array}$ & $\begin{array}{l}5 \\
\mathrm{~N} \\
\mathrm{~N}\end{array}$ & $\mathrm{~N}$ & $\begin{array}{l}70 \\
30 \\
30\end{array}$ & $\begin{array}{l}10 \\
\mathrm{~N} \\
\mathrm{~N}\end{array}$ & $\begin{array}{c}\mathrm{N} \\
>10000 \\
>10000\end{array}$ & $\begin{array}{l}70 \\
\mathrm{~N} \\
\mathrm{~N}\end{array}$ \\
\hline 2 & $\begin{array}{r}78 \mathrm{DB} 185 \mathrm{~A} \\
185 \mathrm{~B} \\
185 \mathrm{C} \\
185 \mathrm{D} \\
185 \mathrm{E} \\
185 \mathrm{~F} \\
185 \mathrm{G} \\
185 \mathrm{H} \\
79 \mathrm{DG} 072 \mathrm{~A} \\
072 \mathrm{~B} \\
072 \mathrm{C} \\
072 \mathrm{D} \\
072 \mathrm{E} \\
072 \mathrm{~F}\end{array}$ & 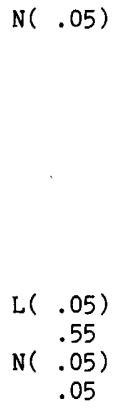 & $\begin{array}{r}35 \\
30 \\
20 \\
15 \\
20 \\
20 \\
850 \\
25 \\
10 \\
30 \\
3000 \\
3900 \\
1400 \\
1000\end{array}$ & $\begin{array}{r}15 \\
25 \\
15 \\
15 \\
25 \\
35 \\
620 \\
25 \\
35 \\
35 \\
2500 \\
1700 \\
1400 \\
910\end{array}$ & $\begin{array}{r}40 \\
120 \\
90 \\
170 \\
130 \\
770 \\
720 \\
380 \\
190 \\
300 \\
44000 \\
38000 \\
88000 \\
16000\end{array}$ & $\begin{array}{r}15 \\
\mathrm{~N} \\
\mathrm{~N} \\
\mathrm{~N} \\
30 \\
30 \\
5 \\
5\end{array}$ & $\mathrm{~N}$ & $\begin{array}{l}\mathrm{L} \\
\mathrm{L} \\
\mathrm{L} \\
\mathrm{N} \\
10 \\
\mathrm{~L} \\
20 \\
\mathrm{~L} \\
\mathrm{~L}\end{array}$ & $\begin{array}{r}500 \\
200 \\
300 \\
300 \\
300 \\
2000 \\
1000 \\
150 \\
70 \\
100 \\
>5000 \\
>5000 \\
5000 \\
>5000\end{array}$ & $\begin{array}{l}2 \\
\mathrm{~N} \\
\mathrm{~N} \\
2 \\
\mathrm{~N} \\
2 \\
1 \\
7 \\
3 \\
5 \\
2 \\
1 \\
1 \\
1\end{array}$ & $\begin{array}{c}70 \\
\mathrm{~N} \\
\mathrm{~N} \\
\mathrm{~N} \\
200 \\
100 \\
500 \\
70\end{array}$ & $\begin{array}{r}5 \\
50 \\
30 \\
N \\
50 \\
N \\
50 \\
N \\
L \\
L \\
20 \\
15 \\
30 \\
15\end{array}$ & $\begin{array}{c}20 \\
100 \\
100 \\
\mathrm{~N} \\
100 \\
\mathrm{~L} \\
\mathrm{~N}\end{array}$ & $\begin{array}{r}20 \\
100 \\
70 \\
10 \\
70 \\
20 \\
700 \\
20 \\
7 \\
15 \\
3000 \\
3000 \\
1500 \\
1500\end{array}$ & $\begin{array}{c}20 \\
\mathrm{~N} \\
\mathrm{~N} \\
100 \\
\mathrm{~N} \\
20 \\
\mathrm{~N} \\
\mathrm{~N} \\
70 \\
70 \\
\mathrm{~N}\end{array}$ & $\begin{array}{r}50 \\
7 \\
5 \\
20 \\
70 \\
50 \\
15 \\
15\end{array}$ & $\begin{array}{r}\mathrm{L} \\
\mathrm{N} \\
\mathrm{N} \\
20 \\
\mathrm{~N} \\
\mathrm{~N} \\
\mathrm{~N} \\
50 \\
50 \\
70 \\
\mathrm{~N}\end{array}$ & $\begin{array}{l}\mathrm{N} \\
30 \\
20 \\
5 \\
20 \\
5 \\
20 \\
10 \\
\mathrm{~L} \\
\mathrm{~L} \\
15 \\
20 \\
10 \\
10\end{array}$ & $\begin{array}{l}20 \\
20 \\
\mathrm{~N} \\
20 \\
20 \\
70 \\
200 \\
20 \\
20 \\
15 \\
3000 \\
3000 \\
1500 \\
1500\end{array}$ & $\begin{array}{r}5 \\
30 \\
30 \\
\mathrm{~N} \\
30 \\
\mathrm{~N}\end{array}$ & $\begin{array}{c}150 \\
200 \\
300 \\
N \\
300 \\
200 \\
N\end{array}$ & $\begin{array}{r}50 \\
200 \\
200 \\
10 \\
200 \\
20 \\
30 \\
10 \\
10 \\
10 \\
30 \\
30 \\
30 \\
20\end{array}$ & $\begin{array}{c}50 \\
30 \\
30 \\
70 \\
30 \\
100 \\
\mathrm{~N} \\
100 \\
100 \\
100 \\
30 \\
30 \\
20 \\
\mathrm{~N}\end{array}$ & $\begin{array}{r}1000 \\
>10000 \\
500 \\
N \\
N \\
>10000 \\
>10000 \\
>10000 \\
10000\end{array}$ & $\begin{array}{c}100 \\
100 \\
100 \\
200 \\
100 \\
200 \\
N \\
300 \\
500 \\
500 \\
20 \\
70 \\
N \\
N\end{array}$ \\
\hline 3 & $\begin{array}{r}79 B G 028 \mathrm{~A} \\
028 \mathrm{C} \\
028 \mathrm{D} \\
028 \mathrm{E} \\
79 \mathrm{DG} 102 \mathrm{~A} \\
102 \mathrm{~B} \\
102 \mathrm{C} \\
102 \mathrm{D} \\
102 \mathrm{E}\end{array}$ & $\begin{array}{c}.20 \\
.45 \\
.40 \\
5.5 \\
.55\end{array}$ & $\begin{array}{r}15 \\
15 \\
5 \\
25 \\
10000 \\
890 \\
1700 \\
20000 \\
1900\end{array}$ & $\begin{array}{r}\text { H30 } \\
5 \\
15 \\
10 \\
180 \\
7600 \\
4100 \\
190 \\
10000\end{array}$ & $\begin{array}{r}95 \\
25 \\
820 \\
80 \\
4300 \\
64000 \\
55000 \\
15000 \\
46000\end{array}$ & $\begin{array}{r}.5 \\
.5 \\
N \\
N \\
20 \\
7 \\
10 \\
10 \\
7\end{array}$ & $\begin{array}{cc}5 & \mathrm{~N} \\
5 & 200 \\
200 \\
\mathrm{~L} \\
\mathrm{~N} \\
\mathrm{~N} \\
\mathrm{~L} \\
1000 \\
\mathrm{~N}\end{array}$ & $\begin{array}{l}\mathrm{L} \\
\mathrm{L} \\
\mathrm{L} \\
20 \\
\mathrm{~L}\end{array}$ & $\begin{array}{r}300 \\
5000 \\
2000 \\
5000 \\
>5000 \\
>5000 \\
>5000 \\
>5000 \\
>5000\end{array}$ & $\begin{array}{l}\mathrm{N} \\
1 \\
\mathrm{~N} \\
1 \\
1 \\
\mathrm{~N}\end{array}$ & $\begin{array}{r}200 \\
200 \\
50 \\
150\end{array}$ & $\begin{array}{r}\mathrm{N} \\
5 \\
5 \\
60 \\
15 \\
\mathrm{~N} \\
\mathrm{~N} \\
5 \\
\mathrm{~N}\end{array}$ & $\begin{array}{c}70 \\
\mathbf{N} \\
\mathbf{N} \\
100 \\
\mathbf{N}\end{array}$ & $\begin{array}{r}15 \\
30 \\
5 \\
70 \\
10000 \\
700 \\
2000 \\
15000 \\
1500\end{array}$ & $\begin{array}{l}20 \\
\mathrm{~N} \\
20 \\
\mathrm{~N} \\
\mathrm{~N}\end{array}$ & $\begin{array}{l}50 \\
15 \\
30 \\
30 \\
15\end{array}$ & $\mathrm{~N}$ & $\begin{array}{r}20 \\
10 \\
5 \\
20 \\
10 \\
5 \\
5 \\
5 \\
5\end{array}$ & $\begin{array}{r}10 \\
20 \\
30 \\
20 \\
500 \\
3000 \\
3000 \\
200 \\
3000\end{array}$ & $\begin{array}{r}\mathrm{L} \\
\mathrm{N} \\
\mathrm{N} \\
20 \\
\mathrm{~N}\end{array}$ & $\begin{array}{c}1000 \\
N \\
N \\
1000 \\
1000 \\
2000 \\
5000 \\
300 \\
2000\end{array}$ & $\begin{array}{r}100 \\
20 \\
20 \\
300 \\
20 \\
10 \\
20 \\
10 \\
10\end{array}$ & $\begin{array}{l}10 \\
50 \\
50 \\
30 \\
30 \\
\mathrm{~N} \\
20 \\
30 \\
\mathrm{~L}\end{array}$ & $\begin{array}{c}\mathrm{N} \\
\mathrm{N} \\
300 \\
\mathrm{~L} \\
5000 \\
>1000 \\
>10000 \\
10000 \\
>10000\end{array}$ & $\begin{array}{r}20 \\
200 \\
100 \\
300 \\
\mathrm{~N}\end{array}$ \\
\hline 4 & $\begin{array}{r}79 \mathrm{DG} 129 \mathrm{~A} \\
130 \mathrm{~A} \\
131 \mathrm{~A} \\
132 \mathrm{~A}\end{array}$ & 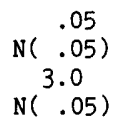 & $\begin{array}{r}230 \\
25 \\
70 \\
45\end{array}$ & $\begin{array}{r}10 \\
H 750 \\
190 \\
10000\end{array}$ & $\begin{array}{r}60 \\
2100 \\
130 \\
38000\end{array}$ & ${ }_{30}^{.5}$ & $\begin{array}{c}\mathrm{N} \\
\mathrm{N} \\
700 \\
\mathrm{~N}\end{array}$ & $\mathrm{~N}$ & $\begin{array}{r}500 \\
200 \\
70 \\
70\end{array}$ & $\mathrm{~N}$ & 200 & $\begin{array}{r}15 \\
\mathrm{~N}\end{array}$ & $\begin{array}{l}70 \\
\mathrm{~N}\end{array}$ & $\begin{array}{r}100 \\
15 \\
50 \\
50\end{array}$ & $\mathrm{~N}$ & $\mathrm{~N}$ & $\mathbf{N}$ & $\begin{array}{r}20 \\
5 \\
5 \\
5\end{array}$ & $\begin{array}{c}\mathrm{N} \\
300 \\
30 \\
2000\end{array}$ & $\begin{array}{r}10 \\
\mathrm{~N}\end{array}$ & $\begin{array}{c}\mathrm{N} \\
100 \\
\mathrm{~N} \\
\mathrm{~N}\end{array}$ & $\begin{array}{l}150 \\
10 \\
20 \\
\mathrm{~L}\end{array}$ & $\begin{array}{l}10 \\
10 \\
\mathbf{N} \\
\mathbf{N}\end{array}$ & $\begin{array}{c}\mathrm{N} \\
500 \\
\mathrm{~N} \\
>10000\end{array}$ & $\begin{array}{l}50 \\
\mathrm{~N}\end{array}$ \\
\hline 5 & $\begin{array}{r}79 \mathrm{BG} 065 \mathrm{~A} \\
79 \mathrm{SH} 134 \mathrm{~A} \\
134 \mathrm{~B}\end{array}$ & $\mathrm{~N}(.05)$ & $\begin{array}{r}30 \\
85 \\
200\end{array}$ & $\begin{array}{r}\text { H25 } \\
\text { H1300 } \\
20\end{array}$ & $\begin{array}{r}35 \\
25000 \\
170\end{array}$ & $\mathrm{~N}$ & $\mathrm{~N}$ & $\begin{array}{l}10 \\
L \\
10\end{array}$ & $\begin{array}{r}1000 \\
>5000 \\
1000\end{array}$ & $\mathrm{~N}$ & $\begin{array}{c}\mathrm{N} \\
200 \\
\mathrm{~N}\end{array}$ & $\begin{array}{l}20 \\
30 \\
50\end{array}$ & $\begin{array}{r}100 \\
30 \\
200\end{array}$ & $\begin{array}{r}20 \\
150 \\
200\end{array}$ & $\mathrm{~N}$ & $\mathrm{~N}$ & $\mathrm{~N}$ & $\begin{array}{r}20 \\
30 \\
100\end{array}$ & $\begin{array}{c}L \\
1500 \\
20\end{array}$ & $\begin{array}{r}20 \\
5 \\
20\end{array}$ & $\begin{array}{l}500 \\
700 \\
200\end{array}$ & $\begin{array}{l}150 \\
100 \\
500\end{array}$ & $\begin{array}{l}30 \\
15 \\
30\end{array}$ & $\begin{array}{c}\mathrm{N} \\
10000 \\
\mathrm{~N}\end{array}$ & $\begin{array}{l}70 \\
10 \\
70\end{array}$ \\
\hline
\end{tabular}




\begin{tabular}{|c|c|c|}
\hline \multirow{2}{*}{$\begin{array}{l}\text { U.S.G.S. } \\
\text { sample } \\
\text { number }\end{array}$} & \multicolumn{2}{|l|}{ Description } \\
\hline & Sample & Locality \\
\hline $\begin{array}{r}\text { 79BG069C } \\
\text { 79DG 135A } \\
135 \mathrm{~B}\end{array}$ & $\begin{array}{l}\text { Felsic metatuff (phyllitic grit). } \\
\text { Massive pyrite, sphalerite, galena. } \\
\text { Massive pyrite, sphalerite, galena. }\end{array}$ & $\begin{array}{l}\text { Lenses as much as } 1 \mathrm{~m} \text { long of massive pyrite, sphaler- } \\
\text { ite, and galena in phyllitic felsic metatuff } \\
\text { intercalated with pyritic carbonaceous phyllite, } \\
\text { phyllitic siltstone, and limestone. Limestone locally } \\
\text { contains sparse Upper Triassic fossils. Exposed } \\
\text { width of massive-sulfide-bearing zone (in creek bed) } \\
\text { is } 30-40 \mathrm{~m} \text {. } \\
\text { Lat } 56^{\circ} 40^{\prime} \cdot 18^{\prime \prime} \mathrm{N} \text {; Long } 133^{\circ} 15^{\prime} 27^{\prime \prime} \mathrm{W} \text {. }\end{array}$ \\
\hline $\begin{array}{r}78 \mathrm{DB} 185 \mathrm{~A} \\
185 \mathrm{~B} \\
185 \mathrm{C} \\
185 \mathrm{D} \\
185 \mathrm{E} \\
185 \mathrm{~F} \\
185 \mathrm{G} \\
185 \mathrm{H} \\
79 \mathrm{DG} 072 \mathrm{~A} \\
072 \mathrm{~B} \\
072 \mathrm{C} \\
072 \mathrm{D} \\
072 \mathrm{E} \\
072 \mathrm{~F}\end{array}$ & $\begin{array}{l}\text { Banded porphyritic felsic metatuff(?). } \\
\text { Diabase dike with pyrite. } \\
\text { Diorite(?) dike with pyrrhotite. } \\
\text { Porphyritic rhyodacite dike? } \\
\text { Basalt dike. } \\
\text { Felsic metatuff(?). } \\
\text { Felsic metatuff(?) with pyrrhotite. } \\
\text { Felsic metatuff(?) with pyrite. } \\
\text { Felsic metatuff with disseminated pyrite. } \\
\text { Felsic metatuff with disseminated pyrite. } \\
\text { Felsic metatuff with massive sulfides. } \\
\text { Felsic metatuff with massive sulfides. } \\
\text { Float sample of banded felsic metatuff with massive sphalerite. } \\
\text { Float sample of banded felsic metatuff with massive sphalerite. }\end{array}$ & $\begin{array}{l}\text { North wall of rock quarry along logging road exposes } \\
\text { approx. 10-m-thick zone of banded greenish-gray } \\
\text { felsic metatuff containing layers as much as } 1.5 \mathrm{~m} \\
\text { thick of massive pyrite, pyrrhotite(?), sphalerite, } \\
\text { chalcopyrite, and galena. Occurrence forms approx. } \\
10 \times 30 \mathrm{~m} \text { wedge-shaped, locally fault-bounded outcrop } \\
\text { enclosed by steeply dipping Tertiary basalt, diabase, } \\
\text { and rhyolite dikes. } \\
\text { Lat } 56^{\circ} 22^{\prime} 56^{\prime \prime N} \text {; Long } 132^{\circ} 53^{\prime} 53^{\prime \prime} \mathrm{W} \text {. }\end{array}$ \\
\hline $\begin{array}{r}79 B G 028 \mathrm{~A} \\
028 \mathrm{C} \\
028 \mathrm{D} \\
028 \mathrm{E} \\
79 \mathrm{DG} 102 \mathrm{~A} \\
102 \mathrm{~B} \\
102 \mathrm{C} \\
102 \mathrm{D} \\
102 \mathrm{E}\end{array}$ & $\begin{array}{l}\text { Carbonaceous limestone with pyrite. } \\
\text { Felsic metatuff with disseminated pyrite. } \\
\text { Banded "rhyolite" with disseminated sulfide. } \\
\text { "Andesite" dike with disseminated pyrite. } \\
\text { Pyrite-rich massive sulfide. } \\
\text { Sulfide-rich banded felsic metatuff. } \\
\text { Pyrite-rich layer in felsic metatuff. } \\
\text { Banded felsic metatuff with layers of pyrite, sphalerite, galena. } \\
\text { Banded massive pyrite and chalcopyrite. }\end{array}$ & $\begin{array}{l}\text { Adit at old prospect (Buddington, 1923, p. 69): layers } \\
\text { and lenses as much as } 2 \text { m thick of massive pyrite, } \\
\text { pyrrhotite(?), sphalerite, chalcopyrite, and galena } \\
\text { in felsic metavolcanic rocks interbedded with recrys- } \\
\text { tallized carbonaceous limestone and calcareous } \\
\text { sedimentary rocks. Intruded by Tertiary(?) andesite } \\
\text { dikes. } \\
\text { Lat } 56^{\circ} 25^{\prime} 08^{\prime \prime} \mathrm{N} \text {; Long } 132^{\circ} 57^{\circ} 07^{\prime \prime} \mathrm{W} \text {. }\end{array}$ \\
\hline $\begin{array}{r}79 D G 129 \mathrm{~A} \\
130 \mathrm{~A} \\
131 \mathrm{~A} \\
132 \mathrm{~A}\end{array}$ & $\begin{array}{l}\text { Schistose rhyodacite. } \\
1.5-m \text {-thick quartz-calcite vein in greenstone. } \\
1.0-m-\text { thick quartz vein at old mine shaft. } \\
\text { Massive pyrite, sphalerite, galena from dump at pit. }\end{array}$ & $\begin{array}{l}\text { "Helen S." group of old lode gold prospects (Buddington, } \\
\text { 1923, p. 67). Occurrence of massive sulfides consists } \\
\text { of crudely banded (10-cm-thick) massive pyrite, pyrrho- } \\
\text { tite(?), arsenopyrite(?), sphalerite, and galena that } \\
\text { has been dug from a small water-filled pit about } 30 \mathrm{~m} \\
\text { inland at elevation about } 15 \mathrm{~m} \text {. Country rocks near pit } \\
\text { 1nclude hematite-bearing phyllitic felsic metatuff, car- } \\
\text { bonaceous phyllite and limestone, and mafic intrusive(?) } \\
\text { rocks. Current owners report boulders of massive sul- } \\
\text { fides in creeks near pit, and possibly at the Maid of } \\
\text { Mexico mine (Buddington, 1923, p. } 67 \text { ) near Harvey Lake } \\
\text { about } 2 \mathrm{~km} \text { east-southeast of locality } 4 \text {. } \\
\text { Lat } 56^{\circ} 34^{\prime} 111 \mathrm{~N} \text {; Long } 133^{\circ} 04^{\circ} 03^{\prime \prime} \mathrm{W} \text {. }\end{array}$ \\
\hline $\begin{array}{r}79 \mathrm{BG} 065 \mathrm{~A} \\
79 \mathrm{SH} 134 \mathrm{~A} \\
134 \mathrm{~B}\end{array}$ & $\begin{array}{l}\text { Calcareous phyllitic metatuff(?). } \\
\text { Silicic metatuff (?). } \\
\text { Recrystallized andesite pillow breccia. }\end{array}$ & $\begin{array}{l}\text { Locality is site of intermittently active barite mine } \\
\text { (Buddington, 1923, p. } 72 \text { ). Country rocks include } \\
\text { phyllitic felsic metatuff with pyrite and minor sphal- } \\
\text { erite and galena, andesitic pillow flows and breccia, } \\
\text { chert(?), and phyllitic calcareous (volcani?) clastic } \\
\text { rocks locally containing poorly preserved fossil clams } \\
\text { possibly of Late Triassic age. } \\
\text { Lat } 56^{\circ} 38^{\prime} 56^{\prime \prime N} \text {; Long } 133^{\circ} 09^{\prime} 45^{\prime \prime} \text {. }\end{array}$ \\
\hline
\end{tabular}


tonostratigraphic terrane (Berg and others, 1978; Berg, 1979), which is an assemblage of biostratigraphically coherent rocks that originated far from its present location and subsequently was accreted by various processes to the North American continent.

The Petersburg area mineral deposits and their host rocks are part of a $300-\mathrm{km}$-long belt of similar deposits and host rocks stretching the length of southeastern Alaska from Juneau to Ketchikan (where the deposits occur in the Annette subterrane of the Alexander terrane). The belt herein is interpreted as a regional metallogenic province comprising syngenetic stratabound volcanogenic massive $\mathrm{Zn}-\mathrm{Pb}-\mathrm{Ag}(-\mathrm{Cu}-\mathrm{Au})$ sulfide and related barite deposits in metamorphosed Upper Triassic strata. This newly recognized province appears to be restricted to the Admiralty and Annette subterranes, and is the first metallogenic province in southeastern Alaska to be recognized by integrating mineral deposit data with the concept of accreted terranes. The discovery has important implications for regional mineral exploration and resource appraisal in southeastern Alaska, a geologically complex region about half the size of the state of California.

\section{REFERENCES CITED}

Berg, H. C., 1979, Significance of geotectonics in the metallogenesis and resource appraisal of southeastern Alaska; a progress report, in Johnson, K. M., and Williams, J. R., eds., The United States Geological Survey in Alaska: Accomplishments during 1978: U.S. Geological Survey Circular 804-B p. B116-B118.

Berg, H. C., and Grybeck, Donald, 1980, Upper Triassic volcanogenic $\mathrm{Zn}-\mathrm{Pb}-\mathrm{Ag}(-\mathrm{Cu}-\mathrm{Au})$-barite mineral deposits near Petersburg, Alaska: U.S. Geological Survey OpenFile Report 80-527, 9 p.

Berg, H. C., Jones, D. L., and Coney, P. J., 1978, Map showing pre-Cenozoic tectonostratigraphic terranes of southeastern Alaska and adjacent areas: U.S. Geological Survey Open-File Report 78-1985, 2 sheets, scale 1:1,000,000.

Buddington, A. F., 1923, Mineral deposits of the Wrangell district: U.S. Geological Survey Bulletin 739, p. $51-75$.

Newly recognized alkali granite stock, southwestern Kupreanof Island, Alaska

By David A. Brew, Ronald A. Sonnevil, Susan J. Hunt, and A. B. Ford

During the 1979 field season, a hitherto unrecognized alkali granite stock was found within the Kuiu-Etolin volcanic-plutonic belt (Brew and others, 1979) on southwestern Kupreanof Island. Its recognition adds to our understanding of the origin of the belt. Sparse evidence suggests that the stock may have mineral resource significance.

The stock underlies about $39 \mathrm{~km}^{2}$ of brushy terrain southwest of Castle River (fig. 51). It is poorly exposed and intrudes rocks mapped as rhyolite, rhyodacite, andesite, and basalt of early to middle Tertiary age (Buddington and Chapin, 1929; Muffler, 1967). These volcanic rocks appear to be much more complex than are the andesite and basalt flows to the west along Keku Strait. The stock appears to be zoned with a biotite alkali granite core and a border of granodiorite, granite, diorite or gabbro, and agmatite. Preliminary study of available samples indicates that the stock is mostly a fine-grained highly altered miarolitic alkali granite. Both biotite and hornblende were indentified in the field, but biotite is probably more common. The biotite is altered to clay minerals; the plagioclase is heavily clouded. Magnetite is present in some specimens. The pluton and the adjacent country rock are extensively epidotized, so the alteration affected both simultaneously.

The age of the stock is not known directly, but comparison with a K-Ar-dated pluton of similar composition on Etolin Island suggests that it may be $20-30 \mathrm{~m} . \mathrm{y}$. old. The stock is locally cut by rhyolite and basalt dikes similar to the rocks it intrudes, and these relations indicate that the volcanism and intrusion are closely linked.

No metallic mineral deposits are known to be associated with this stock, but alkali granite bodies to the east and southeast on Zarembo and Etolin Islands have been studied for molybdenum and uranium-thorium resources (Brew and Morrell, 1980). Preliminary geochemical results from this stock and its vicinity show some unusually high eU values in both stream sediments and bedrock.

As shown in figure 51, this stock and the two others nearest it in the Kuiu-Etolin volcanicplutonic belt intrude complex volcanic flow or dike sill units interpreted to be about the same age as the intrusions. In contrast, the 20 - to 30 m.y.-old stocks to the east in the Coast plutonic complex intrude older granitic and metamorphic rocks (Brew and Morrell, 1980). We suggest that the alkali granite bodies occurring on central 
Kuiu Island, southwestern Kupreanof Island, and southeastern Zarembo Island, and perhaps those in central Etolin Island as well, may mark the main eruptive centers within the Kuiu-Etolin volcanic-plutonic belt.

\section{REFERENCES CITED}

Brew, D. A., Berg, H. C., Morrell, R. P., Sonnevil, R. A., Huie, Carl, and Hunt, S. J., 1979, The Tertiary Kuiu-Etolin volcanic-plutonic belt, southeastern Alaska, in Johnson, K. M., and Williams, J. R., eds., The United States Geological Survey in Alaska: Accomplishments during 1978: U.S. Geological Survey Circular 804-B, p. B129$\mathrm{B} 130$.

Brew, D. A., and Morrell, R. P., 1980, Intrusive rocks and plutonic belts of southeastern Alaska, U.S.A.: U.S. Geological Survey Open-File Report 80-78, 35 p.

Buddington, A. F., and Chapin, T., 1929, Geology and mineral deposits of southeastern Alaska: U.S. Geological Survey Bulletin 800,398 p.

Muffler, L. J. P., 1967, Stratigraphy of the Keku Islets and neighboring parts of Kuiu and Kupreanof Islands, southeastern Alaska: U.S. Geological Survey Bulletin 1241-C, $52 \mathrm{p}$.
Structural and stratigraphic significance of Upper Devonian and Mississippian fossils from the Cannery Formation, Kupreanof Island, southeastern Alaska

By D. L. Jones, H. C. Berg, Peter Coney, and Anita Harris

The name "Cannery Formation" was applied by Loney $(1964$, p. 26) to a sequence of "thinly interbedded chert, argillite, and graywacke typically exposed in and around the mouth of Cannery Cove on the southwest shore of Pybus Bay" [Admiralty Island]. These rocks underlie the Pybus Formation of Early Permian (Leonardian) age and appear to overlie the Gambier Bay Formation of Devonian age. Although no fossils were found in the type locality of the Cannery, a number of fossils found elsewhere suggested a Permian age for the formation.

Subsequent to Loney's formal designation of the Cannery Formation, this unit has been recognized widely elsewhere on Admiralty Island (Lathram and others, 1965) and to the south on Kupreanof Island (Muffler, 1967), a total extent of over 150

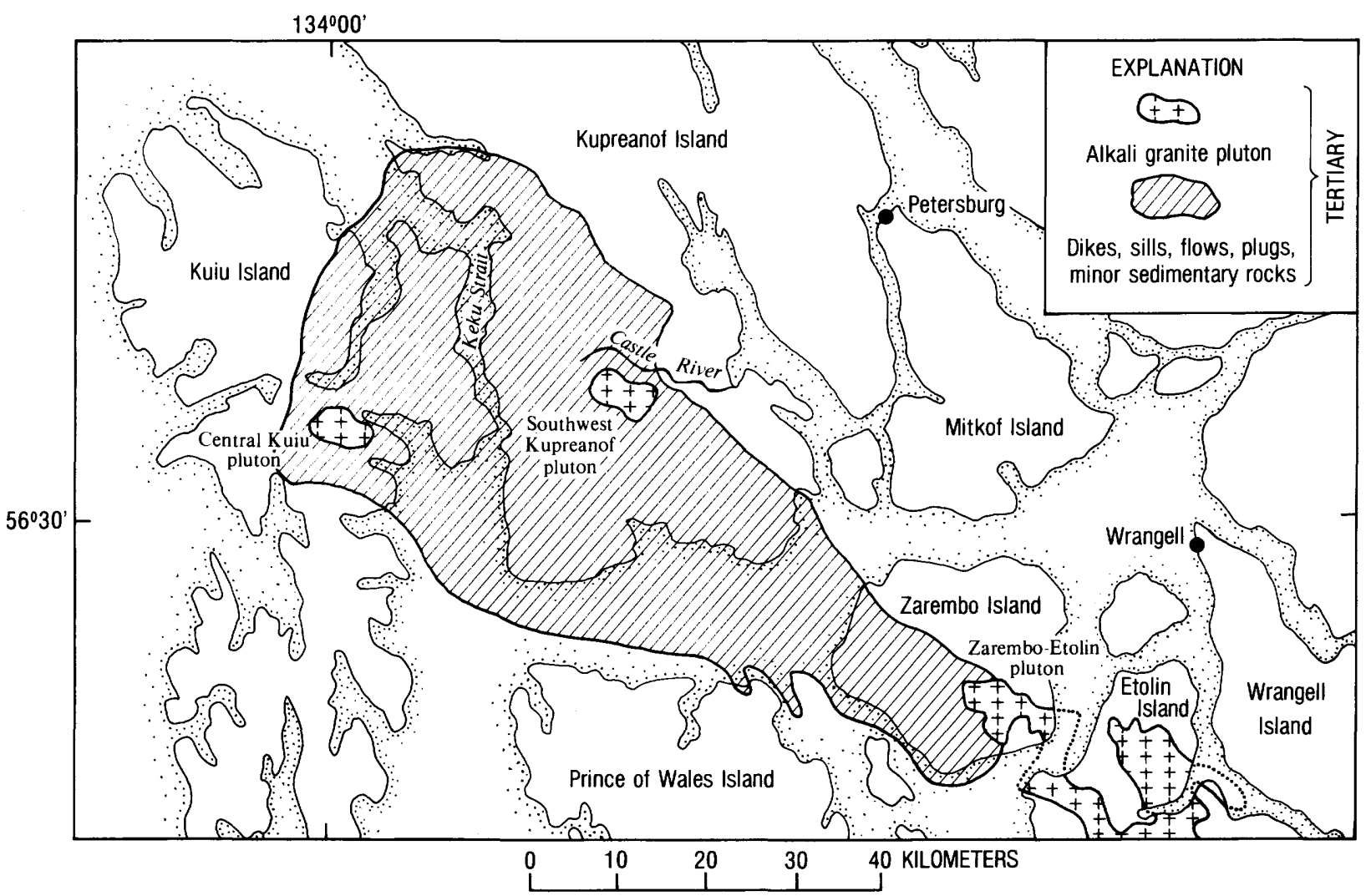

FIGURE 51.-Northwestern part of Kuiu-Etolin volcanic-plutonic belt showing alkali granite plutons. 
$\mathrm{km}$. The age of the Cannery has been considered to be Permian by recent workers, although a Middle(?) and Late Devonian age was assigned to the rocks in Keku Strait (Kupreanof Island) by Buddington and Chapin (1929, p. 106-107). This assignment was based on some poorly preserved specimens of bryozoans identified by Edwin Kirk.

Muffler recognized that the Permian age assigned to the Cannery Formation in the Keku Strait area posed a problem because presumed correlative strata beneath the Pybus Formation on the northeast (Cannery Formation) and southwest (Early Permian Halleck Formation) sides of the strait are lithologically dissimilar. According to Muffler (1967, p. C25), "the Cannery and the Halleck Formations are separated across Keku Strait by only $4 \frac{1}{2}$ miles of water, and beds of transitional lithology do not crop out, although they may be hidden under the waters of the strait. There are no strike-slip faults of large displacement in Keku Strait, nor is there any direct evidence of a major thrust fault that could have brought such strikingly dissimilar facies so close together."

The purpose of this report is to show that (1) at least part of the Cannery Formation is indeed of Devonian age as originally suggested by Kirk, (2) rocks of Mississippian age also occur in the Cannery, (3) detritus of Late Devonian and Mississippian age derived from the Cannery occurs as pebbles and cobbles in the easternmost exposures of the Halleck Formation, and (4) the stratigraphic sequence of the Halleck records collision and amalgamation in Permian time of two unlike tectonostratigraphic terranes as postulated by Berg, Jones, and Coney (1978).

Cherty rocks from several localities within the Cannery Formation were sampled and processed in hydrofluoric acid for microfossils. Only one locality (loc. 1, fig. 52 ) yielded identifiable forms. The unfossiliferous samples are green cherty tuff; the fossiliferous rock is gray, isoclinally folded chert. In addition, calcareous sandstone rich in volcanic debris, originally collected by Muffler in 1963 from a locality 1 mile east-northeast of Pt. Macartney (loc. 2, fig. 52), contains identifiable fossils. Conodonts from locality 1 are Late Devonian in age (table 15), and radiolarians from the same locality are similar to Late Devonian forms known elsewhere in Alaska (Brian Holdsworth, oral commun., 1978). Foraminifers from locality 2 are latest Mississippian (Chesterian) as deter- mined by A. K. Armstrong (written commun., 1979). A siliceous, bioclastic limestone north of Hamilton Bay, mapped as Cannery Formation, is reported to contain Early Permian fossils (Muffler, 1967, p. C24). This limestone is composed of abundant bryozoan and crinoidal debris but lacks foraminifers, algae (A. K. Armstrong, written commun., 1979) and volcanic detritus. The limestone may not belong to the Cannery but may instead be part of the Early Permian Pybus Formation, which crops out nearby.

The Halleck Formation as exposed in the Keku Islands (fig. 2) consists dominantly of conglomerate with clasts ranging in size from pebbles to cobbles. Clasts of cherty rocks are abundant, and bluish-green and gray varieties similar to those predominating in the Cannery Formation are conspicuous. Fossils recovered from chert clasts resembling the Cannery cherts consist of conodonts and radiolarians of Late Devonian and Mississippian age (locs. 3 and 4 , fig. 52 ; table 15 )essentially identical to the age of fossils collected from the unquestioned Cannery Formation.

As Muffler (1967) points out, the stratigraphic sequences below the Pybus Formation on the

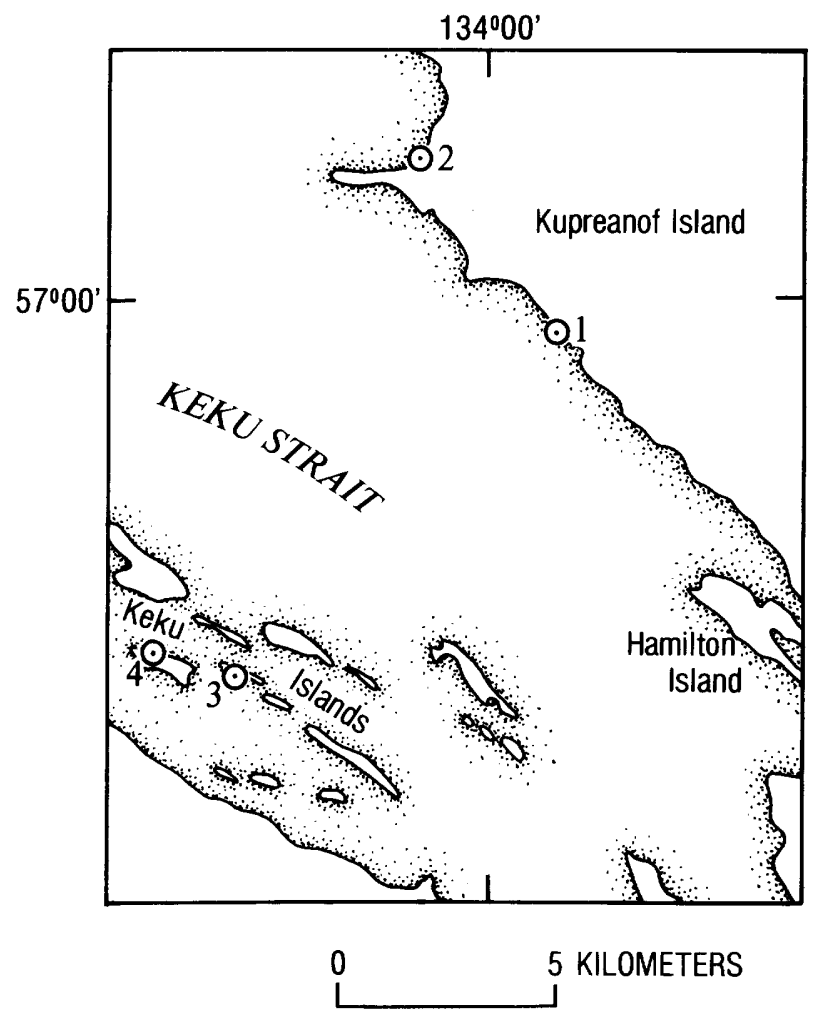

FIGURE 52.-Map of Keku Strait showing fossil localities. 
southwest side of Keku Strait differ markedly from those on the northeast side. The striking differences, however, lie not in the Permian rocks but in Upper Devonian and Carboniferous strata. These differences are shown schematically in figure 53. In brief, Upper Devonian and Carbon- iferous strata on the southwest side are composed mainly of shallow-water fossiliferous limestone and clastic rocks and subordinately of minor volcanic rocks. In contrast, strata of comparable age to the northeast are of deep-water origin and contain abundant volcanic detritus throughout. In

TABLE 15.-New fossil localities in the Keku Strait area, southeastern Alaska

[Conodont identifications by Anita Harris]

\begin{tabular}{|c|c|c|c|}
\hline Locality & $\begin{array}{l}\text { Field } \\
\text { number }\end{array}$ & Fossils & Age \\
\hline 1 & $\begin{array}{l}\text { 78 JSE-6 } \\
\text { (USGS colln. } \\
9905-\mathrm{SD} \text { ) }\end{array}$ & $\begin{array}{l}\text { Conodonts: } \\
\text { Palmatolepis cf. } P \text {. } \\
\text { gracilis Branson } \\
\text { and Mehl } \\
\text { Radiolarians: } \\
\text { Undescribed forms known } \\
\text { elsewhere in Upper } \\
\text { Devonian rocks (B. } \\
\text { Holdsworth, oral } \\
\text { commun., 1978) }\end{array}$ & $\begin{array}{l}\text { Late Devonian } \\
\text { (Famennian) }\end{array}$ \\
\hline 2 & $63 \mathrm{Amp}-278$ & $\begin{array}{l}\text { Foraminifers: } \\
\text { Tetrataxis ex gr. T. } \\
\text { conica (Ehrenberg) } \\
\text { Zellerina sp. indet. } \\
\text { Neoarchaediscus incertus } \\
\quad \text { (Grozdilova and Lebedeva) }\end{array}$ & $\begin{array}{l}\text { Late Mississippian } \\
\text { (Chesterian) }\end{array}$ \\
\hline 3 & $\begin{array}{l}\text { 78JSE-2 } \\
\text { (USGS colln. } \\
27301-P C \text { ) }\end{array}$ & $\begin{array}{l}\text { Conodonts: } \\
2 \text { platform elements of } \\
\text { Polygnathus communis } \\
\text { Branson and Mehl } \\
1 \text { platform element of } \\
\text { Siphonodella cf. S. } \\
\text { sulcata (Huddle) } \\
\text { Gnathodus sp. } \\
\text { Radiolarians: } \\
\text { Mixed Upper Devonian and } \\
\text { Mississippian (Albaillellid) } \\
\text { forms (B. Holdsworth, oral } \\
\text { commun., 1978) }\end{array}$ & $\begin{array}{c}\text { Early Mississippian } \\
\text { (lowest Kinder- } \\
\text { hookian) }\end{array}$ \\
\hline 4 & $\begin{array}{l}\text { 78JSE-1 } \\
\text { (USGS colln. } \\
\text { 9904-SD) }\end{array}$ & $\begin{array}{l}\text { Conodonts: } \\
\text { Palmatolepis glabra } \\
\text { Ulrich and Bassler } \\
\text { Radiolarians: } \\
\text { Late Devonian forms similar } \\
\quad \text { to those from loc. } 1\end{array}$ & $\begin{array}{l}\text { Late Devonian } \\
\text { (Famennian) }\end{array}$ \\
\hline
\end{tabular}


our opinion, these differences are too great to be merely the result of simple facies changes within the intervening few kilometers of water that separate these two sequences. Rather, we suggest that the two were originally more widely separated and were tectonically juxtaposed in Early Permian time. Evidence for this juxtaposition is seen in the sudden appearance of Cannery detritus in the Early Permian Halleck Formation. The two prePermian terranes of Berg, Jones, and Coney (1978) thereafter shared a common history, as evidenced by deposition of the succeeding Pybus Formation on both sides of the strait.

\section{REFERENCES CITED}

Berg, H. C., Jones, D. L., and Coney, P. J., 1978, Map showing pre-Cenozoic tectonostratigraphic terranes of southeastern Alaska and adjacent areas: U.S. Geological Survey Open-File Report 78-1085, scale 1:1,000,000, 2 sheets.

Buddington, A. F., and Chapin, Theodore, 1929, Geology and mineral deposits of southeastern Alaska: U.S. Geological Survey Bulletin 800, 398 p.

Lathram, E. H., Pomeroy, J. S., Berg, H. C., and Loney, R. A. 1965, Reconnaissance geology of Admiralty Island, Alaska: U.S. Geological Survey Bulletin 1181 -R, 48 p.

Loney, R. A., 1964, Stratigraphy and petrography of the Pybus-Gambier area, Admiralty Island, Alaska: U.S. Geological Survey Bulletin 1178, 103 p.

\section{Keku Strait}

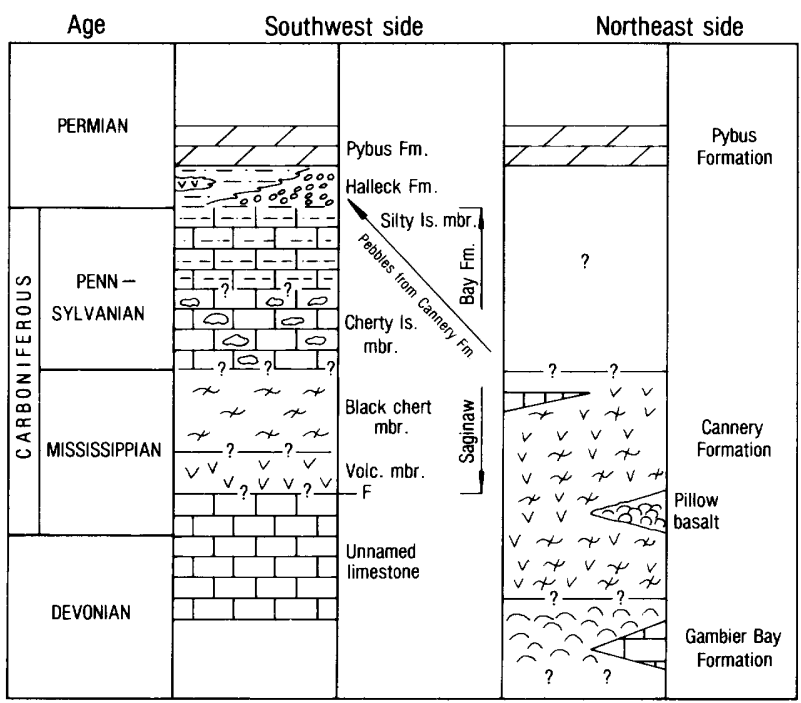

FIGURE 53.-Schematic columnar sections showing stratigraphic relations on northeast and southwest sides of Keku Strait, southeastern Alaska.
Muffler, L. J. P., 1967, Statigraphy of the Keku Islets and neighboring parts of Kuiu and Kupreanof Islands, southeastern Alaska: U.S. Geological Survey Bulletin 1241-C, $52 \mathrm{p}$.

The Chilkat-Prince of Wales plutonic province, southeastern Alaska

By Ronald A. Sonnevil

Petrographic studies of granitic rocks from the Chilkat Range, eastern Chichagof Island, Kuiu Island, and Prince of Wales Island, combined with reconnaissance field studies on Prince of Wales Island and southern Kuiu Island (fig. 54), have defined a petrologically similar suite of Jurassic or Cretaceous plutons herein referred to as the Chilkat-Prince of Wales plutonic province. This province may be offset by the Chatham Strait fault, as suggested by Ovenshine and Brew (1972). The amount of right-lateral offset may be between 100 and $180 \mathrm{~km}$.

Specific structural, compositional, and mineralogical features indicate that at least 18 individual plutons are part of this province. Plutons within the province, bodies 1 through 20 (fig. 54), occur as isolated, circular to elongate bodies that intrude calcareous graywacke, argillite, and limestone of Silurian to Mississippian age (Lathram and others, 1959; Loney and others, 1975; Muffler, 1967; Ovenshine and Brew, 1972). Intrusive contacts are discordant to regional structure, and narrow hornfels zones (a few tens of meters wide) are most commonly developed in the adjacent host rocks (Loney and others, 1967; Loney and others, 1975; A. T. Ovenshine, unpub. data). IUGS compositions (Geotimes, 1973) of the plutons are predominantly quartz monzodiorite and granodiorite, but quartz diorite, gabbro and granite are also present (fig. 55). Six of the plutons that have been studied in some detail (bodies 3 , $7,8,9,18$, and 20; fig. 54) are composite (Lathram and others, 1959; Loney and others, 1975). One of these bodies (body 7 ) contains a mappable dioritic border zone with local gabbro (Loney and others, 1975). All bodies are nonfoliated to weakly foliated. The foliation in bodies 18 and 20 is steeply dipping and conforms to the margins of the plutons. Where aeromagnetic data are available (Kuiu Island, northern Prince of Wales Island, and the Chilkat Range), plutons within the province display positive anomalies (Brew and others, 1978; U.S. Geological Survey, 1979).

Mineralogically, the plutons within the province are characterized by oscillatory zoned plagioclase, interstitial $\mathrm{K}$-feldspar (rarely microcline), and 


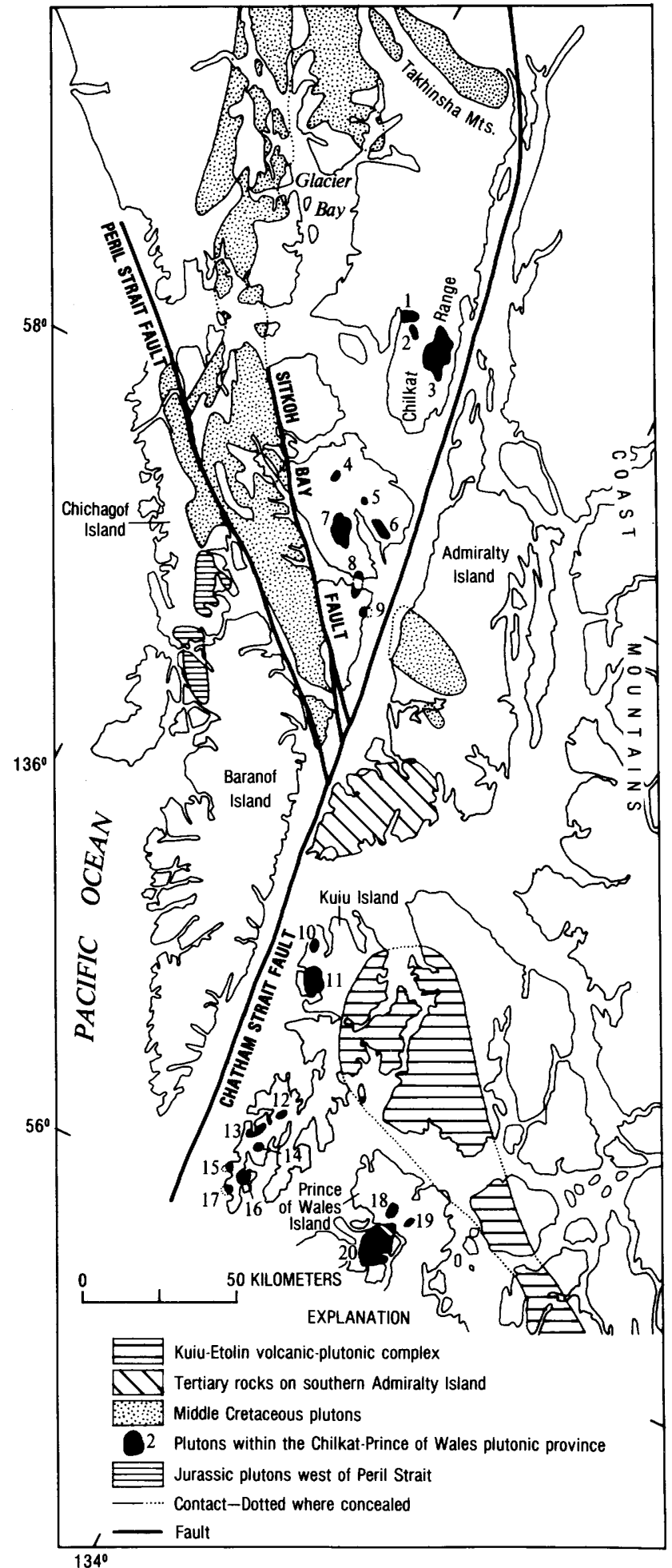

FIGURE 54.-Map showing bodies within the Chilkat-Prince of Wales plutonic province (numbered 1-22); middle Cretaceous plutons on Chichagof Island, Admiralty Island and near Glacier Bay; Jurassic plutons west of Peril Strait; the mid-Tertiary Kuiu-Etolin volcanic-plutonic belt; Tertiary rocks on southern Admiralty Island; and major faults discussed in text. hornblende as the dominant mafic mineral. Quartz is present most commonly as interstitial grains and locally as subhedral phenocrysts. Biotite is commonly absent, and pyroxene is locally present, commonly as cores in hornblende. Sphene is the most abundant accessory mineral, and apatite and zircon are subordinate. Grain sizes are fine to medium, and color indices are mostly between 8 and 15 .

The assignment of bodies 10 and 11 (fig. 54) on northern Kuiu Island to the plutonic province is tentative. Body 11 contains a mappable border zone of olivine-hypersthene gabbro (Muffler, 1967). Neither olivine nor hypersthene has been observed in any of the other plutons within the province. Hornblende gabbro has been mapped at the south end of body 10. Muffler (1967) also reports hornfels zones as much as $3 \mathrm{~km}$ wide surrounding plutons 10 and 11 . These zones contrast with the very narrow hornfels zones (a few tens of meters wide) around other plutons of similar size within the province. Thus, the bodies on northern Kuiu Island may have been emplaced at a different level or represent different magma types than other plutons within the plutonic province. The proximity of the northern Kuiu plutons to the Tertiary Kuiu-Etolin volcanic-plutonic complex (Brew and others, 1979) suggests an association (fig. 54). Muffler (1967) assigned a questionable Cretaceous age to the northern Kuiu plutons, but Loney and others (1975) assigned a questionable Tertiary age.

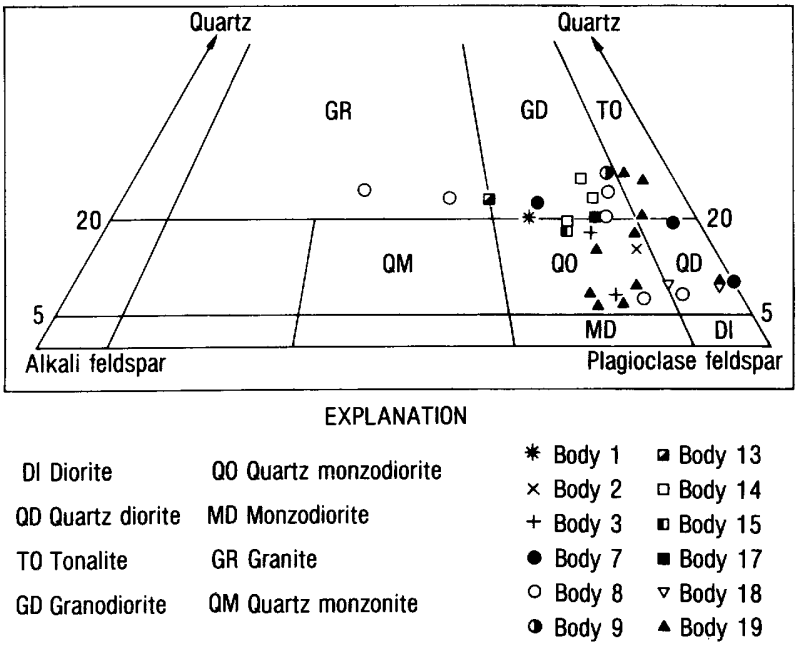

FIGURE 55.-Compostitional diagrams showing IUGS (Geotimes, 1973) modes of selected plutons from the Chilkat-Prince of Wales plutonic province. 
The extent of the Chilkat-Prince of Wales plutonic province is poorly known. To the north, in and beyond Glacier Bay National Monument, the province apparently merges with, or is cut off by, the middle Cretaceous batholithic complex of Chichagof Island and Glacier Bay (MacKevett and others, 1974; Loney and others, 1975; Brew and others, 1978). To the south, the province probably includes many plutons on Prince of Wales Island. To the east, on Revillagigedo Island, plutons dated as Jurassic and Cretaceous (Berg and others, 1978; Smith and others, 1979) are aeromagnetically, texturally, and mineralogically dissimilar to plutons within the Chilkat-Prince of Wales plutonic province (R. L. Elliott and R. D. Koch, oral commun., 1980). Plutons within the Petersburg quadrangle, between Clarence Strait and the Coast Mountains, are similar to those on Revillagigedo Island.(D. A. Brew, unpub. data). Thus, the province is interpreted as not extending east of Clarence Strait.

Radiometric age data for plutons within the Chilkat-Prince of Wales plutonic province are limited to three bodies. Loney, Brew, and Lanphere (1967) report lead-alpha dates (zircon) of $180 \pm 20 \mathrm{~m} . \mathrm{y}$. from body $3,180 \pm 20 \mathrm{~m} . \mathrm{y}$. and $160 \pm 20$ m.y. from body 7 , and $150 \pm 20$ m.y. and $120 \pm 20$ m.y. from body 6 . They also report K-Ar dates of $144 \pm 7$ m.y. (hornblende) from body 7 and $103 \pm 5$ m.y. (biotite) from body 6 . To summarize, a Jurassic age is implied for bodies 3 and 7 , but a middle Cretaceous age should be considered for body 6 . The one available sample from body 6 contains more biotite, quartz, and $\mathrm{K}$-feldspar and less hornblende and sphene than other bodies of the province; thus the relation of body 6 to the Chilkat-Prince of Wales plutonic complex is ambiguous. Until further isotopic data are available, the age of the province is concluded to be Jurassic and (or) Cretaceous.

If the Chilkat-Prince of Wales plutonic province is Jurassic, then it may correlate with the Tonsina-Chichagof belt of Hudson (1979) and the Chilkat-Chichagof belt of Brew and Morrell (1980). If the province is found to be middle Cretaceous, then it probably represents the eastern margin of the uplifted batholithic complex on Chichagof Island and in Glacier Bay National Monument, correlative with the NutzotinChichagof belt of Hudson (1979). Loney and others (1975) interpret bodies $4,5,6,8$, and 9 as middle Cretaceous, separated from the Early Cretaceous batholithic complex to the west by the Sitkoh Bay fault; body 7 , however, is interpreted as Jurassic.

Right-lateral offset of the Chilkat-Prince of Wales plutonic province by the Chatham Strait fault is suggested in figure 54 . To determine the amount of offset accurately, additional data are needed in order to define the age and chemical nature of the plutons and the trend of the province. Tertiary sedimentary and volcanic rocks on southern Admiralty Island (fig. 54) may cover additional plutons within the province, resulting in an apparent offset. If the province is displaced by the Chatham Strait fault, then a rough estimate of offset can be made by juxtaposing plutons on either side of the fault. The amount of offset estimated by this method is dependent upon the assignment of the northern Kuiu plutons (bodies 10 and 11) to the province. If these plutons are included, then the offset may be between $100 \mathrm{~km}$ and $130 \mathrm{~km}$. If the northern Kuiu plutons are excluded from the province, then the offset may be between $150 \mathrm{~km}$ and $180 \mathrm{~km}$. If the larger values are assumed, then palinspastic reconstruction juxtaposes middle Cretaceous plutons on Admiralty Island against plutons of similar age in the Takhinsha Mountains, northwest of Chilkat Inlet (MacKevett and others, 1974; Brew and Morrell, 1980). Ovenshine and Brew (1972) have demonstrated between $179 \mathrm{~km}$ and $205 \mathrm{~km}$ rightlateral offset of a Silurian facies change along the Chatham Strait fault. Thus most, if not all, lateral offset along the fault is probably post-Jurassic.

\section{REFERENCES CITED}

Berg, H. C., Elliott, R. L., Smith, J. G., and Koch, R. D., 1978, Geologic map of the Ketchikan and Prince Rupert quadrangles, Alaska: U.S. Geological Survey Open-File Report 78-73A, scale $1: 250,000$.

Brew, D. A., Berg, H. C., Morrell, R. P., Sonnevil, R. A., Hunt, S. J., and Huie, Carl, 1979, The Tertiary Kuiu-Etolin volcanic-plutonic belt, southeastern Alaska, in Johnson, K. M., and Williams, J. R., eds., The United States Geological Survey in Alaska: Accomplishments during 1978: U.S. Geological Survey Circular 804- B, p. B129B130.

Brew, D. A., Johnson, B. R., Grybeck, Donald, Griscom, Andrew, Barnes, D. F., Kimball, A. L., Still, J. C., and Rataj, J. L., 1978, Mineral resources of the Glacier Bay National Monument Wilderness Study Area, Alaska: U.S. Geologi- 
cal Survey Open-File Report 78-494.

Brew, D. A., and Morrell, R. P., 1980, Preliminary map of intrusive rocks in southeastern Alaska: U.S. Geological Survey Miscellaneous Field Studies Map MF-1048, scale 1:1,000,000.

Geotimes, 1973, Plutonic rocks-classification and nomenclature recommended by the IUGS Subcommission on the systematics of igneous rocks: Geotimes, v. 18, no. 10, p. 26-30.

Hudson, Travis, 1979, Calc-alkaline plutonism along the Pacific rim of southern Alaska: U.S. Geological Survey Open-File Report 79-953.

Lathram, E. H., Loney, R. A., Condon, W. H., and Berg, H. C. 1959, Progress map of the geology of the Juneau quadrangle, Alaska: U.S. Geological Survey Miscellaneous Geological Investigations Map I-303, scale 1:250,000.

Loney, R. A., Brew, D. A., and Lanphere, M. A., 1967, PostPaleozoic radiometric ages and their relevance to fault movements, northern southeastern Alaska: Geological Society of America Bulletin, v. 78, p. 511-526.

Loney, R. A., Brew, D. A., Muffler, L. J. P., and Pomeroy, J. S., 1975, Reconnaissance geology of Chichagof, Baranof, and Kruzof Islands, southeastern Alaska: U.S. Geological Survey Professional Paper 792,105 p.

MacKevett, E. M., Jr., Robertson, E. C., and Winkler, G. R., 1974, Geology of the Skagway B-3 and B-4 quadrangles, southeastern Alaska: U.S. Geological Survey Professional Paper 832, $33 \mathrm{p}$.

Muffler, L. J. P., 1967, Stratigraphy of the Keku Islets and neighboring parts of Kuiu and Kupreanof Islands, southeastern Alaska: U.S. Geological Survey Bulletin $1241-\mathrm{C}$, $52 \mathrm{p}$.

Ovenshine, A. T., and Brew, D. A., 1972, Separation and history of the Chatham Strait fault, southeastern Alaska, North America: International Geological Congress, 24th, Montreal 1972, Sec. 3, p. 245-254.

Smith, J. G., Stern, T. W., and Arth, J. G., 1979, Isotopic ages indicate multiple episodes of plutonism and metamorphism in the Coast Mountains near Ketchikan, Alaska: Geological Society of America, Abstracts with Programs, v. 11, p. 519 .

U.S. Geological Survey, 1979, Aeromagnetic map of the Petersburg area, Alaska: U.S. Geological Survey OpenFile Report 79-832, scale 1:250,000.

Age of basalt flows in the Blue River valley, Bradfield Canal quadrangle

By Raymond L. Elliott, Richard D. Koch, and Stephen W. Robinson

Holocene flows of alkali-olivine basalt in the valley of the Blue River, and its tributary Lava Fork, are probably the youngest eruptive rocks in the southern part of southeastern Alaska. A single radiocarbon date on wood from a partly charred conifer log on the surface of one of the flows yields an age of $360 \pm 60 \mathrm{yr}$ B.P. (USGS-639) for that flow. These basalt flows, here informally called the Blue River flows, were briefly noted by several workers in the early years of this century (Brooks, 1902; Wright, 1906; Wright and Wright, 1908). However, the flows received little further attention until recently when they were studied during reconnaissance geologic mapping of the Bradfield Canal quadrangle.

The flows cover alluvial and glacial(?) deposits in the glacially eroded valleys of Lava Fork, Blue River below Lava Fork, and Unuk River at its confluence with Blue River (fig. 56). Smooth and ropy pahoehoe surfaces are widespread but are

$131^{\circ} 00^{\prime}$

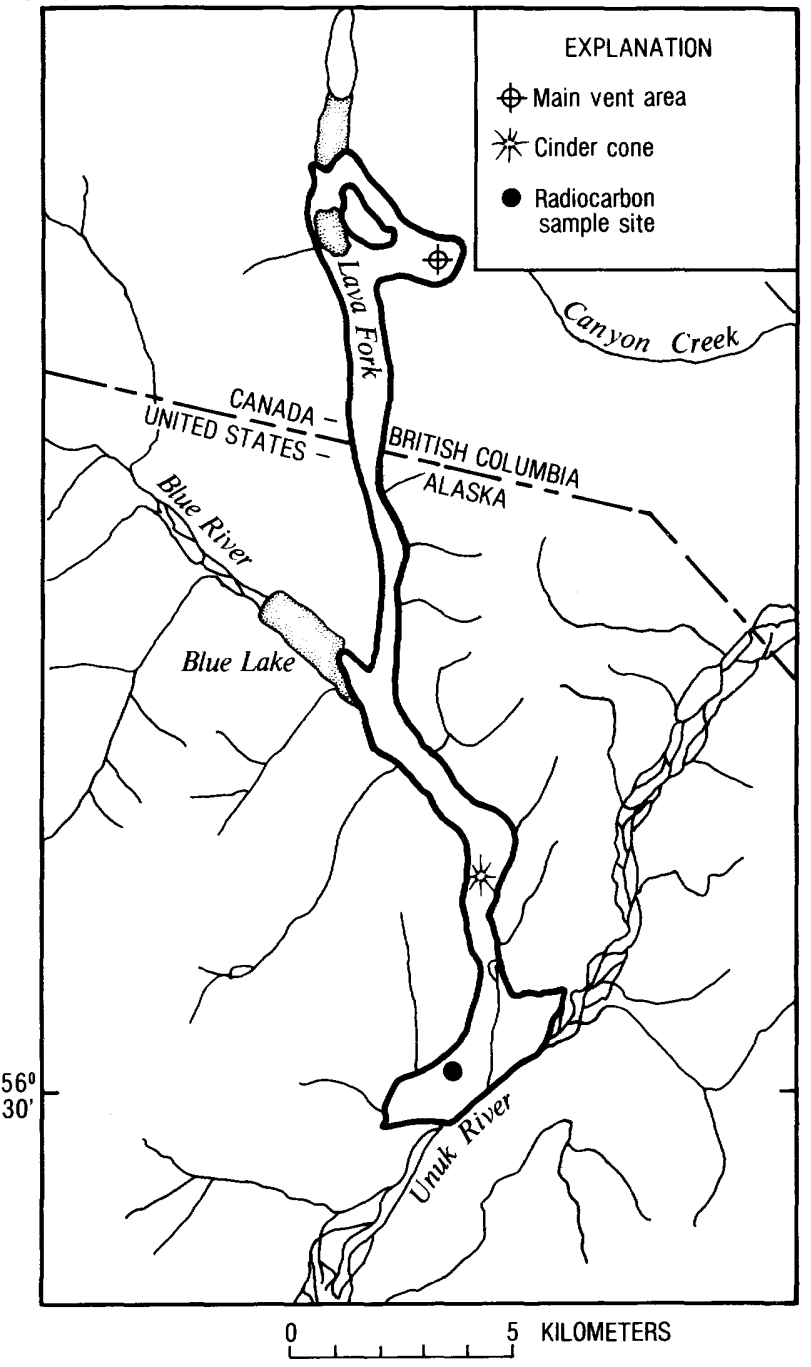

FIGURE 56.-Sketch map showing areal extent of Blue River flows (heavy outline), Bradfield Canal quadrangle, south. eastern Alaska. 
commonly broken into large and small slabs. Blocky lava and rubble are also common, especially in Lava Fork. Steep valley walls adjacent to the flows are mainly granitic rocks of the Coast Range batholithic complex.

The principal vent area is at or near the top of a $1,400 \cdot \mathrm{m}$-high ridge on the east side of Lava Fork, $5 \mathrm{~km}$ north of the international boundary in British Columbia. No well-formed cone is present at the vent area, and none is likely to have formed on the precipitous slopes above Lava Fork. Steep cascades of basalt follow two broad channels down the valley wall from the vent area to Lava Fork where two lakes, 1 and $2 \mathrm{~km}$ long, were formed as the lava and debris fans at the base of the basalt cascades dammed the river.

Lava flowed $12 \mathrm{~km}$ down Lava Fork to its confluence with Blue River where a broad lava fan spread across the $1-\mathrm{km}$-wide valley floor to dam the river and create Blue Lake. Basalt continued to flow southward down the Blue River valley for $9 \mathrm{~km}$ where it spilled out onto the broad alluvial flat of the Unuk River and forced the river against its southeastern valley wall. A broad, gently sloping lava field, extending nearly $1 \mathrm{~km}$ upstream and 3 to $4 \mathrm{~km}$ downstream from the mouth of the Blue River valley, represents the farthest extent of the Blue River flows. A single small steepwalled cinder cone on the floor of the Blue River valley, $15 \mathrm{~km}$ downstream from the main vent area, is surrounded by flows.

Field observations provide evidence of notable youth for these flows:

1 . Surfaces of most of the flows are fresh unaltered rock, largely devoid of any soil cover. Plant growth, other than lichen, on these flows is very sparse. Significant regrowth of trees has occurred only in some areas of older flows, on the cinder cone, and adjacent to river channels where water-borne sediment is present.

2. Surface drainage remains disrupted, especially in the upper reaches of the flows. In these areas drainage is mainly beneath the surface or through broad mazes of ponds and small lakes on the surface of the flows. Only in the lower part of the Blue River valley has the river reestablished one well-defined channel.

3. Ash and other easily erode $\bar{d}$ pyroclastic deposits mantle steep rock slopes and stagnant glacial ice along the margins of the glacier at the head of Canyon Creek near the vent area.
The active stream of ice in the center of this glacier has carried the ash away from the eruptive area and concentrated it at the toe of the glacier.

4. Remains of fallen trees, apparently conifers, are abundant and uniformly distributed over some flow surfaces in the Unuk valley. The undersides of some of these tree trunks have been partially charred. The fallen tree trunks commonly form the axes of irregular conical areas of lesser lichen growth on the flow surface. These areas of lesser lichen growth, resembling the profile of living conifers, suggest that living trees were surrounded by flows and, after being burned off at the base, toppled onto the still hot lava crust. The branches or their organic acid or ash residue suppressed lichen growth for some time and produced an image of the living tree on the flow surface. Evidence that the tree trunks probably were not deposited by river flooding includes the charring, uniform distribution over wide areas, distance from river channels, absence of sediment, and the presence of branches, which are commonly stripped from floodborne tree trunks.

The radiocarbon age, which was determined on fresh wood from the outer $2 \mathrm{~cm}$ of one of the fallen tree trunks, and the field observations listed above indicate very recent eruptive activity. Several successive and partly overlapping flows are recognizable locally, and two or more flows overlap the flow surface from which the radiocarbon sample was obtained. Differences in the degree of reforestation and amount of lichen growth on different flows have been noted. These vegetative differences, as well as the apparent thickness of lava above and below the flow level(s) that bear the fallen trees, suggest intermittent eruptive activity alternating with periods of quiescence. Thus two or more flows above the horizon of the radiocarbon sample may be significantly younger than $360 \pm 60$ yr B.P.

\section{REFERENCES CITED}

Brooks, A. H., 1902, Preliminary report on the Ketchikan mining district, Alaska: U.S. Geological Survey Professional Paper 1, 119 p.

Wright, F. E., 1906, The Unuk River mining region of British Columbia, in Geological Survey of Canada, Summary Report of the Year 1905, p. 46-53.

Wright, F. E., and Wright, C. W., 1908, The Ketchikan and Wrangell mining districts, Alaska: U.S. Geological Survey Bulletin 347, 210 p. 
New data concerning the geology of the North Bradfield River iron prospect, southeastern Alaska

By Ronald A. Sonnevil

Recent mapping at the North Bradfield River iron prospect has demonstrated an alternative structural model that suggests the potential occurrence of undiscovered magnetite deposits in the area. The North Bradfield River iron prospect is located in the Coast Plutonic Complex (Douglas and others, 1970) approximately $65 \mathrm{~km}$ east of Wrangell, Alaska. The prospect is within a 1- to 5 -km-wide septum of gneiss, schist, and minor marble; the septum grades into migmatite to the west and is bounded to the north and south by Cretaceous or Tertiary granodiorite plutons (fig. 57 ). The septum terminates approximately $5 \mathrm{~km}$ northwest of the prospect and extends for at least $24 \mathrm{~km}$ to the east where it crosses the Canadian border (R. L. Elliott and others, unpub. data).

The geology near the eastern part of the prospect was mapped in detail (fig. 58) and consists of heterogeneous gneiss and marble intruded by leucocratic hornblende-biotite granodiorite. This granodiorite is similar to plutons dated as Eocene in the Hyder-upper Portland Canal area (R. L. Elliott, oral commun., 1979) and in the Juneau-

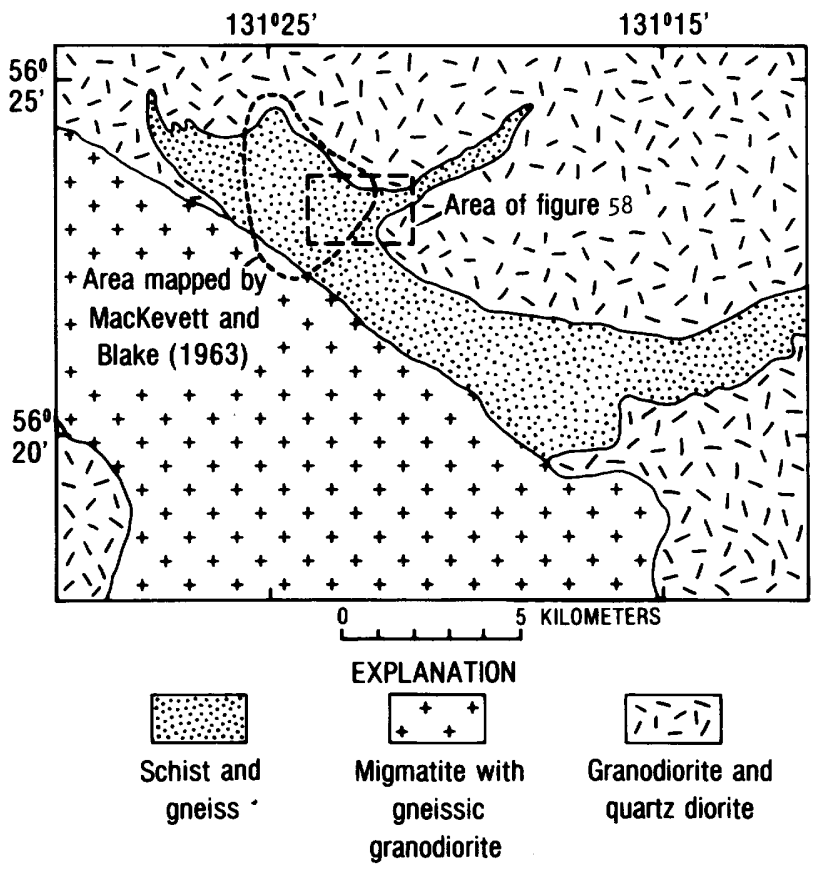

Contact

FiGURE 57.-Generalized geologic map of area surrounding North Bradfield River iron prospect. Area of prospect is essentially that mapped by MacKevett and Blake (1963). Geology generalized from Elliott and others (unpub. data).
Tracy Arm area (D. A. Brew, oral commun., 1979). Rocks mapped as gneiss are extremely variable and include schist, semischist, hornfels, quartztite, marble, banded gneiss, and gneissic quartz diorite. Contacts of rock types within the gneiss are usually gradational and discontinuous. The only mappable units within the metamorphic rocks are marble horizons which indicate that the dominant structure in the area mapped is homoclinal with northwest to northeast dips. Figure 59 is a schematic cross section of the area summarizing the structural interpretation and lithologic variations. This structural interpretation contrasts with that of MacKevett and Blake (1963), who interpret the structure as an overturned syncline with the hinge of the marble horizons near locality A (fig. 58).

Mineralogy within the gneiss unit is characterized by varying amounts of hornblende, biotite, pyroxene, quartz, and feldspars. Marble contains calcite with subordinate pyroxene, quartz, feldspars, and scapolite. Locally marble is replaced by calc-silicate skarn consisting of garnet + pyroxene +quartz+calcite \pm feldspars \pm magnetite \pm sulfide minerals. Associated with calc-silicate skarn are discontinuous bodies (fig. 58) of magnetite with minor pyrrhotite, chalcopyrite, pyrite, and calc-silicate minerals. These bodies range in thickness from 0.5 to $12 \mathrm{~m}$ and in length from 15 to $108 \mathrm{~m}$ (MacKevett and Blake, $1963)$.

Secondary copper and iron oxides commonly accompany the magnetite deposits. Near one deposit (loc. B, fig. 58), copper oxide staining is visible from a distance of $2 \mathrm{~km}$. During this study, an additional copper-stained area was noted approximately $1.5 \mathrm{~km}$ east of the previously reported deposits (MacKevett and Blake, 1963). This area, which is continuous across an inaccessible cliff for approximately $30 \mathrm{~m}$ (loc. C, fig. 58 ), is on strike with the two main marble horizons that contain magnetite. Steep slopes and vegetation cover did not allow mapping of all marble horizons (including those with magnetite) in the eastern part of the area, but the continuity of one of the marble horizons and the copper oxide stain at locality $\mathrm{C}$ suggest that all of the marble horizons probably extend to this area. Thus, the potential for additional magnetite deposits is high to the west and east of locality C. However, the narrowness of the septum near locality $\mathrm{C}$ indicates that deposits at this locality may be cut off at depth by granodiorite. 


\section{REFERENCES CITED}

Douglas, R. J. W., Gabrielse, H., Wheeler, J. O., Stott, D. F., and Belyea, H. R., 1970, Geology of western Canada, in Douglas, R. J. W., ed., Geology and economic minerals of Canada: Geological Survey of Canada Economic Geology Report No.1, p. 367-488.

MacKevett, E. M., Jr., and Blake, M. C., Jr., 1963, Geology of the North Bradfield River iron prospect, southeastern Alaska: U.S. Geological Survey Bulletin 1108-D, 21 p.

\section{OFFSHORE ALASKA}

Preliminary interpretation of the geologic structure beneath the northern Bering Sea shelf, including Norton Basin

By Michael A. Fisher, Mark L. Holmes, and William W. Patton, Jr.

This paper presents a preliminary interpretation of the geologic structure of part of the continental shelf, beneath the northern Bering Sea, which is north of St. Lawrence Island and the Yukon delta and south of Seward Peninsula (fig. 60). Norton Basin lies within this area, and a petroleum lease sale is tentatively scheduled for the basin in August of 1982 .

Seismic-reflection data, used to make the structure map in figure 60, were collected in 1969 and in 1978. In 1969, single-channel airgun (0.66L) data were obtained aboard the USC and GSS Surveyor (Walton and others, 1969), and in 1978, 24-channel airgun (19.6L) data were obtained aboard the R/V SP. Lee. Seismic-refraction data were collected at 35 stations in 1977 and 1978 aboard the R/V S.P. Lee. These data provide the velocity information that was used to convert two-way time to depth $\left(Z=0.80 T+0.167 T^{2}\right)$,

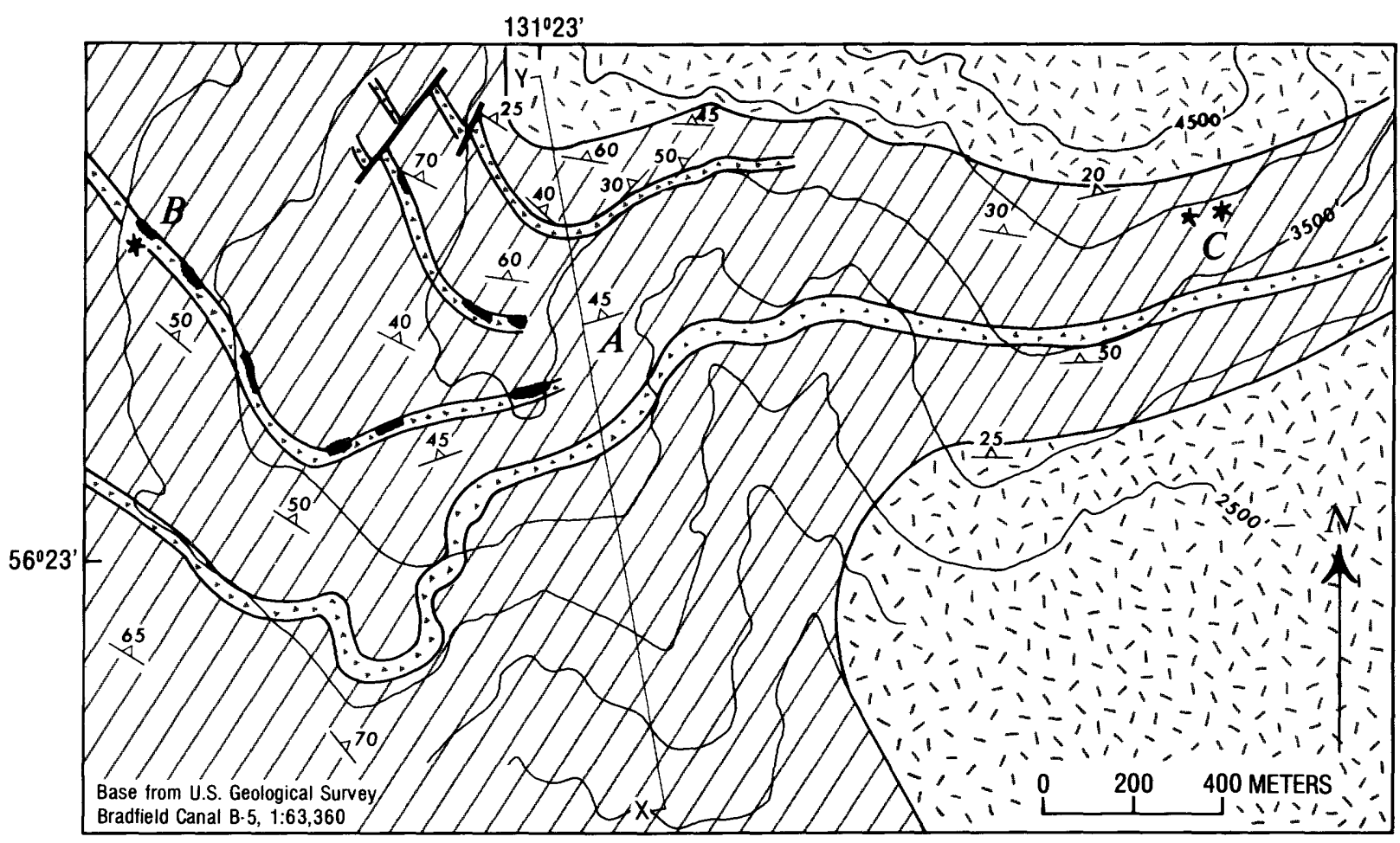

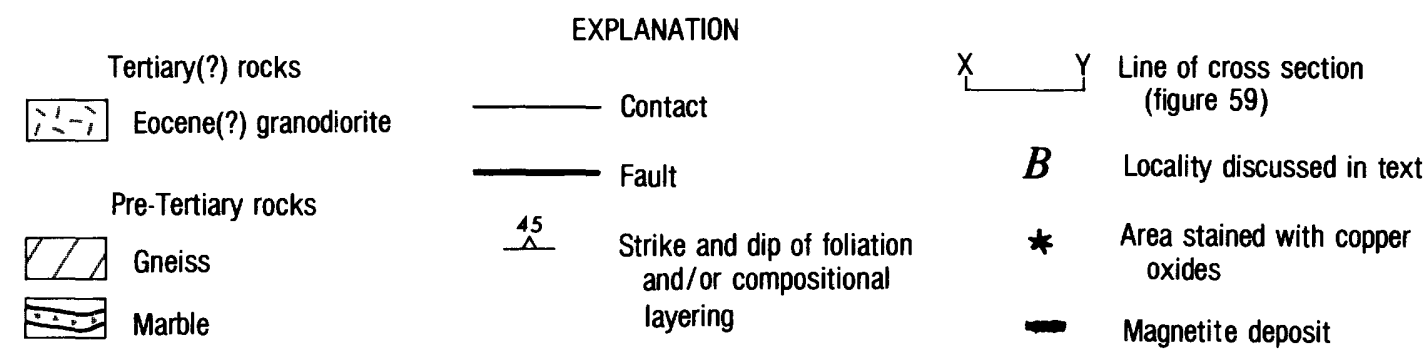

FIGURE 58.-Geologic map of part of North Bradfield River iron prospect and adjoining area. 


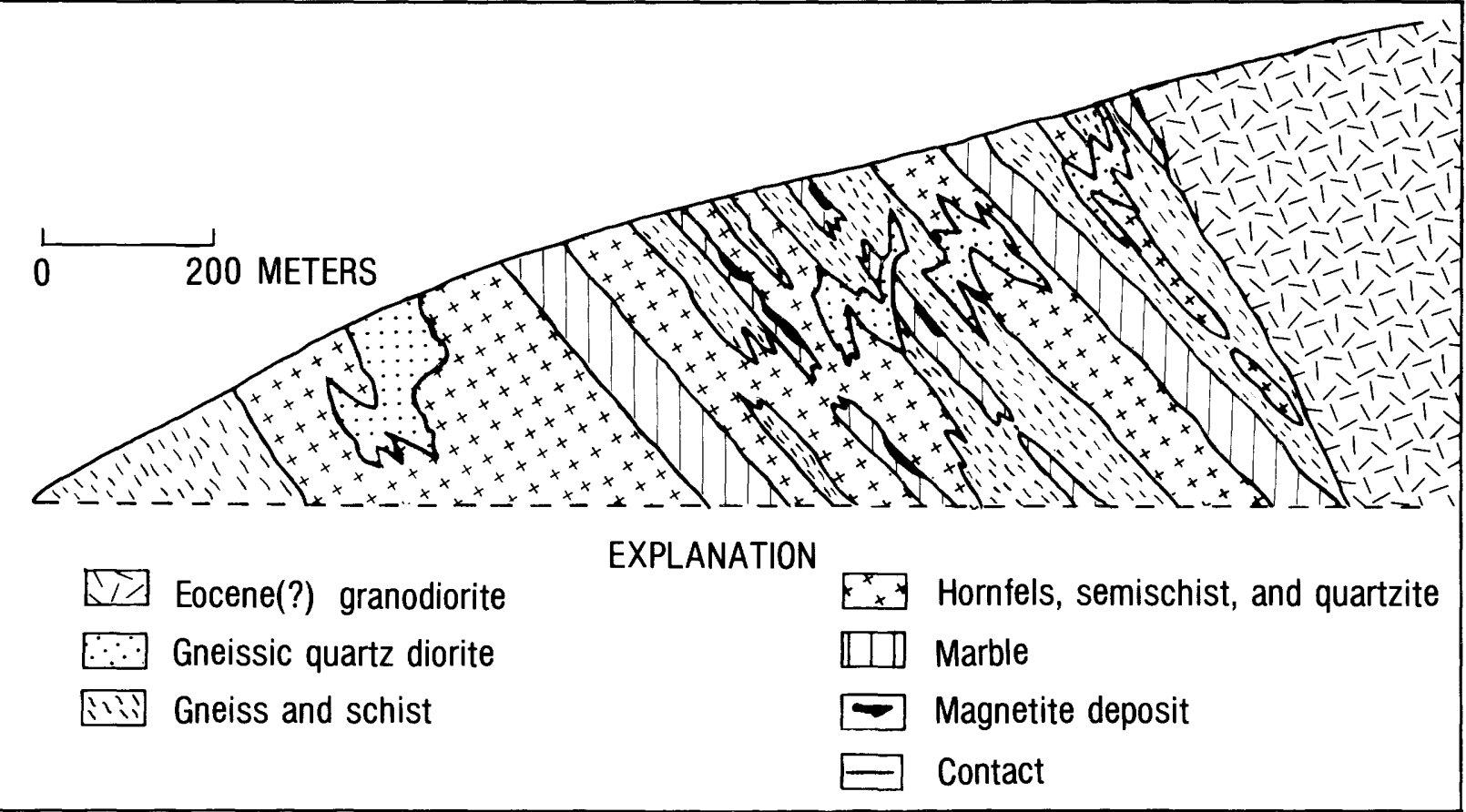

FIGURE 59.-Schematic cross section along line $\mathrm{X}-\mathrm{Y}$ in figure 58 . Scale is twice that of figure 58.

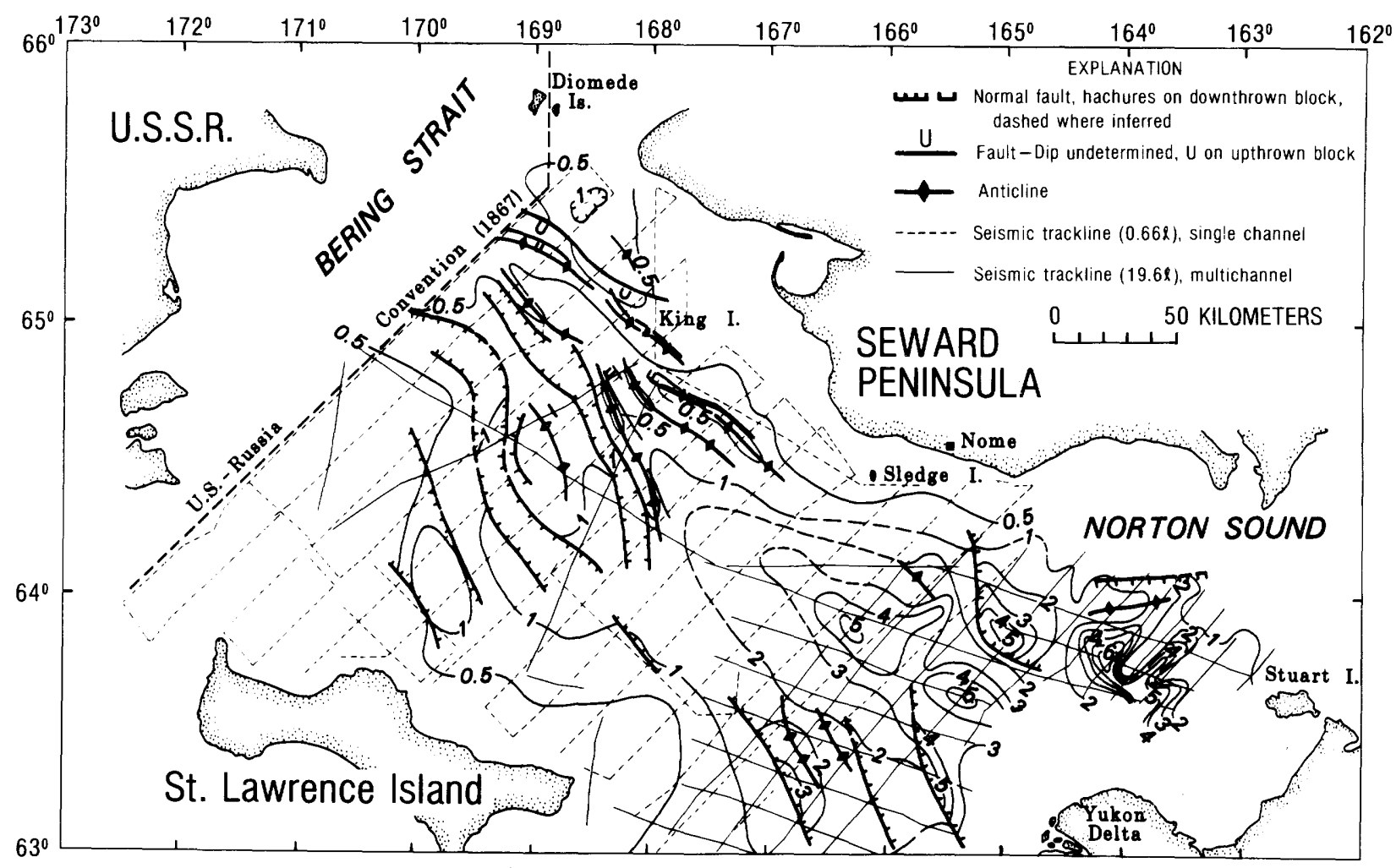

FIGURE 60.-Preliminary structure of northern Bering Sea shelf. Contours show depth in kilometers of bottom of basin fill, which could be as old as Late Cretaceous. Basement is probably Paleozoic through lower Mesozoic rocks. 
where $Z$ is depth in kilometers and $T$ is two-way time in seconds. Position was determined by Raydist in 1969 and by satellite navigation, supplemented by doppler-sonar dead-reckoning, in 1977 and 1978.

For the purpose of discussion, the continental shelf beneath the northern Bering Sea is divided at the $168^{\circ} \mathrm{W}$. meridian into two structural areas: a western area, which is underlain by shallow basement; and an eastern area, which comprises Norton Basin. In the western structural area, most of the information on geologic structure comes from small-airgun (0.66L) data, which show that reflective rocks are thin (less than 2 $\mathrm{km}$ ) and are bounded below by an interface that returns a strong reflection. This interface, contoured in figure 60 , corresponds in depth to a discontinuity in refraction velocities-velocities above the discontinuity range between 2.5 and 3.5 $\mathrm{km} / \mathrm{s}$; velocities below range between 3.5 and 4.5 $\mathrm{km} / \mathrm{s}$ (Holmes and Fisher, 1979; Fisher and others, 1979). The sparse 24-channel data obtained in this structural area show that 100 to 300 $\mathrm{m}$ of strata underlies this velocity discontinuity. Refraction velocities at the base of these deeper strata between 5.0 and $6.9 \mathrm{~km} / \mathrm{s}$ suggest that the base of these deeper strata is probably the contact between Tertiary rocks and what may be Paleozoic and lower Mesozoic rocks in the basement, which are similar to rocks exposed on St. Lawrence Island and on the Seward Peninsula ( see geologic maps by Hudson, 1977; and Patton and Csejtey, 1979).

Structures north of St. Lawrence Island include several grabens and seven anticlines, which generally strike northwest (fig. 60). Sedimentary rocks in the grabens are as thick as $1.5 \mathrm{~km}$, and the grabens generally shoal northwestward from Norton Basin. The seven northwest-striking anticlines lie near Seward Peninsula and are 40 to 60 $\mathrm{km}$ long and 5 to $10 \mathrm{~km}$ wide. Cenozoic strata lap onto the anticlines. King Island, on which Cretaceous granitic rocks are exposed (Hudson, 1977 ), is uplifted along one of the anticlines. Numerous faults are near the anticlines, but the dips of these faults are difficult to determine from the seismic-reflection data; consequently, we cannot determine whether the faults are reverse faults associated with anticlinal folding or normal faults associated with the extension that formed nearby grabens.

The structural area east of the $168^{\circ} \mathrm{W}$. meridian makes up Norton Basin. The western part of Norton Basin contains major northwest-trending normal faults, which in places have throws greater than $2 \mathrm{~km}$ (fig. 60). No reverse faults have been identified in this part of Norton Basin, and major normal faults are all downthrown to the northeast. Where fault throw is greatest, isolated basin lows as deep as $5 \mathrm{~km}$ are formed.

Faulting is complex in the eastern part of Norton Basin, north and northeast of the Yukon delta. Major faults are all normal and change strike from northwest in the west to northeast in the east (fig. 60). In the northern part of Norton Basin, one major fault strikes nearly east and forms the southern boundary of a shallow (less than 1 $\mathrm{km}$ deep) basement platform that extends south from the Seward Peninsula. Adjacent to the south side of this fault is a large east-striking anticline, which may have formed when the south side of the fault dropped down, causing a local reversal of the regional south dip of the basin strata.

Norton Basin is deepest in the southeast. These basin deeps are formed by progressively deeper steps down large-throw ( 1 to $2 \mathrm{~km}$ ) normal faults. The maximum measured thickness of rock in the basin is $7 \mathrm{~km}$. The southerly extent of the basin deeps is unknown because shallow water near the Yukon delta precluded data collection south of the seismic grid shown in figure 60 .

On the basis of refraction velocities and of considerations of regional geology, Fisher and others (1979) and Holmes and Fisher (1979) speculate that fill in Norton Basin is as old as Late Cretaceous. This age and the thickness of basin fill (as much as $7 \mathrm{~km}$ ) suggest that the basin could contain petroleum resources.

\section{REFERENCES CITED}

Fisher, M. A., Patton, W. W., Jr., Thor, D. R., Holmes, M. L., Scott, E. W., Nelson, C. H., and Wilson, C. L., 1979, Resources report for proposed OCS Lease Sale 57: Norton basin, Alaska: U.S. Geological Survey Open-File Report $79-720,72 \mathrm{p}$.

Holmes, M. L., and Fisher, M. A., 1979, Sonobouy refraction measurements from Norton basin, northern Bering Sea [abs.]: American Association of Petroleum Geologists Bulletin, v. 63 , p. 468.

Hudson, Travis, 1977, Preliminary geologic map of Seward Peninsula, Alaska: U.S. Geological Survey Open-File Report 77-796A, scale 1:500,000.

Patton, W. W., Jr., and Csejtey, Béla, Jr., 1979, Geologic map of St. Lawrence Island, Alaska: U.S. Geological Survey Open-File Report 79-945, scale 1:250,000. 
1969, Seismic-reflection profiles northern Bering Sea: U.S. Coast and Geodetic Survey Operational Data Report, Coast and Geodetic Survey DR-8, 26 p.

Environmental geologic studies of the northern Bering Sea By Devin R. Thor and C. Hans Nelson

Seismic studies conducted during 1976-1978 aboard the R/V Sea Sounder in the northern Bering Sea indicate a dynamic environment of moderate tectonism, sediment instability, and active erosional and depositional processes on the shallow sea floor, which create several potential geologic hazards (fig. 61) (Thor and Nelson, 1979). Processes active in the area include faulting, thermogenic gas seeps, sea-floor gas cratering, sediment liquefaction, ice gouging, scour- depression formation, storm-sand deposition, and large-scale bedform movement. Seeps of thermogenic hydrocarbon and carbon dioxide gas result from near-surface faulting south of Nome (Nelson and others, 1978; Kvenvolden, Weliky, and Nelson, 1979; Kvenvolden, Nelson, and others, 1979). Numerous faults also cut the sea floor in the area west of Port Clarence; fault activity is difficult to determine, however, because current scour may be preserving or exhuming old fault scarps (Johnson and Holmes, 1978).

Interaction between the processes of liquefaction, gas crater formation, scour depressions, storm-sand deposits, and slumps may cause sediment instability problems. Liquefaction of the

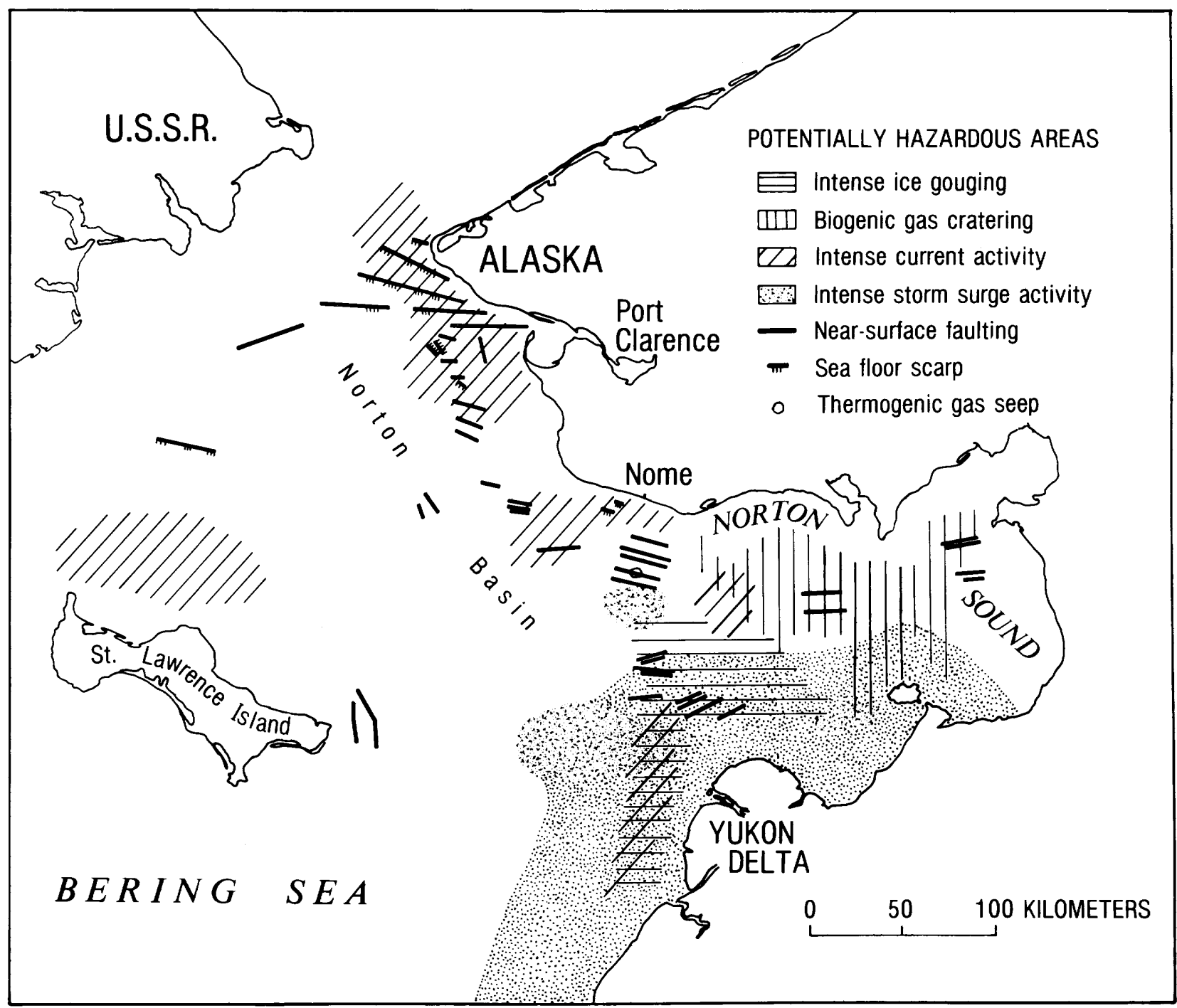

FIGURE 61.-Summary of potentially hazardous areas in Norton Basin. 
upper 1-3 m of the Holocene coarse-grained silt and very fine grained sand covering Norton Sound can be caused by cyclic storm-wave loading (Olsen and others, 1980). The widespread occurrence of gas-charged sediment with small surficial craters (3-8 $\mathrm{m}$ in diameter and less than $1 \mathrm{~m}$ deep) in central Norton Sound suggests that the sea-floor sediment is disrupted by intermittent venting of biogenic gas from the underlying peaty mud (Nelson, Thor, and others, 1980).

During major storms, liquefaction may not only help trigger crater formation, but also may enhance erosional and depositional processes that create large-scale scour areas and transport sand in the Yukon prodelta area. Small-scale surficial slumps on the west flank of the Yukon prodelta may also be triggered by liquefaction.

Interaction of erosional and depositional processes may result in hazards in the shallower parts of the northern Bering Sea. Ice gouges as deep as 1 $\mathrm{m}$ are ubiquitous in the area of the Yukon prodelta (Thor and Nelson, 1979). Although much less common, ice gouges are present throughout the remainder of the northern Bering Sea where water depths are less than $20 \mathrm{~m}$. In the Yukon prodelta area and in central Norton Sound, where currents are constricted by shoal areas and flow is made turbulent by local topographic irregularities (such as ice gouges), storm-induced currents have scoured large (50-150 m diameter), shallow $(<1 \mathrm{~m}$ deep) depressions (Larsen and others, 1979). Abundant storm-surge sand layers in Yukon mud suggest that storm-surge activity has a significant effect on the bottom. Around the Yukon prodelta, storm surge and waves have generated bottom transport currents that deposit layers of sand as far as $75 \mathrm{~km}$ from land. West of Port Clarence, large sand waves $(10-200 \mathrm{~m}$ wavelength and $0.5-5 \mathrm{~m}$ wave height) move intermittently when storm surge run-off reinforces the strong geostrophic currents continually flowing north over the Bering shelf (Field and others, 1977; Nelson and others, 1977; Nelson, Dupré, and others, 1980).

\section{REFERENCES CITED}

Field, M. E., Nelson, Hans, Cacchione, D. A., and Drake, D. E., 1977, Dynamics of bedforms of an epicontinental shelf, northern Bering Sea [abs,]: Transactions, American Geophysical Union, EOS, v. 58, no. 12, p. 1162.
Johnson, J. L., and Holmes, M. L., 1978, Report on surface and subsurface faulting in Norton Sound and northeastern Chirikov Basin, Alaska, in Environmental assessment of the Alaska continental shelf, Annual report of principal investigators for the year ending 1978: Environmental Research Laboratory, Boulder, Colorado, NOAA, U.S. Department of Commerce, v. 12, p. 203-227.

Kvenvolden, K. A., Nelson, Hans, Thor, D. R., Larsen, M. C., Redden, G. D., and Rapp, J. B., 1979, Biogenic and thermogenic gas in gas-charged sediment of Norton Sound, Alaska: Offshore Technology Conference, Houston, Texas, paper no. 3412, Proceedings, p. 479-483.

Kvenvolden, K. A., Weliky, K., and Nelson, C. H., 1979, Submarine seep of carbon dioxide in Norton Sound, Alaska: Science, v. 205, p. 1264-1266.

Larsen, M. C., Nelson, C. H., and Thor, D. R., 1979, Geologic implications and potential hazards of scour depressions on Bering shelf, Alaska: Environmental Geology, v. 3, no. 1, p. 39-47.

Nelson, C. H., Cacchione, D. A., and Field, M. E., 1977, Complex ridge and trough topography on a shallow currentdominated shelf, northwest Alaska [abs.]: American Association of Petroleum Geologists Bulletin, v. 61, p. 817.

Nelson, C. H., Dupré, W. R., Field, M. E., and Howard, J. D., 1980. Linear sand bodies on the Bering epicontinental shelf, in Larson, M. C., Nelson, C. H., and Thor, D. R., Geological, geochemical, and geotechnical observations on the Bering Shelf, Alaska: U.S. Geological Survey OpenFile Report 80- 979, 30 p.

Nelson, C. H., Kvenvolden, K. A., and Clukey, E. C., 1978, Thermogenic gas in sediment of Norton Sound, Alaska: Offshore Technology Conference, Houston, Texas, paper no. 3354, Proceedings, p. 1612-1633.

Nelson, C. H., Thor, D. R., Sandstrom, M. W., and Kvenvolden, K. A., 1980, Modern biogenic gas-generated craters (sea-floor "pockmarks") on the Bering shelf, Alaska: Geological Society of America Bulletin, Part I, v. 90, p. 1144-1152.

Olsen, H. W., Clukey, E. C., and Nelson, C. H., 1980, Geotechnical characteristics of bottom sediments in the northern Bering Sea, in Larson, M. C., Nelson, C. H., and Thor, D. R., Geological, geochemical, and geotechnical observations on the Bering Shelf, Alaska: U.S. Geological Survey Open-File Report 80-979, $31 \mathrm{p}$.

Thor, D. R., and Nelson, C. H., 1979, A summary of interacting surficial geologic processes and potential geologic hazards in the Norton Basin, northern Bering Sea: Offshore Technology Conference, Houston, Texas, paper no. 3400 , Proceedings, p. 377-381.

Geologic constraints for petroleum development of the lower Cook Inlet, Alaska, Outer Continental Shelf lease area

By John W. Whitney and Dennis K. Thurston

Petroleum exploration began in the lower Cook Inlet (LCI) Outer Continental Shelf area after the October 1977 Federal lease sale, and additional leasing is scheduled for 1981. Further petroleum 
exploration and possible development in this area will occur within guidelines resulting from geologic studies by both the U.S. Geological Survey and industry. The geologic factors described below may place constraints on oil and gas drilling and production in LCI. These factors include: shallow gas-charged sediment, sand wave dynamics, seismicity and faulting, consolidation of the Quaternary glacial-marine overburden, and volcanism.

Shallow gas-charged sediment in several areas has been interpreted from high-resolution seismic records. The velocity anomaly and phase reversal on the seismic records, for which the most likely and conservative interpretation is one of shallow gas, are less than $50 \mathrm{~m}$ below the mudline. Because the composition and pressure of this gas are unknown, it is recommended that drilling in such areas be avoided. These areas are outlined on figure 62 (dash-dot line).

Large sand waves, with heights of as much as 12 $\mathrm{m}$ and wavelengths of several hundred meters, cover approximately half of the tracts leased in the 1977 Federal petroleum lease sale. Inasmuch as strong bottom currents (greater than the threshold bed-shear stress necessary to move sand grains) have been measured (Whitney and others, 1979), undesirable sediment scour and transport of these sand waves may occur. In a five-year comparative study, employing "MiniRanger" navigation, seismic profiling, and sidescan sonar equipment, none of the large sand waves was observed to migrate (Whitney and others, 1979). However, the limitations in resolving potential sand-wave movement $( \pm 10 \mathrm{~m})$ indicate that further study is needed prior to installing bottom-founded structures. The area covered by these large sand waves is outlined on figure 62 (dashed line).

The Benioff Zone, 50-75 km beneath the LCI lease area, seems incapable of generating great earthquakes of more than magnitude 7.8 (Pulpan and Kienle, 1979). Such great earthquakes appear to be restricted to the shallow, thrusting part of the Benioff Zone, 200 to $400 \mathrm{~km}$ away from LCI. Frequent earthquakes with a magnitude somewhat greater than 6 could constitute the greatest seismic risk. No large faults offsetting the sea floor have been identified, and the adjacent onshore Bruin Bay and Border Ranges faults show no significant historical activity (Magoon and others, 1976). Although the seismic risk of LCI is sig- nificant, this area is not within one of the socalled "seismic gaps." Detailed studies regarding earthquake recurrence rates, seismic ground response parameters, and seismic energy attentuation relations in LCI are in progress.

Glacial-marine overburden, as much as $100 \mathrm{~m}$ thick, covers most of LCI and in some areas is topped with a thin layer (less than $10 \mathrm{~m}$ ) of loose sand. Bottom-founded structures will probably be anchored to this glacial-marine sediment. The weight of over $300 \mathrm{~m}$ of ice during the last major glacial epoch probably consolidated or overconsolidated the glacial sediment. Stability of very steep sloped channels cut into this glacial section tends to support this premise. Thus, excellent foundation conditions exist in this glacial overburden. The marine part of the overburden, occurring in the deeper water in the southern part of LCI, may be under-consolidated. Further evaluation is needed in order to determine the degree of consolidation and other geotechnical properties of these marine sediments.

Three historically active volcanoes lie within 10 to $40 \mathrm{~km}$ of the Federal lease sale area. Of these three, Augustine Volcano is the closest and youngest and therefore potentially the most dangerous. Augustine had major explosive eruptions in 1883, 1964, and 1976 with several minor eruptions and steaming activity in the interim. An eruption could cause ash falls, tsunamis, and high-temperature shock waves, which could harm offshore and onshore petroleum facilities and personnel. The 1976 eruption resulted in a ground cover of ash in Anchorage, $280 \mathrm{~km}$ away. At a closer range, this ash could have caused major equipment shut-downs and failures. Pyroclastic flows entering the water from the 1883 eruption produced a $25-\mathrm{ft}$ wall of water across LCI at the fishing community of Seldovia, severely damaging the fleet. Figure 61 shows the extent of submerged flows off the east side of Augustine (dotted line). Studies in progress suggest that flows may extend off the west shore to an even greater distance than on the east side.

\section{REFERENCES CITED}

Magoon, L. B., Adkison, W. L., Chmelik, F. B., Dolton, G. L., Fisher, M. A., Hampton, M. A., Sable, E. G., and Smith, R. A., 1976, Hydrocarbon potential, geologic hazards, and infrastructure for exploration and development of lower Cook Inlet, Alaska: U.S. Geological Survey Open-File Report $76-449,124 \mathrm{p}$. 


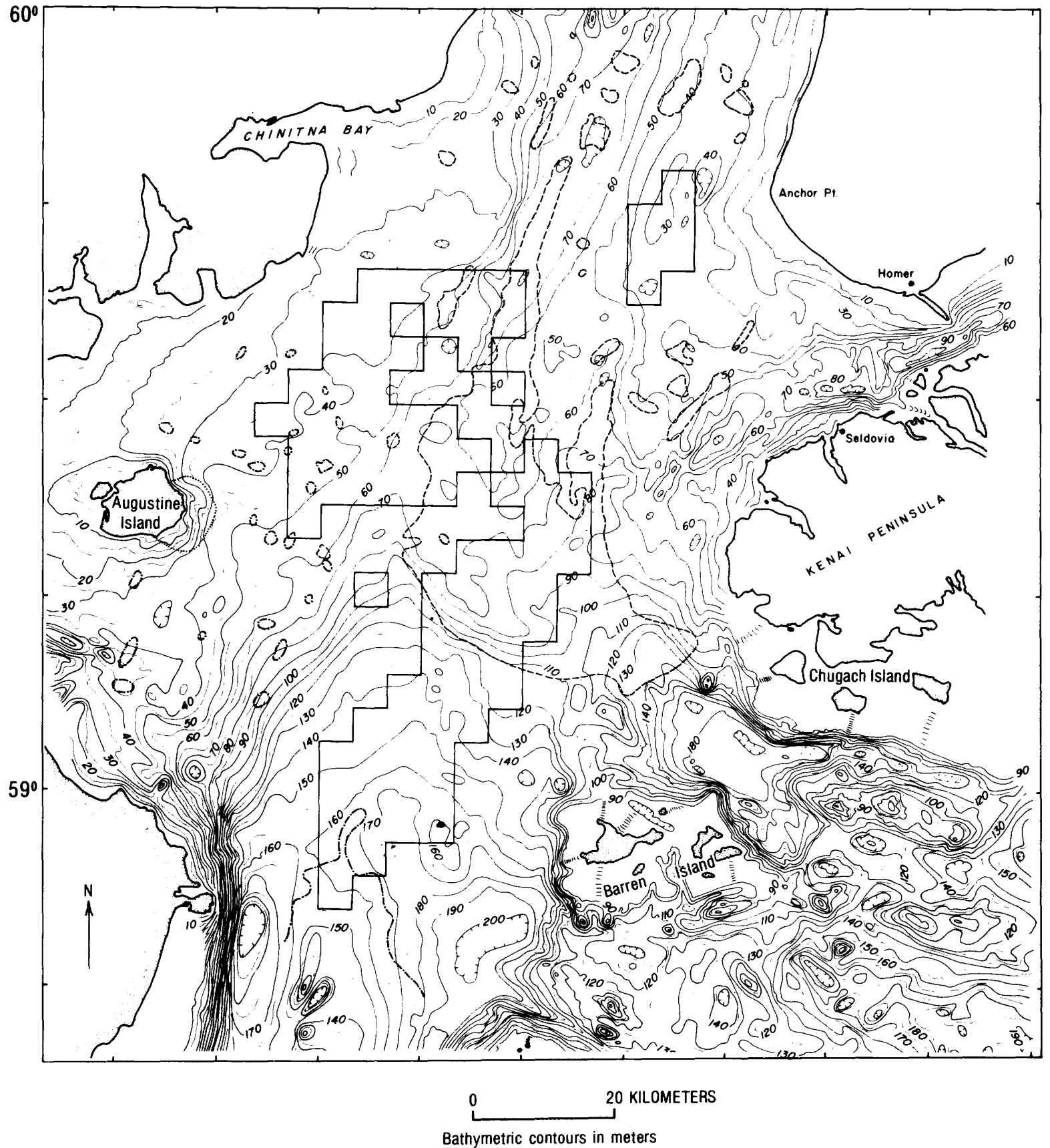

\section{EXPLANATION}

FIGURE 62.-Lower Cook Inlet bathymetry map showing tracts leased during 1977 oil and gas sale and areas that constitute potential geologic hazards to drilling. 
Pulpan, H., and Kienle, J., 1979, Western Gulf of Alaska seismic risk: Offshore Technology Conference, Houston, Texas, Proceedings, v. IV, p. 2209-2218.

Whitney, J. W., Noonan, W. G., Thurston, D. K., Bouma, A. H., and Hampton, M. A., 1979, Lower Cook Inlet, Alaska-Do those large sand waves migrate?: Offshore Technology Conference, Houston, Texas, Proceedings, v. II, p. $1071-1082$.

Distribution of gas-charged sediment and pockmarks in the northeastern Gulf of Alaska, Yakutat Bay to Cross Sound

By Bruce F. Molnia

Six areas of gas-charged sediment have been identified in the northeastern Gulf of Alaska between Yakutat Bay and Cross Sound: (1) on the southeast flank of Yakutat Sea Valley, (2) nearshore between Dangerous River and Alsek River, (3) on the west flank of Alsek Sea Valley, (4) southeast of Lituya Bay, (5) on the northwest wall of Cross Sound Sea Valley, and (6) south of Graves Harbor (fig. 63). The presence of the gas-charged sediment was determined by interpretation of more than $10,000 \mathrm{~km}$ of highresolution seismic and echo sounder profiles, plus gas chromatographic analyses of sediment cores. Seismic profiles from the six areas show combinations of displaced reflectors (pull-ups and pulldowns), acoustic sinks and transparencies in the top $50 \mathrm{~m}$ of sediment, and occasionally, possible gas plumes in the water column. Seismic profiles from other areas in the northeastern gulf showed acoustic sinks or transparencies, but these features could not be confirmed as being gas related.

Five of the six gas-charged areas are small, covering $10 \mathrm{~km}^{2}$ or less; the exception is the area nearshore between the Dangerous and the Alsek Rivers. This area, which encompasses more than $200 \mathrm{~km}^{2}$, is the only one of the six with a surface manifestation of the presence of gas; thousands of seafloor pockmarks and craters range in diameter from less than $2 \mathrm{~m}$ to as much as $400 \mathrm{~m}$. The pockmarks are actively forming today (Molnia, 1979 ) and commonly are the site of gas seepage into the water column.

Most of the gas from sediment cores collected in the gas-charged areas is biologically derived methane (Molnia and others, 1978). The maximum gas concentration measured in 1979 from a sediment core collected in the nearshore between the Dangerous and Alsek Rivers was $3 \times 10^{7} \mathrm{~nL}$ of methane/L of wet sediment, a gas concentration three to four orders of magnitude greater than background. Similar high concentrations were measured in gas-charged sediment west of the study area (Molnia and others, 1978).

In each of the six areas, the gas-charged sediment is present in the upper part of a thick Holocene sediment section. No evidence of leakage from deeper pre-Holocene sources can be seen on the high-resolution profiles. This observation, combined with the biogenic nature of the gas suggests that bacterial breakdown of organic material deposited in the rapidly accumulating Holocene sediment may be the source of the gas.

Gas-charged sediment has lower sediment strength and bearing capacity than sediment not charged with gas. As the gas concentration increases, sediment stability decreases until failure occurs. This characteristic poses a potential hazard to exploitation of mineral resources on the sea floor as drilling into gas-charged sediment, cyclic loading, seismicity, or spontaneous overpressurization may cause the sudden and catastrophic release of gas and pore water and cause failure of pipelines and platforms in the immediate area.

Pockmarks on seismic profiles from the nearshore area between the Dangerous and Alsek Rivers closely resemble other disturbed areas where sediment sliding is active. Only through sitespecific side-scan sonar surveys and sediment coring has the relation been established between the gas-charged sediment and the seafloor pockmarks. This relation suggests that in other areas where sediment sliding is an active process, gas in the sediment may be a major cause of sediment instability.

\section{REFERENCES CITED}

Molnia, B. F., 1979, Origin of gas pockmarks and craters: Geological Society of America Abstracts with Programs, v. 11 , p. $481-482$.

Molnia, B. F., Carlson, P. R., and Kvenvolden, K. A., 1978, Gas-charged sediment areas in the northern Gulf of Alaska: Geological Society of American Abstracts with Programs, v. 10, p. 458-459.

Depth changes in Icy Bay, Alaska caused by sedimentation and melting of ice-cored moraine

By Bruce F. Molnia

Depths in the $256 \mathrm{~km}^{2}$ lower basin of Icy Bay have changed substantially during the 54-year 
period between 1922 and 1976 . A bathymetric survey conducted by the National Oceanic and Atmospheric Administration (NOAA) in 1976 and a seismic survey conducted by the U.S. Geological Survey in 1977 document depth changes exceeding $70 \mathrm{~m}$ in lower Icy Bay when compared to a 1922 Coast and Geodetic Survey bathymetric study.

Planimetry of data from the lower basin surveys indicates that depths have decreased in $143 \mathrm{~km}^{2}$ of the basin, increased in $45 \mathrm{~km}^{2}$ of the basin, and remained the same in $68 \mathrm{~km}^{2}$ of the basin (fig. 64 ). Areas of deepening correspond to the position of the arcuate teminal moraine that marks the 1904 maximum advance of Guyot Glacier (Molnia, 1977).

More than $30 \mathrm{~m}$ of deepening has occurred on the west side of the bay in an area that in 1922 was an onshore ice-cored mound about $1 \mathrm{~km}$ in. land from the 1922 shoreline. By the time of the recent surveys, this same area was covered by more than $10 \mathrm{~m}$ of water and was $3 \mathrm{~km}$ offshore. In all, more than $0.5 \mathrm{~km}^{3}$ of submarine ice and sediment has been removed between surveys. Most of the volume change is due to the melting of the ice core of the submerged moraine rather than to erosion.

Sedimentation is the dominant geologic process

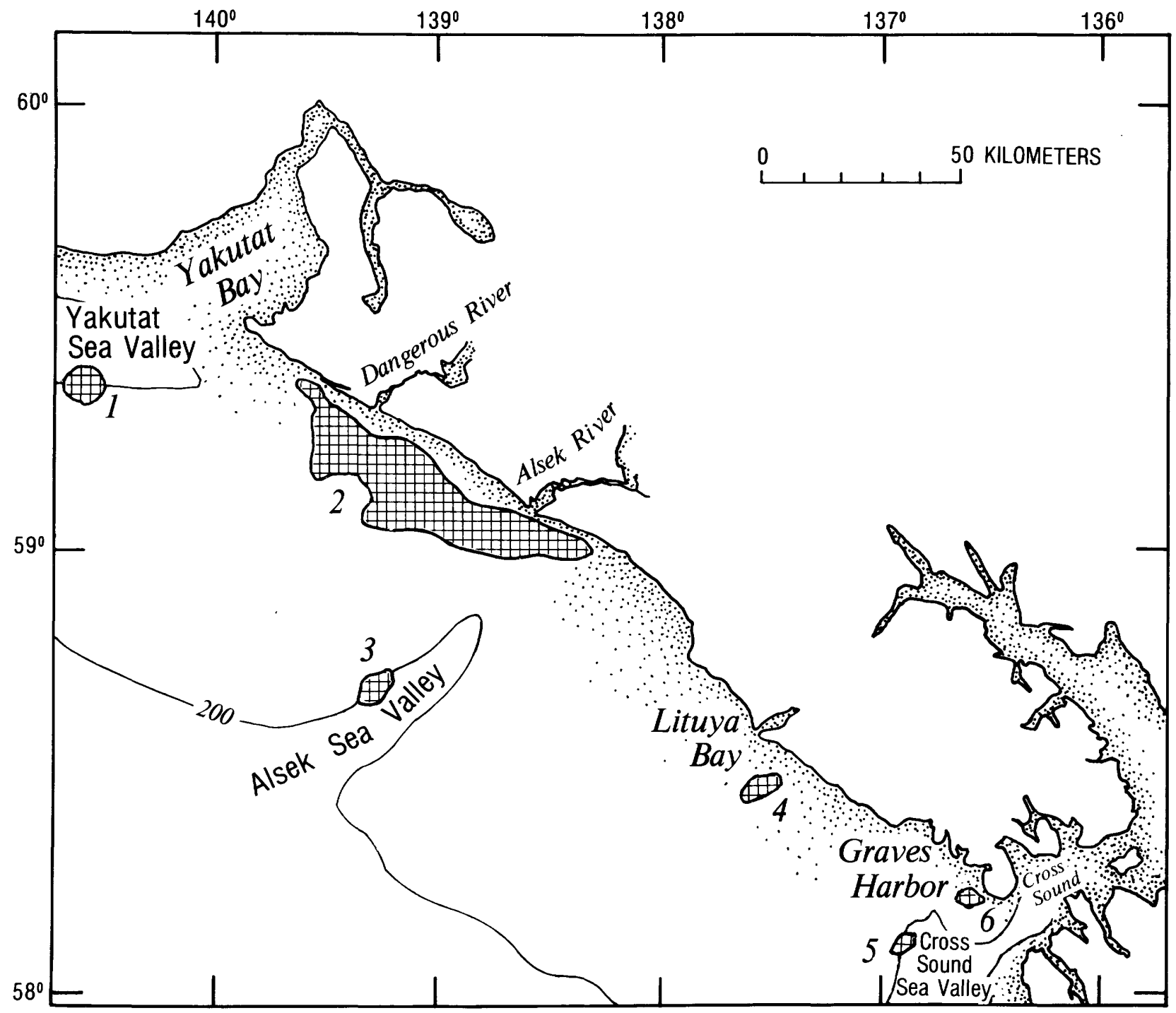

FIGURE 63.-Location of six areas of gas-charged sediment in northeastern Gulf of Alaska between Yakutat Bay and Cross Sound. Numbers on figure correspond to numbers used in text. Gas pockmarks and craters only found in area 2 . Contour line shown is the $200 \mathrm{~m}$ isobath. 


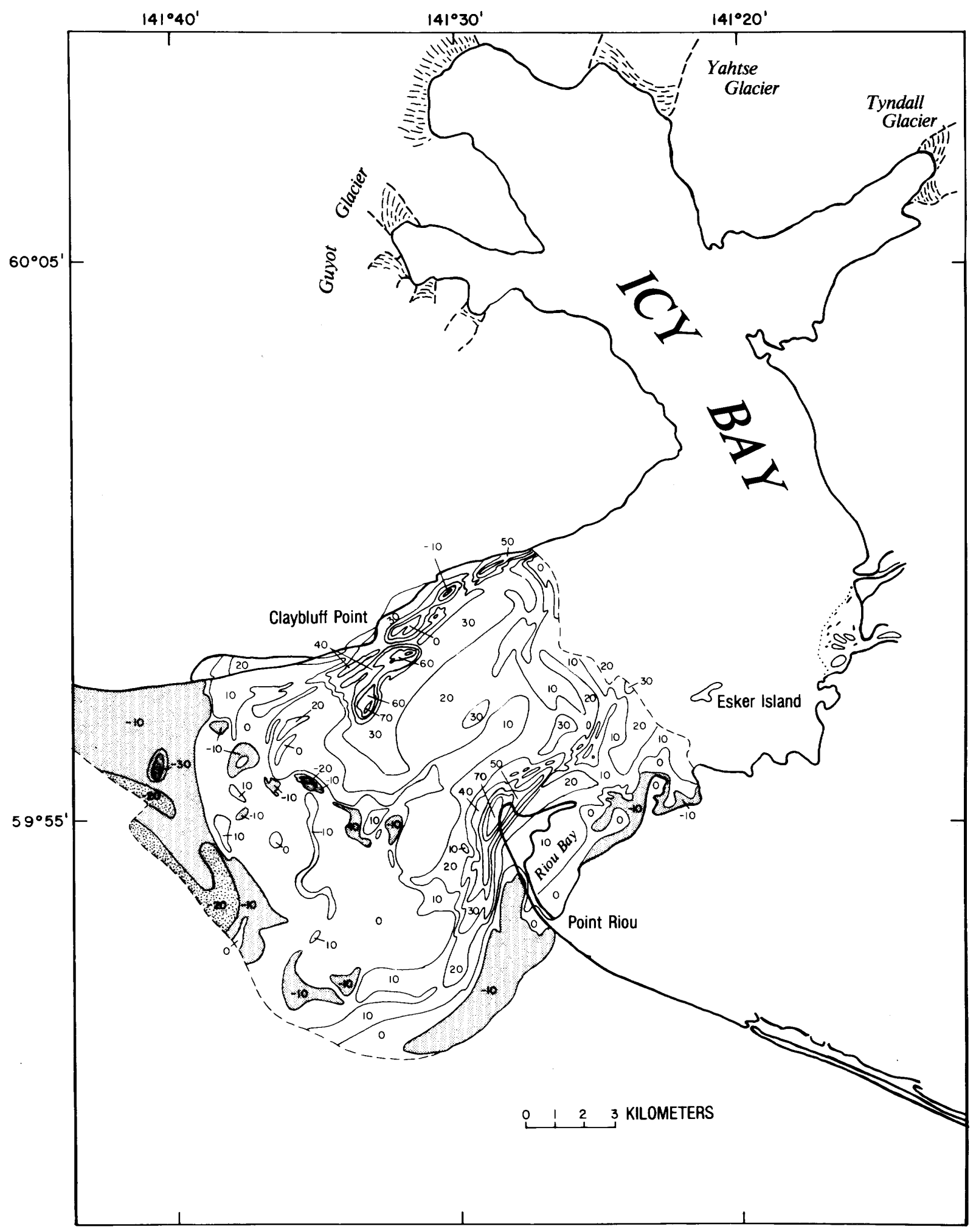

FIGURE 64.-Changes in depth between 1922 and 1976 in lower basin of Icy Bay. Maximum changes are shoaling (positive values) of more than $70 \mathrm{~m}$ and deepening (negative values shaded) of more than $30 \mathrm{~m}$. Much deepening results from melting of ice-cored moraine of Guyot Glacier. This is not an isopach map, rather, it shows the magnitude of depth change at any location. Differences shown in meters with $10 \mathrm{~m}$ between isopleths. 
in lower Icy Bay. Over $2.7 \mathrm{~km}^{3}$ of sediment has accumulated in the lower basin between 1922 and 1976. On the east side of the bay, ridges on Point Riou Spit, reaching elevations of more than $5 \mathrm{~m}$ above sea level, occupy an area that was more than $75 \mathrm{~m}$ below sea level in 1922 . Shoaling of similar magnitude has occurred at Claybluff Point on the northwest side of the basin. Sediment being deposited in lower Icy Bay comes from two sources: (1) longshore transport from the east, which contributes sediment from Malaspina Glacier distributaries, and (2) Tyndall, Yahtse, and Guyot Glaciers at the head of the bay, which contribute huge quantities of fine-grained suspended sediment and coarser material. Maximum sedimentation rates in the upper bay exceed 2 $\mathrm{m} / \mathrm{yr}$ (Molnia, 1979) and exceed $1.4 \mathrm{~m} / \mathrm{yr}$ in the lower bay. The average sedimentation rate for the lower bay is $0.2 \mathrm{~m} / \mathrm{yr}$.

Tectonic uplift and isostatic readjustment are other possible mechanisms that may have created base level changes between the 1922 and 1976 1977 surveys, although neither is offered as an explanation for depth changes observed. Using the rate of uplift from Hudson, Plafker, and Rubin (1976) for this region $(0.5 \mathrm{~cm} / \mathrm{yr})$ and assuming isostatic readjustment at the same rate, a maximum of $0.54 \mathrm{~m}$ of basin-wide shoaling may have occurred during the period of study. This represents less than 5 percent of the total observed changes and leads me to conclude that the observed basin changes mainly are due to sedimentation and melting of the ice-cored moraine.

It is not known how much ice, if any, still exists in the submarine ice-cored moraine or how much additional deepening may occur at the bay mouth. If sedimentation continues, however, at the average rate of the 54-year period between bathymetric surveys, then much of the lower basin of Icy Bay will shoal to near sea level in the next few centuries. A similar depositional regime filled Vancouver's Icy Bay, a nearby fiord, in the early nineteenth century (Molnia, 1977, 1979).

\section{REFERENCES CITED}

Hudson, Travis, Plafker, George, and Rubin, Meyer, 1976, Uplift rates of marine terrace sequences in the Gulf of Alaska: U.S. Geological Survey Circular 733, p. 11-13.

Molnia, B. F., 1977, Rapid shoreline erosion at Icy Bay, Alaska-a staging area for offshore petroleum develop- ment: Offshore Technology Conference, Houston, Texas, Proceedings, v. 4, p. 115-126.

- 1979, Sedimentation in coastal embayments, northeastern Gulf of Alaska: Offshore Technology Conference, Houston, Texas, Proceedings, v. 1, p. 665-676.

Benthic foraminifers as indicators of the Pleistocene-Holocene boundary in the eastern Gulf of Alaska

By Paula Quinterno, Paul R. Carlson, and Bruce F. Molnia

Benthic foraminifers analyzed from five gravity cores and two dart cores from the eastern Gulf of Alaska (fig. 65) indicate that the PleistoceneHolocene boundary occurs at shallow depth within four of the cores $(17,18,359$, and 302$)$; the three other cores $(14,15$, and 16) may be Holocene throughout. Faunas in the lower sections of cores 17,18 , and 359 and throughout core 302 differ from those in the upper sections (table 16). Smith (1963) noted a similar change in faunas with depth in three cores collected from southwest of Kodiak Island (table 17) and suggested that the change in faunas might mark the PleistoceneHolocene boundary in the sediments.

Trifarina angulosa, Astrononion gallowayi, Bolivina decussata, Epistominella pacifica, and Uvigerina spp. are most abundant in the upper sections of cores 17,18 , and 359 . The lower sections of the cores and the sample from core 302 have higher percentages of Buccella and Elphidium clavatum, which are characteristic of shallower, more nearshore conditions than are the assemblages found in the tops of the cores (table 16). One possible explanation for the faunal change with depth in the cores may be that the sediments in the lower core sections were deposited during the Pleistocene when sea level was lower.

In some parts of core 14 and the top of core 15, more than 25 percent of the foraminifers are $\mathrm{El}$ phidium clavatum and 5 percent or more are Buccella (table 18). These shallow-water faunas, however, may be Holocene rather than Pleistocene, as seismic profiles show a thick wedge of Holocene sediment that probably has not been completely penetrated by these cores (fig. 65C). This shallow-water fauna may be present owing to downslope displacement. For example, high abundances of Elphidium and Buccella occur in sand layers in core 14 (table 18). Because Holocene sand is generally restricted to the inner shelf in the northeastern Gulf of Alaska (Carlson and others, 1977), the occurrence of shallow- 
water Elphidium and Buccella in sand layers in a core beneath $295 \mathrm{~m}$ of water is evidence for downslope displacement.

Although core 15 has fairly high abundances of Elphidium and Buccella, fragile specimens of Fursenkoina dominate the fauna ( 30 percent), which also contains Seabrookia. The occurrence of these four species together is unusual because the fragile Fursenkoina and Seabrookia generally occur in deeper water than do Elphidium and Buccella. Their occurrence together suggests mixing by downslope displacement.

Seismic data from the eastern Gulf of Alaska support the benthic foraminiferal evidence for the Pleistocene-Holocene boundary at shallow depth below the seafloor. Holocene sediment, mainly
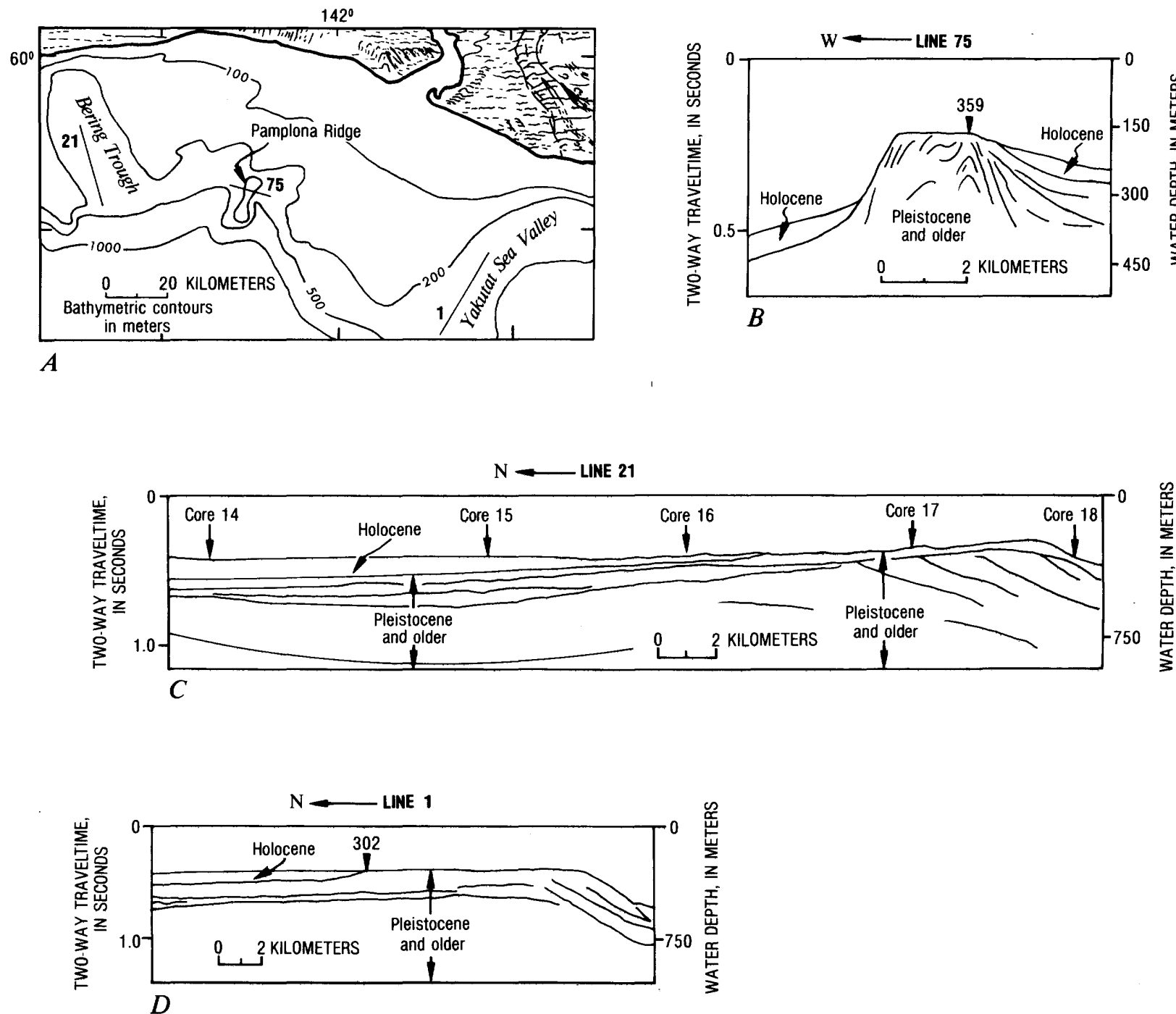

FIGURE 65.-Location map and line drawings of seismic profiles. $A$, Location map showing track lines 75,21 , and 1 along which seismic profiles were obtained. $B$, Line drawing of high resolution $400 \mathrm{~J}$ mini-sparker record along Pamplona Ridge. The ridge appears to be nearly devoid of Holocene sediment. $C$, Line drawing of seismic reflection record ( 40 in. ${ }^{3}$ air gun) down Bering Trough showing pinch out of Holocene sediments at the seaward end. $D$, Line drawing of seismic reflection record ( $40 \mathrm{in}^{3}$ air gun) down the axis of Yakutat Sea Valley showing pinch out of Holocene sediments at the seaward end. 
clayey silt, thins toward the seaward extremes of Bering Trough and Yakutat Sea Valley and is thin or absent on the crest of Pamplona Ridge (fig. $65 B, C$, and $D)$. Although figure 65 shows no Holocene sediment at stations 17,18 , and 359 , a thin layer, as much as $1 \mathrm{~m}$ thick, may exist, as indicated on table 16. This apparent discrepancy is a result of the inability to resolve thicknesses of less than about $2 \mathrm{~m}$ on seismic profiles.

\section{REFERENCES CITED}

Carlson, P. R., Molnia, B. F., Kittelson, S. C., and Hampson, J. C., Jr., 1977, Map of distribution of bottom sediments on the continental shelf, northern Gulf of Alaska: U.S. Geological Survey Miscellaneous Field Studies Map MF876,2 sheets.

Smith, P. B., 1963, Possible Pleistocene-Recent boundary in the Gulf of Alaska, based on benthonic foraminifera, Article 78 in U.S. Geological Survey Professional Paper 475-C, p. C73-C77.

TABLE 16.-Percentage distribution of benthic foraminifers from the eastern Gulf of Alaska

[Except for Fursenkoina and Seabrookia, only those species recorded by Smith (1963), and which were also found in this study, are listed in this table.]

\begin{tabular}{|c|c|c|c|c|c|c|c|c|c|c|c|c|c|}
\hline \multirow[b]{3}{*}{ Depth in core $(\mathrm{cm})$} & \multicolumn{7}{|c|}{ Core 17} & \multicolumn{3}{|c|}{ Core 18} & \multicolumn{2}{|c|}{ Core 359} & \multirow{3}{*}{$\frac{\text { Core } 302}{\text { Pleistocene (?) }}$} \\
\hline & \multicolumn{3}{|c|}{ Holocene } & \multicolumn{4}{|c|}{ Pleistocene (?) } & \multicolumn{2}{|c|}{ Holocene } & \multirow{2}{*}{$\frac{\text { Pleistocene(?) }}{100-102}$} & \multirow{2}{*}{$\frac{\text { Holocene }}{0-2}$} & \multirow{2}{*}{$\frac{\text { Pleistocene(?) }}{4-5}$} & \\
\hline & $0-2$ & $0-2$ & $10-12$ & 27 & $38-40$ & $66-68$ & $80-82$ & $0-2$ & $8-10$ & & & & \\
\hline Water depth $(\mathrm{m})$ & 265 & & & & & & & 315 & & & 163 & & 227 \\
\hline Sediment type-- & Mud & Sand & Gravel & $\begin{array}{l}\text { Gravelly } \\
\text { sand }\end{array}$ & $\begin{array}{l}\text { Sandy } \\
\text { gravel }\end{array}$ & Mud & $\begin{array}{l}\text { Gravelly } \\
\text { mud }\end{array}$ & $\begin{array}{l}\text { Sandy } \\
\text { grave1 }\end{array}$ & $\begin{array}{l}\text { Gravelly } \\
\text { sand }\end{array}$ & $\begin{array}{l}\text { Sandy } \\
\text { gravel }\end{array}$ & $\begin{array}{l}\text { Sandy } \\
\text { gravel }\end{array}$ & $\begin{array}{l}\text { Gravelly } \\
\text { sand }\end{array}$ & $\begin{array}{c}\text { Gravelly } \\
\text { sand }\end{array}$ \\
\hline
\end{tabular}

Species:

Trifarina angulosa-------

Astrononion gallowayi-...

Bolivina decussata----.--

Epistominella pacifica---

Globobulimina auriculata-

Pseudononion auricula---

Svigerina spp.

Seabrookia sp.----------

Fursenkoina sp.

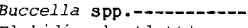

Elphidium bartletti----

Florilus Iabradoricus---

Other species--.--.---

$\begin{array}{rrr}2 & 1 & 10 \\ 2 & - & - \\ - & - & - \\ 3 & 15 & 3 \\ 2 & - & 1 \\ 1 & 1 & - \\ 4 & 4 & 5 \\ 5 & - & - \\ - & - & - \\ - & 1 & 2 \\ - & - & - \\ 5 & 14 & 1 \\ 3 & 2 & - \\ 73 & 62 & 78\end{array}$

18
1
9
-
-
5
1
-
-
-
66

$\begin{array}{rr}- & - \\ - & - \\ - & - \\ - & 2 \\ 1 & - \\ - & - \\ - & - \\ - & - \\ 2 & 1 \\ - & - \\ 16 & 27 \\ 5 & 14 \\ 76 & 56\end{array}$

Number of specimens

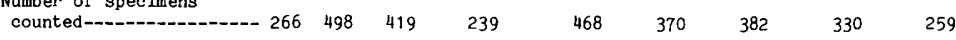

$\begin{array}{rr}10 & 1 \\ 2 & 1 \\ 8 & - \\ - & - \\ - & - \\ - & - \\ - & - \\ - & - \\ 1 & - \\ - & - \\ - & - \\ 75 & 76\end{array}$

\begin{tabular}{rr}
1 & 18 \\
1 & 2 \\
- & 6 \\
- & - \\
- & - \\
- & - \\
- & - \\
\hline- & - \\
- & - \\
8 & - \\
76 & 71
\end{tabular}

$\begin{array}{rl}18 & 4 \\ 2 & - \\ 6 & 2\end{array}$

$-$

$-$

(1)

-

TABLE 17.-Percentage distribution of benthic foraminifers from southwest of Kodiak Island

[Only those species that were found in both Smith's study and the present study are listed in this table.]

\begin{tabular}{|c|c|c|c|c|c|c|c|c|c|c|c|c|}
\hline \multirow[b]{2}{*}{ Depth in core $(\mathrm{cm})$} & \multicolumn{3}{|c|}{ Holocene } & \multicolumn{9}{|c|}{ Pleistocene(?) } \\
\hline & $0-2$ & $2-14$ & $14-26$ & $26-29$ & $29-32$ & $41-42$ & $51-52$ & $60-62$ & $71-72$ & $81-82$ & $91-92$ & $101-102$ \\
\hline Water depth (m) - & 240 & & & & & & & & & & & \\
\hline Sediment type --n--n--n--- & Sand & & & & & & & & & & & \\
\hline
\end{tabular}

Species:

Trifarina angulosa-------Astrononion gallowayi----Bolivina decussata----.--Epistominella pacifica---Globobulimina, auriculata-Pseudononion auricula----Uvigerina spp.----------Buccella spp.-----------Elphidium bartletti------Elphidium clavatum-------Florilus labradoricus-----

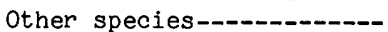

5
-
95
-
-
19
-
-
-
-
22

$\begin{array}{rccc}23 & 30 & 8 & 5 \\ 1 & 2 & - & - \\ 4 & 1.5 & 6 & 6 \\ 12 & 7 & - & - \\ - & - & - & - \\ - & - & - & 1 \\ 28 & 30 & 1 & - \\ 1.5 & 1 & 4 & 8 \\ - & - & 1.5 & 5 \\ - & - & 10 & 12 \\ 1 & - & - & - \\ 29.5 & 28.5 & 69.5 & 63\end{array}$

$\begin{array}{rcr}- & - & - \\ - & - & - \\ - & - & - \\ 1 & 1 & 1 \\ - & - & - \\ - & - & - \\ - & - & - \\ 2 & 3.5 & 5 \\ 2 & 7 & 6 \\ 30 & 30 & 26 \\ 6.5 & 3.5 & 4 \\ 58.5 & 55 & 58\end{array}$

-
-
-
-
-
-
-
3
6
40
-
51

$\begin{array}{ll}- & \\ - & \\ - & \\ - & \\ - & \\ - & \\ - & \\ 5 & \\ 4.5 & 32 \\ 13 & \\ 2 & \\ 75.5 & 56\end{array}$

-
-
-
-
-
-
-
4.5
5.5
31
2
57
460

Number of specimens

counted----- 
Unusually diverse and well preserved Eocene foraminifers in dredge samples from the eastern Gulf of Alaska continental slope

By Weldon W. Rau ${ }^{1}$

Ten samples dredged from outcrops on the continental slope in the eastern Gulf of Alaska contain unusually diverse and well preserved assemblages of Eocene foraminifers (table 19). The samples were collected during 1979 by the R.V. Sea Sounder as part of the U.S. Geological Survey's program to evaluate the petroleum potential of the outer continental shelf in the vicinity of Lease Sale 55, planned for the latter part of 1980 ( table 20; fig. 66). Eight samples (S10-79-EG-24, $34,36,37,38,39,41$, and 43 ) are from an area approximately $125 \mathrm{~km}$ southwest of Yakutat. Faunas previously discussed from 1978 collections (S5-78-EG-43 and 44) came from this same general area (Rau, 1979). Two additional 1979 sam-

${ }^{1}$ Washington State Department of Conservation ples (S10-79-EG-20 and 21) are from an area about $100 \mathrm{~km}$ southwest of Lituya Bay.

This paper lists the foraminiferal faunas in the 10 samples and discusses their implications for the age and depositional environment of the containing strata. These strata are of considerable interest for their petroleum potential because they contain both potential source and reservoir rocks and because they dip northward beneath the segment of the outer continental shelf where Lease Sale 55 is scheduled for late 1980 (Plafker and others, 1979).

The assemblages generally can be divided into two groups with respect to age-those indicative of either an early or middle Eocene age and those indicative of a late Eocene age.

Early or middle Eocene assemblages occur in samples S10-79-EG-20, 21, 34, and 41. Nearly all taxa are well known in early and middle Eocene strata of California, Oregon, and Washington. Samples 20 and 21 have yielded unusually diverse assemblages (table 19) and are therefore particularly diagnostic of age. Both assemblages are in-

TABLE 18.-Percentage distribution of benthic foraminifers from Bering Trough

[Asterisk indicates that sample was nearly barren of foraminifers. Except for Fursenkoina and Seabrookia, only those species recorded by Smith (1963), and that were also found in this study, are listed in this table.]

\begin{tabular}{|c|c|c|c|c|c|c|c|c|}
\hline \multirow{3}{*}{$\begin{array}{l}\text { Depth in core }(\mathrm{cm}) \\
\text { Water depth }(\mathrm{m})\end{array}$} & \multicolumn{6}{|c|}{ Core 14} & \multirow{2}{*}{$\frac{\text { Core } 15}{0-2}$} & \multirow{2}{*}{$\frac{\text { Core } 16}{50-52}$} \\
\hline & $0-2$ & $20-22$ & $48-50$ & $68-70$ & $88-90$ & $94-95$ & & \\
\hline & \multicolumn{6}{|l|}{295} & 307 & 303 \\
\hline 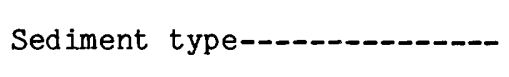 & Mud & Sand & Mud & Mud & $\begin{array}{l}\text { Fine } \\
\text { sand }\end{array}$ & $\begin{array}{l}\text { Fine } \\
\text { sand }\end{array}$ & Mud & Mud \\
\hline \multicolumn{9}{|l|}{ Species: } \\
\hline Trifarina angulosa---------- & 2 & - & - & - & - & - & - & - \\
\hline Astrononion gallowayi-- & 2 & - & - & - & 3 & - & - & - \\
\hline Bolivina decussata---------- & 1 & - & - & - & - & - & - & - \\
\hline Epistominella pacifica----- & 1 & 1 & - & - & - & - & 2 & 1 \\
\hline Globobulimina auriculata---- & 2 & - & - & - & - & - & 2 & - \\
\hline Pseudononion auricula------- & 1 & - & - & - & - & - & - & - \\
\hline Uvigerina spp.--_-_-_-_--_- & 1 & - & - & - & - & - & - & - \\
\hline Seabrookia sp.-- & 4 & - & - & - & - & - & 2 & 7 \\
\hline Fursenkoina sp.----- & 2 & - & - & - & - & - & 30 & 1 \\
\hline Buccella spp.-- & 1 & 14 & - & - & 18 & 17 & 5 & - \\
\hline Elphidium bartletti--------- & - & 5 & $33^{*}$ & - & - & 2 & - & - \\
\hline Elphidium clavatum---------- & - & 55 & - & $100 *$ & 38 & 25 & 13 & 2 \\
\hline Florilus labradoricus------- & - & - & - & - & - & - & - & 1 \\
\hline Other species------------- & 83 & 25 & 67 & 0 & 41 & 56 & 46 & 88 \\
\hline $\begin{array}{l}\text { Number of specimens } \\
\text { counted- }\end{array}$ & 350 & 155 & 3 & 2 & 78 & 48 & 40 & 390 \\
\hline
\end{tabular}


dicative of an age no younger than the middle Eocene Ulatisian Stage of Mallory (1959). Although these two assemblages may be coeval, the assemblage from sample 21 contains faunal evidence of an age no younger than the early Eocene Penutian stage. Silicosigmoilina californica, Siphonia cf. S. wilcoxensis, and several planktonic species are among taxa that are known to range from the Paleocene, to no higher than the early Eocene Penutian Stage.

The assemblage from sample 41 , although less diverse, is comparable in composition to faunas from samples 20 and 21 . The combined range of species in sample 41 suggests an age no older than the early Eocene Penutian Stage and no younger than the middle Eocene Ulatisian Stage.

TABLE 19.-Foraminifers in outcrop samples dredged from the continental slope, eastern Gulf of Alaska

[R - rare; F - few; C - common; ? - questionably identified.]

\begin{tabular}{|c|c|c|c|c|c|c|c|c|c|c|}
\hline \multirow{2}{*}{ Species } & \multicolumn{10}{|c|}{ S10-79-EG } \\
\hline & 20 & 21 & 24 & 34 & 36 & 37 & 38 & 39 & 41 & 43 \\
\hline Amphimorphina ignota Cushman and Siegfus--- & - & - & - & - & - & $\mathrm{R}$ & - & - & - & - \\
\hline Amphistegina cf. A. californica Cushman and M. A. Hanna-- & - & - & - & $\mathrm{C}$ & - & - & - & - & - & - \\
\hline Angulogerina hannai Beck-- & - & - & - & - & - & $\mathrm{R}$ & - & R & - & - \\
\hline Anomalina aff. A. garzaensis Cushman and Siegfus----- & - & - & - & - & $\mathbf{F}$ & - & - & - & - & $\mathbf{R}$ \\
\hline Anomalina dorri aragonensis Nuttal1--1- & $\mathbf{F}$ & - & - & - & - & - & - & - & - & - \\
\hline Anomalina regina minor Smith- & $\mathrm{R}$ & - & - & - & - & - & - & - & - & - \\
\hline Asterigerina crassaformis Cushman and Siegfus----------- & $\mathrm{R}$ & - & - & - & - & - & - & - & - & - \\
\hline Bulimina cf. B. callahani Galloway and Morrey----------- & - & - & - & - & - & - & - & - & $\mathrm{R}$ & - \\
\hline Bulimina corrugata Cushman and Siegfus------ & - & $\mathrm{F}$ & - & - & - & $\mathrm{F}$ & - & - & - & $\mathrm{F}$ \\
\hline Bulimina cf. B. curtissima Cushman and Siegfus---------- & - & - & - & - & - & $\mathrm{R}$ & - & $\mathrm{R}$ & - & $\mathbf{R}$ \\
\hline Bulimina microcostata Cushman and Parker---------------- & - & - & - & - & C & $\mathbf{R}$ & - & $\mathrm{R}$ & - & - \\
\hline Bulimina cf. B. pachecoensis Smith---- & $\mathrm{R}$ & $\mathrm{R}$ & - & - & - & $\mathbf{F}$ & - & - & - & - \\
\hline Bulimina cf. B. Schencki Beck-----m-- & $\mathrm{R}$ & - & - & - & - & - & - & - & - & - \\
\hline Buliminella sp.--n- & $\mathrm{R}$ & - & - & - & - & - & - & - & - & - \\
\hline 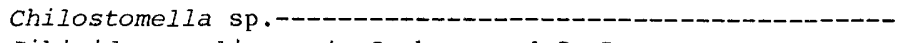 & $\mathrm{F}$ & $\mathbf{R}$ & - & - & - & - & $\mathrm{R}$ & $\mathrm{R}$ & $\mathbf{R}$ & - \\
\hline Cibicides coalingensis Cushman and G. D. Hanna--------- & $\mathbf{R}$ & - & - & - & - & - & - & - & - & - \\
\hline Cibicides eponidiformis Martin-- & - & $\mathrm{F}$ & - & - & - & - & - & - & - & - \\
\hline Cibicides hodgei Cushman and Schenck-- - - - - - --------- & - & - & - & - & $\mathbf{F}$ & - & - & - & - & - \\
\hline Cibicides cf. C. laimingi Nuttal1- & - & - & - & - & - & - & - & - & $\mathrm{R}$ & $\mathbf{R}$ \\
\hline Cibicides martinezensis Cushman and Barksdale----------- & $\mathrm{R}$ & $\mathrm{F}$ & - & - & - & - & - & - & - & - \\
\hline Cibicides cf. C. pseudowuellerstorfi Cole---n & $\mathrm{F}$ & - & - & - & - & - & - & - & - & $\mathrm{F}$ \\
\hline Cibicides venezuelanus Nuttall- & $\mathrm{F}$ & $\mathrm{F}$ & - & - & - & F & - & - & $\mathbf{R}$ & - \\
\hline 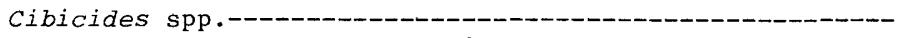 & R & - & - & $\mathbf{R}$ & - & $\mathrm{R}$ & $\mathbf{R}$ & - & $\mathbf{R}$ & $\mathbf{R}$ \\
\hline Dentalina cf. D. consobrina d'Orbigny-------- & - & - & $\mathbf{F}$ & - & $\mathbf{F}$ & - & C & $\mathbf{R}$ & - & $\mathbf{F}$ \\
\hline Dentalina spp.-----n- & $\mathrm{R}$ & $\mathbf{F}$ & - & - & - & - & $\rightarrow$ & - & - & - \\
\hline 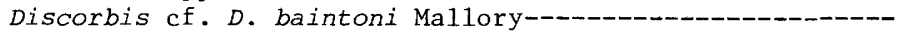 & $\mathrm{R}$ & $\mathrm{R}$ & - & - & - & - & - & - & - & - \\
\hline Dorothia oxycona (Reuss) & $\mathbf{F}$ & $\mathrm{F}$ & - & - & - & - & - & - & - & - \\
\hline Dorothia principiensis Cushman and Bermudez------------- & $\mathrm{R}$ & - & - & - & - & - & - & - & - & - \\
\hline Epistomina eocenica Cushman and M. A. Hanna-------------- & $R$ & - & - & - & - & - & - & - & - & - \\
\hline Eponides mexicanus (Cushman)- & $F$ & - & - & - & - & - & - & - & - & - \\
\hline 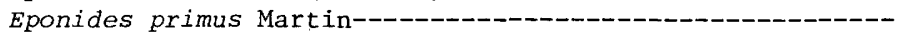 & - & $\mathrm{R}$ & - & - & - & - & - & - & - & - \\
\hline 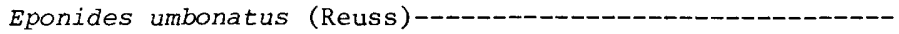 & $\mathrm{R}$ & $\mathrm{R}$ & - & - & - & - & - & $\mathrm{R}$ & $\mathbf{R}$ & - \\
\hline Gaudryina coalingensis Cushman and Hanna-------------- & F & $\mathrm{R}$ & - & - & - & - & - & - & - & - \\
\hline 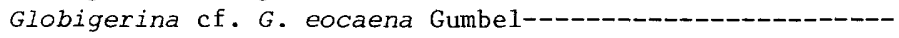 & - & $\mathbf{R}$ & - & - & - & - & - & - & - & - \\
\hline Globigerina cf. G. Iinaperta Finlay--------ー------------ & C & F & - & - & - & - & - & - & - & - \\
\hline Globigerina cf. G. primitiva (Finlay)-- & $\mathrm{C}$ & C & - & - & - & - & - & - & - & - \\
\hline Globigerina spp.------- & - & - & R & $\mathbf{R}$ & - & $\mathrm{R}$ & - & $\mathrm{C}$ & $\mathbf{F}$ & F \\
\hline Globobulimina pacifica oregonensis Cushman, Stewart, & & & & & & & & & & \\
\hline and Stewart--n--1-n- & - & - & $\overline{-}$ & - & $\overline{-}$ & - & $F$ & $\mathbf{F}$ & - & $\overline{-}$ \\
\hline Globocassidulina globosa (Hantken)- & - & - & C & - & $\mathbf{F}$ & - & - & - & - & $\mathbf{R}$ \\
\hline Globorotalia cf. $G$. aequa Cushman and Renz---- & - & $\mathrm{R}$ & - & - & - & - & - & - & - & - \\
\hline Globorotalia aragonensis Nuttal1- & $\mathbf{F}$ & C & - & $?$ & - & - & - & - & - & - \\
\hline Globorotalia planoconica Subbotina----- & - & $\mathrm{F}$ & - & - & - & - & - & - & - & - \\
\hline Guttulina sp. & - & - & - & $\mathrm{R}$ & - & - & - & - & - & - \\
\hline
\end{tabular}


The fauna of sample 34 is composed largely of Amphistegina cf. A. californica. In Pacific Coast Tertiary sequences, this taxon is known to be confined largely to the middle Eocene Ulatisian Stage and is most common in the upper part of the stage. Although not positively identified, Globorotalia aragonensis may also be present.
This species also indicates an age no younger than middle Eocene.

Shallow, warm-water conditions, perhaps at depths less than $50 \mathrm{~m}$, are suggested by the common occurrence of $A$. californica in sample 34 . However, deeper and colder water conditions are suggested by the composition of assemblages

TABLE 19.-Foraminifers in outcrop samples dredged from the continental slope, eastern Gulf of Alaska-Continued

S10-79-EG

Sample nos.

Species

$\begin{array}{llllllllll}20 & 21 & 24 & 34 & 36 & 37 & 38 & 39 & 41 & 43\end{array}$

Gyroidina condoni (Cushman and Schenck)---------Gyroidina soldanii d'Orbigny-

Lenticulina cf. L. Coaledensis Detling-

Lenticulina cf. L. inornatus d'Orbigny

Lenticulina cf. L. limbosus hockleyensis (Cushman

and Applin)-

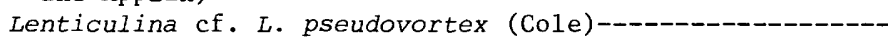

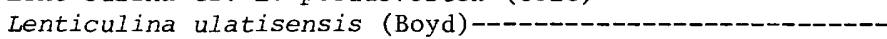

Lenticulina welchi (Church)--

Lenticulina spp.--

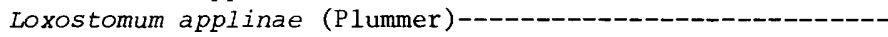

Marginulina cf. M. eximia Neugeboren--_--_-_-_-------

Marginulina subbullata Hantken-

Martinottiella cf. M. eocenica Cushman and Bermudez--.---

Nodosaria deliciae Martin--_-

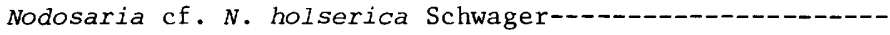

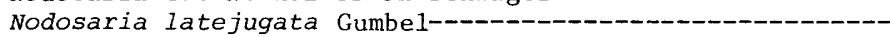

Nodosaria longiscata d'Orbigny--

Nodosaria cf. N. pyrula d'Orbigny-_-_-_-

Planularià markleyana Church---------------------------

Planularia cf. $P$. truncana (Gumbel)

Plectofrondicularia cf. P. kerni Cook-------------------

Plectofrondicularia cf. P. searsi Cushman, Stewart,

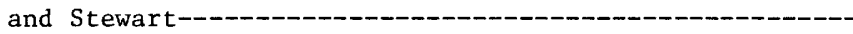

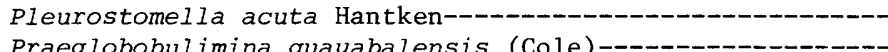

Praeglobobulimina guayabalensis (Cole)-
Pseudoglandulina inflata (Bornemann)--

Pseudoglandulina inflata (Bornemann)

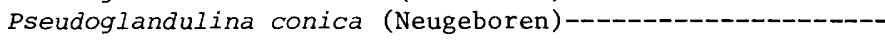

Pullenia cf. P. eocenica Cushman and Siegfus----------

Pullenia salisburyi R. E. and K. C. Stewart-----------

Silicosigmoilina californica Cushman and Church----------

Siphonina cf. S. wilcoxensis Cushman------

Spiroloculina cf. S. wilcoxensis Cushman and Garret------

Spiroplectammina richardi Martin-----------------------

Stilostomella cf. S. bradyi (Cushman)--

Stilostomella cf. S. nuttalli gracillima

(Cushman and Jarvis)

Trifarina advena californica Mallory---_-_-_-_-_-_-_-_-_-

Tritaxilina colei (Cushman and Siegfus)-----------------

Uvigerina garzaensis Cushman and Siegfus------------------

Uvigerina lodoensis miriamae Mallory-

Vaginulinopsis asperuliformis (Nutta11)------------------

Vaginulinopsis vacavillensis (Hanna) - mexicana

var. A and B of Laiming----_---

Valvulineria jacksonensis welcomensis Mallory--
Valvulineria tumeyensis Cushman and Simonson---

- -

F

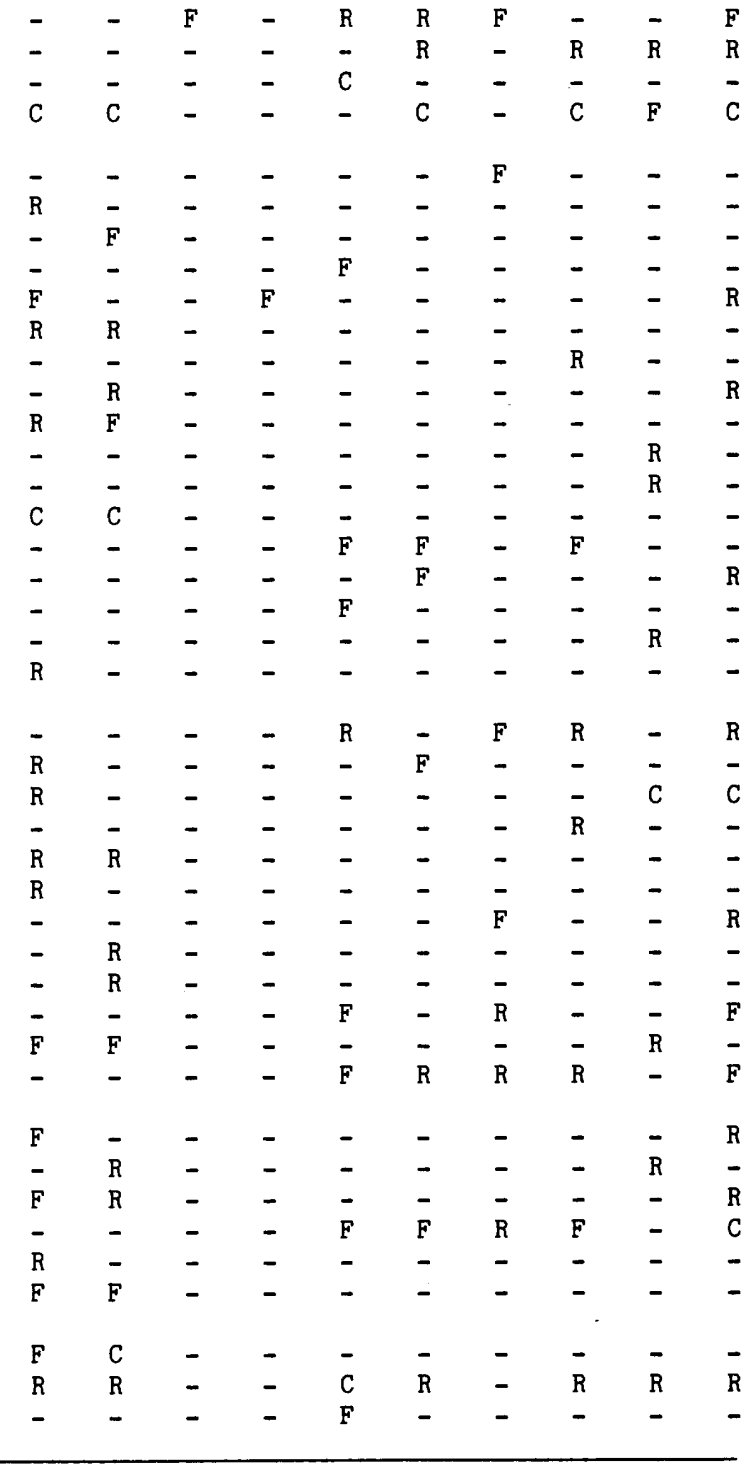


from samples 20,21 , and 41 . The combined occurrence of a variety of arenaceous taxa, abundant Lenticulina in addition to robust and heavily costate lagenids, suggests upper slope to outer shelf environments, perhaps as deep as from 100 to $1,000 \mathrm{~m}$. The general composition and diversity of benthonic taxa in assemblages from samples 20,21 , and 41 suggest that water temperatures. during deposition were cool to temperate. The common occurrence and variety of planktonic foraminifers suggest good circulation of currents in a relatively warm open sea.

The late Eocene assemblages from samples S10-79-EG-24, 36, 37, 38, 39, and 43 contain taxa that are well known in late Eocene strata of California, Oregon, and Washington and are characteristic of the benthic foraminiferal Narizian Stage of Mallory (1959). Variations between individual assemblages suggest stratigraphic positions ranging through the stage.

Sample 43 contains elements of two distinct assemblages; one that is well preserved characterizes an upper part of the Narizian Stage, and the other, not so well preserved, characterizes a lower part of the stage or possibly the Ulatisian Stage. Because this material is from a single piece of rock, the two assemblages did not result from mixing of materials in the dredge haul. More

TABLE 20.-Coordinates for samples dredged from eastern Gulf of Alaska continental shelf

[Depths indicate start and finish of dredge casts.]

\begin{tabular}{|c|c|c|c|}
\hline Sample No. & $\begin{array}{c}\text { Water } \\
\text { depth (m) }\end{array}$ & Latitude & Longitude \\
\hline S10-79-EG-20 & $\begin{array}{r}2040 \\
650\end{array}$ & $\begin{array}{l}58^{\circ} 12.90^{\prime} \\
58^{\circ} 13.25^{\prime}\end{array}$ & $\begin{array}{l}139^{\circ} 03.61^{\prime} \\
139^{\circ} 02.40^{\prime}\end{array}$ \\
\hline 21 & $\begin{array}{l}735 \\
295\end{array}$ & $\begin{array}{l}58^{\circ} 19.04^{\prime} \\
58^{\circ} 20.16^{\prime}\end{array}$ & $\begin{array}{l}139^{\circ} 28.74^{\prime} \\
139^{\circ} 27.10^{\prime}\end{array}$ \\
\hline 24 & $\begin{array}{r}1340 \\
480\end{array}$ & $\begin{array}{l}58^{\circ} 35.99^{\prime} \\
58^{\circ} 38^{\prime} .33^{\prime}\end{array}$ & $\begin{array}{l}140^{\circ} 21.36^{\prime} \\
140^{\circ} 20.47^{\prime}\end{array}$ \\
\hline 34 & $\begin{array}{l}2405 \\
1600\end{array}$ & $\begin{array}{l}58^{\circ} 41.43^{\prime} \\
58^{\circ} 42.53\end{array}$ & $\begin{array}{l}140^{\circ} 58.30^{\prime} \\
140^{\circ} 56.51\end{array}$ \\
\hline 36 & $\begin{array}{l}930 \\
390\end{array}$ & $\begin{array}{l}58^{\circ} 44.03^{\prime} \\
58^{\circ} 46.11^{\prime}\end{array}$ & $\begin{array}{l}140^{\circ} 57.40^{\circ} \\
140^{\circ} 55.23^{\circ}\end{array}$ \\
\hline 37 & $\begin{array}{l}2870 \\
2560\end{array}$ & $\begin{array}{l}58^{\circ} 45.26^{\prime} \\
58^{\circ} 46.81^{\prime}\end{array}$ & $\begin{array}{l}141^{\circ} 12.25^{\prime} \\
141^{\circ} 10.24^{\prime}\end{array}$ \\
\hline 38 & $\begin{array}{l}2510 \\
1690\end{array}$ & $\begin{array}{l}58^{\circ} 47.48^{\prime} \\
58^{\circ} 48.79^{\prime}\end{array}$ & $\begin{array}{l}141^{\circ} 09.67^{\prime} \\
141^{\circ} 07.61^{\prime}\end{array}$ \\
\hline 39 & $\begin{array}{l}2125 \\
1470\end{array}$ & $\begin{array}{l}58^{\circ} 47.48^{\prime} \\
58^{\circ} 48.79^{\prime}\end{array}$ & $\begin{array}{l}141^{\circ} 09.67^{\prime} \\
141^{\circ} 07.61^{\prime}\end{array}$ \\
\hline 41 & $\begin{array}{l}2170 \\
1850\end{array}$ & $\begin{array}{l}58^{\circ} 43.37^{\prime} \\
58^{\circ} 43.72^{\prime}\end{array}$ & $\begin{array}{l}141^{\circ} 06.07^{\prime} \\
141^{\circ} 05.89^{\prime}\end{array}$ \\
\hline 43 & $\begin{array}{l}1980 \\
1518\end{array}$ & $\begin{array}{l}58^{\circ} 48.87^{\prime} \\
58^{\circ} 50.06^{\prime}\end{array}$ & $\begin{array}{l}141^{\circ} 10.31^{\prime} \\
141^{\circ} 08.84^{\prime}\end{array}$ \\
\hline
\end{tabular}

likely, an older assemblage was reworked and redeposited during the late Narizian.

All late Eocene assemblages suggest intermediate to deep-water deposition. The consistent occurrence of relatively deep-water taxa such as hispid uvigerinids, several species of Gyroidina, and finely costate buliminids, together with substantial numbers and variety of lagenids, suggest cold water at middle to upper slope depths perhaps ranging between 500 and $1,500 \mathrm{~m}$.

The assemblages of Eocene foraminifers documented above are unique in that they are the most diverse, well preserved, and age-diagnostic Eocene assemblages on record from the Gulf of Alaska. Additionally, although late Eocene foraminifers have previously been recorded from petroleum exploration wells and onshore outcrop areas in the Gulf of Alaska area, early or middle Eocene assemblages previously have been recorded only at depths of more than $3,000 \mathrm{~m}$ in the Middleton Island No. 1 well (Rau, 1979).

\section{REFERENCES CITED}

Mallory, V. S., 1959, Lower Tertiary biostratigraphy of the California Coast Range: Tulsa, Oklahoma, American Association of Petroleum Geologists, 416 p., 42 pls.

Plafker, George, Carlson, P. R., Coonrad, W. L., Hunt, S. J., and Quinterno, Paula, 1979, Geologic implications of 1978 outcrop sample data from the continental slope in the eastern Gulf of Alaska, in Johnson, K. M., and Williams, J. R., eds., The United States Geological Survey in Alaska: Accomplishments during 1978: U.S. Geological Survey Circular 804-B, p. B143-B146.

Rau, W. W., 1979, Unusually well preserved and diverse Eocene foraminifers in dredge samples from the eastern Gulf of Alaska continental slope, in Johnson, K. M., and Williams, J. R., eds., The United States Geological Survey in Alaska: Accomplishments during 1978: U.S. Geological Survey Circular 804-B, p. B139-B141.

Onshore and offshore studies, Amlia Island area, Aleutian Ridge By Jonathan R. Childs, David W. Scholl, and Tracy Vallier

Thick sedimentary deposits overlie the basement rocks of the Aleutian Ridge in the vicinity of Amlia Island (fig. 67). These sedimentary sequences record the tectonic development of the ridge during Cenozoic time and are prospects for oil and gas resources. In order to assess the economic potential of the sedimentary basins and to better understand the geologic history recorded in the associated igneous and sedimentary rocks, a joint offshore-onshore geologic and geophysical investigation was carried out in the 
Amlia Island area in June of 1979. The onshore and coastal work was conducted by Tracy Vallier, Hugh McLean, and Jim Hein, with the aid of guides from nearby Atka Village. The Geological Survey's research vessel Sea Sounder supported the onshore work and also provided the offshore geophysical surveys and rock dredging. Dave Scholl, Mike Marlow, Alan Cooper, Jon Childs, and Andy Stevenson directed the offshore investigations.

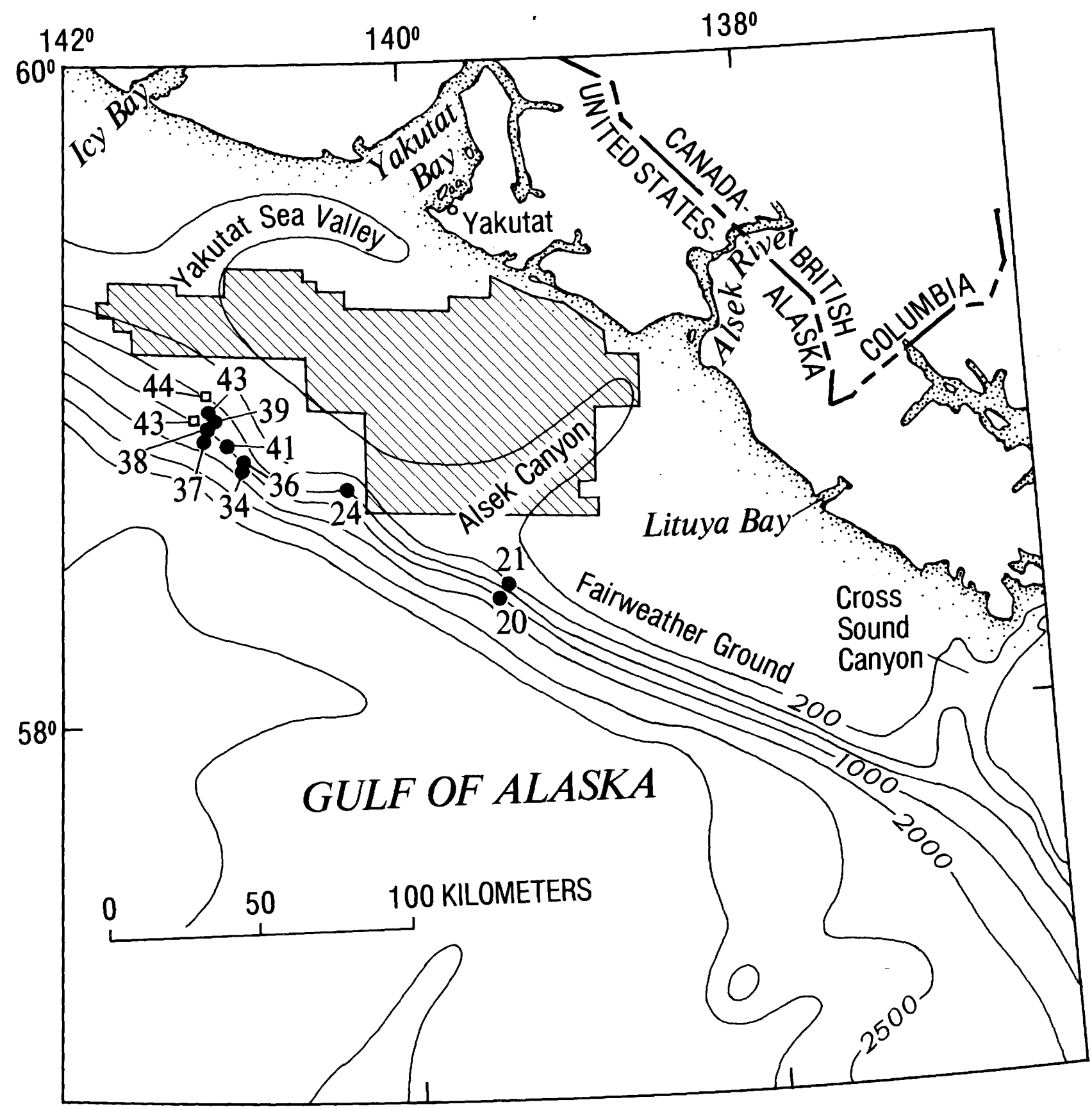

FIGURE 66.-Locations of dredged bedrock outcrop samples from eastern Gulf of Alaska outer continental shelf discussed in this Squares are 1978 samples; dots are 1979 samples. Hachured area is proposed outer continental shelf Lease Sale No. 55. 
Reconnaissance geologic mapping of Amlia Island indicates that the island is an uplifted segment of the Aleutian Ridge consisting of upper Eocene and lower Oligocene marine volcanic flow and volcaniclastic rocks, which are at least in part correlative with the older stratified rocks on nearby Atka Island. These Tertiary sequences are structurally simple with rare normal faults and

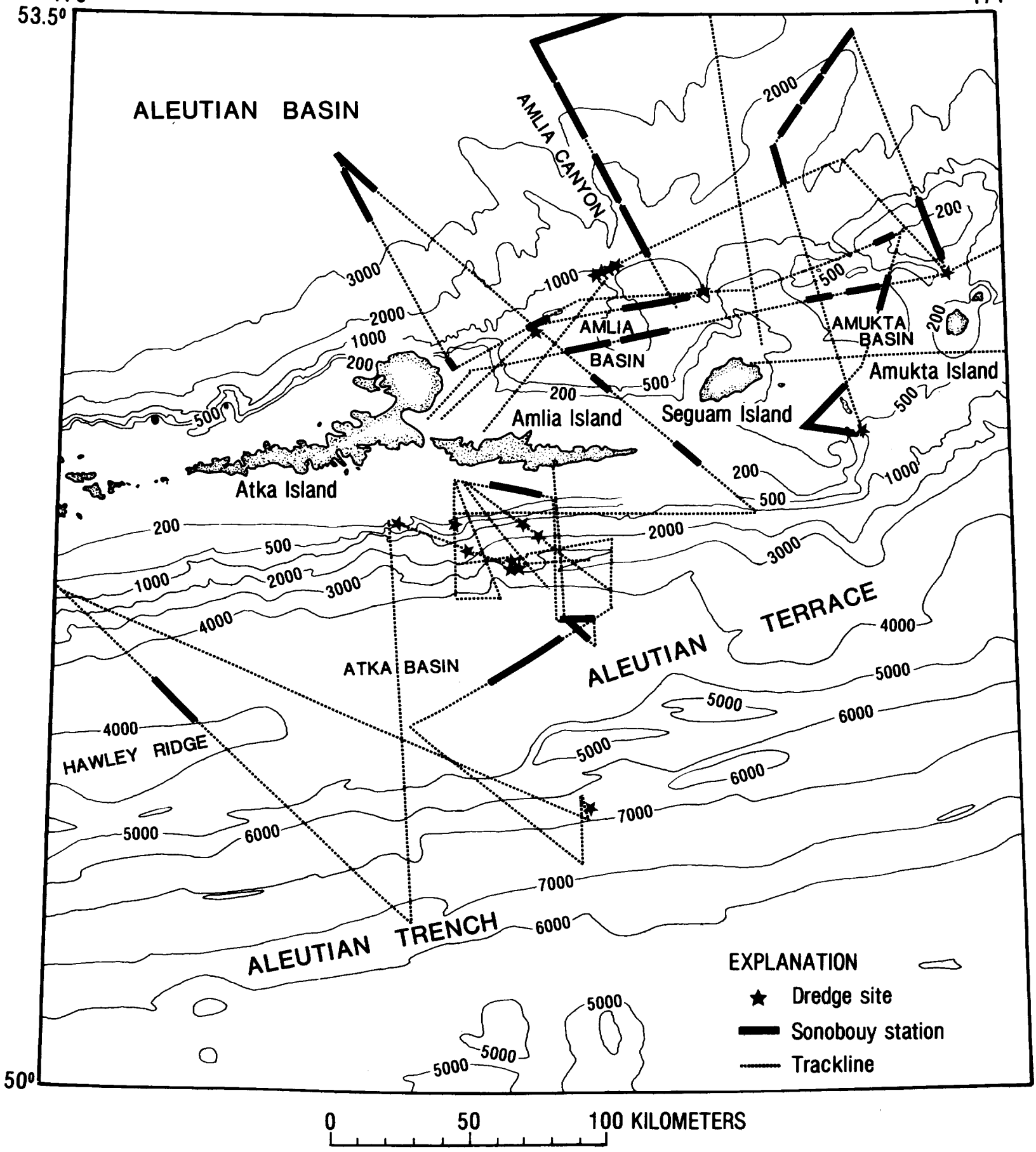

FIGURE 67.-Offshore geologic sampling locations, sonobuoy reflection/refraction lines, and geophysical tracklines in Amlia Island region. Bathymetric contours in meters. 
shallowly dipping strata. Two major rock units, apparently of the same age, were mapped. One is well exposed along the eastern coastline of the island and consists of green and gray andesitic flow and pyroclastic rocks. The other unit is best exposed on the western part of the island and is composed of interbedded andesites, basalts, and shallow-water marine volcaniclastic rocks. Pillow lavas are common in this unit, and many of the clastic rocks were deposited in submarine channels. Low-grade metamorphism and diagnesis have produced the secondary minerals prehnite, pumpellyite, albite, and smectite, as well as several zeolites including laumontite, clinoptilite, mordenite, stilbite, and natrolite. All of these minerals suggest low temperature and pressure conditions of formation.

In the vicinity of Amlia Island, the crestal area of the Aleutian Ridge is underlain by two structural basins, Amlia and Amukta basins (fig. 67). These basins are grabens of presumed late Cenozoic age (Scholl and others, 1975), but little is known about the thickness and age of their sedimentary sections. Offshore geophysical investigations were therefore directed toward determining the thickness and structure of the deposits filling the basins and the geometry and geophysical characteristics of the basement rocks exposed on Amlia Island and in submarine canyons cutting the flanks of the ridge. Offshore geological work was principally rock dredging in areas where seismic reflection profiles revealed outcrops of key subsurface units (fig. 67).

An exceptionally thick (greater that $4 \mathrm{~km}$ ) section of sedimentary rock also underlies Atka basin, which forms part of the Aleutian Terrace, an immense forearc basin located midway between the crest of the ridge and the Aleutian Trench to the south. Geophysical data were gathered over this basin to learn more about the internal geometry and thickness of the sedimentary sequence. Dredging was carried out along the southern flank of the ridge adjacent to Amlia Island to determine the age and lithology of the sedimentary and igneous rocks associated with Atka basin.

The geophysical data collected include shipboard gravity, magnetics, and sonobuoy reflection/refraction lines. In total, 40 sonobuoy stations were run, including those shown in figure 67 and five others over Umnak Plateau to the north- east. Preliminary sonobuoy results over Amlia and Amukta basins indicate sediment cover of at least 1 to $2 \mathrm{~km}$, underlain by high-velocity (basement?) refractor ( 3.8 to $4.5 \mathrm{~km} / \mathrm{s}$ ). The magnetic data suggest shallow magnetic sources; the basins are characterized by a series of east-trending positive anomalies (100-600 gammas), with negative gradients to the north and south. This positive trend is cut by a negative anomaly over Amlia Canyon. Interpretation of free-air gravity anomalies over these basins, as well as magnetic depth-tobasement calculations and modeling is in progress.

Preliminary examination of offshore seismic reflection profiles indicates that the sedimentary sequences in Amlia and Amukta basins are slightly deformed. Folds and high-angle faults are common. Dredged rock samples (fig. 67) are typically silty and sandy diatomaceous mudstone, which may be as old as late Miocene. Basement rock in the basins are typically thermally altered volcanic and volcaniclastic deposits of presumed Paleogene age. South of Amlia Island, the slope of the Aleutian Ridge (leading down to the Aleutian Terrace) is underlain by Eocene through Pliocene sandstone, siltstone, and mudstone. Evidently, the exposed Eocene and early Oligocene beds are the deeper water facies of the more thermally altered volcanic and sedimentary rocks exposed on Amlia Island. The Paleogene and Miocene beds exposed on the southern insular slope of Amlia Island can be traced downdip beneath virtually horizontal beds of Pliocene and Quaternary age that underlie the central floor of Atka basin. The geometry, age, and lithology of the sedimentary sequences associated with Atka basin suggest that the Aleutian Terrace is underlain by deformed and undeformed sedimentary deposits shed southward from the Aleutian Ridge during the past 40 to 50 m.y. Exceptionally large anticlinal $(150 \mathrm{~km}$ long, 20-30 km wide) structures have formed along the outer or southern flank of Atka basin. Although the water depths are great $(4,000 \mathrm{~m})$, these structures are intriguing petroleum prospects.

\section{REFERENCES CITED}

Scholl, D. W., Marlow, M. S., and Buffington, E. C., 1975, Summit basins of Aleutian Ridge, North Pacific: American Association of Petroleum Geologists Bulletin, v. 59, no. 5, p. 799 . 


\section{REPORTS ON ALASKA PUBLISHED BY THE U.S. GEOLOGICAL SURVEY IN 1979}

\author{
Compiled by Edward H. Cobb
}

AhIbrandt, T. S., 1979a, Introduction to geologic studies of the Nanushuk Group, North Slope, Alaska, in Ahlbrandt, T. S., ed., Preliminary geologic, petrologic, and paleontologic results of the study of Nanushuk Group rocks, North Slope, Alaska: U.S. Geological Survey Circular 794, p. 1-4.

1979b, Preliminary geologic, petrologic, and paleontologic results of the study of Nanushuk Group rocks, North Slope, Alaska: U.S. Geological Survey Circular $794,163 \mathrm{p}$.

Ahlbrandt, T. S., Huffman, A. C., Jr., Fox, J. E., and Pasternack, Ira, 1979, Depositional framework and reservoir-quality studies of selected Nanushuk Group outcrops, North Slope, Alaska, in Ahlbrandt, T. S., ed., Preliminary geologic, petrologic, and paleontologic results of the study of Nanushuk Group rocks, North Slope, Alaska: U.S. Geological Survey Circular 794, p. 14-31.

Albert, N. R. D., 1978, Map showing interpretation of Landsat imagery of the Ambler River quadrangle, Alaska: U.S. Geological Survey Open-File Report 78-120-J, scale 1:250,000, 2 sheets.

Albert, N. R. D., Le Compte, J. R., and Steele, W. C., 1978, Map showing interpretation of Landsat imagery of the Chandalar quadrangle, Alaska: U.S. Geological Survey Miscellaneous Field Studies Map MF-878J, scale $1: 250,000,2$ sheets.

Albert, N. R. D., and Steele, W. C., 1979, Maps showing interpretation of Landsat imagery of the Big Delta quadrangle, Alaska: U.S. Geological Survey OpenFile Report 78-529-C, scale 1:250,000, 2 sheets.

Barnes, Peter, and Reimnitz, Erk, 1979, Ice gouge obliteration and sediment redistribution event: 1977-1978, Beaufort Sea, Alaska: U.S. Geological Survey Open-File Report 79-848, $22 \mathrm{p}$.

Barnes, P. W., Reimnitz, Erk, Toimil, L. J., and Hill, H. R., 1979, Fast-ice thickness and snow depth in relation to oil entrapment potential, Prudhoe Bay, Alaska: U.S. Geological Survey Open-File Report $79-539,30 \mathrm{p}$.

Barnes, Peter, Reimnitz, Erk, Toimil, Larry, Maurer, Douglas, and McDowell, David, 1979, Core descriptions and preliminary observations of vibracores from the Alaska Beaufort Sea shelf: U.S. Geological Survey Open-File Report 79-351, 12 p.

Barnes, P. W., and Toimil, L. J., 1979, Maps showing inner shelf circulation patterns, Beaufort Sea, Alaska: U.S. Geological Survey Miscellaneous Field Studies Map MF-1125, various scales.

Bartsch-Winkler, Susan, 1979, Textural and mineralogical study of some surface and subsurface sandstones from the Nanushuk Group, western North Slope, Alaska, in Ahlbrandt, T. S., ed., Preliminary geologic, petrologic, and paleontologic results of the study of Nanushuk Group rocks, North Slope, Alaska: U.S. Geological Survey Circular 794, p. 61-76.

Bird, K. J., and Andrews, Jack, 1979, Subsurface studies of the Nanushuk Group, North Slope, Alaska, in Albrandt, T. S., ed., Preliminary geologic, petrologic, and paleontologic results of the study of Nanushuk Group rocks, North Slope, Alaska: U.S. Geological Circular 794 , p. 32-41.

Brook, C. A., Mariner, R. H., Mabey, D. R., Swanson, J. R., Guffanti, Marianne, and Muffler, L. J. P.,
1979, Hydrothermal convection systems with reservoir temperatures $\geq 90^{\circ} \mathrm{C}$, in Muffler, L. J. P., ed., Assessment of geothermal resources of the United States, 1978: U.S. Geological Survey Circular 790 , p. $18-85$.

Brosge, W. P., Reiser, H. N., Dutro, J. T., Jr., and Detterman, R. L., 1979a, Bedrock Geologic map of the Philip Smith Mountains quadrangle, Alaska: U.S. Geological Survey Miscellaneous Field Studies Map MF-879B, scale 1:250,000, 2 sheets.

Brosge, W. P., Reiser, H. N., Dutro, J. T., Jr., and Nilsen, T. H., 1979b, Geologic map of Devonian rocks in parts of the Chandler Lake and Killik River quadrangles, Alaska: U.S. Geological Survey Open-File Report 79-1224, scale 1:200,000.

Burrows, R. L., Parks, Bruce, and Emmett, W. W., 1979, Sediment transport in the Tanana River in the vicinity of Fairbanks, Alaska, 1977-78: U.S. Geological Survey Open-File Report 79-1539, 37 p.

Cady, J. W. , 1978, Aeromagnetic map and interpretation, Chandalar quadrangle, Alaska: U.S. Geological Survey Miscellaneous Field studies Map MF-878-C, scale $1: 250,000,2$ sheets.

Case, J. E., Sikora, Robert, Tysdal, R. G., Barnes, D. F., and Morin, Robert, 1979, Geologic interpretation of the gravity anomaly map of the Seward and Blying Sound quadrangles, Alaska: U.S. Geological Survey Miscellaneous Field Studies Map MF-880-C, scale $1: 250,000$.

Case, J. E., Tysdal, R. G., Hillhouse, J. W., and Gromme, C. S., 1979, Geologic interpretation of aeromagnetic map of the Seward and Blying Sound quadrangles, Alaska: U.S. Geological Survey Miscellaneous Field Studies Map MF-880-D, scale $1: 250,000,2$ sheets.

Cathrall, J. B., Billings, T. M., and Cooley, E. F., 1979a, Distribution and abundance of antimony in the minus-80-mesh fraction of stream-sediment samples, Survey Pass $1^{\circ} \times 3^{\circ}$ quadrangle, Alaska: U.S. Geological Survey Open-File Report 79-837-T, scale $1: 250,000$

- 1979b, Distribution and abundance of barium in the minus-80-mesh fraction of stream-sediment samples, Survey Pass $1^{\circ} \times 3^{\circ}$ quadrangle, Alaska: U.S. Geological Survey Open-File Report 79-837-J, scale $1: 250,000$.

- 1979c, Distribution and abundance of barium in the nonmagnetic fraction of heavy-mineral concentrates from stream sediments, Survey Pass $1^{\circ} \times 3^{\circ}$ quadrangle, Alaska: U.S. Geological Survey OpenFile Report 79-837-K, scale 1:250,000.

1979d, Distribution and abundance of beryllium in the minus-80-mesh fraction of stream-sediment samples, Survey Pass $1^{\circ} \times 3^{\circ}$ quadrangle, Alaska: U.S. Geological Survey Open-File Report 79-837-R, scale $1: 250,000$.

1979 e, Distribution and abundance of beryllium in the nonmagnetic fraction of heavy-mineral concentrates from stream sediments, Survey Pass $1^{\circ} \times 3^{\circ}$ quadrangle, Alaska: U.S. Geological Survey OpenFile Report 79-837-S, scale 1:250,000.

- $1979 \mathrm{f}$, Distribution and abundance of beryllium of copper in the minus-80-mesh fraction of streamsediment samples, Survey Pass $1^{\circ} \times 3^{\circ}$ quadrangle, Alaska: U.S. Geological Survey Open-File Report 79-837-C, scale 1:250,000.

$1979 \mathrm{~g}$, Distribution and abundance of copper in the nonmagnetic fraction of heavy-mineral concentrates from stream-sediments, Survey Pass $1^{\circ} \times 3^{\circ}$ quadrangle, Alaska: U.S. Geological Survey OpenFile Report 79-837-D, scale 1:250,000.

$1979 \mathrm{~h}$, Distribution and abundance of lanthanum in 
the nonmagnetic fraction of heavy-mineral concentrates from stream sediments, Survey Pass $1^{\circ} \times 3^{\circ}$ quadrangle, Alaska: U.S. Geological Survey OpenFile Report 79-837-U, scale 1:250,000.

Cathrall, J. B., Billings, T. M., and Cooley, E. F., 1979i, Distribution and abundance of lead in the minus-80-mesh fraction of stream-sediment samples, Survey Pass $1^{\circ} \times 3^{\circ}$ quadrangle, Alaska: U.S. Geological Survey Open-File Report 79-837-E, scale $1: 250,000$.

- 1979j, Distribution and abundance of lead in the nonmagnetic fraction of heavy-mineral concentrates from stream sediments, Survey Pass $1^{\circ} \times 3^{\circ}$ quadrangle, Alaska: U.S. Geological Survey Open-File Report 79-837-F, scale 1:250,000.

$1979 \mathrm{k}$, Distribution and abundance of molybdenum in the minus-80-mesh fraction of stream-sediment samples, Survey Pass $1^{\circ} \times 3^{\circ}$ quadrangle, Alaska: U.S. Geological Survey Open-File Report 79-837-N, scale $1: 250,000$.

19791, Distribution and abundance cf molybdenum in the nonmagnetic fraction of heavy-mineral concentrates from stream sediments, Survey Pass $1^{\circ} \times 3^{\circ}$ quadrangle, Alaska: U.S. Geological Survey OpenFile Report 79-837-0, scale 1:250,000.

$1979 \mathrm{~m}$, Distribution and abundance of silver, arsenic, bismuth, tungsten, and thorium in the nonmagnetic fraction of heavy-mineral concentrates from stream sediments, Survey Pass $1^{\circ} \times 3^{\circ}$ quadrangle, Alaska: U.S. Geological Survey Open-File Report 79-837-M, scale 1:250,000.

$1979 n$, Distribution and abundance of silver, bismuth, and tungsten in the minus-80-mesh fraction of stream-sediment samples, Survey Pass $1^{\circ} \times 3^{\circ}$ quadrangle Alaska: U.S. Geological Survey Open-File Report 79-837-L, scale 1:250,000.

19790, Distribution and abundance of tin in the minus-80-mesh fraction of stream-sediment samples, Survey Pass $1^{\circ} \times 3^{\circ}$ quadrangle, Alaska: U.S. Geological Survey Open-File Report 79-837-P, scale $1: 250,000$.

1979p, Distribution and abundance of tin in the nonmagnetic fraction of heavy-mineral concentrates from stream sediments, Survey Pass $1^{\circ} \times 3^{\circ}$ quadrangle, Alaska: U.S. Geological Survey Open-File Report 79-837-Q, scale 1:250,000.

1979q, Distribution and abundance of zine determined by atomic absorption analysis in the minus80 -mesh fraction of stream-sediment samples, Survey Pass $1^{\circ} \times 3^{\circ}$ quadrangle, Alaska: U.S. Geological Survey Open-File Report 79-837-G, scale 1:250,000.

$1979 r$, Distribution and abundance of zinc determined by spectrographic analysis in the minus-80mesh fraction of stream-sediment samples, Survey Pass $1^{\circ} \times 3^{\circ}$ quandrangle, Alaska: U.S. Geological Survey Open-File Report 79-837-H, scale 1:250,000. 1979s, Distribution and abundance of zinc in the nonmagnetic fraction of heavy-mineral concentrates from stream sediments, Survey Pass $1^{\circ} \times 3^{\circ}$ quadrangle, Alaska: U.S. Geological Survey Open-File Report 79-837-I, scale 1:250,000.

Cathrall, J. B., Cooley, E. F., McDanal, S. K., and Billings, T. M., 1979t, A listing and statistical summary of spectrographic analyses of heavy-mineral concentrates for the Survey Pass quadrangle, Alaska: U.S. Geological Survey Open-File Report 79-837-B, $52 \mathrm{p}$.

Cathrall, J. B., Cooley, E. F., O'Leary, R. M., Billings, T. M., and McDanal, S. K., 1979u, A listing and statistical summary of spectrographic and chemical analyses of stream-sediment samples from the Survey Pass quadrangle, Alaska: IJ.S.
Geological Survey Open-File Report 79-837-A, 56 p.

Childers, J. M., Kernodle, D. R., and Loeffler, R. M. 1979, Hydrologic reconnaissance of western Arctic Alaska, 1976 and 1977: U.S. Geological Survey Open-File Report 79-699, 70 p.

Childs, J. R., and Cooper, A. K., 1979, Marine seismic sonobuoy data from the Bering Sea region: U.S. Geological Survey Open-File Report 79-371, 5 sheets.

Cobb, E. H., 1979a, Alaskan papers and abstracts published by the Geological Society of America, 1890-1978, indexed by quadrangle: U.S. Geological Survey Open-File Report 79-1640, 201 p.

1979b, Alaskan papers and abstracts published in American Association of Petroleum Geologists Bulletin, 1950-1978, indexed by quadrangle: U.S. Geological Survey Open-File Report 79-1475, 78 p. - 1979c, Selected Geological Survey, U.S. Bureau of Mines, and Alaska Division of Geological and Geophysical Surveys reports and maps on Alaska released during 1978, indexed by quadrangle: U.S. Geological Survey Open-File Report 79-706, 187 p. 1979d, Summary of references to mineral occurrences (other than mineral fuels and construction materials) in the Afognak, Karluk, Kodiak, and Trinity Islands quadrangles, Alaska: U.S. Geological Survey Open-File Report 79-860, 47 p.

- 1979 e, Summary of references to mineral occurrences (other than mineral fuels and construction materials) in the Anchorage quadrangle, Alaska: U.S. Geological Survey Open-File Report 79-1095, $183 \mathrm{p}$.

1979f, Summary of references to mineral occurrences (other than mineral fuels and construction materials) in the Bering Glacier, Icy Bay, Middleton Island, and Yakutat quadrangles, Alaska: U.S. Geological Survey Open-File Report 79-1246, 40 p. - $1979 \mathrm{~g}$, Summary of references to mineral occurrences (other than mineral fuels and construction materials) in the Cordova quadrangle, Alaska: U.S. Geological Survey Open-File Report 79-973, 74 p. -1979h, Summary of references to mineral occurrences (other than mineral fuels and construction materials) in the Gulkana quadrangle, Alaska: U.S. Geological Survey Open-File Report 79-1247, 36 p. -1979i, Summary of references to mineral occurrences (other than mineral fuels and construction materials) in the Mount Hayes quadrangle, Alaska: U.S. Geological Survey Open-File Report 79-238, $140 \mathrm{p}$.

$1979 j$, Summary of references to mineral occurrences (other than mineral fuels and construction materials) in the Valdez quadrangle, Alaska: U.S. Geological Survey Open-File Report 79-1241, 166 p.

Coffman, J. L., and Stover, C. W., eds., 1979, United States earthquakes, 1976: National Technical Information Service PB-288 937, $106 \mathrm{p}$.

Connelly, William, and Moore, J. C., 1979, Geologic map of the northwest side of the Kodiak and adjacent islands, Alaska: U.S. Geological Survey Miscellaneous Field Studies Map MF-1057, scales 1:250,000, $1: 63,360,2$ sheets.

Coury, A. B., Hendricks, T. A., and Tyler, T. F., 1978, Map of prospective hydrocarbon provinces of the world, North and South America: U.S. Geological Survey Miscellaneous Field Studies Map MF-1044A, scale $1: 20,000,000$.

1979, Bibliography for map of prospective hydrocarbon provinces of the world: U.S. Geological Survey Open-File Report 79-201, 88 p.

Crim, W. D., Cooley, E. E., Hampton, J. O., McDanal, S. K., and O'Leary, R. M., 1979, Spectrographic and 
chemical analyses of geochemical samples collected during 1978 from the Lake Clark quadrangle,

Alaska: U.S. Geological Survey Open-File Report $79-871,46 \mathrm{p}$.

Csejtey, Bella, Jr., and Griscom, Andrew, 1978, Preliminary aeromagnetic interpretive map of the Talkeetna Mountains quadrangle, Alaska: U.S. Geological Survey Open-File Report 78-558-C, 14 p., scale $1: 250,000,2$ sheets.

Csejtey, Bela, Jr., and Miller, R. J., 1978, Map and table describing metalliferous and selected nonmetalliferous mineral deposits, Talkeetna Mountains quadrangle, Alaska: U.S. Geological Survey OpenFile Report 78-558-B, 20 p., scale 1:250,000.

Curtin, G. C., O'Leary, R. M., Tripp, R. B., and Cooley, E. F., 1979, Geochemical and generalized geologic maps showing the distribution and abundance of thorium, and the distribution of uranium in selected samples, in the central Alaska Range, Talkeetna quadrangle, Alaska: U.S. Geological Survey Open-File Report 79-430, scale 1:250,000.

Curtis, S. M., and Rossiter, Richard, 1979, Gamma-ray values in Barrow, Teshekpuk, and Harrison Bay quadrangles, Alaska: U.S. Geological Survey Open-File Report 79-1146,

Curtis, S. M., Rossiter, Richard, Ellersieck, I. F., Mayfield, C. F., and Tailleur, I. L., 1979, Gammaray values in the Misheguk Mountain region, northwestern Alaska: U.S. Geological Survey OpenFile Report 79-1086, 2 sheets.

Day, G. W., Curtin, G. C., and Billings, Theodore, 1979, Spectrographic data for the ash of ground birch (Betula rotundifolia Sarg.) leaves and black spruce (Picea mariana B.S.P.) needles collected from the Tanacross 1:250,000-scale quadrangle, Alaska: U.S. Geological Survey Open-File Report $79-1355,81 \mathrm{p}$.

Day, G. W., Curtin, G. C., and Tripp, R. B., 1979a, Geochemical maps showing the distribution and abundance of copper and molybdenum in the ash of black spruce needles and ground birch leaves from the Tanacross quadrangle, Alaska: U.S. Geological Survey Open-File Report 79-1320, scale 1:250,000.

1979b, Geochemical maps showing the distribution and abundance of lead, zinc, and cadmium in the ash of black spruce needles and ground birch leaves from the Tanacross quadrangle, Alaska: U.S. Geological Survey Open-File Report 79-1319, scale $1: 250,000$.

Dearborn, L. L., Anderson, G. S., and Zenone, Chester, 1979, Water resources data of the Seward area, Alaska: U.S. Geological Survey Water-Resources Investigations Open-File Report 79-11, $45 \mathrm{p}$.

Detterman, R. L., Miller, T. P., Yount, M. E., and Wilson, F. H., 1979, Generalized geologic map of Chignik and Sutwik Island quadrangles, Alaska: U.S. Geological Survey Miscellaneous Field Studies Map MF - 1053-A, scale 1:250,000.

Dickinson, K. A., 1979a, A uranium occurrence in the Tertiary Kootznahoo Formation on Kuiu Island, southeast Alaska: U.S. Geological Survey Open-File Report $79-1427,5 \mathrm{p}$.

1979b, Uraniferous phosphate occurrence on Kupreanof Island, southeast Alaska: U.S. Geological Survey Open-File Report 79-1316, 2 p.

Ellersieck, Inyo, 1978a, Analytical results for streamsediment samples, Ambler River quadrangle, Alaska: U.S. Geological Survey Open-File Report $78-120-C$, scale $1: 250,000,2$ sheets.

1978b, Map showing barium, silver, and arsenic stream-sediment geochemical anomalies, Ambler River quadrangle, Alaska: U.S. Geological Survey Open-
File Report 78-120-G, scale 1:250,000.

Ellersieck, Inyo, 1978c, Map showing chromium, nickel, and cobalt stream-sediment anomalies, Ambler River quadrangle, Alaska: U.S. Geological Survey OpenFile Report 78-120-H, scale 1:250,000.

1978d, Map showing copper and molybdenum streamsediment geochemical anomalies, Ambler River quadrangle, Alaska: U.S. Geological Survey Open-File Report 78-120-E, scale 1:250,000.

1978e, Map showing lead and zinc stream-sediment geochemical anomalies, Ambler River quadrangle, Alaska: U.S. Geological Survey Open-File Report 78-120-D, scale 1:250,000.

-1978f, Map showing stream-sediment geochemical sample locations, Ambler River quadrangle, Alaska: U.S. Geological Survey Open-File Report $78-120-B$, scale $1: 250,000$.

1978g, Map showing tin and beryllium streamsediment geochemical anomalies, Ambler River quadrangle, Alaska: U.S. Geological Survey Open-File Report 78-120-F, scale 1:250,000.

Fabiano, E. B., Jones, W. J., and Peddie, N. W., 1979, The magnetic charts of the United States for epoch 1975: U.S. Geological Survey Circular 810, 15 p.

Fisher, M. A., Patton, W. W., Jr., Thor, D. R., Holmes, M. L., Scott, E. W., Nelson, C. H., and Wilson, C. L., 1979, Resource report for proposed OCS Lease Sale 57: Norton Basin, Alaska: U.S. Geological Survey Open-File Report 79-720, 45 p.

Foster, H. L., Albert, N. R. D., Griscom, Andrew, Hessin, T. D., Menzie, W. D., Turner, D. L., and Wilson, F. H., 1979, The Alaskan Mineral Resource Assessment Program: Background information to accompany folio of geologic and mineral resource maps of the Big Delta quadrangle, Alaska: U.S. Geological Survey Circular 783, $19 \mathrm{p}$.

Fogleman, K., Stephens, C. Lahr, J. C., Helton; S., and Allan, M., 1978, Catalog of earthquakes in southern Alaska, October-December 1977: U.S. Geological Survey Open-File Report 78-1097, 28 p.

Fox, J. E., 1979, A summary of reservoir characteristics of the Nanushuk Group, Umiat test well 11, National Petroleum Reserve in Alaska, in Ahlbrandt, T. S., ed., Preliminary geologic, petrologic, and paleontologic results of the study of Nanushuk Group rocks, North Slope, Alaska: U.S. Geological Survey Circular 794, p. 42-53.

Gardner, J. V., Vallier, T. L., Dean, W. E., Kvenvolden, K. A., and Redden, G. D., 1979, Sedimentology and geochemistry of surface sediments and the distribution of faults and potentially unstable sediments, St. George Basin region of the outer continental shelf, southern Bering Sea: U.S. Geological Survey Open-File Report 79-1562, 88 p.

Gerin, Marybeth, 1979, Gazetteer of coastal and offshore features of the Bering Sea and Aleutian Arc: U.S. Geological Survey Open-File Report 79$1219,49 \mathrm{p}$.

Gerin, Marybeth, and Alpha, T. R., 1979, Gazetteer of coastal and offshore features of the Chukchi and Beaufort Seas: U.S. Geological Survey Open-File Report 79-1563, $21 \mathrm{p}$.

Gerin, Marybeth, and Stevenson, A. J., 1979a, Equalarea base maps of the northeast Pacific Ocean: U.S. Geological Survey Open-File Report 79-855, scale $1: 2,500,000,4$ sheets.

1979b, Equal-area base maps of the North Pacific Ocean and the northeast Pacific Ocean: U.S. Geological Survey Open-File Report 79-857, scale $1: 5,000,000$.

Giovannetti, D. M., and Bird, K. J., 1979, Gravity and magnetic profiles, and rock property data for the 
Shaviovik and Echooka Rivers area, North Slope, Alaska: U.S. Geological Survey Open-File Report $79-1504,14 \mathrm{p}$.

Grantz, Arthur, and Eittreim, Stephen, 1979, Geology and physiography of the continental margin north of Alaska and implications for the origin of the Canada Basin: U.S. Geological Survey Open-File Report 79-288, 69 p.

Greenberg, Jonathan, Hart, P. E., and Grantz, Arthur, 1979 , Bathymetric map of the continental shelf, slope, and rise of the Beaufort Sea north of Alaska: U.S. Geological Survey Open-File Report 79-1313, scale 1:250,000 (approximately), 6 sheets.

Griscom, Andrew, 1979, Aeromagnetic and geologic interpretation maps of the Talkeetna quadrangle, Alaska: U.S. Geological Survey Miscellaneous Field Studies Map MF-870B, 5 p., scale 1:250,000, 2 sheets.

Hamilton, T. D., 1979a, Geologic road log, Alyeska haul road, Alaska, June-August, 1975: U.S. Geological Survey Open-File Report 79-227, 64 p.

1979b, Quaternary stratigraphic sections with radiocarbon dates, Chandalar quadrangle, Alaska: U.S. Geological Survey Open-File Report 79-751, 17 p.

1979c, Radiocarbon dates and Quaternary stratigraphic sections, Philip Smith Mountains quadrangle, Alaska: U.S. Geological Survey Open-File Report 79-866, $95 \mathrm{p}$.

1979d, Surficial geologic map of the Chandler Lake quadrangle, Alaska: U.S. Geological Survey Miscellaneous Field Studies Map MF-1121, scale $1: 250,000$.

- 1979e, Surficial geologic map of the Wiseman quadrangle, Alaska: U.S. Geological Survey Miscellaneous Field Studies Map MF-1122, scale $1: 250,000$.

Hamilton, T. D., and Trexler, J. H., Jr., $1979 \mathrm{f}$, Analyses of surficial deposits, central Brooks Range, Alaska, U.S. Geological Survey Open-File Report 79-228, 95 p.

Hampton, M. A., and Bouma, A. H., 1979, Notes on the acquisition of high resolution seismic reflection profiles, side-scanning sonar records, and sediment samples from lower Cook Inlet and Kodiak Shelf, $\underline{R / V}$ Sea Sounder cruise S8-78-WG, August 1978: U.S. Geological Survey Open-File Report 79-1311, $17 \mathrm{p}$.

Hartz, R. W., Holden, K., Hopkins, D. M., and Shearer, G., 1979, Location map and summary logs for the U.S. Geological Survey's 1979, Beaufort Sea over the ice drilling program: U.S. Geological Survey Open-File Report 79-1303, 33 p.

Hoare, J. M., and Coonrad, W. L., 1978, Geologic map of the Goodnews and Hagemeister Islands quadrangles region, southwestern Alaska: U.S. Geological Survey Open-File Report 78-9-B, scale 1:250,000, 2 sheets.

Hopkins, D.M., and Hartz, R. W., 1978, Coastal morphology, coastal erosion, and barrier islands of the Beaufort Sea, Alaska: U.S. Geological Survey OpenFile Report 78-1063, 54 p.

Hudson, Travis, 1979a, Calc-alkaline plutonism along the Pacific rim of southern Alaska: U.S. Geological Survey Open-File Report 79-953, $31 \mathrm{p}$.

1979b, Igneous and metamorphic rocks of the Serpentine Hot Springs area, Seward Peninsula, Alaska: U.S. Geological Survey Professional Paper $1079,27 \mathrm{p}$.

Huffman, A. C., Jr., 1979, Stratigraphy and petrography of a measured section on the south limb of Barbara Syncline, North Slope, Alaska, in Albrandt, T. S., ed., Preliminary geologic, petrologic, and paleontologic results of the study of Nanushuk Group rocks, North Slope, Alaska: U.S. Geological Survey Circular 794, p. 77-88.

Hunter, R. E., Sallenger, A. H., and Dupre, W. R., 1949, Maps showing directions of longshore sediment transport along the Alaskan Bering Sea coast: U.S. Geological Survey Miscellaneous Field Studies Map MF-1049, $7 \mathrm{p}$, at various scales, 5 sheets.

Johnson, Paula, 1979, Hydrogeologic data for the Eagle River-Chugiak area, Alaska: U.S. Geological Survey Water-Resources Investigations 79-59, $17 \mathrm{p}$.

Johnson, Paula, Wilcox, D. E., Morgan, W. D., Merto, Josephine, and McFadden, Ruth, 1978, Arsenic, nitrate, iron, and hardness in ground water, Fairbanks area, Alaska: U.S. Geological Survey Open-File Report 78-1034.

Jones, D. L., and Silberling, N. J., 1979, Mesozoic stratigraphy--The key to tectonic analysis of southern and central Alaska: U.S. Geological Survey Open-File Report 79-1200, $41 \mathrm{p}$.

King, H. D., Cooley, E. F., O'Leary, R. M., Tripp, R. B., McDanal, S. K., and Spiesman, D. L., Jr., 1979, Spectrographic and atomic-absorption analyses of geochemical samples from the Medfra quadrangle, Alaska: U.S. Geological Survey Open-File Report 79-959, $43 \mathrm{p}$.

Lahr, J. C., Plafker, George, Stephens, C. D., Fogleman, K. A., and Blackford, M. E., 1979, Interim report on the St. Elias earthquake of 28 February 1979: U.S. Geological Survey Open-File Report 79-670, $35 \mathrm{p}$.

Lamke, R. D., 1979, Flood characteristics of Alaskan streams: U.S. Geological Survey Water Resources Investigations Open-File Report 78-129, $61 \mathrm{p}$

Lanfear, K. J., Nakassis, Anastasis, Samuels, W. B., and Schoen, C. T., 1979, Oilspill risk analysis for the northern Gulf of Alaska (Proposed Sale 55): U.S. Geological Survey Open-File Report 79-1284, $79 \mathrm{p}$.

Lankford, S. M., and Hill, J. M., 1979, Stratigraphy and depositional environment of the Dutch Harbor Member of the Unalaska Formation, Unalaska Island, Alaska: U.S. Geological Survey Bulletin 1457-B, p. B1-B14.

Larsen, M. C., Nelson, Hans, and Thor, D. R., 1979, Continuous seismic reflection profile records, SEA 9-78-BS cruise, northern Bering Sea: U.S. Geological Survey Open-File Report 79-1673, 8 p.

Le Compte, J. R., 1979a, Map showing interpretation of Landsat imagery of the Philip Smith Mountains quadrangle, Alaska: U.S. Geological Survey Miscellaneous Field Studies Map MF-879-F, scale $1: 250,000,2$ sheets.

1979b, Map showing interpretation of Landsat imagery of the Seward and Blying Sound quadrangles, Alaska: U.S. Geological Survey Open-File Report 78-737, scales $1: 250,000,1: 500,000,2$ sheets.

Lee-Wong, Florence, Vallier, T. L., Hopkins, D. M., and Silberman, M. L., 1979, Preliminary report on the petrography and geochemistry of basalt from the Pribilof Islands and vicinity, southern Bering Sea: U.S. Geological Survey Open-File Report 79$1556,51 \mathrm{p}$.

MacCabe, M. P., 1979, Earthquake hazards reduction program project summaries - fiscal year 1978, with a list of publications for 1977, compiled by Patricia J. Meader and Wanda H. Seiders: U.S. Geological Survey Open-File Report 79-387, 113 p.

Magoon, L. B., Bouma, A. H., Fisher, M. A., Hampton, M. A., Scott, E. W., and Wilson, C. L., 1979, Resource report for proposed OCS Sale No. 60, Lower Cook Inlet-Shelikof Strait: U.S. Geological Survey Open-File Report 79-600, 38 p. 
Magoon, L. B., and Claypool, G. E., 1979a, Hydrocarbon source potential of the Nanushuk Group and the Torok Formation, a preliminary report, in Ahlbrandt, T. S., ed., Preliminary geologic, petrologic, and paleontologic results of the study of Nanushuk Group rocks, North Slope, Alaska: U.S. Geological Survey Circular 794, p. 54-60.

- 1979b, Petroleum geology of Cook Inlet basin, Alaska--An exploration model: U.S. Geological Survey Open-File Report 79-548, $23 \mathrm{p}$.

- 1979c, Two oil types on the North Slope of Alaska --implications for future exploration: U.S. Geological Survey Open-File Report 79-1649, $13 \mathrm{p}$.

Marlow, M. S., and Cooper, A. K., 1979a, Hydrocarbon prospects for the Navarin and Aleutian basin provinces: U.S. Geological Survey Open-File Report 79-1667, $59 \mathrm{p}$.

Marlow, M. S., and Cooper, A. K., 1979b, Multichannel seismic-reflection profiles collected in 1977 in the northern Bering Sea: U.S. Geological Survey Open-File Report 79-1147, 2 p.

Marlow, M. S., Cooper, A. K., Scholl, D. W., Vallier, T. L., and McLean, Hugh, 1979, Description of dredge samples from the Bering Sea continental margin: U.S. Geological Survey Open-File Report $79-1139,6 \mathrm{p}$.

Marlow, M. S., Gardner, J. V., Vallier, T. L., McLean Hugh, Scott, E. W., and Lynch, M. B., 1979, Resource report for proposed OCS Lease Sale No. 70, St. George Basin, shelf area, Alaska: U.S. Geological Survey Open-File Report 79-1650, 79 p.

Marsh, S. P., Detra, D. E., and Smith, S. C., 1978a, Geochemical and generalized geologic map showing distribution and abundance of barium, arsenic, boron, and vanadium in stream sediment in the Chandalar quadrangle, Alaska: U.S. Geological Survey Miscellaneous Field Studies Map MF-878G, scale $1: 250,000$.

1978b, Geochemical and generalized geologic map showing distribution and abundance of zinc in stream sediments in the Chandalar quadrangle, Alaska: U.S. Geological Survey Miscellaneous Field Studies Map MF-878E, scale 1:250,000.

Marsh , S. P., Detra, D. E., and Smith, S. C., 1979a, Geochemical and generalized geologic map showing distribution and abundance of antimony and niobium in stream sediments, Chandalar $1^{\circ} \times 3^{\circ}$ quadrangle, Alaska: U.S. Geological Survey Miscellaneous Field Studies Map MF-878-H. scale 1:250,000.

1979b, Geochemical and generalized geologic map showing distribution and abundance of nickel, cobalt, lanthanum and yttrium in stream sediments, Chandalar $1^{\circ} \times 3^{\circ}$ quadrangle, Alaska: U.S. Geological Survey Miscellaneous Field Studies Map MF-878F, scale $1: 250,000$.

May, F. E., 1979, Dinoflagellete and acritarch assemblages from the Nanushuk Group (Albian-Cenomanian) and the Torok Formation (Albian), Umiat test well 11, National Petroleum Reserve in Alaska northern Alaska, in Ahlbrandt, T. S., ed., Preliminary geologic, petrologic, and paleontologic results of the study of Nanushuk Group rocks, North Slope, Alaska: U.S. Geological Survey Circular 749, p. 113-127.

May, F. E., and Stein, J. A., 1979, Dinoflagellate and acritarch assemblages from the Grandstand Formation (middle to upper Albian) of the Nanushuk Group, Simpson Core Test 25, National Petroleum Reserve in Alaska, northern Alaska, in Ahlbrandt, T. S., ed., Preliminary geologic, petrologic, and paleontologic Alaska: U.S. Geological Survey Circular 794, p. $128-145$.

Mayfield, C. F., Curtis, S. M., Ellersieck, I. F., and
Tailleur, I. L., 1979, Reconnaissance geology of the Ginny Creek zinc-lead-silver and Nimiuktuk barite deposits, northwestern Brooks Range, Alaska: U.S. Geological Survey Open-File Report 79-1092, $20 \mathrm{p}$.

Mayo, L. R., Trabant, D. C., March, Rod, and Haeberli, Wilfried, 1979, Columbia Glacier stake location, mass balance, glacier surface altitude, and ice radar data, 1978 measurement year: U.S. Geological Survey Open-file Report 79-1168, 72 p.

McLean, Hugh, 1979, Observations on the geology and petroleum potential of the Cold Bay-False Pass area, Alaska Peninsula: U.S. Geological Survey Open-File Report 79-1605, 34 p.

Menzie, W. D., and Foster, H. L., 1979, Metalliferous and selected nonmetalliferous mineral resource potential in the Big Delta quadrangle, Alaska: U.S. Geological Survey Open-File Report 78-529-D, 61 p., scale 1:250,000.

Miller, R. J., Curtin, G. C., and Csejtey, Bela Jr., 1978a Map showing geochemical distribution and abundance of arsenic in stream sediments and heavymineral concentrates, Talkeetna Mountains quadrangle, Alaska: U.S. Geological Survey OpenFile Report 78-558-P, scale 1:250,000.

Miller, R. J., Curtin G. C., and Csejtey, Bela, Jr., $1978 \mathrm{~b}$, Map showing geochemical distribution and abundance of barium in heavy-mineral concentrates, Talkeetna Mountain quadrangle, Alaska: U.S. Geological Survey Open-File Report 78-5580, scale $1: 250,000$.

$1978 \mathrm{c}$, Map showing geochemical distribution and abundance of bismuth in stream sediments and heavy mineral concentrates, Talkeetna Mountains quadrangle, Alaska: U.S. Geological Survey Open-File Report 78-558-L, scale 1:250,000.

1978d, Map showing geochemical distribution and abundance of chromium in stream sediments and heavy mineral concentrates, Talkeetna Mountains quadrangle, Alaska: U.S. Geological Survey Open-File Report 78-558-M, scale 1:250,000.

1978 e, Map showing geochemical distribution and abundance of copper in stream sediments and heavy mineral concentrates, Talkeetna Mountains quadrangle, Alaska: U.S. Geological Survey Open-File Report, 78-558-I, scale 1:250,000.

1978f, Map showing geochemical distribution and abundance of gold in stream sediments and heavy mineral concentrates, Talkeetna Mountains quadrangle, Alaska: U.S. Geological Survey Open-File Report 78-558-H, scale 1:250,000.

$1978 \mathrm{~g}$, Map showing geochemical distribution and abundance of lead in stream sediments and heavy mineral concentrates, Talkeetna Mountain quadrangle, Alaska: U.S. Geological Survey Open-File Report 78-558-J, scale 1:250,000.

1978h, Map showing geochemical distribution and abundance of molybdenum in stream sediments and heavy mineral concentrates, Talkeetna Mountains quadrangle, Alaska: U.S. Geological Survey OpenFile Report 78-558-K, scale 1:250,000.

1978i, Map showing geochemical distribution and abundance of silver in stream sediments and heavy mineral concentrates, Talkeetna Mountains quadrangle, Alaska: U.S. Geological Survey Open-File Report 78-558-G, scale 1:250,000.

$1978 j$, Map showing geochemical distribution and abundance of tin in stream sediments and heavy mineral concentrates, Talkeetna Mountains quadrangle, Alaska: U.S. Geological Survey Open-File Report 78-558-E, scale 1:250,000.

1978k, Map showing geochemical distribution and 
abundance of tungsten in heavy mineral concentrates, Talkeetna Mountains quadrangle, Alaska: U.S. Geological Survey Open-File Report 78-558-N, scale $1: 250,000$.

Miller, R. J., Curtin, G. C., and Csejtey, Bela, Jr., 19781, Map showing geochemical distribution and abundance of zinc in stream sediments and heavy mineral concentrates, Talkeetna Mountains quadrangle, Alaska: U.S. Geological Survey Open-File Report 78-558-F, scale 1:250,000.

Minsch, J. H., Stover, C. W., and Simon, R. B., 1979, Earthquakes in the United States, April-June 1977: U.S. Geological Survey Circular 788-B, p. B1-B22.

Mull, C. G., 1979, Nanushuk Group deposition and the late Mesozoic structural evolution of the central and western Brooks Range and Arctic Slope, in Ahlbrandt, T. S., ed., Preliminary geologic, petrologic, and paleontologic results of the study of Nanushuk Group rocks, North Slope, Alaska: U.S. Geological Survey Circular 794, p. 5-13.

Nichols, K. M., and Silberling, N. J., 1979, Early Triassic (Smithian) ammonites of paleoequatorial affinity from the Chulitna terrane, south-central Alaska: U.S. Geological Survey Professional Paper 1121-B, p. B1-B5.

Nilsen, T. H., and Moore, G. W., 1979, Reconnaissance study of Upper Cretaceous to Miocene stratigraphic units and sedimentary facies, Kodiak and adjacent islands, Alaska: U.S. Geological Survey Professional Paper 1093, 34 p.

Ohl, J. P., 1979, Bibliography of selected reports relating to studies on earthquakes tectonics and risk, 1975-1978: U.S. Geological Survey Open-File Report $79-1184,36 \mathrm{p}$.

Palmer, I. F., Jr., Bolm, J. G., Maxey, L. R., and Lyle, W. M., 1979, Petroleum source rock and reservoir quality data from outcrop samples, onshore North Slope of Alaska east of Prudhoe Bay: U.S. Geological Survey Open-File Report 79$1634,52 \mathrm{p}$.

Patton, W. W., Jr., and Csejtey, Bela, Jr., 1979, Geologic map of St. Lawrence Island, Alaska: U.S. Geological Survey Open-File Report 79-945, scale $1: 250,000$.

Person, W. J., 1979, Earthquakes, January-February 1979: Earthquake Information Bulletin, v. 11, no. 4, p. 143-147.

Pickthorn, W. J., Yount, M. E., Cooley, E. F., O'Leary, R. M., Detra, D. E., and Ito, Gail, 1979, Sample location map and analytical data for rock samples collected in 1978, Chignik and Sutwik Island quadrangle, Alaska: U.S. Geological Survey Open-File Report 79-1506, scale 1:250,000.

Plafker, George, and Claypool, George, 1979, Petroleum source rock potential of rocks dredged from the continental slope in the eastern Gulf of Alaska: J.S. Geological Survey Open-File Report 79-295, 24 p.

Reed, B. L., Curtin, G. C., Griscom, Andrew, Nelson, S. W., Singer, D. A., and Steele, W. C., 1979, The Alaskan Mineral Resource Assessment Program: Background information to accompany folio of geologic and mineral resource maps of the Talkeetna quadrangle, Alaska: U.S. Geological Survey Circular 775, $17 \mathrm{p}$.

Reed, K. M., ed., 1979, The U.S. Geological Survey in Alaska, 1979 programs: U.S. Geological Survey Circular 804-A, $94 \mathrm{p}$.

Reimnitz, Erk, Barnes, Peter, and Kempema, Edward, 1979, Marine geologic studies in the Beaufort Sea, Alaska, 1978; data type, location, records obtained, and their availability: U.S. Geological
Survey Open-File Report 79-384, 4 p.

Reimnitz, Erk, Barnes, Peter, and Maurer, Douglas, 1979 , U.S.G.S. marine geologic studies in the Beaufort Sea, Alaska, 1976: data type, location, and records obtained: U.S. Geological Survey OpenFile Report 79-766, 4 p.

Reimnitz, Erk, and Ross, Robin, 1979, Lag deposits of boulders in Stefansson Sound, Beaufort Sea, Alaska: U.S. Geological Survey Open-File Report $79-1205,26$ p.

Reiser, H. N., Brosge, W. P., DeYoung, J. H., Jr., Marsh, S. P., Hamilton, T. D., Cady, J. W., and Albert, N. R. D., 1979, The Alaskan Mineral Resource Assessment Program: Guide to information contained in the folio of geologic and mineral resource maps of the Chandalar quadrangle Alaska: U.S. Geological Survey Circular 758, 23 p.

Reiser, H. N., Norris, D. K., Dutro, J. T., Jr., and Brosge, W. P., 1978, Restriction and renaming of the Neruokpuk Formation, northeastern Alaska, in Sohl, N. F., and Wright, W. B., eds., Changes in stratigraphic nomenclature by the U.S. Geological Survey, 1977: U.S. Geological Survey Bulletin 1457-A, p. A 106-A 107.

Richter, D. H., Smith, R. L., Yehle, L. A., and Miller, T. P., 1979, Geologic map of the Gulkana A-2 quadrangle, Alaska: U.S. Geological Survey Geologic Quadrangle Map GQ-1520, scale 1:63,360.

Rodeick, C. A., 1979, the origin, distribution, and depositional history of gravel deposits on the Beaufort Sea continental shelf, Alaska: U.S. Geological Survey Open-File Report 79-234, 87 p.

Roehler, H. W., and Sticker, G. D., 1979, Stratigraphy and sedimentation of the Torok, Kukpowruk and Corwin Formations of Cretaceous age in the KokolikUtukok River region, National Petroleum Reserve in Alaska: U.S. Geological Survey Open-File Report $79-995,80 \mathrm{p}$.

Sammel, E. A., 1979, Occurrence of low-temperature geothermal waters in the United States, in Muffler, L. J. P., ed., Assessment of geothermal resources of the United States, 1978: U.S. Geological Survey Circular 790, p. 86-131.

Schwab, W. C., and Bruns, T. R., 1979, Preliminary residual magnetic map of the northern Gulf of Alaska: U.S. Geological Survey Miscellaneous Field Studies Map MF-1054, scale 1:500,000.

Scott, K. M., 1979, Arctic stream processes--an annotated bibliography: U.S. Geological Survey WaterSupply Paper $265,78 \mathrm{p}$.

Scott, R. A., and Smiley, C. J., 1979, Some Cretaceous plant megafossils and microfossils from the Nanushuk Group, Northern Alaska, a preliminary report, in Ahlbrandt, T. S., ed., Preliminary geologic, petrologic, and paleontologic results of the study of Nanushuk Group rocks, North Slope, Alaska: U.S. Geological Survey Circular 794, p. 89-111.

Sikonia, W. G., and Post, Austin, 1979, Columbia Glacier: Recent ice loss and its relationship to seasonal terminal embayments, thinning, and glacier flow: U.S. Geological Survey Open-File Report 791265.

Simon, R. B., Stover, C. W., and Reagor, B. G., 1979, Earthquakes in the United States, January-March 1977: U.S. Geological Survey Circular 788-A, p. A $1-A 31$.

Sims, John, 1979, Records of prehistoric earthquakes in sedimentary deposits in lakes: Earthquake Information Bulletin, v. 11, no. 6, p. 228-233.

Singer, D. A., and Ovenshine, A. T., 1979, The assessment of metallic mineral resources in Alaska: U.S. 
Geological Survey Open-File Report 78-1-A, 40 p.

Sliter, W. V., 1979, Cretaceous foraminifers from the North Slope of Alaska, in Ahlbrandt, T. S., ed., Preliminary geologic, petrologic, and paleontologic results of the study of Nanushuk Group rocks, North Slope, Alaska: U.S. Geological Survey Circular 794, p. 147-157.

Sloan, Charles, Trabant, Dennis, and Glude, William, 1979, Reconnaissance snow surveys of the National Petroleum Reserve in Alaska, April 1977 and AprilMay 1978: U.S. Geological Survey Water-Resources Investigations Open-File Report 79-1342, 31 p.

Sloan, E. G., Shearer, G. B., Eason, J. E., and Almquist, C. L., 1979, Reconnaissance survey for coal near Farewell, Alaska: U.S. Geological Survey Open-File Report 79-410, 18 p.

Smith, R. L., and Shaw, H. R. 1979, Igneous-related geothermal systems, in Muffler, L. J. P., ed. Assessment of geothermal resources of the United States, 1978: U.S. Geological Survey Circular 790, p. $12-17$.

Smith, R. L., Shaw, H. R., Luedke, R. G., and Russell, S. L., 1978, Comprehensive tables giving physical data and thermal energy estimates for young igneous systems of the United States: U.S. Geological Survey Open-File Report $78-925,15 \mathrm{p}$. , and 13 sheets of tabular material.

Sohl, N. F., and Wright, W. B., 1978, Changes in stratigraphic nomenclature by the U.S. Geological Survey, 1977: U.S. Geological Survey Bulletin 1457-A, p. A1-A136.

Stephens, C. D., Lahr, J. C., Fogleman, K. A., Allan, M. A., and Helton, S. M., 1979, Catalog of earthquakes in southern Alaska, January-March 1978: U.S. Geological Survey Open-File Report 79$718,31 \mathrm{p}$.

Stover, C. W., Minsch, J. H., and Simon, R. B., 1979a, Earthquakes in the United States, October-December 1977: U.S. Geological Survey Circular 788-D, p. D1-D35.

Stover, C. W., Simmon, R. B., and Person, W. J., 1979b, Earthquakes in the United States, July-September 1977: U.S. Geological Survey Circular 788-C, p. C1-C26.

Thrasher, G. P., 1979, Geologic map of the Kodiak outer continental shelf, western Gulf of Alaska: U.S. Geological Survey Open-File Report 79-1267, 2 sheets, scale 1:250,000.

Townshend, J. B., Papp, J. E., Sauter, E. A., and Tilton, S. P., 1979a, Preliminary geomagnetic data, College Observatory, Fairbanks, Alaska, April 1979: U.S. Geological Survey Open-File Report 79300-D, 22 p.

1979b, Preliminary geomagnetic data, College Observatory, Faírbanks, Alaska, August 1979: U.S. Geological Survey Open-File Report 79-300-H, 22 p. - 1979c, Preliminary geomagnetic data, College Observatory, Fairbanks, Alaska, February 1979: U.S. Geological Survey Open-File Report 79-300-B, $20 \mathrm{p}$.

1979d, Preliminary geomagnetic data, College Observatory, Fairbanks, Alaska, July 1979: U.S. Geological Survey Open-File Report 79-300-G, 20 p. 1979e, Preliminary geomagnetic data, College Observatory, Fairbanks, Alaska, June 1979: U.S. Geological Survey Open-File Report 79-300-F, 20 p. -1979f, Preliminary geomagnetic data, College Observatory, Fairbanks, Alaska, March 1979: U.S. Geological Survey Open-File Report 79-300-C, 22 p. 1979g, Preliminary geomagnetic data, College Observatory, Fairbanks, Alaska, May 1979: U.S. Geological Survey Open-File Report 79-300-E, 21 p.
Townshend, J. B., Papp, J. E., Sauter, E. A., and Tilton, S. P., 1979h, Preliminary geomagnetic data, College Observatory, Fairbanks, Alaska, September 1979: U.S. Geological Survey Open-File Repor't 79-300-I, $21 \mathrm{p}$.

Townshend, J. B., Papp, J. E., and Tilton, S. P., 1978a, Preliminary geomagnetic data, College Observatory, Fairbanks, Alaska, December 1978: U.S. Geological Survey Open-File Report 78-300-L, 22 p.

1978b, Preliminary geomagnetic data, College Observatory, Fairbanks, Alaska, November 1978: U.S. Geological Survey Open-File Report 78-300-K, $22 \mathrm{p}$.

1978c, Preliminary geomagnetic data, College Observatory, Fairbanks, Alaska, October 1978: U.S.Geological Survey Open-File Report 78-300-J, 22 p.

1978d, Preliminary geomagnetic data, College Observatory, Fairbanks, Alaska, September 1978: U.S. Geological Survey Open-File Report 78-300-I, $21 \mathrm{p}$.

Tripp, R. B., and Crim, W. D., 1978, Mineralogical map showing the distribution and abundance of gold, scheelite, chalcopyrite, arsenopyrite, minium and sapphire corundum in heavy-mineral concentrates in the Seward and Blying Sound quadrangles, Alaska: U.S. Geological Survey Miscellaneous Field Studies Map MF-880-G, scale $1: 250,000,2$ sheets.

Tripp, R. B., Crim, W. D., Cooley, E. F., and Day, G. W., 1978a, Geochemical map showing the distribution and abundance of copper in stream sediments in the Seward and Blying Sound quadrangles, Alaska: U.S. Geological Survey Miscellaneous Field Studies Map MF-880-E, scale 1:250,000.

Tripp, R. B., Crim, W. D., and O'Leary, R. M., 1978b, Geochemical maps showing the distribution and abundance of gold in stream sediments and of gold and silver in heavy-mineral concentrates in the Seward and Blying Sound quadrangles, Alaska: U.S. Geological Survey Miscellaneous Field Studies Map MF-880-F, scale $1: 250,000,2$ sheets.

Tripp, R. B., Karlson, R. C., and Curtin, G. C., 1978c, Maps showing mineralogical data for nonmagnetic heavy-mineral concentrates in the Talkeetna quadrangle, Alaska: U.S. Geological Survey Miscellaneous Field Studies Map MF-870-I, scale 1:250,000.

Turner, B. W., Thrasher, G. P., Shearer, G. B., and Holden, K. D., 1979, Bathymetric maps of the Kodiak Outer Continental Shelf, western Gulf of Alaska: U.S. Geological Survey Open-File Report 79-263, scale 1:250,000, 13 sheets.

Tysdal, R. G., 1978a, Map showing placer deposits of the Seward and Blying Sound quadrangles, Alaska: U.S. Geological Survey Miscellaneous Field Studies Map MF-880-B, scale $1: 250,000,2$ sheets.

$1978 \mathrm{~b}$, Mines, prospects, and occurrences map of the Seward and Blying Sound quadrangles, Alaska: U.S. Geological Survey Miscellaneous Field Studies Map MF-880-A, scale $1: 250,000,2$ sheets.

Tysdal, R. G., and Case, J. E., 1979, Geologic map of the Seward and Blying Sound quadrangles, Alaska: U.S. Geological Survey Miscellaneous Investigations Series Map I-1150, 12 p., scale 1:250,000.

Tysdal, R. G., and Plafker, George, 1978, Age and continuity of the Valdez Group, southern Alaska, in Sohl, N. F., and Wright, W. B., Changes in stratigraphic nomenclature by the U.S. Geological Survey, 1977: U.S. Geological Survey Bulletin 1457-A, p. A 120-A 124 .

Underwood, M. B., Vallier, T. L., Gardner, J. V., and Barron, J. A., 1979, Age, grain size, mineralogy, 
and carbon/carbonate content of Miocene and Pliocene samples from dredge hauls, DSDP holes 184B and 185 , and the Sandy River well, southern Bering Sea continental margin and Alaska Peninsula: U.S. Geological Survey Open-File Report 79-450, 34 p.

U.S. Geological Survey, 1972, Water resources data for Alaska 1971: $318 \mathrm{p}$.

p.

1974, Water resources data for Alaska 1973: 298

p.

1975, Water resources data for Alaska 1974: 322

p.

1978a, Aeromagnetic map of part of Blying Sound quadrangle, Alaska: Open-File Report 78-1082, scale $1: 250,000$.

1978b, Aeromagnetic map of Seward quadrangle, Alaska: Open-File Report 78-1080, scale 1:250,000.

1978c, Aeromagnetic maps of part of Blying Sound quadrangle, Alaska: Open-File Report 78-1083, scale $1: 63,360,10$ sheets.

1978d, Aeromagnetic maps of Seward quadrangle, Alaska: Open-File Report 78-1081, scale 1:63,360, 32 sheets.

1979a, Aeromagnetic map of part of the Valdez $1^{\circ} \times 3^{\circ}$ quadrangle, Alaska: Open-File Report 79-381, scale $1: 250,000$.

$1979 \mathrm{~b}$, Aeromagnetic map of parts of the Cordova and Middleton Island $10 \times 30$ quadrangles, Alaska: Open-File Report 79-223, scale 1:250,000.

1979c, Aeromagnetic map of the Medfra $1^{\circ} \times 3^{\circ}$ quadrangle, Alaska: Open-File Report 79-380, scale $1: 250,000$

1979d, Aeromagnetic map of the Petersburg area,

Alaska: Open-File Report 79-832, scale 1:250,000. $1979 \mathrm{e}$, Aeromagnetic map of Yakobi and Chichagof Islands, Alaska: Open-File Report 79-529, scale $1: 250,000$
U.S. Geological Survey, 1979f, Aeromagnetic maps of parts of the Ketchikan, Prince Rupert, and Craig quadrangles, southeastern Alaska: Open-File Report 79-937, scale 1:63,360, 19 sheets.

1979g, Aeromagnetic profiles of the Prince William Sound area, Alaska: Open-File Report 79224 , scale 1:250,000, 2 sheets.

$1979 \mathrm{~h}$, Aeroradioactivity map of Cone Mountain, Alaska: Open-file Report 79-830, scale 1:63,360. 1979i, Aeroradioactivity map of Kosciusko Island, Alaska: Open-File Report 79-831, scale 1:63,360. -1979j, Seismic engineering program report, MayAugust 1978: Circular 785-B, p. 1-18.

Vhay, J. S., 1979, Cobalt in the United States (material compiled up to 1963): U.S. Geological Survey Open-File Report 79-1436, 26 p.

Wallace, A. R., 1979, Occurrence of uranium in rocks of the Ekiek Creek complex, western Alaska: U.S. Geological Survey Open-File Report 79-1653, 20 p.

Wilson, F. H., 1978, Map showing preliminary results of $\mathrm{K}$-Ar studies in the Chignik and Sutwik Island quadrangles, Alaska: U.S. Geological Survey Open-File Report 78-1064.

Wilson, F. H., Dadisman, S. v., and Herzon, P. L., 1979, Map showing radiometric ages of rocks in southeastern Alaska: U.S. Geological Survey OpenFile Report 79-594, 33 p.

Winkler, G. R., 1979, Sedimentary petrology, in Nilsen, T. H., and Moore, G. W., Reconnaissance study of Upper Cretaceous to Miocene stratigraphic units and sedimentary facies, Kodiak and adjacent islands, Alaska: U.S. Geological Survey Professional Paper 1093 , p. 23-29.

Yehle, L. A., 1979, Reconnaissance engineering geology of the Yakutat area, Alaska, with emphasis on evaluation of earthquake and other geologic hazards: U.S. Geological Survey Professional Paper 1074, $44 \mathrm{p}$. 


\section{GEOLOGICAL SURVEY AUTHORS IN OUTSIDE} PUBLICATIONS, 1979

\section{Compiled by Ellen R. White}

Ager, Thomas, 1979, A long Quaternary pollen record from the Yukon delta, Alaska [abs.], in American Association of Stratigraphic Palynologists Foundation, 1979: Palynology v. 3, p. 277-278.

Allison, R. C., and Marincovich, Louie, 1979, Asiatic molluscs in late Paleogene and Neogene strata of the western Gulf of Alaska: Prospects for circum-north Pacific correlation [abs.]: Pacific Science Congress, 14th, Khabarovsk, U.S.S.R., 1979, Abstracts of Papers, sec. B 3, p. 15-17.

Armentrout, J. M., 1979, Paleocene plutonism in southern Alaska [abs.]: Pacific Science Congress, $14 \mathrm{th}$, Khabarovsk, U.S.S.R., 1979, abstracts of Papers, sec. B 4, p. 46-47.

Barnes, D. F., and Strange, W. E., Jr., 1979, Only small gravity changes accompany some recent crustal uplifts in Alaska [abs.]: Eos (American Geophysical Union Transactions), v. 60 , no. 18, p. 317.

Barnes, Ivan, and McCoy, G. A., 1979, Possible role of mantle-derived $\mathrm{CO}_{2}$ in causing two "phreatic" explosions in Alaska! Geology, v. 7 , no. 9, p. 434435.

Barnes, P. W., Fox, Dennis, and Reimnitz, Erk, 1979, Sediment load carried by seasonal ice off northern Alaska, 1978 [abs.] : Geological Society of America Abstracts with Programs, v. 11, no. 7, p. 384.

Barnes, P. W., Reimnitz, Erk, Toimil, L. J., and Hill, H. R., 1979, Fast ice thickness and snow depth relationships related to oil entrapment potential, Prudhoe Bay, Alaska: Ports and Ocean Engineering under Arctic Conditions Conference, 5th, Trondheim, Norway, 1979, Proceedings, v. 2. p. 1205-1225.

Bartsch-Winkler, Susan, and Huffman, A. C., 1979, Petrographic study of some surface and subsurface sandstone, Nanushuk Group, North Slope, Alaska [abs.]: Geological Society of America Abstracts with Programs, v. 11 , no. 3, p. 68.

Berg, H. C., 1979, Significance of geotectonics in the metallogenesis and resource appraisal of southeastern Alaska: A progress report [abs.]: Alaska Geological Society Symposium, Anchorage, 1979, Program and Abstracts, p. 42-43.

Boucher, Gary, 1979, Restoration of the Beaufort Sea rifted margin on the basis of gravity anomalies [abs.]: Eos (American Geophysical Union Transactions), v. 60 , no. 18, p. 373.

Bouma, A. H., Rappeport, M. L., Orlando, R. C., Cacchione, D. A., Drake, D. E., Garrison, L. E., and Hampton, M. A., 1979, Bedform characteristics and sand transport in a region of large sand waves, lower Cook Inlet, Alaska: Offshore Technology Conference, Houston Texas, 1979, Proceedings, no. 11, v. 2, p. 1083-1094, Paper OTC 3485.

Brew, D. A., and Morrell, R. P., 1979, Plutonic belts of southeastern Alaska, U. S. A. [abs.] : Pacific Science Congress, 14th, Khabarovsk, U.S.S.R., 1979, Abstracts of Papers, Symposia A, sec. B 4, p. 33-35.

Bruns, T. R., 1979, Late Cenozoic structure of the continental margin, northern Gulf of Alaska, in Sisson, Alexander, ed., 1979, The relationship of plate tectonics to Alaskan geology and resources: Alaska Geological Society Symposium, 6th, Anchorage, 1977, Proceedings, p. I 1-I 30.
Bruns, T. R., Schwab, W. C., von Huene, R. E., Atwood, T. J., Blakeley, R. J., and Case, J. E., 1979, Geological significance of the slope anomaly, northern Gulf of Alaska [abs.]: Eos (American Geophysical Union Transactions), v. 60 , no. 46, p. 951.

Cacchione, D. A., Drake, D. E., and Wiberg, Patricia, 1979 , Bottom shear stress generated by waves and currents in the northern Bering Sea [abs.]: Eos (American Geophysical Union Transactions), v. 60, no. 46, p. 848 .

Callahan, J. E., 1979, Coal resources of the Cretaceous Nanushuk Group, western Arctic, Alaska [abs.]: Alaska Geological Society Symposium, Anchorage, 1979, Program and Abstracts, p. 24.

Carlson, P. R., 1979, Extensive sliding of continental slope sediments, eastern Gulf of Alaska [abs.]: Geological Society of America Abstracts with Programs, v. 11 , no. 7 , p. 398.

Carlson, P. R., Wheeler, M. C., Molnia, B. F., Post, Austin, and Powell, R. D., 1979, Neoglacial sedimentation in west arm of Glacier Bay, Alaska [abs.]: Geological Society of American, Abstracts with Programs, v. 11, no. 3, p. 72 .

Childs, J. R., Cooper, A. K., and Parker, A. W., 1979, Sonobuoy studies of Umnak Plateau, Bering Sea [abs.]: Eos (American Geophysical Union Transactions), v. 60 , no. 18 , p. 390.

Churkin, Michael, Jr., and Carter, Claire, 1979a, Collision-deformed Paleozoic continental margin in Alaska--A foundation for microplate accretion: Geological Society of America, Cordilleran Section, Abstracts with Programs, v. 11, no. 3, p. 72. 1979b, Continental and oceanic basement terranes of Alaska - implications for plate motions in Alaska - Chukotka [abs.]: Pacific Science Congress, 14th, Khabarovsk, U.S.S.R., 1979, Abstracts of Papers, sec. B 2, p. 8-10.

Churkin, Michael, Jr., Carter, Claire, and Johnson, Bruce, 1979, Reply ["Subdivision of Ordovician and Silurian time scale using accumulation rates of graptolite shale" ]: Geology, v. 7 , no. 3, p. 114115.

Churkin, Michael, Jr., and Nokleberg, W. J., 1979, Collision-deformed Paleozoic continental margin, western Brooks Range, Alaska [abs.]: Geological Society of America Abstracts with Programs, v. 11, no. 7, p. 401 .

Churkin, Michael, Jr., Nokleberg, W. J., and Huie, Carl, 1979, Collision-deformed Paleozoic continental margin, western Brooks Range, Alaska: Geology, v. 7, no. 8, p. 379-383.

Churkin, Michael, Jr., and Trexler, J. H., Jr., 1979, Comment [on "The Siberian connection: A case for Precambrian separation of the North American and Siberian cratons"]: Geology, v. 7 , no. 10, p. 467469.

Cooper, A. K., and Ben-Avraham, Zvi, 1979, Multifold seismic evidence for the origin of Bowers Ridge, Bering Sea [abs.]: Eos (American Geophysical Union Transactions), v. 60 , no. 46 , p. 950 .

Cooper, A. K., Childs, J. R., Scholl, D. W., Marlow, M. S., and Gardner, J. V., 1979, Evolution of Umnak Plateau, Bering Sea [abs.]: Eos (American Geophysical Union Transactions), v. 60 , no. 18 , p. 390.

Cooper, A. K., Marlow, M. S., and Scholl, D. W., 1979a, Cenozoic collapse of the outer Bering Sea continental margin [abs.]: Geological Society of America Abstracts with Programs, v. 11, no. 3, p. 73 . 1979b, Thick sediment accumulations beneath continental margin of outer Bering Sea [abs.] : American Association of Petroleum Geologists Bulletin, v. 63 , no. 3, p. 436 . 
Cooper, A. K., Scholl, D. W., Marlow, M. S., Childs, J. R., Redden, G. D., Kvenvolden, K. A., and Stevenson, A. J., 1979, Hydrocarbon potential of the Aleutian Basin, Bering Sea: American Association of Petroleum Geologists Bulletin, v. 63, no. 11, pt. 1, p. 2070-2087.

Dearborn, Larry, 1979, Potential and developed watersupply sources in Alaska [abs.]: Alaska Geological Society Symposium, Anchorage, 1979, Program and Abstracts, p. 32 .

Dupre, W. R., and Nelson, C. H., 1979, A comparison of an ice-dominated and a tide-dominated delta on the Bering epicontinental shelf, Alaska [abs.]: Geological Society of America Abstracts with Programs, v. 11 , no. 7 , p. 418 .

Ehm, Arlen, and Tailleur, I. L., 1979, Petroleum exploration of NPRA [abs.]: Alaska Geological Society Symposium, Anchorage, 1979, Program and Abstracts, p. 9 .

Eittreim, Stephen, and Grantz, Arthur, 1979a, CDP seismic sections of the western Beaufort continental margin, in Keen, C. E., and Keen, M. J., eds., Crustal properties across passive continental margins: Tectonophysics, v. 59, no. 1-4, p. 251-262.

-1979b, Stratigraphy and petroleum potential of Hope Basin, southeast Chukchi Sea [abs.]: American Association of Petroleum Geologists, Pacific Section, 54th Annual Meeting, 1979, Abstracts and Program, p. 10-11.

Eittreim, Stephen, Grantz, Arthur, and Greenberg, Jonathan, 1979, The Barrow submarine canyon system, western Beaufort Sea [abs.]: Geological Society of America Abstracts with Programs, v. 11, no. 7, p. 420 .

Eittreim, Stephen, Grantz, Arthur, and Whitney, 0. T., 1979, Cenozoic sedimentation and tectonics of Hope Basin, southern Chukchi Sea, in Sisson, Alexander, ed., The relationship of plate tectonics to Alaskan geology and resources: Alaska Geological Society Symposium, 6th, Anchorage, 1977, Proceedings, p. B 1-B 11 .

Field, M. E., Richmond, W. C., and Nelson, C. H., 1979, Videotapes of active primary physical and biogenic sedimentary structures of epicontiental shelf, northern Bering Sea [abs.]: American Association of Petroleum Geologists Bulletin, v. 63, no. 3, p. 449-450.

Fisher, M. A., 1979, Structure and tectonic setting of continental shelf southwest of Kodiak Island, Alaska: American Association of Petroleum Geologists Bulletin, v. 63, no. 3, p. 301-310.

Fisher, M. A., Patton, W. W., Jr., Thor, D. R., Holmes, M. L., Scott, E. W., Nelson, C. H., and Wilson, C. L., 1979, The Norton Basin of Alaska: Oil and Gas Journal, v. 77, no. 21, p. 97-98.

Gardner, J. V., Vallier, T. L., Dean, W. E., Kvenvolden, K. A., and Redden, G. D., 1979, Sedimentology and geochemistry of surface sediments and the distribution of faults and potentially unstable sediments, St. George Basin region of the outer continental shelf, southern Bering Sea, in OCSEAP, 1979, Environmental Assessment of the Alaskan Contiental Shelf, Final Reports of principal Investigator: Boulder, Colo., National Oceanic and Atmospheric Administration, v. 2, p. 181-271.

Grantz, Arthur, 1979, Geologic structure and development of the Alaskan continental margin in the Beaufort Sea [abs.]: Eos (American Geophyscial Union Transactions), v. 60 , no. 18, p. 375 .

Grantz, Arthur, Eittreim, Stephen, and Dinter, D. A.,
1979, Geology and tectonic development of the continental margin north of Alaska: Tectonophysics, v. 59, no. 1-4, p. 263-291.

Hampton, M. A., Bouma, A. H., Frost, T. P., and Colburn, I. P., 1979, Volcanic ash in surficial sediments of the Kodiak shelf - an indicator of sediment dispersal patterns: Marine Geology, v. 29 , no. $1 / 4$, p. 347-356.

Hampton, M. A., Bouma, A. H., Pulpan, H., and von Huene, Roland, 1979, Geo-environmental assessment of the Kodiak Shelf, western Gulf of Alaska: offshore Technology Conference, Houston, Texas, 1979, Proceedings, no. 11, v. 1, p. 365-376, Paper OTC 3399.

Hein, J. R., Bouma, A. H., Hampton, M. A., and Ross, Robin, 1979, Clay mineralogy, fine-grained sediment dispersal, and inferred current patterns, lower Cook Inlet and Kodiak Shelf, Alaska: Sedimentary Geology, v. 24, no. 3/4, p. 291-306.

Hein, J. R., O'Neil, J. R., and Jones, M. G., 1979, Origin of authigenic carbonates in sediment from the deep Bering Sea: Sedimentology, v. 26 , no. 5 , p. 681-705.

Hill, Malcolm, Whelan, Joseph, 1979, Involvement of sediment anatexis in the genesis of early Tertiary granodiorite and granite, southwestern Alaska [abs.]: Geological Society of America Abstracts with Programs, v. 11, no. 7, p. 444.

Hillhouse, J. W., 1979, Triassic paleomagnetism of the Alexander terrane, southeastern Alaska [abs.]: Geological Society of America Abstracts with Programs, v. 11, no. 7 , p. 444 .

Holmes, M. L., and Cline, J. D., 1979, Geologic setting and source depth of the Norton Basin gas seep: Journal of Petroleum Technology, v. 31, no. 10, p. 1241-1248.

Holmes, M. L., and Fisher, M. A., 1979, Sonobuoy refraction measurement measurements from Norton Basin, northern Bering Sea: American Association of Petroleum Geologists Bulletin, v. 63, no. 3, p. 468 .

Hopkins, D. M., 1979a, Landscape and climate of Beringia during late Pleistocene and Holocene time, in Laughlin, W. S., and Harper, A. B., eds., The first Americans: Origins, affinities, and adaptations: New York, Gustave Fischer, p. 15-41. 1979b, Short resume of the geology of the Cape Nome-Safety Lagoon area, in Bockstoce, John, The archaeology of Cape Nome, Alaska: Philadelphia, University of Pennsylvania, University Museum Monograph 38, p. 97.

Hopkins, D. M.,1979c, The Flaxman Formation of northern Alaska: record of early Wisconsinan shelf glaciation in the high arctic? [abs.]: Pacific Science Conference, 14th, Khabarovsk, U.S.S.R., 1979, Abstracts of Papers, Additional volume, p. 15-16.

Hudson, Travis, 1979a, Mesozoic plutonic belts of southern Alaska: Geology, v. 7 , no. 5, p. 230-234. -1979b, Regional geology and metallization of Seward Peninsula, Alaska [abs.]: Northwest Mining Association Annual Meeting, Spokane, Wash., 1979, abstracts.

Hudson, Travis, Plafker, George, and Peterman, Z. E., 1979, Paleogene anatexis along the Gulf of Alaska margin: Geology, v. 7 , no. 12, p. 573-577.

Hudson, Travis, Plafker, George, and Rubin, Meyer, 1979, Tectonism and marine terrace development in the eastern Gulf of Alaska [abs.]: Geological Society of America Abstracts with Programs, v. 11, no. 3, p. 85 .

Hudson, Travis, Smith, J. G., and Elliott, R. L.., 1979, Petrology, composition, and age of intrusive rocks 
associated with the Quartz Hill molybdenite deposit, southeastern Alaska: Canadian Journal of Earth Sciences, v. 16, no. 9, p. 1805-1822.

Hunt, Susan, Plafker, George, and Hudson, Travis, 1979, Active fault map of Alaska: A progress report [abs.]: Geological Society of America Abstracts with Programs, v. 11 , no. 3, p. 85.

Hutchison, W. W., Berg, H. C., and Okulitch, A. V., 1979, Geology, Skeena River, British ColumbiaAlaska: Geolpgical Survey of Canada Map 1385 A, scale $1: 1,000,000$

Jones, D. L., 1979a, Mesozoic accretionary tectonics of southern and central Alaska [abs.]: Geological Society of America Abstracts with Programs, v. 11, no. 7, p. 452

1979b, Mesozoic stratigraphy - the key to tectonic analysis of southern and central Alaska [abs.]: American Association for the Advancement of Science, Pacific Division, Annual Meeting, 60th, Abstracts, p. 21.

Kvenvolden, K. A., Blunt, D. J., Robinson, S. W., and Bacon, Glenn, 1979, Amino-acid dating of an archaeological site on Amaknak Island, Alaska [abs.]: Geological Society of America Abstracts with Programs, v. 11, no. 7, p. 462.

Kvenvolden, K. A., Nelson, C. H., Thor, D. R., Larsen, M. C., Redden, G. D., Rapp, J. B., and Des Marais, D. J., 1979, Biogenic and thermogenic gas in gascharged sediment of Norton Sound, Alaska: Offshore Technology Conference, Houston, Texas, 1979, Proceedings, v. 1, no. 11, p. 479-486, Paper OTC 3412.

Kvenvolden, K. A., Weliky, Karen, Nelson, Hans, and Des Marais, D. J., 1979, Submarine seep of carbon dioxide in Norton Sound, Alaska: Science, v. 205, no. 4412 , p. 1264-1266

Larsen, M. C., Nelson, Hans, and Thor, D. R., 1979, Geologic implications and potential hazards of scour depressions on Bering Shelf, Alaska: Environmental Geology, v. 3, no. 1, p. 39-47.

Lisowski, M., Prescott, W. H., and Savage, J. C., 1979, Geodetic tilt near the epicenter of the St. Elias, Alaska, earthquake of February 22, 1979 [abs.] : Eos (American Geophysical Union Transactions), v. 60 , no. 46, p. 936

Lohrenz, John, Dougherty, E. L., and Dobey, P. L., 1979, State of Alaska oil and gas lease bonus bids: a statistical study [abs.]: Alaska Geological Society Symposium, Anchorage, 1979, Program and Abstracts, p. 7.

Magoon, L. B., and Claypool, G. E., 1979, Origin of Cook Inlet oil, in Sisson, Alexander, ed., The relationship of plate tectonics to Alaskan geology and resources: Alaska Geological Society Symposium, 6th, Anchorage, 1977, Proceedings, p. G1-G17.

Marlow, M. S., 1979, Hydrocarbon prospects in Navarin basin province, northwest Bering Sea Shelf: 0il and Gas Journal, v. 77 , no. 44, p. 190-196.

Marlow, M. S., Scholl, D. W., Cooper, A. K., and Jones, D. L., 1979a, Mesozoic rocks from the Bering Sea: The Alaska-Siberia connection [abs.] : Geological Society of America, v. 11, no. 3, p. 90. 1979b, Shallow-water Upper Jurassic rocks dredged from the Bering Sea continental margin [abs.] : American Association of Petroleum Geologists Bulletin, v. 63, no. 3, p. 490-491.

May, F. E., 1979, Dinoflagellate assemblages from surface and subsurface Nanushuk Group (Albian Cenomanian), northern Alaska [abs.]: American Association of Petroleum Geologists Bulletin, v. 63, no. 3, p. 492

McLean, Hugh, 1979a, Observations on the geology and petroleum potential of the Cold Bay - False Pass tectonics, in Sisson, Alexander, ed., The relationship of plate tectonics to Alaskan geology and resources: Alaska Geological Society, Symposium, 6th, Anchorage, 1977, Proceedings, p. C1-C7.

Nokleberg, W. J., Plahuta, J. T., and Lange, I. M., 1979, Volcanogenic zinc-lead-barite deposits in pelagic rocks of late Paleozoic and early Mesozoic age, northwestern Brooks Range, Alaska [abs.]: Geological Society of America Abstracts with Programs, v. 11 , no. 7 , p. 487-488.

Nokleberg, W. J., Plahuta, J. T., Lange, I. M., and Grybeck, Donald, 1979, Volcanogenic zinc-lead mineralization in pelagic sedimentary rocks of late Paleozoic age, northwestern Brooks Range, Alaska [abs.]: Geological Association of Canada, Cordilleran Section, Abstracts with Programs, p. 21.

Olhoeft, G. R., Watts, R. D., Frischknecht, F. C., Bradley, J. A., and Dansereau, D. A., 1979, Electromagnetic geophysical exploration in the National Petroleum Reserve in Alaska, in Symposium on Permafrost Field Methods and Permafrost Geophysics, Proceedings: Ottawa, National Research Council, Association Committee on Technical Research, Technical Memorandum 124, p. 184-190.

Patton, W. W., 1979, Ophiolites of western Alaska and their tectonic significance: Pacific Science Congress, 14 th, Ophiolites of the Pacific BeIt, Khabarovsk, U.S.S.R., p. 34-35.

Pewe, T. L., 1979a, Permafrost - and its affects on human activities in arctic and subarctic regions: GeoJournal, v. 3, no. 4, p. 333-344.

_ 1979b, Permafrost reviewed: Geology, v. 24, no. 7, p. 21-23. Report on the 3rd International Conference on Permafrost, 1978, Edmonton, Canada.

Plafker, George, Winkler, G. R., Carlson, P. R., and Bruns, T. R., 1979, Petroleum potential of eastern Gulf of Alaska shelf based on dredge samples from adjacent continental slope [abs.]: American Association of Petroleum Geologists Bulletin, v. 63 , no. 4, p. 700 .

Quinterno, Paula, Carlson, P. R., and Molnia, B. F., 1979, Distribution of benthic foraminifers in the Gulf of Alaska [abs.]: Geological Society of America Abstracts with Programs, v. 11, no. 7, p. 500 .

Rappeport, M. L., Cacchione, D. A., Bouma, A. H., and Drake, D. E., 1979, Seafloor microtopography, tidal current characteristics and bottom boundary layer time-series data, Cook Inlet, Alaska [abs.]: Eos (American Geophysical Union Transactions), v. 60, no. 18, p. 285.

Redden, G. D., Rapp, J. B., and Kvenvolden, K. A., 1979, Gases in sediments of Norton Sound, Alaska [abs.]: Geological Society of America Abstracts with Programs, v. 11, no. 3, p. 123.

Reimnitz, Erk, Dunton, Kenneth, and Barnes, P. W., 1979, Anchor ice and lack of delta accretion in the Arctic - a possible link [abs.]: Geological Society of America Abstracts with Programs, v. 11, no. 7, p. 501.

Reimnitz, Erk, and Maurer, D. K., 1979a, Effects of storm surges on the Beaufort Sea coast, northern Alaska: Arctic, v. 32, no. 4, p. 329-344.

1979b, Eolian sand deflation - A cause for gravel barrier islands in arctic Alaska: Geology, v. 7, no. 10 , p. 507-510.

Riva, John, Carter, Claire, and Churkin, Michael, Jr., 1979, The Ordovician-Silurian boundary in graptolitic sequences in the southwestern and western United States and in Alaska [abs.]: Pacific Science Congress, 14th, Khabarovsk, U.S.S.R., 1979, Abstracts of Papers, sec. B 3, p. 66-67. 
Roth, Barry, Marincovich, Louie, and Ullberg, L. W., 1979, Glendonites: Pacific Discovery, v. 32, no. 5 , p. 29-31.

Sallenger, A. H., Jr., and Dingler, J. R., 1979, Coastal processes and morphology of the Bering Sea coast of Alaska, in OCSEAP, 1979, Environmental Assessment of the Alaskan Continental Shelf, Final Reports of Principal investigators: Boulder, Colo., National Oceanic and Atmospheric Administration, v. 2, p. 377-441.

Schwab, W. C., Bruns, T. R., von Huene, R. E., 1979, Magnetic lineaments in the northern Gulf of Alaska and their geologic significance [abs.]: Geologica] Society of America Abstracts with Programs, v. 11, no. 7, p. 512 .

Silberling, N. J., and Richter, D. H., 1979, Recognition of Wrangellia in the Talkeetna and Clearwater Mountains, south-central Alaska [abs.]: Geological Society of America Abstracts with Programs, v. 11, no. 7, p. 517.

Silberman, M. L., Csejtey, Bela, Jr., and Connor, C. L., 1979, K-Ar ages of metamorphic rocks, granitic intrusions, and hydrothermal alteration - mineralization in the Willow Creek area, southwestern Talkeetna Mountains, Alaska [abs.]: Geological Society of America Abstracts with Programs, v. 11, no. 3 , p. 128 .

Singer, D. A., and Ovenshine, A. T., 1979, Assessing metallic resources in Alaska: American Scientist, v. 67 , no. 5 , p. 582-589.

Smith, J. G., Stern, T. W., and Arth, J. G., 1979, Isotopic ages indicate multiple episodes of plutonism and metamorphism in the Coast Mountains near Ketchikan, Alaska [abs.]: Geological Society of America Abstracts with Programs, v. 11, no. 7, p. 519.

Souther, J. G., Brew, D. A., and Okulitch, A. V., 1979, Geology, Iskut River, British Columbia Alaska: Geological Survey of Canada Map 1418A.

Stephens, C. D., Horner, R. B., Lahr, J. C., and Fogleman, K. A., 1979, The St. Elias, Alaska, earthquake of 28 February 1979: Aftershocks and regional seismicity [abs.]: Eos (American Geophysical Union Transactions), v. 60 , no. 42, p. 738 .
Thenhaus, P. C., Ziony, J. I., Diment, W. H., Hopper, M. G., Perkins, D. M., Hanson, S. L., and Algermissen, S. T., 1979, Probabilistic estimates of maximum seismic acceleration in rock in Alaska and the adjacent outer continental shelf, in American Association for the Advancement of Science, 1979, Science for Alaska: Fairbanks, Alaska, p. 68-69.

Thor, D. R., and Nelson, H., 1979, A summary of interactions, surficial geologic processes and potential geologic hazards in Norton Basin, northern Bering Sea: Offshore Technology Conference, Houston, Texas, 1979, Proceedings, no. 11, v. 1, p. 377-385, Paper OTC 3400 .

von Huene, Roland, Fisher, M. A., Bruns, T. R., and Shor, G. G., Jr., 1979, Continental margins of the Gulf of Alaska and late Cenozoic tectonic plate boundaries, in Sisson, Alexander, ed., The relationship of plate tectonics to Alaskan geology and resources: Alaska Geological Society Symposium, 6th, Anchorage, 1977, Proceedings, p. J 1-33.

von Huene, Roland, Moore, G. W., Moore, J. C., and Stephens, C. D., 1979, Cross section, Alaska Peninsula - Kodiak Island - Aleutian Trench: Summary: Geological Society of America Bulletin, v. 90 , no. 5 , pt. 1 , p. 427-430.

Whitney, J. W., Noonan, W. G., Thurston, D., Bouma, A. H., and Hampton, M. A., 1979, Lower Cook Inlet, Alaska: Do those large sand waves migrate?: offshore Technology Conference, Houston, Texas, 1979, Proceedings, no. 11, v. 1, p. 1071-1082, Paper OTC 3484.

Wilson, F. H., 1979, K-Ar geochronology and Tertiary igneous history. Chignik and Sutwik Island area, Alaska Peninsula, Alaska: Geological Society of America Abstracts with Programs, v. 11, no. 7, p. 541-542.

Winkler, G. R., and Miller, R. J., 1979, Disparate terranes proximal to Border Ranges fault system in the Valdez quadrangle, southern Alaska [abs.]: Geological Society of America Abstracts with Programs, v. 11 , no. 7 , p. 542 .

Wong, F. L., Vallier, T. L., Hopkins, D. M., and Silberman, M. L., 1979, Petrology of alkali basalt from the Pribilof Islands region, southern Bering Sea [abs.]: Eos (American Geophysical Union Transactions), v. 60 , no. 46, p. 972 . 
A

Page

Albert, N. R. D. . ...... B64, 66

Aleinikoff, J. N. . . . . . . . . . B34

Armstrong, A. K. . . . . . . . . B94

B

Barnes, D. F. . . . . . . . . B15

Barnes, Ivan ....... . . . B28

Bartsch-Winkler, Susan . . . . . . . .B6

Berg, H. C. . . . . . . B104, 109

Brew, D. A. . . . . . . B96, 99, 108 Brosge, W. P. ........ B20, 24

Bryn, Sean .......... B14

C

Carlson, P. R. . . . . . . . . B128

Carter, Claire . . . . . . . . B32

Carter, L. D. . . . . . . . .B8, 32

Carter, R. D. . . . . . . . . . . . . . B3

Case, J. E. ......... . B72, 74

Chapman, R. M. . . . . . . B B0, 32

Childs, J. R. . . . . . . . . . . . B134

Churkin, Michael, Jr. . . . . . . B32

Coney, P. J. . . . . . . . B56, 109

Connor, C. L. . . . . . . . . B61

Coulter, H. W. . . . . . . . . B78

Csejtey, Bela, Jr. . . . . . . . B B

Curtis, Steven ......... . B17

D

Decker, John ........... . B102

Detterman, R. L. . . . . . . . B B1

Douglass, R. C. . . . . . . . . B94

Dusel-Bacon, Cynthia ...... B34

Dutro, J. T., Jr. . . B20, 24, 42, 94

E

Egbert, R. M. ........ . B86, 88

Elliott, R. L. . . . . . . . . B115

F

Feulner, A. J. . . . . . . . . . . B12

Fisher, M. A. . . . . . . . . B118

Ford, A. B. . . . . . . B96, 99, 108 Foster, H. L. . . B25, 28, 34, 37, 38

Frank, C. 0.......... B14

G

Giovannetti, D. M. ....... . B84

Grantz, Arthur . . . . . . . B74

Gromme, Sherman ..... B $55,58,70$
$\mathrm{H}$

Page

Hamil ton, T. D. ......... B21

Harris, Anita ........ . . B109

Herzon, P. L. ........ B64, 66

Hillhouse, J. W. . . . . . B55, 58, 70

Hoare, J. M. . . . . . . . . . B44

Holmes, M. L. . . . . . . . . . . .B118

Hudson, Travis ......... . . B90

Huffman, A. C. . . . . . . . . . B6

Hunt, S. J. . . . . . . . . B108

$\mathrm{J}$

Johnson, B. R. . . . . . . . . . . B102

Johnson, K. M. . . . . . . . . B76

Jones, D. L..... . B44, 46, 51, 56, 109

$\mathrm{K}$

Kalechitz, Georgiana ...... . B61

Keith, T. E. C. . . . . . . . B25, 28

Klock, P. R. . . . . . . . . . . B61

Koch, R. D. . . . . . . . . . . B115

L

Lanphere, M. A. . . . . . . . B39

Le Compte, J. R. . . . . . . . . . . . . B1

M

MacKevett, E. M., Jr. ....... B61

Magoon, L. B. .......... . B86

Mamet, B. L. . . . . . . . . . . . B94

McClellan, P. H. . ....... . B84

Menzie, W. D. . . . . . . . . B38

Miller, R.J. ........ B72, 74

Miller, T. P. ....... . . . B39

Mitchell, P. A. . . . . . . . B81

Miyaoka, R. T. . . . . . . . B64, 66

Molenaar, C. M. . . . . . . . . .B4

Molnia, B. F. . . . . .B125, 125, 128

Moore, T. E. . . . . . . . . B20

Mosier, D. L. . . . . . . . . . B38

Murchey, B. L. . . . . . . . B17

N

Nelson, C. H. . . . . . . . . . . . B121

Nelson, R. E. . . . . . . . . . . . . . B9

Nilsen, T. H. . . . . . . . . B20

Nokleberg, W. J. . . . . . . B64, 66

0

O'Neil, J. R. ........... 
$\mathrm{P}$

Page

Patton, W. W., Jr. . .....B42, 118

Pickthorn, W. J. . . . . . . B74

Plafker, George . . . . . . B68, 90

Presser, T. S. . . . . . . . B25

Q

Quinterno, Paula . . . . . . B128

$\mathrm{R}$

Rau, W. W. ......... . . B131

Reiser, H. N. .......... . B24

Richter, D. H. . . . . . B B6, 51, 56

Robinson, S. W. ...... . B8, 115

S

Scholl, D. W. ......... . . . 134

Silberling, N. J. . . . . . B46, 51, 56

Silberman, M. L. . . . . . B61, 74, 81

Sonnevil, R. A. . . . . .B108, 112, 117

Spicer, R. A. . . . . . . . . B B1

St. Aubin, D. R. . . . . . . . . B49

Steele, W. C. . . . . . . . . . B1

Swain, P. B. . . . . . . . B17
T

Page

Thor, D. R. . . . . . . . . . B121

Thurston, D. K. . . . . . . . B122

Trexler, J.H., Jr. ....... . B32

$\mathrm{V}$

Vallier, Tracy .......... . . B134

W

Wardlaw, Bruce ........ . B B46

Whitney, J. W. . . . . . . . . B122

Williams, J.R. . . . . . B12, 76, 78

Wilson, F. H. . . . . . . . . B45

Winkler, G. R. . . . . . . B68, 72

Y

Yeend, Warren ......... . B134

Z

Zehner, R. E. ....... . B64, 66

Zimmerman, Jay ........ . B14 
GPO $789-036 / 64$ 